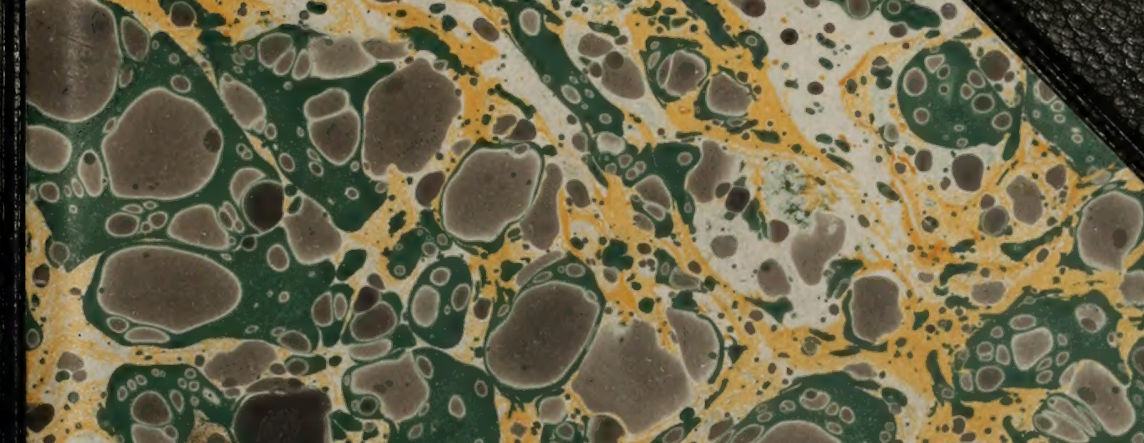

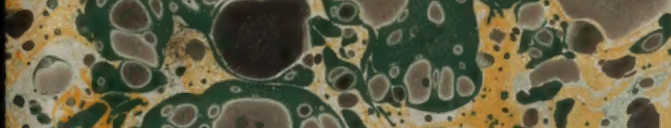

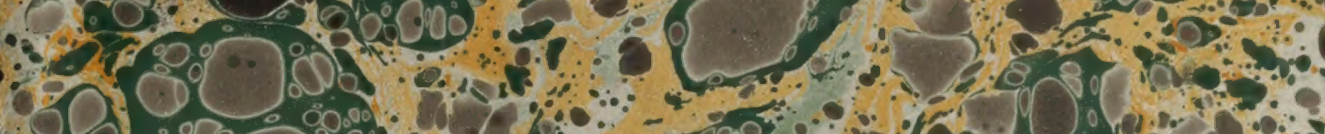

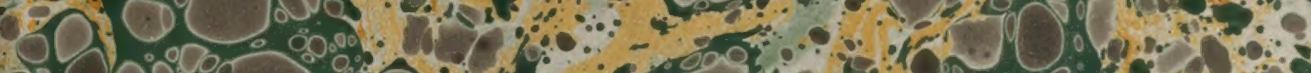

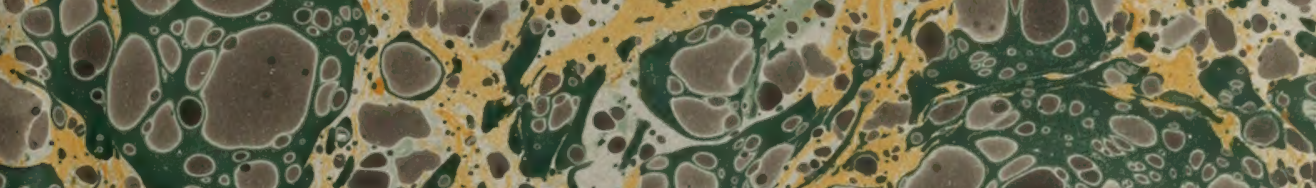

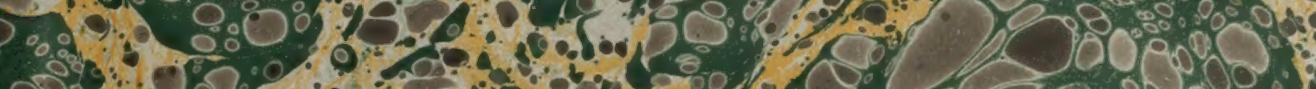

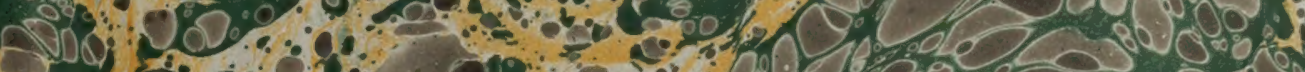

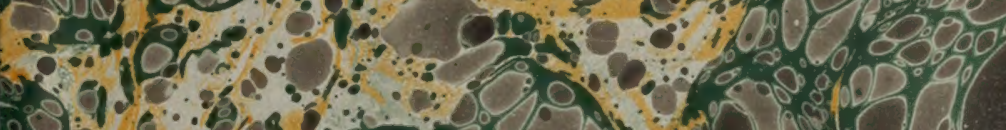

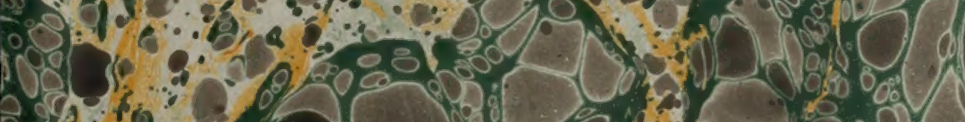

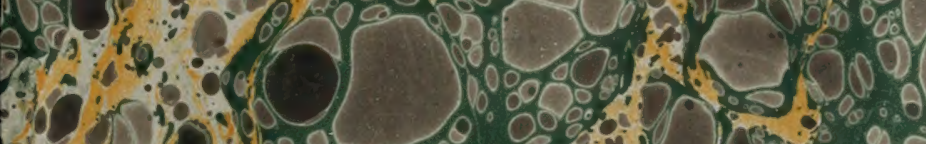

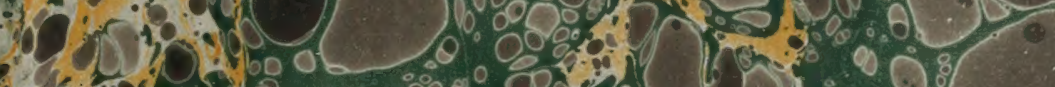
8.

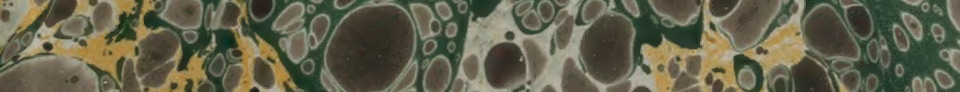

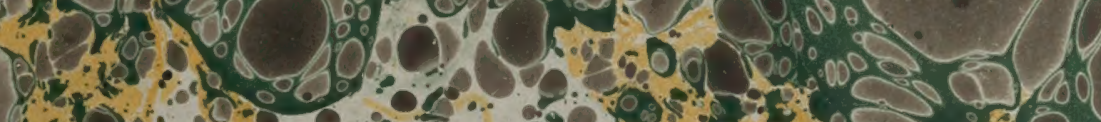

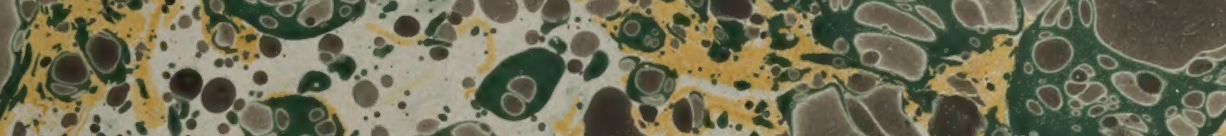

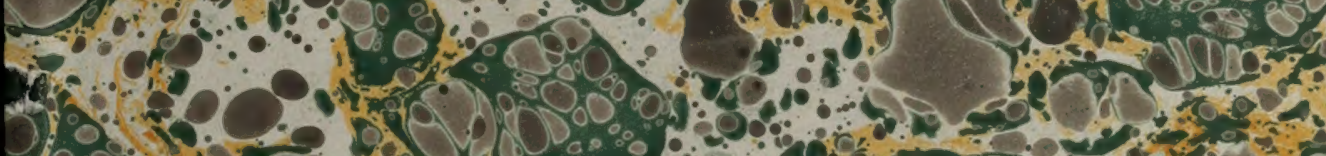
1000 .

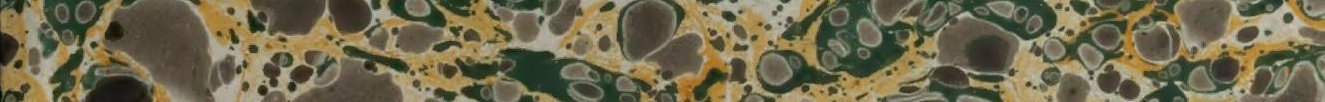
$\therefore$ I.

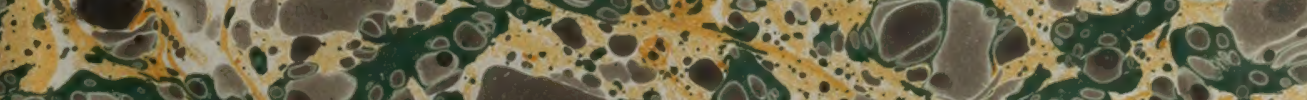

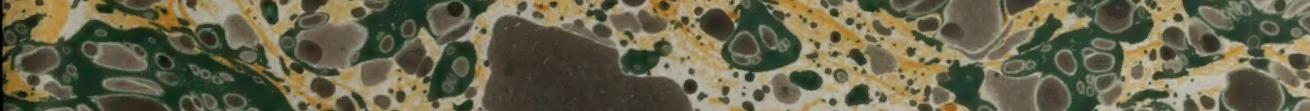

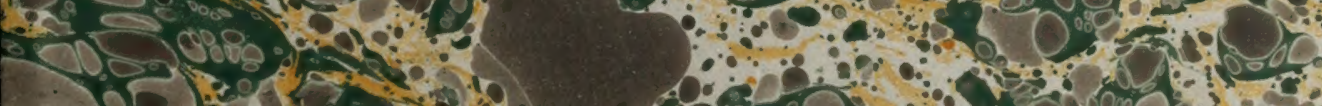

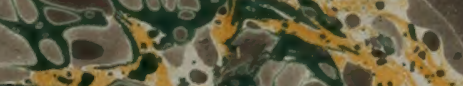

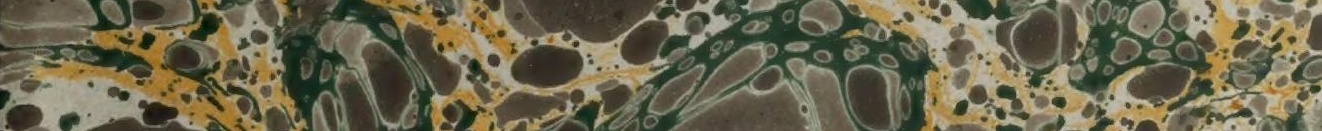

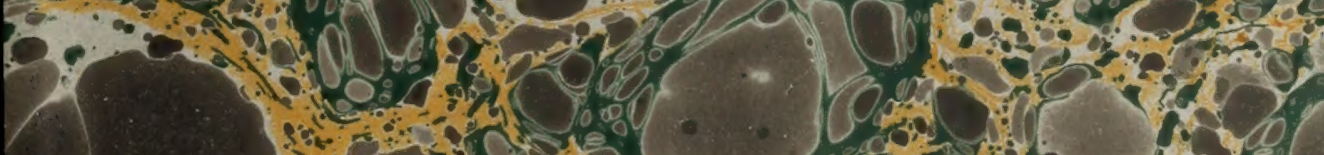
$\therefore$ a 1.

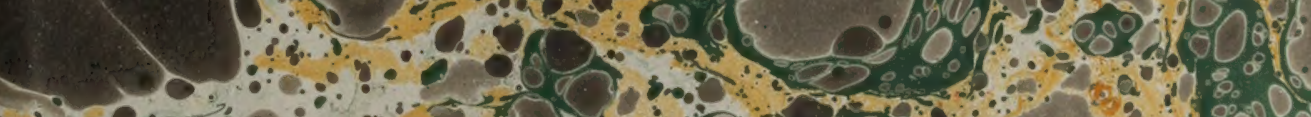

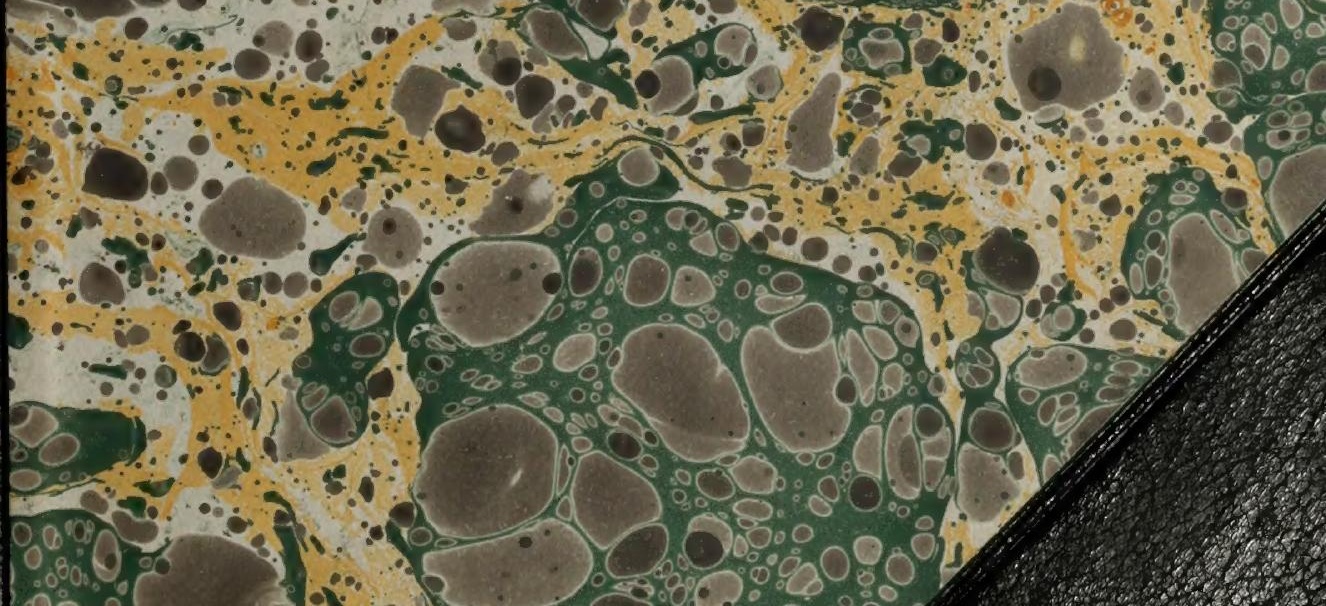


HAROLD B. LEE LIBRAAY BRIGHAM YOUNG UNIVERSITY

PROVO, UTAH 
DN 51285

$$
=70 .
$$




Digitized by the Internet Archive in 2011 with funding from Brigham Young University 




Rend hor In de lar Re. Rid Rd: Water.

1533. 



\section{FLORA OF OXFORDSHIRE,}

AND ITS

\section{CONTIGUOUS COUNTIES,}

(COMPRISING THE FLOWERING PLANTS ONLY:)

ARRANGED IN EASY AND FAMILIAR LANGUAGE,

ACCORDING TO THE

LINNAAN AND NATURAL SYSTEMS;

PRECEDED BY

\section{AN INTRODUCTION TO BOTANY,}

WITH ILLUSTRATIVE PLATES.

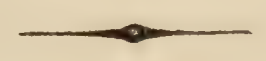

B BY

RICHARD WALKER, B.D. F.L.S.

FELLOW OF MAGDALEN COLLEGE, OXFORD.

"The love of Nature's works

Is an ingredient in the compound man, Infused at the creation of the kind.

And, though th' ALMIGHTY MAKER has throughout

Discriminated each from each, by strokes

And touches of His hand, with so much art

Diversified, that two were never found

T'wins at all points-yet this obtains in all,

That all discern a beauty in His works,

And all can taste them. Minds that have been form'd

And tutor'd, with a relish more exact,

But none without some relish, none unmoved."-Cowper's Task, B. IV.

\section{OXFORD :}

HENRY SLATTER, HIGH STREET.

LONGMAN, REES, ORME, BROWN, GREEN, AND LONGMAN; ANN WHITTAKR, TREACHER, AND ARNOT, LONDON. 
PRYNTEDRY J. MUNDAY, OXFORD.

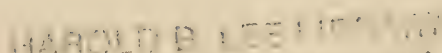

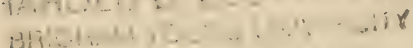
Prio, U., U. 
To

JOHN SHUTE DUNCAN, Esquire,

HONORARY L.L.D.

THE LATE CURATOR OF THE ASHMOLEAN MUSEUM,

AND TO

PHILIP BURY DUNCAN, Esquire,

THE PIESENT CURATOR OF THE ASHMOLEAN MUSEUM,

MEN

OF DIFFUSIVE BENEVOLENCE, AND CLASSIC TASTE,

TO WHOSE

LIBERALITY AND EXERTIONS,

NATURAL SCIENCE AND THE FINE ART'S,

IN THIS UNIVERSTTY,

ARE PRE-EMINENTLY INDEBTED,

THE FOLLOWING WORK,

INTFNDED TO FACILITATF A PIEASING,

AND,

AS CONNECTED WITH NATURAL THEOLOGY AND MEDICINE,

A HIGHLY IMPOR'TAN'T PURSUIT,

IS

WITH ALL RESPECT

DEDICATED BY THE COMPILER,

RICHARD WALKER. 



\section{PREFACE。}

$\mathbf{M}_{\mathrm{ANY} \text { new arrangements have taken place, and various }}$ discoveries have been made in Botany, since the publication of Sibthorp's Latin Flora. ${ }^{I}$ Under these obvious circumstances, the present work was undertaken, in which will be found additions to the Oxfordshire flowering plants, and an enumeration and brief description of the native plants, growing in the contiguous counties. Sibthorp's Work, Mr. Purton's valuable Midland Flora, Mr. Perry's List of Plants, Turner and Dillwyn's Botanist's Guide, with the liberal communications of Mr. Baxter, Curator of the Botanic Garden, and those of other friends, form the principal authorities for stations of the rarer plants described, and mentioned.

The design of the present work is to furnish the Botanical Student, in the plainest language, with sufficient elementary instruction, to ascertain the name of any wild, flowering plant, he may discover, within the assigned limits of the work, and to point out to him any economical uses, medicinal virtues, or peculiarity of structure as bearing upon Natural Theology, in the plant made out.

'Sibthorp's concise Flora Oxoniensis, creditable alike to the rescarch and science of the author, was published in 1794. 
Several Botanical Authors have been consulted: but in the amalgamation of materials, it was found almost impossible to refer every obligation to its respective claimant. The well-read Botanist will, however, easily perceive, that the descriptions and various observations are principally drawn from the classical works of Linnæus, Sir James Edward Smith, Willdenow, Curtis, Withering, Hooker, and Greville; with such additions, or alterations, as the compiler deemed suitable to the plan, and execution of a work, intended chiefly for the English reader. The plain, botanical language here adopted, is, for the most part, that of Berkenhout, Martyn, Withering, and Sir James Edward Smith.

Throughout the volume, the Linnæan system has been chiefly kept in view. All Botanists are, I believe, agreed, that this artificial arrangement is most convenient for discovering the name of a plant, and I think that, notwithstanding its imperfections, the Linnæan system cannot, in the present state of science, be advantageously discarded. For, it will, in most cases, conduct the student to the required name of the plant; which name being obtained, the Student may be referred to a description and enucleation of the Natural Order, or Group, in which the plant is arranged by Jussieu, or by some one of his followers. The Natural System of Botany thus studied, in connexion with the Linnæan, will enable those persons, who are desirous of examining the natural affinities of plants, to acquire such knowledge, in a comparatively easy method. We lay considerable stress on the point of facility, in the acquisition of this branch of knowledge in regard to the affinities of plants, because the leisure and inclination of 
most persons do not enable them, or dispose them, to apply much attention to microscopic Botany, and its minute dissections, as connected with the Natural System of Plants. To the busy Student the easiest mode, so far as is compatible with science, will be found the best. For example, the Medical Student, by uniting the Linnæan with the Jussieuan System, would readily detect the name of his plant; next, refer it to its Natural Group or Order, and afterwards learn, without difficulty, the qualities, attributed to such group, whether poisonous, or salutary, \&c. Some artificial key appears necessary for Natural Systems, even in their present state of developement, and such a key is afforded by means of the Linnæan System. To those, whom genius, or inclination prompts to devote time and attention to these minute and curious, and by no means, despicable investigations, in the scale of knowledge, we abandon the Natural System, by itself, without artificial aids. But, so long as the study of Botany is allowed to remain, as an elegant recreation for the leisure hours of nearly all classes of society, so long must the Linnæan, or some other system equally manageable, continue in use. And, on these grounds, we have given the Linnæean System the lead, referring for ample information on the Natural System of Plants, in the first instance to Richard's excellent book, ${ }^{1}$ and in the second, to Professor Lindley's learned and critical works.

In connection with the peculiarities of structure in the

1 "This work of Richard, (His Elements, \&c.) contains an excellent Introduction to, and a Table of the Natural Orders, and ought to be in the hands of every one who desires information upon the subject."-Honker. 
parts of the vegetable kingdom, we particularly recommend to the reflecting mind, the perusal of Paley's chapter on Plants, in his Natural Theology. Paley there shews, that the one great aim of nature in the structure of plants, seems to be the perfecting of the seed, and the preservation of that seed, until it is perfected. He shews, also, nature's care to disperse the seeds, when matured: their admirable contrivance and constitution are also explained, their structure, germination, \&c.

The varied, yet harmonious structure of plants must, indeed, ever excite the admiration of the philosophic mind; but our ignorance of the uses of their many minuter organs and contrivances, reminds us of the limited faculties of dependent human beings. The Almighty Maker of All has enabled man, by what he can trace and discover, through his own sagacity, to attain sufficient knowledge, even in the works of creation, to judge of infinite power and greatness; but, on the other hand, He has fixed certain boundaries to human knowledge, beyond which the mortal ken cannot pass, to keep man humble, and to make him irresistibly feel his own littleness ${ }^{\mathrm{I}}$.

Before I conclude these prefatory remarks, the introduction of a few observations on the utility of Botany, will not be deemed irrelevant.

Without insisting upon the advantages which arise in the pursuit-from its accustoming the student to the accurate use of words, through previous definition,-- 
from its contributing to order, and regular disposition in our ideas, thereby enlarging the capacity, and strengthening the memory:- without dwelling upon the advantage arising from its easy exemplification of the Analytic method, in the processes exercised for discovering the name of any unknown plant:-without long considering the tendency, that a comparison and balancing of nice distinctions in this science possess, to sharpen the discriminative powers of the mind:-without enlarging upon the importance of the science, in connection with Vegetable Chemistry, which furnishes an analysis of the secretions of plants :- without dwelling long upon its connection with Comparative Anatomy, where the analogies of the animal and vegetable systems are laid open:without enlarging on its connection-with Gardening, one of the purest of human pleasures;-with Medicine, in the various plants used in the Materia Medica, and as affording economical uses, subservient to the comfort and conveniences of social life:-without long adverting to the many pleasing associations in the study of Botany, connected with plants, alluded to by the poet : -without urging the utility of the science, as prompting to bodily exercise, and as rendering that exercise more healthful, by the grateful stimulus given to the mind, in pursuit of a favourite object, as an innocent recreation, affording an exhilarating change of ideas, after severer studies, and as tranquillizing the mind by a gentle exertion of the reasoning powers, on pleasing objects; -without viewing the science as an innocent succedaneum for boisterous pleasures, as a sort of antidote, in some cases, to heartless dissipation, which blunts 
all moral feeling:-without insisting upon all these topics in favour of the study of Botany, we believe, that if this branch of knowledge be pursued, in reference to, and in connection with Natural Theology, that Botany at once, like other branches of Natural History, then rises into high importance. The student who traces the wisdom of the Almighty in the works of creation, can never be said to be alone. He who rambles into the fields to scan and examine the works of creation with a cheerful curiosity, chastised by lowly piety, ever keeping in view the Great Creator and Mighty Contriver of All, cannot be ill-employed. "The profound researches," observes Sir James Edward Smith, " of grammarians, the taste and erudition of critics, the sublime efforts of poets, justly demand and receive the homage of the world. They are conversant with the whole scope of human conception, and of intellectual power. But the Naturalist traces, in all humility, the counsels of the Eternal Mind. The laws, the principles, which he studies, are of Divine origin. While he discriminates or combines his ideas, he catches glimpses of Infinite Wisdom, and there is no boundary to his attainments, but the imperfection of his own nature. The study of language embraces all that ever has been, or can be communicated from one human mind to another; but, the study of Nature, like that of Truth and Virtue, leads man to acquaint himself with Gov." "And, in a moral view," observes Paley, "I shall not, I believe, be contradicted, when I say, that if one train of thinking be more desirable than another, it is that which regards the phenomena of Nature with a constant reference to a Supreme, Intelligent Author. To have made this the ruling, 
habitual sentiment of our minds, is to have laid the foundation of every thing which is religious. The world thenceforth becomes a temple, and life itself one continued act of adoration "."

In conclusion, I beg to offer my sincere acknowledgments to those friends who have encouraged the publication of this work, and to express my obligations to Professor Daubeny, for a specimen of a Botanico-Geological

1 "It is difficult to conceive that any man of taste or curiosity should despise the examination of that part of the creation, which meets his eye continually under the most beauteous and graceful forms, which administers innumerable supplies to his various wants, and abounds with the most admirable proofs of the wisdom and goodness of the Supreme Berva. The physiological and the systematical part of Botany have each their advantages. The former is the best introduction to a knowledge of organised nature, exhibiting the first and plainest links of that vast chain which connects all living substances; the latter affords the most perfect specimen of classification, so that all that the Dialectic Art teaches respecting genus and species in general propositions, Botany demonstrates in a far more pleasant and intelligible way by actual examples. This study, besides the useful and agreeable exercise of the understanding, is adapted to infuse the purest tastes, prepares a fund of never-failing delight for every rural walk, and often forms a bond of union among cultivated and amiable minds: and if Religion ought to enter into the scheme of a wellconducted education;-if Natural Religion is the foundation of a just and enlightened faith in Divine Revelation;-then Botany may assume a still more dignified rank among the sciences; for certainly there is no branch of natural knowledge which affords proofs so clear, so accessible, so abundant and various, so striking and interesting and attractive, of the existence, attributes, and providence of the Great First Cause."-James Yates, F.L.S. 
xii PREFACE.

Index; and to Dr. Williams, Professor of Botany, in this University, for access to Herbaria, and for the liberal use of that noble Library ${ }^{\mathrm{I}}$ over which he so judiciously presides.

The Radcliffe.

Mingdalen Colleye, Oxford. 


\section{INTRODUCTION}

To

\section{BOTANY,}

INCLUDINA A SKETCH OF THE PHYSIOLOGY, STRUCTURE, FUNCTIONS, AND NATURAL ARRANGEMENT OF PLANTS.

\section{of the Fructification.}

W Iтhout dwelling upon the usual division of Plants into Trees, Shrubs, and Herbs, we will, at once, begin with the consideration of the Fructification of Plants. In the FRUCTIFICATION we include the flower and fruit. It consists of seven principal parts :-

1. Calyx, or Flower-cup. 2. Corolla, or Blossom. 3. Stamens. 4. Pistil. 5. Seed-vessel, or Pericarp. 6. Seeds. 7. Receptacle.

The first four are properly parts of the flower. The fifth, sixth, and seventh, are parts of the fruit.

I. The CALYX, or Flower-cup, is formed of one or more green or yellow leaves, at a small distance from, or close to the blossom.

The kinds of Calyx are seven

1. Perinath, or Flower-cup close to the other parts of the flower, example, the primrose. See Plate, 109. b. 110, $a$.

1. It is called the perianth of the flower, when it includes the stamens, and not the germen', and, 2. the perianth of the fruit, when the germen is included, but not the stamens. 3. It is the perianth of the fructification, if it includes both the germen and the stamens.

\footnotetext{
I See these terms explained further on
} 
2. Involucre, is the Calyx particularly of an Umbel, but applied to other kinds of inflorescence (see plate, 88.) placed at some distance from the flower: it is chiefly found in the umbelliferous, or parsley-like tribe. See Plate, 102.

1. The involucre is called universal, when placed under a universal umbel. See Plate, 89. a, the general involucre, with its umbels. $b$, the partial involucre with its partial umbels. 2. 'The involucre is termed partial, when placed under a partial umbel. See Plate, 89. $b$.

3. Catkin, or Amentum, consisting of a cylindrical common receptacle, beset with numerous scales, each scale accompanied by one or more stamens, or pistils, or both; example, the hazel. See Plate, 105.

4. The Sheath, or Spatha, opens lengthwise, and puts forth a kind of flower-stalk, called a spadix; example, the snowdrop, (galanthus,) the cuckoo-pint, (arum.) See Plate, 87.

5. Husk, or Glume, the chaffy calyx of grasses, with its dry leaves, called valves. See Plate, 116. Husks $b$. $b$. Awn (arista,) is the sharp point, or beard issuing from the husk or glume. See Plate, 96.

6. Perichetium, is the scaly sheath of mosses.

7. Volva, is the wrapper, surrounding the stem of funguses, or mushrooms.

The CaLYX of flowers, with respect to number, may be single, or one, double, or wanting.

II. With respect to composition, it may be-

1. Tiled, (imbricated,) that is, of various scales lying over each other: example, hawk-weed, (hieracium,) sow-thistle, (sonchus.) See Plate, 113, 114.

2. Wide-spreading, (squarrose, ) of scales widely spreading, every way; example, thistle, (carduus,) plume-thistle, (cnicus.)

3. Augmented, that is, with a series of distinct leaves, shorter than its own, surrounding the outer part of the base; example, the pink, (dianthus.) See Plate, 100.

4. Many-flowered, that is, common to many florets; example, scabious, (scabiósa,) and plants of the class syngenesia, daisy, dandelion, \&c.

III. The Calyx, with respect to situation, may be- 
1. Beneath the seed-vessel; example, the pea. See Plate, 140.

2. Above the seed-vessel; example, the rose. See Plate, 110.

IV. With respect to margin, the Calyx, may be-

1. entire. 2. saw-toothed, (serrate.) 3. fringed with hairs, (ciliated;) example (centauréa) knap-weed.

V. The Calyx at the top, may be-

1. acute or sharp. 2. prickly, (aculeated.) 3. blunt, (obtuse.) 4. lopped, (truncate, that is, with one of its indentations, appearing as if cut off.

VI. With respect to duration, the Calyx may be-

1. cadúcous, that is, falling off at the first opening of the flower; example, poppy. 2. deciduous, falling off with the corolla. 3. persistent, continuing until the fruit arrives at maturity; example, plants of the class, didynamia, snapdragon, mint, thyme, \&c.

\section{Corolla, or Blossom.}

The leaves, generally coloured, of which the Corolla consists, are called petals.

The Corolla is either-

1. Monope'talous, that is, one-petalled, the whole in one petal. The one-petalled (monopetalous) Corolla, consists usually of two parts: the tube, or lower part, and the limb, or upper part, this latter usually spreads wider, (see Plate, 117. $a$. the tube, $b$. the limb.)

The Monopetalous Corolla, in figure is either-

1. Bell-shaped, (campanulate, that is, bellying out, without any tube; example, bell-flower, (campánula,) deadlynight-shade, ('Atropa.) See Plate, 120.

2. Funnel-shaped (infundibuliform, that is, tubular in the lower, and conical in the upper part; for example, the tobacco plant, (nicotiána.) See Plate, 122.

3. Salver-shaped, (hypocrateriform, that is, with a flat border, standing on a tube; for example, the primrose, (prímula.) See Plate, 117.

4. Wheel-shaped, (rotate, that is, expanded, flat, without any tube, or with a very short one; for example, borage, 
(borago;) speedreell, (veronica.) See Plate, 156. Veronica Chamædrys.

5. Gaping, (ringent, ) an irregular corolla, usually divided into 1. an upper. 2. a lower lip: the first sometimes termed, the helmet, (gálea;) the second, the beard, (barba;) the opening of the tube is called the throat, (faux :) the prominent swelling in the throat, (faux,) is called the palate: the gaping or ringent corolla is exemplified in the class didynamia; for example, dead nettle, (lámium.) See Plate, 123.

6. Masqued, (personate,) a corolla closed between the lips by the palate; for example, snap-dragon, (antirrhinum.) See Plate, 124. The lips represented open.

2. Two-petalled (Dipetalous.) 3. Many-petalled (PolyPETALOUS, each petal of which is usually furnished with a narrow part, or clare, by which it is fixed, and with a border (lámina) the upper part; for example, the rose, (rosa.) See Plate, $125 . \quad a$. the calyx; $b$. the border or lámina.

The Polypetalous Corolla, is-

1. Cross-shaped, (cruciform), of four-equal petals, spreading out in form of an equal sided cross; for example, wall-flower, (cheiranthus,) and stock-gilly-flower, (cheiranthus.) See Plate, 126.

2. Butterfly-shaped, (papilionaceous,) usually four-petalled, the lower petal is shaped like a boat, and is called the keel, (carina,) the back or upper petal, which spreads and rises upwards, is called the standard or banner, (vexillum:) the two side ones stand singly, being separated by the keel, and are called the roings, (alæ:) when the keel is split, the corolla is properly five-petalled; for example, the pea. These flowers form a natural class, papilionaceæ, or leguminósæ, the peatribe. See Plate, 129. the standard. 130. one of the wings. 131. the keel.

3. Rosaceous cor. that is, spreading like a rose. See Plate, 127. A many-petalled corolla, with the exception of those forms just mentioned, is named according to the number of petals of which it consists; for example, of six petals, (hexapetalous,) \&c.

I. The Corolla in shape may be waved, (undulate; for example, the horse-chestnut, (æsculus.) 2. folded, (plicate;) 
for example, convolvulus. 3. rolled back, (revolute.) 4. twisted, (contorted,) the edge of one petal, lying over the next, in an oblique direction; for example, periwinkle, (vinca.)

II. With respect to margin, the Cor. may be-1. notched, (crenate.) 2. saw-toothed, (serrate.) 3. fringed, (ciliate;) for example, buck-bean, (menyanthes.) 4. toothed, (denticulate.)

III. In duration the Cor. may be-1. cadícous, falling off as soon as the flower is blown. 2. deciduous, falling off before the fruit is ripe. 3. persistent, lasting till the fruit is ripe. 4. withering, (marcescent, ) but not falling; for example, the orchis.

The honcy-cup, (or nectary,) is an appendage to the corolla of some plants, for the secretion of honey. It may be a spur, or horn, (see plate, 132.) as in the larkspur, snap-dragon, (antirrhinum,) and columbine, (aquilegia:) a hollow cavity in the substance of the petals, in the crown-imperial, and crorofoot, (ranúnculus:) in the narcissus it crowns the corolla, like a funnel: in the bee-ophrys, (ophrys apifera,) it is shaped like a bee : it is singularly beautiful in the grass of parnassus, (parnassia palustris.)

N.B. Petals and stamens in plants are ranged alternately: but the segments of the calyx and stamens answer to each other, in their arrangement.

III. STA MENS, are slender thread-like substances placed within the blossom, surrounding the pistil, (or pistils.) See Plate, 108, \&c. Each stamen is usually made up of 1. the filarnent, ${ }^{\prime}$ or thread, supporting the anther. See Plate, 133. $a$. the filament. $b$. the anther, and of the anther, or summit, fixed upon the filament, containing the pollen, or anther dust. The pollen is a curious and beautiful microscopic object.

IV. The PISTIL, is in the centre of the flower, and receives the pollen. This is called the female part of the flower. See Plate, 136.

The pistil is divided into the (see plate, 136. a.) germen, or lorvest part. 2. the style, (see plate, 136. b.) which stands 
upon the germen. 3. the stigma, or summit of the pistil. See Plate, 136, $c$.

Many flowers have the stigma situated immediately upon the germen : being without any style.

V. SEED-VESSEL, or PERICARP, (see plate, 137.) is the germen at maturity, and contains the seeds. Its kinds are-

1. The Capsule, a membranaceous, hollow, dry, seed-vessel opening in some determinate manner. See Plate, 137. Its parts are-1. the valves, or outer covering. See Plate, 173. 2. the seams, or sutures, the edges by which the valves are connected. See Plate, 173. 3. the cells, (loculaments, that is, hollow places in which the seeds are situated. 4. partitions, (dissepiments, ) which separate the cells from each other. See Plate, 173. 5. the column, (columella,) that is, an upright substance passing through the centre of some capsules, and connecting the several partitions and seeds. See Plate, 173.

2. The Nut, a seed covered by a hard, woody shell; for example, the hazel-nut. See Plate, 141.

3. The Stone-fruit, (drupe,) (see plate, 142.) is a pulpy seed-vessel, containing a nut or stone with a kernel; for example, plum, cherry.

4. The Berry, (see plate, 14.4.) is a pulpy fruit, containing naked and dispersed seeds; for example, gooseberry, strawberry, blackberry.

5. The Pome, or Apple-like fruit, (see plate, 143.) is a pulpy seed-vessel, containing a capsule. It includes all the moist fruits, with seeds lodged in a core; for example, apple, pear, quince, \&c.

6. The Silique, or Pod, (see plate, 138.) is an oblong, membranaceous, two-valved seed-vessel, having the seeds fixed along both sutures or seams; for example, the common stock gilliflower, (cheiranthus.)

7. The Silicle, or Pouch, (see plate, 139.) is a two-valved seed-vessel, generally broader than long, with seeds fixed along both seams or sutures; for example, honesty, (lunaria, shepherd's purse, (thlaspi bursa-pastoris, in shape it may be round, egg-shaped, or flattened; entire, or notched at the end.

8. The Pod, (or legume, is a seed-vessel of two valves, in 
which the seeds are fixed along one suture or seam only; it is usually membranaceous; for example, the pea. See Plate, 140.

9. The Cone, (strobile, is a catkin, composed of woody scales, usually opening, and has a seed at the base of each scale; for example, the fir. See Plate, 146.

VI. 'The SEED. See its parts described in the physiological part of this Introduction further on.

VII. The RECEPTACLE, (see plate, 154, flat recept. 155, conical recept. :) it is the base by which the other six parts of fructification are connected. It is called 1. proper, that is, a peculiar recept., when it appertains to one fructification only; and this has the name of-

1. A receptacle of the fructification, when it is common to both flower and fruit, that is, embraces the corolla and germen.

2. Receptacle of the flower, when it is the base, to which the parts of the flower only, exclusive of the germen, are fixed.

3. Receptacle of the fruit, that is, that of the fruit only, distant from the receptacle of the flower.

4. Receptacle of the seeds, the base to which the seeds are fixed; for example, pheasant's-eye, (adónis.

5. A common receptacle, that is, one connecting several florets, or distinct fructifications, so that if any one of them be removed, an irregularity is occasioned; for example, in the umbel, cyme, compound flowers. The receptacle may be naked, that is, entirely smooth, or chaffy, bristly, \&c.

\section{Of the different kinds of Flowers.}

I. Simple flowers have not any part of the fructification common to many florets : a simple flower is opposed to that, which is made up of several florets.

II. Aggregate flowers, may be thus explained: when several florets are so combined by the intervention of some part of the fructification, that taking away one of them destroys the uniformity of the whole.

Aggregate flowers are connected by the receptacle, or 
the calyx : the partial, or several small flowers of which they are composed, are called florets.

1. Aggregate flowers properly so called, have a common, undivided receptacle, the anthers all separate, and the florets usually on stalks; for example, Scabiósa, teasel, (dípsacus,) \&c.

2. Compound flowers, contain several florets, inclosed in a common calyx, and seated on a common receptacle, with the anthers connected in a cylindrical form.

Compound flowers are-1. Strap-shaped, (ligulate, that is, with flat florets, shaped like a fillet, expanded towards the outer side, with the base only tubular; for example, dandelion, (leóntodon.) See Plate, 196.* 2. Tubulose, with all the florets tubular, that is, having a bell-shaped border, with five segments, rising from a tube, (tubulose, ) is the same as flosculose; example, thistle, (carduus.) See Plate, 198.* 3. Radiate, when the florets of the middle part are tubulose, and those of the circumference of another form, that of a ray; for example, yarrow, (achilléa,) blue-bottle, (centauréa:) in artemisia, the florets are nearly naked.

3. Glumose flowers, have a thread-shaped receptacle, with a common husk, or glume, at the base; for example, grasses.

\section{of the Linncan Classification of Plants.}

In the system of Linnæus the stamens represent the male, the pistils, the female part of fructification. This artificial system consists of twenty-four classes, which are principally founded on the number, situation, and proportion of the stamens.

The classes are divided into orders, which are again divided into genera; and these last are divided into species, or individuals. ${ }^{1}$

I. The characters of the classes are taken from the number, length, connexion, or situation of the stamens.

II. The characters of the orders are, for the most part, taken from the number of the pistils.

III. The characters of the GENERA are taken from the parts of the flower.

${ }^{1}$ See these terms explained further on, p. xxiv. 
IV. the characters of the species are drawn chiefly from peculiarities in the stem, or leaves, the flower, and the roots. The leaves and flowers of plants vary from circumstances of soil and situation, and from other causes: hence arise varieTIES in plants.

\section{CLASSES.}

The first eleven classes are known by the number alone of stamens in each perfect flower.

\section{MONA'NDRIA.-One Stamen.}

II. DIA'NDRIA.-Two Stamens.

III. TRIA'NDRIA. - Three Stamens.

IV. TETRA'NDRIA.-Four Stamens of equal length.

V. PENTA'NDRIA.-Five Stamens.

VI. HEXA'NDRIA.-Six Stamens.

VII. HEPTA'NDRIA.-Seven Stamens.

VIII. OCT A'NDRIA.-Eight Stamens.

IX. ENNEA'NDRIA. - Nine Stamens.

X. DECA'NDRIA.-Ten Stamens.

XI. DODECA'NDRIA.-Twelve to Nineteen Stamens, fixed to the receptacle.

The two next classes depend upon the situation, or insertion of the stamens.

XII. ICOSA'NDRIA.-Stamens twenty or more, inserted into the calyx.

XIII. POLYA'NDRIA.-Stamens numerous, inserted into the receptacle. See Flora, for examples.

The XIV. and XV. Classes depend on the proportion of the stamens.

XIV. DIDYNA'MIA.-Stamens four, two long, and two short ; flowers gaping, (ringent,) or masqued, (personate.)

XV. TETRADYNA'MIA.-Stamens six; four long, and two short; flowers cross-shaped, (cruciform.) See Flora, for examples.

The XVIth, XVIIth, XVIIIth, XIXth, and XXth, Classes are distinguished by some union of the stamens to each other, or to the pistil.

1 For numerous examples of the Classes and Orders, see the Flora. 
XVI. MONADE'LPHIA.-Stamens combined by their filaments into a single tube. 17. DIADE'LPHIA, stamens combined by their filaments into two sets: the parcels of filaments are sometimes combined at their base: (see Plate, 129, 130, butterfy-shaped, (papilionaceous.) 18. POLYADE'LPHIA, stamens united into more than two sets, by their filaments. 19. SYNGENE'SIA, stamens united by their anthers into a tube, flowers compound. See Flora, for examples. 20. GYNA'NDRIA, stamens inserted into the germen or style. See Flora, for examples. (Linnæan example, plate, 165.)

The 21 st, 22nd, and 23rd Classes, are known by the stamens and pistils, being by themselves on separate flowers.

21. MONOE'CIA, stamens and pistils in different flowers, on the same plant. 22. DIOE'CIA; stamens and pistils in different flowers, on two separate plants. 23. POLYGA'MIA ; stamens and pistils separate in some flowers, united in others, either on the same plant, or on trwo or three different ones. See Flora, for examples.

24. CRYPTOGA'MIA, fructification concealed, comprising the orders, ferns, mosses, liverworts (hepáticæ,) lichens, flags, (algæ,) funguses.

\section{ORDERS.}

I. Those of the first thirteen classes, to Polyandria inclusive, are characterised by the number of the styles or stalkless stigmas: the titles end in gy'nia, as those of the classes in ándria.

1. Monogynia, one style, or stalkless stigma. 2. Digynia, two styles, \&c. 3. Trigýnia, three styles, \&c. 4. Tetragýnia, four styles, \&c. 5. Pentagýnia, five styles, \&c. 6. Hexagy'nia, six styles, \&c. 7. Heptagy'nia, seven styles, \&c. 8. Octagy'nia, eight styles, \&c. 9. Enneagýnia, nine styles, \&c. 10. Decagýnia, ten styles, \&c. 11. Dodecagynia, about twelve pistils, or, \&c. 12. Polygynia, many pistils, or, \&c. See Plate, 166.

II. The orders of the fourteenth class are two, from the nature of the seeds. 1. Gymnospérmia, seeds apparently naked, usually four, never more. See Plate, 106. 2. Angios- 
pérmia, seeds in a capsule, mostly numerous: snapdragon, (Antirrhinum.)

III. The orders of the fifteenth class are distinguished by the shape of their seed-vessel. 1. Siliculósa, fruit, a pouch or silicle. See Plate, 139. 2. Siliquósa, fruit, a silique, or lengthened pod. See Plate, 138.

In the classes Monadélphia, Diadélphia, Polyadélphia, and Gynándria, the orders are characterised by the number of the stamens; for example, Pentandria, \&c.

IV. In the nineteenth class, Syngenésia, the orders are marked by the perfect, separated, barren, fertile, or abortive nature of the florets. 1st order-Polygámia cquális ; florets all perfect, and alike, each producing one seed. See Flora, for examples. 2nd. Polygámia superflua, florets of the disk, or centre, perfect; those of the margin or ray, furnished with pistils only, but both kinds of florets producing perfect seed. 3rd. Polygámia frustránea, florets of the disk, or centre, perfect, that is, with stamens and pistils; those of the margin, with an abortive pistil only, or none at all. See Flora, for examples. 4th. Polygámia necessária, florets of the disk, or centre, with stamens only; those of the margin, with pistils only. See Flora, for examples. 5th. Polygámia segregáta, several flowers either simple, or compound, but with united anthers, and a proper or peculiar calyx, all included in one general or common calyx. No English plant, for an example.

V. The orders of the twentieth class, Gynándria, are distinguished by the number of their stamens; for example, Gynándria Monándria, \&c. Those of the twenty-first and twenty-second are marked by the stamens also; including in their orders the classes Monadélphia, and Polyadélphia. See Flora, for examples, here and elsewhere.

VI. In the twenty-third class, Polygámia, are three orders, Mono'cia, Dioe'cia, Trioe'cia, of which last, there is no British plant known.

(The orders of the 24th class, Cryptoga'mia, have been already noticed.)

In the order 1. Moncécia, the two or three different descriptions of flowers are all on the same plant. 2. In the 
order Dioécia, the different descriptions of flowers are, on two separate plants.

We have given a brief explanation of the Linnæan Classes and Orders. We may next observe, that generic distinctions are founded on the fructification, that is to say, the flower and fruit. Hence plants agreeing in their parts of fructification, are placed under one genus or kind; and all such plants as differ in their parts of fructification are to be placed under different genera, or kinds. The characteristic mark of each gcnus is to be determined from the number, figure, proportion, and situation of all the parts of fructification. We also endeavour to fix upon some one single mark, that is constant in the flower, and we make it the essential generic character; for example, the pore in the claw of the petal in the genus (ranunculus, crore-foot; the singular construction of the petalform stigma, in the genus, iris.

Specific differences in plants arise from any circumstance, in which plants of the same genus are found to disagree; provided such circumstance be constant. Where plants agree in certain peculiarities of flower and fruit, they are placed under the same genus or kind, and have one common name, applicable to all the species or sorts, contained under a genus or kind; for example, the term rosa, or rose, is given to all the different sorts, or species of roses; for example, the dog-rose, (Rosa canína,) the briar-rose, (Rosa rubiginosa,) and so on; the term rose is applied to all species, or sorts of rose. The species, or different sorts of plants are distinguished by various marks, for example, by differences in the root, trunk, leaves, supports, (fulcra,) thorns, prickles, bracteas, stipulas, modes of flowering, (inflorescence.) The parts of the flower and fruit, also furnish marks to distinguish one species from another.

The parts just mentioned upon which the specific differences depend shall next be described in order.

\section{Parts on which Specific Differences chiefly depend: viz.-}

The Root, \&c. The root may be spindle-shaped, (fusiform, 
that is, long, thick, and tapering ; for example, the carrot, and radish. See Plate, 3. 2. branching, (ramose,) that is, divided into side branches, as in trees. 3. bulbous, that is, fleshy with fibres at the bottom: the bulb is 1. scaly; (see Plate, 8.) for example, lily. 2. solid; (see Plate, 6.) for example, crocus, turnip. 3. coated, (see Plate, 7.) (tunicated;) for example, the onion. 4. tuberous roots, that is, knobbed, (see Plate 4.) consisting of roundish, fleshy bodies, connected into a bunch by intervening threads or fibres; for example, potato, peony, dropwort, (spiræa filipendula.) 5. fibrous, (see Plate, 1.) that is, consisting wholly of slender threads or filaments; for example, most of the grasses 6. granulated, or beaded root, (see Plate, 9.) consisting of several little fleshy knobs, or beads, resembling grains of corn, intermixed with the fibres; for example, white saxifrage, (saxífraga granuláta.) 7. creeping, (repent,) (see Plate, 2.) where the root extends horizontally, and puts forth fibres at intervals; for example, mint. See Plate, 2. 8. bitten off, (premorse, root, that is, not tapering, but ending blunt, as though it had been bitten off; for example, devil's bit scabious, (scabiósa succísa.) See Plate, 5.

The herb or plant comprehends the I. Trunk. II. Leaves. III. SupPorts or PRops (fulcra.)

I. The TRUnk, or main body of the vegetable produces the leaves and fructification; it is of several kinds: viz. I. The stem, which bears and elevates from the root both the leaves and flowers : this in its growth may be-

1. Upright (erect, ) that is, when it approaches to a perpendicular with the ground, for example, yellow centaury, (chlora perfoliáta.) 2. Straight, (strictus,) that is, entirely perpendicular without any bending; for example, garden lilies. 3. Trailing, prostrate, or procumbent stem, that is, lying down, unable to support itself, resting on the ground, but without sending forth roots from itself. 4. Creeping, (repent,) that is, resting on the ground, and throwing out roots at intervals, (Plate, 11.) for example; Ivy-leaved crowfoot (ranúnculus hederáceus.) 5. Rooting or clinging stem, (radícant,) that is, clinging to any object for support, by means of fibres, which do not, perhaps, imbibe nourishment; for example, the ivy, (hédera.) (See Plate, 12.) 6. Climbing, (scandent,) that is, 
weak, and requiring support in mounting; the clasper or tendril is the usual agent; for example, the pea, and many other legúminous (pea-like) plants. 7. the turning or twining stem ascends spirally round other plants. See Plate, 13. 8. loosely spreading, (diffuse and lax;) for example, biting stone-crop, ) sedum acre. 9. zigzag, (flexuous, that is, changing its direction in a curve, from left to right, and the contrary. 10. repeatedly forked, (dichótomous, ) continually and regularly dividing by pairs, or, in other words, repeatedly forked; for example, lamb's lettuce, (fédia locusta,) mistletoe, (viscum album. See Plate, 10. 11. proliferous, that is, putting forth new branches from the summits of the former ones; for example, fir-tree, (pinus.) 12. jointed, (see Plate, 14.)

A STEM, in shape, may be-

1. round. 2. angular. 3. winged, that is, with angles extended into flat, leafy-like borders; for example, everlasting pea, (láthyrus latifólius, \&c.) See Plate, 167.

2. The Straw (or Culm, is the stem of grasses, rushes, and such kind of plants.

3. The SCAPE, is a stalk rising from the root, supporting the flowers only, and not the leaves; for example, narcissus, primrose, hyacinth. See Plate, 19.

4. Flower-stalk or peduncle, a partial or smaller stem, supporting the flowers only, and not the leaves. The flowerstalk, (peduncle,) is 1 . axillary, when proceeding from the bosom of the leaf; for example, between the leaf and the stem. See Plate, 156. 2. opposite to a leaf. 3. terminal, when it is at the end of a stem or branch; for example, tulip. 4. clustered, (aggregate, when several flower-stalks grow together. 5. scattered, or dispersed irregularly, \&c.

5. The Leaf-stalk, (or petiole, is a partial or smaller stem supporting the leaf, but not the flowers.

6. In the frond, the branch and leaves are united together, for example, ferns.

7. A stipe is the stem of a frond.

II. The LEaves of plants are considered as 1. Simple. 2. Compound. 3. Determinate. Simple leaves have one leaf only on a leaf-stalk. In shape they may be-1. round (orbiculate.) 2. roundish (subrotund,) that is, nearly circular. 
3. egg-shaped (ovate, the shape of an egg cut through lengthways, that is, when the length is somewhat greater than the breadth, and the base rounded and wider than the other end See Plate, 36. 4. egg-shaped inversely (ob-ovate) of the same shape as the last, but with the broader end uppermost; for example, primrose, daisy. 5. oval or eiliptic, of like figure to egg-shaped, and somewhat egg-shaped, except its being of equal breadth at each end. See Plate, 37. 6. oblong, that is, much longer, than broad, and narrowed and rounded at the ends. 7. spear-shaped, (lancéolate, here the figure is oblong, narrowing gradually towards each end. See Plate, 40. 8. battledore-shaped, (spatulate, roundish, with a long, narrow, linear base. See Plate, 38. 9. reedge-shaped, (cuneiform, broad and abrupt at the end, and narrowing gradually downwards; for example, wild celery, (apium gravéolens,) rue-leaved saxifrage, (saxifraga tridactylites.) See Plate, 39. 10. linear (strap-shaped,) that is, nearly the same breadth throughout, long and narrow; for example, daffodil, rosemary, and most of the grasses. SeePlate, 41. 11. arol-shaped, (súbulate, that is, linear at the bottom, and gradually tapering towards the end. See Plate, 72. 12. needle-shaped, (acerose,) linear and evergreen, mostly sharp and stiff; for example, juniper, yew, fir. 13. kidney-shaped, (réniform, that is, roundish, and hollowed at the base without angles, resembling the section of a kidney; for example, ground-ivy, (glechóma.) See Plate, 43. 14. heart-shaped, (cordate,) that is, oval, or somewhat egg-shaped, hollowed at the base, the lower part without angles or sharp corners; for example, black-briony, (tamus commúnis.) See Plate, 44. 15. crescent-shaped, (lúnulate,) that is, round-shaped, and hollowed at the base, with angles at the hinder or lower part. 16. triangular-shaped, that is, with three sides nearly equal, and three angles or corners. See Plate, 42, 17. trowelshaped, (deltoid,) triangularly spear-shaped, that is, having three angles, of which the end one is much further from the base, than the side ones, as in mercury, goose-foot, (chenopódium Bonus-Henrícus.) 18. arrore-shaped, (sagittate, like the

\footnotetext{
1 In such compound terms, as egg-shaped-heart-shaped, the latter term designates an approach to the latter shape.
} 
head of an arrow, that is, triangular, hollowed at the base, with angles at the hinder part; for example, common arrore-head, (sagittaria sagittifolia. See Plate, 45. 19. halbert-shaped, (hastate,) like the head of a halbert, that is, triangular, hollowed at the base, and on the sides, with the angles spreading; for example, sheep's sorrel, (rumex acetosella.) See Plate, 46. 20. diamond-shaped, (rhomboid,) that is, approaching to a square-diamond: for example, black poplar, (pópulus nigra,) stinking goose-foot, (chenopódium ólidum.) 21. lobed, that is, divided to the middle into parts distant from each other, rounded at the margins ; which last circunstance distinguishes the lobed, from the cleft or cloven, (fissum, see Plate, 51.) leaves may be two-lobed, three-lobed, \&c. See Plate, 52. 22. fiddle, or violin-shaped (pandúriform, that is, oblong, broader at the two extremities, and contracted in the middle; for example, fiddle-dock, (rumex pulcher.) 23. lyrate, or lyreshaped, that is, divided into several segments or jags, the lower ones smaller and more distant, than the upper ones, which are of course larger; for example, yellow-rocket,(barbaréa vulgáris.) See Plate, 48. 24. ríncinate, (from rúncina, a large sawg) that is, cut into several cross, sharp jags, pointing backwards; for example, dandelion, (leóntodon taráxacum.) See Plate, 49. 25. hand-shaped, (palmate, that is, divided beyond the middle into several lobes, that are nearly equal; for example, common passion flower, and red berried bryony, (bryónia dioíca. See Plate, 53. 26. wing-cleft, (pinnatifid,) that is, deeply divided by oblong, transverse, horizontal jags, not extending to the mid-rib. See Plate, 47. 27. doubly, or troice roing-cleft, (bipinnatifid, that is, when the common leafstalk has wing-cleft leaves on each side of it; for example, long, rough-headed poppy, (papáver Argémone.) 28. comb-like, (péctinate, a sort of wing-cleft leaf, in which the leaflets are parallel and very narrow, that is, toothed like a comb ; for example, common water milfoil, (myriophyllum spicatum.) See Plate, 50. 29. jagged, (laciniate, variously divided into lobes, and these again divided in an irregular manner; for example, long-stalked crune's bill, (geránium columbínum.) See Plate, 63. 30. partite, that is, simple, but divided almost down to the base: according to the number of divisions, the leaf may be-twice, 
(bi-) partite, thrice, (tri-) partite, \&c. 31. sinuate, (hollowed out, ) that is, having large, curved breaks, in the margin, resembling (sinus, that is, bays; for example, oak. 32. unequal, when the halves are unequal in dimension, and their bases not parallel. 33. lopped, (truncate, when the leaf appears, as if its tip had been cut off; for example, tulip tree, (liriodendron tulipífera.) See plate, 54. 34. jugged, (præmorse, that is, pointed, very blunt, with various irregular notches. See Plate, 63 . 35. retuse, that is, ending in a blunt, shallow notch. See Plate, 55. 36. notched, (emarginate,) that is, with a notch at the end. See Plate, 56. 37. blunt, (obtuse.) 38. acute, sharp, that is, ending in an acute angle. See Plate, 57. 39. pointed, (acuminate, that is, ending in an awl-shaped point; for example, common reed, (arundo Phragmites. See Plate, 58. 40. dagger-pointed, (múcronate,) sharp at the point, and tipped with a stiff thorn. See Plate, 59. 41. entire, that is, free from all kinds of teeth, notches, or incisions. See Plate, 36, 43. 42. saw-toothed, (serrated,) toothed like a saw, that is, having sharp notches about the edge, and these pointing towards the extremity of the leaf. (see Plate, 61.) leaves are sometimes doubly saw-tonthed, that is, have the teeth again cut into other smaller teeth. 43. notched, (crenate, ) that is, with rounded teeth, and those not directed towards either end of the leaf. See Plate, 62. 44. toothed, (dentate, ) that is, having horizontal, and somewhat distant points, or teeth, of the same substance as the leaf; for example, corn blue bottle, (centauréa cy'anus. See Plate, 60. 45. wavy, (repand,) that is, having a border with numerous very small angles, and small segments of circles alternately; for example, fringed buck-bean, (menyanthes nymphæoides.) See Plate, 55. 46. veiny, (venose,) with branched fibres on the surface. 4.7. curled, (crisp,) when the border of the leaf is more expanded than the middle part, so as to appear curled and twisted; for example, in the common garden parsley. 48. wrinkled, or rugged, (rugóse, when the veins are tighter, than the surface between them, causing the veins to swell into inequalities; for example, common sage. 49. plaited, (plicate,) that is, folded like a fan; distinguished from waved, by the folds of the plaited being angular; for example, common mallow. See 
Plate, 69. 50. waved, (undulate, when the surface rises and falls in waves, or bluntly; not in angles: for example, curled pondweed, (potamogéton crispus,) wild mignonette, (reseda lútea.) 51. ribbed, (costate, nervose, when the veins extend in simple lines from the base to the point of the leaf; for example, Solomon's seal, (convallaria multiflóra. See Plate, 68. 52. sword-shaped, (ensiform, that is, two-edged, tapering from the base to the point; for example, irises. 53. semicylindric, that is, flat on one side, and rounded on the other: seni-columnar, means the same; for example, broad-leaved garlick, (allium ursínum.) 54. tubular, that is, hollow. 55. Aleshy, (succulent,) that is, of a thick, pulpy substance; for example, house-leek, (sedum.) 56. channelled, (caniliculate,) that is, having a deep furrow, from the base to the end of the leaf. See Plate, 70. 57. keeled, (carinate, when the back is prominent lengthways; for example, two-flowered narcissus, (narcissus biflórus.) See Plate, 71. 58. furrowed, (sulcate,) that is, with deep lines running lengthways. 59. slightly furrowed, (striated,) or streaked. 60. cylindric, round one way, and long the other: columnar a better term. 61. tongueshaped, (linguiform,) that is, linear, fleshy, blunt at the end, convex underneath, with usually a skinny border.

2. Compound Leaves, that is, such as have several leaves to one leaf-stalk: the component leaves are called leaflets; under compound leaves we have those of 1. two-leaflets, (binate, ) that is, a simple leaf-stalk, connecting two leaflets at the top of it. See Plate, 74. 2. of three leaflets, (ternate;) that is, having three leaflets on one leaf-stalk, for example, trefoil, strareberry, bramble. See Plate, 75. 3. of five leaflets, (quinate, ) on one stalk; for example, potentilla reptans. 4. fingered, (digitate, ) when a simple or undivided leaf-stalk connects several distinct leaflets at the end of it. Linnæus makes the binate, ternate, and quinate leaves species of the fingered, (digitate;) the horse-chestnut, is an example of a fingered leaf. See Plate, 73. 5. rwinged, (pinnate,) that is, where a simple leaf-stalk, has several leaflets fastened to each side of it. Winged (pinnate) leaves are of several kinds. 1. with one pair of leaflets, it is called cónjugate. 2. with troo pair, (bijugate, \&c.) 3. unequally roinged, that 
is, terminated with an odd one, or single leaflet; for example, elder, rose, \&c. See Plate, 77, 80, 84. 4. abruptly winged, that is, not terminated by a leaflet or tendril. See Plate, 79. 5. oppositely winged, that is, having the leaflets placed over against each other in pairs. See Plate, 79. 6. alternately winged, that is, having the leaflets alternate, along the common leaf-stalk. See Plate, 80. 7. interruptedly winged, that is, having smaller leaflets interposed between the principal ones; for example, silver-weed, (potentilla anserína, ) dropwort, (spiræa filipéndula.) 8. winged, running down the stem, (decursively winged,) that is, when the leaflets run into one another along the common leaf-stalk. 9. trice-roinged, or doubly roinged, (bipinnate, that is, when the common leafstalk has winged leaves on each side of it. See Plate, 83. 10. doubly ternate, or doubly three-leaved, (biternate,) that is, when a leaf-stalk has three ternate leaves, that is, three leaflets of three, or nine leaflets; for example, gout-weed, (ægopódium podagrária,) any one of the clusters of all the nine leaflets in Plate, 170. 11. a triply-three-fold-leaf, or thriceternate, that is, when a leaf-stalk has three, doubly ternate leaves, or three times nine leaflets, or twenty-seven leaflets, in three groups of nine leaflets in each; for example, yellow fumitory, (fumária lútea.) Plate, 170. 12. bird-footed, (pedate, leaf, that is, a leaf divided into three, with its side leaflets, compounded in their fore part; for example, common passion-flower, stinking hellebore, (helléborus fœe'tidus.) See Plate, 76.

3. Determinate Leaves. - By the determination of leaves is meant their character, derived from situation, insertion, or direction.

In respect to determination leaves may be-

1. seed ones, (seminal,) that is, the first which appear ; example, in the radish. 2. stem-leaves, (cauline.) See Plate, 23, 24. 3. target-shaped, (peltate, when the leaf-stalk is inserted into the disk or middle of the leaf, or nearly so; for example, nasturtium, navel-rort, (cotylédon umbilícus.) See Plate, 35. 4. erect, when the angle, they form with the stem is very small; for example, smooth tower-mustard, (turrítis glabra.) 5. spreading, i. e. in a direction between upright, 
and horizontal. 6. horizontal, that is, at right angles with the stem. 7. root-leaves, (rádical,) sưch as proceed immediately from the root; for example, corslip. See Plate, 19. 8. depressed, that is, where the root-leaves are pressed close to the ground; for example, hoary plantain, (plantágo média.) 9. floating, (natant.) 10. under water, (demersed.) 11. growing partly above the water, (emersed;) for example, common arrore-head, (sagittária sagittifólia. 12. stalkless, (sessile,) that is, without a leaf-stalk. See Plate, 23, \&c. 13. running down the stem, (decurrent,) when the base of a stalkless leaf extends itself downwards along the stem; for example, in several species of thistles. See Plate, 34. 14. stalkembracing, (ampléxicaul,) that is, clasping the stem by its base, (see Plate, 30 :) when leaves go only half round, they are called half-embracing, (semi-ampléxicaul. 15. perfoliate, as if the stem had been driven through the middle of the leaf; having the base of the leaf entirely surrounding the stem ; for example, thorongh-rax, (bupleurum rotundifólium.) See Plate, 32. 16. growing together, (connate,) when two opposite leaves are so united at their bases, as to resemble one leaf; for example, garden honey-suckle, lonicéra Caprifólium. See Plate, 31. 17. sheathing, (vagínant,) when a leaf invests the stem or branch by its base, in the form of a tube; for example, polygonum, dock, most of the grasses. See Plate, 16. 18. equitant, folding over each other, when the sides of a leaf tend to converge towards one point in nearly parallel lines, so that the inner leaves are inclosed by the outer ones; for example, Iris, Acorus, Carex, Lancashire asphodel, (narthécium ossífragum.) See Plate, 33. 19. starry, (stellate,) or whorled, (verticillate,) when the stalk is surrounded by leaves, radiating from the stem, like the spokes of a wheel; for example, goosegrass, (gálium aparíne,) (see Plate, 26 ;) these leaves, more than two, seldom fewer than four, may also be three, (tern, four, (quatern,) five, (quine,) six, (sene,) \&c. 20. opposite, growing in pairs, opposite to each other. See Plate, 21, 23. 21. alternate, when the leaves themselves not being opposite, grow out regularly one above another, on the opposite sides of the stem. See Plate, 22. 22. chaffy, (acerose, that is, needleshaped, linear, and permanent; for example, fir, yero. 23. 
tiled, (imbricated,) lying over each other, like tiles on a roof; for example, common heath, (callúna vulgáris.) See Plate, 28. 24. bundled, or tufted, (fasciculated, growing in bunches from nearly the same point; for example, the larch. See Plate, 27. 25. cross-paired, (decussate, growing in pairs, which alternately cross each other at right angles. See Plate, 29. 26. two-ranked, (distiched,) spreading in two directions, and yet not regularly opposite at the inscrtion; for example, yere, (taxus.)

Supports, Props, (fulcra:) those parts which serve to give strength and support to plants. Linnæus reckons seven kinds of these. 1. stípula, a scale or small leaf, on each, or on one side at the base of the leaf-stalk, or flower-stalk. See Plate, 84. 2. bráctea, or floral-leaf, a leaf differing from the other leaves in shape and colour; generally situated on the flowerstalk, and often so near the corolla, as to be mistaken for the calyx, at first sight. The bractea is generally more permanent than the calyx: the last withers, when the fruit is ripe; example of bracteas in lime-tree, (tilia,) sage, (sálvia.) See Plate, $85, a .86, a$. 3. thorn, (spine, a sharp process growing from the woody part of a plant. See Plate, 91. 4. prickle, (acúleus, a sharp process or projection, fixed into the bark only; for example, rose, \&c. See Plate, 92. 5. clasper, (tendril,) a thread-shaped, spiral band by which a plant is fastened to some other body, or supports itself on other plants; for example, vine, pea, \&c. See Plate, 78, 90. 6. gland, a small tumour, serving for the excretion, or discharge of some kind of fluid : it is usually found on the leaves, leaf-stalks, flowerstalks, or stipulas; example of glands, moss-rose. 7. hair or down.

INFLORESCENCE; the various modes in which flowers are fastened to the plant, by means of the flower-stalk. Under inflorescence we may class the-1. rohorl, (verticillus, where the almost stalkless flowers surround the stem in a kind of ring: the flowers, in some cases, are not inserted on all sides of the stem. See Plate, 93. 2. bunch, cluster, or raceme, consists of one common flower-stalk, with many somewhat distant flowers, each on its own proper stalk, from the side of the common flower-stalk. See Plate, 98. 3. spite, where 
stalkless or nearly stalkless flowers are scattered along a common, simple flower-stalk; for example, lavender, plantain. See Plate, 94, 95. Spikelet in grasses, a smaller spike, or sub-division of the spike. See Plate, 96. 4. corymb, where the partial flower-stalks are gradually longer as they stand lower on the common stalk, all forming nearly an even surface at top; for example, cuckoo-flower, (cardamine pratensis.) See Plate, 99. 5. bundle, (fascículus,) where several upright, parallel approaching flowers, variously inserted and forming a top of the same height, are collected in a close bundle; for example, sweet-william, (dianthus barbátus.) See Plate, 100. 6. head, or tuft, bears the flowers stalkless, (sessile, in a kind of ball; for example, thrift, (statice arméria,) clover. See Plate, 101. 7. umbel, has several flower-stalks, or rays, nearly equal in length, spreading from one common centre, the summit forming a level, convex, globular, or concave surface; for example, parsley, \&c. See Plate, 89, 102. 8. cyme, in appearance resembles an umbel, but differs from it, in having the stalks variously and alternately sub-divided; for example, elder, guelder-rose. See Plate, 103. 9. panicle, where the flowers or fruits are scattered on stalks variously divided, in a sort of loose cluster; for example, London-pride, (saxífraga umbrósa,) common oats. See Plate, 104. 10. thyrsus, (close-bunch,) that is, a panicle contracted into an eggshaped form, more or less; for example, butter-bur, (tussilago Petasites.) Plate, 172. 
PHYSIOLOGY, STRUCTURE, FUNCTIONS, AND

\author{
NATURAL ARRANGEMENT
}

OF

\title{
PLANTS,
}

(EXTRACTED AND CONDENSED, CHIEFLY FROM RICHARD'S NOUVEAUX E'LE'MENS, 8Vo. TRANSLATED BY CLINTON.)

IT is difficult to draw precisely the line of demarcation between the vegetable and animal. We may, however, find well-marked differences between animals and vegetables. In the animal, is a system of contractile fibres, whose state of relaxation or of tension determines the motion of the animal; these are the muscular fibres, wanting in the vegetable. In vegetables, there is properly speaking no circulation; the nutritious fluids are diffused through the vegetable, but they want that agent of impulse, the heart, which, in animals, is the point from which the blood takes its departure, and to which it finally returns.

It may be observed, that vegetables are composed of simple and similar elementary parts, which, combined in various ways, constitute organs.

\section{The Elementary Parts of Vegetables.}

The internal organization of a vegetable is composed of cells with thin, transparent partitions, (or walls,) extremely minute, and of various forms, sometimes regular, sometimes irregular, and of cylindrical tubes, either scattered, or united in bundles. These two forms of the elementary parts of vegetables, have received the names of 1. cellular tissue, and of 2. vascular tissue. See Plate, 11. fig. 163, cellular tissue.

d 2 
A vegretable in its perfection consists of a root, stem, leaves, flowers, pistil, stamens, corolla, calyx, fruit; which last is composed of the pericarp, and of the seed.

The pericarp, or seed-vessel, is the full grown germen, in which were contained the ovules, (rudimental seeds,) now become perfect seeds. It is composed of three parts; of 1 . the epicarp, or outer membrane. 2. of the endocarp, or membrane, which lines its inner cavity, and 3rdly. of the sarcocarp, a parenchymatous substance, situated and contained between the two former mentioned membranes. See Plate 12, and explanation.

The seeds contained in a pericarp, are attached to it by the trophosperm, or placenta: this is formed of vessels, which convey nourishment to the seeds.

The hilum, or umbilicus, (eye, or navel, ) is the point on the surface of the seed to which the trophosperm is attached. See Plate, 178. $a$.

The arillus, or coat, of the seed, is a peculiar prolongation of the trophosperm, which instead of stopping at the circumference of the hilum, is more or less continued over the seed, so as even to cover it completely.

The seed essentially consists of two distinct parts, 1. episperm, that is, its proper membrane or covering; and 2. its kernel, or the body contained in the episperm.

The kernel is essentially composed of the embryo, that is to say, that which tends to be developed and to produce a vegetable similar to that which gave it birth. The kernel sometimes contains another body, to which the embryo is applied, or within which it is entirely concealed: this is called the endosperm, perisperm, or albuimen: see Plate 12, and Explanation. The embryo is the essential part of the vegetable: it is composed of three parts; one inferior or the radicular body, which in germinating gives rise to the root; another superior, or the gemmule, produces the stem, the leaves, and the other parts. Lastly, an intermediate and lateral part, which is the cotyledonary body, or either simple, or divided into two parts, which are called cotylédons. Hence, the division of vegetables, provided with an embryo, into two great classes, 1. the monocotylédons, or those whose embryo has but one cotyledon; and 
2. the dicotyledons, or those whose embryo has two cotyledons. See Plate 12, and Explanation. We do not find the different parts, which have been mentioned always united in the same plant. There is a certain number of vegetables, which, by the constant deficiency of stamens and pistils, by their external forms, their mode of vegetation and reproduction, differ so much from the other known plants, that they are separated and form a distinct class. Linnæus gave the name of cryptogámic, that is, plants with concealed, invisible, sexual organs, to distinguish them from the flowering, or phanerogamic. The cryptogamic plants, include ferns, mosses, lichens, \&c. and constitute nearly the seventh or eighth part of the fifty thousand vegetables, known. As they have no seeds, they have neither embryo, nor cotylédons, and are also called in-embryonate or acotyledonous. Hence the three divisions of vegetables into 1. in-embryonate, or acotyledonous, including ferns, mosses, \&c. 2. embryonate or phanerogámic, that is, flowering plants; those with evident flowers, seeds, and embryo: these last are distinguished into monocotylédons, or those in which the cotyledonary body of the embryo is of a single piece, and produces a single leaf by germination; for example, grasses, lilies, \&c. (see Plate 12.) and into dicotylédons, or those, (with embryo having two cotyledons,) which produce two leaves by germination; for example, the oak, elm, \&c. See Plate, 12. The number of the dicotyledonous plants is greater than that of the monocotyledonous and aco. tyledonous united.

\section{The Organs of Vegetables}

Are divided into two classes-1st. Organs of Nutrition or $V$ egetation; they serve for absorbing nutritious substances fit

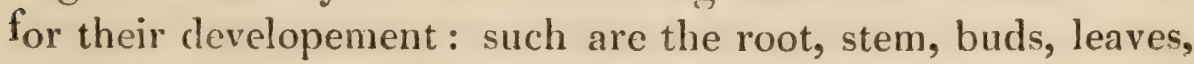
\&c. 2d. Organs of Reproduction or Fructification.

\section{Organs of Nutrition or Vegetation.}

These are the root, stems, leaves, stípulas, and some of these organs in a degenerated state; for example, thorns, prickles, tendrils. These organs all conduce to the maintenance of vegetable life: for example, the root, buried in the ground, 
absorbs a part of the fluids destined for nutrition and repair ; the stem transmits these fluids into all points of the vegetable, while the leaves perform the same office as the roots in the earth, and seem at once organs of absorption and of exhalation.

\section{Of the Root.}

A remarkable character of the root is, that it never turns green, in its tissue, when exposed to the action of air and light. Roots serve commonly to fix plants in the soil, and to draw from it a part of their nourishment.

The division of vegetables into annuals, biennials, and perennials, is subject to variation, from climate, temperature, situation of a country, and cultivation; for example, annual plants will not uncommonly vegetate for two years, and even more, if placed in a suitable soil, and protected from the cold.

Roots absorb from the earth the substances, serving for the growth of the vegetable. It is only by the extremity of the minutest fibres of the root, that absorption is effected. Some maintain that the fibres are terminated by small vesicles or spongioles; others, that they are terminated by a species of open mouths. To prove that the extremities alone perform the office of absorption; immerse a radish or a turnip in water, by the extremity of the rootlet, which terminates it, it will shoot forth leaves, and vegetate. If the lower extremity be not immersed, it will not shoot out. Roots have a marked tendency to grow in the direction of veins of good soil. They possess a natural and invincible tendency to move towards the centre of the earth: this is particularly observable during the germination of the embryo. From different experiments, mentioned by Richard, it appears that the roots are directed towards the centre of the earth; not because they contain a less elaborated fluid, nor because they are attracted to it by the moisture or even the nature of the earth; but by a spontaneous movement, an interior force, a kind of subjection to the general laws of gravitation. Some vegetables, however, seem exempt from this law ; for example, parasitical plants, and the mistletoe, (viscum album,) in particular. This plant shoots out its radicle (rootlet) in whatever situation chance may place it; and it has a constant tendency to shun the light. 
Many roots are useful articles of food. A sugar is extracted from the beet; some are useful in dying: many are valuable in medicine.

\section{Organization of Dicotyledonous Stems.-See \\ Plate 11, 169. and Explanation.}

The trunk of these is formed of concentric layers placed within each other; it may be compared to a series of tubes set the one within the other, and increasing in magnitude from the centre to the circumference. A transverse section presents the following objects: 1 . in the centre, the medullary canal, formed of the medullary (pith) tube, which constitutes the parietes (side walls of the canal,) and of the pith which occupies its cavity. 2. At the circumference is seen the bark, composed of the epidermis, or that external pellicle, (thin skin,) which covers all parts of the vegetables of the herbaceous integument, of the cortical, (bark, ) layers, and of the liber, (true bark.) 3. Between the medullary tube and the bark are found the woody layers, composed externally of alburnum, or false rood; internally of wood properly so called. ${ }^{1} \quad$ See Plate, 11.

\section{§. 1. Of the Epidermis, or Outermost-covering.}

It is a thin, nearly transparent layer, of an uniform tissue, which appears to consist of cells of variable form : it presents a great number of small openings or pores. Plate, 11, 162. It covers all parts of the vegetable. It tears and cracks, when the trunk has acquired a certain size; it falls off in patches or plates; for example, birch, and plane. The true office of cortical pores, says Richard, consists in affording a passage to air.

\section{§. 2. Of the Herbaceous Integument.}

Under the epidermis is observed this layer of cellular tissue. In young stems its colour is generally green. It covers the trunk, the branches, and their divisions, and fills up the spaces

1 The different parts of the stem are described in succession, proceeding from the circumference to the centre. 
between the ramifications of the nerves of leaves. The herbaceous integument constitutes the part known by the name of cork in the cork-tree, (quercus suber.) Within its substance, is effected the decomposition of the carbonic acid ${ }^{1}$, (fixed air,) absorbed by the plant from the surrounding air. The carbon remains within the vegetable, the oxygen, (pure part of the air,) being set free, is expelled from it. This decomposition takes place only when the plant is exposed to the rays of the sun; the carbonic acid is given out unchanged when the vegetable is not under the influence of that body. This organ, (the herb. integ.) is partly renewed every year. At the return of spring, it invites the sap to ascend towards the buds, and thus becomes one of the most powerful causes of their developement. The herbaceous integument is the part, observed on removing the epidermis, or outermost covering of branches; for example, the common elder, (sambúcus.)

\section{§. 3. Of the Córtical Layers.}

These are sometimes very difficult to recognise. Placed under the herbaceous integument, they are applied to the outer layers of the liber, (the true bark, from which they can hardly be distinguished.

\section{§. 4. Of the Liber.}

This is found between the cortical layers, on its outside, and the woody body which lies within it. It consists of a vascular net-work, whose elongated meshes are filled up with cellular tissue. By maceration, it may be separated into distinct layers. The liber is capable of being reproduced. To the viscid substance poured out from the denuded, (stripped,) parts to reproduce the liber, the name of cambium, has been given. The cámbium is considered by many to be nothing more than the descending and elaborated sap. The liber is indispensable for the process of vegetation; for example, a graft will not succeed, unless its liber be in contact with that of the tree on which it is inserted : a cutting, stripped of

1 See Parke's Chemical Catechism, last edition. The clearest and most entertaining work on Chemistry, with which $\mathbf{I}$ an acquainted. 
its liber in the lower part, will not strike root: remove the liber, in a circular band, from the trunk of a tree, so as to leave the woody body naked, the entire tree will ultimately perish.

The liber hardens, every year; new layers are formed on its inner surface by means of the cambium.

\section{§. 5. Of the Alburnum, or False Wood. See Plate, 11, fig. 169, and Explanation.}

The external woody layers, in contact with the liber, constitute the alburnum. The alburnum is real wood, still young.

\section{§. 6. Of the Wood, properly so called.}

The wood derives its origin from the innermost layers of the alburnum, which successively acquire a greater degree of hardness, and are ultimately converted into true wood. The latter, therefore, consists of all the circular layers between the alburnum and the medullary tube. At a certain period of the life of vegetables, there are annually formed a layer of wood and a layer of alburnum; that is to say, the innermost layer of alburnum is changed into wood, at the same time that a new layer of alburnum is produced externally, so that every year a new concentric zone is added.

The alburnum is destitute of vessels; the wood abounds with them. These vessels are either false spirals, or porous vessels, (see plate, 11, and explanation,) but with no true spirals. It is by means of these tubes, that the sap is conveyed into the body of the stem. Through age, the cavity of these vessels becomes diminished, and the course of the fluids in the wood is for ever arrested.

\section{§. \%. Of the Medullary Tube. See Plate, 11. and Explanation.}

This occupies the middle of the stem : its office is to contain the pith. Its parietes, (or sides, ) are the very long vessels, parallel, and disposed in a longitudinal direction. Its vessels are spirals, false spirals, and porous vessels. See Plate, 11, and Explanation. 


\section{§. 8. Of the Pith.}

It is that spongy, light substance, composed almost exclusively of cellular tissue in its simple state, which fills the medullary tube. The pith communicates with the herbaceous cellular layer of the bark, by means of peculiar prolongations, which cross the true wood, (corpus lígueum.) These medullary prolongations serve to establish a direct communication between the pith, and the external cellular tissue of the stem. The medullary rays exist also in the greater part of the thickness of the bark, and serve to establish a communication between the inner medulla, and the outer; but those of the bark have no direct communication with those of the woody layers. The use of the pith seems uncertain.

\section{Of the Stem of Monocotyledons. See Plate, 11, and Explanation.}

In this, all the parts seem to be united with each other. The pith occupies the entire thickness of the stem; the wood, disposed in longitudinal bundles, is, as it were, dispersed without order in the midst of the medullary substance. The bark does not always exist, or is very indistinct.

\section{Organization of the Root.}

All roots are generally organized like the stems : the latter generally grow in height by every point of their extent; roots are lengthened only by their extremity.

\section{Growth of Vegetables,}

Takes place, as in animals, within outwards, or in other words by intus-susception. In proportion as the height of vegetables increases, their diameter becomes more considerable.

\section{Of the Growth of Dicotylédonous Trees.}

Of the growth in diameter there are three opinions. 1st. 'That it is carried on by the annual change of liber into alburnum, of the alburnum into wood, and by the successive renewal of the liber. Such is the foundation of Du Hamel's 
theory. 2d. That it is produced by the developement of buds. This is the theory of Du Petit Thouars. 3d. That the annual formation of woody layers is owing to the cambium, which, every year, forms at one and the same time, a new layer of alburnum, and a new layer of liber. This opinion is professed by Mirbel, and considered by Richard as the most probable. According to this third opinion, there is, every year, formed in the trunk of dicotyledonous trees a new layer of wood. This layer is produced by a part of the cambium, which becomes organized and solidified. The alburnum formed on the preceding year, acquires greater density, and is changed into wood. But the liber undergoes no change; it is only repaired and increased on its inner surface by means of the cambium, which successively forms new layers.

\section{§. 1. Growth in Height of Dicotyledonous Stems.}

At the time of germination, the radicle, (rootlet, descends into the earth, while the ascending caudex rises upwards. See Plate, 12, and Explanation. From the upper part of the stem proceeds a new centre of vegetation, from which arises a young shoot. To this succeeds a third, which on the following year is surmounted by a fourth, and so on.

The trunk is, therefore, composed of a series of cones, greatly lengthened out, whose tops are turned upwards, and which are placed one above the other. The top of the innermost cone terminates at the base of the second shoot, and so on in succession, so that the number of woody layer's corresponds with the number of years that the plant has lived, only at the base of the trunk. Thus a stem of ten years old will shew only nine layers of wood, when cut at the second shoot, only eight at the third, and, lastly, only one, near the top.

\section{§. 2. Growth of the Stems of Monocotyledonous Trees. See Plate, 11, 12.}

In a palm, after germination, the leaves, which are usually folded, become expanded, and appear under the form of a circular cluster which springs from the collar of the root. On 
the second year, a new cluster springs up from the centre of the former, and pushes outwards those that existed before. Then the oldest begin to wither, to dry, and to fall off. But their bases adhering intimately to the top of the root, are persistent, and form, by their union, a solid ring, which becomes the base of the stipe. A new central bud being developed every year, the outer leaves of that which preceded it, fall off, and their base, which is persistent, forms a new ring, which is superadded to those that already existed.

The stipe, instead of being formed of concentric layers like the trunk of the dicotyledons, is composed of rings placed above one another.

\section{Grafting.}

The union of grafts is effected by means of the cambium, or proper juices of vegetables. This fluid substance serves as a means of union between the graft and the stock, as in animals the coagulable lymph is poured out between the edges of a recent wound, which it unites and approximates.

\section{Slips.}

A slip will succeed with greater certainty, if we leave two or three buds under ground.

\section{Height of Trees.}

The forests of South America, are, in general, full of fine, lofty trees. Some plants are of very rapid growth. The Agáve Americána will grow nearly a foot every day. In general, the greatest height attained by our forest trees, is from one hundred and twenty, to one hundred and thirty feet. In America, the palms, and other trees often exceed one hundred and fifty feet.

\section{Thickness of Trees.}

The famous chestnut-tree of Mount Etna, is one hundred and sixty feet in circumference. Of the baobabs in the Cape De Verd islands, some were one hundred and twenty feet, in circumference. In our own climate, there are oaks, \&c. from 
twenty-five to thirty feet in circumference. See Flora, under Oak.

\section{Duration of Trees.}

The olive may live three hundred years; the oak nearly six hundred. The cedars of Lebanon appear to be indestructible. The baobabs, mentioned above, are supposed to be nearly six thousand years old.

\section{Uses of Stems}

Very various : for building, food, sugar, dying: bark of the oak for tanning. Stems, woods, and barks, occupy a considerable rank in the Materia Medica.

\section{Buds properly so called,}

Are generally composed of scales, closely tiled, containing within, the rudiments of stems, branches, leaves, and the organs of fructification. They are covered externally, in trees of our climate, with a viscid, resinous substance; having within a close, downy texture, destined to defend the organs, contained in them, from the cold. No provision of the kind is made for trees of the torrid zone, nor for those, kept in our green-houses. In fruit trees, the flower bud is conical and swollen; that which contains leaves only, is slender, lengthened out, and pointed.

\section{Túrio.}

A name given to the subterraneous buds of perennial plants. Thus, the part of the asparagus, which we eat, is the turio.

\section{Bulb.}

A kind of bud belonging to certain perennial plants, particularly to the monocotyledons: they are reproduced every year.

\section{Bulbils.}

A species of small, solid, or scaly buds, which being de- 
tached fiom the parent plant, become developed, and produce a vegetable exactly similar to that from which they derive their origin. Plants of this kind bear the name of vivíparous. In bulbils there is no embryo.

The uses of buds, bulbs, \&c. are various; for example, in domestic economy, the genus állium, including the onion, garlick, \&c.; in medicine the squill-bulb, is a powerful expectorant, and diuretic.

\section{Of Leaves.}

The arrangement of leaves in the bud is called prefoliation. Genera are sometimes well arranged from this into natural families. Leaves, as considered after their developement, by the numerous pores on their surfaces, serve for the purpose of exhaling and absorbing the gases, (airs, which are either become useless, or which are adapted for the nutrition of the vegetable. Leaves seem to be formed by the expansion of a bundle of fibres proceeding from the stem. These fibres, which are vessels, by branching out in various directions, form a kind of net-work, which represents the skeleton of the leaf, and whose meshes are filled up with cellular tissue, which is more or less abundant, and which derives its origin from the herbaceous integument of the stem.

The upper surface of the leaf is covered with a closely adhering epidermis, and has but few cortical pores : the under surface is also covered with an epidermis, has a greater number of small pores, which are the orifices of the internal vessels of the vegetable. It is particularly by this under surface, that leaves absorb the fluids, that are exhaled from the surface of the earth, and that are diffused through the atmosphere.

Nerves of leaves, properly so called, are very prominent: veins are less prominent.

The nerves are bundles of porous vessels, of spirals, and of false spirals, enveloped in a certain quantity of cellular tissue. (See Plate, 1], and Explanation.) The disposition of nerves in leaves deserves the greatest attention. In most of the monocotyledons, they are almost always simple, and often parallel to each other. 
The leaves and the roots are the principal organs of absorption and nutrition in vegetables : they absorb from the atmosphere nutritive substances which are made subservient to their growth. They also serve for the purpose of expiring and of exhaling fluids, which are become useless to the vegetable, and it is by their means, that the sap is divested of its watery constituent, and acquires all its nutritious qualities.

The leaves of herbaceous plants, which are immersed in an atmosphere constantly moist, absorb equally by their upper and under surfaces. Place the leaves of trees upon water, on their under surfaces, they will continue green for several months; place them on their upper surfaces, and in a few days, they will completely wither.

When leaves are exposed to the action of the sun, they decompose carbonic acid gas, (fixed air,) retain the carbon, and set free the oxygen, (pure part of the air.) 'The contrary takes place when they are withdrawn from the action of the light; they then take a portion of oxygen from the air, and replace it with an equal quantity of carbonic acid.

Leaves are susceptible of certain motions, which depend on the irritability with which they are endued.

\section{Fall of the Leaf.}

Trees whose leaves are earliest expanded, are generally the first to lose them. In the elder, (sambúcus,) however, the leaves appear very early, and are late in falling: in the common ash, the leaves appear very late, and fall towards the end of summer.

The fall of the leaf may be ascribed to the suspension of vegetation, to the want of nourishment, which leaves experience at that period of the year. The vessels of the leaf become contracted and dry, and the leaves fall off.

Medical leaves are chiefly those possesed of emollient, tonic, stimulant, narcotic, and purgative qualities.

\section{Stipulas}

Never exist in monocotyledonous vegetables. They furnish excellent characters for the construction of natural orders. The 
use of stipulas is, probably, to protect the leaves before their developement.

\section{Tendrits}

Are abortive organs. Sometimes they are fioral stalks, at other times, leaf-stalks, stipulas, or abortive branches.

\section{Spines, (thorns,)}

Are very often only abortive branches; example, the sloetree: for if this tree be transplanted into a richer soil, its spines are converted into branches. Prickles have been considered by some, as hardened hairs.

\section{Of Nutrition in Vegetables.}

In nutrition, vegetables assimilate a part of the solid, liquid, or gaseous substances contained in the earth, or diffused through the atmosphere. The absorption of these substances is effected by suction. Water serves as a solvent for the bodies which they are to assimilate. The force with which the sap ascends from the root of a vine into the stem is greater than the pressure of the atmosphere.

\section{Course of the Sap.}

The sap holds the nutritive principles in solution, and deposits them in the different parts of the vegetable as it circulates through them. The sap ascends through the woody layers, and the lymphatic vessels of the wood, and the alburnum convey that fluid : a coloured fluid will be absorbed, particularly by those vessels, which are nearest to the medullary tube, but not by the pith, or bark. The sap passing through the layers of wood in its course upwards, communicates with the lateral parts and branches of the stem, either directly, by the anastomósis (peculiar union) of their vessels, or by diffusing itself gradually through pores in the (parietes) sides of the canals, which convey it. In the same sap vessel there are always four different currents ; an ascending and descending, and two horizontal ones in different directions. 
To account for the cause of the sap's rising, Richárd supposes a vital principle, to have a powerful influence; but other internal and external causes may assist in promoting this rise, for example, light, electricity, warmth, transudation inwards, and outwards.

\section{Descent of the Sap}

Proved by tying a strong ligature to the trunk of a dicotyle donous tree, when a circular swelling will be produced above, which will become gradually larger. The swelling can arise only from the obstacle opposed to the juices descending, through the cortical layers from the upper to the lower part of the vegetable. The descending sap continually renews and maintains the cambium, and it contributes chiefly to the growth and developement of dicotyledonous trees.

A striking difference exists between vegetables and animals; the former live almost exclusively on inorganic substances, as water, carbon, hydrogen, oxygen, \&c ; the latter on those taken from the animal and vegetable kingdoms. ${ }^{1}$

\section{Organs of Reproduction.}

These are the flower, the fruit, and the different parts that compose them : they serve for the preservation of the species.

With regard to the calyx and corolla, Linnæus gave the latter name, corolla, to a single floral covering around the stamens or pistils, or both, where the colours are vivid, and the former name of calyx, where the colour is green. Jussieu considers the single floral covering as a calyx, and gives it that name of calyx, whatever be its colour, provided it be single: others call the single floral covering a perigonium; for example, the tulip.

For a further account of the organs of reproduction the reader is referred to Richard's Elements of Botany, by Clinton, or Macgillivray. We will proceed to enter into an examination

' See all chemical terms, clearly explained in Parkes' Chemical Catochism, \&c. lost edition. 


\section{of the Fruit,}

One of the organs of reproduction, in order that the student may understand the brief sketch given of the Natural System of Jussieu.

The fruit is composed essentially of two parts, the pericarp, and the seed.

The pericarp, or covering of the seed is always present, however thin: there are in fact, no naked seeds.

The pericarp is always composed of three parts: viz. 1. a thin external membrane, called the epicarp: 2nd. of an internal membrane, lining the seed-bearing cavity, called the endocarp. Between these two membranes is a fleshy part, called the sarcocarp or mesocarp. See Plate 12.

The seeds are attached in the pericarp to a peculiar fleshy body, called the trophosperm or placenta.

When the surface of the trophosperm has manifest prolongations, each of them bearing a seed, these prolongations are called podosperms.

The arillus being only an expansion of the trophosperm, belongs not to the seed, but to the pericarp. The arillus never occurs in plants, whose corolla is monopetalous.

Concerning the pericarp in general, we may observe that its axis is sometimes material, and has a real existence: it is then called columella: or the axis may be fictitious or rational, that is to say, represented by an imaginary line passing from the base to the summit of the pericarp, and running through its centre.

The columella is a small column, which supports the different parts of the fruit.

The number of the valves of a pericarp is always known by the number of longitudinal sutures visible on its outer surface. The valvar dehiscence (that is, opening of the valves) is threefold: 1st. it may take place in the middle of the cells, that is to say, between the partitions, which, in that case correspond with the middle part of the valves. This is called loculicidal, as in most ericinea. See Plate 12. 2nd. the dehiscence may occur, opposite to the partitions., it is then called septicidal, as in the scrophularinea. See Plate 12. 3rd. when the 
pericarp bursts near the dissepiments, which remain free and entire on the separation of the valves, the dehiscence is called septífragal, as in bignónia, and callúna vulgáris.

The organization of the pericarp, and seed is one of the most difficult parts of botany. To give a clear idea of the parts, an analysis of the fruit of the common peach (amy'gdalus persica) is here given.

The fruit is composed essentially of two parts, the pericarp and the seed. The seed is always contained within the pericarp. Let a peach be cut in two: its centre is found occupied by a cell or cavity, containing a single seed, and rarely two. All outside the seed belongs to the pericarp. First, on the outside, is a thin coloured pellicle, covered with a soft down, easily removed; this is the pericarp. The internal cavity of the pericarp, lined with another soft membrane, adhering intimately to the hard part, which forms the nut, is called the endocarp. The whole of the thick, fleshy substance, contained between the latter membrane and the epicarp forms the sarcocarp. The nut or bony part in the centre of the peach is formed of the endocarp, to which is added an ossified portion of the sarcocarp. We find similar parts as above described, in the apricot, plum, cherry, \&c.

We will next give an analysis of the common pea fruit, (pisum sativum.)

The two longitudinal sutures, indicate that the fruit, when ripe, opens by two segments or valves: hence it is called, a two-valved pericarp. This pod, is found to have a single cavity, with eight or ten seeds, in other words, it is one celled, and many seeded. Every thing outside the seed is a part of the pericarp. On the outer surface is a thin membrane closely adhering to the subjacent part; this is the epicarp. 'The inner cavity is lined with another membrane, which adheres less intimately; this is the endocarp. The fleshy, green, vascular part, between the two membranes, though not very thick, is the surcocarp. The small, longitudinal prominence, which runs along the sutures, and to which the seeds are attached, is the trophosperm, or placenta.

Each of its prolongations belonging to a particular seed, is a podosperm, or umbilical cord. 
Observe, when the tróphosperm or pódosperm covers the seed so as to embrace it to a greater or less extent, this prolongation takes the name of arillus.

We will next examine

\section{The Seed.}

Every seed, essentially contains an organized body, which, becoming developed, produces a being, perfectly similar to that which gave it birth: this body is the embryo, the essence of the seed. The seed is composed of two parts; 1 st. the episperm, or proper covering: 2nd. the kernel within the episperm. 'The point of the seed by which it is connected with the pericarp, is called umbilicus, or hilum : this last, is always marked with a kind of scar. The centre of the hilum always represents the base of the seed. 'The summit of the seed is the point opposite to the hilum.

For a minute account of the several parts above named, and much additional matter, the reader is referred to Richard's Introduction, and to Lindley's.

\section{Germination of Seeds.}

Seeds through time, lose their germinative power. Some retain this power for a considerable number of years; for example, kidney-beans, kept for sixty years, have germinated. Seeds of the sensitive plant have been perfectly developed about one hundred years after they have been gathered. In these cases, they must have been excluded from the air, light, and moisture.

Water, heat, and air are necessary agents for germination.

Seeds, plants, and animals can neither grow, respire, nor live in pure oxygen gas: the best mixture for the purposes above, is in the proportion of one part of oxygen, and three parts of azote, (that is, nitrogen, or of hydrogen.

From the moment the embryo of a seed becomes developed, it takes the name of plantule. Its two extremities grow in opposite directions. The one is formed by the gemmule, and grows upwards into the air; this is called the caudex ascendens. 
The other, sinks into the earth, and bears the name of caudex descendens; this is formed by the rooting body, (or radicle.)

For a classification of the different species of fruits, the reader is referred to Richard.

The uses of fruits and seeds are too obvious, to dwell upon at any length. Bread, for example, is prepared from the farinaceous albúmen of the wheat: a variety of fleshy fruits, as peaches, apples, \&c. are of use in domestic economy. The fleshy pericarp of the olive, (olca europæa, yiclds a pure oil. 'I'he fruits of the orange, and lemon contain citric acid, nearly pure. The berries of the buck-thorn, (rhamnus cathárticus,) are strongly purgative: not to mention, at length, the carminative seeds of the umbelliferous plants, the roasted sceds of the coffee, \&c.

\section{Of Botanical Classifications.}

Theophrastus, ${ }^{1}$ was the first who wrote a particular treatise on vegetables: but the science of botany, it may be said, did not exist in his day. It was not until the sixteenth century that Gessner, of Zurich, first demonstrated, that characters taken from the flower and the fruit were the most important for establishing a good classification. He also shewed, that groups exist in vegetables, composed of several species, united by common characters. Shortly after, Cæsalpínus, (born 1519,) of Arezzo, gave the model of the first botanical method; his species being arranged from a consideration of vegetable, organic characters. Amongst the subsequent authors of systems we may mention the Bauhins, Ray, Magnolius, Rivinus, and Tournefort, Professor of Botany, at Paris, in the reign of Louis XIV.

Tournefort's system was succeeded by the artificial system of Linnæus, published in 1734. The natural system, or method of affinities was first sketched by Adanson. Bernard de Jussieu pursued this subject. But it was reserved for his nephew, Antoine Laurent de Jussieu to bring it nearer to perfection. This system of Jussieu is founded not on the consideration of a single organ; but it regards the whole of the

1 Died B. C. 288. 
characters furnished by all the organs of a vegetable, and unites all those, which have the greatest number of points of contact and resemblance. The systems of Tournefort, and of Linnæus had for their basis only the consideration of a single organ; for example, Tournefort employed the corolla, and Linnæus the stamens for establishing their principal divisions. These systems of Tournefort and Linnæus, have for their object the discovery of the name of a plant, without griving ideas of its organization. The study of the natural system, and families of plants gives more precise ideas respecting the structure and organization of the different vegetables.

\section{Jussieu's Method of Natural Families.}

The plants arranged by this system of families, have closer affinities with those which immediately precede or follow them, than with any other. This system unites and arranges plants in groups and families, according to the greatest number of their common characters. The embryo of the seed furnishes the foundations of Jussieu's divisions, the stamens and pistils occupy the second rank. Stems, leaves, and roots, supply accessary characters.

In explaining the means by which vegetables have been united into natural groups or families; we will first give an idea of the words species, variety, genus, order, and family.

A species is a collection of individuals which constantly reproduce each other of the same form. The seed of any given species will produce an individual, perfectly similar to itself. Species which exhibit some differences in respect to the colour of their flowers, or of their more or less considerable stature, constitute varieties, which may be distinguished from species, in this respect, that in a state of nature, they are not reproduced from seeds with all their characters; for example, the flowers of the lilac are usually light violet; but sometimes white, without any corresponding change in any of its other characters: here, the white lilac is merely a variety of the violet flowered one.

A genus consists of a more, or less considerable number of species, united by common characters, taken from the organs of fructification, but all distinct from each other by specific 
characters peculiar to each, and furnished by the organs of vegetation; for example, the genus anagallis, (pimpernel,) has for its characters, a peculiar corolla, and box-like fruit, (pyxídium.) Now, all the species (or sorts) of this genus, anagallis, must have these peculiar characters of corolla, and fruit; but the species will be distinguished from each other by the forms of their stems, and leaves, \&c.

By uniting together genera in the same manner as species; that is, by collecting into the same group those, which have common and similar characters, we form orders, properly so called, if we regard only a single character, such as the number of stigmas, or the form of the fruit, \&c. and natural orders, or families, when for the formation of such an assemblage, there is required the concurrence of all the characters that may be derived from the form, structure, and relative situation of all the organs of the vegetables which are classified. A natural order, or family of plants, is, therefore, a series or assemblage of genera, more or less numerous, which have all the same characters in the organs of fructification. Thus the cruciform (or crucíferæ) family have all peculiar characters: and all the genera of this family must have the same characters, with some slight modifications, which will serve to establish the differences of the genera, whose union constitutes this family.

The families being numerous, it has been found necessary to distribute them into more or less numerous classes. We will now mention the characters, employed by Jussieu for the formation of his different classes.

The classes are fifteen. The first divisions are marked by the presence, or absence of the embryo in the seed. Hence we have 1. embryonate, 2. inembryonate vegetables.

The 1st. embryonate, are distinguished according to the number of their cotylédons; 1st. into monocotyledons, or those with one, and $2 \mathrm{~d}$. into dicotyledons, those with two or more cotyledons. See Plate 12. Those without cotyledons, are called acotyledonous.

That which serves for the establishment of classes properly so called, is founded on the relative insertion of the stamens, or 
of the one-petalled, stamen-bearing corolla. There are three kinds of insertion.

1st. The hypógynous, in which the germen or ovary being entirely free, the stamens or stamen-bearing corolla are inserted around its base. See Plate 12.

2 nd. The perigynous insertion, wherein the ovary or germen being free or parictal,' the stamens are inserted, or one-petalled, stamen bearing corolla is inserted on the calyx, at a certain distance from the circumference of the base of the ovary or germen. See Plate 12.

3rd. The epigynous insertion, wherein the ovary or germen is always inferior, or where the stamen-bearing corolla, or the stamens are inserted on the upper part of the ovary or germen. See Plate 12.

The acotyledonous plants, the mosses, \&c. being destitute of embryos, and of flowers and fruit, do not enter into this classification, but they constitute a first class : and

The acotylédons, and monocotylédons four classes; for example :-

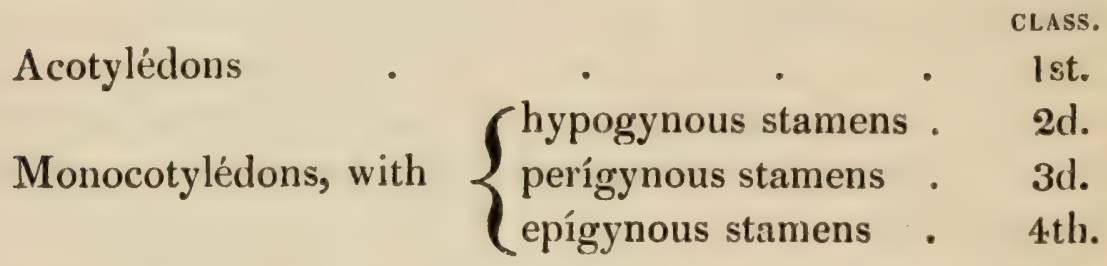

We remark that dicotyledonous plants, are either destitute of a corolla, that is, apétalous, or are one-petalled (monopétalous,) stamen-bearing, or their corolla is many-petalled (polypetalous.) Hence we have three divisions in the dicotyledonous plants, viz. :DIVISION.

1. Dicotylédonous apetalous.

2. monopetalous.

3. polypétalous.

These three sections just mentioned of apetalous, \&c. are again divided into classes, by the above mentioned character of insertion. Thus, the dicotyledonous apetalous, form three 
classes, in which the insertion is 1. epigynous, 2.perígynous, and 3. hypógynous.

The monopetalous, whose corolla always bears the stamens, also form three classes:-

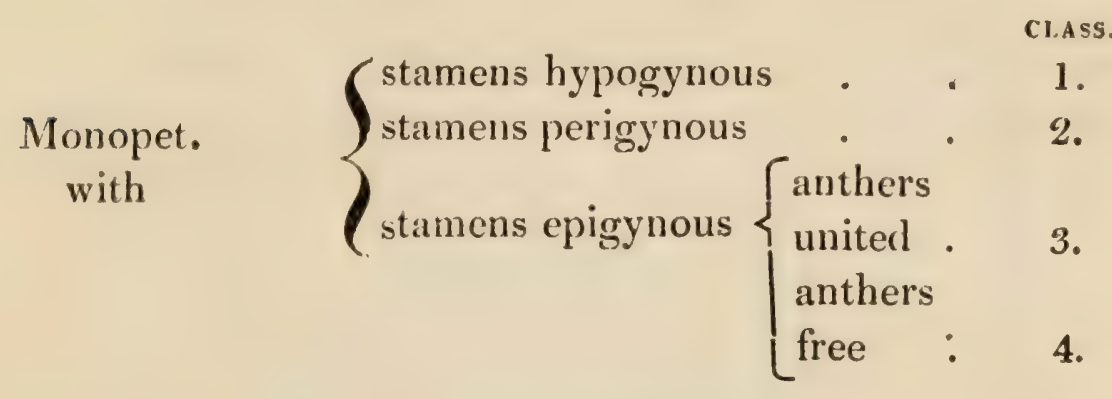

It will be observed that the third class of stamens epigy. nous, has been subdivided, according as the stamens are with free, or united anthers, thereby increasing the number of monopetalous classes to four.

These four classes, with the three classes of dicotyledonous apetalous plants, and the four monocotyledonous and acotyledonous plants, form in all, eleven classes.

The dicotyledonous polypetalous plants are divided into three classes of 1. epígynous, 2. perígynous, 3. hypógynous.

In the fifteenth and last Jussieuian class are placed all the dicotyledonous plants, whose flowers are essentially monocious, (unisexual,) and those separated on distinct individuals, that is, diccious. These are called irregular diclinous plants. Each of these fifteen classes, contains a more or less considerable number of natural families, all united by the common character, which constitutes the class. The characters of the different families are given by Jussieu, in his Genera of Plants. De Candolle, ${ }^{1}$ the great botanist, has published a series of families of plants, arranged in an order, almost the inverse of Jussieu's.

1 Professor Daubeny, in 1832, delivered several able Lectures, at the Laboratory, illustrative of Decandolle's system. 


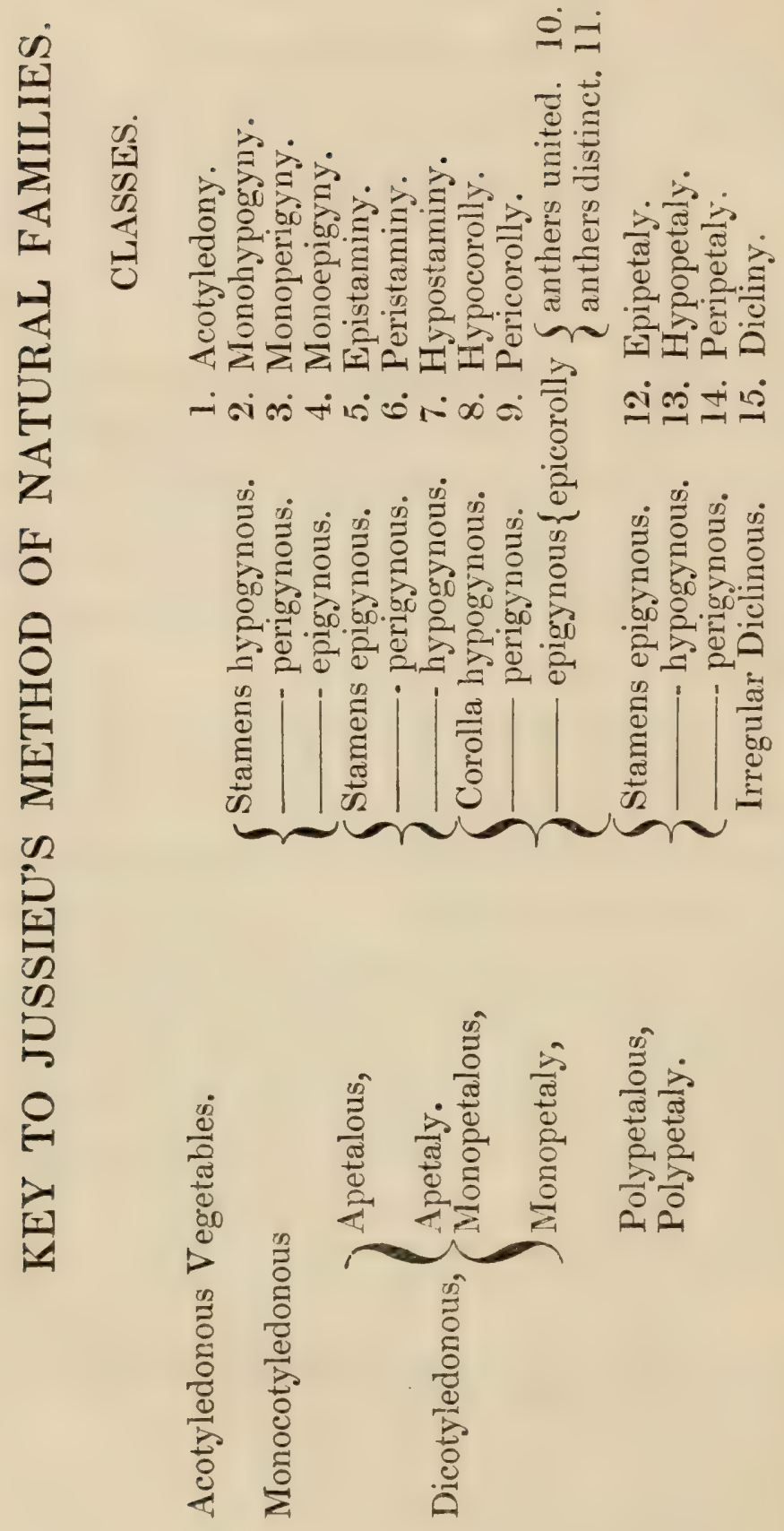


We subjoin a list of those natural families, or groups, chiefly according to Richard, which occur in the Flora of Oxfordshire, and its contiguous counties. The Genera arranged under each family are also given. For the characters of the different families or groups, we refer the student to Richard by Clinton, or by Macgillivray, or to Lindley's Introduction, or to Sir James Smith's Grammar of Botany, or to De Candolle's Botanicon Gallicon, a work in Latin.

\section{DIVISION $\mathrm{I}$.}

\section{The Inembryonate Plants, or Acolyledons,}

Including the algæ, or sea-weeds, and confervæ, funguses, lichens, hepaticæ, mosses, ferns, and some other cryptogamic classes, do not belong to our subject, except the tenth family of Charáceæ.

1. Chara genus and its species.

\section{DIVISION II.}

Embryonated, or flowering plants, that is, plants furnished with stamens, and pistils. According to the structure of the embryo, these are divided into two groups, the monocotyledonous, and the dicotyledonous.

\section{Monocotyledonous Plants.}

Besides the embryo being monocotyledonous, it is to be observed that in this division of plants, the internal structure of the stem is composed of cellular tissue, in which are scattered vasicular bundles; the nerves of the leaves in general, are parallel; the perianth is a calyx only, sometimes coloured, (according to Jussieu,) like petals; the floral organs, are in general three, or a multiple of three; in the dicotyledons, the number five prevails.

\section{CLASS II.}

Monohypogyny, (that is, monocotyledonous, and hypogynous.) 
1. Nayadece. Juss.-Potanophilece. Richard Fluviáles, Lind. Potámeæ DC. Under this family, are the

Gcn.' Potamogéton. Zannichéllia. This family is nearly related to the next.

2. Aroídece. (Juss.) or Arum Tribe.

Gen. Arum. 'Acorus. The roots of this family abound with fécula, which may be used as an article of food, when deprived of its acrimony by roasting, or washing.

3. Typha. (Juss.) Typháceæ. DC.

Gen. Typha. Sparganium.

4. Cyperácea. (Juss.) or Sedge Tribe.

Gen. Schœnus. Rhyncóspora. Eleócharis. (Isólepis.) Scirpus. Erióphorum. Carex.

This family is very natural, and has close affinity to the grasses.

5. Graminece.

The Grasses, Agrostis, Alopecurus, \& c. One of the most natural families of the vegetable kingdom. This family is distinguished from the Cyperacex, by its cleft leaf sheath : the sheath of the Cyperacex is entire: there is also only one flower scale in the Cyperaceæ, two in the Gramineæ, or Grass Tribe.

\section{CLASS III.}

Monoperigyny, or Monocot. and Perigynous.

6. Juncece, or Rush Tribe.

Gen. Juncus. Luciola.

7. Alismácea. Part of Juss. Junci.

Gen. Bútomus. Alisma. Sagittaria. Triglóchin. Juss.

8. Colchicaceee, DC. Cólchicum Tribe. Part of Junci.

Gen. Cólchicum. Narthecium.

An active principle called verátria, found in the colchicun. 9. Asparagínece.

Gen. Asparagus. Paris. Convallaria. Ruscus. Tamus. None of the plants in this family are poisonous.

10. Liliácece. Lilia and Asphodeli. Juss. 
Gen. Tulipa. Fritillaria. Scilla. Gagea. Ornithógalum. 'Allium.

The bulbs of this family usually contain a mixture of a mild, gummy, extractive substance, which is bitter, volatile, acrid, but dissipated by heat.

\section{CLASS IV.}

Monoepigyny, or Monocotyledonous, and Epigynous.

11. Narcíssece, Amarillidece, $B R$.

Gen. Narcissus. Leucoium. Galanthus. The bulbs of these more or less acrid; in small doses emetic.

12. Irídece. Juss.

Gen. Iris. Crocus. This family easily distinguished by an inferior ovary, and three stamens.

13. Orchidece, Orchis Tribe. One of the most natural families.

Gen. Orchis, \&c.

14. Hydrocharidece. Juss.

Gen. Stratiótes. Hydrócharis.

15. Nymphacacea. Salisb.

Gen. Nymphæa. Nuphar. 'This family is placed by some among the dicotylédonous plants, near the Papaveráceæ, or Poppy Tribe. The roots of the Nuphar lutea, mixed with the inner bark of pinus sylvestris may be made into bread.

\section{Dicotyledonous Plants,}

Or those, whose embryo presents two cotylédons. In the coniferæ family from three to ten cotyledons are found.

In the dicotyledons the stem is disposed in concentric layers, the nerves of the leaves are branched: the number five, or one of its multiples prevails in the flower: a calyx and corolla are also very frequently present.

I. Apetalous Dicotyledons.

CLASS V.

Epistaminy, or Stamens Epigynous.

16. Aristolóchiea.

Gen. Aristolóchia. 'Asarum. 
17. Santalácea. BR.

Gen. Thésium.

\section{CLASS VI.}

Peristaminy, or Stamens Perígynous.

18. Thymélece. Juss.

Gen. Daphne.

The barks of this family contain a green, resinous principle, a bitter crystalline substance, called daphnine, and a yellow colouring matter: more or less acrid; most, in some degree, poisonous.

19. Polygónece. Juss.

Gen. Rumex. Poly'gonum. This family a striking example of plants agreeing in chemical composition, which possess the same botanical characters. The roots of a great number of Polygóneæ contain tannin and gallic acid, and are hence astringent, \&c. The seeds with a large and farinaceous, nutritive albúmen.

20. Chenopódice DC. Atriplíceæ. Juss.

Gen. Chenopodium. 'Atriplex.

Plants of this family sweet, mucilaginous, sugary.

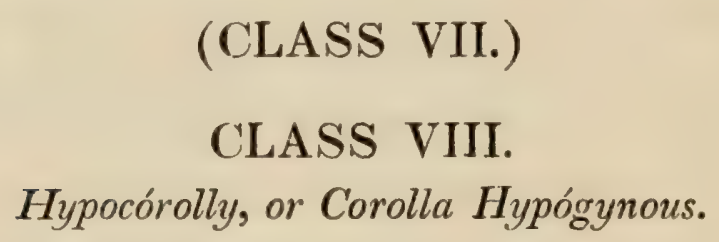

21. Plantagínece. Juss.

Gen. Plantágo.

The seeds of this family contain a large quantity of mucilage.

22. Primulacę. Vent. Iysimáchice. Juss.

Gen. Hottonia. Lysimáchia. Anagállis. Prímula. Sámolus.

23. Orobanchece. Ventenat.

Gen. Orobanche. Lathræa.

24. Scrophularínece. BR. Scrophulariæ and Pediculares. Juss.

Gen. Digitális. Antírrhinum. Scrophularia. Limosella. Melámpyrum. Pediculáris. Rhinanthus. Bártsia. Euphrásia. 
'The plants in this family, not uniform in their properties.

25. Solánece. Juss.

Gen. Solánum. 'Atropa. Hyoscy'amus. Verbascum.

This family has a close affinity to the Scrophularíneæ. Most of the family strongly narcotic. All the verbascums are mild, and mucilaginous.

26. Jasminece. Juss.

Gen. Ligustrum. Fráxinus.

27. Verbenacece. Juss.

Gen. Verbéna.

28. Labiátce. Juss.

The Labiate plants form a very natural family, and include the class didynamia of Linnæus, besides the genera Ly'copus, and Sálvia: they contain essential oil and bitter extractive.

29. Boragínea. Juss.

Gen. 'Echium. Lithospermum. Symphytum. Lycopsis. Anchúsa. Borảgo. Myosótis. Cynogìlossum.

This family contains a large quantity of mucilage, with some astringency.

30. Convolvulacece. Juss.

Gen. Convolvulus. Cúscuta.

This family, acrid and purgative.

31. Polemoniácece. Juss.

Gen. Polemonium.

32. Gentiánea. Juss.

Gen. Menyanthes. Villársia. Chlora. Gentiána. Erythræa.

The plants of this family intensely bitter.

33. Apocy'nea. Juss.

Gen. Vinca.

This family abounds in a milky, poisonous juice.

\section{CLASS IX. \\ Pericorolly, or Cor. Perig.}

34. Ericínece. Juss. Vaccinieæ. DC.

Gen. Eríca, Callúna, Pyrola, Empetrum. Vaccinium.

Vaccinium is here included under the Ericíneæ.

3.5. Campanulácere. 
Gen. Jasione. Prismatocarpus. Campánula.

Almost all the plants of this family are milky : their juice is bitter, and sometimes very acrid; unless abundant mucilage be present.

\section{CLASS $\mathrm{X}$.}

'Epicorolly, and Synantherere, (that is, Anthers united.)

36. Synanthérex, Richard. Cichoráceæ, Corymbíferæ, and Cynarocéphalæ, of Juss. Compositæ of authors.

A great family, and one of the best characterized, comprising the whole class Syngenesia of Linnæus. The plants of this family stimulant, tonic: those abounding in a milky juice, in some degree narcotic : their seeds usually mild.

\section{CLASS XI.}

Epicorolly-Chorisanthery, (that is, with Anthers distinct.)

37. Dipsácere. DC. Part of Juss. Dipsaceæ.

Gen. Dípsacus. Scabiosa.

38. Valeriánex. DC.

Gen. Fédia. Valeriána.

39. Rubiácece. Juss.

A very natural family including Gálium, Aspérula, Sherárdia. This family supplies some of the most valuable articles of the Materia Medica, among which is the Peruvian bark.

40. Caprifoliácea. Richárd.

Gen. Hédera, Cornus, Sambúcus, Viburnum, Lonicéra.

41. Loranthea. Richard.

Gen. Viscum.

\section{CLASS XII.}

\section{Epipetaly.}

42. Umbellifera, Parsley-tribe.

One of the most natural families, but not uniform in its chemical composition, or in its effects on the animal economy.

1 Epi, means upon. 
The warmer the climate, and dryer the soil, the greater the proportion of aromatic principle; the poisonous and narcotic principles will prevail in those species, which grow in cold and moist situations.

\section{CLASS XIII.}

Hypopetaly, or Stamens Hypógonous.

43. Ranunculáceæ. Juss.

Gen. Clématis, Thalictrum, Anemóne, Adónis, Myosúrus, Ranúnculus, Caltha, Tróllius, Helléborus, Aquilégia.

All this family more or less acrid and poisonous : most of them rendered harmless by boiling. The kernels of the seeds usually mild; the integuments acrid.

44. Berberídere. Juss.

Gen. Bérberis.

45. Geraniácere. Aug. Hilaire.

The Geraniaceæ are here united with the Oxalídex, and Lineæ, of DC.

Gen. Geránium, Eródium, Oxális, Linum, Radíola.

This family does not exhibit much uniformity in its medicinal virtues.

46. Malvácea, Mallow-tribe. Part of Juss. Malvaceæ。

Gen. Malva, Althæa.

All this family, mucilaginous, emollient.

47. Tiliácece. Juss.

Gen. Tília.

48. Hypericinea. Juss.

Gen. Hypéricum. Aromatic, resinous.

49. Aceriner. DC.

Gen. Acer.

50. Polygálere. Juss.

Gen. Poly'gala.

51. Fumariácere. DC.

Gen. Fumária, Cory'dalis.

52. Papaverácea, Poppy-tribe. Part of Juss. Papaveraсеæ.

Gen. Papáver, Chelidónium.

Plants of this family contain an acrid, milky juice, many, a 
narcotic power. The seeds of this family except the Argémone Americána, mild and oily.

53. C'rucíferce, Cruciform-tribe.

One of the largest, and most natural families, containing the Tetradynamia of Linnæus.

All the parts of this family contain an essential oil, on which their stimulant effects depend; and their antiscorbutic virtues.

54. Resedacere. DC.

Gen. Reséda.

55. Cistea. DC. Part of Juss. Cisti.

Gen. Cistus, Heliánthemum.

56. Droseracea. DC.

Gen. Drósera, Parnássia.

57. Violariece. DC.

Gen. Víola.

58. Caryophy'llea, Pink-like tribe. Juss.

Zontains the class Decandria of Linnæus, at least all those of the British Flora, besides Sagína, Mœnchia.

\section{CLASS XIV.}

Peripetaly, that is, with Stamens Perigynous.

59. Paronychiea. Aug. Hilaire.

Gen. (Polycarpon,) Scleranthus, Larbrea.

60. Portulacece. Juss.

Gen. Móntia.

61. Saxifragea. Juss.

Gen. Saxífraga, Chrysosplénium, Adoxa.

62. Crassulacea. DC. Sempervíveæ Juss.

Gen. Cotylédon, Sedum, Sempervívum.

63. Ribésiece. Richard. Grossularieæ. DC.

Gen. Ribes.

64. Cucurbitacea. Juss.

Gen. Bryónia.

Properties of this family, not uniform.

65. Hygrobiea. Richd. Halorágeæ. BR.

Gen. Myríophyllum, Callitriche.

66. Onograrice. Juss. 
Gen. Epilóbium. Circæa.

67. Salicariea. Juss.

Gen. Lythrum. Peplis.

68. Rosacec. ${ }^{1}$ Juss. (Class, Icosandria. Linn.)

Divided into these tribes-1. Drupacere. Gen. Prunus, Cérasus. 2. Spiraceer. Gen. Spiræa. 3. Fragariacea. Potentilla, Fragária, Geum, Rubus, Cómarum. 4. Sanguisorbiece. Poterium, Alchemilla, \&c. 5. Rósea, Gen. Rosa. 6. Pomacex. Gen. Cratægus, Méspilus, Pyrus.

All the Rosáceæ astringent, particularly the Fragariáceæ. The young fruits of the Pomaceæ contain a good deal of oxalic acid. The Drupáceæ in their leaves, and kernels contain a large quantity of prussic acid. Several of this tribe afford a mild gum.

69. Leguninósa, Pea-tribe. Juss.

Contains the papilionaceous, or diadelphous plants of the British Flora, at least. Is a large, and very natural family. Exhibits little uniformity in its properties.

70. Rhamnea. BR. Part of Juss. Rhamni.

Genus. Rhamnus,

71. Celastrinece. BR. Part of Juss. Rhamni.

Gen. Euónymus.

72. Aquifoliacece. DC. Ilicíneæ Ad. Brong.

Gen. Ilex.

\section{CLASS XV.}

\section{Dícliny. (Part of Mon. and Dicecia. Linn.)}

73. Euphorbiacea. Juss.

Gen. Buxus, Euphorbia, Mercuriális.

The acrimony of this family resides in their milky juice.

74. Urticece. Juss. And Celtidece. Richard.

To the tribe Celtideæ, of Richard, belongs Ulmus. The true Urtíceæ, are-Gen. Parietária, Urtíca, Húmulus.

75. Salicínece, Willow-tribe. Richard.

Gen. Salix.

76. Betulinea. Richard.

Gen. Bétula, Alnus. These agree with the Saliciner in their astringency, and medicinal properties. 
77. Cupuliferce. Richard. Part of Juss. Amentáceæ.

Gen. Fagus, Castánea, Quercus, Córylus, Cárpinus.

There is great uniformity in the properties of plants, belonging to this family (Cupulíferæ.) The barks abound with tannin and gallic acid, their seeds with fecula and fixed oil; are mild, and nutritious.

78. Coniferce. Juss. Richard.

Gen. Taxus, Juníperus, Pinus.

This family abounds in essential oil, and resin. In this country the turpentine and essential oil are obtained from the common fir (pinus sylvestris.) 


\section{ABBREVIATIONS AND MARKS EXPLAINED.}

Bor. Mr. Borrer.

Bx. Mr. Baxter, ${ }^{1}$ Curator of the Botanic Garden, Oxford. The compiler of the work has found this excellent Botanist a valuable and friendly referee on all difficult points, and is obliged to him for the use of his collection of Oxfordshire and other habitats, and for several scattered observations.

$P n$. Mr. Purton, Author of the valuable Midland Flora. R. Pr. Mr. Roundell Palmer, Trin. Coll. Oxford.

Y. Mr. N. B. Young, Fellow of New Coll. Oxford.

$W h$. The Rev. R. M. White, Fellow of Magdalen College, Oxford: obliged to him for habitats, and for several Ang. Sax. derivations.

T. Rev. Mr. Teasdale, Lincoln College, Oxford.

Pr. Mr. Perry, Author of a List of Warwickshire Plants.

J. H. Mr. John Haines, Radcliffe Library.

Sch. Schkur's Cárices, in his Handbuch, \&c. admirable figures.

Sm. Sir James Edward Smith.

J. Jussieu. Br. Brown. DC. Decandolle.

II. Hooker.

R. W. The Compiler of this work.

M. Morton. Morton's Northamptonshire, folio.

H. L. Hooker's Flora Londinensis, folio, plates, \&c.

E. B. English Botany, (Original Edition,) 8vo. A useful, cheap edition, is in the course of publication, in numbers : these plates ${ }^{2}$ indispensable.

G. E. Johnson's Gerarde's Herbal, folio. Gerarde's names being quoted at full length, the reader will easily refer to the first; Gerarcle's own edition of his Herbal, if possessed of that edition, plates, \&.c.

1 Founder of the Natural History and Botanical Society, Oxford, 1831

2 Plates of all our British flowering plants. 
C. Curtis's Flora Londinensis, folio, plates, \&c.

Curt. Gr. Curtis's Grasses, 8vo. plates, \&c.

Still. Stillingfleet's Tracts on Natural History, \&c. 8vo.

Sb. Sibthorp's Flora Oxoniensis, 8vo. 1794.

Ang. Sax. Anglo-Saxon. The derivations are quoted from

Benson's Vocabularium. The curious and learned reader is referred by a distinguished AngloSaxon Scholar, to "Wanleii Cat. Librorum MSS. Anglo-Sax. forming one vol. of Hickesii Thes. p. 72. for a list of one hundred and eightyfour plants, in Greek, Latin, and Saxon," folio.

'Tur. Turner's, and Dillwyn's Botanist's Guide, 2 vols. duod.

B. $\boldsymbol{T}$. Johnson's Flora of Berwick-upon-Tweed. duod.

* One asterisk placed after a habitat, indicates that the plant is rare in the neighbourhood of Oxford. ** Two asterisks, that it is very rare.

* A marginal asterisk, placed before the name of a plant indicates, that it is not truly wild, or probably only naturalized in Britain.

Discrim. Discriminative marks.

Such abbreviations as $\mathrm{Cal}$. for Calyx. $\mathrm{Fl}$. for Flower. Ls. for Leaves. Caps. for Capsule. Bract. for Bractea. Anth. for Anther, \&c. will easily be understood by the student who has previously perused the Introduction to Botany.

$\mathrm{N}$. B. $C h$. in the Linnæan names must be pronounced hard like k: Sch also: thus: Schoénus, is pronounced Skénus.

\section{Directions to the Botanical Student.}

Let the student first master the Introduction to Botany : he will then be enabled to reduce his plant to its Class, Order, Genus, and Species. In examining a plant let him study the specific distinctions, printed in a larger type, before he proceeds to the minuter description, and observations. Let him by no means have recourse to a plate or figure of his plant, before duly examining, and endeavouring to discover the plant under examination, by the description given. After 
ascertaining the name, and uses of any plant, the student may proceed to the study of the Natural Order, referred to in the Second Part of the Introduction to Botany. The Grasses, Cárices, and Umbelliferous plants are too difficult of investigation for the first season. It is desirable to have recourse *o some experienced botanist in pursuing this study: Mr. -axter, of the Botanic Garden, gives able lessons in Botany; and his Generic Plates, with the Plates of Sowerby to English Botany, or those of Gerarde in his Herbal, will prove useful aids to the student; but, in no case, we repeat it, should the student attempt learning botany, by a mere reference to plates. To reap advantage, and to derive satisfaction from the study, he must proceed scientifically, and examine nature herself. He will find the Compendium of Smith's Finglish Flora, bound in the smallest form, a convenient pocket Vade-Mecum.

\section{The following additional books may be recommended to the Student of Natural History.}

White's Selborne.

Journal of a Naturalist.

Drummond's Letters on Natural History. Botany.

Sir James Edward Smith's different Publications, including his Grammar, Introduction to Botany, and English Flora.

Hooker's British Flora, 8 vo.

Lindley's Works.

Loudon's Magazine of Natural History, 8vo.

Paley's Natural Theology.

Duncan's Botanical Theology, 2nd edit. and his "Analogies."

The learned reader, who is desirous of prosecuting his botanical studies further, will find ample catalogues of botanical works, in the first vol. of Decandolle's Regni Vegetabilis Systema Naturale, 1818, and in the volumes of Sir James Edward Smith's English Flora.

The Linnæan Transactions contain many admirable Botanical Papers : a useful selection might, perhaps, be published from that expensive and voluminous work. 


\section{Directions for preparing an Herbarium of dried Specimens, \& \& .}

If plants be properly dried, their different parts may be restored by plunging the specimen in hot water. Dried specimens of plants, with access to the field, the garden, and to books, are obviously requisite to the practical botanist. When a press cannot conveniently be obtained, plants may be dried very well between the leaves of any large folio book, piling up weights and other books to afford the suitable pressure. Should the specimens be crowded, they require frequent shifting; and the moist paper must be dried, before replacing the specimens. Where the paper is abundant, and the specimens few, they require but little, if any shifting. Those vegetables which are very tenacious of life, must be immersed in boiling water previous to drying. In exhibiting the plants to be dried, avoid too formal a display of the several parts, except the single flowers, for shewing a genus, \&c. To prevent heaths, and firs from shedding their leaves in drying, immerse the specimen, previous to drying, in boiling water.

When the specimens become completely dry, they may be glued down; each to half a sheet of small folio paper, and all the species of each genus may be placed together within a sheet of paper, writing the generic name on the outside of each paper of species: the name of each species should be inscribed near the plant. To preserve the Herbárium from depredations of insects, the following poisonous application was strongly recommended by Sir James E. Smith-a solution of corrosive sublimate of mercury, in rectified spirits of wine, about two drachms to a pint, with a little camphor. Apply a small portion of this liquid to each specimen, when it becomes perfectly dry, before gluing down, unless the plant be very delicate. A few drops of the solution may be mixed with the glue. The Herbárium should, of course, be kept from damp, in a dry situation. See Smith's Introduction to Botany.

1 The botanist should be provided with a common pocket microscope, a needle, and a pair of forceps. For minute purposes, Gould's Microscope, sold by Cary, Strand, London, price $£ 116$ s. may be recommended. 


\section{SPECIMEN}

OF $A$

\section{PROPOSED INDEX}

TO THE

\section{OXFORDSHIRE FLORA,}

Indicating the particular station of each plant, as well as the geological character of the spots in which it has been found.

BY

DR. DAUBENY,

PROFESSOR OF CHEMISTRY, OXFORD. 



\section{SPECIMEN，\&c.}

Amongst other suggestions, which the Committee of the British Association for the advancement of Science, at their Meeting in York, in 1831, threw out to the consideration of naturalists, is one to the following effect:-

" That botanists in all parts of Great Britain and Ireland be invited to compose, and communicate to the meetings of the Association, catalogues of county or other local Floras, with indications of those species which have been recently introduced, of those which are rare or very local, and of those which thrive, or which have become or are becoming extinct; with such remarks as may be useful towards determining the connexion which there may be between the habitats of particular plants and the nature of the soils or strata upon which they grow, with statements of the mean winter and summer temperature of the air and water at the highest as well as the lowest elevation at which species occur, the hygrometrical condition of the air, and any other information of an historical, economical, and philosophical nature."

"If," it is observed, "a complete botanical survey of the British Islands could be obtained, the results would be important, when the Flora in the aggregate came to be compared with its relations to soil, climate, elevation, \&c."

It was with the view of accomplishing, with reference to the neighbourhood of Oxford, a part of the objects contemplated in the passage just quoted, that I was led to undertake a sort of Index to the Flora of Oxfordshire, to which the botanical station of each species, and the geological character of each of its habitats, were to be subjoined, in all those cases at least in which the plant was sufficiently circumscribed in its distribution over the district under survey, to render such an attempt either useful or practicable.

An Index of this kind accurately drawn up, might, I con- 
ceive, constitute an appropriate appendage to a Flora of Oxfordshire, but its insertion would be more likely to mislead, than to inform, until the geological habitats of the plants therein enumerated had undergone a more thorough revision, than has as yet been accomplished.

The specimen, therefore, now given of the Index in question, is intended merely to convey such an idea of its construction, as may enable Oxford Botanists, if they please, to co-operate with myself, and with each other, in collecting the data necessary for perfecting the design, so far as this county is concerned; and likewise to engage others in distant parts of Great Britain to draw up Indexes of a similar description to Floras of their own neighbourhood, and thus to realize the views of the Association by acting on one uniform plan.

The utility of such an Index with reference to the Oxford Botanist, is chiefly that of enabling him to perceive at a glance, in what particular soil and situation each plant is here met with, serving, therefore, to abridge the labour of reference, and to keep alive in his recollection the important fact, that a certain, though as yet an imperfectly understood influence is exerted upon plants, by the combined agency of the soil, the air, and the temperature.

But a collection of such Indexes, which should embrace the whole or the greater part of Great Britain, would, as is observed in the Report, serve a more important purpose, by supplying us with the data requisite for determining, what kind of relation may subsist between particular plants, and certain kinds of soil or situation.

In enumcrating the different Stations in which the plants of Oxfordshire are found, I have adopted the classification given by $M$. Decandolle in his admirable Essay on the Geography of Plants, which is inserted in the eighteenth volume of the Dictionnaire d'Histoire Naturelle. The Stations, of which Oxfordshire affords any examples, will, according to this method of arrangement, be nine in number, and though (as Professor Lindley observes in his Introduction to Botany) some of them are rather vague and uncertain of application, yet they seem to comprise the most remarkable differences of station, and, therefore, deserve to be attentively noted. 
The following is the description given by M. Decandolle, and adopted by Professor Lindley, of the classes of plants, distinguished according to the station in which they occur :-

1. Aquatic plants, living plunged in fresh water; either entirely immerged, as confervæ; or floating on its surface as stratiotes; or fixed in the soil by their roots, with the foliage in the water, as several kinds of potamogeton; or rooted to the soil, as nymphæa; or rising above it, as alisma Plantago. This latter division approaches very near to the following class.

2. Plants of fresh rwater marshes, and of very rot places, among which it is chiefly necessary to distinguish, those of bogs, of marshy meadows, of the banks of running streams, and finally, of places inundated in winter, but more or less dried up during the summer.

3. Plants of meadores and pastures, in the study of which it is chiefly necessary to distinguish, those, that being collected together either by art or nature constitute the turf of the meadow, and those others, which grow with greater or less abundance and facility intermixed with the foregoing.

4. Plants of cultivated soil, many of which have been accidentally transplanted from one country to another with the seeds of other plants intentionally introduced.

5. The plants of rocks, which pass by insensible gradations into those of walls, of stony places, and even of gravel, and these again into those of sands or of very barren soil. For my pre-sent purpose I have thought it sufficient to place the whole of these in the same class.

6. Plants occurring near droelling places, in consequence of requiring for their nutriment a supply, either of nitrous salts, or of azotised matter. These consequently frequent the haunts of man, and abound in and about rubbish containing animal matter in a state of decomposition.

7. Forest plants, among which are to be distinguished; 1 stly, the trees that form the forest; and 2ndly, the herbs which grow beneath its shade. The latter are separated into two kinds : those which can support a considerable degree of shade during all the year, which are found in evergreen woods; or such as require light in the winter, like those which are found among deciduous trees. 
8. Bushes and hedge plants. The shrubs which compose this division differ from the plants of the forest in their smaller size, and in the thinness of their leaves; the herbaceous kinds that grow among them are ordinarily climbing plants.

9. Parasitical plants; that is to say, such as either absorb the cambium already elaborated from the liber of the plant on which they feed; or merely derive the ascending sap from the latter, converting it into nutriment themselves. The former are destitute of leaves; the latter provided with these organsthe former require only to plant their suckers into the bark of the vegetable which supports them; the latter must insert them into the alburnum or new wood. Such at least are M. Decandolle's distinctions, with which Professor Lindley appears to coincide. Both, however, separate from the class of true parasites, those, which, like the common ivy (Hedera Helix,) grow upon either dead or living vegetables, without deriving any nourishment from them: Decandolle denominating these latter, false parasites, Lindley, epiphytes, and such as these may be conveniently thrown into the class either of forest or bush plants, according to the kind of station which they affect.

These then are the botanical stations which I propose to distinguish in my intended Index; with regard to the habitats of the plants that occur within the limits of this Flora, I conceive, they may be placed with sufficient accuracy in one of the last five columns, distinguished according to the geological character of the substratum. The country comprehended within these limits includes indeed the whole range of strata from the lyas to the tertiary clays, besides various diluvial and alluvial formations; but it does not seem likely, that any decided difference in the character of the vegetation should occur between one kind of clay or sand, and another, merely on account of the distinction in their relative ages, unless some corresponding variation can be detected in their chemical or mechanical condition. I have, therefore, thought it sufficient to divide the soils of Oxfordshire into five classes; 1stly. the gravelly, which, as it consists chiefly of the débris of limestone rocks, may be regarded perhaps only as a modification of a calcareous soil. 2ndly. the oolitic, of which the neighbourhood of Oxford, where the substratum is not covered 
with gravel, principally consists. 3rdly. the chalky, which as it is composed of a purer and softer form of limestone, deserves to be distinguished from the oolitic. 4thly. the argillaceous, such as the Oxford or Kimmeridge clays, together with any other that may occur within the district, distinguishing as much as possible such as are covered with calcareous gravel; and 5thly. the arenaceous, of which the rock at the summit of Shotover-Hill affords an example.

As, however, the description of plants that grow on any one of the above rocks must be supposed to vary with the character of the soil, and as the latter may not in all cases be identical with the substratum, it would be useful to notice every such case of discrepancy by introducing a separate series of columns for the soils, or at least by appending a note at the bottom of the page in which the plant is noticed, with an asterisk refering to the locality mentioned in the column above, in which the plant is stated to occur.

The following Specimen taken from the first page of the Index will serve to illustrate the method I have adopted, and may, therefore, perhaps deserve insertion, though the geological localities even of the few plants given require further examination, before they can be looked upon as ascertained.

Where nothing further has been remarked with respect to the habitudes of a plant than its occurrence in one of the Slations above enumerated, an horizontal line in the column opposite to its name has been deemed sufficient to indicate the fact: but in other cases, where the nature of the situation congenial to it has been more particularly ascertained, the same is indicated in the above position. Thus opposite to Ranunculus repens, in the third column, an horizontal line is affixed, in order to shew that it has merely been remarked, that meadows and pastures are the spots most favourable to its growth; whilst opposite to R. bulbosus the particular kind of meadow-land, which it chiefly affects, will be seen specified.

In conclusion I ought to repeat, what indeed has before been stated in other language, that the principle on which this Index is constructed proceeds not upon the existence of an acknowledged connection between soil and vegetation, but 
on the admission of the best botanists, such as Decandolle and Lindley, that much may at present be said on both sides of the question, ${ }^{1}$ and that the subject is one of sufficient interest, to induce botanists, to bestow upon it the labour requisite for its more complete elucidation.

1 Some remarks in favour of the supposed connexion between the vegetation and the geological character of the substratum, may be seen in Loudon's Magazine, by W. Thomson, and a reply to them in Jameson's New Philosophical Journal, vol. ii. for 1830, by D. A. Murray, of Aberdeen. 

on the admission of the best botanists, such as Decandolle and Lindley, that much may at present be said on both sides of the question, ${ }^{1}$ and that the subject is one of sufficient interest, to induce botanists, to bestow upon it the labour requisite for its more complete elucidation.

1 Some remarks in favour of the supposed connexion between the vegetation and the geological character of the substratum, may be seen in Loudon's Magazine, by W. Thomson, and a reply to them in Jameson's New Philosophical Journal, vol. ii. for 1830, by D. A. Murray, of Aberdeen. 
SPECIMEN OF A PROPOAED INDEX TO THE FLORA OF OXFORDSHIRE, \&E.

NAME, \&. .

Class Docotgledonew

Vamily ist-Ranunculaceas.

Gen. Clomatis (Polyanel. Polyg 1 ..

1 Vitulita

(: Thalictrum (Pohs anus. l'aly: )

1. llav um

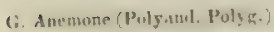

1. Pulsatilla.

: nenurriga

(4) Adens (Polyand L'ulye)

1. autumaals.

c. Myosurus (Pent. Polyg.)

1. minimus.

G. Ranunculus (Polyand. Polys)

1 bederaceus

2 aquatilis.

3. Liogua

4. Flammuia

6. вurscotaus.

6 sceleratus

7. acrns

8 repens

9. bulboaus

10. Lursutus.

11 atvensis

12. pervitlorus.

13 Ficaria.

(i) Cal tha :Polyand. Polyg )

1. palustrin.

G Helleborus (Polyand. Polyg.) 1 viridis.

2. toetsdus.

0. Aquilogıa.

1 vulgara.

STATION

แ

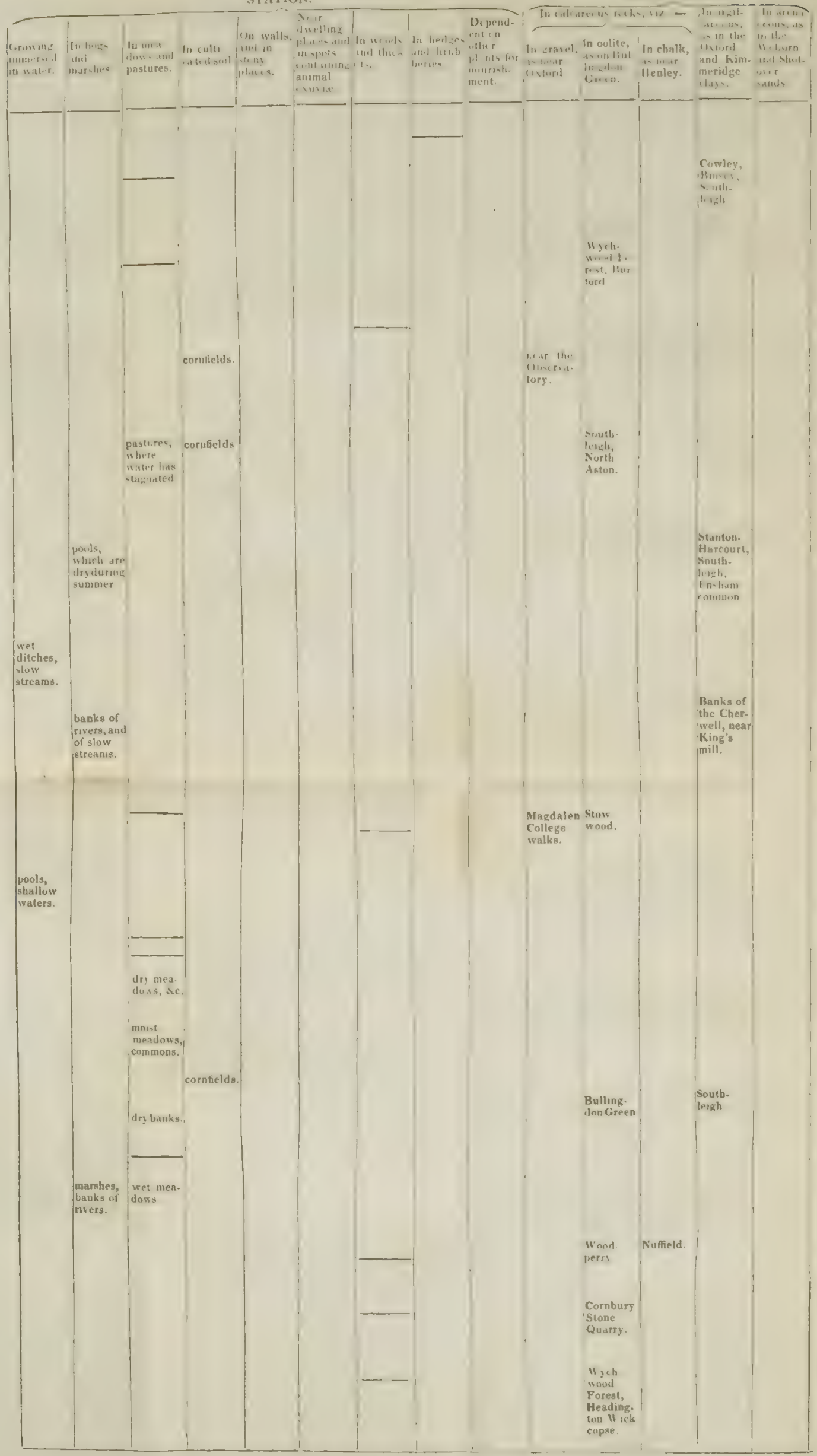





\section{EXPLANATION OF THE PLATES.}

\section{PLATE I.}

Fig. 1. Fibrous root.

2. Creeping root.

3. Tapering, or spindle-shaped root.

4. Tuberous, or knobbed root.

5. Abrupt root.

6. Solid bulbous root.

7. Coated bulbous root.

8. Scaly bulbous root.

9. Granulated root.

10. Forked, or dichótomous stem.

11. Creeping stem.

12. Clinging stem.

13. Twining stem.

14. Jointed, (articulated,) stem.

15. Scaly stem.

\section{PLATE II.}

16. Jointed stem.

17. Knotted stem.

18. Kneed, (geniculated,) stem.

19. Scape, flower-stalk, and leaves immediately from the root, (radical.)

\section{LEAVES.}

20. Stalkless, (sessile.)

21. Stalked.

22. Alternate.

23, 24. Stem, (cauline,) leaves.

23. Also opposite.

24. Also scattered. 
Fig. 25. Clustered.

26. Whorled, (verticillated.)

27. Tufted, (fasciculated.)

28. Tiled, (imbricated.)

29. Cross-paired, (decússated.)

30. Embracing, (amplexicaul.)

31. Growing together, (connate.)

32. Perfoliate.

\section{PLATE III.}

33. Equitant.

34. Running down the stem, (decurrent.)

35. Target-shaped, (peltate.)

36. Egg-shaped, (ovate,) entire, and blunt.

37. Oval, or elliptical.

38. Battledore-shaped, (spatulate.)

39. Wedge-shaped, (cúneiform.)

40. Spear-shaped, (lanceolate.)

41. Linear.

42. Triangular.

43. Kidney-shaped, (reniform,) and entire.

44. Heart-shaped, (cordate.)

45. Arrow-shaped, (sagittate.)

46. Halbert-shaped, (hastate.)

47. Wing-cleft, (pinnatified;) fig. not good.

48. Lyre-shaped, (lyrate.)

49. Rúncinate.

\section{PLATE IV.}

50. Comb-like, (péctinate.)

51. Cleft.

52. Lobed.

53. Hand-shaped, (palmate.)

54. Abrupt, (truncate,) lopped.

55. Bluntly notched at the end, (retuse.)

56. Notched, (emarginate,) at the end.

57. Sharp, (acute.)

58. Taper-pointed, (acuminate.) 
Fig. 59, Bristle-pointed.

60. 'Toothed, (dentáted.)

61. Saw-toothed, (serráted.)

62. Notched, (crenate.)

63, 171. jagged, (laciniated.)

64. Fringed, (ciliáted.)

65. Prickly, (spinous.)

67. Veined.

\section{PLATE V.}

68. Ribbed.

69. Plaited, (plicate,) folded.

70. Channelled, (canaliculate.)

71. Keeled, (carinate.)

72. Awl-shaped, (súbulate.)

73. Fingered, (digitate.)

74. In pairs, (binate.)

75. In threes from the same point, (ternate.)

76. Bird-footed, (pedate.)

$77,80,84$. Winged, (pinnate, in a lyrate manner, with an odd leaflet; leaflets opposite.

78. Winged, (pinnate,) with a tendril, leaflets opposite.

79. Abruptly winged, (pinnate;) leaflets opposite.

80. Alternately winged, (pinnate.)

81. Thrice-paired, (trigeminate.)

82. Doubly three-fold, (biternate.)

170. Triply three-fold, (thrice-ternate,) (triternate.)

83. Twice-winged, (bipinnate.)

( $73,74,75,76$, compound.) $(82,83$, thrice-compound.)

84.* Stipula (below the leaves.)

\section{PLATE VI.}

85, a. 86, a. Floral-leaf, (bractea.)

87. Sheath, (spatha.)

88. Involucre.

89, a. Common involúcre, at the base of the common, (or universal,) umbel. $\quad b$. Partial involúcre, at the base of its partial umbel.

00, 78. Tendril. 
Fig. 91. Thorn, or spine.

92. Prickle.

93. Whorl, (verticillus.)

94, 95. Spikes.

94. Uniláteral, (spike,) growing from one side only.

96. Spikelet, with awns.

97, 98. Raceme, (cluster.)

99. Corymb.

100. Bundle, (fascículus,) fáscicle.

101. Head, (capítulum.)

102. Simple umbel.

103. Cyme.

\section{PLATE VII.}

104. Panicle.

105. Catkin.

106. Four seeds in the bottom of a calyx, as in the class Didynámia Gymnospermia.

107. Seed vessel, and calyx, as in Didynámia Angiospermia.

108. $a$. style, with six stamens.

109. $a$. the corolla. $b$. the calyx.

109. Perianth, or calyx, properly so called, 109, b. 110, $\alpha$.

111. Double calyx.

112. One-leaved, (monophyllous,) calyx.

113, 114. Tiled, (imbricated,) calyx.

113. Spherical, globose, or globular ealyx.

114. Hemispherical calyx.

115. Scales of the catkin, (105.)

116. Outer husk, or chaff-scale. $b . b$. husks.

117. One-petalled, (monopétalous,) corolla, (salver-shaped,) $a$, the tube. $b$. the limb.

118. Túbular corolla.

119. Spherical, or globose corolla.

120. Bell-shaped, (campánulate,) corolla.

121. Cup-shaped corolla.

122. Funnel-shaped, (infundibuliform, corolla.

123. Gaping, (ringent,) corolla, (irregular.) 


\section{PLATE VIII.}

Fig. 124. Masqued, (personate,) (corolla, lips not shewn closed,) (irregular.)

125. Petal of a many-petalled, (polypétalous,) corolla. $a$. thr claw. $b$. the border, or lámina.

126. Cross-like, (cruciform,) corolla, regular.

127. Rose-like, (rosaceous,) corolla, regular.

128. Butterfly-like, (papilionáceous,) corolla.

129. Standard, (vexillum.)

130. Wings, (alæ.)

131. Keel, (carína.)

132. Spur.

133. $a$. filament. $b$. anther, erect.

134. Incumbent anther.

135. Lateral anther, (on one side.)

136. $a$. the germen. $b$. the style. $c$. the stigma.

137. Capsule.

138. Pod, (silique.)

139. Pouch, (sílicle.)

140. Pod, (legume.)

PLATE IX.

141. Nut.

142. Stone-fruit, (drupe.)

143. Apple, (pome.)

144. Berry.

145. Compound-berry.

146, 147. Cone, (stróbilus.)

148. Two cotylédons. $a$. embryo. $b$. rostellum. $c$. the ascending part.

149. Simple seed-down, (pappus,) stalkless, (sessile.)

150. Feathery seed-down, (pappus.)

151. Stalked seed-down.

152. Tail of the seed.

153. Wing of a seed.

154. Flat receptacle.

155. Conical receptacle. 


\section{PLATE $X$.}

Fig. Verónica Chamædrys. See Flora, p. 5.

\section{PLATE XI.}

157. A slit vessel, or false spiral magnified.

158. The slit vessel, or false spiral magnified.

159. Portion of a porous vessel magnified.

160. Porous vessels.

161. Beaded, (moniliform,) vessels.

162. Portion of the epidermis, to shew the cortical pores.

163. Regular céllular tissue.

164. Spiral vessel, or trachéa.

165. Example of the class Gynándria, (passiflóra,) after Linnæus: since removed to other classes. See Hort. Kewensis, \&c.

166. Example of the order Polygy'nia.

167. A winged stem, as in the everlasting pea.

168. Portion of the trunk of a monocotylédonous tree, formed of bundles of woody fibres, scattered in the midst of medullary, (pithy,) substance.

169. Portion of the trunk of a dicotylédonous tree, composed of concentric layers : $a$. the bark. $b$. the alburnum, or false wood. c. the wood, properly so called. $d$. the medullary, (pith,) canal.

170. Thrice-ternate, or triply-three-leaved, (triternate.)

171. Jagged, (laciniate.)

172. Thyrsus, (bunch.)

173. Capsule, $a$. the valves. $b$. the dissepiments, (partitions.) $c$. the columella, (column.) d. receptacle of the seeds.

\section{PLATE XII.}

174. A germinating kidney-bean, with its shooting radicle.

175. $a$. the radicle. $b$. the caulicle. c. c. the gemmule.

176. Section of a kidney-bean, $a$. the radicle. $b$. the gemmule. $c$. one of the cotylédons.

177. $a$. the radicle. $b . b$. the cotylédons.

178. $a$. the hilum, (scar.) b. the micropile.

179. Seed of the castor-oil seed, (rícinus,) cut lengthways, $\boldsymbol{a}$ the carincula. h. the endosperm. $d$. the embryo. 


\section{EXPLANATION OF THE PLATES. Ixxxvii}

Fig. 180. The embryo separated from the interior of the albumen. $a$. the radicle. $b . b$. the cotylédons. $c$. the gemmule.

181. The embryo of 182, (Canna indica,) separated: $a$. the cotylédon. $b$. the gemmule enclosed in the cotylédon, which in growing, pierces the cotylédon laterally, and becomes $b ; c$. the radicle enclosed in the coleorhízon, (root-sheath,) which it must pierce at $c$, in order to sink into the earth.

182. A seed of the Indian shot, (Canna indica,) cut lengthways : $a$. its episperm. $b$. its endosperm. $c$. its monocotylédonous embryo.

183. Tríticum sativum, (wheat,) its monocotylédonous embryo being laid bare.

184. Two incumbent cotylédons, and rootlet, (radicle.) $\boldsymbol{B} x$.

185. Section of incumbent cotylédons, and rootlet, (radicle.) $B x$.

186. 187. Two accumbent cotylédons, and rootlet. 187. Section of the same. $B x$. See Fig. 189, and 191.

188. Dog-rose, (rosa canína,) several paríetal óvaries attached to the side or (wall) of a monosépalous, pitcher-shaped, (urcéolate,) calyx.

189, 191. Two-folded incumbent cotylédons, and rootlet. 191. Section of the same. $B x$.

190. Hypógynous stamens, that is, inferior, inserted beneath the germen. (See Fig. 193, 194, 195, and 197.)

191. (See back.)

192. A kidney-bean, which has germinated: $a_{0}$ the radicle. $b . b$. the two cotylédons, which are become séminal, (seed,) leaves. $c$. the stem. $d . d$. the leaflets of the gemmule, forming the two (first) or primordial leaves.

193. Perigynous stamens, borne by the calyx.

194, and 197. Perígynous stamens, borne by the corolla.

195. Epigynous stamens, that is, stamens inserted above the germen, (in the common snow-drop,) Galanthus nivális.

196. From Lindley; " $a$. Plants that have but one cotylédon, or if two, then the cotylédons alternate with each other, are called Monocotyledonous."

196. *Strap-shaped, (lígulate,) floret of a compound flower. $196^{*}$, the strap-shaped corolla. $f$. the germen. $g$. the anthers forming a hollow cylinder, through which the pistil passes, with two reflected stigmas.

197. See back, under fig. 194.

198. Pericarp with loculicídal dehiscence, (opening.) See Lind- 
Ixxxviii EXPLANATTON OF THE PLATES.

ley's First Principles of Botany, p. 81. s. 435. 1830. duod.

Fig. 198.*'Túbular floret. $d$. corolla. c. germen. $f$. pistil.

199. Pericarp with septicidal dehiscence, (opening.) See Lindley's First, \&c. p. 80. s. 433.

200. $c$ c . the cotyledons. $b$. the plúmula, or gemmule. $a$. " the neck, or line of separation between the radicle and the cotylédons." Lindley. 200. The radicle, (or rootlet.) 


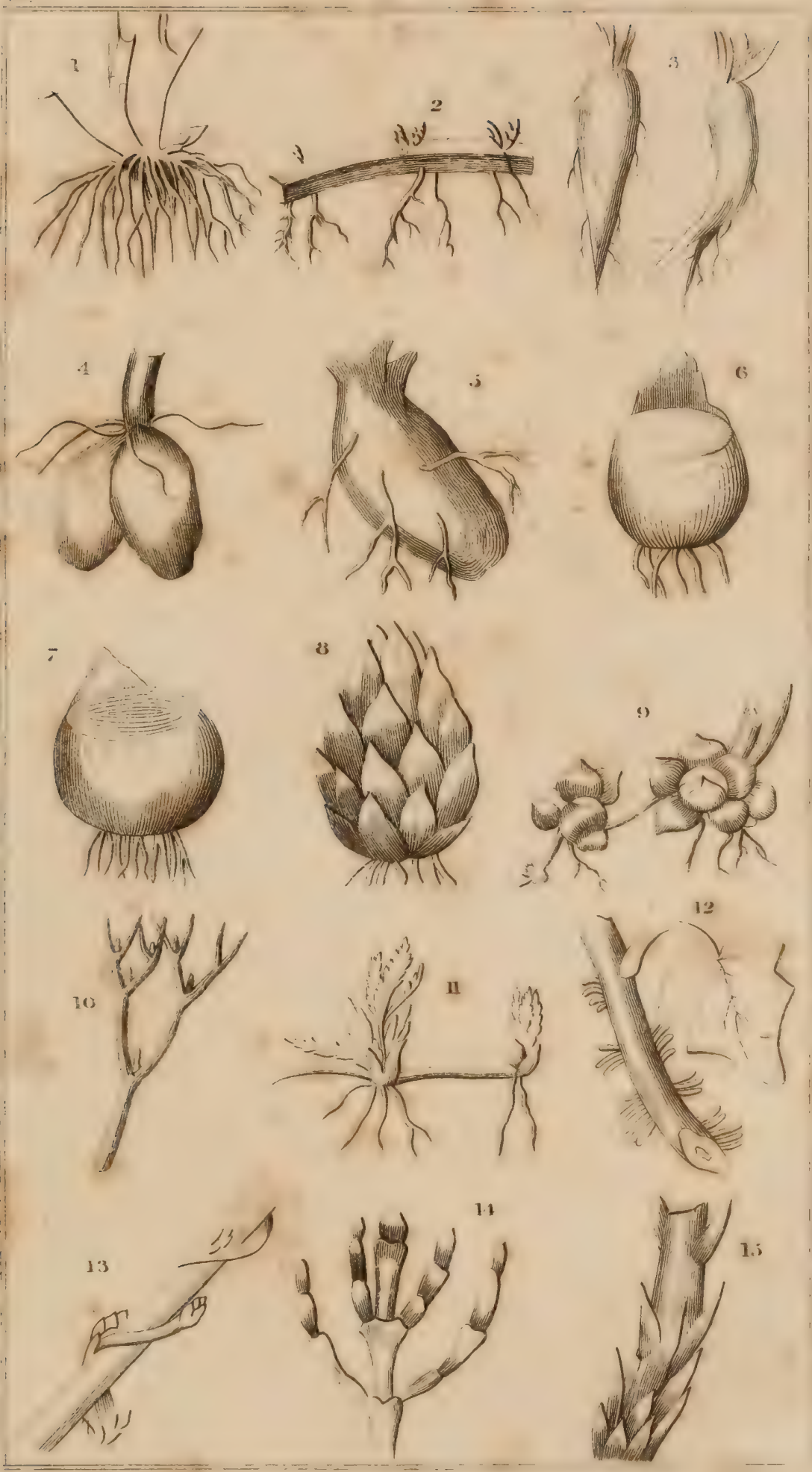




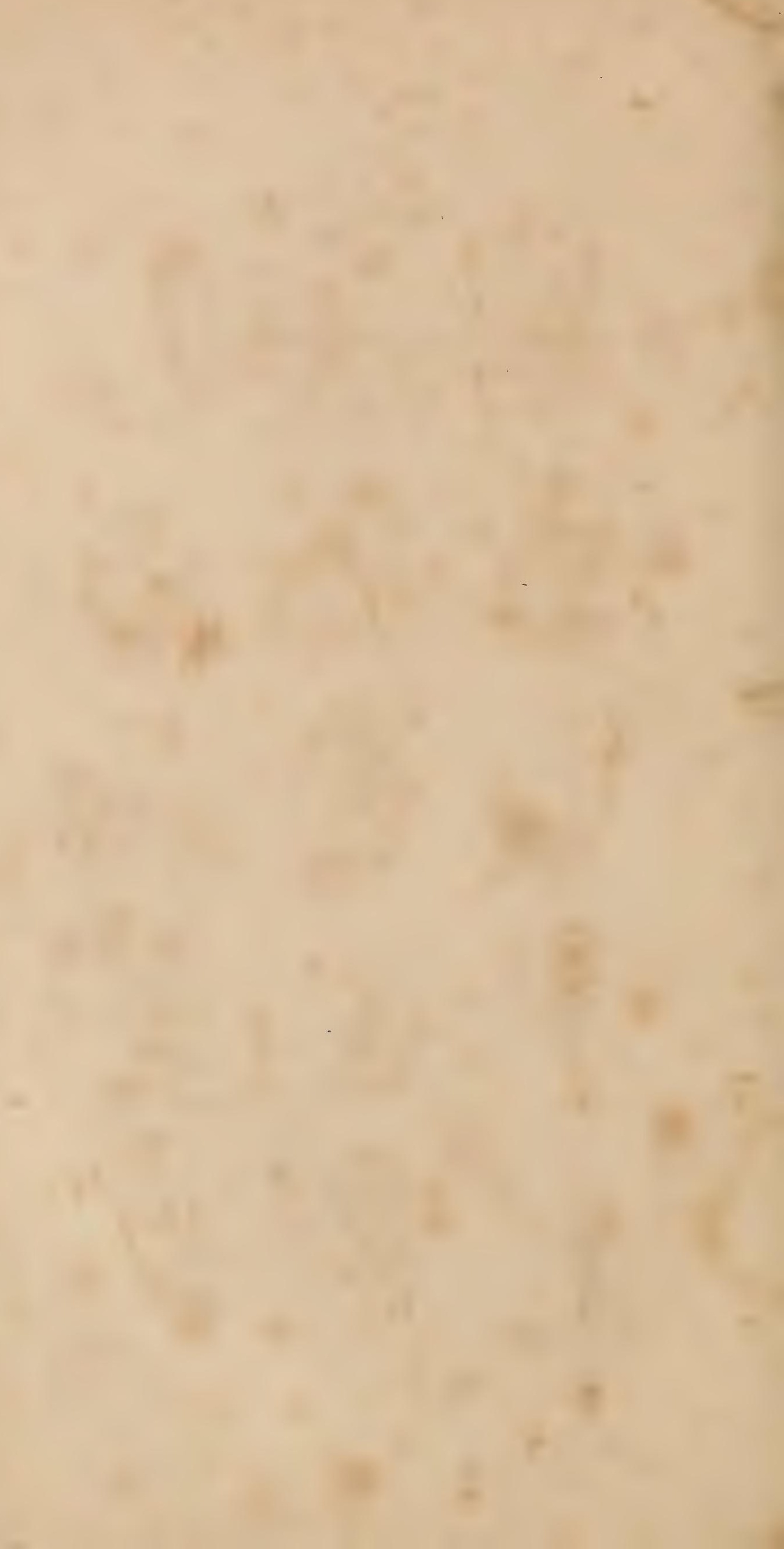




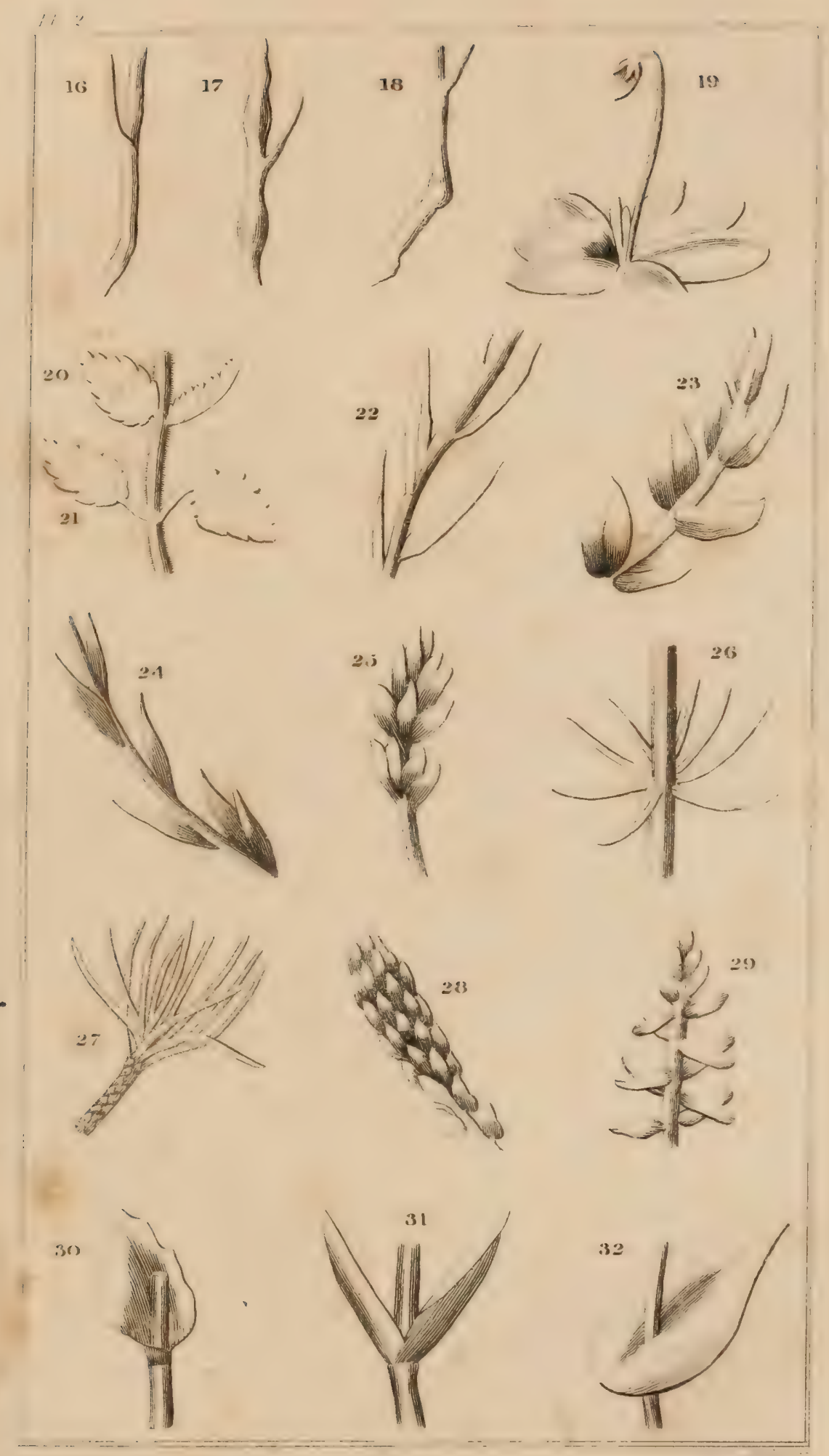





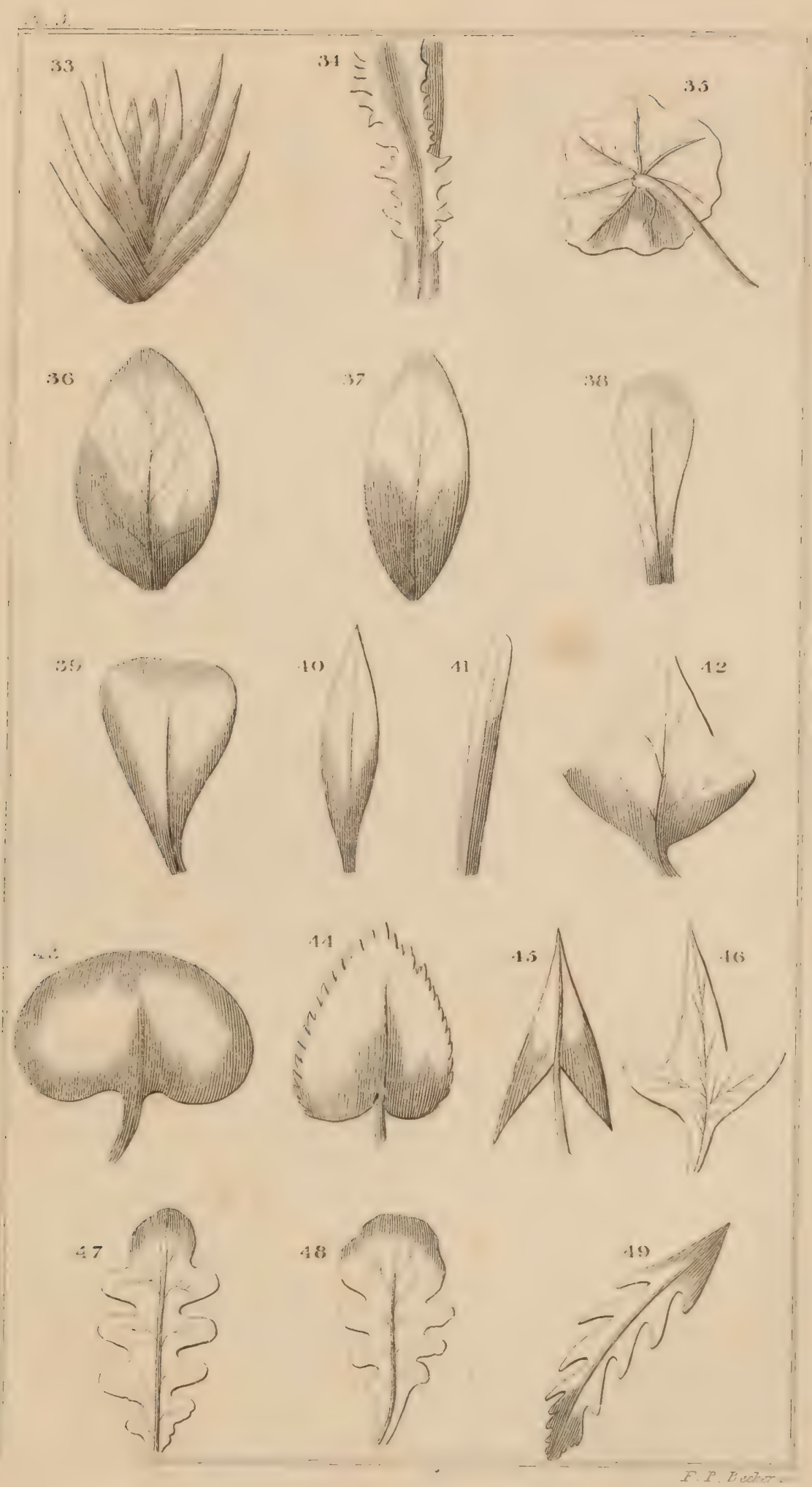




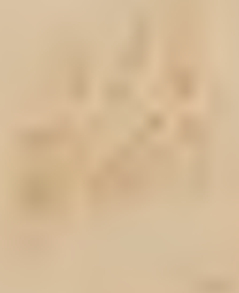

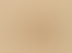




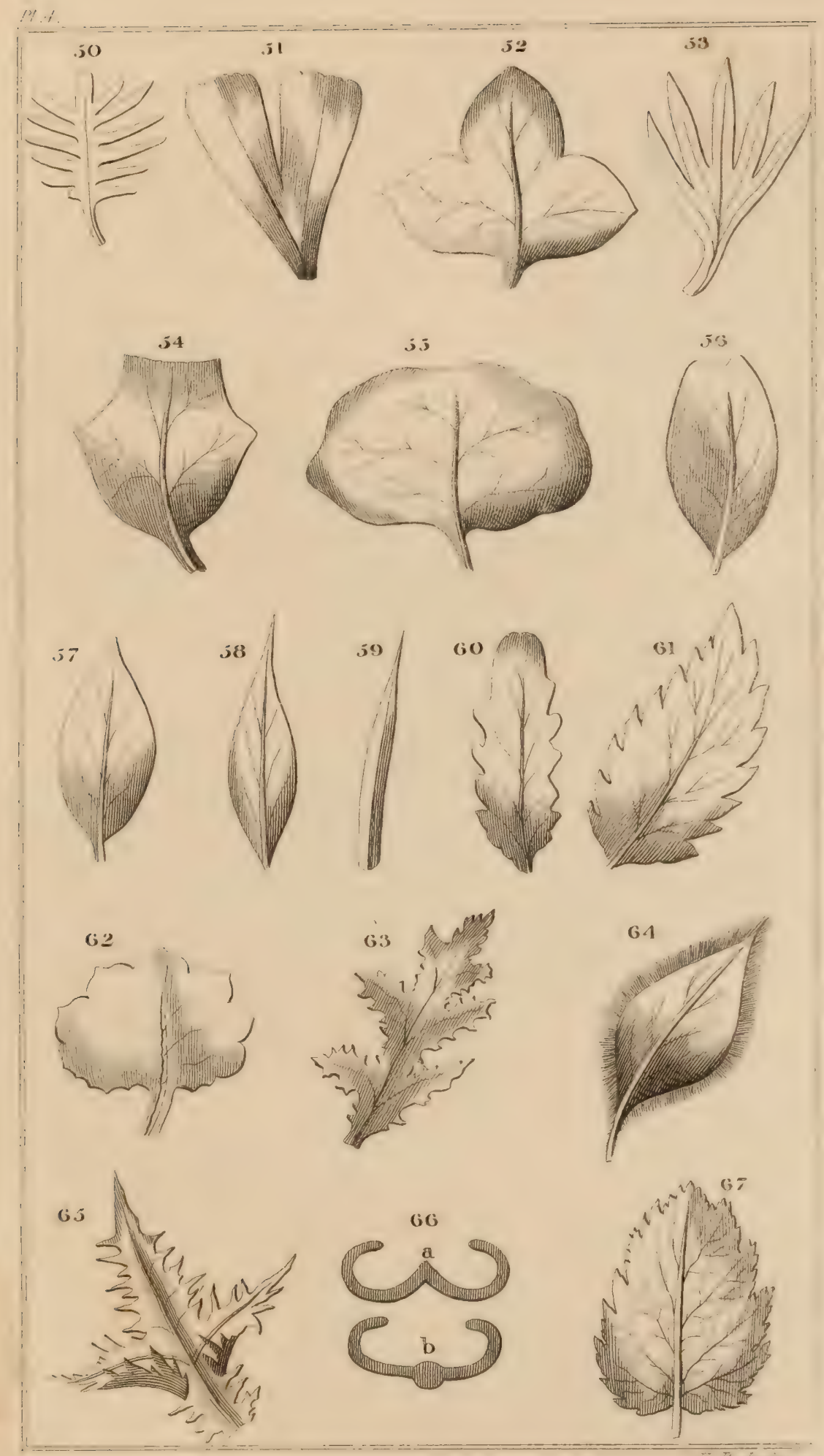





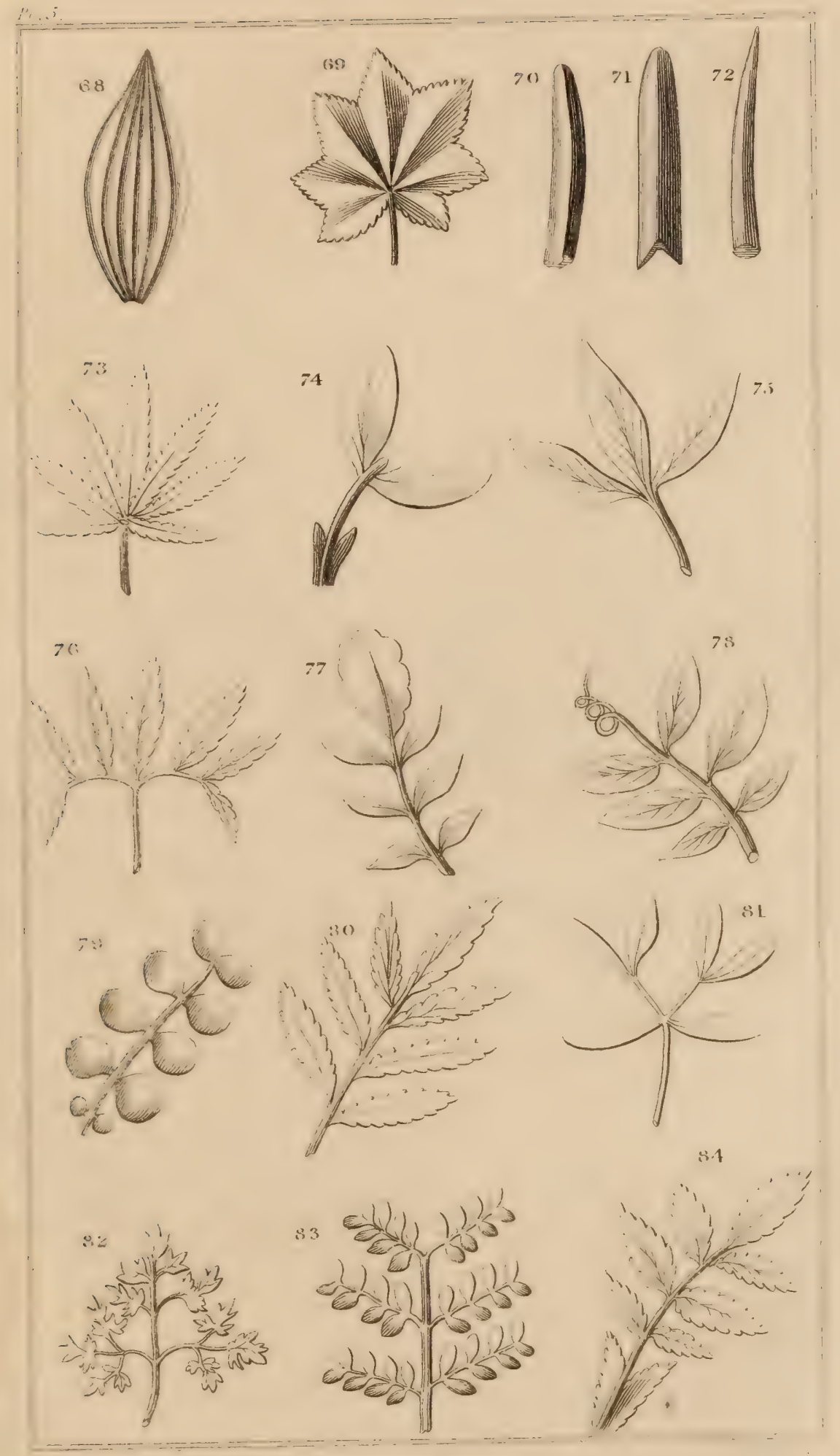





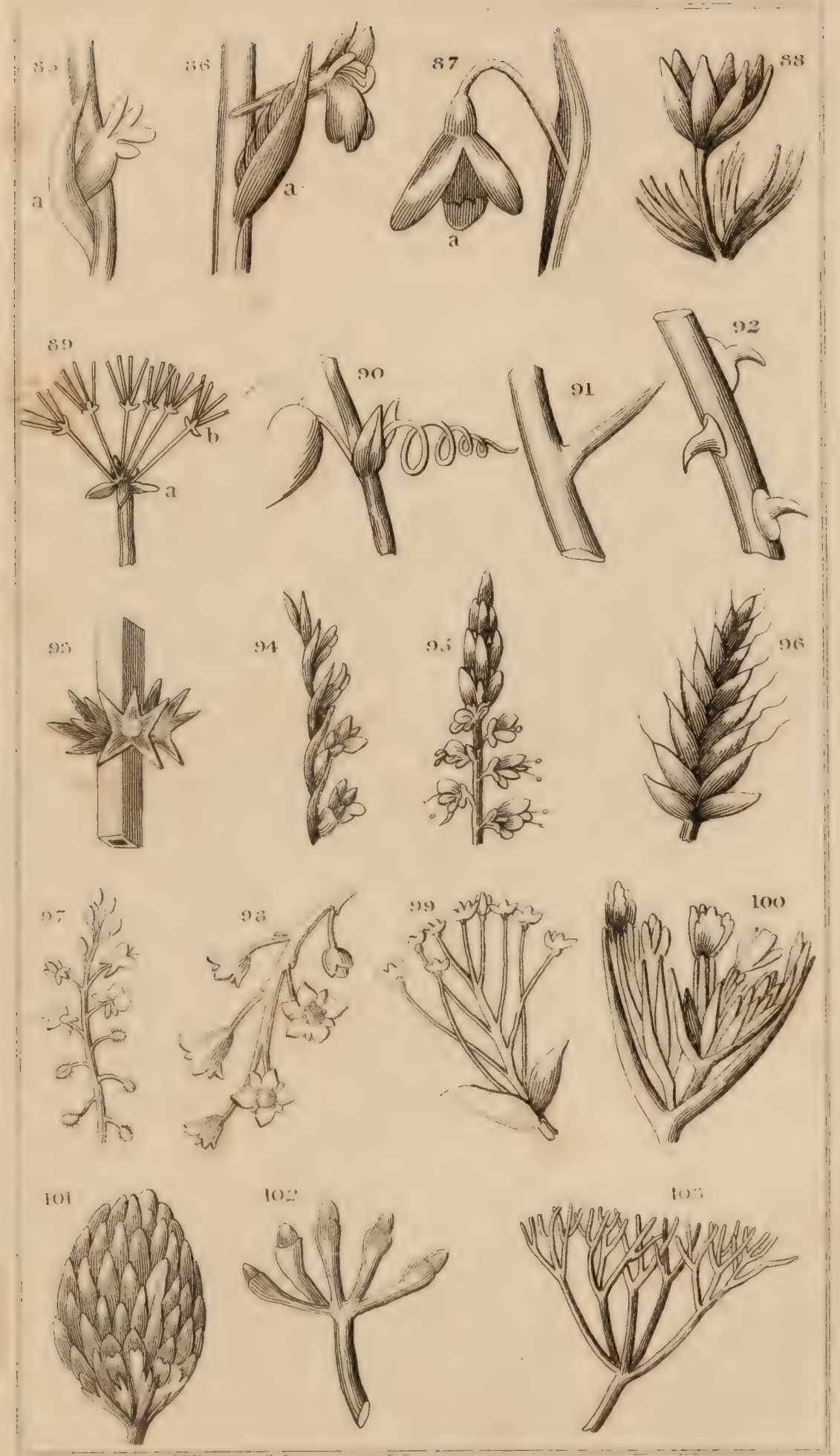





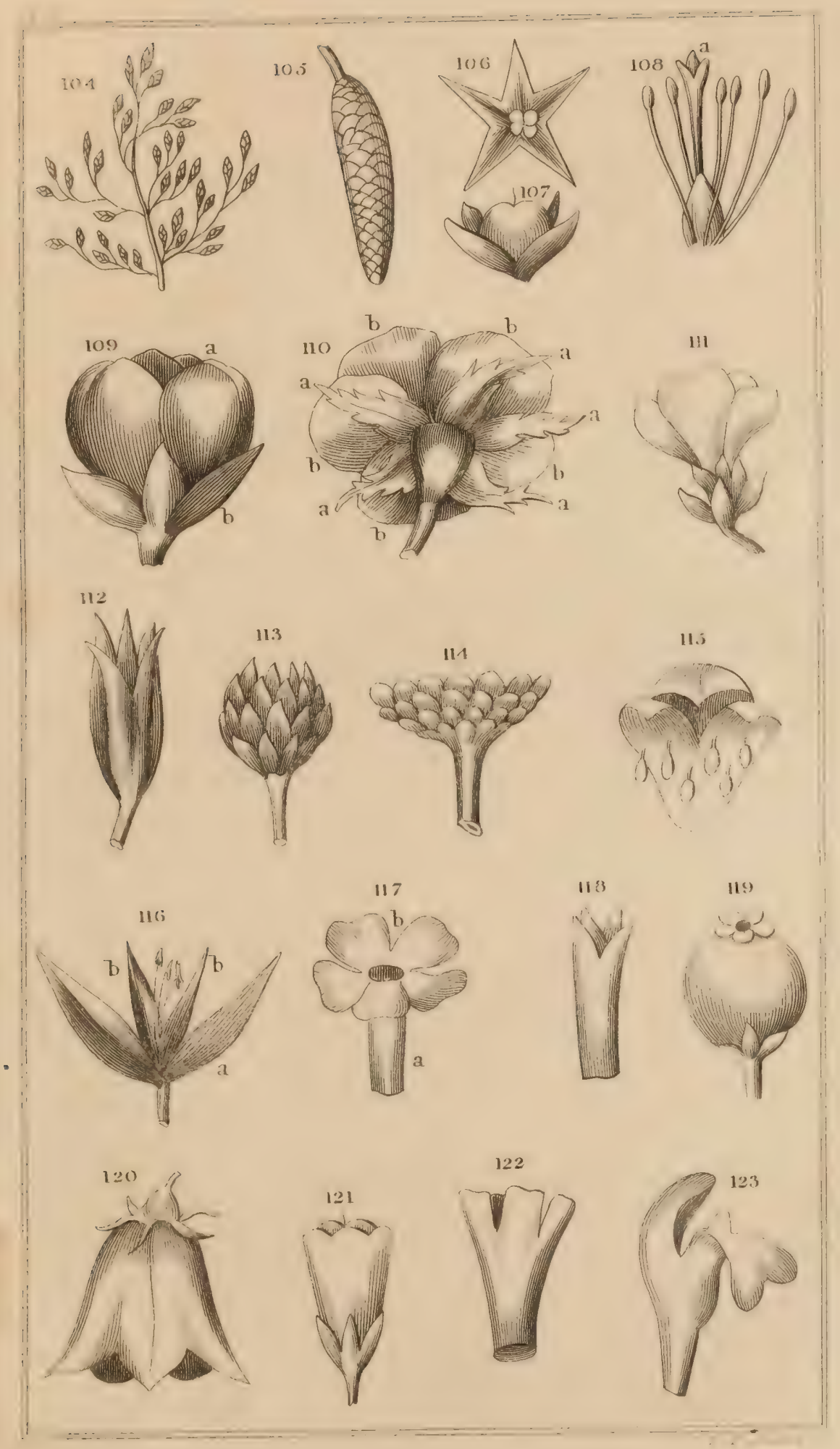





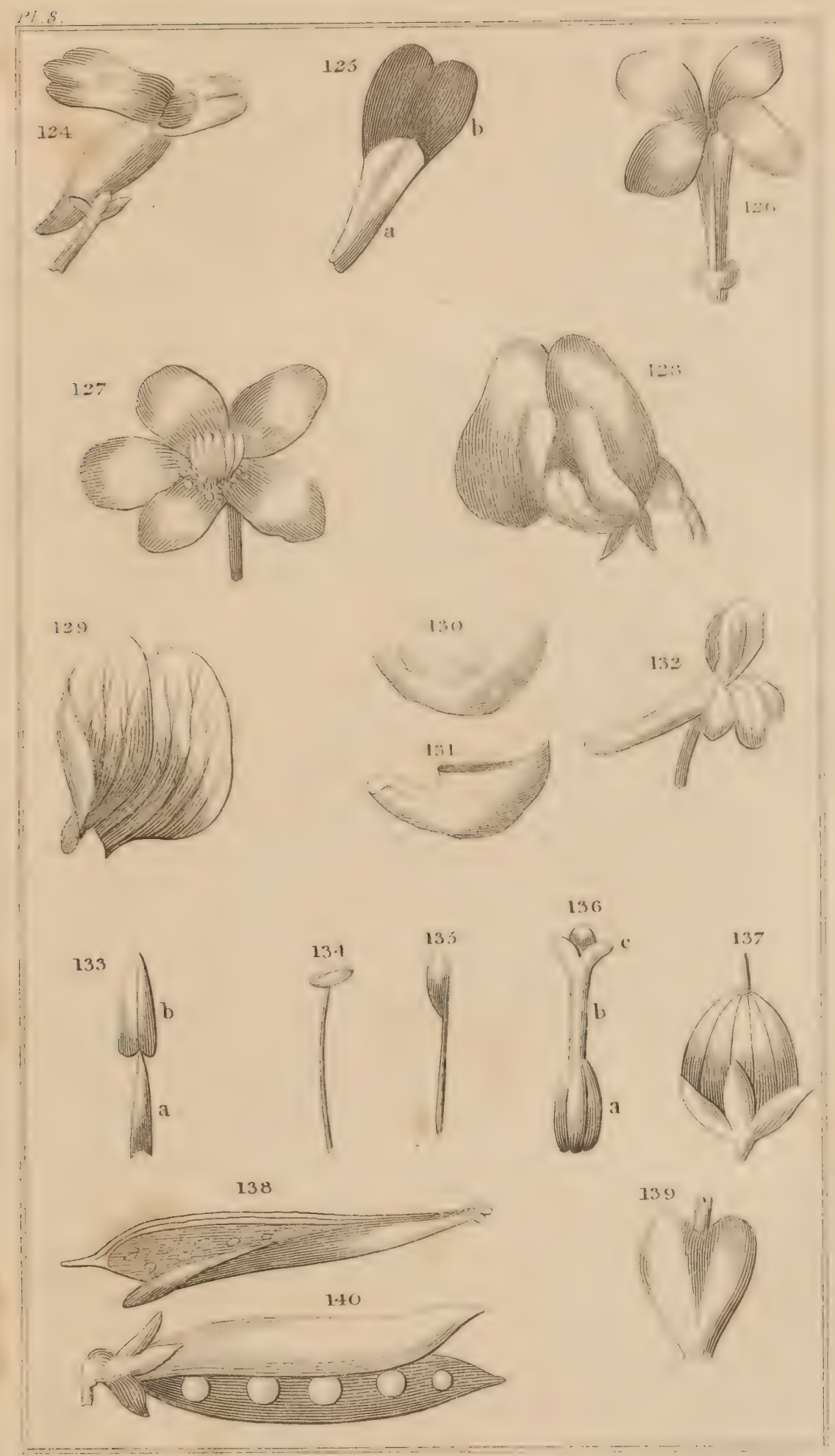



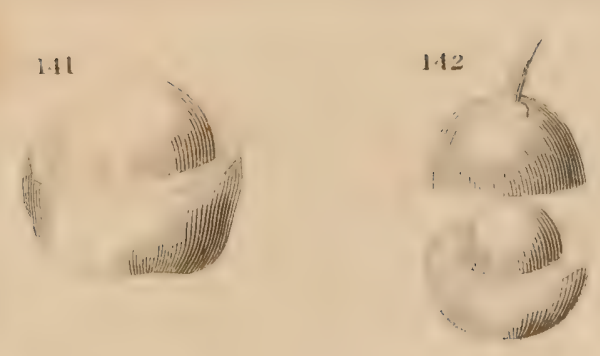

$11: 3$
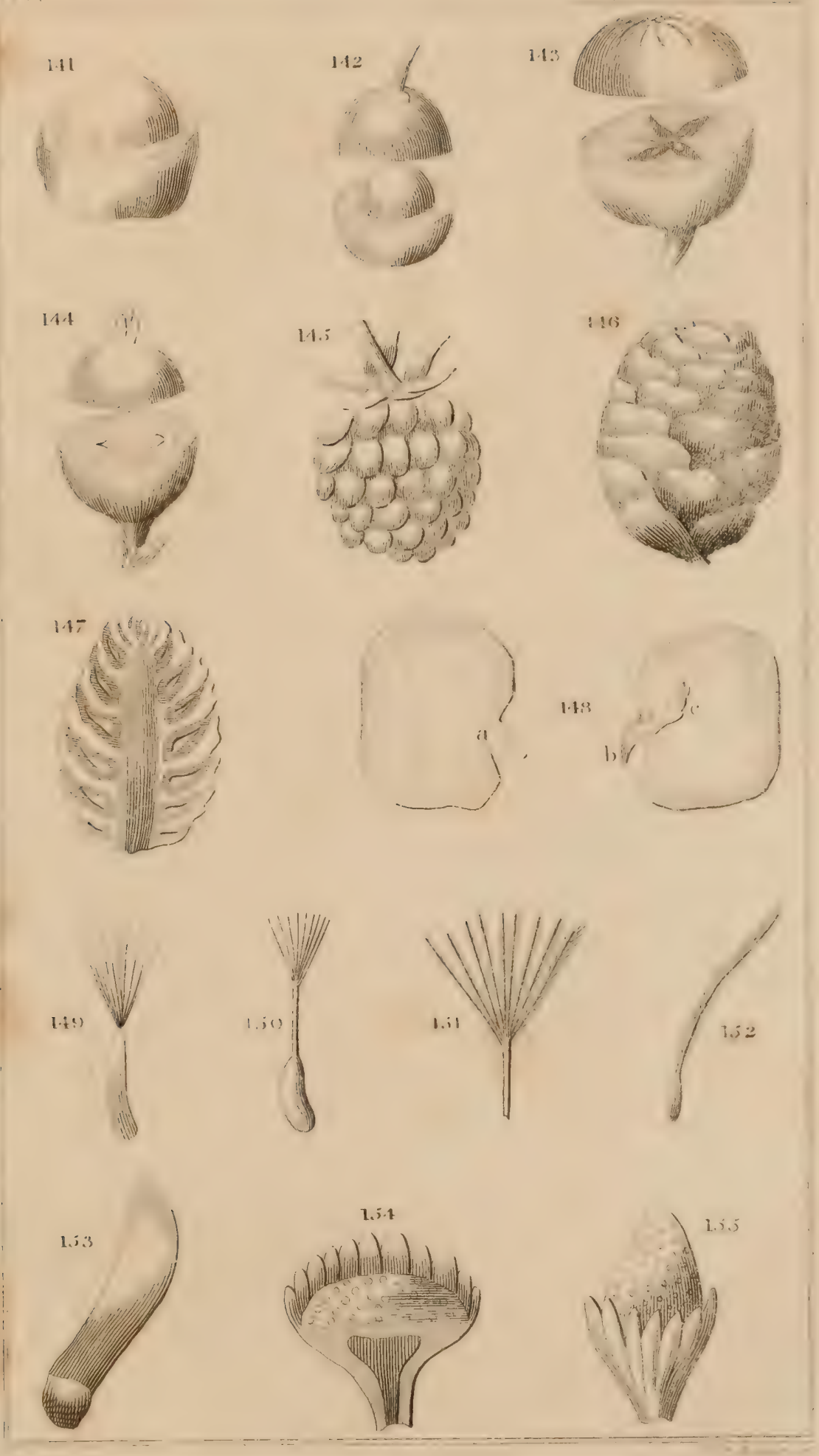



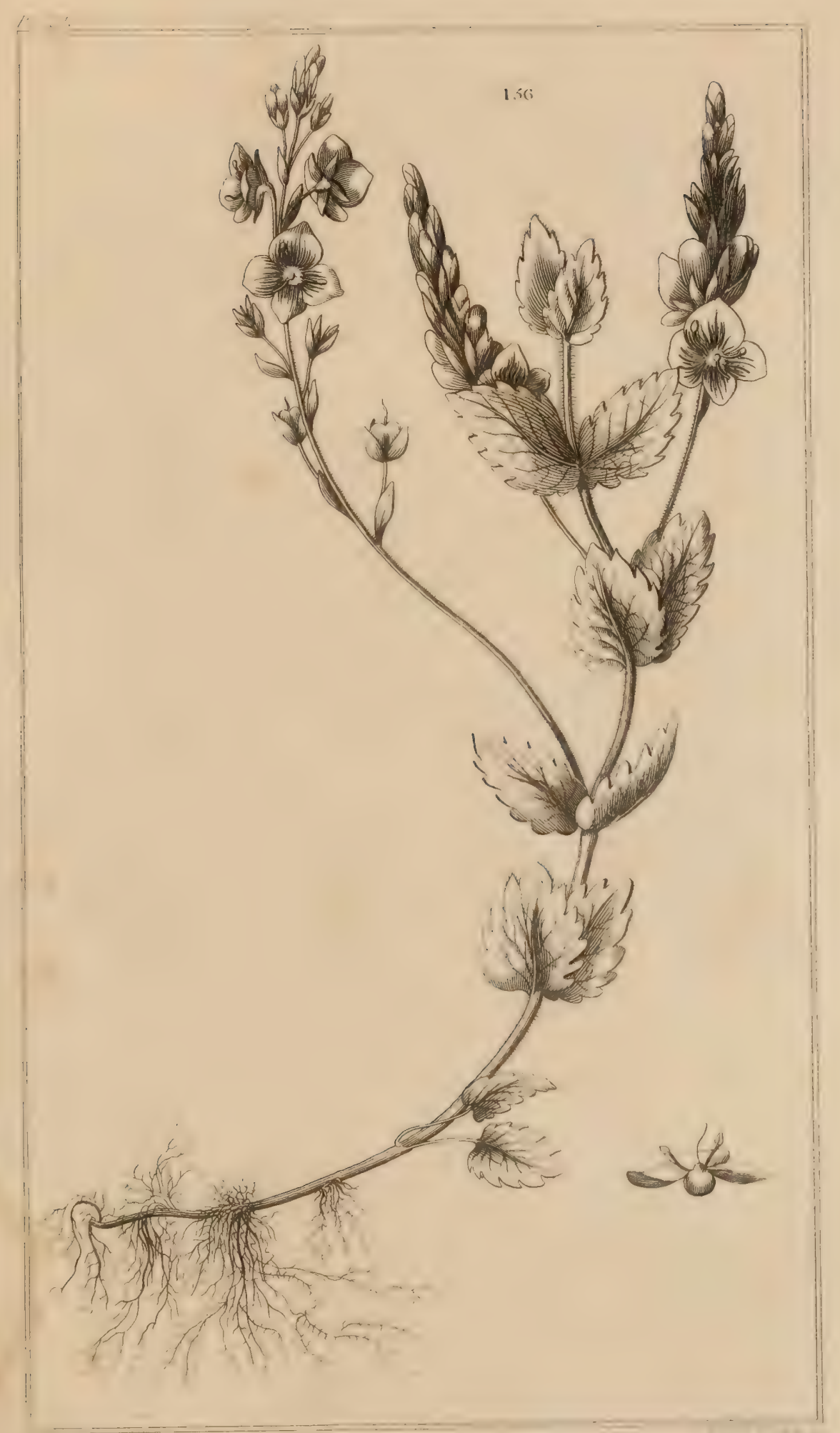


, 


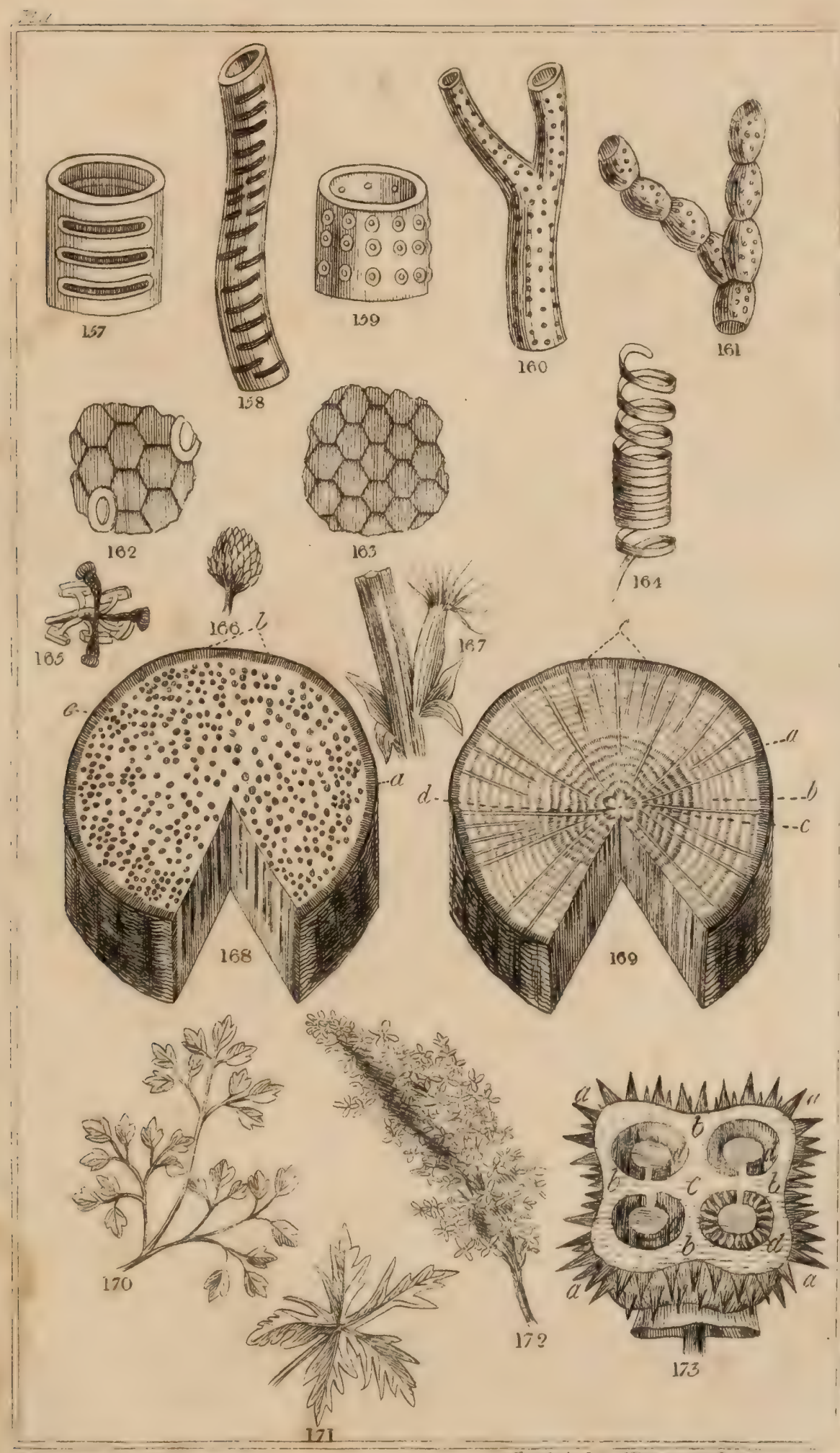





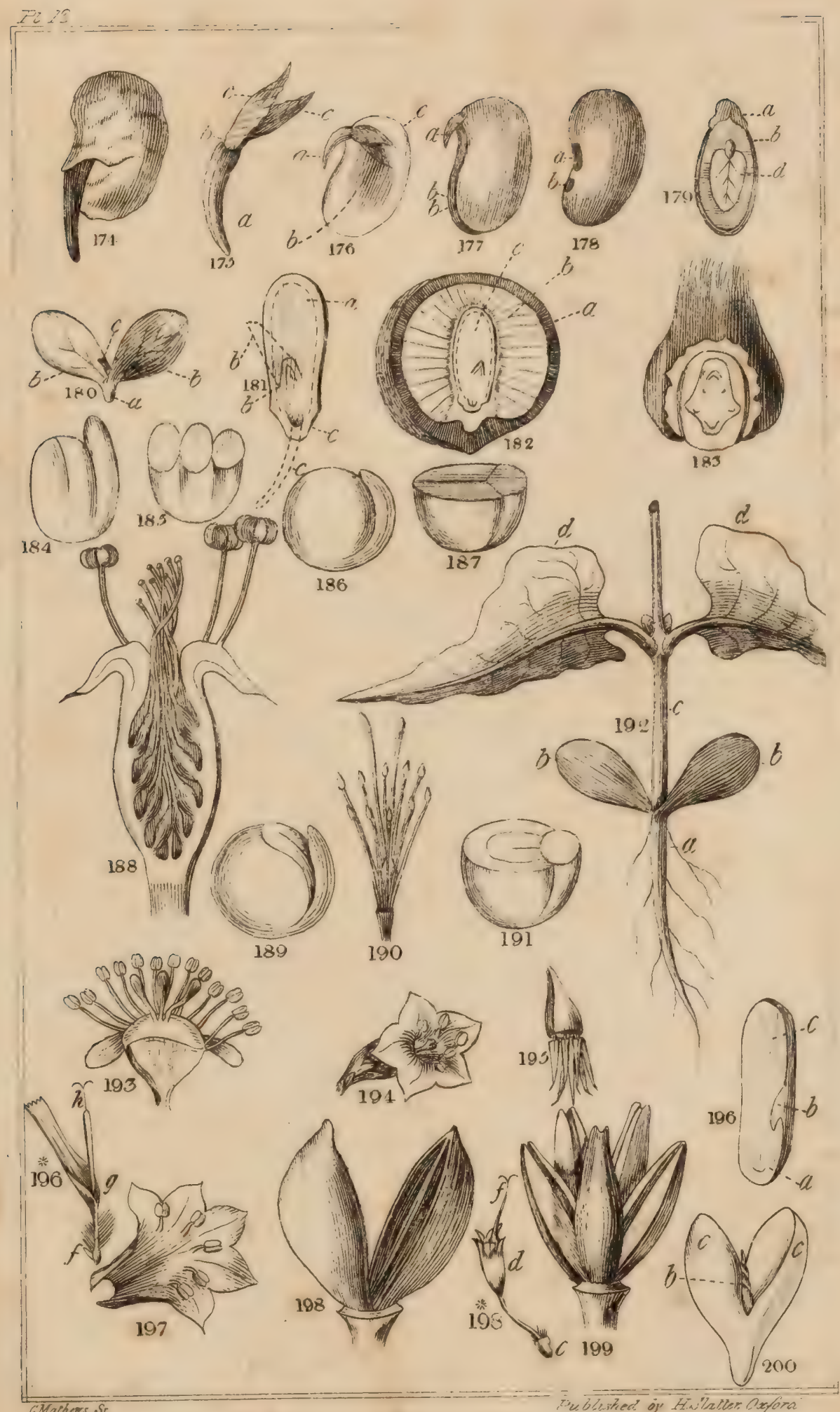




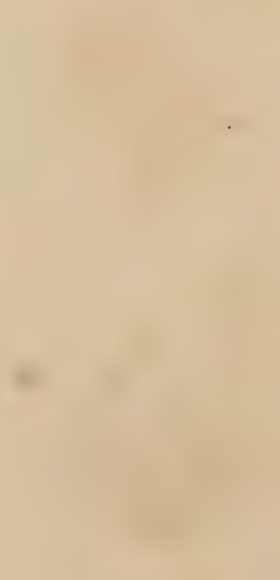

-

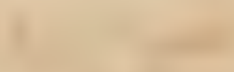

tan 


\section{LINNEAN CLASSES AND ORDERS,}

WIIH THEIR RESPECTIVE GENERA. 



\title{
LINNEAN CLASSES AND ORDERS,
}

\author{
WITH THEIR RESPECTIVE GENERA,"
}

Defined and arranged chiefly according to essential, ${ }^{2}$ and artificial characters, with notices of the species belonging to anomalous classes, at the end of each Class, and Order. N. O. Natural Order.

\section{First Class. MONANDRIA. 1 Stamen.}

Order I. MONOGYNIA. 1 Pistil.

$$
\text { (Divisions)* Seed one. }
$$

Hippu'ris, (Mare's-tail.) Calyx a slight border crowning the germen. Corolla none. Seed inferior, (a small one-seeded nut. H.) N. O. Halorageæ. Hygrobieæ. $\boldsymbol{R} d$. Hippurideæ.Page 1. Valeriana rubra, one-stamened; its genus in Triandria. Alchemilla arvensis. See its genus, in Tetrandria.

$$
\text { ** Seeds several. }
$$

Chara, (Chara,) referred to Cryptogamia by many botanists. Calyx none. Style none. Anther stalkless, round. Berry manyseeded. N. O. Characeæ.-Page 1.

Some species of Salix, (Willow, belong to this Class.

\section{Order II. DIGYNIA. 2 Pistills.}

Caluitriche, (Water-Starwort,) is under Monoecia in H. Calyx none. Petals or Bracteas, two, inferior. Seeds four, apparently naked, compressed. Some of the genus, with stamens and pistils on separate flowers. N. O. Callitrichíneæ. Part of Halorageæ. Lindl.-Page 2.

I See Gaertner's fine work, and Baxter's Plates.

2 In the body of the Flora, the Genera are placed in a series of natural affinity. The essential characters " comprehend the distinctions requisite to discriminate each genus from every other." 


\section{Class II. DIANDRIA. 2 Stamens.}

Order I. MONOGYNIA, 1 Pistil.

* Flowers inferior, one-petalled, regular.

Ligustrum, (Privet.) Corolla four-cleft. Berry two-celled, with each cell two-seeded. N. O. Jasmineæ,-Page 3.

Fra'Xinus, (Ash.) Corolla none, or four-cleft. Capsule compressed, leafy at the end, one or two-seeded. (Some flowers stamenless.) N. O. Jasmíneæ.-Page 3.

* Flowers inferior, one-petalled, irregular, with a seed-vessel.

Vero'nica, (Speedwell.) Corolla wheel-shaped, deeply four-cleft. Capsule two-celled. N. O. Scrophularineæ, Veroniceæ of some.-Page 3 .

Pinguícula, (Butterwort.) Corolla gaping, (ringent,) spurred. Calyx five-cleft. Capsule one-celled, (seeds attached to a central receptacle. H.) N. O. Lentibulariæ.-Page 6.

Utricula'ria, (Bladderwort. ${ }^{1}$ ) Corolla masqued, (personate,) spurred. C'apsule one-celled. Calyx two-leaved. N. O. Lentibulariæ.-Page 7.

***Flowers inferior, one-petalled, irregular; seeds apparently naked. Lx'copus, (Gypsy-wort.) Corolla nearly equal, tubular, four-cleft. Stamens distant, simple. Seeds abrupt. N. O. Labiátæ.Page 8.

S'Alvia, (Sage, or Clary.) Corolla gaping, (ringent.) Stamens; filaments with two straddling branches. N. O. Labiátæ.Page 8.

$$
\text { **** Flowers superior. }
$$

CircÆA, (Enchanter's-night-shade.) Corolla two-petalled. Calyxsegments two. Capsule two-celled. Cells one-seeded. N. O. Onagrárieæ. Juss. Circeáceæ. Lindl.-.-Page 3.

****** Flowers without petals, or four-petalled.

Lemna, (Duckweed.) Corolla none. Calyx one-leaved. Capsule one-seeded. N. O. Lemnáceæ. D.C. Pistiáceæ. Rd.Page 7.

Cládium, (Twig-rush.) Formerly part of Schœnus, pronounce $k$. Corolla none. Glumes chaffy, sheathing, one-flowered; outer ones empty. Fruit, a nut with a loose outward coat, without any bristles at the base. N. O. Cyperáceæ.-Page 9 .

1 Weort, a herb. Ang. Sax. 
Fraxinus, $(A s h$, ) without petals. See above.

Schœnus 4. See Eng. Fl. Carex.

Lepidium ruderale, has two stamens only.

Order II. DIGYNIA. 2 Pistils.

Anthoxanthum, (Vernal-grass.) Calyx, a glume of two valves, single-flowered. Corolla glume two-valved, the outward awned. Seed one. N. O. Gramíneæ.-Page 9.

\section{Class III. TRIANDRIA. 3 Stamens.}

Order I. MONOGYNIA. 1 Pistil.

* Flowers superior.

VAleria'NA, (Valerian.) Corolla five-cleft, one-petalled, gibbous, or spurred at the base. Fruit with one seed, crowned with the feathery seed-down. N. O. V aleriáneæ--Page 10.

FE'dia, (Corr-salad.) Formerly part of the genus Valeriana. Corolla one-petalled, five-cleft, gibbous at the base. Capsule crowned with the toothed calyx, without valves, from one to three fertile cells. Seeds solitary. N. O. Valeriáneæ.-Page 11.

Crocus, (Crocus.) Corolla segments six, deep, equal; tube very long. Stigmas plaited. N. O. Irídeæ.-Page 11.

Iris, (Iris, or Flower-de-luce.) Corolla in six, segments deep, unequal, each alternate segment longer, and bent back. Stigmas two-lipped, like-petals, covering the stamens. N. O. Irídeæ.Page 11.

\section{** Flowers inferior, chaffy. Seed one.}

Schonus, ${ }^{1}$ (Bog-rush.) Corolla none. Spikelets two ranked, of one to three flowers. Outer glumes smaller, empty. Style simple at the base, falling off, (deciduous.) N. O. Cyperáceæ. J.-Page 12.

Ruyncho'spora, ${ }^{2}$ (Beak-rush.) Corolla none. Spike fewflowered. Glumes, (husks,) tiled all round, with many smaller, empty, outer ones. Seed beaked with the dilated, hardened, permanent base of the style. N, O. The same.-Page 12.

Scirpus, (Club.rush, and Bull-rush.) Corolla none. Glumes, (husks,) tiled all round, uniform, concave, expanded. Style

\footnotetext{
1 Pronounce skénus.

2 Ch pronounce like $\mathbf{k}$.
} 
simple at the base, falling off, (deciduous,) "leaving only a small point." N. O. The same.-Page 12.

Eleo'charis, (Spike-rush.) Corolla none. Glumes, (husks,) tiled all round, uniform, expanded. Seed crowned and jointed with the dilated, hardened base of the style. "Dilated base of the style, jointed upon the germen." H. B. Fl. N. O. The same. The solitary spike better distinguishes this genus, \&c. $H$. -Page 14.

Erio'phorum, (Cotton-grass.) Corolla none. Glumes, (husks,) tiled all round, uniform, expanded. Seed accompanied by numerous, very long silky hairs. N. O. The same.-Page 14 . Nardus, (Mat-grass.) Calyx none. Corolla two-valved. N. O. Gramíneæ. J.-Page 15. Juncus conglomeratus, and $J$. effusus. See in Hexandria Monogynia.

Order II. DIGYNIA. 2 Pistils. True Gramíneæ. (Grasses.)-Jussieu.

* Flowers dispersed. Calyx of two to three valves, one-flowered.

Alopecu'rus, (Fox-tail grass.) Calyx two-valved. Corolla onevalved; simple at the top; awned at the base. Styles combined.-Page 17.

Phleum, (Cat's-tail-grass,) Calyx of two close, parallel, pointed valves, concealing the corolla of two awnless valves. Seed free. -Page 16.

Phálaris, (Canary-grass.) Calyx of two close, parallel valves, concealing the double corolla of three or four valves; two innermost downy, subsequently hardened, investing the seed.Page 16.

Mr'Lum, (Millet-grass.) Calyx of two swollen, close valves, inclosing the two-valved corolla. Seed clothed with the hardened corolla.-Page 18.

Agrostis, (Bent-grass.) Calyx of two acute valves, shorter than the corolla, ("longer." $\boldsymbol{H}$.) Corolla membranous, tufted with hairs at the base, unchanged. Seed free.-Page 18.

Arundo epigejos, and Ar. Calamagrostis. See in the division, ***, and Melica uniflora in division **.

**Flowers dispersed. Calyx two-valved, cortaining two or three florets.

Arra, (Huir-grass.) Florets two without any intermediate rudiment. ("Corolla two-valved, membranaceous, thin; the outer 
valve awned (rarely awnless near the base.") Seed free. Corolla unchanged.-Page 19.

Me'LicA, (Melic-grass.) Florets one or two, with the rudiments of one or two intermediate ones. Seed free, covered with the hardened cartilaginous corolla. (Panicle lax.)-Page 21.

Holcus, (Soft-grass.) One floret barren. ("Upper floret with stamens only, and awned: lower floret perfect, awnless.") Calyx keeled. Seed covered by the hardened corolla. (Panicle lax.)-Page 21.

*** Flowers dispersed. Calyx containing many florets.

BrizA, (Quaking-grass.) Corolla awnless, bellying out, concave, keelless. Seed depressed, united to the corolla. (Panicle) lax.Page 24.

PoA, (Meadow-grass.) Corolla awnless, compressed, keeled, valves somewhat egg-shaped, acute. Seed free, elliptic-oblong. -Page 23.

Guyc'eria, (Sweet-grass.) Part of Linnéan Genus Poa. Corolla awnless, cylindrical, furrowed, ribbed, abrupt, not keeled. Seed free, cylindric-oblong.-Page 22.

Trio'dia, (Heath-grass.) Part of Poa Linn. Corolla round, expanded, obscurely ribbed, two-valved; outer valve with three nearly equal teeth, the middle tooth straight. Panicle in a raceme, (cluster.) Seed loose, depressed.--Page 24.

DA'Cryurs, (Cock's-foot-grass.) Corolla awned at the top, spearshaped, keeled, compressed; inner valve folded, two-ribbed. Seed loose, oblong. Calyx compressed, taper-pointed, unequal. -Page 25.

Festu'ca, (Fescue-grass.) Corolla awned at the top; or pointed, keeled, almost cylindric, concave; inner valve flat, two-ribbed, downy at the ribs. Seed loose, oblong. Caly:x concave, acute, of (two) unequal valves. ("6 Panicle lax, or close, or spiked.") - Page 25.

Crnosu'rus, (Dog's-tail-grass.) Calyx two-valved, equal, awned, having a comb-like (pectinated) involucre. Corolla two-valved, valves linear-spear-shaped.-Page 25.

Bromus, (Brome-grass.) Corolla awned at the back, cloven, concave, hollow; inner valve flat, two-ribbed, bristly at the ribs. Seed united to the inner valve.-Page 28.

Ave'na, (Oat, or Oat-grass.) Corolla nearly cylindric, of two spear-shaped valves, firmly inclosing the seed; outer valve bearing a twisted backward dorsal awn.-Page 30. 
Arundo, (Reed.) Florets one, or many. Corolla surrounded with long, permanent hairs.-Page 31.

**** Flowers crowded (aggregate) on a jointed, or toothed common stalk, with side, small hollows.

Lo'Lium, (Darnel.) Calyx of one valve, opposite to the stalk, fixed, many-flowered.-Page 31.

Tríticun, (Wheat, or Wheat-grass.) Calyx of two, cross, opposite valves, solitary, many-flowered: "the sides of one of the valves directed to the spilke-stalk, (rachis.)-Page 33.

'Euymus, (Lyme-grass.) Calyx of two parallel valves, crowded; with two or more florets. "Spikelets two or three from the same point. Calyx lateral, both the valves on one side the spikelet.") - Page 32 .

Ho'Rdeum, (Barley.) Calyx of two parallel valves, crowded, divided into three, (ternate,?). "Central floret perfect, side ones mostly imperfect, (having often at the back of the inner valve a bristle, or abortive floret: outer valve of the corolla awned. Fruit incorporated with the corolla." )-Page 32.

\section{Order III. TRIGYNIA. 3 Pistils.}

Mo'ntia, (Blinks.) Calyx two-leaved. Corolla of five irregular petals, united at the base into one, (one-petalled.) Capsule three-valved, three-seeded. N. O. Portuláceæ. J.-Page 34.

\section{Class IV. TETRANDRIA. 4 equal Stamens.}

Order I. MONOGYNIA. I Pistil.

* Flowers one-petalled, superior, one-seeded.

Dípsacus, (Teasel.) Common calyx many-leaved. Proper caly $x$ single, superior, one-leaved, cup-shaped, crowning the seed. (Flowers in a very close head.) N. O. Dipsáceæ.-Page 34.

Scabio'sa, (Scabious.) Common calyx many-leaved. Proper caly $x$ double, superior, crowning the seed. N. O. Dipsáceæ.-Page 35 .

* Flowers one-petalled, superior, two-seeded. N. O. Stellátæ. Linn. Rubiaceæ. Juss.

Galium, (Bed-straw.) Corolla flat. Fruit dry.-Page 37. 
Aspe'rula, (Wood-ruff.) Corolla tubular. "Fruit without any distinct margin to the calyx.-Page 36.

Sherárdia, (Field-madder.) Corolla tubular. Fruit crowned with the calyx, each seed three-toothed.-Page 36.

*** Flowers one-petalled, inferior, (belong to the germen.)

Planta'go, (Plantain.) Corolla bent back. Stamens very long. Capsule bursting all round, across, two, or four-celled. N. O. Plantagineæ. J.-Page 40.

Centu'nculus, (Chaff-weed.) Corolla tubular, spreading, fourpartite. Stamens short within the tube. Caps. one-celled, bursting all round, across. N. O. Primuláceæ. Ventenat.-Page 41 .

\section{Some of the Gentians belong here. \\ **** Cor. four-petalled.}

Convus, (Cornel.) Pet. without any nectary. Nut of the drupe (stone-fruit,) two-celled, two seeded.--Page 41.

For Cardamine. See Tetradynamia.

\section{***** No Petals.}

Parieta'ria, (Wall-Pellitory.) Cal. four-cleft, inferior. Stamenfilaments, first curved inwards, afterwards expanding with an elastic force. Seed clothed with the lengthened out cal. (Some of the flowers are stamenless, their caly $x$ remaining unaltered.)

N. O. Urtíceæ. J.-Page 42.

Sanguisorba, (Burnet.) Cal. four-cleft, superior, coloured, with four scales on bracteas at the base. Stamens dilated upward. Caps. square, one-celled, "surrounded by the persistent base only of the calyx." N. O. Rosáceæ. J.-Page 41.

Alchemilua, (Lady's mantle.) Cal. eight-cleft, inferior. Fruit one, or two-seeded, "surrounded by the persistent calyx." N. O. Rosáceæ. J.-Page 42.

\section{Order II. DIGYNIA. 2 Pistils.}

Alchemilla (pron. ke,) see above. The Gentians and Cuscutas; see in Pentandria.

\section{Order III. TETRAGYNIA. 4 Pistils, or Stigmas.}

ILEx, (Holly.) Cor. wheel-shaped, one, or four-petalled. Berry four-seeded. Styles none. Some flowers without any pistil (barren.) N. O. Aquifoliaceæ. DC. Ilicineæ. Brongniart.-Page 43. 


\section{teviii CLASSES, \&c. AND GENERA ARRANGED.}

Moe'nchia, (Moénchia.) Cal. four-leaved. Pet. four, (" as long as the calyx.") Caps. one-celled, one-valved, opening at the end, with eight teeth. N. O. Caryophylleæ. J.-Page 46.

Sagl'Na, (Pearl-wort.) Cal. four-leaved. Pet. four, " shorter than the calyx.") Caps. one-celled, four valved. N. O. Ca. ryophylleæ. J.-Page 45.

RAdílla, (Flax-seed.) Cal. in four principal segments, each segment three cleft. Pet. four. Caps. eight-celled, eight-valved. N. O. Lineæ DC.-Page 46.

Potamogréton, (Pond-weed.) Cal. none. Pet. four. Stamenanthers stalkless. Seed-nuts four, (apparently naked,) stalkless. (" Flowers stalkless upon a spike or spadix, which issues from a sheathing bractea, or spatha." --Page 43.

Cerastium; see in Decandria.)

\section{Class V. PENTANDRIA. 5 Stamens.}

\section{Order I. MONOGYNIA. 1 Pistil.}

* Flowers one-petalled, inferior (below the germen,) sceds two or four, apparently naked. N. O. Asperifoliæ. Linn. Boragíneæ. Jussieu.

E'cнium, (Viper's-bugloss.) Cor. irregular, throat dilated, naked. Stig. cloven deeply.-Page 51.

Lithospermum, (Gromwell.) Cor. funnel-shaped, throat naked. Cal.-segments five, deep.-Page 48.

Sx'mphytum, (Comfrey.) (Cal. five-cleft.) Cor. closed with converging, awl-shaped scales; limb bell-shaped.--Page 50.

Lycopsis, (Bugloss.) (Cal. five-cleft.) Cor. closed with convex, blunt scales; tube doubly bent. Seed-nuts hollow at the base. - Page 51.

Anchu'sa, ('Alkunet.) (Cal. five-cleft.) Cor. funnel-shaped, closed with convex, blunt scales; tube straight, swollen below. Seed-nuts hollow at the base.-Page 49.

Mroso'tis, (Scorpion-grass.) (Cal. five-cleft.) Cor. salver-shaped, lobes blunt, mouth half-closed with short rounded valves. Seednuts perforated at the base, borne by the calyx.-Page 46.

Crnoglossum, (Hound's-tonyue.) (C'al. five.cleft.) Cor. funnelshaped, (short,) its mouth closed with convex, rounded scales. 
Seed-nuts depressed, not perforated, fixed to the style or central column.-. Page 49.

* *lowers one-petalled, inferior. Seeds convex in a distinct capsule.

Avagallis, (Pimpernel.) (Cal. five-partite.) Cor. wheel-shaped. Stam. hairy. Caps. one-celled, bursting all round, across. N. O. Primuláceæ. Vent.-Page 54.

Lysima'chia, (Loose-strife.) (Cal. five-partite.) Cor. wheelshaped. Caps. one-celled, ten-valved. N. O. Primuláceæ. Vent.-Page 54.

Primula, (Primrose; Cowslip; Oxlip.) (Cal. tubular, fivetoothed.) Cor. salver-shaped; tube cylindric; open-mouthed. Stig. round. Caps. one-celled, opening with ten teeth. N. O. Primuláceæ. Vent.-Page 52.

Hotro'nia, (Featherfoil.) Cal. five-partite. Cor. salver-shaped, (tube short.) Stam. inserted at the mouth of the tube. Stig. round. Caps. (round,) one-celled, opening with five teeth. N. O. Primulaceæ. Vent.-Page 53.

Menyanthes, (Buskbean.) Cal. five-partite. Cor. funnel-shaped; the segments hairy within. Stig. two-lobed. Caps. one-celled; seeds parietal. H. Br. Fl. N. O. Gentianeæ,-Page 52.

Villa'rsia, (Yellow Buck-bean Villarsia.) Cal. five-partite. Cor. wheel-shaped, the limb often fringed, (as with hair.) Caps. onecelled; seeds paríetal. H. Br. Fl. N. O. Gentiáneæ.-Page 53.

Ervturæ'A, (Centaury.) Cal. five-cleft. Cor. salver-shaped. Anthers finally spiral. Caps, linear, two-celled. N. O. Gentiáneæ. J.-Page 64.

DAtu'RA, (Thorn-apple.) Cal. tubular, falling off, (deciduous.) Cor. funnel-shaped, (plaited.) Caps. "s half-four celled," fourvalved. N. O. Soláneæ. J.-Page 62.

Hroscr'amus, (Henbane.) (Cal. tubular, five-cleft.) Cor funnelshaped, (oblique.) Caps. two-celled, opening with a lid.( Stig. headed.)-Page 62.

Verbascum, (Mullein.) (Cal. five-partite.) Cor. wheel-shaped, irregular. Stam. descending archwise, (declining.) Stig. blunt. Caps. two-celled; (two-valved.) N. O. Soláneæ. J.-Page 61.

Convo'lvulus, (Bind-weed.) (Cal. five-cleft.) Cor. bell-shaped, plaited. Stig. two. Caps. from two, to three-celled, with as 
many valves. Cells one, to two-seeded. N. O. Convolvuláceæ. J.-Page 55.

Polemónium, (Jacob's Ladder.) (Cal. five-cleft.) Cor. deeply five-cleft. "Stam. inserted upon the five teeth, or valves, which close the mouth of the corolla." Caps. three-celled, threevalved. (Stig. three.) N. O. Polemoniáceæ. J.-Page 56.

Vinca, (Periwinkle.) (Cal. five-partite.) Cor. salver-shaped, the segments oblique, "spirally tiled in the bud." Seed-follicles two, erect. Seeds simple; (without seed-down.) N. O. Apocy'neæ. J.-Page 68.

Sola'num, (Night-shade.) (Cal. five to ten-partite.) Cor. wheelshaped. Anthers opening with two pores at the extremity. Berry (roundish,) two (or more) celled. N. O. Soláneæ. J. -Page 63.

'Atropa, (Dwale.) (Cal. five-partite.) Cor. bell-shaped, (lobes equal.) Stam. distant, (curved inward.) Anthers heart-shaped. Berry two-celled. N. O. Soláneæ. J.-Page 62.

*** Flowers one-petalled, superior.

S'Molus, (Brookweed.) (Cal. five-cleft.) Cor. funnel-shaped, five-cleft, tube short, with five scales at its mouth, alternate with the corolla lobes. Caps. " half-inferior," one-celled, many seeded, with five valves curved back. "Seeds upon a large central, free receptacle." $\mathbf{N}$. O. allied to Primuláceæ $\boldsymbol{B r}$. -Page 64.

Jasio'ne, (Sheep's-bit.) (Flower's in this genus, collected into a head, involucre many-leaved.) Cor. wheel-shaped, segments five, deep. Anthers united at the base. Stig. club-shaped. Caps. (half?) two-celled, opening at the top. N. O. Lobeliaсеæ. J. Campanuláceæ.-Page 58.

Campa'nula, (Bell-flower.) Cor. bell-shaped, (or sometimes somewhat wheel-shaped.) Stam.-filaments dilated at the base. Stig. two, or three.cleft, turned back, (revolute.) Caps. two, to fivecelled, bursting on the side, "rarely at the extremity." N. O. Campanulaceæ. J.-Page 56.

LoNicE'RA, (Honey-suckle.) Cor. irregular. Berry one, to threecelled, many-seeded. N. O. Caprifoliáceæ. J.-Page 65.

**** Flowers of five, or of four petals, inferior (below the germen.)

Rhamnus, (Buckthorn.) Cal. "pitcher-shaped." $H$. Funnelshaped. Sm. bearing the petals. (Stam. opposite the petals.) 
Berry several-celled, " two to four-celled, four-seeded." (Pet. sometimes none.) N. O. Rhámneæ, J.-Page 65.

Euo'nymus, (Spindle-tree.) "Cal. flat, four to five-cleft, having a targeted (peltate) disk within. Pet. four to five. Stam. alternating with the petals, inserted upon glands at the margin of the disk. Caps. with three to five angles, and as many cells and valves. Seeds with a coloured, fleshy seed-coat, (arillus.)" $H$. N. O. Celastrineæ. Br.-Page 66.

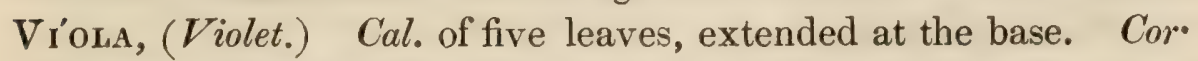
irregular, five-petalled, the under petal spurred at the base. (Anthers joined together, (connate,) two-spurred behind.) Caps. one-celled, three-valved. N. O. Violarieæ. DC.-Page 59. ***** Flowers five-petalled, superior.

Ribes, (Currant and Gooseberry.) Cal. five-cleft, bearing the petals (and stamens.) Style divided. Berry one-celled, manyseeded. N. O. Grossulárieæ. DC.-Page 66.

He'dera, (Ivy.) Cal. (five-toothed) surrounding the germen. Style simple. Pet. broadest at the base. Berry three, to five-seeded, " crowned by the calyx." N. O. Caprifoliaceæ. J.-Page 67.

\section{****** Corolla none.}

The'sium, (Bastard-toad-flax.) Cal. five-cleft, leathery, bearing the stamens, persistent. "Stam. with a small tuft of hairs." Drupe (nut) inferior, dry. N. O. Santaláceæ. Br.-Page 68.

\section{Order II. DIGYNIA. 2 Pistils.}

* Corollas one-petalled, inferior (below the germen.)

Gentin'Na, (Gentian.) Cal. four, to five-cleft. Cor. tubular at the base, without nectar-bearing pores. Caps. one-celled, twovalved. N. O. Gentiáneæ. J.-Page 73.

Cu'scuta, (Dodder.) Cal. four, to five-cleft. Cor. bell-shaped, four, to five-lobed. Caps. two-celled, bursting all round, across, at the base. Cells two-seeded. N. O. Convolvuláceæ. J.Page 72.

* Corolla wanting. Seed one.

Chenopódium, (Goosefoot.) Cal. inferior, five-cleft, persistent, and unchanged, closing upon, yet not wholly clothing the fruit. Seed one, round, coated. N. O. Chenopódeæ. DC.-Page 69. 
Uluus, (Elm.) Cal. superior, persistent, four, to five-cleft. Caps. closed, mémbranous, compressed, winged all round, (this fruit, styled a Samara ;) one-seeded. N. O. Ulmáceæ. Mirb.-Page 71. Pólýgonum amphíbium; see Octandria.

*** Corolla five-petalled, superior (above the germen.) Seeds two. Umbellate plants. N. O. Umbelliferce to the end of Pentandria Digynia.

Leaves mostly repeatedly compound. Flowers white, reddish, or yellow, (generally small.)

Dr. Hooker allows that "Sprengel and Smith have made great improvements in the formation of the Genera" of this Natural Order : but Dr. Hooker gives a preference to a different arrangement, to which the reader is referred, in his masterly British Flora, vol. i. p. 112. 1830. The arrangement and characters here adopted, are those of Sir J. E. Smith.

A. Fruit a single, or double globe.

Coriandrum, (Coriander.)

B. Fruit beaked.

Scandix, (Shepherd's-needle.) Beak (very) much longer than the seeds. Fruit somewhat bristly. Cal. none. Pet. unequal, undivided. Floral-receptacle ${ }^{1}$ five-lobed, coloured.--Page 76.

Antruriscus, (Beak-parsley.) Beak shorter than the seeds, even. Fruit rough with scattered, prominent bristles. Cal. none. Pet. equal, inversely heart-shaped. Floral-receptacle slightly bordered.-Page 76.

Charophyluum, (Chervil.) Beak shorter than the seeds, angular. Fruit smooth, ribless. Cal. none. Pet. inversely heart-shaped, rather unequal. Floral-receptacle wavy.-Page 76 .

C. Fruit solid, prickly, beakless.

ERY'NGIUm, (Eringo.) Fruit egg-shaped, clothed with straight bristles. Cal. pointed. Pet. oblong, equal, bent inwards, undivided. Fl. crowded. Common receptacle scaly.-Page 74.

Sanícula, (Sanicle.) Fruit egg-shaped, clothed with hooked bristles. Cal. acute. Pet. spear-shaped, bent inwards, nearly equal. Fl. separated, unlike-Page 74.

Daucus, (Carrot.) Fruit elliptic-oblong, compressed transversely. Seeds with four rows of flat prickles, and rough intermediate ribs. Cal. scarcely distinguishable. Pet. inversely heartshaped, unequal. $F l$. separated.-Page 74.

1 Or Disk, a glandular ring, under the swollen bases of the styles, mostly united therewith. Sm. 
CaúCalis, (Bur parsley.) Fruit elliptic-oblong, compressed across. Seeds with four rows of ascending, awl-shaped, hooked prickles, the interstices prickly or rough. Cal. broad, acute, unequal. $\boldsymbol{P e t}$. inversely heart-shaped, unequal. $\boldsymbol{F l}$. imperfectly separated.-Page 75.

To'rilis, (Hedge-parsley.) (Part of the Genus, Caúcalis. Linn.) Fruit egg-shaped, slightly compressed on the sides. Seeds ribless, rough with scattered, prominent, ascending, stiff prickles. Cal. short, broad, acute, nearly equal. Pet. inversely heartshaped, nearly equal. $\quad \mathbf{F l}$. united.-Page 75.

Myrrhis (odoráta.) See D.

D. Fruit solid, nearly round, unarmed, wingless.

Mrrruis, (Cicely.) Fruit deeply furrowed. Cal. none. Pet. inversely heart-shaped, rather unequal. Floral-receptacle none. Fl. imperfectly separated.-Page 77.

Bu'vium, (Earth-nut.) Fruit slightly ribbed. Cal. small, acute, unequal. Pet. inversely heart-shaped, equal. Floral-receptacle none. $\mathbf{F l}$. imperfectly separated.-Page 77.

Enanthe, (Water-dropwort.) Fruit ribbed, somewhat spongy. Cul. large, spear-shaped, acute, spreading, unequal. Pet. inversely heart-shaped, radiant, very nnequal. Floral-receptacle dilated, depressed. $\quad F l$. separated.-Page 80.

Pimpinecla, (Burret-saxifrage.) Fruit egg-shaped, ribbed, with convex interstices. Styles hair-like, (capillary,) as long as the fruit. Cal. none. Pet. inversely heart-shaped, nearly equal. Floral-receptacle none. $F$. either united, or diœcious.-Page 83.

E. Fruit solid, unarmed, wingless, compressed on the side, its cross diameter being at least twice the breadth of the joining (juncture.)

Sium, (Water-parsnep.) Fruit egg-shaped, or round, ribbed, furrowed. Cal. small, acute, unequal, or scarcely distinguishable. $\boldsymbol{P}$ et. inversely heart-shaped, equal. Styles cylindric, shorter than the petals. Floral-receptacle none. $\boldsymbol{F l}$. uniform, united. -Page 78.

Sisov, (Honewort.) Fruit egg-shaped, or nearly round, (orbicular,) ribbed. Cal. scarcely distinguishable, or blunt. Pet. elliptical, or inversely heart-shaped, with a rolled in point, equal. Styles very short and thick. Floral-receptacle none. Fl. uniform, united-Page 79.

Coni'um, (Hemlock.) Fruit egg-shaped, with ten acute ribs, wavy in an unripe state. Cal. scarcely distinguishable. Pet. in- 
versely heart-shaped, slightly unequal. Styles a little swollen at the base. Floral-receptacle dilated, depressed, wavy, permanent. $\mathbf{F l}$. slightly irregular, united.-Page 80.

Smy'rium, (Alexanders.) Fruit broader than long, hollow at each side, with six, sharp ribs, at the back (dorsal;) interstices convex. Cal. very small, acute. Pet. equal, spear-shaped, curved inwards, or inversely heart-shaped. Styles swollen, depressed at the base. Floral-receptacle none. Fl. nearly regular) partly barren.-Page 81 .

'Apium, (Parsley.) Fruit roundish-egg-shaped, with six, sharp ribs, at the back (dorsal;) interstices flat. Cal. scarcely distinguishable. Pet. roundish, with a point bent inwards; pet. very nearly equal. Styles greatly swollen at the base. Floral-receptacle thin round, (orbiculir,) wavy. $F l$. nearly regular, united. -Page 82.

Faopo'dun, (Grout-weed.) Fruit elliptic-oblong, with equaldistant ribs; interstices flattish. Cal. none. Pet. inversely heart-shaped, broad, a little unequal. Styles egg-shaped, at the base. Floral-receptacle none. $\mathbf{F l}$. united, all perfect, slightly radiant.-Page 82.

Conidum, (Pepper-sa:ifrage.) Peucédanum. Linn. Fruit eggshaped, acute, with equal-distant, very sharp ribs; interstices deep, hollow; joining (juncture) contracted. Cal. none. Pet. equal, inversely egg-shaped, or inversely heart-shaped. Styles hemispheric at the base; subsequently lengthened out, spreading, cylindric. Floral-reseptasle annular, (ring-like,) thin, waved, erect; afterwards depressed. $F \boldsymbol{l}$. imperfectly separated, nearly regular.-Page 83.

Bupleurum, (Hare's-ear, or Thorough-wax.) Fruit egg-shapedoblong, blunt, with prominent, sharp, abrupt ribs; interstices flat; joining (juncture) contracted. Cal. none. Pet. equal, broadish-wedge-shaped, very short, rolled inwards. Styles very short, not extending beyond the circumference of their broad, swollen bases. Floral-receptacle none. $F l$. all perfect, regular. -Page 84.

Hydroco'Tyle, (White-root.) Fruit nearly round, (orbicular,) rather broader than long, angular, much compressed; joining (juncture) very narrow. Cal. none. Pet. equal, egg-shaped, spreading, undivided. Styles cylindric, shorter than the stamens; swollen at the base. Floral-receptacle none. $\mathrm{Fl}$. all perfect, regular.-Page 8.4. 
F. Fruit solid, unarmed, compressed across, the joining (juncture) being broader than the cross diameter.

Atru'sa, (Fool's-parsley.) Seeds egg-shaped, convex, with five, swollen, rounded, sharply keeled ribs; interstices deep, sharpangular; border none. Cal. pointed, very minute. Pet. inversely heart-shaped, rather irregular. Floral-receptacle none. Fl. all perfect, slightly radiant.-Page 79.

Avgélica, (Angelica.) Seeds elliptic-oblong, convex, with three back(dorsal) wings, and a narrow, flat, even border. Cal. none. Pet. spear-shaped, flattish, undivided, contracted, at each end, equal. Floral-receptacle thin, wavy, narrow, permanent. $\mathbf{F l}$. all perfect, regular.-Page $\mathbf{8 2}$.

G. Fruit thin, almost flat, compressed across without back (dorsal) wings.

Pastina'CA, (Parsnep.) Seeds elliptic-inversely egg-shaped, with a slight notch at the top, very nearly flat, with three back (dorsal) ribs, and two marginal ones; border narrow, flat, thin, even, smooth, entire. Cal. very small, scarcely distinguishable. $\boldsymbol{P}$ et. broadly spear-shaped, rolled inwards, equal. Floral-receptacle broad, round, wavy, rather thin, concealing the calyx. Fl. regular, uniform, perfect.-Page 84.

Heracléum, (Cow-parsnep.) Seeds inversely heart-shaped, with a notch at the summit, very nearly flat, with three slender, back (dorsal) ribs, two distant, marginal ones, and four intermediate, coloured, depressed, abrupt lines from the top; border narrow, slightly swollen, smooth, even, entire. Cal.-teeth five, small, sharp, withering away (evanescent.) Pet. inversely heartshaped, radiant. Floral-receptacle wavy, notched, blunt. $\mathbf{F l}$. separated.-Page 85.

Tordy'lum, (Hart-wort.) Seeds rounded, (orbicular,) nearly flat, roughish, ribless; border swollen, wrinkled, or notched, naked, or bristly. Cal. five-toothed; teeth awl-shaped, unequal. Pet. inversely heart-shaped, radiant, variously unequal, and irregular. Floral-receptacle none. Fl. separated.-Page 85.

End of the Umbelliferous Genera.

Order III. TRIGYNIA. 3 Pistils.

* Flowers superior (above the germen.)

Viburnum, (Guelder-rose.) Cal. five-cleft. Cor. one-petalled, fivelobed. Berry inferior, mostly one-seeded. N. O. C'aprifo iáсеæ. J.-Page 86. 
Sambu'cus, Elder. Cal. five-cleft. Cor. one-petalled, wheelshaped, five-cleft. Berry inferior, three (or four) seeded. N. O.

Caprifoliáceæ. J.-Page 86.

* Flowers inferior (below the germen.)

Chenopódium; see Pentand. Digynia: und Stellaria, in Decandria.

Order IV. TETRAGYNIA. 4 Pistils.

Parnd'ssia, Grass of Parnassus. Cal. deeply five-cleft. Cor.pet. five. Nect. fringed with bristles, bearing globes. Caps. one-celled, four-valved. N. O. Saxifrágeæ. Lindley.-Page 87.

()

Linum, Flax. Cal. five-leaved, persistent. Cor.-pet. five. Caps. round, sharp-pointed, ten-celled, ten-valved. Seeds egg-shaped, compressed. N. O. Líneæ. DC._Page 88.

Cerastium semidecandrum; see in Decandria; Spérgula also.

\section{Order VI. HEXAGYNIA. 6 Pistils.}

Dro'sera, Sundew. Cal. five-cleft. Cor.-pet. five. Caps. onecelled, three-valved. Seeds many. (Leaves of this genus clothed with glandular hairs.) N. O. Droseráceæ. DC.-Page 89.

Order VII. POLYGYNIA. Many Pistils.

Mrosu'rus, Mouse-tail. Cal. five-leaved, spurred at the base. Cor.-pet. five, with tubular, honey-bearing claws. "Caps. (called seeds by some) not opening (indehiscent,) one-seeded, collected upon a very long, columnar receptacle." N.O. Ranunculáceæ. J.-Page 90.

Ranúnculus; see in Polyundria.

\section{Class VI. HEXANDRIA. 6 Stamens of equal height.}

Order I. MONOGYNIA. 1 Pistil.

* Flowers with calyx and corolla.

BE'Rberis, Barberry. Cal. six-leaved, inferior, (coloured,) falling off, (deciduous.) Pet. six, (each with two glands at the base.) 
CLASSES, \&c. AND GENERA ARRANGED. cvii

Berry two, to three-seeded. N. O. Berberídeæ. Vent.-Page 101.

Peplis, Purslane. Cal. bell-shaped, with six, deep segments, and six, intermediate plaits. Cor. six-petalled, (inserted upon the calyx. Caps. two-celled, superior. N. O. Lythráriæ. J.Page 101.

Lythrum hyssopifolium; see in Dodecandria.

* * Flowers without calyx, superior (above the germen.)

Leuco'sum, Snow-flake. Cor. bell-shaped. Pet. six, equal. Stam. simple, equal. ( $\boldsymbol{F l}$. from a sheath (spatha.)-Page 90.

Galantuus, Snow-drop. Cor. six-petalled, three, inner petals shorter, abrupt, notched. ( $F$. from a sheath.) N. O. Amaryllideæ. $B r$.-Page 90 .

Narcissus, Narcissus, or Daffodil. Cor. six-petalled, attached to a bell-shaped, (or cup-shaped,) crown or nectary, within which are the stamens. N. O. Amaryllideæ. Br.-Page 91.

*** Flowers without a calyx, inferior (below the germen.)

Coxvalla'ria, Lily of the Valley; and Solomon's Seal. Cor. falling off, (deciduous,) six-cleft, (round, or cylindric. Berry threecelled. Stig. triangular. N. O. Smiláceæ. Br.-Page 95.

Hyacintuus, Hyacinth. Cor. falling off, (deciduous;) limb in six-segments; tube swelling. Stam. uniform. Caps. threecelled. Seeds round. N. O. Liliáceæ. Tribe Asphodeleæ. DC.-Page 94. (Better perhaps to adopt Duby's characters of the genus Múscari.) See $\boldsymbol{H} . \boldsymbol{B r} . \boldsymbol{F l}$.

'Aluium, Garlick. Cor.-petals six, egg-shaped. Stam. awl-shaped, flattened. Stig. acute. (Caps. triangular.) Seeds angular. ( $F l$. in umbels from a two-leaved sheath.) N. O. Liliáceæ. Tribe Asphodeleæ. DC.-Page 91.

Narthécium, Bog-asphodel. Cor. spreading. Pet.. six, linearspear-shaped. Stam. woolly. (Germ. pyramidal.) Seeds with an appendage at each end, coated. N. O. Junceæ. J.Page 94.

Ornitho'galum, Star of Bethlehem. Cor. partly spreading permanent. Pet. spear-shaped. Stam. dilated at the base. N. O. Liliáceæ. Tribe Asphodéleæ. DC. (Ornith. lúteum, better referred to the genus $\mathrm{GA}^{\prime} \mathrm{GE} \Lambda_{\text {. }}$. See $H . B . \mathbf{B l}$.)-Page 93 .

Scrlla, Squill. Cor. of six, egg-shaped-oblong petals spreading, falling off, (deciduous.) Stam. all thread-shaped. N. O. Liliáceæ. Tribe Asphodéleæ. DC,-Page 94. 
Fritilla'ria, Fritillary. Cor. bell-shaped, six-petalled; each petal with a nectary-bearing cavity at the base within side. N. O. Liliáceæ. Tribe Tulipáceæ. DC.-Page 92.

Tulipa, Tulip. Cor. six-petalled. Nect. none. Stig. stalkless, (three-lobed.) Caps, three-cornered. Seeds flat. N. O. Liliáceæ. Tribe Tulipáceæ. DC.-Page 92.

'Aconus, Sweet-flay. Cor. six-petalled. Fl. stalkless, on a spadix, without sheath (spatha.) Stig. stalkless. Caps. not opening, many-seeded. N. O. Aroídeæ. J.-Page 95.

**** Flowers husky, with no petals, inferior.

Juncus, Rush. Cal. six-leaved. Caps. three-celled, three-valved, (valves with the seed-bearing partitions in their middle.) Seeds many, horizontal. (Ls. stiff, seldom quite flat.) N. O. Junceæ. DC.--Page 96.

I.ucíola, Lúzula Wood-rush. Cal. six-leaved. Caps. one-celled, three valved, (valves with no partitions. Seeds three, at the bottom of the cell, erect.) N. O. Júnceæ. DC.-Page 99.

Peplis. See in division*; and the genus Polygonum, in Octandria.

\section{Order II. DIGYNIA. 2 Pistils.}

Oxy'rra, Mountain-sorrel. Rumex. Linn. Cal. two-leaved. Cor. two-petalled. Seed-nut with three-sides, compressed; margin broad, winged. N. O. Polygóneæ. J.-Page 304.

Order III. TRIGYNIA. 3 Pistils, or Stigmas.

Cólchrcum, Meadow Saffron. Cor. one-petalled, tubular, (very long, from a sheath;) limb bell-shaped. Caps. three-celled, inflated; cells joined at the base. Seeds many. N. O. Melantháceæ. $B r$.-Page 105.

Triglóchin, Arrow-grass. Cal. three-leaved. Pet. three. Caps. three to six valved, opening at the base. N. O. Juncagíneæ. Richd._Page 104.

Rumex, Dock, and Sorrel. Cal. three-leaved, combined at the base. Cor. three-petalled. Seed-nut triangular, covered by the enlarged petals. N. O. Polygóneæ. J.-Page 102.

Elatine; see Octand. At p. 116.-For "Near, \&c." read Virginia Water, Surrey.

Order IV. POLYGYNIA. Many Pistils.

Alisma, Water-plantain. Cal. three-leaved. Pet, three. Caps. 
six, or more, clustered. Seeds one, or two. N. O. Alismaсеæ. DC.-Page 105.

\section{Class VII. HEPTANDRIA. 7 Stamens.}

Order I. MONOGYNIA. 1 Pistil.

Trientutis europoea is the only British plant, of this Class, and Order. For Ulmus montana. See Pentandria.

\section{Class VIII. OCTANDRIA. 8 Stamens.}

Order I. MONOGYNIA. 1 Pistil.

* Flowers with calyx and corolla (complete.)

Acer, Maple; Sycamore. Cal. five-cleft, inferior. Pet. five. Caps. two, united at the base, each with a long-winged membrane, (this seed-vessel, termed a Sámara.) Seeds one, or two. N. O. Acerineæ. J.-Page 112.

Epilóbium, Willow-herb. Cal. four-cleft, superior. Pet. four. Caps. lengthened out, four-celled, four-valved, many-seeded. Seeds hair-tufted at one end. N. O. Onagrariæ. J.-Page 106.

Chlora, Yellow-wort. Cal. inferior; segments, eight, deep. Cor. one-petalled, nearly wheel-shaped, in eight or six segments. Stig. two-cleft. Caps. one-celled. N. O. Gentiáneæ. J.Page 108.

Vacci'nium, Whortle-berry. Cal. four to five-cleft. Cor. onepetalled. Anthers with two-pores. Berry round, inferior, (four-celled.) N. O. Vaccineæ. DC.-Page 109.

ErícA, Heath. Cal. four-leaved, inferior. Cor. one-petalled, bellshaped, often bellying. Caps. four-celled, four-valved; partitions simple, from the middle of the valves. N. O. Ericeæ. J.-Page 110 .

Callu'na, Ling. Cal. double, each of four leaves. Cor. onepetalled, bell-shaped.) Caps. superior; " partitions adhering to the axis of the fruit, valves opening at the partitions, and separating from them." N. O. Ericeæ. J.-Page 110.

Monotropa Hypopitys; see Decandria. 
* Flowers without corolla (apétalous.)

DApнse, Mezereon. Cal. coloured. four-cleft, inferior. Berry one-seeded. N. O. Thyméleæ. J.-Page 111.

\section{(DIGYNIA. 2 Pistils.)}

Poly'gonum; see in Octand. Trigyn. and Chrysosplenium, and Scleranthus, in Decandria Digynia.

\section{Order II. TRIGYNIA. 3 Pistils.}

Polv'gonum, Persicária; Bistort; Knot-grass; and Buck-wheat. Cal. coloured, inferior; segments deep, several. Cor. none. Fruit-nut one-seeded, compressed, or three-cornered. (Styles two to three.) N. O. Polygóneæ. J.-Page 112.

Order III. TETRAGYNIA. 4 Pistils.

Adoxa, Móschatell. Cal. half-inferior, three-cleft. Cor. four or five-cleft. Berry clothed with the calyx. Seeds four, bordered. N. O. Saxifrágeæ. J.-Page 116.

Paris, Herb Paris. Cal. four-leaved. Pet. four. (Cells of the anthers, fixed one on each side the middle of an awl-shaped filament.) Berry superior, four-celled, each cell with several seeds in two rows. N. O. Smilaceæ. Br.-Page 116.

\section{Class IX. ENNEANDRIA. 9 Stamens.}

Order I. HEXAGYNIA. 6 Pistils.

Bu'tomus, Flowering-rush. Cal. none. Cor. inferior. Pet. coloured, six-partite. Caps. six, many-seeded. N. O. Butómeæ. Richd.-Page 117.

\section{Class X. DECANDRIA. 10 Stamens.}

Order I. MONOGYNIA. 1 Pistil.

* Flowers many-petalled (polypétalous.)

Monótropa, Bird's-nest. Cor.; pet. ten or eight; five or four, outer-ones protuberant at the base (hooded.) Anth. one-celled, 
two-lipped. Caps. superior, four to five-celled. N. O. Monotrópeæ. Nutt.-Page 117.

Py'rola, Winter-green. Cal. five-cleft. Cor.; pet. five. Anth. opening with two-pores. Caps. superior, five-celled. N. O. Monotropeæ. Nutt.-Page 118.

\section{** Flowers one-petalled, (monopetalous,) equal.}

Andrómeda, Andrómerla. Cor. egg, or bell-shaped. Caps. fivecelled. N. O. Ericeæ. J.-Page 304.

Vaccínium Myrtillus; see Octandria.

\section{Order II. DIGYNIA. 2 Pistils.}

Scleranthus, Knawel. Cor. none. Cal. of one piece, five-cleft. (Stam. inserted upon the calyx; five often wanting. Caps. oneseeded. H. Seeds two. Sm. N. O. Sclerántheæ. Link. -Page 120.

Chrysosple'vium, Golden-saxifrage. Cor. none. Cal. somewhat coloured, superior. Caps. two-beaked, many-seeded. N. O. Saxifrágeæ. J.-Page 118.

Saxífraga, Saxifrage. Cal.-segments, five, deep. Cor. fivepetalled. Caps. two-beaked, two-celled, many-seeded, (" opening between the beaks. Seeds upon a receptacle attached to the partition." ( N. O. Saxifrageæ. J.-Page 119.

SAPONÁRIA, Soap-wort. Cal. one-leaved, tubular, (without angles,) five-toothed, without bracteas at the base. Cor.-pet. six, clawed. Caps. oblong, one-celled. N. O. Caryophy'lleæ. J.-.Page 120.

Dianthus, Pink. Cal. tubular, one-leaved, tubular, five-toothed, with about four, tiled, scales at the base. Cor.-pet. five, clawed. Caps. cylindric, one-celled. N. O. Caryophy'lleæ. J.-Page 121.

\section{Order III. TRIGYNIA. 3 Pistils.}

Arena'ria, Sandwort. Cal. five-leaved. Cor.-pet. undivided. Caps. one-celled, many-seeded. N. O. Caryophy'lleæ. J.Page 124.

Stella'ria, Stitchwort. Cal. five-leaved. Cor.-pet. deeply cloven. Caps, opening with six-teeth, many-seeded. N. O. Caryophylleæ. J.-Page 122. (St. uliginósa, is Larbréa aquatica. DC. \&c.)

Srle've, Catch-fy; Bladder-Cumpion. Cal. one-leaved, tubular, 
five-toothed, sometimes bellying. Cor.-pet. clawed; linb cloven generally. Caps. three-celled, six-toothed, many-seeded. N. O. Caryophy'lleæ. J.-Page 121.

Poly'gonum aviculáre; see Octandria.

Order IV. PENTAGYNIA. 5 Pistils.

Cotylédon, Navelwort. Cal. five-partite. Cor. one-petalled, tubular, five-cleft. Caps. five, each with a scale at its base.Page 125.

Sedum, Stone-crop; Orpine. Cal.-segments, five; (or from four to eight,) deep. Cor.-pet. five, spreading. Germ. five, each with a scale at its base. N. O. Crassuláceæ. DC.-Page 125.

OxA'us, Wood-sorrel. Cal. five-partite. Cor.-pet. five, often connected by the base of their claws. Caps. angular, five-celled. Seeds two, coated with an elastic arillus, (seed-coat.) N. O. Oxalídeæ. DC.-Page 127.

Lychis, Lychnis. Cal. tubular, five-toothed, of one-leaf, (monophyllous,) membranous. Cor.-pet. five, clawed, crowned at the mouth, mostly divided at the border.) Caps. five-celled, or onecelled, many-seeded. N. O. Caryophy'lleæ. J.-Page 128.

Agrostemina, Cockle. Cal. tubular, leathery, of one-leaf, fivetoothed. Cor.pet. five, clawed, their border undivided. Caps. opening with five teeth, one-celled, many-seeded. N. O. Caryophy'lleæ. J.-Page 128.

Cera'stium, Mouse-ear Chickweed. Cal. five-leaved. Cor-pet five, cloven. Caps. one-celled, bursting at the top with ten teeth, (but five-teeth in caps. of C. aquáticum.) N. O. Caryophy'lleæ. J.-Page 129.

Spe'rgula, Spurrey. Cal. five-leaved. Cor.-pet. five, undivided. Caps. egg-shaped, five-celled, five-valved. H. One-celled. Sm. N. O. Caryophy'lleæ. J.-Page 130.

Stellaria uliginosa (Larbréa. DC. See in Decandria Trigynia. Adoxa; see in Octandria. 


\section{Class XI. DODECANDRIA. 12 to 19 Stamens inclusive.}

- Order I. MONOGYNIA. I Pistil.

'Asarum, Asarabacca. Cor. none. Cal. three-cleft, superior. Caps. six-celled. N. O. Aristolochiæ. J-Page 131.

Lyrurum, Purple Loosestrife. Cal. inferior, tubular, with twelve teeth alternately smaller. Cor.-pet. six, inserted upon the calyx. N. O. Lythráriæ. J.-Page 132.

\section{Order II. DIGYNIA. 2 Pistils.}

Agrimo'nis, Agrimony. Cal. top-shaped, (turbinate,) five-cleft, inferior, with hooked bristles. Cor.-pet. five, borne on the calyx. Fruit of two capsules, not opening, (indehiscent,) clothed with the hardened calyx. N. O. Rosaceæ. J.-Page 132.

Order III. TRIGYNIA. 3 Pistils.

Rese'DA, Rocket; Mignonette. Cal. of one piece. Cor.-pet. more or less divided, unequal. Caps. one-celled, gaping at the top. N. O. Resedáceæ. DC._Page 133.

\section{(TETRAGYNIA. 4 Pistils.)}

Tormentilla officinális; see in Icosandria.

Order IV. DODECAGYNIA. Pistils 12.

Sempervirvum, Houseleek. Cal.-segments twelve, deep. Cor.-pet. twelve. Caps. twelve. N. O. Crassulaceæ. DC.-Page 133.

Class XII. ICOSANDRIA. 20 Stamens, or more, placed on the calyx.

The genera and species of this class belong to the Nat. Order Rosáceæ of Jussieu.

\section{Order I. MONOGYNIA. 1 Pistil.}

Prunus, Plum, and Cherry. Cal. inferior (below the germen,) five-cleft. Cor.-pet. five. Nut of the stone-fruit (drupe) with slightly prominent seams.-Page 134. 
Order II. PENTAGYNIA. 2 to 5 Pistils.

Me'spilus, Hawthorn, and Medlar. Cal. superior, five-cleft. Cor.pet. five. Apple, (pome,) with two, to five, bony, single-valved capsules. Seeds two.-Page 135.

Pyrus, Pear; Apple; Service-tree. Cal. superior, five-cleft. Cor.-pet. five. Apple, (pome,) with two, to five membranous, two-valved capsules. Cells two-seeded.-Page 136.

Spiræa, Drop-wort, Meadow-sweet. Cal. inferior, five-cleft, persistent. Cor.-pet. five. Caps. three to twelve, one-celled, twovalved; valves mémbranous. Seeds few, $\boldsymbol{H}$. numerous, Sm.Page 137.

\section{Order III. POLYGYNIA. Many Pistils.}

Rosa, Rose. Cal. urn-shaped, fleshy, contracted at the mouth, five-cleft. Cor.-pet. five, pericarps, seeds, (carpels) many, bristly, fixed to the inside of the calyx, whose tube is, at length, pulpy, and lined with hairs.-Page 138.

Rubus, Bramble, and Raspberry. Cal. five-cleft. Cor-pet. five. Fruit superior (placed above the calyx,) of many single seeded juicy stone-fruits, (drupes,) upon a protuberant, permanent, spongy receptacle.-Page 142.

Tormentilla, Tormentil. Cal. eight-cleft, with segments alternately smaller. Cor.-pet. four. Fruit numerous, small nuts upon a dry, small receptacle.-Page 145.

Geum, Avens. Cal. ten-cleft, alternate segments very small. Cor.pet. five. Pericarps (by some called seeds) each with a long, jointed, bent, hooked awn, or tail. Receptacle lengthened out.Page 146.

Fraga'ria, Strawberry. Cal. ten-cleft, with segments alternately smaller. Cor.-pet. five. Fruit of many very small nuts, (by some called seeds), upon a large, pulpy, deciduous, (falling) receptacle.-Page 144.

Co'marum, Marsh-cinque-foil. Cal. ten-cleft, or more, segments alternately smaller. Cor.-pet. five, (or more,) shorter than the calyx. Pericarps, (seeds,) inserted on a large, spongy, permanent, hairy receptacle.-Page 147.

Potentilla, Cinque-foil. Cal. ten-cleft, segments alternately smaller. Cor.-pet. five. Fruit of numerous very small nuts (seeds,) placed upon a dry, small receptacle. Seeds naked, rugged, beardless. Sm.-Page 144.

Spirca Filipendula, and Sp. Ulmaria; see in Icosand. Pentagynia. 


\section{Class XIII. POLYANDRIA. Numerous Stamens on the Receptacle.}

Order I. MUNOGYNia. 1 Pistil.

* Petals four.

Papa'ver, Poppy. Cal. two-leaved. Stig. stalkless, rayed. Caps. one-celled, seeds escaping by pores beneath the permanent stigma._Page 148. N. O. Papaveráceæ. J.

Chelido'nium, Celandine. Cal. two-leaved. Pod one-celled, twovalved. Seeds crested.-Page 147. N. O. Papaveráceæ. J. ** Petals five.

Cistus, Cistus. Cal.-leaves, five, permanent, two outer leaves, smaller. Caps. of several valves. Seeds numerous.-Page 151. N. O. Cistíneæ. J.

TŕLIA, Lime-tree. Cal. of five, deep, valvular, equal segments; cal. falling before the flower, (deciduous.) Fruit leathery, of several close cells, without valves. Seeds few.-Page 150. N. O. Tiliáceæ. J.

Delphinium Consolida; see under Pentagyn. *** Petals numerous.

Nymph жa, White Water Lily. Cal. larger than the petals. Pet. apparently rising from the germen. Nect. in the centre of the stigma. Berry many-celled, coated.-Page 149. N. O. Nymphæáceæ. DC.

Nuphar, Yellow Water Lily. Pet. inserted upon the receptacle, furrowed, honey-bearing at the back. Berry many-celled, coated.-Page 149. N. O. Nymphæáceæ. DC.

\section{Order II. PENTAGYNIA. 2 to 6 Pistils.}

Delphi'nium, Larkspur. Cal. none. Pet. five, or more, the upper one spurred. Nect. divided, tubular, stalkless, within the spur.-Page 152. N. O. Ranunculáceæ. J.

Aquile'gia, Columbine. Cal. none. Pet. five, equal. Nect. five, each spurred below.-Page 152. The same N. O.

Reseda Lutéola; see in Dodecand. Trigyn.

Helléborus, both species, in Polyand. Polygyn.

Order III. POLYGYNIA. Many Pistils.

All the Genera of this third Order belong to N. O. Ranunculáceæ. J. 
Thalictrum, Meadow-rue. Cal. none. Pet. four, or five, tiled. Pericarps without awns.--Page 153.

Cle'matis, Traveller's-joy. Cal. none. Pet. four, or eight, valvular, or folded in at the edges. Pericarps terminated by a long, generally feathery awn. Receptacle headed (capitate.)-Page 153.

Anemóne, Anémony. Cal. none. Pet. from five to nine. Involucre of three divided leaves, more, or less distant from the flower. Seeds numerous. (Pericarps with, or without awns.--) Page 152.

Heldéborus, Hellebore. Cal. none. Pet. five, permanent. Nect. tubular, two-lipped. Pericarps, or follicles, nearly erect, many. seeded.-Page 158.

Caltha, Marsh-marigold. Cal. none. Pet. five, or more. Nect. none. Pericarps, or follicles, several, (compressed, spreading, many-seeded.) - Page 159.

Ranu'Nculus, Crowfoot, or Ranunculus. Cal. five-leaved (rarely 3, H.) Pet. five, sometimes more, with a nectary at the base of each. Pericarps (seeds) without awns, numerous.-Page 154.

Ado'nis, Pheasant's-Eye. Cal. five-leaved. Pet. five to ten, without any nectary. Pericarps (seeds) without awns.-Page 154.

\section{Class XIV. DIDYNAMIA. Four Stamens, of which, two are longer.}

Order I. GYMNOSPERMIA. Seeds apparently naked, four (at most.)

All the Genera of this order, (Gymnos.) belong to Jussieu's N. O. of Labiátæ; Linnæus's Verticillátæ. In this order, the stems are square, leaves opposite. Fl. mostly whorled. The genera, Ly'copus, and Salvía, diandrous plants, belong to this N. O. Labiátæ.

\footnotetext{
* Calyx in five segments, nearly regular.
}

Glecho'ma, Ground-ivy. Anth. before bursting, approaching in pairs, in the form of a cross, saltier. Lip, upper, cloven.Page 164.

Mentha, Mirt. Cor nearly regular, four-cleft, tube very short. Stam.-filaments naked, spreading wide, straight. (Anthers with two parallel cells.)_-Page 162. 
Teu'crium, Germander. Cor. upper lip in two very deep, distant, side lobes.-Page 160.

'AJuga, Bugle. Upper lip of the cor. minute, abrupt, notched; (lower lip, larger, spreading, three-cleft)_Page 160.

Betónica, Betony. Cor. upper lip, nearly flat, ascending; tube cylindrical, curved inwards, (incurved.) Stam. not longer than the throat. ("Cal. egg-shaped, ten-ribbed, teeth equal, awned." H. Fl.)-Page 167.

LA'mium, Dead-nettle. Cor. toothed on each side of the throat.Page 165.

Galeopsis, Hemp-nettle. Cor. upper lip with a pair of hollow prominences at the base, in front. Page 166.

Galeo'bdolon, Weasel-snout. Cor. lower lip in three, nearly equal, sharp, undivided lobes.-Page 167.

Stachys, Wound-wort. Cor. lower lip with two side lobes, bent back. Stam. finally spreading outwards on each side: (scarcely differs from the gen. Betonica, except in the shorter, corolla-tube. H. Br. Fl.)-Page 168 .

Ne'Peta, Cat-mint. Cor. lower lip with numerous notches; throat bordered, bent back on each side.-Page 161 .

Ballo't A, Black-Horehound. Cal. ten furrowed. Cor. upper lip vaulted, shaggy.-Page 169.

Marru'Bium, White-Horehound. Cal. ten furrowed. Cor. upper lip straight, linear, cloven.-Page 169.

Verbe'sA, Vervain. Cal. five-toothed, one tooth abrupt, generally shorter. Cor. nearly equal, curved. Stam. included in the tube, sometimes two, instead of four.) N. O. Verbenáceæ. J. This genus placed by $\boldsymbol{H}$. in the Order, Angiospermia.-Page 162.

\section{* *alyx two-lipped.}

ScUtella'ria, Skull-cap. Cal. after flowering, its two nearly, equal, entire lips closed, as it were, by a back lid.-Page 172.

Thr'mus, Thyme. Cal. closed with dense, converging hairs, that is, approaching each other at the top.-Page 170.

Clinopódium, Wild Basil. Cal. many-ribbed. Involucre, or linear bracteas, composed of numerous taper leaves, under the flowers.-Page 170.

Oríganum, Marjoram. Cal. ribless. Involucre of numerous, dilated, flat leaves, one to each flower, (" resembling a catkin tiled with bracteas." - Page 170.

Prunella, Self-heal. Stam.-filaments forked, one of the points anther-bearing.-Page 173. 
Order II. ANGIOSPERMIA. Seeds in a distinct capsule, mostly numerous.

* Calyx four-cleft.

Lathrea, Toothwort. A depressed gland at the base of the germen. Caps. one-celled, with two spongy receptacles in the middle of each valve. N. O. Orobáncheæ. Richd.-Page 175.

Ba'rtsia, Bartsia. Caps. two-celled. Seeds angular. (Anth. generally hairy.) N. O. Scrophularíneæ. J.-Page 173.

Rinnantuus, Yellow-rattle. Caps. two-celled. Seeds compressed, tiled, flat. N. O. Scrophularineæ. J.-Page 173.

Mera'mpyrum, Cow-wheat. Caps. two-celled. Seeds in pairs, gibbous at the base, smooth. N. O. Melampyráceæ. Richd. -Page 174.

Euphra'sia, Eye-bright. Stam. anth. thorny, (spinous,) "cells of the anthers, spurred at the base." Caps. two-celled. Seeds slightly furrowed, (striated.) N. O. Scrophularineæ. J.Page 174.

\section{* Calyx five-cleft.}

Limoselta, Mud-wort. Cor. bell-shaped, nearly equal. (Stigma headed.) Caps. round, two-valved, imperfectly two-celled. N. O. Scrophularíneæ. J.-Page 181.

Digita'Lis, Fox-glove. Cor bell-shaped, swollen beneath. Stam. bent. Caps. egg-shaped, two-celled.-Page 180. N. O. same. Antírrhivum, Snap-dragon, Toad-flax. Cor. masqued, (closed with a palate;) gibbous, or spurred at the base behind. Caps. two-celled, bursting at the top, unequally. N. O. Scrophularineæ. J.-Page 176.

Pedicula'ris, Lousewort. Cor. gaping, (ringent,) lip, upper, compressed on the sides. Caps. two-celled, compressed. Seeds pointed, (angular.) N. O. Scrophularíneæ. J-Page 176. *** Calyx two-leaved.

Orobanche, Broom-rape. Cal.-leaves lateral (from the side.) Germ. with a gland at its base beneath. Caps. one-celled, with four receptacles.'-Page 181.

I That part of the pericarp, the placenta, to which the seeds are attached, is said to be parietal, when fixed to the walls of the cells of a pericarp. Richd. Seeds on parietal longitudinal receptacles in this genus. 


\section{Class XV. TETRADYNAMIA. Six Stamens, four longer than the rest.}

This class forms the Natural Order of Jussieu's Cruciferæ, (Cruciform plants, ) in which the stem is round. Ls. generally alternate. $\mathbf{F l}$. without bracteas, mostly white, or yellow. Cor. fourpetalled, cross-shaped, (cruciform.) Seeds warm, pungent.

Order I. SILICULO'SA. Fruit a short pod, or pouch.

The sections of this class, Tetradynamia, are made from distinctions in the cotylédons; distinctions easily perceived by a removal of the seed-skin. The two cotylédons are either incumbent, that is, lying upon the émbryo laterally, (sideways,) or accumbent, that is, when their edges, at one side, meet the émbryo lengthwise.See notes, over leaf.

\section{* Cotylédons accumbent.}

Draba. Whitlow-grass. Pouch entire, (oval,) compressed sideways, (laterally.) Valves nearly flat. Seeds many.-Page 183. Hutchinsia. Pouch nearly entire; valves keeled, not bordered. Seeds two, at least, in each cell. Stam.-filaments simple.-Page 307.

Cochlea'Ria, Scurvy-grass, (Horse-rádish.) Pouch nearly entire, rugged; valves two, swollen. Seeds many.--Page 185.

Thuaspi, Shepherd's Purse. Pouch cloven, inversely heartshaped; valves with a bordered keel. Seeds many.-Page 184. IBE'RIS, Candy-tuft. Pouch cloven, inversely heart-shaped. Cells one-seeded. Pet. unequal.-Page 186.

Teesdátia, Teestália. Stam. Filaments each bearing a scale within at the base. Pouch cloven, inversely heart-shaped, valves keeled. Cells two-seeded.-Page 184.

\section{* Cotylédons incumbent.}

Camelína, Gold of Pleasure. Stam.-filaments simple. Pouch entire; valves swollen. Seeds many, without border.-Page 183.

Senebíera, Wart-cress. Pouch two-lobed, nearly entire; transversely compressed, wrinkled; valves none. Seeds one in each cell.-Page 186.

Lepidium, Pepperwort. Pouch cloven, elliptical, two-celled, the two valves keeled. Cells one-seeded.-_Page 183. 
Order II. SILIQUO'SA. Fruit, a long pod, with numerous seeds.

* Cotylédons flat, accumbent.

Cheiranthus, Wall-flower. Cal. closed, two of its leaflets prominent at the base. Stig.-lobes, two spreading ones, or headed, (capitate.) Pod somewhat compressed, straight.-Page 192.

Nastu'rtium, Cress. Cal. spreading, equal at the base. Stig. blunt, notched. Pod almost cylindrical, (sometimes short;) valves hollow, (concave,) not keeled, nor nerved.-Page 188.

Barbare'A, Winter-cress. Cal. upright. Stam.-glands between the shorter filaments. Pod four-cornered, somewhat two-edged. Seeds in a single row.-Page 191.

'Arabis, Wall, or Rock-cress. (Cal. erect.) Pod linear; valves flat. Seeds in one row.-Page 193.

Turri'Tis, Tower-mustard. Pod linear, and (lengthened out;) valves flat, keeled. Seeds in two rows.-Page 194.

Carda'mine, Ladies' Smock, or Cuckoo-Flower. Pod linear; valves flat, nerveless, generally separating elastically from the base. Seed-stalks slender.-Page 187.

Dentária, Coralwort. Pod narrow-spear-shaped; valves flat, narrower than the partition, nerveless, generally separating elastically. Seed-stalks broad, flat.-Page 187.

\section{* Cotyledons flat, incumbent. ${ }^{2}$}

Sisy'mbrium, Hedge-Mustard. Pod nearly cylindrical. Stigma headed, notched. Cal. spreading, sometimes erect.--Page 190. He'speris, Dame's-violet. Cal. closed, with two protuberances at the base. Stig. nearly stalkless, of two converging, (approach-

1 Cotylédons flat, accumbent, i. e. embryo-rootlet lying sideways, along the chink, made by the cotyledons. In this case the embryo rootlet is in the same line, (or nearly so,) with the two cotyledons. Not unlike the blade of a clasp knife, slightly open; the blade representing the embryo-rootlet, and the hollow handle the two accumbent cotyledons. Cotylédons flat, incumbent, i.e. the embryo-rootlet, lying over the middle of the back of one of the incumbent cotyledons. Three leaves of a cut book, would represent the positions; for example, the two bottom leaves of the book would represent the positions of the two incumbent cotyledons, and the remaining topmost third leaf, would represent the position of the embryo-rootlet upon, or under the two cotyledons. The seeds of the common garden candy tuft, (Iberis,) afford an easy example of accumbent cotyledons : the seed of Lepídium campestre, of incumbent cotyledons. The seeds of Ráphanus Raphanistrum, of folded cotyledons. The outer skin of the green, full grown seeds should be carefully stripped off with a needle: they may be examined with the microscope, or with the naked eye. R. W.

2 In the case of incumbent cotyledons, the back of one of the cotyledons is ap. plied to the curved radicle; in the case of accumbent, the edges of the cotyledons are applied to it.-Baxter. See Plate, 184, \&c. 
CLASSES, \&c. AND GENERA ARRANGED. exxi

ing each other at the top,) lobes. Pod inaccurately four-cornered.-Page 192.

Ery'sinum, Treasle-mustard. Stig. headed, notched. Cal. erect. Pod four-cornered.-Page 191.

*** Cotylerlons folded, incumbent.

Bra'ssica, Cabbage; Turnip; Cole-seed. Cal. closed. Pod nearly cylindric, two-valved, beaked.-Page 194.

Sina'PIs, Mustard. Cal. spreading. Pod almost cylindric, twovalved, somewhat beaked. Seeds nearly round.-Page 195.

Ra'Phanus, Radish. Cal. erect. Pod swollen, jointed imperfectly, valveless. Seeds round.-Page 197.

\section{Class XVI. MONADELPHIA. Stamen-filaments}

\section{combined in one set.}

The union of filaments is not easily seen in Erodium, and Geranium.

\section{Order I. PENTANDRIA. 5 Stamens.}

Ero'drum, Stork's-bill. Style one. Five alternate stamens imperfect. Fruit beaked, crowded together, (aggregate,) separating into five, one-seeded capsules, each capsule with a finally spiral awn, bearded on the inside. N. O. Geraniáceæ. J.-Page 197.

Lysimachia vulgúris; see Pentand. Monog.

Linum; see Pentand. Pentag.

Geräium pusillum; see Monadelp. Decandria.

\section{Order II. DECANDRIA. 10 Stamens.}

Geranium, Crane's-bill. Style one. Fruit beaked, crowded together, (aggregate,) separating into five, one-seeded capsules, each capsule with a naked awn, curved back. N. O. Geraniaceæ. J.-Page 198.

For the genera Oxális, Spurtium, Genista, Anthyllis, Ulex, Onónis; see Diadelphia; except the first which is placed in Decandria Pentag.

Order III. POLYANDRIA. Many Stamens.

Matva, Mallow. Styles many. Cal. double; outer one, three$\mathrm{m}$ 
leaved. Caps. placed round, in a circle, (whorled,) one-seeded. N. O. Malvaceæ. J.-Page 201.

Class XVII. DIADELPHIA. Filaments combined in two sets,

Except in the genera Spartium, Genista, Anthyllis, Ulex, and Ononis, where they are all connected at the base, (monadelphous.)

Order I. HEXANDRIA. 6 Stamens.

Fúmária, Fumitory. Cal. two-leaved. Cor. gaping, (ringent,) prominent, honey-bearing at the base. Stam. each filament furnished with three anthers. N. O. Fumariáceæ. DC.Page 202.

Order II. OCTANDRIA. 8 Stamens.

Poly'gala, Milkwort. Cal. five-leaved, two segments wingshaped, (coloured.) Cor.-standard cylindric. Caps. two-celled, two-valved. Seeds solitary, crested at their scar. N. O. Polygáleæ. J.-Page 203.

Order III. DECANDRIA. 10 Stamens; comprising the N. O. Leguminósæ, Juss. Papilionáceous. Linn. \&c.

* Stamen-filaments all connected at the base, the tube generally split above.

Spa'rtium, Broom. Stam.-filaments, all forming a simple tube. Stig. lateral (fixed to the upper side of the end of the style. With.) linear, hairy. Legume-pod flat.-Page 204.

Genista, Green-weed. Stam.-filaments, upwards in two sets. Stig. terminal somewhat headed. Pistil depressing the flower and keel. Standard bent back. Legume-pod swollen.-Page 204.

Ulex, Furze. Cal. two-leaved, with a small scale, each side, at the base. Legume-pod swollen, not much longer than the calyx. -Page 205. 
Antuyluis, Kidney-vetch. Cal. swollen, permanent, enclosing the leyume-pod.-Page 206.

Ono'nis, Rest-harrow. Cal.-segments, five, deep. Standard (large,) slightly furrowed. Legume-pod swollen, somewhat rhomboid, stalkless. Seeds few.-Page 205.

* Stigma or style downy. Stamens nine united, with one free, (diadelphous.)

'Orobus, Bitter-vetch. Style linear, almost cylindric. Stig. downy along its upper side.-Page 206.

LA'thyrus, Vetchling. Style flattened, broader upwards. Stig. downy along the broad upper half of the style.-Page 207.

VI'CIA, Vetch. Style hair-tufted beneath the stigma, in front.-Page 208.

Ervum, Tare. Stig. headed, downy all over.-Page 209.

*** Legume-pod two-celled more or less completely; without the former characters.

AstráGalus, Milk-vetch. Legume-pod swollen, cells two, longitudinal, " cells formed by the bent in margins of the lower suture.")-Page 211.

*** Legume-pod scarcely more than one-seeded; without the former characters.

Trifo'lium, Trefoil, Clover, Melilot. Legume pod scarcely, if longer than the calyx, one-seeded, seldom more, falling off, (deciduous,) not opening. (The $F l$. are in heads. Ls. in threes.) -Page 212.

**** Legume-pod jointed, excluding the former characters.

Hedy'sarum, Sain-foin, Fr. Legume-pod of one or more compressed, (roundish,) close, one-seeded joints. Fl.-keel very blunt_Page 211.

ORníthopus, Bird's-foot. Fl.-keel rounded. Legume-pod somewhat cylindric, curved, of many close joints, one-seeded.-Page 210.

HiPPOCRE'PIS, Horse-shoe-netch. Legume-pod compressed, curved inwards, with many curved joints, (" so that each legume-pod has several deep notches on one side.") - Page 210.

****** Legume-pod spiral, or hooked; (excluding the former characters.)

MedicA'Go, Medick. Legume-pod spiral, or hooked, compressed. $P$ istil pressing back the flower-standard.-Page 216.

******* Legume-pod one-celled, many seeded, (excluding the former characters.) 
Lotus, Bird's-foot-trefoil. Legume-pod cylindric, somewhat spongy within, (imperfectly many-celled.) Fl.-wings, approaching at their upper edges. Stam.-filaments partly dilated.--Page 215.

Class XVIII. POLYADELPHIA. Combined Filaments in more sets than two.

\section{Order I. POLYANDRIA. Many Stamens.}

HYPE'RICUM, Saint John's-Wort. Cal. inferior, (below the germen,) divisions five, deep. Pet. five. Stam.-filaments united at the base, into three, or five sets. Caps. many seeded.-Page 217.

Class XIX. SYNGENESIA. Anthers united into a tube. Compound flowers. N. O. Compósitæ of Linn., and Jussieu.

Order I. POLYGAMIA EQUALIS. Florets all perfect, each with five Stamens, one Pistil, and one-seeded.

* Corolla of each floret strap-shaped, (ligulate.) The semi-flosculous order of Tournefort, and the perfectly N. O. Cichoricea, of Jussieu.

Milky, bitter plants. Ls. alternate. Fl. mostly yellow.

Hуроснжris, Cat's-ear. Cal. somewhat tiled; oblong. Receptacle chaffy. Seed-down feathery; (stalked, or stalkless.)-Page 227.

Crcho'Rium, Succory. Cal. double; "Involucre of eight scales, surrounded by five smaller ones at the base." $H$. Receptacle slightly chaffy. Seed-down chaffy, shorter than the seed.--Page 227.

Crepis, Hawk's-beard. Cal. double; outer one lax, swollen, falling off, (deciduous.) Receptacle naked. Seed-down simple, stalkless.-Page 226.

Hierácium, Hawk-weed. Cal. tiled, egg-shaped. Recept. nearly naked, dotted. Seed-down simple, stalkless.-Dage 22.5. 
Apa'rgia, Hawk-bit. Cal. double; inner one tiled. Recept. naked, pitted. Seed-down feathery, stalkless, unequal and various.-Page 224.

Picris, Ox-tongue. Cal. double; inner one equal; outer one lax. Recept. naked. Seed-down feathery. Seeds transversely furrowed.-Page 221.

T'RAgopo'Gon, Goat's-beard. Cal. simple, scales several, equal, in two rows. Recept. naked. Seed-down stalked, feathery. "Fruit slightly furrowed lengthways." -Page 220.

Leóntodon, Dandelion. Cal. tiled, double; outer scales lax. Recept. nalked. Seed-down stalked, simple.-Page 223.

Lactu'ca, Lettuce. Cal. tiled, cylindric, simple; scales with a membranous margin. Recept. naked. Seed-down stalked, naked.-Page 222.

Prenanties, Wall-lettuce. Cal. double. Florets in one row, (few.) Recept. naked. Seed-down nearly stalkless, simple.Page 223.

Sonchus, Sow-thistle. Cal. simple, tiled, swollen at the base. Recept. naked. Seed-down stalkless, simple.-Page 221.

LAPSA'NA, Nipple-wort. Cal. double; inner one of equal channelled scales. Seed-down none. Recept. naked. Fruit quickly falling off, (deciduous.) - Page 227.

* All the florets tubular, mostly spreading in the limb, forming an hemispheric head. Capitati (headed.) Cirarocéphalæe of Jussien, Thistle-tribe.

Ls. alternate. $F l$. mostly red, or purple.

Carlína, Carline-thistle. Cal. swollen, tiled; outer scales thorny (spinous ;) inner ones coloured, polished, spreading, membranous, radiant. Recept. chaffy. Seed-down feathery--Page 233.

-Arctium, Burdock. Cal. round, (globose,) each calyx-scale with a hook curved inwards, at the end.-Page 228.

CA'Rduus, Thistle. Cal. swollen, tiled; scales thorny, (spinous.) Recept. hairy. Seed-down falling off, (deciduous,) roughish.-Page 229.

Cnicus, Plume-thistle. Cal. swollen, tiled; scales, thorny, (spinous.) Recept. hairy. Seed-down falling off, (deciduous,) feathery.Page 231.

Onopordum, Cotton-thistle. Cal. swollen; scales thorny, spreading. Recept. honey-combed, (cellular.) Fruit four cornered. -Page 231. 


\section{cxxvi CLASSES, \&c. AND GENERA ARRANGED.}

Serra'tula, Saw-wart. Cal. almost cylindric, tiled with unarmed scales. Seed-down permanent. (Diœecious. H.)-Page 229.

*** Florets all tubular, parallel, forming nearly a level top, rayless. (Discoid flowers.) Part of the N.O. Corymbiferce of Jussieu.

Eupatórium, Hemp-agrimony. Cal. tiled, oblong. (Fl. few.) Style cloven half way down, prominent. Recept. naked. Seeddown rough.-Page 234.

Bidens, Bur-marigold. Cal.-scales many, parallel, channelled. (Cor. sometimes rayed.) Recept. plain, chaffy. Seed-down rough, with minute bristles, bent downwards.-Page 234.

Tanacetum vuly. See in Polyg. superfl, also Sercécio vulgáris.

Order II. POLYGAMIA SUPERFLUA. Florets of the centre complete, that is, with Stamens and Pistils; those of the circumference with Pistils only: all seed-bearing.

- Corollas of the marginal florets scarcely distinguishable, or wanting. (Discoid.) N. O. Part of Corymbiferce, Juss.

'Tanace'tum, Tansy. Cal. hemispheric, tiled. Fl. of the ray three-cleft, scarcely distinguishable, sometimes wanting. $R$ ecept. naked. Fruit crowned with a membranous margin.-Page 235.

Conv'zA, Spike-nard. Cal. roundish, tiled. Fl. of the circumference three-toothed. Recept. naked. Seed-down rough.-Page 238.

Gnapha'uium, Cudweed. Cal. tiled; srales mémbranous; (filmy) often coloured. $\mathbf{F l}$. of the circumference awl-shaped. Recept. naked. Seed-down rough, or feathery.-Page 236.

Artemisia, Wormwond, Mugwort. Cal. tiled; scales rounded, converging, (approaching each other at the top.) Fl. of the circumference awl-shaped, entire. Seed-down none. Recept. naked, or hairy.-Page 235.

Tussilaigo Petasites. See in Polyg. Superf.

* Corollas of the marginal florets strap-shaped, (ligulate.) Radiate, (or rayed) flowers.

Besus, Daisy. Cal. hemispheric; scales equal. Recept. naked, conical. Seed-down none. Seed inversely egg-shaped.-Page 244.

Matrica'ria, Wild-C'hamomile. Cal. almost flat, tiled; scales membranaceous at their edges. Recept. naked, nearly cylindric. Seed-down none.-Page 246. 
Chrysa'nthemum, Ox-eye. Cal. hemispheric, tiled; scales with a dilated, membranaceous border. Recept. naked, somewhat convex. Seed-down none.-Page 245.

Py'rethrum, Feverfew. Cal. hemispheric, tiled; scales somewhat acute, with membranaceous margins. Recept. naked. Seed crowned with a border.-Page 245.

'InuLA, Elecampane, and Flea-bane. Cal. tiled. $\boldsymbol{F l}$. of the ray very numerous, linear. Anth. two-bristled at the base. Recept. naked. Seed-down simple.--Page 243.

Erígeron, Fleabane Erigeron. Cal. tiled. Fl. of the ray many, linear, (very narrow.) Stam.anth. simple. Recept. naked. Seed-down simple.-Page 238.

Solida'Go, Golden-rod. Cal. with close scales, tiled. $\mathrm{Fl}$. of the ray, about five; (yellow.) Recept. naked, pitted. Seed-down simple, stalkless.-Page 242.

Senécio, Groundsel, or Ragwort. Cal. double; the inner one cylindric; scales numerous, equal, outer calyx of smaller scales at the base, all withered, or brown at the end. Recept. naked. Seed-down simple.-Page 240.

Tussila'Go, Colt's-foot; and Butter-bur. Cal. simple, swollen at the base; scales many, equal, somewhat membranaceous. Recept. naked. Seed-down simple. Seed inversely egg-shaped, compressed.-Page 239.

Cinera'ria, Flea-wort. Cal. simple, cylindric ; scales many, equal, upright. Recept. naked. Seed-down simple. Seed four-cornered. (Fl. yellow.)-Page 244.

'Anthemis, Chamomile. Cal. hemispheric; scales nearly equal. $F l$. of the ray oblong. Recept. chaffy, convex. Seed crowned with a slight border.-Page 247.

Achille' A,' Yarrow. Cal. egg-shaped; scales, tiled, unequal. $F l$. of the ray from five to ten, roundish, somewhat inversely heartshaped. Recept. chaffy. Seed-down none--Page 248.

Bidens cernua, occasionally rayed. See the Genus.

Order III. POLYGAMIA FRUSTRANEA. Florets of the centre (disk) perfect, and seed-bearing; those of the circumference barren, (neuter.) N. O. Part of Juss. Cinarocephalæ.

Centaure'a, Knapweed; Blue-bottle; and Star-thistle. Cal.tiled. $F$. of the ray, (without stamens, or style, funnel-shaped, irre-

: Pronounce killéa. 


\section{cxxviii CLASSES, \&c. AND GENERA ARRANGED.}

gular, longer than those of the centre, or disk. Recept. bristly. Seed-down simple, or feathery; rarely none.-Page 249.

Class XX. GYNANDRIA. Stamens situated upon the style, or column, or upon the germen. All of $\mathrm{N}$. O. Orchídeæ. J., except Aristolochia.

Order I. MONANDRIA. Stamen, or stalkless Anther one.

* Anther of two distinct, vertical cells, fixed to the top of the column.

Orchis, Orchis. Nect. with a spur behind.-Page 251.

Ophrys, Insect-orchis. Cal. somewhat spreading. Lip (Nect. Sm.) without a spur, convex.-Page 256.

Herminium, Musk-orchis. Cal. somewhat spreading. Cor.-pet. with side lobes, like the nectary, which is flat without a spur.Page 256.

* * Anther parallel to the stigma, of two-cells, close together, permanent.

Neo'Ttia, Lady's Tresses. Cal. converging, embracing the base of the flat rectary, which is without a spur. Cor.pet. converging. Column wingless.-Page 257.

Liste'ra, Twayblude. Cal. spreading. Lip two-lobed. Nect. spurless, nearly flat. Cor.pet. spreading. Column wingless -Page 258.

*** Anther terminal, fixed.

EPIPACTIS, Helleborine. Lip (Nectary) very hollow at the base, the extremity undivided or three-lobed, the middle lobe largest, and as it were jointed.-Page 259.

Order II. DIANDRIA. 2 Stamens, or stalkless Anthers.

Cypripe'dium. Lady's Slipper.-Page 260.

Order III. HEXANDRIA. 6 Stamens, or stalkless Anthers.

Aristolóchia, Birthwort. Cal. superior, tubular, often swollen at the base, the mouth on one side dilated, one-lipped. Cor. none. Stig. six-lobed, Caps, inferior, six-celled. N. O. Aristolochieæ. J.-Page 260. 


\section{Class XXI. MONOECIA. Stamens and Pistils in} separate flowers, on the same plant.

\section{Order I. MONANDRIA. I Stamen.}

Eupho'rbia, Spurge. Involucre of one piece, with several stamenbearing (barren) flowers, and one pistil-bearing (fertile) flower. Stamen-bearing flower. Cal. none. Cor, none.

Pistil-bearing flower. A single pistil. Cal. none, (or rarely any.) Cor. none. Germ. three-lobed. Styles three, cloven. Caps. three-seeded. N. O. Euphorbiáceæ. J.-Page 261.

ZANNICHE'LiLia, Horned-pondweed. Involucre none.

Stamen-bearing flower. Cal. and Cor. none.

Pistil-bearing flower. Cal. one-leaved. Cor. none. Germ. four, or more. Caps. (seeds) four, nearly stalkless. Stig. targetshaped, (peltate.) N. O. Fluviáles. Vent.

Callitriche, and Chara? See Monandria.-Page 263.

\section{(DIANDRIA. 2 Stamens.)}

Carex. See in Order $\boldsymbol{I I}$.

\section{Order II. TRIANDRIA. 3 Stamens.}

Sparga'nium, Bur-reed. $F l$. in spherical, close heads.

Stamen-bearing flower. Cal. three-leaved.

Pistil-bearing flower. Cal. three-leaved. Cor. none. Drupe (stone-fruit) dry, one-seeded. N. O. Typháceæ. J.-Page 264.

CAREx, Sedge. $F l$. collected into a tiled spike, herbage grassy.

Stamen-bearing flower. Cal. a scale. Cor. none.

Pistil-bearing flower. Cal. a scale. Cor. a hollow, permanent glume (husk,) clothing the loose seed. Fruit-nut three-cornered. N. O. Cyperáceæ. J.-Page 265.

Trрна, Reed-mace. $\quad F l$. collected into very close, cylindric spikes or catkins.

Stamen-bearing flower. Cal. none. Cor. none. "Stam. three together upon a chaffy, or hairy receptacle, united below into one filament."

Pistil-bearing flower. Cal. none. Catkin hairy. Pericarp (seed,) on a hairy stalk. N. O. Typháceæ. J.-Page 264. 
Order III. TETRANDRIA. 4 Stamens.

URTI'CA, Nettle. Stamen-bearing flower. Cal. four-leaved, containing the cup-shaped rudiment of a pistil.

Pistil-bearing flower. Cal. two-leaved. Cor. none. Pericarp (seed) one-seeded, polished. N. O. Urtíceæ. J.-Page 277.

Anvus, Alder. $\mathrm{Fl}$. collected into tiled catkins. Stamen-bearing flower. Cal.-scale of the catkin, three-lobed, three-flowered. Cor. deeply four-cleft.

Pistil-bearing flower. Cal.-scale of the catkin, permanent, twoflowered. Cor. none. Styles two. Nut compressed. N. O. Amentáceæ. J.-Page 277.

Order IV. PENTANDRIA. 5 Stamens.

Bry'onia, Bryony. Stamen-bearing flower. Cal. five-toothed. Cor. five-cleft. Stam.-filaments three; anthers five.

Pistil-bearing flower. Cal. five-toothed, falling off. Cor. five-cleft. Style three-cleft. Berry inferior, round, many-seeded. N. O. Cucurbitáceæ. J.-Page 278.

Fagus; Quercus; see in Monoecia Polyandria: Atriplex, in Polygamia.

\section{Order V. HEXANDRIA. 6 Stamens.}

Rúmices. See in Hexandria. Quercus in Monoecia Polyandria.

Order VI. POLYANDRIA. 7 Stamens, or more.

Myriophyluum, Water-milfoil. Stamen-bearing flower. Cal. inferior, four-leaved. Cor.-pet. four. Stam. eight.

Pistil-bearing flower. Cal. four-leaved. Cor.-pet. four. Stig. four, stalkless. Nuts (drupes) four, stalkless, somewhat round, oneseeded. N. O. Halorágeæ. Br.-Page 279.

Potérium, Salad-burnet. $\boldsymbol{F} l$. collected into a head: upper ones fertile.

Stamen-bearing flower. Cal. three-leaved, Sm. of four deep segments. H. Cor. deeply four-cleft. Sm. (Cor. six-cleft, $\boldsymbol{H}_{\text {. }}$ ) Stam. thirty, to forty, or more.

Pistil-bearing flower. Cal. "tubular, contracted, at the mouth, with four deciduous (falling off) teeth. $H_{\text {." }} \quad \mathbf{C a l}$. three-leaved. Sm. Pistils one, or two. Stig. tufted. Pericarps two, one- 
seeded, clothed with the hardened, four-angled tube of the calyx. N. O. Rosáceæ. J.-Page 281.

Sagitta'ria, Arrow-head. Stamen-bearing flower. Cal. threeleaved. Cor.-pet. three. Stam. many, (about twenty. four.)

Pistil-bearing flower. Cal. three-leaved. Cor.-pet. three. Pistils, very numerous collected into a head. Pericarps (seeds) oneseeded, compressed, bordered. N. O. Alismáceæ. Richd.-Page 280.

Ceratophyluum, Hornwort. Stamen-bearing flower. Cal. inferior, many-cleft. Cor. none. Stam. sixteen to twenty.

Pistil-bearing flower. Cal. many-cleft. Cor. none. Germ. one. Stig. nearly stalkless, oblique. Nut (drupe) superior, oneseeded. N. O. Ceratophy'lleæ. Gray.-Page 279.

FAGUS, Beech, and Sweet Chestnut. Stamen-bearing flower, in a catkin. Cal. one-leaved, in several segments. Cor. none. Stam. five to twenty.

Pistil-bearing flower. Cal. double; outer inferior, prickly, in several deep segments, two, or three-flowered, inner calyx superior, five, or six cleft. Cor. none. Styles five, or six. Nuts two, or three, loosely clothed with the spreading outer calyx. N. O. Amentáceæ. J.-Page 283.

Quercus, Oak. Stamen-bearing flower in a lax catkin or spike. Cal. five, to seven.cleft. Stam. five, eight, or more.

Pistil-bearing flower. Cal. double; outer one, inferior, scaly, undivided; inner one superior, in six, deep segments. Cor. none. Style one. Stig. three. Nut, (acorn,) one-celled, one-seeded, closely invested at its base, with the hemispheric outer calyx. N. O. Amentáceæ. J.-Page 281.

Co'Ry Lus, Hazel-nut. Stamen-bearing flower in a cylindric catkin. Cal. a three-cleft scale. Cor. none. Stam. eight, or more.

Pistil-bearing flower. Cal. double; outer one inferior, divided; inner one superior, scarcely distinguishable, (obsolete.) Cor. none. Styles two. Nut solitary, bony, clothed with the enlarged, leathery, jagged outer calyx. N. O. Amentáceæ. J.-Page 284.

$\mathrm{CA}^{\prime}$ Rpinus, Hornbeam. Stamen-bearing flower in a cylindric catkin. Cal. a rounded scale. Cor. none. Stam. ten, or more.

Pistil-bearing flower, in a lax catkin. Cal. double; outer one inferior, of several deciduous (falling off) scales; inner calyx superior, in three, deep, sharp segments, permanent. Cor. none. 
Styles two. Nut egg-shaped, angular, naked. N. O. Amentáceæ. J.-Page 284.

BE'Tula, Birch. Stamen-bearing flower in a cylindric catkin. Cal. a three-divided (ternate) scale. Cor. none. Stam. ten, to twelve.

Pistil-bearing flower in a catkin. Cal. an imperfectly three-lobed scale, three-flowered. Cor. none. Styles two. Nuts compressed, winged (with a membranaceous margin,) one-seeded. N. O. Amentáceæ. J.-Page 283.

Arum, Cuckoo-pint Arum. Sheath (spatha) one-leaved, rolled inwards at the base, enclosing a common-stalk, naked above. Cor. none. Spadix with germens at the base. Stam. stalkless, near the middle of the spadix which is naked above. Berry one-celled, many-seeded. N. O. Aróideæ. J.-Page 280.

Order VII. MONADELPHIA. Filaments united below.

(Pinus, Fir.)

Typha. See in Monoecia Triandria.

\section{Class XXII. DIOECIA. Stamens and Pistils in} separate flowers, on different plants.

In MONANDRIA. 1 Stamen.

Several Sálices, (Willows.)

Order I. DIANDRIA. 2 Stamens.

Salix, Willow, Sallow, and Osier.

By Osiers are meant, in general, the narrow-leaved willows, with long, bending twigs: by Sallows, those with broadish, inversely egg-shaped, or rounded, downy leaves, silky catkins, and two yellow stamens in each floret.

Stamen-bearing flower. Catkin tiled. Scales of the catkin oneflowered, with a honey-bearing gland, or glands, at the base. Cal. a scale. Cor. none. Stam. one to five.

Pistil-bearing flower. Stig. two. Caps. superior, one-celled, twovalved, many-seeded. Seeds tufted. For the catkin; scales, 
CLASSES, \&c. AND GENERA ARRANGED. cxxxiii

and cor. none; See above, in description of stamen-bearing flower. N. O. Amentáceæ. J.-Page 285.

Order II. TRIANDRIA. 3 Stamens.

Ruscus, Butcher's Broom. Stamen-bearing flower. Cal. sixleaved. Cor. none. Stam.-filaments combined at the base. Anth. three to six. Nect. egg-shaped, tubular, bearing the stamens internally.

Pistil-bearing flower. Cal. and Nect. as in the stamen-bearing (barren) flower. Style one. Stig. one. Berry superior, threecelled. Cells two-seeded. (Seeds in pairs.) N. O. Smiláceæ. Br.-Page 294.

Valeriuna dioíca. See in Triandria Monog.

Some Sálices, (willows,) in this second order.

\section{Order III. TETRANDRIA. 4 Stamens.}

Viscum, (Mistletoe.) Stamen-bearing flower. Cal. none. Cor. pet. four, calyx-like, egg-shaped, fleshy, united at the base Anth. stalkless on the petals.

Pistil-bearing flower. Cal. a slight border. Cor.-pet. four, dilated at the base, erect, egg-shaped, very small. Stig. stalkless. Berry inferior, with one compressed seed. N. O. Lorántheæ. J.-Page 295.

Rhamnus cathárticus, and Euonymus europaus. See in Pentandria Monog. Urtíca dioíca in Monoecia Tetrandria.

\section{Order IV. PENTANDRIA, 5 Stamens.}

Hưnulus, Hop. Stamen-bearing flower. Cal. five-leaved. Cor. none. Anth. with two pores at the end.

Pistil-bearing flower in a catkin. Catkin-scales large, hollow, entire, one-flowered, persistent. Cor. none. Styles two. Seed one, coated, winged with the calyx. N. O. Urtíceæ. J.Page 295.

Pimpinella dioŕca. See in Pentand. Digyn. Bryónia in Monoecia Pentand. Salix pentandra, and Salix frágilis in Dioecia Diandria.

Order V. HEXANDRIA. 6 Stamens.

TAMus, Black Bryony. Stamen-bearing flower. Cal. none. Cor. in six, deep segments. 
Pistil-bearing flower. Cal. none. Cor. in six, deep segments, contracted at the neck, superior. Style three-cleft. Berry inferior, three-celled. Seeds in pairs. N. O. Smiláceæ. J.-Page 296.

Rumex Acetósa, and Rumex Acetosella. See in Hexand. Trigyn.

\section{Order VI. OCTANDRIA. 8 Stamens.}

Po'pulus, Poplar. Stamen-bearing flower. Catkin tiled with jagged scales. Cor. top-shaped, (turbinate,) oblique, entire, undivided.

Pistil-bearing flower. Catkin, calyx, and corolla, as above. Stig. four, or eight. Caps. superior, two-celled, H., one-celled, Sm., two-valved, many-seeded. Seeds tufted. N. O. Amentáceæ. J.-Page 296.

\section{Order VII. ENNEANDRIA. 9 Stamens.}

Mercuria'lis, Mercury. Stamen-bearing flower. Cal.-segments, three, deep. Cor. none. Stam. nine to twelve. Anth. lobes two, round.

Pistil-bearing flower. Cal. as above. Cor. none. Styles two. Caps. two-lobed, two-celled; cells one-seeded. N. O. Euphorbiáceæ. J.-Page 298.

Hydro'charis, Frog-bit. Fl. in a sheath (spatha.) Stamenbearing flower. Cal. three-cleft. Cor. three-petalled. Stam. nine in three rows, within which are three imperfect styles. (Inner-filaments beaked. Sm.)

Pistil-bearing flower. Cal. and pet. as above. Styles six, each with two stigmas. Caps. inferior, leathery, roundish, six-celled, many-seeded. N. O. Hydrocharídeæ. J.-Page 299.

(DECANDRIA. 10 Stamens.)

Lychnis dioica. See in Decandria Pentay.

(ICOSANDRIA. Many Stamens, growing from the Calyx.)

Fragária elátior. See in Icosand. Polyg.

(POLYANDRIA. Many Stamens, growing from the Receptacle.)

(Stratiótes.) See Pópulus alba, $P$. trémula, and P. nigra, in Dioec. Octandria. 
Order VIII. MONADELPHIA. Stamen filaments combined in one set.

JUNI'PERUS, Juniper. Stamen-bearing flower. Scales of the catkin somewhat target-shaped (sub-peltate.) Cor. none. Stam. three. Sm. (four to eight. $\boldsymbol{H}$.)

Pistil-bearing flower. Scales of the catkin fewer than in stamenbearing flower, at length, fleshy, united into a berry, of three seeds. N. O. Coníferæ. J.-Page 299.

Taxus, Yew. Stamen-bearing flower. Cal. none. Cor. none. Stam. many. Ath. target-shaped, (peltate,) lobed; cells opening beneath.

Pistil-bearing flower. Cal. cup-shaped, entire, scaly. Cor. none. Style one, $\boldsymbol{S} m$. none, $\boldsymbol{H}$. Seed one, enclosed in the enlarged, pulpy, unconnected calyx. ("Drupe fleshy, bored at the extremity.") N. O. Coníferæ. J.-Page 300.

Salix rubra. See in Dioecia Diandria.

Class XXIII. POLYGAMIA. Stamens and Pistils in the same flower; or in different flowers, and on the same, or different plants; " having two different kinds of calyx (perianth.")

Order I. MONOECIA. Flowers different on the same plant.

'Atriplex, Orache. Barren flowers and united flowers. Cal. inferior, deeply five-cleft. Cor. none. Stamens five. Style deeply cloven. Seed one, depressed, covered by the calyx.

Pistil-bearing flower. Cal. of two persistent, enlarged valves. Cor. none. Stam. none. Style deeply cloven. Seed one compressed, covered by the calyx. N. O. Chenopódeæ. J.-Page 300.

\section{OMISSIONS.}

After Symphytum, p. xcviii.-insert BorA'Go, Boraye. Cor. closed with awl-shaped or notched valves: limb wheel-shaped. Sm. After Limosella, p. cxix.-insert Scrophula'ria, Figwort. Caps. two-celled, two-valved. Cor. somewhat globose, reversed; tube swollen : limb rounded, considerably shorter. 


\section{FLORA OF OXFORISHIRE,}

AND

ITS CONTIGUOUS COUNTIES.

Class I. MONANDRIA. Stamen 1.

Order I. MONOGYNIA. Pistil 1.

* Seed one.

HIPPU'RIS. Gr. Mare's-tail.

H. vulgáris. Common Mare's-tail.

Leaves linear, many in each whorl. E. B. 763. G. E. 1114. f. 6.

Ponds, wet meadows, ditches. Blenheim Park, Ensham Common, Binsey Common. Sb. Ditches near the Canal, between High Bridge and Heyfield's Hut. Port Meadow. Near the third bridge from Botley. $B \boldsymbol{x}$.

Per. May, June.

Erect, simple. $F l$. axillary, solitary, stalkless.

\section{CHARA. Chara.}

C. vulgáris. Common Chara. Slightly furrowed, without prickles. Whorled branches tapering, with internal partitions. Bracteas four together. E. B. 336. G. E. 1115 .f. 8 .

Ponds, wet ditches, stagnant waters. Binsey Common, peat bogs on Bullingdon Green. $\quad \$ \quad$.

An? June.

Often incrustated with earth. 
C. hispida. Prickly Chara. Furrowed. Whorled branches tapering, with internal partitions. Bracteas whorled. Prickles on the stem bristly, bent downwards. E. B. 463. C. tomentosa. Sb.

Clay-pits, pools, ditches. * Peat bogs under Headington Wick copse. Sh. Old gravel pits, St. Clement's, Oxford. Ponds on the Botley road. Bx. Encrusted.

An. July, August.

(C. Aléxilis. Smooth Chara. Smooth, transparent, without prickles. Whorled branches cylindrical, blunt, with a minute point, no internal partitions; some cloven. Bracteas none.

Ditches und ponds. Ditches about Drayton, Warwickshire. $\boldsymbol{P} n$. An. April, August.

Slender, green, floating. Anth. naked. Stem. 1, to three feet long, and more. $\boldsymbol{P}_{n}$.)

\section{MONANDRIA DIGYNIA.}

\section{CALLI'TRICHE . Water-starwort.}

C. verna. Vernal Water-starwort. Fertile flower stalks very short, with two petals at their base, fruit regularly four cornered, margin of the seeds blunt. Leaves triple-ribbed; the uppermost crowded, inversely eggshaped. C. aquatica E. B. 722. $\beta$ Fl. Brit. 9. H. L. 127. See Sb. varieties $\gamma$ ?

Ditches, ponds, slow streams.

An. April, May.

$\boldsymbol{L} s$. opposite, linear, or battledore-shaped. $\boldsymbol{F}$ l. white, axillary, separated.

C. autumnális. Autumnal Water-starwort. Fertile flower stalks, very short, without petals, fruit irregularly four cornered, margin of the seeds membranous. Ls. linear, abrupt, single-ribbed, uniform. C. aquatica $\gamma$. Fl. Brit. 9. E. B. 722. the small figure. Sb. 2. Var. $\gamma$.

Clear pools.

An. June, October.

Flowers united. Gray.

${ }^{3}$ Gr. kalos, handsome, and thrix, hair, from its slender stems. 


\section{Class II. DIANDRIA. Stamens 2.}

\section{Order I. MONOGYNIA. Pistil 1.}

LIGUSTRUM. Privet.

L. vulgáre. Common Privet, Print, or Prim Print. Leaves oval-spear-shaped, blunt, with a small point. E. B. 764. C. 5. t. 1. Ligustrum. G. E. 1394. Moist thickets and hedges, on a gravelly, or chalky soil. Sm.

Shrub. June.

Fl. panicled, and white. Berries black.

For cut hedges in gardens.

\section{FRA'XINUS. Ash。}

F. excélsior. Common Ash. Leaflets saw-toothed. Flowers without calyx, or corolla. E. B. 1692. G. E. 1472 .

Woods, hedges, especially on hills in limestone countries. Sm.

Tree. April, May.

Lofty, smooth. Ls. winged. $F l$. panicled. Caps. spear-shaped.

* F. heterophylla. Simple-leaved Ash. Christ Church Meadows. B.x.

CIRCÆ'A ${ }^{1}$. Enchanter's Nightshade.

\section{C. lutetiána. Common Enchanter's Nightshade. Stem} erect. Leaves egg-shaped, slightly toothed, opaque, and downy. E. B. 1056 . C. 3. 3. G. E. 351.

Moist shady woods, under hedges.

Per. June.

Branches somewhat solitary. $\mathrm{Fl}$. white, or reddish. Fruit bent downwards, clothed with hooked bristles.

Formerly, in incantations, and philters, mistaken for the Mandrake, Atropa Mandragora?

\section{VERONICA ${ }^{2}$. Speedwell.}

\section{Clusters or spikes terminal. Root perennial.}

V. serpyllifolia. Smooth Speedwell. Paul's Betony. Cluster terminal, somewhat spiked. Leaves egg-

${ }^{1}$ From Circe.

2 The I. usually pronounced short. From ver, the spring; or from the name of the fernale saint.

В 2 
shaped, slightly notched, three-ribbed, smooth. Capsule inversely kidney-shaped, shorter than the style. E. B. $1075 . \quad$ C. 1. 3. V. minor. G. E. $62 \%$. Moist meadow's, cultirated grounds.

Per. May.

Stems trailing, smooth in wet situations, in dry ones, covered with hairs, which are bent inwards. $F l$. whitish, with dark blue streaks.

** Clusters or spikes from the side of the stem. Root perennial.

V. Beccabunga. Brooklime. (Bach ${ }^{\text {I }}$, Germ. a rivulet, Bungen, Germ. a drum.) Clusters from the side of the stem. Leaves oval, blunt, flat, smooth, somewhat fleshy, toothed at the edges, each little tooth terminated by a gland. Stem creeping at the base. E. B. 655 . C. 2. 3. Anagallis, seu Becabunga. G. E. 620 .

Wet ditches, brooks.

Per. June.

Plant somewhat floating, shining. $\quad L s$. blunt. $\quad F l$. dull blue. Leaves mild, eaten in salads, in the spring.

V. Anagallis. Water Speedwell. Long-leaved Brooklime. Clusters from the sides of the stem, opposite. Leaves spear-shaped, saw-toothed. Stem erect. E. B. 781 . C. 5. 2. G. E. 620 .

Banks of rivers, wet meadows.

Per. July.

Larger than the last plant, upright, smooth. Ls. acute. $F \boldsymbol{F l}$. pale dull blue, occasionally flesh-coloured.

V. scutelláta. Narrow-leaved Marsh Speedwell. Clusters from the sides of the stem, alternate; fruit stalks bent back. Leaves linear-spear-shaped, slightly toothed. E. B. 782. C. 5.3. Anagallis aquatica quarta. G. E. 621 .

Peat bogs, moors. * Peat bogs on Bullingdon Green. Otmoor. Sb. Port Meadow. (Bagley Wood.) St. Clement's, Oxford, between the Cowley, and Henley road. Bx.

Per. July.

Stem weak, wide spreading. $F l$. pale, flesh-coloured, purple veined, on slender stalks, which become more and more straddling after flowering. $S m$.

V. montána. Mountain Germander Speedwell. Mountain Madwort. Clusters from the sides of the stem,

1 Becc. A. Sx. 
lax, of few flowers. Leaves egg-shaped, stalked, sawtoothed. Stem spreading, hairy all round. E. B. 766. C. 4. 2.

Shady woods. Shotover plantations. Stokenchurch. Nettlebed woods. Sb. (Bagley Wood.) Bx. Pig's Lane, Tilehurst, Berks. R.W.

Per. May.

Stem lying down, hairy. $\boldsymbol{F}$. pale, painted with purple. Caps. formed, as it were, of two round cells, compressed.

V. officinális. Male, or Common Speedwell. Clusters from the sides of the stem; partial stalks shorter than their bracteas. Leaves broadly elliptical, saw-toothed, roughish. Stem lying down. Stigma headed. E. B. 765. C. 3. 1. V. vera et major. G. E. 626.

Dry hilly pastures.

Per. June.

$F l$. light blue, with dark streaks.

This species formerly recommended as a substitute for the Chinese tea, but it is more astringent, and bitter, and less grateful.

V. Chamadrys. Germander Speeduell. Wild Germander. Clusters from the sides of the stem. Leaves egg-shaped, stalkless, rugged, deeply saw-toothed. Stem spreading, with a hairy line on each side. Calyx four-cleft, spear-shaped. E. B. 623. C. 1.2. Ch. sylvestris. G. E. $65 \%$.

Pastures, urder hedges.

Per. May.

$L s$. egg-shaped, inclining to heart-shaped. $F l$. large bright blue. Caps. inversely heart-shaped.

Few of our wild flowers can vie in elegance, and brilliancy with this species. At night, and in moist weather the corolla closes, expands in dry, bright weather. This is not the German "Forgetme-not." Myosbtis palustris is the true one.

*** Flowers axillary, solitary. Root annual.

V. agrestis. Sm. Green Procumbent Field Speedwell. Germander Chickweed. Flowers solitary. Leaves egg-shaped, deeply saw-toothed, shorter than the flower-stalks. Stems lying down. Segments of the calyx egg-shaped. Seeds about six in each cell. Herbage pale green, not greyish. Cal.-segments more narrow, egg-spear-shaped, or oblong, blunt : not eggshaped, acute. $C r$. pale blue, or rose colour in the upper half, white in the lower, or quite white. Caps. 
obscurely keeled. Bor. Seeds cupped, in form. Suppl. E. B. 2603. Alsine foliis trissaginis. G. E. 616. f. 1.

Fields: not so common as $V$. polita.

An. May.

V. polita. H. B. F. Grey Procumbent Sp. Leaves stalked, heart-egg-shaped, cut-saw-toothed, shorter than the flower-stalks, segments of the calyx egg-shaped, acute, stem lying down, capsule two swollen lobes, cells many seeded. V. agrestis, E. B. r83. Often growing with the preceding. H. See Borrer Suppl. E. B. 2603.

Common weed.

An. March.

Fl. small, bright blue.

V. arvensis. Wall Sp. Speedwell Chickweed. Flowers solitary, nearly stalkless. Leaves egg-shaped, deeply saw-toothed. The floral ones spear-shaped, entire. Stem erect, seeds flat. E. B. 734。 C. 2. 2. Alsine foliis Veronicæ. G. E. 613.

Walls, cultivated ground.

An. May.

Ls. opposite, nearly stalkless; by Linneus, styled heart-shaped. Lower leaves chiefly on short foot-stalks. Pl. erect, pale. $F l$. small, light blue, white in the centre. Caps. compressed.

V. hederifólia. Ivy-leaved Sp. Small Henbit. (Winter Weed, in Norfolk.) Flowers solitary. Leaves heart-shaped, flat, five-lobed. Segments of the calyx heart-shaped, acute. Seeds cupped, wrinkled. E. B. 784. C. 2. 1. Alsine hederacea. G. E. 616.

Cultivated grounds.

An. April.

Stem prostrate. Fl. light, purplish blue. Caps. swollen.

PINGUI'CULA. Butteru'ort : (So called on account of the glutinous, oily, and soft leaves of one species, P. vulgaris.)

P. vulgáris. Common Butterwort. Yorkshire Sanicle. Nectary cylindrical, acute, as long as the very irregular petal. Segments of the calyx oblong. Capsule eggshaped. E. B. \%0. P. sive Sanicula Eboracensis. G. E. 788 . 
Bogs, morassy ground. Peat bogs on Bullingdon Green. Under Headington Wick copse. $\mathbf{S} b$. and $B \cdot$. Cotesford Heath. R. $\boldsymbol{P r}$. Henley Hill. $W h$.

Per. May.

Plant smooth. $F l$. tube, and spur, pale purple; limb deep blue, its five segments very unequal.

The clammy juice of the herb reputed good for the sore dugs of cows. G. The Welch prepare a purgative syrup from the plant.

\section{UTRICULA'RIA ${ }^{3}$. Bladder-wort, or Hooded Milfoil.}

U. vulgáris. Greater Bladder-wort. Spur conical. Scape straight. Cluster somewhat corymbose. Upper lip of the corolla, the length of the palate, bent back at the sides. E. B. 253. G. E. 828.

Ditches on the right-hand side of the Botley road. Otmoor. $\mathbf{S} b$. Ditch by the Devil's Back Bone, going to South Hinksey. Opposite the first drawbridge, beyond Heyfield's Hut. Bx.*

Per. July.

$L s$. hair-like, under water, (root-like?) bearing numerous crested bladders which float the plant at the flowering season by means of air formed within them. This air gives place subsequently to water, and the plant sinks to ripen its seed. $\boldsymbol{F l}$. large, yellow, with an orange striped palate.

\section{LEMNA. Duck-weed.}

L. trisulca. Ivy-leaved $D$. Fronds stalked, oval-spearshaped, proliferous. E. B. 926. H. L. 119. Hederula aquatica. G. E. 830 .

Ditches.

An. Aug.

$L s$. crossing each other at right angles, swimming on the surface of the water. $\boldsymbol{F l}$. white.

A cooling application to inflamed parts. The infusion in white wine, according to Bates, an infallible secret in jaundice.

L. minor. Less $D$. Fronds inversely egg-shaped, flattish above and beneath. Roots solitary. E. B. 1095. H. L. 120. G. E. 829.

Ditches.

An. June.

$L s$. connected at the base. $F \boldsymbol{~}$. very rare.

L. gibba. Gibbous D. Fronds inversely egg-shaped, 
slightly convex above, hemispherical beneath. Roots solitary. E. B. 1233.

Ditches, ponds.

An. July.

Larger than the last. $L s$. above, often of a purplish hue, coarsely veined like net-work on the other side.

L. polyrrhiza. Greater $D$. Fronds roundish, inversely egg-shaped, convex beneath. Roots clustered. E. B. 2458.

Ditches.

An. July. Sb. Fl. not observed in Britain. Eng. Fl. 1824.

$\boldsymbol{L} \boldsymbol{s}$. green above, deep purple beneath, much larger than either of the two last species.

\section{LY'COPUS ${ }^{1}$. Gipsy-wort.}

L. europa'us. Common G. Water-horehound. Leaves deeply saw-toothed. E. B. $1105 . \quad$ C. 3. 2. Marrúbium aquaticum. G. E. 700.

Banks of rivers, wet ditches.

Per. August.

$\boldsymbol{F l}$. whorled, and white, with purple dots.

The juice gives a permanent colour to linen, wool, and silk. Vagabonds stain their faces with the juice to appear like gipsies.

\section{SA'LVIA. Sage, or Clary.}

S. pratensis. Meadow C. Leaves oblong, notched, heart-shaped at the base : uppermost clasping the stem. Bracteas very small. Summit of the corolla glutinous. E. B. 153. Horminum sylvestre, F. etc. G. E. 769. Dry pastures.** Between Middleton Stoney and Ardley. Sb. and R. $P r$.

Per. June.

Stalk erect. $\quad F l$. large and handsome, of a fine purplish blue.

S. verbenáca. Wild English C. Leaves saw-toothed, sinuated, smoothish. Corolla much more contracted than the calyx. E. B. 154 . C. 6. 1. H. sylvestre G. E. 771 .

Road sides, dry banks. Meadow bank between St. Clement's, and Iffley. R. W.

Per. June, October.

Stalks more or less lying down. Fl. small, violet blue.

'Wolf's foot. Gr. 
The seeds produce a great quantity of soft, tasteless mucilage, when moistened; hence they become serviceable for removing extraneous matter from the eye, put under the eyelid for a few moments. See G. E.

"The seeds of Sulvia verbenaca, S. pratensis, and some other species are covered with a dense mucilage, which is not visible till the seeds are wetted. This mucilage consists mostly of very minute spiral vessels, like those first described, by Professor Lindley, (in the Botanical Register, fol. 1166, and in his Introduction to the Natural System of Botany, p. 220.) as composing the mucous matter which envelopes the seeds of Collomia linearis.

"If a seed of Salvia rerbenaca, be put on a small bit of glass, and placed on the stage of a microscope, and then wetted by letting fall upon it a drop or two of clear water, the spiral vessels will be seen to dart forth in great numbers from the outside of the testa, or skin, forming a complete and beautiful radius round the seed, which, if suffered to dry upon the glass, may be preserved as an interesting object for the microscope, at any future time.

"I can find no account of this in any work which I have consulted. Sir James Edward Smith, Dr. Withering, and others, have noticed the mucilage which covers the seed of Salvia verbenaca, but they are quite silent with respect to the spiral vessels, which are so abundantly produced amongst it."-Wm. Baxter, Sept. 24, 1831.

\section{CLA'DIUM ${ }^{\mathrm{I}}$. Twig-rush.}

(C. Mariscus. Prickly $\boldsymbol{T}$. Panicle repeatedly compound, leafy. Spikes in heads. Stem round, leafy, smooth. Leaves prickly at the edge and keel.

Fens. Boggy places by the river Thames, near Tamworth. Ray. Per. July, August.

Erect, polished, three, or four ft. Ls. keeled. Fruit pointed.)

\section{DIANDRIA DIGYNIA.}

\section{ANTHOXANTHUM ${ }^{2}$. Vernal Grass.}

A. odorátum. Sweet-scented $V$. G. Panicle spiked, egg-shaped, oblong. Flowers longer than their awns, on short partial stalks. E. B. 64\%. C. 1. 4. Still. f. Curt. Gr. f.

Meadows, pastures.

Per. May.

1 Klados, Gr. $2 \mathrm{Gr}$. yellow flower. 
In drying, the plant exhales an odour similar to Woodruff, (Asperula odorata;) chief cause of the fragrancy in new hay. Its fresh stalks chewed, highly aromatic, not unlike lavender. $F$ turn yellow with age; abounds chiefly in wet lands; not very productive, nor very palatable to cattle. For a curious contrivance of nature in the seeds:- See With.

\section{Class III. TRIA'NDRIA. Stamens 3.}

\section{Order I. MONOGYNIA. Pistil 1. \\ * Flowers above the germen.}

\section{VALERIA'NA. Valerian.}

V. rubra. Red $V$. Flowers with one stamen, and a long spur. Leaves egg-spear-shaped, nearly entire. E. B. 1531. V. rubra Dodonæi. G. E. 678.

Old walls. Merton College Walls. Sb. More of the white flowered var.-31. R. W.

Per. July.

Cor. slender, elegant, rose-coloured, sometimes white. Stems a foot and a half high.

V. dioica. Small Marsh $V$. Flowers with three stamens, dioecious. Stem-leaves wing-cleft, root ones egg-shaped. E. B. 628. V. minor. G. E. 1075.

Per. May.

Ls. winged. Livn. Cor. of the pistil-bearing plant, much smaller than those of the stamen-bearing. $\mathbf{F l}$. flesh-coloured. Stem six or eight inches high. Ls. called lyrato-pinnate, in $\mathrm{Fl} . \mathrm{Br}$.

V. officinális. Great Wild $\boldsymbol{V}$. Stamens three. Leaves all winged, leaflets spear-shaped, nearly uniform. E. B. 698. C. 6. 3. V. sylvestris major. G. E. 1075.

Per. June.

Stalk three or four feet high. $\quad \boldsymbol{F l}$. flesh-coloured.

A variety $(\beta)$, narrower leaves, found in dry, mountainous woods, and pastures, which, as more aromatic, is preferred for medical use.

This species is the Valerian of the shops, and possesses strong antispasmodic virtues. Excellent medicine in habitual constipation, the root in decoction. Cats delighted with the roots. Rats said to be equally fond of them. 


\section{FE'DIA ${ }^{\mathrm{x}}$. Corn Salad.}

\section{F. olitória. Common Corn Salad, or Lamb's Lettuce.} Leaves linear-tongue-shaped, blunt. Flowers growing in heads. Caps. swollen, two lobed. V. Locusta. E. B. 811 . C. 5. 4. Lactuca agnina. G. E. 310. 1. 2 .

Corn fields.

An. April.

Stem forked, twice, or thrice. Fl. in little heads, small, pale-blue, or flesh-coloured.

Eaten in spring as salad.

F. dentáta. Oval fruited $C . S$. Leaves linear-tongueshaped. Flowers with one solitary in the forks of the stem. Capsule egg-shaped, ribbed. Crown erect. E. B. $13 \% 0$.

Fields. * By the road side between Shotover Hill, and Bullingdon Green. $T$.

An. April, June.

Ls. narrow. Fl. small, purplish. Cal. unequal.

\section{CROCUS. Crocus.}

(C. nudiflórus. Naked flowering Cr. Stigma within the flower, in three deeply-jagged tufted segments. Flower without leaves. E. B. 491. C. montanus autumnalis. G. E. 154 . f. 6 .

Sandy, inundated meadows. * Pigwell Fields, and Lammas Fields. $\boldsymbol{P}_{n}$.

Per. October.

Fl. tube one foot long. Stig. yellow. Ls. flattish.)

\section{IRIS ${ }^{2}$. Iris, or Flower-de-luce.}

I. Pseud-ácorus. Yellow Water Iris. Corolla beardless; inner segments smaller than the stigmas. Leaves sword-shaped. Seeds angular. E. B. 578. C. 3.4. Iris palustris lutea. G. E. 50.

Banks of rivers, wet ditches.

Per. June.

$F l$. large, bright yellow, disk of the larger segments, pencilled, as it were, with dark purple.

Juice of the fresh root very acrid, purgative; in some cases, proves diuretic; too uncertain in its effects to come into general use.

1 From fedus, syn. with hoedus, a kid. Sim. ${ }^{2}$ Gr. From its hues. 
The roots used in the Island of Jura to dye black. A slice of the fresh root, held between the teeth removes some kinds of toothache. E. B. Not eaten by cattle. Fl. Suec. Seeds roasted resemble coffee, having more nearly the same aroma than other substitutes.

I. foetidissima. Stinking Iris. Corolla beardless ; inner segments spreading. Stem with one angle. Leaves sword-shaped. Seeds globose. E. B. 596.

Thickets. Copse, Elsfield. P $n$. (Bagley Wood.) Bx.*** Per. June.

$L s$. dull green. $F l$. pencilled with dark veins.

Bruised leaves smell very offensively, yet with some resemblance to roast-beef.

SCHENUS. Bog-rush.

** Flowers beneath the germen, chaffy. Seed 1 .

S. nígricans. Black B. R. Stem round, naked. Head roundish, abrupt, overtopped by one of the two floral leaves. E. B. 1121.

Peat bogs. Under Headington Wick Copse. Sb. and R. W.

Per. July.

A foot high, smooth. Head black.

\section{RHYNCHO'SPORA ${ }^{\mathrm{I}}$. Beak-rush.}

(R. alba. White Beak-rush. Heads abrupt. Stamens two. Leaves tapering. Seed with numerous bristles at the base. Schonus albus. E. B. 985. Gramen junceum leucanthemum G. E. 30.

Turfy bogs. Coleshill bog, Warwickshire. $P_{n}$.

Per. July, August.

A smooth, slender plant, with white $f$. Stigm. two.)

\section{SCIRPUS. Club-rush, and Bull-rush.}

* Spikes solitary.

(S. caspitósus. Scaly-stalked Club-rush. Stem round slightly furrowed; sheathed and clothed with numerous scales at the base. Spike terminal. Outer glumes largest, with leafy points. E. B. 1029.

Turfy, barren heaths. * Coleshill bog, Warwickshire. Pn.

Per. July.

Stems erect. Spike small, reddish brown.) 
S. pauciflórus. Chocolate-headed Club-rush. Stem round, with a tight leafless sheath at the base. Spike terminal, of few flowers, longer than its blunt, membranous-tipped outer glumes. E. B. 1122.

Peat bogs, morasses. Peat bogs on Bullingdon Green.

Per. June.

Stems slender. Spikes somewhat four-flowered.

S. Aluitans. Floating Club-rush. Stem branched, leafy, limber, and floating. Flower-stalks alternate, naked. Spikes terminal, of few flowers. E. B. 216.

Pools where the water has stagnated during the winter. Southleigh Heath. $S b . *$ **

Per. June.

Stem branched, sending out roots. Ls. linear. ** Stem round, with several spikes.

S. lacustris. Bull-rush. Stem round, naked. Panicle cymose, twice compound, terminal. Spikes eggshaped. Bracteas generally much shorter than the panicle. E. B. 666 . H. L. 91 .

Rivers, stagnant waters.

Per. July.

Culm five or six feet high, dark green, simple, leafless. Ls. at the base, one or two, short, with long sheaths.

From its stems, the rush bottoms of chairs are made: cattle in hard seasons will eat it: also, used for thatching, and packages, occasionally.

S. setáceus. Bristle-stalked Club-rush. Stem bristleshaped, leafy at the base. Spikes about two, stalkless, surmounted by a leafy bractea. Seed furrowed, without bristles. E. B. $1693 . \quad$ H. L. 97.

Wet gravelly grounds.

An. July.

Spikelets generally in pairs, egg-shaped. Plant from two to five inches high.

S. caricinus. Compressed C. R. Stem roundish, leafy about the lower parts. Spikelets clustered, tworanked, many flowered. Leaves flat, edges and keel rough. Seed six bristled, at the base. Schœnus compressus. E. B. 791.

Boygy meadows. Under Bullingdon Green, \&c. B Bx.

Spikes bright chestnut. Stem about one ft. simple. Style permanent.

Stigm. falling off. Lower spikelet sub-tended by a bractea, 
commonly longer than the general spike: this bractea triangular, and rough at the end.

*** Stem triangular. Panicle leafy.

S. sylváticus. Wood Club-rush. Millet Cypress-grass. Stem triangular, leafy throughout. Panicle terminal, leafy, cymose, repeatedly compound. Flower-stalks sheathed at the base. Spikes clustered. E. B. 919. Cyperus gramineus miliaceus. G. E. 30. 5.

Moist woods. *** Heythorp Woods. Sb. Beyond South Hinksey. $B x$.

Per. July.

\section{ELEO'CHARIS '. Spike-rush.}

E. palustris. Creeping S. $R$. Culm round, naked, with leafless sheaths at the base; spike naked, oblongegg-shaped. Root creeping. Stigmas two. Seed roundish, most convex at one side. Scirpus palustris. E. B. 131. Juncus minor, capitulis equiseti. G. E. 35. f. at p. 1631.

Banks of rivers, marshes.

Per. June.

Three stigmas are erroneously represented, in $\boldsymbol{E}$ ngl. Bot.

Culms erect. Ls. none. Spike brown.

The fresh herb is greedily devoured by swine.

E. aciculáris. Least Spike-rush. Stem four-cornered. Stigmas three. Seed numerously furrowed, without bristles at the base. Filaments permanent. Scirpus acicularis E. B. 749. H. L. 49.

In damp spots, upon heaths, where water has stagnated during winter. * Binsey Common. Near Ensham bridge. Sb. Port Meadow, near Medley Lock. Side of Canal, going from Oxford to Wolvercot. $B x$.

Per. August.

Base invested with a light, blunt, beardless sheath. Spike terminal, of few flowers. Culms very slender. "Fruit oblong, beautifully impressed with points in lines, tipped with the spherical base of the style." H.

\section{ERIO'PHORUM ${ }^{2}$. Cotton-Grass.}

(E. vaginátum. Hare’s-tail $C . \quad$ Stem triangular above;

1 Gr. Delighting in marshes.

${ }^{2} \mathrm{Gr}$. wool-bearing. 
round below, with a swelling, tubular sheath. Spike egg-shaped. Glumes membranous. E. B. 873.

Boggy heaths. Coleshill Bog, Warwickshire. $P_{n}$.

Per. March, April.

Ls. triangular, sharp pointed. Spike erect, of a silvery grey; finally with long, white hairs.)

E. pubescens. Downy-stalked $C$. Stem angular upwards. Leaves flat, spear-shaped, with a triangular point. Stalks of the spikes downy. Hairs twice the length of the spike.

Bogs, marshes. Bog near Stow Wood. Bogs near Headington Wick Copse. Bx. First observed in Oxfordsh. by Mr. Bx. Ls. darkish, olive-green. Spikes two to eight, nine. Glumes blackish.

E. angustifólium. Common $C$. Stem nearly round. Leaves linear, triangular; channelled towards the base. Stalks of the spikes smooth. Hairs four times the length of the spike. E. B. 564. E. polystachion. C. 4. 9. Sb. 24 .

In turfy, boggy, and muddy meadows.

Per. April.

After flowering, the spikes are partly erect. Involucre, longer than the flowering spikes. The brilliant, white tufts of this plant, look throughout the summer, like feathers scattered over the country. Food for cattle in the earlier part of the spring, in the Isle of Skye. The down, a stuffing for pillows, among the poor: also for candle wicks, which become brittle, when quite dry.

\section{NARDUS. Mat-grass. *}

* From the matted order of the stems. Purton.

N. stricta. Common M. Spike bristled-shaped, straight, florets all pointing one way. Leaves thrice the length of their sheaths. E. B. 290. Spartum nostras parvum. G. E. 41. 1631.

Barren, sandy, rather moist, heaths and moors. * Shotover-Hill,

Southleigh Heath. $\mathbf{S} b$. Cumnor Hurst. $\boldsymbol{B} x$. Per. June.

Ls. bristle-shaped. Schrank celebrates this deep-rooted grass as a safe support to the hands of the Alpine botanist, in precipitous situations, though it renders his path very slippery. Stocked up by crows for the larvas of Tipulæ, found at the root. This grass being stiff, and short, eludes the stroke of the scythe, takes off its edge, and is, in consequence, disliked by mowers. Holds its spike until winter. Cattle in general refuse it. $\boldsymbol{E}$. $\boldsymbol{B}$. 
TRIANDRIA DIGYNIA. Stamens 3. Pistils 2.

PHA'LARIS. Canary-grass.

* P. canariensis. Manured C. G. Panicle egg-shaped, resembling a spike. Calyx-glumes boat-shaped; entire at the summit. Outer corolla of two naked valves, E. B. 1310 . Phalaris. G. E. 86.

In cultivated and waste ground, naturalized. * Grows amongst the corn in the Canaries Willd. Sp. Pl.

An. June.

Panicle compact, erect, compound, though resembling a simple egg-shaped spike, elegantly variegated with green and white. The seeds a well known food for the canary-bird.

P. arundinácea. Reed $C$. Panicle upright, with spreading branches. Flowers crowded, growing from one side only. Outer corolla of two bearded valves. E. B. 402. and 2160. f. 2. Calamagrostis colorata. $\$ b$. Banks of rivers. $\mathbf{S b}$.

Per. June.

Stems from two to five feet high. Panicle rough.

Used to thatch ricks, and cottages: lasts much longer than straw. In Scandia mowed twice a-year, for cattle to feed on. The oftener mowed, the more acceptable to cattle. The striped variety, chosen by the Welch peasantry, with Gnaphalium margaritaceum, to decorate the graves of their departed friends. Knapp. A beautiful variety with striped leaves is common in gardens.

\section{PHLEUM. Cat's-tail-grass.}

P. pratense. Common C. Timothy-grass. Cluster spiked, cylindrical. Calyx abrupt, fringed at the keel, longer than its awns. E. B. 1076. Gramen typhinum minus. G. E. 12.

Moist meadows, pastures. The bulbous var. in barren ground, occasionally flooded, or in very dry situations. Sm.

Per. July.

Spike two to five inches. Root in dry situations becomes swollen and succulent. In this state it is the Phleum nodosum of Linnæus, Sibthorp, \&c. Awns straight, short, rough. Once celebrated for its agricultural merits, but now out of fashion, though it spontaneously makes a part of the hay crop. $S \mathrm{~m}$.

P. ásperum. Rough C. Panicle spiked, cylindrical, awnless. Calyx wedge-shaped, swelling upward, pointed, rough; keel naked. Stem branched. $\boldsymbol{P}$. panicula- 
TRIANDRIA DIGYNIA. Alopecúrus.

tum. E. B. 1077. P. paniculata. Sibth. Oxon. 34.

In dry, open fields, * *. Wall of Rose Lane. Sb.

An. June.

Root fibrous. Panicle rough to the touch. Whole plant bright green.

\section{ALOPECU'RUS. Fox-tail-grass.}

A. pratensis. Meadow $F$. Stem erect, smooth. Spike somewhat panicled. Calyx-glumes acute, hairy, united at the base, shorter than the awn, twice the length of the corolla. E. B. 759. C. 5. 5. Gramen alopecuroides majus. G. E. 10.

Meadows, pastures.

Per. May.

Spike two inches long, thick, soft, of a silky, hoary aspect. Best grass to sow in low meadow grounds, or in boggy places which have been drained. Liable to the depredations of the larvæ of a species of musca; they devour the seed. These larvæ the prey of cimex campestris. These circumstances an impediment to the general cultivation of this grass. Mr. Swayne in With. An excellent grass for pasturage, being early, plentiful in produce, and grateful to cattle in general.

A. agrestis. Slender $F$. Stem erect, roughish. Spike racemose, nearly simple, tapering. Calyx-glumes almost naked, united at the base, dilated at the keel. E. B. 848. A. myosuroides. C. 2. \%. Gramen alopecurinum minus. G. E. 11.

Corn fields, way-sides.

An. June.

Spike slender, tapering at each end, often purplish. A troublesome weed among wheat, called by farmers " Black Bent." Swayne in With.

A. geniculátus. Floating $F$. Stem ascending, bent in an angle at the joints. Spike cylindrical, slightly panicled. Calyx-glumes united at the base, abrupt, fringed. Corolla notched, its awn twice the length of the calyx. E. B. 1250. C. 5.6. Gramen Aluvia. tile spicatum. G. E. 14.

Ponds, ditches, slow streams, floating widely on the surface.

Per. June.

Culms floating. In dry situations, root bulbous, 


\section{MI'LIUM. Millet-grass.}

The hardened corolla, forming a coat to the seed, affords a mark of distinction between this genus and Agrostis. Sm.

M. effísum. Spreading $M$. Flowers in a loose spreading panicle, without awns. E. B. 1106. C. 4. 12, Gramen miliaceum. G. E. 6. bad.

Wilcot, Mungewell, Ardley, Tar Woods. Sb. (Bagley Wood.) $B x$.

Per. May.

Light, elegant, lofty plant. The middle branches of the panicle droop, and point directly downward. Ls. sweet-scented: they drive away cicari.

\section{AGROSTIS. Bent-grass.}

* Awned.

(A. Spica venti. Silky B. Awn straight, stiff, many times longer than the corolla. Panicle loosely spreading. E. B. 951.

Moist sandy fields. Corn fields near Old Windsor. Tur.

An. June, July.

Stems, two to three ft. erect. Pan. large, silky, waving on one side.)

A. canina. Brown B. Awn incurved, from below the middle of the corolla; inner valve scarcely distinguishable. Calyx egg-shaped, coloured. Stems lying down, with prostrate shoots. Stipula spear-shaped. E. B. 1856 .

Moist meadows.

Per. June.

Panicle spreading, yet somewhat erect. Herbage trifling; of no agricultural use. $\boldsymbol{E} . \boldsymbol{B}$. The awn varies in length, and is occasionally absent, nothing being more uncertain than the back awns of grasses. The terminal ones, whether of the calyx, or corolla, are much more to be trusted. Sm.

A. setácea. Bristle-leaved B. Awn incurved, from near the base of the corolla; inner valve minute. Calyx spear-shaped, tapering, rough. Root leaves bristleshaped. Stem nearly erect. Panicle close, oblong. E. B. 1188 . C. 6. 12. C. Gr. 42 .

Southleigh. Stanton St. John's. Sb.

Per. July.

$$
\text { * Generally without awns. }
$$


A. vulgáris. Fine $\boldsymbol{B}$. Panicle spreading; with straddling, hair-like branches. Calyx-valves nearly equal. Stem erect. Stipula abrupt, very short. E. B. 1671. A. tenuis. $\quad S b$.

Per. June.

This grass was always taken for Aira capillaris of Linn. till his Herbarium came among us. $\boldsymbol{E}$. $\boldsymbol{B}$.

Panicle upright, purplish, with very numerous spreading, hair-like, zigzag branches, variously forked, and subdivided, with little egg-shaped, shining flowers. $\boldsymbol{E}$. $\boldsymbol{B}$. The earliness of this grass, its chief agricultural value.

A. alba. Marsh $B$. Panicle condensed at the base of the main divisions; stalks rough. Calyx-valves spearshaped, bristly at the keel. Stem spreading, creeping. Stipula oblong, ribbed. E. B. 1189. $\beta$. A. stolonifera. E. B. 1532. Gramen caninum supinum. G. E. 26.

Moist meadows. Fields inundated in autumn.

Per. June.

Stems often throwing out fibres from their lower joints. Panicle palish. In $\beta$ the stem more extensively creeping, sometimes floating; distinguished by its still more dense and tufted lobes of the panicle, and the calyx generally rough all over, with little bristly points. Sm.

\section{AIRA, Hair-grass.}

* Corolla awnless.

A. cristáta. Crested $\boldsymbol{H}$. Panicle spiked. Calyx longer than its flower-stalk, shorter than the florets. Glumes all pointed. E. B. 648. Poa cristata. Sb. 42.

Dry Pastures.

Per. June.

Stems simple, erect, about six inches high. Panicle erect, dense, of a silvery green hue.

This species is a Festuca, except in the small number of the florets. Sm.

A. aquática. Water $\boldsymbol{H}$. Panicle spreading. Florets awnless, even, blunt, longer than the calyx. Leaves flat. Stipula oblong. E. B. 155\%. C, 1. 5.

Ditches, pools. Margins of rivers.

Per. June.

Stems leafy, floating upon the water. Glumes equal, blunt. The flowers abound with honey. When growing accidentally out of c 2 
the water, this grass sometimes assumes a very dwarf habit. In natural affinity it comes near to Poa fuitans. $\mathbf{S m}$.

$$
\text { * Corolla awned, hairy at the base. }
$$

A. caspitósa. Turfy H. Panicle spreading. Florets about the length of the calyx, abrupt, hairy at the base; one of them on a hairy stalk. Awn short, from the bottom of the outer valve. Leaves flat. E. B. 1453. Gramen segetale. G. E. 5 .

Moist woods, pastures.

Per. June.

Stems a yard high, rigid, and harsh. Punicle, large and spreading. E. B. Droops very gracefully before flowering; as the florets open, it becomes erect, and the branches of the panicle spread equally. $L s$. neatly striated. Plant very apt to grow in tufts: called by the common people, Hassocks, Rough Caps. Swayne in With.

A. flexuósa. Wavy Mountain $\boldsymbol{H}$. Panicle spreading, triple-forked, with wavy branches. Florets about the length of the calyx, acute. Awn from the middle of the outer valve, longer than the calyx, twisted. Leaves bristle shaped. E. B. 1519.

Heathy, sandy places. Northleigh Heath. Sb. Foot path going from Childswell Farm to Wootten Heath. Shotover Hill. Bx. Per. June.

A. pracox. Early $\boldsymbol{H}$. Panicle close, erect. Florets the length of the calyx, both stalkless. Awn nearly twice as long, from the base of the valve. Leaves bristle-shaped, with angular sheaths. E. B. 1296. C. 3. 7.

Dry gravelly ground.

An. April.

This trifling grass is of no agricultural use. It withers away as summer comes on. $\mathbf{S} m$.

A. caryophylléa. Silver $\boldsymbol{H}$. Panicle spreading, tripleforked. Florets not longer than the calyx, both stalkless. Awn twice as long, from above the middle of the valve. Leaves bristle-shaped, with ribbed close sheaths. E. B. 812 . C. 6.6 .

Barren sandy heaths. Pastures above Headington Wick Copse. R. W. An. July.

The whole plant is soon dried up, and can yield nothing but a little early food for sheep. $\mathbf{S} m$. 
HOLCUS. Soft-grass.

H. lanátus. Meadow S. Calyx woolly. Lower floret perfect, awnless; upper with an arched awn. Leaves downy on both sides. Root fibrous. E. B. 1169. C. 4.11 .

Meadows, pastures.

Per. June.

H. mollis. Creeping S. Calyx partly naked. Lower floret perfect, awnless; upper with an acutely-bent, prominent awn. Leaves slightly downy. Root creeping. E. B. 1170 . C. 5.8 .

Pastures, shady copses, hedges.

Per. July.

Root widely creeping, difficult of extirpation, but not very common nor troublesome in arable land. Whole plant more slender than the former, and less downy. $\mathbf{S m}$.

H. avenáceus. Oat-like $S$. Calyx smooth. Barren floret lowest, with a sharply-bent prominent awn; fertile one slightly elevated, scarcely awned. Leaves rather harsh. Root knotty. E. B. 813. Avena elatior. C. 3. 6. Gramen caninum nodosum. G. E. 23.

Hedges, pastures.

Per. June.

The plant has the habit of an avena. Ls. of a darkish green. Branches of the panicle half-whorled. The roots sometimes very troublesome to farmers in arable lands. Crop abundant, but unpalatable to cattle. Swayne.

\section{ME'LICA. Melic-grass.}

M. uniflóra. Wood M. Petals beardless. Panicle branched, drooping toward one side. Flowers erect. Spikelet with only one perfect floret. E. B. 1058. C. 5.10 .

Groves, thickets.

Per. May.

Root fibrous, or somewhat creeping. The only perfect floret, stalkless. The neuter one on a stout bent stalk, its glumes small, abrupt, and shapeless. Its red blossoms suspended by hair-like, and almost invisible stalks, seem like insects dancing in the air. E. $B$.

M. coerúlea. Purple M. Petals beardless, acute. Pa- 
nicle close, erect, compound. Flowers upright, cylindrical. E. B. 750 . C. 5. 11.

Moist heaths.

Per. August.

Root with a sort of bulb at the base. Panicle of a violet hue, many flowered. Straw with one knot, close to the root.

Fishermen in the isle of Skye make ropes for their nets of this: it bears the water well, without rotting. In shady situations, panicle pale, brownish, or whitish. Stems are said to be used for brooms, or even baskets, where better materials are rare. $\mathrm{S} m$.

\section{GLYCE'RIA ${ }^{\mathrm{I}}$. Sweet-grass.}

G. aquática. Reedy Sw. Panicle erect, repeatedly branched, spreading. Florets numerous, blunt, with seven ribs. Nectary cloven, acute. Poa aquatica E. B. 1315. C. 5. 12. Gramen aquaticum majus. G. E. 6 .

Banks of rivers.

Per. August.

Smooth, four feet high. Ls. sword-shaped, broad, flat. Stip. short, blunt.

The most gigantic of all our meadow grasses, often six feet high. A coarse grass, acceptable to cattle, making a great part of the hay in marshy lands. It is sometimes viviparous, but sparingly. Usefully sown on the banks of rivers, or brooks. With. The chrysalis of the beautiful Phal. festuca, gold-spot moth, sometimes found attached to its leaves. $\boldsymbol{E} . \boldsymbol{B}$.

G. fluitans. Floating Sw. Panicle oblong, branched, nearly erect. Spikelets close-pressed. Florets numerous, blunt, seven-ribbed, with short intermediate ribs at the base. Nectary blunt, swollen. Poa fluitans. E. B. 1520. Festuca fluitans. Sb. 45. C. 1.7. Gramen fluviatile. G. E. 14 .

Wet meadows, ditches, banks of rivers.

Per. June.

Root creeping. Ls. flat, broad, blunt. Stip. short, pointed, often torn. Seeds small, sweet, nourishing. Collected in Germany and Poland, by name of Manna seeds; esteemed a delicacy in soups. When ground to meal, make bread little inferior to that of wheat. The seeds collected for food, of which a more ample account in the $\mathbf{F l}$. Lond. They are said to be very sweet, especially before they arrive at maturity; whence the name of Manna

1 Essent. Char. The little scale (nectary, Linn.) at the base of the germen, of one, fleshy piece, and the stigmas much divided. 
grass. The fine sharp bran is said to kill intestinal worms in horses. Lin. Fl. Suec. The flowers, like those of Aira aquatica, have a sweet taste.

G. rigida. Hard Sw. Panicle spear-shaped, very rigid, leaning one way, two-ranked, close, with smooth stalks; branchlets alternate, the main one bordered. Florets about seven, acute, scarcely ribbed. Poa rigida. E. B. 1371 . C. 2. 4. Sb. 42 .

Walls, dry ground.

An. May.

May be known readily by the extreme rigidity of its stems, and panicle. $\boldsymbol{E}$. $\boldsymbol{B}$. The whole plant generally assumes a brown or purplish hue, remaining bleached and dry after midsummer.

\section{POA. Meadow-grass.}

P. compressa. Flat-stalked $M$. Panicle leaning one way, rather close. Culm compressed. Root creeping. Spikelets egg-shaped oblong. Florets connected by a web. E. B. 365.

Tops of walls, dry barren ground.

Per. June.

Easily distinguished by its compressed stem. Cannot be cultivated in moist, or manured ground. Its produce not abundant. Sm.

P. triviális. Roughish $M$. Panicle spreading. Spikelets about three-flowered. Florets spear-shaped, fiveribbed, connected by a web. Stipula lengthened out, tapering to a point. Stem and leaves roughish. Root fibrous. E. B. 1072. C. 2. 6 .

Meadows, pastures.

Per. June.

One of the most valuable for pasturage, and hay, yielding abundantly, though not particularly early. Curtis.

P. pratensis. Smooth-stalked $\boldsymbol{M}$. Panicle spreading. Spikelets about four-flowered. Florets spear-shaped, five-ribbed, connected by a web. Stipula short and blunt. Stem and leaves smooth. Root creeping. E. B. 1073. C. 2. 5. Gramen pratense minus. G. E. 2.

Walls, pastures.

Per. May.

The clear and essential mark of this species, compared with the last, consists in its very short, abrupt, pointless stipula, which in every leaf, and every variety, proves constant and invariable. P. 
pratensis is not less valuable than the trivialis. It is earlier in leaf, and will thrive with less moisture, though the latter produces, at last, a better crop. $\mathbf{S}$.

P. ánnua. Annual M. Panicle spreading at right angles. Spikelets egg-shaped, about five-flowered. Florets a little remote, five-ribbed, without a web. Culms oblique, compressed. E. B. 1141. C. 1. 6. Gramen minimum album. G. E. 3.

Meadows, pastures, waste and cultivated ground, almost every where.

An. April, November.

A good grass for fodder, abundant in proportion to the richness of the soil, easily raised, but not durable. Not damaged, but rather improved, by being trodden upon. $\mathbf{S}$.

P. nemorális. Wood M. Panicle spreading, slender, very lax. Calyx-glumes spear-shaped, taper-pointed, each three-ribbed. Spikelets spear-shaped. Florets about three, five-ribbed, acute; silky at the keel and side ribs; hairy at the base, without a web. Stipulas very short, notched. E. B. 1265.

Groves, woods.

Per. June.

Culms erect, slender. Spikelets small. Fl. diffuse. In Switzerland P. nemoralis often bears on the stems, rigid, bristly tufts like rootlets, analogous to the mossy balls of the dog-rose, and like them probably the effect of the puncture of some insect. $\mathrm{Sm}$.

\section{TRIO'DIA. ${ }^{\circledR} \quad$ Heath-grass.}

T. decumbens. Decumbent $\boldsymbol{H}$. Panicle nearly simple, close, erect. Florets four; their middle tooth shortest. Calyx smooth. Stipula hairy. Culm lying down. Poa decumbens. E. B. 792. Festuca decumbens. Sb. 46.

Dry pastures, heaths. Shotover Hill, Southleigh Heath. Sb. Bogs under Bullingdon Green. (Bagley Wood.) Bx.

Per. July.

Calyx-glumes (about) as long as the spikelet. Linn. Fl. Suec. Ls. stiff, rolled inwards. Spikelet swelling.

BRIZA. Quaking-grass.

B. média. Common Q. Spikelets egg-shaped, about 
seven flowered. Calyx shorter than the florets. Stipula very short and blunt. E. B. 340 .

Pastures.

Per. June.

Panicle diffuse, tremulous. Culm simple, solitary.

DA'CTYLIS. Cock's-foot-grass.

D. glomeráta. Rough $C$. Panicle distantly branched. Flowers in close globular tufts, leaning one way. Corolla somewhat awned, five-ribbed, taper-pointed. E. B. 335 .

Meadows, Pastures.

Per. July.

$\boldsymbol{L} s$. harsh and rough. Lower branches of the panicle very straddling, sometimes compound. A harsh coarse grass, not very acceptable to cattle; but when cultivated on dry, open land, its quality becomes excellent, and the crop abundant. $S m$.

\section{CYNOSU'RUS. Dog's-tail-grass.}

C. cristátus. Crested D. Spike simple, linear. Neuter spikelets without awns. E. B. 316. Gramen cristatum. G. E. 29.*

Dry pastures, meadows.

Per. June.

Each spikelet with another abortive one, resembling a small double-toothed comb.

Valuable grass for sheep and deer, thriving on dry open ground. One of Cobbett's grasses for straw plat.

\section{FESTU'CA. Fescue-grass.}

F. ovina. Sheep's $F$. Panicle leaning one way, rather close. Florets cylindrical, pointed or awned; smooth at the base, and at the edges of the inner valve. Stem square towards the upper part. Leaves folded, bristleshaped. Stipula short and blunt. E. B. 585. F. tenuifolia $\mathrm{Sb}$. 44?

Dry open pastures.

Per. June.

The square stem, a distinctive mark; also the smooth-edged inner valve of the cor.

Supposed peculiarly excellent for sheep.

Cattle leave the stalks of this, and other grasses untouched: a provision of nature to increase the grasses. The flowers vary with, and without awus, Sibthorp's F, tenuifolid in Smith's Eng. Fl. 
var. $\delta$. is ovina, with awnless florets; found on Bullingdon Green. Sb.

F. duriúscula. Hard $\boldsymbol{F}$. Panicle leaning one way, spreading. Florets longer than their awns. Stem round. Upper leaves flat. Root fibrous. E. B. 470. Still. f. C. Gr. f.

Pastures, dry meadows, waste ground, thickets.

Per. June.

Root and stem $l s$. bristle-shaped, generally twice or thrice the size of ovina. Spikelets become flattened, by the expansion of the glumes.

Yields a good and early crop, acceptable to all kinds of cattle. Swayne.

F. bromoides. Brome $\boldsymbol{F}$. Panicle nearly erect, racemose. Florets tapering, shorter than their awns, rough at the top. Leaves tapering, shorter than their sheaths. Upper half of the stem naked. E. B. 1411. Walls, dry pastures.

An. June. B.?

A pale, smooth, slender, insignificant grass. Ls. light green. Calyx-valves, one entire, the other tapering to an awnlike point. Differs from F. Myurus by its sub-spiked panicle, and unfringed glumes. Linn.

F. Myúrus. Wall $F$. Panicle drooping, lengthened out, spike-like, pointing one way. Florets tapering, shorter than their awns, rough at the top. Leaves awl-shaped. Stem leafy to the summit. E. B. 1412. Walls, barren sandy ground.

An. May. B?

More frequent than F. bromoides. Its long, silky panicles wave with every breath of wind. Its panicle much longer, and more slender than that of $\mathrm{F}$. bromoides, and somewhat drooping.

F. gigantéa. Tall $F$. Panicle large, branched, drooping, twice compound, spreading. Florets from three to six, egg-spear-shaped, shorter than their awns. Stipula abrupt, eared, clasping the stem. E. B. 1820. Bromus giganteus. C. 5. $7 . \quad \mathrm{Sb} .48$.

Woods, hedges.

Per. July.

Habit of a Bromus-placed among Festucas from the absence of fringe to the inner valve of cor. H. This is easily mistaken for Bromus asper, which is rough, and hairy: in F. gigantea, leaves and stem, bright glossy green, smooth. Stip. bright purple and cloven. Ls, a finger's breadth. 
F. loliácea. Darnel $\boldsymbol{F}$. Spike two-ranked, drooping. Spikelets nearly stalkless, distant, linear-oblong. Florets cylindrical, awnless, pointed, with five slight ribs at the top. E. B. 1821 . C. 6.9 .

Moist pastures, meadows.

Per. June.

Greatly resembles Lolium perenne: distinguished from it by its two-valved calyx, and paler hue: its seeds rarely ripened: a good pasture grass, two feet high. Spikelets alternate, lengthened out.

F. pratensis. Meadow $F$. Panicle nearly upright, branched, spreading, pointing to one side. Spikelets linear, compressed. Florets numerous, cylindrical, obscurely ribbed. Nectary four-cleft. Root fibrous. E. B. 1592 . C. 6.7 .

Pastures, meadows.

Per. June.

A hardy, early grass, affording a plentiful crop. C. Reryuires a rich soil. Linn. Fl. Suec. Two feet high. Upper leaves, rough on both sides. $\mathrm{Fl}$. numerous.

F. elátior. Tall $F$. Panicle somewhat drooping, much branched, spreading loosely every way. Spikelets eggspear-shaped. Florets numerous, cylindrical, somewhat awned, obscurely ribbed. Nectary four-cleft. Root creeping. E. B. 1593 . C. 6. 8 .

Moist meadows, banks of rivers.

Per. June.

From three to nearly five feet high. Ls. twice the size of F. pratensis: its panicle much more branched, and drooping. Spikelets egg-shaped, acute, less compressed. Ls. rough on the margin. A nutritious grass for marshland hay.

F. sylvática. Slender Wood $\boldsymbol{F}$. Spike simple, drooping. Spikelets alternate, stalkless, nearly cylindrical, turned to one side. Awns longer than their glumes. Leaves hairy. Root fibrous. Bromus sylvaticus. E. B. 729 .

Dry copses, thickets.

Per. July.

A Festuca, as the beards arise from the extremity of the glumes: very slender, bright green. Referred to Festuca from its perfectly loose seed. Sm.

F. pinnáta. Spiked Heath F. Spike simple, erect, two-ranked. Spikelets alternate, somewhat stalkless; 
plain side towards the culm, nearly cylindrical. Awns shorter than their glumes. Leaves nearly smooth. Root somewhat creeping. Bromus pinnatus. E. B. 730.

Open fields, heaths on a chalky soil. Sm. Woodstock Park. Sb. Copses and hedges, common enough about Oxford. D. Bobart. in Raii Synop. Ed. 3rd. Burford Downs. Goodenough. Shadwell Copse. Between Upper Heyford, and Northbrook, \&c. Bx. Per. July.

Whole plant more rigid, and less hairy than the last, the spike more elegant, erect, and smooth. Sm. Joints smooth, silvery, spikelets not as in F. sylvatica, close pressed to the spike-stalk, but very distant.

Geological strata may be marked through this plant in the surface without excavation. Sedgwick in Geol. Trans. See Winch's Transactions of Northumberland.

\section{BROMUS. Brome-Grass.}

B. secalinus. Smooth Rye Br. Panicle spreading; slightly subdivided below. Spikelets oblong-egg-shaped, of about ten, distinct, somewhat cylindrical, smooth, somewhat remote florets. Awns wavy, shorter than the glumes. Leaves slightly hairy. Spike half an inch. E. B. 1171 .

Cornfields.

An. May.

A useless, and rather troublesome weed in arable land. Swayne.

B. mollis. Soft Br. Panicle erect, rather close, compound. Spikelets egg-shaped, downy. Florets tiled, depressed, ribbed. Awns straight, as long as the glumes. Leaves and sheaths very soft and downy. E. B. 1078 . C. 1.8 .

Walls, pastures.

Bien.? May.

Crop of herbage small, and of little value. Sinclair.

B. racemósus. Smooth Br. Panicle nearly erect, spreading, simple. Spikelets egg-shaped-oblong, smooth. Florets tiled, depressed, ribbed. Awns as long as the glumes. Leaves somewhat downy. E. B. 10\%9. B. pratensis. E. B. 1984. B. arvensis. E. B.920.

Meadows and pastures. Christ Church, and Merton Meadows, Oxford. Cowley Fields. Cheney Lane. Meadows between St. Clement's and Iffley. $B x$. 
An. or Bien. June.

More slender in habit than the preceding, not soft to the touch. The panicle is generally simple. Spikelets larger, more swollen, rough to the touch, but naked and shining. Outer valve of the corolla marked with two green ribs at each side.

B. arvensis. Taper Field Br. Panicle spreading, drooping, compound, half-whorled. Spikelets spearshaped, acute. Florets about eight, tiled, smoothish, with two close ribs at each side. Leaves hairy. E. B. 1984.

Cornfields, rare. Ditchley. Mr. Woodward in Bot. Guide.

An. July.

Distinguished by its rather large, but slender, at length drooping panicle, and spikelets mostly of a purplish tinge.

B. erectus. Upright Perennial Br. Panicle erect, slightly branched. Spikelets linear-spear-shaped. Florets about eight, loosely tiled, spear-shaped, compressed. Awn shorter than the glumes, straight. Root leaves very narrow, fringed with scattered hairs. E. B. 471 .

Fields, road sides, in a sandy soil over chalk. Sm. Ditchley Park. Mr. Woodward. Not rare in Oxfordshire. Sm. and R. W.

Per. June.

Two or three feet high, habit of a Festuca. Glumes minutely fringed. Anth of a fine saffron colour.

B. asper. Hairy $W_{o o d} B r$. Panicle drooping, branched. Spikelets linear-oblong. Florets about eight, rather distant, spear-shaped, compressed, downy. Awns shorter than the glumes. Leaves uniform; lower ones hairy. E. B. 1172. Bromus hirsutus. C. 2. 8. $\mathrm{Sb} .48$.

Moist woods, hedges.

Per. July.

Florets about nine. Sheaths of the leaves very hairy. Ls. broad. The awn on the back, and fringed inner husk, distinguish this from Fest. gigantea. A gigantic grass, often six feet.

B. stérilis. Barren Br. Panicle drooping, a little branched. Spikelets linear-spear-shaped, their foot stalks very long. Florets about seven, spear-shaped, seven-ribbed, furrowed. Awns longer than the glumes. Leaves downy, narrow. E. B. 1030 . C. 1. 9 .

Fields, waste ground, hedges.

An. June. 
Spikelets long, narrow, much awned, distant: about one foot and a half high. Styles grow sideways out of the germ., as in Br. diandrus. Specific name from the unprofitable nature of the grass.

B. diandrus. Upright Annual Br. Panicle upright, a little spreading, scarcely subdivided. Florets spearshaped, with two close marginal ribs, and only two stamens generally. E. B. 1006 . C. 6. 5 .

Sandy ground, walls. Iffley. $\$ b$. Old walls about Oxford. Hudson.

An. May.

A foot high: less downy than B. sterilis. With an erect, more compact pan. never lax, nor drooping.

\section{AVE'NA. Oat, or Oat-Grass.}

A. fátua. Wild Oat, or Haver. Panicle erect, much branched. Spikelets drooping. Florets about three, shorter than the calyx, hairy at the base, with an oblique scar, all awned. E. B. 2221. Fgilops bromoides. G. E. $7 \%$.

Cornfields. Upper Heyford, abundant. Rose Hill. $B x$.

An. July.

$L s$. rough. Glumes yellow, with brown hairs. Awn two inches long; an excellent hygrometer. The oblique scar at the base of each floret distinguishes this species from A. sativa, whose scar is transverse, and the glumes smooth. The flowers may serve for artificial flies. A troublesome weed; extirpated by burning, and fallowing.

A. pubéscens. Downy Oat-grass. Panicle erect, nearly simple. Florets about three, longer than the calyx. Partial stalk bearded. Leaves flat, downy. Root somewhat creeping. E. B. 1640.

Dry chalky pastures. Sm. Cowley, Littlemore, Bullingdon. Sb. Per. June.

Straight. Flos. club-shaped, cylindrical, summit of the glumes, shining, and transparent. Pan. purplish, shining, white. Not liked by cattle. Swayne.

A. pratensis. Narrow-leaved Oat-grass. Panicle erect, somewhat spiked. Florets about five, longer than the calyx. Partial stalk all over hairy. Leaves rolled inward, finely saw-toothed, naked; sheaths smooth. E. B. 1204.

Dry, chalky, or lime-stone pastures. Sm.

Per. July. 
A. flavescens. Yellow O. Panicle lax, much branched, spreading, erect. Florets about three, longer than the very unequal calyx. Leaves flat, a little downy. Root somewhat creeping. E. B. 952 . C. 3. 5 .

Meadows, pastures, in chalky and lime-stone situations. Sm.

Per. June.

All the flos. bearded. Pan. yellowish, shining. $\boldsymbol{F l}$. very small. Root creeping. Culm about one foot.

A good agricultural grass.

\section{ARUNDO. Reed. Ang. Sax.}

\section{A. Phragmites. ${ }^{\mathrm{I}}$ Common Reed. Florets about five,} awnless, longer than the calyx. Panicle loose. E. B. 401. A. vallatoria. G. E. 36. f. 1.

Marshes, ditches, and about the banks of pools and rivers.

Per. July.

Six feet. Cal. smooth. At the base of each floret a large tuft of white silky hairs. Used for thatching, garden-fences, \&c. and is annually cut for these purposes. More durable than straw for thatching; laid across the frame of wood-work, as a foundation for plaster floors. Reed pens for sketching. Pan. used by Swedes to dye woollen green. Its waving silvery plumes ornamental on banks of rivers, \&c. The young shoots, if cut off from the root where not exposed to the light, are said to make an excellent pickle.

A. epigejos. ${ }^{2}$ Wood Reed. Calyx single-flowered, longer than the corolla. Panicle erect, close. Flowers crowded, leaning one way. Corolla with a back awn about as long as the hairs and calyx. Leaves spearshaped, smooth beneath. E. B. 403.

Moist woods. Magdalen College copse. Tar Wood. Sb. Copse, near Horsepath, by the foot-path. R. W. Furze field, near Bullingdon Green. $B \boldsymbol{B}$.

$\mathrm{Cal}$. valves rough. Stem nearly as tall, but rather more slender than Ar. Phragmites: leafy, smooth.

\section{LO'LIUM. Darnel.}

L. perenne. Perennial D. Rye-Grass. Corolla very slightly awned. Spikelets compressed, longer than the calyx. Florets spear-shaped. E. B. 315. H. L. 1. 18. L. rubrum. G. E. 78. f. 1.

Meadows, pastures.

${ }^{1}$ Gr. phrasso, to fence.

2 Gr. creeping on the ground. 
Per. June.

Spike sometimes branched alternately. Side of the spike-stalk supplies the defect of the two inner valves. Makes excellent hay upon dry, chalky soils; comes early : best suited to the light land of Norfolk: does not last many years, unless the soil be rich. Var. with short, broad, egg-shaped, close spike. Sometimes termed battledore-grass. $\boldsymbol{B} x$.

L. temulentum. Bearded D. Awns longer than the corolla. Spikelets shorter than the calyx. Florets elliptical. Stem rough in the upper part. E. B. 1124. L. album. G. E. 78 .

Fields. Rare about Oxford. B.x.

An. July.

Stem two feet, erect; smooth below. Ls. green, rough. Seeds said to be poisonous, intoxicating, and fatal. Monthly Rev.v.67.

L. arvense. Short-awned $D$. Corolla slightly awned. Spikelets as long as the calyx. Florets elliptical. Stem very smooth. E. B. 1125.

Fields, rare. Cowley Field. $B x$.

An. July.

Smaller; almost all smooth. Awns indistinct, or scarcely distinguishable.

\section{E'LYMUS. Lyme-grass.}

E. europaus. Wood Lyme-grass. Spike erect. Florets about two, rough, awned, as well as the calyx. Leaves flat, pliant. E. B. $131 \%$.

Woods, thickets, hedges, on a chalky soil. Sm.* Stokenchurch Woods, Oxfordshire, plentifully. Bobart in Raii Synops. and Sb. Ardley, $i d$. Not rare in Oxfordshire, according to Smith.

Per. June.

Grassy green: two fect. Spike two or three inches: flor. often solitary. Habit of a Hordeum. Harsh, coarse grass.

\section{HO'RDEUM. Barley.}

H. murinum. Wall Barley. Mouse B. Way Bennet. side flowers barren. Calyx-valves of the intermediate one, spear-shaped, fringed. E. B. 1971. C. 5.9. H. spurium. G. E. 73.

Waste grourd, way-sides.

An. Per.? June.

Culms lying down at the base. Ls. rough, brightish green. Inrolucrets of the intermediate florets fringed. Twelve to eighteen inches high. Root fibrous. Of no agricultural use. 
H. pratense. Meadow $\boldsymbol{B}$. Side flowers imperfect, with awns. All the calyx-valves bristle-shaped and rough. E. B. 409. Gramen secalinum. G. E. 29. Meadows, pastures, especially such as are rather moist.

Per. June.

Culms erect, eighteen inches, to two feet. Ls. roughish. Cul. valve-awns shorter than in $\mathrm{H}$. murinum. Involucrets bristly, rough. Spike more close, and narrow than in $\mathrm{H}$. murinum. In moist meadows, produces a considerable crop of hay.

\section{'TRI'TICUM. Wheat.' Wheat-grass.}

\section{T. repens. Creeping Wheat-grass. Couch-grass. Ca-} lyx-valves pointed, or awned, spear-shaped, manyribbed. Florets about five, sharp-pointed, or awned. Leaves flat. Root creeping. E. B. 909.

Waste, as well as cultivated land, almost every where.

Per. July.

Slender, erect, two feet. Ls. upper side rough.

Roots mildly aperient, diuretic: may be made into bread. Sold in the market at Naples to feed horses with. Sweet liquorish taste. Recommended by Boerhaave, and Plenck in visceral, and hepatic obstructions. Dogs eat the leaves to excite vomiting. Gerarde observes in his Herbal, " although that couch-grasse be an unwelcome guest to fields and gardens, yet his physicke vertues do recompence those hurts." The fibres of the root downy ; a provision of nature, found in most grasses of very dry situations, in order to fix them more securely, or to multiply the surface, and points of absorption.

T. caninum. Fibrous-rooted Wheat-grass. Calyxvalves somewhat awned, with three or five ribs. Florets four, awned. Leaves flat. Root fibrous. E. B. 1372 .

Woods, shady hedges, on a chalky, or lime-stone soil. Sm. Stokenchurch Woods plentifully. Ray. Stow Wood, Tar Wood, Stokenchurch, Ardley. $S b$. Road side of towing-path, near Oxford. $B x$.

Per. July.

Straight, erect, bright green. Ls. rough on both sides. The opposite calyx-valves distinguish T. caninum from an Elymus. Divided from Triticum by Linn. on account of the lower spikelets being double. The fibrous root distinguishes this from T. repens.

1 Ang. Sax. 


\section{TRIANDRIA TRIGYNIA.}

\section{MO'NTIA.' Blinks.}

M. fontána. Small Water-Chickweed. Blinks. E. B. 1206 . C. 3. 8 .

In watery places, by the sides of little clear rills, especially on a gravelly soil. Shotover Hill, Southleigh Heath. Sb. Near Horsepath. (Bagley Wood.) Bx.

An. May, June. Bx.

Smooth, spreading. Ls. opposite, rather fleshy, elliptic-spearshaped, entire. $F l$. white, on long foot stalks. Seeds black. Its minute flowers seldom entirely open: hence one of its names, Blinks. A larger variety found. With. $\mathbf{F l}$. open in the brightest sunshine only. A diminutive plant.

\section{Class IV. TETRANDRIA. Stamens 4. equal.}

\section{Order I. MONOGYNIA. Pistil 1.}

\section{DI'PSACUS. ${ }^{2}$ Teasel. ${ }^{3}$}

D. sylvestris. Wild $T$. Leaves opposite, saw-toothed. Scales of the receptacle straight. Common calyx bent inwards, longer than the head. E. B. 1032. C. 3. 9. G. E. $116 \%$.

About moist hedges, and by road sides.

Bien. July.

Stem about four feet, straight, branched, prickly. Ls. sometimes joined at the base, oblong, veiny, prickly: root-ones blunter, depressed. $F l$. heads terminal, solitary, egg-shaped, erect. $F l$. very numerous, dense, palish purple, each with a linear-spearshaped scale of the recept. Not so stout a plant as D. fullonum, involucre not spreading.

Heads of this sometimes mixed with those of the D. fullonum : its straight scales render it useless for dressing cloth. Cavities of the $l s$. contain a considerable quantity of water, after rain.

D. pilósus. Small Teasel. Shepherd's Staff. Leaves stalked, with side leaflets. Involucres bent back, about

1 After Monti, a Bolognese Professor.

2 Gr. Dipsao, to be thirsty, the united leaves round the stem holding a quantity of water after rain.

3 Tresan. A. Sax. to card, from teasing, i. e. combing wool, \&c. 
the length of the head. E. B. 877 . C. 1. 10. D. minor, sive Virga pastoris. G. E. 1168.

Moist, shady places. Near Thame Park. Sb. Ditch, near Bayswater. Bx.***

Bien. July.

Stem three or four feet, erect, branched, very rough, with ascending hooked prickles. Ls. opposite, egg-shaped, pointed, sawtoothed. $F$ l. white, heads small, round, terminal, long-stalked. Cal. common, ls. spear-shaped. Cor. funnel-shaped, five lobed, hairy. Anth. purple.

\section{SCABIO'SA. Scabious.}

S. succisa. Devil's-bit Sc. Corolla in four equal segments. Heads nearly round. Stem leaves distanitly toothed. E. B. 878. C. 3. 10. Morsus diaboli. G. E. 726.

Grassy, rather moist pastures.

Per. July.

Root abruptly bitten off at the lower end. Stem one to two feet, erect, leafy, with three or more $f$. Ls. dark-green, hairy: rootones egg-shaped, bluntish, entire: uppermost ones smaller, spearshaped, entire. $\boldsymbol{F l}$. dark, purplish blue; heads on long terminal $f$. stalks : the central one most considerable: hairs on the main stem bent back, downwards, not elsewhere. Called Devil's-bit from a legend, that the Devil, says Ger. in envy of the plant's virtues, bit off the end of the root: it has been remarked, that after this bite, no virtues can be found remaining, in the root, or elsewhere. Dried ls. to dye wool yellow or green. $F l$. sometimes white. The hairs on every part of the flower stalks point upwards. Seed-crown chiefly of five bristles.

S. arvensis. Field Sc. Corolla in four segments; the marginal flowers radiate. Leaves wing-cleft, cut. Stem bristly. E. B. 659. C. 4. 13. S. major vulgaris. G. E. 719 .

Cornfields, pastures.

Per. June.

Stem about one yard, branched. Ls. root-ones numerous, spearshaped, more or less saw-toothed. Branches spreading, with a solitary terminal flower. Fl. large, pale purple. Anth. fleshcoloured. Seed four cornered.

The flowers held over tobacco smoke, changed to a beautiful green; the alkali of the smoke acting on them. Var. $F l$. white. Plant slightly astringent. Sheep and goats are said to eat this herb, but its bitter and nauseous flavour is not agreeable to domestic cattle.

S. columbária. Small Sc. Corolla in five unequal segD 2 
ments. Root leaves egg-shaped, or lyrate, notched; the rest wing-cleft, linear. E. B. 1311. S. minor, sive columbaria. G. E. 719.

Pastures, waste ground. Bullingdon Green. Sb. Abundant on sandy banks between Stow Wood, and Beckley, \&c. Bx.

Per. June.

Smaller, more slender than S. arvensis: twelve to eighteen inches. Stem erect, round, leafy. Ls. stalks of lowermost $l s$. longish, remaining $l s$. stalkless; the segments entire. $F l$. terminal, stalks long, naked. $F l$. light purple, marginal $f l$ large, radiant, much larger than the inner. Stem $l s$. very narrow. Discrim. Cor. five cleft.

\section{SHERA'RDIA. ${ }^{x} \quad$ Sherardia, or Field-madder.}

S. arvensis. Blue Sh. Little F.-m. All the leaves whorled. Flowers terminal. E. B. 891. C. 5. 13. Fallow fields, or among corn.

An. June.

Plant small, slender; habit of a Galium. Stems several, branched, spreading in every direction. Ls. elliptic, or inversely eggshaped, pointed, entire. $F l$. ls. inclosing three or four blossoms. $\mathrm{Fl}$. purplish-blue, tube slender, tapering to the base. Cal. of two, three-clefted, permanent leaves. Fruit two dry seeds.

\section{ASPE'RULA. ${ }^{2} \quad$ Woodruff. ${ }^{3}$}

A. odoráta. Sweet $W$. Leaves about eight in a whorl, spear-shaped. Panicles stalked, of few flowers. E. B. 755. C. 4. 15. Asperula. G. E. 1124.

Dry woods.

Per. May.

Stem upright, simple, leafy, about a span high. Ls. bright green, rough only at the margin. Panicle forked, terminal; stalks longish. $F l$. snowy white, sometimes fragrant. Fruit rough, with ascending bristles. The dry, or drying herb exhales a pleasant, and lasting fragrance, resembling new hay. To drive away ticks; to give a grateful flavour to wine. The $L s$. infused an aromatic tea.

\section{A. cynánchica. Small $W$. Squinancy-wort. ${ }^{4}$ Leaves}

1 Named after Dr. William Sherard, founder of a Botanical Professorship at Oxford, and reputed author of Schola Botanica. Died 1728.

2 Asper, Lat. rough. $\quad{ }^{3}$ From the position of leaves, like a ruff.

- From its supposed efficacy in quinsy. 
linear, four in a whorl; the upper ones very unequal. Flowers all four-cleft. Fruit smooth. E. B. 33. Synanchica. G. E. 1120.

Dry, chalky banks.* Bullingdon Green, Stokenchurch Hills, Wychwood Forest. Sb. Headington Quarry, Shooter's Hill, Pangbourn, Berks. R. W.

Per. July.

Stems four to six inches, generally trailing, erect at the extremities. $F l$. white, or blush-coloured, elegantly marked with red lines. $L s$. upper ones three, or two at a joint.

\section{GA'LIUM.' Bed-straw.}

* Fruit smooth.

G. cruciátum. Cross-wort, Bed-s. Mug-weed. Leaves egg-shaped, hairy, four in a whorl. Stem hairy, simple above. Flowers axillary, clustered from the side of the stalks, with two leaves. E. B. 143. Cruciata. G. E. 1123.

Thickets. Tar Wood, Wychwood Forest. Sb.

Per. May.

Stems one foot and a half, branched at the base, resting against bushes, \&c. weak. $F l$. in small corymbs, polygamous, yellow, variable in structure : segments from three to five. Ls. light green. Plant, particularly the roots, to dye red: astringent.

G. palustre. White Water B. Leaves oblong-spearshaped, blunt; the upper ones four in a whorl, unequal in size. Stem weak; spreadingly branched. E. B. 1857. H. L. 1. 20.

Moist meadows, ditches, borders of rivers.

Per. July.

Stem among tall water plants, rising to three or four feet, four cornered. $\mathbf{F l}$. white, three cleft, and somewhat umbellate, and again sub-divided. Panicle large, loose, at the base two leaves or one. Segm. of Cor. broad, acute, but not pointed. Ls. sometimes more than four in a whorl.

G. saxátile. Smooth Heath B. Leaves six in a whorl, inversely egg-shaped, blunt with a small point. Stem much branched, trailing, smooth. Fruit granulated. E. B. 815. G. procumbens. Sb. 59 .

Heaths, hilly ground.

Per. June.

1 From Gala, milk, Gr. because one at least of the genus, Gal. verum, coagulates milk. 
Plant small. Stem two to six inches, very slender at the base. $\boldsymbol{F}$. panicles terminal, and lateral, three forked, smooth, milk-white, small. Fruit small, studded with minute granulations. Ls. roughish at the edges.

Discriminated by its granulated fruit, which is found also in Gal. tricorne, a very different species.

G. uliginósum. Rough Marsh B. Leaves six in a whorl, inversely egg-spear-shaped, rigid, bristle-pointed; their edges rough, like the stem, with prickles pointing backwards. Fruit smooth, smaller than the corolla. E. B. 1972. H. L. 1. 21.

Wet meadows, \&c.

Per. July.

Stem one foot or more, branched, rough, weak, and brittle. Ls. from the side of the stem, adhering to almost every thing in contact with them. $F l$. small, white, terminal, and from the side, cloven. Fr. small, dotted. Ls. variable in number.

Discriminated by prickles at the edge of the Ls. and the sharp bristle point, from G. saxatile.

G. erectum. Upright $B$. Leaves whorled, about eight, spear-shaped, bristle-pointed; rough at their edges with prickles, all pointing forward. Stem weak, a little hairy under each joint. E. B. $206 \%$.

Mountainous Pastures. Henley. Sb.

Per. June.

Pan. close, terminal. Cor. white, taper-pointed. Ls. scarcely inversely egg-shaped, except some of the lower; slightly glaucous, much veined with net-work, smooth on both sides; the edges, and adjoining portion of the disk above with a double row of hooked prickles. Stems one and a half to two feet; plant larger than G. uliginósum.

G. tricorne. Rough-fruited Corn B. Three-flowered Goose-grass. Leaves about eight in a whorl, spearshaped, with marginal prickles, bent back, like those on the stem. Stalks axillary, three-flowered. Fruit sharply granulated, drooping. E. B. 1641. G. spurium. Sb. 59.

Dry, chalky fields. Headington Field, Stanton Harcourt, Southleigh. Sb. Between Cowley Marsh and Rose Hill. R. W. Wheatley Road, and Headington Quarry. Between Tackley and Northbrook. $\boldsymbol{B} x$.

Stems one foot or more, weak, simple. Fl. stalks scarcely so long as the $L_{s}$. three-cleft, with mostly three $f$. and a pair of bracteas. $\mathrm{Fl}$. cream-coloured. Stalks after flowering curved downwards. Fr. appearance of having been cut with a sharp instrument. 
G. vérum. Yellow B. Leaves eight in a whorl, linear, channelled, entire, rough. Flowers in close panicles. Fruit smooth. E. B. 660. C. 6. 13. G. luteum. G. E. 1126.

Dry ground. Var. white fl. Sonning, Berks. Tur.

Per. June.

Stems about one foot and a half, seldom quite upright, without support, roundish, smooth. $L s$. pointing downwards, dark green. $F$ \% stalks much branched, smaller ones short. $F l$. yellowgolden.

A strong decoction of the plant, a good rennet to curdle boiling milk. The root to dye red. Flowers smell strongly before rain, and wind. Fl. Suec. The whole herbage to dye yellow: supports the finest verdure in the dryest weather.

G. Mollúgo. Great Hedge-B. Leaves about eight in a whorl, elliptical, bluntish, bristle-pointed, rough-edged. Flowers in loose, spreading panicles. Corolla thicktipped. Seeds smooth, round. E. B. 1673. Rubia sylvestris. G. E. 1118 .

Hedges, thickets.

Per. July.

Stems weak, and sometimes rising to three or four feet, with support; branched, leafy, swollen, and pale above the joints, mostly smooth. $F l$. numerous, pure-white. Cor. segments, each tipped with an erect point. $\boldsymbol{F l}^{\prime}$. stalks terminal, rising from the whorls of the $L s$. Leaf prickles pointing forwards. $L s$. of the lower whorls very blunt, almost oblong-battledore-shaped, with a very short sudden point.

\section{(Galium ánglicum. See Appendix.)}

G. Aparíne. Goose-grass, or Cleavers. Leaves eight in a whorl, spear-shaped, keeled, rough, fringed with prickles bent back. Stem weak. Fruit bristly. E. B. 816. C. 2. 9. Aparine. G. E. 1122.

Hedges.

An. July.

Stem remarkably adhesive, long, four-cornered, joints woolly, branches opposite. $F l$. few, pale-whitish, from the bosom of the $L s$. Fr. a double globe, bristles hooked, and seeds thus dispersed by adhering.

Leaves and branches, a filter for milk. Four ounces of the expressed juice, night and morning, taken internally for several weeks, to remove what have commonly been styled scorbutic complaints. The roots dye red. The seeds instead of coffee. 


\section{PLANTA'GO. ${ }^{I} \quad$ Plaintain.}

P. major. Greater $\boldsymbol{P}$. Leaves broadly egg-shaped, smoothish, somewhat toothed, on longish foot-stalks. Flower-stalks round. Spike tapering. Seeds numerous. E. B. 1558. C. 2. 11. P. latifolia. G. E. 419 .

Pastures, way-sides.

Per. June.

Stalks nine to eighteen inches. Ls. root-ones upright or spreading, ribs seven or nine. Spike long, slender, acute. $F l$. very numerous, closely tiled. Cor. and filam. white. Anth. reddish. Plant varies greatly in size.

Seeds eaten by small birds. Plant astringent, mucilaginous. Green $l s$. applied to cuts.

P. média. Hoary $\boldsymbol{P}$. Leaves egg-shaped, downy, with very short foot-stalks. Flower-stalks round. Spike cylindrical. Seeds solitary. E. B. 1559. C. 4. 14 . P. incana. G. E. 419 .

Dry pastures.

Per. June.

Stems five to ten inches. Ls. pressed close to the ground, about five-ribbed, entire. Foot-stalks broad. Fl. stalks tall, hoary. Filam. long, pale-purple. Anth. whitish. Caps. cell oneseeded.

This plant a nuisance on lawns, destroyed by applying a drop of sulphuric acid on the crown of each root. Medical properties, like those of the former.

P. lanceoláta. Ribwort $\boldsymbol{P}$. Leaves spear-shaped, entire, tapering at each end; nearly woolly at the base. Flower-stalks angular. Spike egg-shaped. E. B. 507. C. 2. 10. P. quinquenervia. G. E. 422.

Meadows, pastures.

Per. June.

Stalks about one foot, and shoot to a considerable length after flowering. $L s$. root-ones for the most part upright, ribbed. Spike tiled with black scales. Anth. prominent, cream-coloured. Eaten by cattle, mixed with other herbage.

P. Corónopus. ${ }^{2}$ Buck's-horn P. Star of Earth. Leaves in many wing-cleft linear segments. Flower-stalks round. E. B. 892. Cornu cervinum. G. E. $42 \%$.

1 i. e. called the plant, by way of excellence.

2 Koróne, a crow, and pous, a foot. Gr. 
Dry, sandy, gravelly ground. Bullingdon Green. Behind the Observatory. Sb. New College Gardens. Rev. Mr. Young.

An. June.

Stalk four to seven inches. $L s$. root-ones numerous, spreading in a star-like form, mostly pressed close to the ground. Spike close, greenish, short.

Plant very variable in size, and in the clefts of $l s$.

\section{(CENTU'NCULUS. Chaff-weed.}

C. minimus. Small Ch. Flowers stalkless. Corolla glandless at the base. E. B. 531. C. 3. 11.

Watery heaths. On Gerard's Cross Common, near Bulstrode, Bucks, in great plenty with Radiola millegrana. Tur.

An. June, July.

Very diminutive, one to two inches high. Ls. egg-shaped. $\boldsymbol{F l}$. axillary, solitary, stalkless, white or reddish, opening in bright sunshine only.)

\section{SANGUISORBA. ${ }^{I} \quad$ Burnet.}

S. officinális. Great B. Spikes egg-shaped. E. B. 1312. P. sylvestris. G. E. 1045.

Meadows, pastures.

Per. July.

Stem two feet, erect, with few $l s$. panicled above. Ls. winged, with an odd one at the end. Leaflets opposite, egg-shaped, sharply notched: a pair of small toothed appendages at the base of their partial stalks. Root Ls. on long foot-stalks: the rest nearly stalkless, with stipulas. $\boldsymbol{F l}$. dark, dull purple. Spikes terminal.

\section{CORNUS. ${ }^{2}$ Cornel.}

C. sanguínea. Wild $C$., Dog-wood. Branches straight. Leaves green on both sides, Cymes with no involucre, flat. E. B. 249. C. foemina. G. E. $146 \%$.

Hedges, thickets.

Per. a shrub. June.

Four or five feet: bark smooth; dark red, in the older branches. $L s$. opposite, egg-shaped, entire, strongly nerved, entirely red, before falling. $\mathbf{F l}$. in cymes, terminal, greenish white: pet. rolled back in the margin. Germ. crowned with a glandular ring. Berries dark purple, bitter.

1 From a supposed astringent power of the plant, to suppress and absorb blood : sanguis, blood, and sorbeo, to absorb.

2 From Lat. cornu, a horn: from the hardness of the wood. $\boldsymbol{H}$. 
Wood very hard for turners. A lamp, or salad oil from the pressed berries, boiled in water. Berries dye purple.

\section{PARIETA'RIA.' Wall-pellitory.}

P. officinális. Common Wall-P. Leaves egg-spearshaped, without side ribs at the base. Involucre threeflowered, with many egg-shaped segments. Stem ascending. E. B. 879. C. 4. 63. Parietaria. G. E. 331.

Walls.

Per. June.

Stem bushy, ascending, leafy, shining, generally very red. $L s$. alternate, obliquely twisted, dark-green. $\boldsymbol{F}$. . axillary, greenish white. Stam. filam. curiously jointed, or wrinkled, starting back elastically, once touched, and thus discharging the pollen copiously.

Mucilaginous, emollient, but inferior to the Mallow tribe in that respect : contains a considerable quantity of nitre.

\section{ALCHEMILLA. ${ }^{2}$ Lady's Mantle. ${ }^{3}$}

A. vulgáris. Common $L$. Leaves lobed, somewhat kidney-shaped, plaited, sharply saw-toothed. E. B. 597. Alchimilla. G. E. 949 .

Dry pastures. Pastures near Stow Wood. Burford Downs. Wychwood Forest. Sb. Between Burford and Wychwood Forest, just above the Hit or Miss Public-house. Cassington. $B x$. Finmere Church-yard. $R . P r$.

Stems more or less trailing, leafy. $L s$, root-ones on long footstalks, large, roundish, saw-toothed: verdure of upper surface very fine. Stem Ls. smaller, connected with a pair of large toothed stipulas, upper $L s$. gradually diminishing into bracteas. $\mathrm{Fl}$. corymbose, terminal, numerous, green, downy, yellow in the centre.

A very elegant plant in habit and appearance. Astringent: said to have proved fatal to cows, producing an irremediable constipation.

A. arvensis. Field L. Parsley Piert. Leaves flat, three-lobed, cut. E. B. 1011. Percipier anglorum. G. E. 1594 .

Sandy, gravelly fields.

An. April.

' From paries, Lat. a wall, on which the plant generally grows. Constantine used to call Trajan, Parietaria, on account of the numerous buildings on which his name appeared.

${ }^{2} \mathbf{A}$ plant formerly in renown among the alchemists. $\quad 3$ i. e. of our Lady? 
Stems numerous, spreading, or prostrate, leafy. Ls. alternate, plain, stalks short. $F l$. tufted, axillary, hairy, green, inconspicuous, from the side of the stems. Cal. urn-shaped. Stam. sometimes only one.

Altogether smaller than Alch. vulgáris. Formerly esteemed diuretic.

\section{TETRA'NDRIA TETRA' GYNIA.}

\section{ILEX. Holly. ${ }^{1}$}

I. Aquifólium. ${ }^{2}$ Common $H$. (In Norfolk, Christmas.) Leaves egg-shaped, acute, thorny and wavy. Flowers axillary, somewhat cymose. E. B. 496. Agrifolium. G. E. 1338.

Hedges, bushy places. Shotover Hill. Sb.

Tree. April.

Ls. alternate, shining. $F l$. white. Berry scarlet, rarely yellow.

Upper $L s$. entire :

"But as they grow where nothing is to fear,

Smooth and unarmed the pointless leaves appear.-Southey.

Branches of this with its ripe berries, mixed with the misseltoe, and spindle-tree, (Euonymus) to ornament churches and houses at Christmas; a supposed relic of Druidism, to afford a shade for the abode of sylvan spirits in the cheerless winter. Vars. with variegated $L s$. very numerous. Sheep and deer fed with the branches in winter. Birdlime from the fermented bark, washed from the woody fibre. Plant an impenetrable fence, very hardy, with its berries. Wood for veneering, handles of knives, cogs for mill-wheels, stained black to imitate ebony: flourishes under the shade of trees.

\section{POTAMOGE'TON. ${ }^{3}$ Pond-weed.}

Four British species found in New Holland.

P. natans. Broad-leaved Floating $\boldsymbol{P}$. Upper leaves oblong-egg-shaped, stalked, floating, leathery; lower ones linear, membranous, stalkless. E. B. 1822. P. latifolium. G. E. 821.

Pools, ditches, slow rivers.

Per. July.

Stem immersed, round, leafy. Stip. large, spear-shaped, concave, acute. Fl. stalks as large as the stem, solitary, axillary, (with a

1 Holegn. Sax.

2 Perhaps for acui folium, sharp-leaved.

3 Gr. Potamos, a river, and geiton, a neighbour. 
bractea like the stip.) thick, almost cylindric, contracted just under the spike. Fl. dull-green, pollen whitish. Spike raised above the water. Ls. foot-stalks long.

Floating $L s$. a shade to fish : roots favourite food of swans.

P. perfoliátus. Perfoliate $\boldsymbol{P}$. Leaves heart-eggshaped, clasping the stem, uniform, all beneath the water; spikes of flowers above water. E. B. 168. G. E. 822.

Ponds, rivers.

Per. June.

Stems long, round. Ls. pellucid, olive-coloured, crowded about the top, and branches. Spikes a few brown $f$.

The respiration of these submersed plants probably different from that of plants, which inhale atmospheric air: the $l s$. of a thin, pellucid texture, very vascular; the surface destitute of hair, or down.

P. densus. Close-leaved $\boldsymbol{P}$. Leaves egg-shaped, stalkless, pointed, opposite, crowded. Stem forked. Spike of about four flowers. E. B. 397.

Ditches, ponds, slow streams.

Per. July.

Ls. lengthened into a point, ribbed waved, entire, much crowded towards the end of the stem. $F l$. stalks short, round, curved back, bearing a small short head of two or four green $f$. much resembling those of Adoxa Moschatellina. Plant immersed, except the spike. Smaller than P. perfoliatus.

P. lucens. Shining P. Leaves elliptic-spear-shaped, pointed, membranous, stalked, repeatedly triple-ribbed, all under water. Spike dense, many-flowered, above water. E. B. 376. P. longis acutis foliis. G. E. 822. Ditches, ponds, lakes, slow streams.

Per. July.

Stems long, slightly zigzag, round, leafy. Ls. alternate, except where $f$., foot-stalk short: stip. long, blunt, folded, membranaceous within the $L s . \quad F l$. on a solitary spike; the longest, and most crowded of the genus; from the axil of one of the opposite Ls. dark-green; plant olive-green or reddish. Var. one with spear-shaped, tapering $L_{s}$.

P. crispus. Curled P. Freshwater Caltrops. Leaves spear-shaped, waved; saw-toothed, alternate; the upper ones opposite. Flowers in loose spikes. E. B. 1012. C. 5. 15. Tribulus aquaticus minor, quercûs floribus. G. E. 824. 
Ditches, ponds, rivulets. Ditch round Christ Church Meadow. Sb. Per. June.

Ls. remarkably waved, saw-toothed, lower ones alternate, all stalkless, pellucid, dull-green. Fl. stalks a little longer than the Ls. solitary. $\mathbf{F l}$. tinged with purple; styles purple, anth. yellow. Plant under water.

$L s$. and seeds food for ducks.

P. grámineus. Grassy $\boldsymbol{P}$. Leaves linear, tapering downward, with solitary, very slender side ribs. Stem round, forked. Flower-stalks from the forks, scarcely longer than the spikes. E. B. 2253.

Ponds, ditches. Binsey Common. Ditches by the Road-side, going to Port Meadow. $\mathbf{S b}$.

Per. June.

Plant under water, except the flower. Stem slender, zigzag, much branched. Ls. grassy, alternate, except at the forks, crowded, bluntish, entire. Stip. narrower than the $l s$. rolled inward cylindrically, pale brown. Spikes egg-shaped, dense, solitary: fl. few.

P. pusillus. Small $\boldsymbol{P}$. Leaves linear, spreading at the base, opposite or alternate, with solitary, very slender side ribs. Stem round. Flower-stalks axillary, mostly from the side of the stems, many times longer than their spikes. E. B. 215.

Ponds, ditches. Port Meadow. Sb.

Per. June.

$\boldsymbol{L} \boldsymbol{s}$. very narrow, stalkless, opposite under every flower-stalk. Stip. membranaceous, spear-shaped, broader than the $l s$. above each l., stem-embracing. $\boldsymbol{F l}$. three or four, greenish, spiked. Stem much branched, slender. Plant under water, except the $f$.

P. pectinátus. Fennel-leaved $\boldsymbol{P}$. Leaves bristle-shaped, single ribbed, parallel, thickly set in two directions; sheathing at the base. Spikes interrupted. E. B. 323. Millefolium tenuifolium. G. E. 828.

Rivers, ditches, ponds.

Per. June.

Root from a tuberous lump. Ls. flat, very long, alternate. Plant under water, except the stalkless $f$. Pet. dull olive: anth. yellow.

\section{SAGI'NA. ${ }^{\times} \quad$ Pearl-wort.}

S. procumbens. Procumbent $\boldsymbol{P}$. Stems trailing, smooth. Leaves minutely pointed. Petals half as long as the calyx. E. B. $880 . \quad$ C. 3. 12.

1 From Sagino, Lat. to fatten; a name ill-applied to this genus. 
Sandy ground, walks, beds of neglected gardens.

Per. July.

Stems thread-like, two to four inches, rooting at the joints. Ls. opposite, evergreen, minute, linear, convex beneath. $\mathbf{F l}$. stalks axillary, solitary, longer than the $l s$. each bearing a small, nod$\operatorname{ding} f$. Pet. white, roundish, sometimes wanting.

S. apétala. Annual Small-flowered $\boldsymbol{P}$. Stems nearly upright, hairy. Leaves bristle-pointed, fringed. Petals scarcely distinguishable, or wanting. E. B. 881 . C. 5. 14.

Dry, sandy, barren ground, walls, waste places.

An. June.

Stems not rooting. Ls. fringed at the base. Fl. stalks slender, long. Pet. white, very minute. Plant small, slender.

\section{MOE'NCHIA." Møenchia.}

M. erecta. Sagina erecta. E. B. 609. C. 2. 12. Sb. 6\%. Pastures, heathy ground. Shotover Hill. Southleigh Heath. Ensham Heath. $\mathbf{S b}$.

An. April.

Stem erect, nearly single-flowered, two or three inches. Ls. opposite, spear-shaped, acute. Fl. stalks very long, often purplish. Fl. upright, pearly white : pet. about as long as the cal. Cal. ls. spear-shaped, acute, Caps. that of a Cerastium with ten teeth. A plant not devoid of neatness.

\section{RADI'OLA. Flax-seed.}

(R. millegrana. Thyme-leaved $\boldsymbol{F}$. E. B. 893. Millegrana minima. G. E. 569.

Wet, sandy ground. Coleshill Pool, Warwickshire. Pn. Near Rugby, road to Barby. Bx.

An. July, August.

Smooth, erect, one to two inches, forked. $F l$. white.)

\section{Class V. PENTANDRIA. Stamens 5.}

\section{Order I. MONOGYNIA. Pistil 1.}

\section{MYOSO'TIS. ${ }^{2}$ Scorpion-grass. ${ }^{3}$}

\section{M. palustris. Great Water S. Forget-me-not. Seeds}

1 Named after Professor Conrad Moench.

2 Muss, and ous, Gr. mouse's ear.

${ }^{3}$ From the Raceme of the $f$. being bent back like the tail of a soorpion. Ray. 
smooth, calyx with straight, close-pressed bristles, when in fruit bell-shaped, open, shorter than the spreading partial flower-stalks. Limb of the corolla flat, longer than the tube. Hairs on the stem spreading (or wanting.) Root creeping. E. B. 1973. M. scorpioides palustris. C. 3. $13 . \quad$ G. E. $33 \%$.

Clear rivulets, ditches.

Per. June.

$F$ l. in a long, spike-like bunch, fine sky-blue, valves forming a bright yellow eye. Herbage shining, green. Ls. stalkless, elliptic-oblong, one and a half to two inches long. Partial stalks at first crowded into a close, bent-back spike, after flowering much lengthened out, stalks at length spreading almost horizontally. Cor. admired for its enamelled brilliancy. This plant the Forget-me-not of the Germans. Origin of this name:-Two lovers, loitering on the margin of a lake one summer's eve; the maiden desired some flowers of the plant growing close to the bank of an island, at a distance from the shore. The lover plunged into the water, and gathered the wished-for prize. On his return, unable to regain the shore, though very near it, he threw the flowers on the bank, and, as he sank to his watery grave, his last words to the beloved lady were-Forget-me-not. Mill's Chivalry, vol. i. p. 315.

Var. Fl. flesh-coloured.

M. caspitósa. Tufted Water S. Seeds smooth. Calyx, when in fruit, bell-shaped, open, clothed, as is the whole plant, with straight, close-pressed bristles. Limb of the corolla about as long as the tube; segments entire. Style shorter than the stamens. E. B. 2661.

Watery places, and in places where water has stagnated during winter. Wet pastures, \&c. Sides of old gravel pits, and in wet places near St. Clement's, especially on the left hand side of a footpath leading from the back of St. Clement's, between the Cowley and Henley roads, to Cowley Marsh. In great abundance, June 9, 1831. I observed it in the same place four or five years ago. $B x$.

Bien.? May, July.

Root fibrous. In dryish situations the stem is often not more than three or four inches high: in wet ones from six inches to one foot or more, often procumbent at the base, and producing fibres from the lower joints, the upper part much branched. Ls. stalkless, or slightly decurrent, between linear and spear-shaped, blunt. Clusters forked, with frequently a solitary flower in the forks, and sometimes a leaf or two among the partial flowerstalks. Partial $f$ l. stalks longer than the calyx, lengthening out to nearly or quite twice its length after flowering. Calyx bellshaped, clothed with straight close-pressed bristles, cut half way 
into five broad somewhat pointed, oblong, triangular segments, spreading when in seed. Corolla smaller than in M. palustris; limb pale blue, nearly white just above the throat; segments entire; valves yellow. Style capitate, concave, shorter than the stamens. Seeds polished, shining, egg-shaped or roundish, sharply two-edged, and slightly keeled towards the point on the upper side. Whole plant besprinkled, more or less, with straight, close-pressed bristles. $B x$. June 15, 1831.

M. arvensis. Field $S$. Seeds smooth. Calyx clothed with spreading, hooked bristles, half-five-cleft, when in fruit, egg-shaped, closed, shorter than the spreading, partial flower-stalks; limb of the corolla concave, equalling the tube. Racemes stalked, with one remote axillary flower. Root fibrous. E. B. 2558.'

Dry, sandy fields, open places.

An. May.

Stem divided from the bottom into wide spreading branches. Stem $L s$. more tapering at the base, than in the other species. $\mathbf{F l}$. clusters very lax in their lower part. Cor. small, palish-purple before expansion, then sky-blue; smaller than in M. palustris. Plant altogether smaller.

M. versícolor. Yellow and Blue S. Seeds smooth Leaves hairy. Racemes on long, naked stalks. Calyx with spreading, hooked bristles. When in fruit, oblong (closed,) longer than the almost erect partial flowerstalks. Limb of the corolla concave, shorter than the exserted tube. Root fibrous. E. B. 2558. t. 480. f. 1. M. nana. Sb. 69.

Dry, sandy fields, pastures, walls, moist meadows. Shotover Hill. $\boldsymbol{B} x$. Besselsleigh, Berks. Y. Cumnor Hurst. Y. Near Childswell Farm. $B x$.

An. May.

$\boldsymbol{F l}$. some of them yellow, and some blue. Ls. narrow, oblong. $\boldsymbol{F l}$. clusters elevated, single, or in pairs, on terminal stalks, without a solitary distant $f$. Cor. small. Discr. colour of $f$.; short calyx-stalks, and generally long calyx. Scarcely any two authors agree with regard to the species of Myosotis. $H$.

\section{LITHOSPERMUM. ${ }^{2}$ Gromwell.}

L. officinále. Common G. Grey Mill. ${ }^{3}$ Grey Millet. Seeds even. Corolla not much longer than the calyx.

According to Greville the fig. is of Myos. versicolor.

2 Lithos, Gr. a stone, and Spermu, a seed, from the hardness of the seeds.

3 i. e. millet. 
Leaves spear-shaped, rather acute, with side cross-ribs. E. B. 134. L. minus. G. E. 609.

Dry, gravelly, chalky situations. Shotover Hill. Headington Wick. Sb. (Between South and Ferry Hinksey, \&c.) $\boldsymbol{B} x$.

Per. May.

Stems roundish, rough. Ls. alternate, hairy beneath, rough above. $F l$. clusters pale-yellow, in seeding state, erect, lengthened out. Seeds much polished in appearance, of a stony substance; the stony shells composed of silica (flint,) sulphate of lime, and iron. The hard ivory-like seeds do not effervesce with acids. $F l$. Suec.

L. arvense. Corn G. Bastard Alkanet. Seeds wrinkled. Corolla not much longer than the calyx. Leaves blunt, without side ribs. E. B. 123. Anchusa degener, facie Milii Solis. G. E. 610 .

Cornfields, waste ground.

An. May.

Ls. spear-shaped, rough, stiff. $F l$. in the axils of the upper $L s$. solitary, nearly stalkless. Spikes terminal, leafy, at length elongated. Cor. white, small, swollen at the base of the limb. Cal. segments after flowering, three or four times as long as the seeds. Seeds pitted. Bark of the root tinges wax, and oil of a red colour; also paper, \&c. hence called Bastard Alkanet.

\section{ANCHU'SA. Alkanet.}

A. semper.virens. Evergreen $A$. Flower-stalks axillary, each stalk with two close spikes, with an intermediate flower, and two chief egg-shaped bracteas. Leaves egg-shaped. E. B. 45. G. E. Borago, etc. $79 \%$.

Waste ground. * Rousham. Miss Armetriding. (Near Birmingham, Alcester road, Warwickshire. With.

Per. May, June.

Ls. broad; plant rough. Fl. bright-sky-blue; buds reddish.

\section{CYNOGLO'SSUM. Hound's-tongue.}

C. officinále. Common H. Stamens shorter than the corolla. Stem-leaves broadly spear-shaped, tapering at the base, downy, stalkless. Flowers without bracteas. E. B. 921. C. 4. 16. C. majus vulgare. G. E. 804 . Waste ground, road sides.* About two miles on the Oxford side of Abingdon, \&c. Bx. Elsfield. R. W.

Bien. June.

Stem about two feet, round, leafy. Ls. dull-green, upper ones embracing the stem, almost heart-shaped. $F l$. clusters terminal, curved back, growing into panicles. Cor. dull purplish red. 
Seeds rough with hooked prickles. Smell of the whole plant strongly fetid, compared to that of mice.

The fresh plant bruised, and laid in a place frequented by rats and mice, will, it is said, cause them to forsake the premises. Narcotic.

C. sylváticum. Green-leaved $\boldsymbol{H}$. Stamens shorter than the corolla. Leaves spear-shaped, somewhat battledoreshaped; the upper ones clasping the stem; all smooth and shining above; hairy and warty beneath. Flowers without bracteas. E. B. 1612.

Road sides, hedges. Sm. Woods. * Wychwood Forest. $\mathbf{S b}$.

Bien. May.

Discrim. from Cyn. officinale by its more dilated $L s$. at the base. $L s$. bright, shining green, smooth above. $F l$. first reddish, afterwards blueish. Plant almost without smell.

\section{SY'MPHYTUM.' Comfrey.}

S. officinále. Common $C$. Leaves egg-shaped-spearshaped, much running down the stem, finely hairy. E. B. $81 \%$ C. 4. 18. Consolida major. G. E. 806. ß. symphytum patens. Sb. 70 .

Watery meadows, banks of rivers, ditches.

Per. May.

Root externally black. Stem two or three feet, leafy, winged. Ls. root ones, stalked, broader. $F \boldsymbol{F}$. clusters in pairs, rolled back. Cor. yellowish white, sometimes purple. Sb. Sym. patens, a var. with red or purple flowers, and said to have a spreading, and shorter cal. Sb.70. Banks of the Thames by Caversham. $\mathbf{S b}$. Side of the towing-path between High Bridge, and Heyfield's Hut. $B x$.

The root abounds in a pure mucilage. Ls. give a grateful flavour to cakes and panada. Young stems and $l s$. good when boiled. Decoction of the $l s$. to extract the colouring matter from Gum Lac.

\section{BORA'GO. Borage.}

* B. officinális. Common B. Lower leaves inversely egg-shaped, tapering at the base. Limb of the corolla flat, much longer than the tube; mouth with a double row of valves; the innermost awl-shaped, bearing the stamens. E. B. 36. B. hortensis. G. E. 797.

1 From Sumphuo, Gr. to grow together, from its supposed healing qualities, in uniting wounds. 
Waste or cultivated ground, road sides. Near the Parks. Sb. Side of the Banbury road going from the Parks to Summer Town. Bx. Bien. May.

Plant succulent, mucilaginous, hispid, with sharp, white bristles. $\mathbf{F l}$. bright blue, bunches terminal, drooping. $\boldsymbol{L}$ s. alternate, eggshaped, wavy, lower ones broadest, stalked. Cor. valves and anthers black.

Originally from Aleppo : the juice affords nitre. Ls. used in cool tankards: young ones in salad. Dodonæus recommends such kind of salad to exhilarate the mind; this agrees with the old adage: Ego Borago gaudia semper ago: quaintly translated by Gerarde: "I Borage bring alwaies courage."

\section{LYCOPSIS. ${ }^{1}$ Bugloss.}

L. arvensis. Small $\boldsymbol{B}$. Leaves spear-shaped, wavy, somewhat toothed, very bristly, with bulbous hairs. Stalks of the flowers and fruit erect. Limb of the corolla slightly unequal. E. B. 938 . C. 5. $1 \%$. Buglossa sylvestris minor. G. E. 799 .

Fields, waste grounds, dry banks.

An. June.

Stem upright, leafy. Ls. alternate, stem-clasping at the base, except the root ones. $F$. in terminal, rolled back, paired spikes. Cor. tube and valves white, limb bright blue. Seeds four, vertical, angular.

\section{E'CHIUM. ${ }^{2} \quad$ Viper's-bugloss.}

E. vulgáre. Common Viper's-b. Stem bristly, with warts. Stem-leaves spear-shaped, bristly, singleribbed. Spikes from the side of the stem, bending down arch-wise. E. B. 181 G. G. 802.

Fields, waste ground, sandy or gravelly soil; old walls, rubbish. Shotover Hill. Abundant between Gibraltar and Tackley. Bx.

Bien. June.

Stem strong, erect. Ls. root ones stalked, growing in a starry form. Fl. clusters bent back, as the flowers open erect. $\mathbf{F l}$. buds red. Cor. purple, then bright blue, large: sometimes white.

A remarkably handsome plant, when in flower. The name from its blue flowers corrupted by the vulgar into Blue-glass, for Bugloss. Bees very fond of the flowers.

1 Differing from Anchusa in the curvature of its tube. H. Gr. Wolf's face.

${ }^{2}$ From Echis, Gr. a viper. From its supposed virtue against the bite of the viper. 


\section{PRI'MULA.' Primrose and Cowslip. ${ }^{2}$}

P. vulgáris. Common Primrose. Leaves inversely eggshaped, oblong, toothed, wrinkled. Stalks singleflowered. Limb of the corolla flat. E. B. 4. P. acaulis. C. 6. 16 . Sb. 72 . P. veris minor. G. E. 781.

Groves, thickets, hedges.

Per. March.

$\boldsymbol{L} \boldsymbol{s}$. directly from the root. $\boldsymbol{F l}$. large, sulphur-coloured; darker radiating spot in the middle, slightly sweet-scented.

Of the cultivated varieties, that with double sulphur-coloured flowers very elegant. Dried roots strongly emetic, drachm and half, a dose. Ls. of this and the Cowslip food for silk worms. Linnæus supposed the Primrose, Oxlip, and Cowslip var. of each other: this seems proved recently. See Trans. Horticultur. Society, vol. iv. and Henslow in Loud. Mag. Nat. Hist. Sept. 1830. The fl. stalks in reality constitute an umbel, at the base.

P. elátior. Oxlip ${ }^{3} \boldsymbol{P}$. Leaves toothed, wrinkled, contracted towards the middle. Stalk many flowered. Limb of the corolla flat. E. B. 513. P. pratensis inodorata lutea. G. E. 780. 2.

Woods, thickets, pastures. Headington Wick Copse. Stow Wood. Southleigh. Sb.

Per. April.

$\boldsymbol{F l}$. sweet-scented, umbellated, outer ones drooping, less expanded limb than in Pr. vulgaris; larger, paler than in the (P. veris) Cowslip.

P. veris. Common Cowslip. Leaves toothed, wrinkled, contracted towards the middle. Stalk many-flowered. Limb of the corolla concave. E. B. 5. P. officinalis. C. 6. 15. P. veris major. G. E. 780 .

Meadows, pastures, chiefly on clay, or chalk. Sm.

Per. Aprit.

$F l$. all drooping, umbellated, deep yellow, with five orange spots, sweet-scented.

Blossoms from them a pleasant, soporific wine. Ls. a pot-herb, and in salads. Root smells like anise.

MENYANTHES. Buckbean.

M. trifoliáta. Common B. or Bog-bean. Marsh Trefoil. Leaves in threes. Disk of the Corolla densely

1 i. e prime or early rose. by cows.
${ }^{2}$ Cu-slippe. Ang. Sax, a plant not eaten ${ }^{3}$ Oxan slippan. Ang. Sax. 
shaggy. E. B. 495. C. 4. 17. Trifolium paludosum. G. E. 1194.

Watery meadows, pools, ditches, spongy, boggy ground. Peat bogs on Bullingdon Green. Behind Headington Hill. Sb. Bogs between the old and new road to Ensham, abundant. North side of Shotover Hill. $B \boldsymbol{B}$.

Per. May.

Stem with sheathing foot-stalks. $F l$. thyrsus stalked, opposite to ls., each fl. bracteated. Cor. flesh-coloured, and clothed with white. Anth. yellow.

Many of our aquatics beautiful : this particularly so. Ls. bitter, in infusion for rheumatism: powdered in the dose of one dram purgative and emetic. Substitute for hops, two ounces supply the place of one pound of hops. The bitter powdered roots eaten instead of bread, in Lapland, during scarcity. The powder with the infusion destructive to worms. $\mathbf{F l}$. Suec.

\section{VILLA'RSIA. ${ }^{\prime} \quad$ Villársia.}

V. nymphaoides. Fringed $V$. Fringed Water-lily. Leaves heart-shaped, wavy at the edges, floating. Corolla fringed. Menyanthes nymphroides. E. B. 21\%. Sb. 73.

Ponds, rivers. River near Botley-Bridge. Godstow-Bridge.

Hincksey Ferry. Sb. Near Medley Lock, abundant. Between Sandford and Nuneham. $B x$.

Per. June.

$F$ F. axillary, foot-stalks long. Cor. yellow, fringed, with the disk darker. A beautiful plant, with its yellow, brilliant flowers.

The salted $l s$. become very glutinous, and in Japan are boiled in soups.

\section{HOTTO'NIA. ${ }^{2}$ Featherfoil, or Water-violet.}

\section{H. palustris. Water Featherfoil. Common Water-v.} Stalks solitary, many-flowered; partial stalks whorled. E. B. 364. C. fas. 1. 11. Viola palustris. G. E. 826.

Clear ditches, ponds. Ditch round Christ Church Meadow. Sb. \&c. Per. May.

$L s$. under water, deeply wing-cleft, or comb-like in shape, the segments linear, entire. $\boldsymbol{F l}$. whorls, and stalk above water, eight or ten inches, solitary, erect. $F \boldsymbol{F}$. stalked, bracteated, pink, or rose-colour, resembling those of the Primrose.

1 After M. de Villars, author of a Flora of Dauphiny.

${ }^{2}$ So named after a Leyden Professor, Hotton. 
This plant vies in beauty with many of the most admired exotics.

\section{LYSIMA'CHIA.' Loosestrife.}

* Stalks many-flowered.

L. vulgáris. Great Yellow Loosestrife. Clusters panicled, terminal. Leaves egg-spear-shaped, acute. E. B. 761. C. fas. 5. 19. L. lutea. G. E. 474 .

Watery, shady places, reedy margins of rivers. Lane going to Binsey. Southleigh Meadows. Otmoor. Sb. Side of the Botley Road. Long Meadow, between Oxford and Iffley. Bx. Per. July.

Stems three or four feet, panicled at the top. Ls. shortly stalked, mostly opposite, or three or four in a whorl. $F \mathrm{Fl}$. panicles large, handsome, yellow, axillary, and terminal. Each partial fl. stalk bracteated. Stam. monadelphous. Cal. and Cor. sometimes in six divisions.

\section{* Stalks sirigle-flowered.}

L. némorum. Wood Loosestrife. Yellow Pimpernel. Leaves egg-shaped, acute. Flowers solitary. Stem trailing. Stamens smooth. E. B. 52\% C. fas. 5. 18. Anagallis lutea. G. E. 618.

Moist woods, shady, rather watery places. Stow Wood. Stokenchurch Woods. Sb. Shotover Hill. Headington Wick Copse. $B$.

Per. June.

Stems branched, with somewhat creeping roots, square, red. Ls. opposite, stalked. Whole plant smooth. Fl. stalks long. Cor. yellow, large. Cal. awl-shaped. An elegant plant.

L. Nummulária. Creeping Loosestrife. Money-wort, or Herb-Twopence. Leaves somewhat heart-shaped. Flowers solitary. Stem prostrate, creeping. Stamens glandular. E. B. 528. C. fas. 3. 14. Nummularia. G. E. 630 .

Wet meadows, boggy pastures, borders of rivulets.

Per. June.

Stems four-cornered, but compressed. Ls. rounder than in Lys. nemorum. $F$. pale-lemon, large, clothed with small glands on footstalks, as the stamens also. Cal. segments pointed, eggshaped.

\section{ANAGALlis. Pimpernel.}

A. arvensis. Common Scarlet Pimpernel. Leaves egg-

${ }^{1}$ Named after Lysimachus, king of Thrace. Plin. 
shaped; dotted beneath. Stem trailing. Corolla minutely notched. E. B. 529. C. fas. 1. 12. A. mas. G. E. $61 \%$.

Fields, gardens.

An. May.

Stem much branched at the bottom, square, leafy. Ls. opposite, stalkless, many ribbed. $\mathbf{F l}$. axillary, solitary, stalks longer than the $l s$. Cal. $l s$. spear-shaped. Cor. scarlet; purple at the base. Stam. purple.

Called Poor-man's weather-glass, from the $f$. closing at the approach of rain. $F \boldsymbol{F l}$. before expansion in dose of gr. xx., four times a day in epilepsy. $F \boldsymbol{F}$. sometimes white, Cowley Field. Ls. sometimes in fours. Cor. represented as fringed in fig. E. B. not correctly. Every part of this plant beautiful, and worth attention. If the $f$. open in the morning, a fair day may be expected. Small birds fond of the seeds. $F \boldsymbol{F}$. opens at eight, shuts in the afternoon. $F$. Suec.

A. coerúlea. Blue Pimpernel. Leaves egg-shaped, or somewhat spear-shaped; dotted beneath. Stem erect. Corolla strongly notched. E. B. 1823. A. arvensis. var. $\beta$. Sb. p. 75. See Henslow in Loudon's Nat. Mag. Nov. 1830. A. fœinina. G. E. $61 \%$

Cornfields, Charlbury. Middleton Stoney. Sb.*** Beyond Cowley Marsh, under Bullingdon Green. Rev. W. Kay, Lincoln Coll. In a Cornfield, S. W. of South Hinksey. B.x.

An. May.

$L s$. narrower than in An. arvensis. Cor. smaller, more deeply notched, vivid blue. No difference but in the col. and margin of the cor. $H$.

A. tenella. Bog Pimpernel. Leaves roundish, somewhat pointed, stalked. Stem creeping. Stigma acute. E. B. 530. C. fas. 3. 15. Nummularia minor, flore purpurascente. G. E. 630.

Wet, spongy, mossy bogs. Peat bogs on Bullingdon Green. Under Headington Wick Copse. Sb. (Bagley Wood.) Bx.

Per. June.

$\boldsymbol{L} s$. opposite, small. $\boldsymbol{F l}$. erect, stalks very long, axillary, solitary, rose-coloured, streaked, deeply divided, rather funnel-shaped. Stam. jointed, woolly. An elegant plant.

\section{CONVO'LVULUS.' Bindweed.}

C. arvensis. Small Bindweed. Leaves arrow.shaped, acute at each end. Stalks mostly single-flowered.

1 From the twining stem of many of its species. 
Bracteas minute, remote from the flower. E. B. 312.

C. fas. 2. 13. Smilax lènis minor. G. E. 861 .

Hedges, fields, gardens.

Per. June.

Root running very deep in the ground. Stems long, twining, climbing, angular. $L s$. alternate. $F l$. stalks long. Cor. deep rose-coloured, plaits yellowish: mostly closing before rain: sweet smelling, in dry, warm weather. A very troublesome, handsome weed.

C. sépium. Great Bindweed. Leaves arrow-shaped, lopped at the hinder lobes. Stalks square, singleflowered. Bracteas heart-shaped, close to the flower. E. B. 313. C. fas. 1. 13. Smilax lenis, sive lævis major. G. E. 861 .

Moist hedges, osier holts, thickets.

Per. July.

Roots long, creeping. Stems very long, twining. Ls. alternate. $F$ F. solitary, on axillary, square stalks. Cor. large, white. Bract. heart-shaped, red-bordered. Its large milk-white blossoms very ornamental. Plant may be trained to a great height. Inspissated juice, a powerful purge; dose twenty or thirty gr. The scammony a species of convolvulus. Fl. sometimes rose. coloured.

\section{POLEMO'NIUM. ${ }^{1} \quad$ Jacob's Ladder. ${ }^{2}$}

* P. corríleum. Blue Jacob's Ladder. Greek Valerian. Leaves winged. Flowers erect. Root fibrous. E. B. 14. Valeriana Græca. G. E. 1076 .

Bushy places. Near the plantations, under the ochre pits at Shotover Hill. $S b$. Woodstock road, between first and second milestone from Oxford. $B x$.

Per. June.

Stem eighteen to twenty inches. $\mathbf{F}$. panicled. Leaj\% ellipticspear-shaped, with an odd one. Cor. blue, sometimes white: a common ornament of rustic gardens.

\section{CAMPA'NULA. Bell-flower.}

C. rotundifólia. Round-leaved $B$. Root leaves heart, or kidney-shaped, saw-toothed; stem leaves linear, entire. E. B. 866 . C. fas. 4. 21. G. E. 452.

1 From polemos, war. Gr. From the contention of two kings, l'olemon, and Philetærus, both claiming the honour of finding the plant. Plin.

${ }^{2}$ From the leaves. 
Heaths, walls, banks, borders of fields. Bullingdon Green. Shotover Hill. Stonesfield. $\mathbf{S} b$.

Per. June.

Herbage dark-green, smooth. Stems upright, slender. Ls. lower stalked, but soon withering, and sometimes wanting. $\mathbf{F l}$. stalks panicled, bracteated. Cor. sky-blue, sometimes white, drooping, tremulous.

One of our prettiest wild fl. A green pigment from the $\mathrm{fl}$.

(C. Rapúnculus. Rampion B. Leaves wavy, notched, roughish ; root-ones elliptic-spear-shaped. Panicle compact. Calyx entire. E. B. 283. Rapuntium parvum. G. E. 453.

Banks. Warwickshire. $\boldsymbol{P}$. Bagley Wood Whittlewood Forest. Tur. *

Bien. July, August.

Stem three feet, angular; hairy below. $\quad \boldsymbol{F l}$. blue; swollen below.)

(C. latifólia. Giant B. Leaves roughish, egg-spearshaped. Stem unbranched, round. Stalks singleflowered. Fruit drooping. E. B. 302. Trachelium majus Belgarum. G. E. 448.

Moist thickets. Cransley Wood, Northamptonshire. $Y$. Banks of the river Arrow, the Alne, \&c. $P_{n}$.

Per. July, August.

Very large, four feet. $\quad \boldsymbol{F}$. erect, deep blue, large.)

C. rapunculoídes. Creeping $\boldsymbol{B}$. Leaves roughish; root-ones heart-spear-shaped, notched, stalked; uppermost stalkless, spear-shaped. Flowers drooping, growing on one side, in a terminal, bracteated, upright cluster. Calyx bent back. E. B. 1369.

Woods, fields.* In some woods in Oxfordshire. Amongst yewtrees. Buddle's Herbarium. $\mathbf{S} m$.

Per. July, August.

$L s$. root-ones resemble those of violets. Stem about one foot and a half. $F l$. large, bright-purplish, stalks short, solitary, axillary, or bracteated.

C. Trachélium. ${ }^{I}$ Nettle-leaved $\boldsymbol{B}$. Stem angular. Leaves spear-shaped, partly heart-shaped, sharply saw-toothed, bristly as well as the calyx. Stalks axillary, with few flowers. E. B. 12. H. L. 109. Trachelium majus. G. E. 448 .

Groves, thickets, hedges. Shotover plantations. Magdalen College

1 Gr. trachelos, the neck, from the supposed virtue of the bitter, and somewhat acrid $l s$. in decoction as a gargle in sore throats. 
Copse, under Shotover Hill. Bx. Tar Wood. Stonesfield. $\mathbf{S b}$.

Per. July.

Stem two or three feet. Ls. harsh, rough, resembling those of a nettle. $F l$. hairy within, blue, sometimes white, sometimes double, large. Discrim. from Camp. latifolia, by the membranaceous angles of the stem, and its different heart-shaped $l s$.

C. glomeráta. Clustered $\boldsymbol{B}$. Stem angular, simple. Flowers stalkless, most of them in a terminal head. Leaves egg-shaped, notched. E. B. 90. Trachelium minus. G. E. 449 .

Dry, open, chalky pastures. Littlemore. Stonesfield. Heythorp. Burford Downs. $S b$. Bullingdon Green. $B \boldsymbol{x}$.

Per. July.

Stem seldom branched, erect, six to eighteen inches. Ls. rough, lower ones on long stalks, pale beneath. $F l$. bracteated: the pet. sometimes turn to $l s$. Cor. blue, or white, hairy within. Stam. four or five.

Ornament for rock-work: a dry soil suiting the plant. Variable in size and habit.

C. $h y^{\prime} b r i d a$. Corn B. Prismatocarpus, etc. DC. Stem often branched from the base, straight. Leaves oblong, notched, wavy. Corolla widely spreading, shorter than the calyx. Capsule prismatic. E. B. 375. Speculum Veneris minus. G. E. 439.

Dry, or chalky cornfields.

An. June.

Root small, fibrous. Stem nearly erect, about one span high. Ls. alternate. $\mathbf{F l}$. terminal, solitary. Cor. nearly wheel-shaped, pale purple, seldom fully expanded, about half as long as the calyx $l s$.

Discrim. great length of caps. and the segments of cal. extending above the cor. Plant scarcely different from Camp. speculum, Venus's Looking-glass.

(C. hederácea. Ivy-leaved $\boldsymbol{B}$. Stem flaccid, much branched, trailing. Leaves stalked, smooth, heartshaped, with angular lobes. E. B. 73. H. L. 93. C. Cymbalariæ foliis. G. E. 452.

Watery, shady places.* (Bagley Wood.) Bx. Lawson.

Per. June, August.

Fl. solitary, light blue. A delicate, little plant.)

JASIO'NE. Sheep's-bit.

J. montána. Common Sheep's-bit. Sheep's Scabious. 


\section{E. B. 882. C. fas. 4. 58. Scabiosa minima hirsuta.}

G. E. 723.

Dry, sandy fields, heathy ground.* Nuneham. Henley. Sb. Shotover Hill. $\boldsymbol{B} x$.

An. June.

Stems spreading, scarcely one foot, leafy, branched above. $L s$. stalkless, oblong, blunt, gradually smaller from the root upwards: stem-ls. alternate, wavy. $\mathbf{F l}$. blue or white, each tuft terminal, solitary, on permanent bracteas of many $l s$.

\section{VI'OLA. ${ }^{\prime}$. Viola.}

V. hirta. Hairy $\boldsymbol{V}$. Stem none. Leaves heartshaped, rough with hairs, as well as their foot-stalks. Calyx-leaves blunt. Side petals with a hairy central line. E. B. 894. C. fas. 1. 64.

Groves, thickets, on chalk, or lime-stone. Sm. Copse under Shotover Hill. Cheney Lane. Sb. (Bagley Wood.) Between South Hinksey and Childswell. Bx.

Per. March.

Scions prostrate, not rooting. Ls. on long upright stalks. Stip. spear-shaped, toothed. $\mathbf{F l}$. light greyish blue. $\quad \boldsymbol{F}$ \% stalks taller than the $l s$., smooth. Bract. smooth below the middle of the $f$. stalk. Cal. smooth.

Plant throws out, after a time, fl. destitute of pet. or nearly so, but producing perfect seed. Fl. stalks lengthen after flowering, take a downward direction, and bury the caps. to the depth of two or three inches. $B . F l$.

V. odoráta. Sweet $V$. Stemless. Scions creeping. Leaves heart-shaped, nearly smooth, as well as their foot-stalks. Calyx-leaves blunt. Side petals with a hairy central line. E. B. 619. C. fas. 1.63. V. nigra, sive purpurea. G. E. 850. V. flore albo. G. E. 850. Woods, hedges.

Per. March.

Scions long, prostrate, rooting. Ls. foot-stalks longish. Stipul. in pairs, spear-shaped, toothed. $\boldsymbol{F l}$. stalks taller than the $l s$. smooth. Bract. narrow, above the middle of the fl. stalk, when the fl. fully expanded. Cor nodding, dark purple or white, fragrant. Cal. smooth. Spur short, blunt. Fl. producing seed, with, or without pet. Var. double, more fragrant than the single.

$\boldsymbol{F l}$. and seeds mild laxatives. Root in powder, in doses of forty to

' Gr. Ion. Some derive Viola, from Vitula, a heifer, in reference to Io, leaving out the letter $t$. G. E. 
eighty gr. emetic, purgative. Syrup of violets, as a test to detect an acid, or alkali, the former changing the blue colour to a red, the latter to a green. Sorbet of the Turks made of the $\mathrm{fl}$. and sugar. (Hasselquist.) Old Gerarde mentions a preparation of violets and sugar, called sugar violet, " most pleasant and wholesome," violet cakes?

(V. palustris. Marsh $V$. Stemless. Leaves kidneyshaped, smooth. Root creeping. Side petals with a hairy central line. E. B. 444. C. fas. 3. 58.

Mossy bogs.* (In a bog beyond Childswell Farm. Benwell. Wootten Heath, near Shadwell Copse. $B x$.) Between Oxford and Water-Eaton. Plot.

Per. April.

Scions none. $F$. very pale blue, with purple streaks.)

V. canina. Dog's $V$. Stem at length ascending, channelled. Leaves oblong-heart-shaped. Calyx acute. Stipulas saw-toothed. Bracteas awl-shaped, entire. E. B. 620. C. fas. 2.61. V. canina sylvestris. G. E. 851 .

Groves, thickets, hedges, heathy ground.

Per. April.

Stems square, branched. Ls. smooth, somewhat dilated at the top. Fl. stalks axillary, solitary, erect. Cor. nodding, scentless, blue, (or white) with purple lines in the mouth. Spur greenish white, abrupt. Bract. two, awl-shaped, near the top of the fl. stalk.

V. tricolor. Pansy V. Heart's-ease. Stem angular, spreading, divided. Leaves oblong, deeply notched. Stipulas lyrate, wing-cleft. Bracteas obsolete. E. B. 128\%. C. fas. 1. 65. G. E. 854. V. tricolor petriea. G. E. 854 .

Cornfields.

An. April, May.

Ls. alternate, stalks long. $F l$. stalks, axillary, solitary. Cor. pet. variable in size and colour, mostly longer than the cal. the odd one broadest and yellow: side one pale bluish, two upper reversed, pet. purple, all with black radiating streaks. In Sibth. $\mathrm{V}$. arvensis, a var. of this; in it, the petals all shorter than the cal. the odd one only yellow, the rest whitish; or we may say, blossoms white, or yellow white; small with a few purple streaks.

This plant the origin of our Garden Heart's-ease, and its var. or as it has been called_- "Three Faces under a Hood. Love in Idleness, \&c." 
A handful of the fresh, or half a drachm of the dried $l s$. boiled in half a pint of milk, recommended strongly to be given night and morning, for some weeks, in scabby complaints, Crusta lactea of young children. Med. Jour. ii. p. 188.

\section{VERBASCUM.' Mullein. ${ }^{2}$}

\section{Thapsus. ${ }^{3}$ Great Mullein. High Taper. Leaves} running down the stem, notched, woolly on both sides. Stem simple. Cluster dense. Flowers almost stalkless. E. B. 549. Tapsus barbatus. G. E. 773.

Road sides, walls, on chalk or gravel. Sm.

Bien. July.

Stem erect, straight, three to five feet, leafy, woolly, winged. Ls. alternate. $\mathbf{F l}$. spike terminal, erect, cylindric, many flowered: Fl. large, bright yellow, rarely white. Stam. yellow, hairy, three in number, two long, smooth: not so fig. in E. B. Anth. red.

A handful of the $L s$. boiled in a pint of cow's milk to half a pint, sweetened, and strained, an emollient medicine, and to allay irritation in piles. This draught may be taken at bed-time. Has been recommended in obstinate diarrhœa, and as an external application to piles. Said to intoxicate fish. The down may serve for tinder, as the leaves of the Coltsfoot. $F \boldsymbol{l}$. dried in the sun, give out a fatty matter, which may be used as a cataplasm in hemorrhoidal complaints.

V. nígrum. Dark, or Black $M$. Sage-leaved $M$. Leaves oblong-heart-shaped, stalked, waved, notched, slightly downy. Spike mostly solitary. E. B. 59. H. L. fas. 2. 103. G. E. 775 .

Banks, way-sides, on gravel or chalk.* Sm. Nettlebed. Henley. Stokenchurch. $\mathbf{S b}$. (Road between Besselsleigh and Appleton Common. Bx.)

Per. July.

Stem two or three feet, angular, brown or purplish. Fl. spike long, not very compact, upright, cylindrical, one only, for most part. $\mathrm{Fl}$. bright yellow; filam. densely elothed with violet coloured hairs.

Beauty of the golden cor. much enriched by the tints of purplish brown at the mouth of the tube, and the yellowish scarlet of the anth.

1 Verbascum. Irritability of some species, e. g. V. pulverulentum. Two or three smart blows being given to the stem with a stick, all the corollas open, and in a few minutes fall off. The calyx closes round the germens. This takes place in still warm weather.

2 Myl, dust, An. Sax. from the leaves.

${ }^{3}$ Name of an island. 
(V. Blattária. Moth M. Leaves clasping the stem, oblong, smooth, saw-toothed; root-ones sinuated. Clusters panicled, simple. Flower-stalks longer than the bracteas. E. B. 393 . G. E. B. Plinii. 776.

Banks, rare.* Binfield, Berks. Tur.

An. July.

Stem slightly angular, three to four feet. Cor. yellow, streaked with purple at the base, stained with brown at the back. Stam. bearded with purple hairs. Herb fetid.)

(* Datúra Stramónium. Common Thorn Apple. Mentioned in Tur. as growing near Reading, Berks.)

\section{HYOSCY'AMUS.' Henbane.}

H. niger. Common Henbane. Leaves sinuated, clasping the stem. Flowers stalkless. E. B. 591. G. E. 353.

Waste ground, banks, commons.

An. June.

Stem bushy, leafy. Ls. alternate, stalkless. $F l$. spikes terminal, curved back. Fl. nearly stalkless, erect, straw-coloured, pencilled with dark purple veins. Anth. and style purplish. Whole plant downy, clammy, very fetid.

Highly narcotic. The seeds and caps. smoked together as tobacco a dangerous remedy in tooth-ache. The oily seeds may be safely eaten. The fumes from the seeds in tooth-ache: beat the seeds in the bowl of a tobacco pipe placed in the fire: convey the fumes from the pipe to the tooth by a tin tube. Extract of Henbane a substitute for opium : opening, not constipating. Dose three grains to twenty in pills. The Tinct. dose half a drachm to two drachms not liable to affect the head, nor disturb the biliary secretion like opium. It may be advantageously combined with Vinum. Opii, or with Tinct. of Opium. Extract diluted to dilate the pupil in cataract, and contracted pupil. The roots strung as beads are the anodyne necklaces of children. Mice said to avoid the smell of the plant.

\section{A'TROPA. ${ }^{2}$ Dwale.}

A. Belladonna. Common Dwale. Deadly Nightshade. Stem herbaceous. Leaves egg-shaped, undivided. Flowers solitary. E. B. 592. C. fas. 5. 16 . Solanum lethale. G. E. 340 .

Hedges, waste ground, calcareous soil. Sm. ** Wychwood Forest.

1 Gr. Hus, a swine, and kúamos, a bean.

Fury.

Atropos, one of the Fates : named by mistake, after a supposed Atropa, or 
Near Witney. Between Nettlebed and Henley. Sb. Woodstock Park, near the Monument. Bx. (Tilehurst Common, and Englefield, Berks. R. W.)

Per. June.

Stem about three feet, branched, leafy. $L s$. from the side of the stems, in pairs, one smaller, all dull green. $F l$. drooping, axillary. Cor. dull purplish, of a lurid look. Berry about the size of a small cherry, shining, black, when ripe.

Frequently about ancient ruins. Abbeys.

A most dangerous narcotic, occasioning a deadly stupor: the taste of the berries not unpleasant. Antidote, draught of warm vinegar, and keeping the patient walking. The $\boldsymbol{L}_{\boldsymbol{s}}$. in infusion internally, and externally, in cancer. To be used with the greatest caution. See also Pharmacop. Chirurgica. The extract to dilate the pupil of the eye. A quantity of bread, wine, and ale, into which had been infused the juice of this plant, sent to the Danish army under Sueno, in the reign of Duncan I. The Danes partaking liberally of the poisonous boon were intoxicated, and became an easy prey to the Scots. See the Classical Buchanan, in Hist. Scot. 1. vii. p. 112. fol. ed. Ruddiman. Juice of the ripe berries to stain paper of a durable and fine purple.

\section{SOLA'NUM. Nightshade.}

\section{S. Dulcamára. Woody N. Bitter-Sweet. Stem} shrubby, zigzag, without thorns. Upper leaves halbertshaped. Clusters cymose, opposite to the leaves. E. B. 565 . C. fas. 1. 14. Amara dulcis. G. E. 350. Hedges, thickets, especially in watery situations.

Shrub. Per. July.

Stem woody, branched, several feet high. Ls. alternate, stalked, smooth, lowermost heart-shaped, undivided. $\quad F l$. clusters opposite to the $l s$., or terminal. $\quad k l$. elegant, purple, with two green dots at the base of each segm. Anth. large, yellow. Berry scarlet, oval, poisonous.

Decoction of the plant, diuretic, narcotic, useful in humoral asthma, dropsy, Lepra vulgaris, alphos, and ptyriasis. T. T. See Decoct. Dulcamaræ, T. T. Recommended by Boerhaave as superior to Sarsaparilla : by Linn. in infusion in acute rheumatisms.

S. nigrum. Common, or Garden $N$. Stem herbaceous, without thorns. Leaves egg-shaped, bluntly toothed, or wavy. Umbels from the sides of the stem, drooping. E. B. 566. C. fas. 2. 14. S. hortense. G. E. 339. Waste, cultivated, ground, dunghills.

An. Per. sometimes. July.

Stem branched, spreading. Ls. alternate, stalked, lengthened at the base. Umbels from the spaces between the $L s$. Fl. white, 
few, musky. Berry black, globular, sometimes yellow. Whole plant fetid, narcotic, diuretic, sudorific, to be cautiously used. One to three grains ample dose of the dried $l s$. in infusion: effects uncertain on the nervous system. Ls. externally to abate inflammation, and assuage pain.

Solano de Luque proposed as a cure for an incurable disease, consumption, an ointment of this plant: burying the patient up to the chin in his mother earth, and afterwards rubbing him with the ointment. Ray in his Syn. ed. 3. under a var. of this plant quotes a Dr. Brown, his acquaintance, as a very skilful botanist, of Magd. Coll. Oxford.

\section{ERYTHRÆA.' Centaury. Chironia. Br.}

\section{E. Centaurium. ${ }^{2}$ Common C. Stem nearly simple.} Panicle forked, corymbose. Leaves egg-spear-shaped. Calyx half the length of the tube; its segments partly combined by a membrane. Chironia centaurium. E. B. $41 \%$ C. fas. 4. 22. C. parvum. G. E. 547.

Dry, gravelly pastures. Shotover Hill. Bullingdon Green. Southleigh. Sb. Between Woodstock Park, and Stonesfield, \&c. $B \boldsymbol{B}$. An. July.

Stem solitary, erect, about one foot, four edged, leafy. $F \boldsymbol{F}$. branches several, opposite, forked, forming an upright panicle. Ls. opposite, stalkless, three nerved, root-ones somewhat battledoreshaped. $\quad F l$. stalkless, tube greenish, limb pink, polished. Var. fl. white. (Cor. closes as soon as gathered, and against rain.) Anth. spiral, after discharging the pollen. Whole plant smooth, very bitter : called by rustic practitioners, Lesser C. Basis of the famous Gout Portland Powder, which prevented the fits, but in the end the patient died, by induration of liver, palsy, or apoplexy. The plant a stomachic, but like other bitters, injurious to the stomach if long persevered in. A decoction of the plant to destroy lice.

\section{SA'MOLUS. Brook-weed.}

S. Valerandi. Common B. Water Pimpernel. Leaves inversely egg-shaped, blunt. Clusters corymbese, many-flowered. Bracteas solitary, in the middle of each partial stalk. E. B. 703. C. fas. 4. 20. Anagallis aquatica rotundifolia. G. E. 620 .

Clear, watery places, gravelly soil. Sides of the ditch in Cowley

Gr. from its red $f$.

${ }^{2}$ From Chiron, the Centaur, the $I$ made long by Beckmann, Lex. Botanicum. 
Marsh. Peat bogs under Headington Wick Copse. Sb. Between Heyfield's Hut and Port Meadow. $B x$.

Per. July.

Root fibres many, simple. Plant smooth, pale green, about one foot. Stem round, terminating in one or more long clusters of many, small, white fl. $L s$, alternate.

Found in almost every quarter of the globe, and in different latitudes; this happens to several aquatics.

\section{LONICE'RA.' Honeysuckle.}

L. Caprifólium. Pale Perfoliate H. Flowers gaping, whorled, terminal. Leaves deciduous ; the uppermost united at the base and perfoliate. E. B. 799. Periclymenum perfoliatum. G. E. 891.

Woods, thickets. In a wood near Elsfield, plentifully, Rev. T. Butt.

Shrub. July.

$L s$. opposite, smooth. $F l$. stalkless, in the bosom of the upper $l s$., fragrant. Cor. yellowish, tube blush.coloured. Berr. elliptic, orange-red, crowned with the $c a l$. nearly entire.

L. Pericly'mĕnum. Common H. or Woodbine. Heads of flowers egg-shaped, tiled, terminal. Leaves all separate, deciduous. Flowers gaping. E. B. 800. C. fas. 1. 15. Periclymenum. G. E. 891.

Hedges, groves, thickets. Var. $\beta$. found near Oxford by Mr. Jenner. Dil. in R. p. 458.

Shrub. July.

Discrim. from L. Caprifolium by its $l s$, all distinct, not perfoliate, $f$. in an egg-shaped head, not axillary, fruit crowned with a five toothed cal. Berry rounder, darker red. Stems climbing high. $L s$. entire, mostly stalkless, sometimes downy.

$\boldsymbol{F l}$. delightfully fragrant in the evening, or after rain. The Woodbine of poets, Milton's "Twisted Eglantine." The climbing action of plants curious; such phenomenon adduced in favour of an instinctive, or perceptive power in vegetables.

In var. $\beta$. ls. sinuated like those of an oak, and variegated; called Oak-leaved Honeysuckle. $F l$. variable in colour, externally deep red, or pale yellowish.

\section{(L. Xylósteum. Upright Fly H. See Appendix.)}

\section{RHAMNUS. ${ }^{2}$ Buckthorn.}

R. cathárticus. Common B. Thorns terminal. Flowers four-cleft, diœcious. Leaves egg-shaped, saw-toothed.

1 Named after Adam Lonicer, Botanist.

2 Gr. Ramnos, a branch : a branchy shrub. 
Stem erect. Berry with four seeds. E. B. 1629. R. solutivus. G. E. 133\%. f. 1. 2.

Hedges, groves, thickets. Lane leading from the Botley road to Binsey. Sb. Magd. Coll. Walks, Oxford. R. W.

Shrub. May. Fruit in September.

Shrub stiff, spreading, branches alternate, or nearly opposite, each tipped with a strong thorn. $L s$. earlier ones in clusters from the flowering buds, the rest opposite. Fl. stalks short, simple, clustered, yellowish-green. Cal. lobes, pet. and stam. four. Berry globular, bluish-black, nauseous, purgative. Stig. four-cleft.

Berry unripe dyes yellow. A syrup from the ripe berr., a griping purgative. Flesh of the birds feeding on the berr. said to be purgative. Juice of the ripe berr. mixed with alum, is sap-green of painters. From the bark a fine yellow dye. This plant known to attain the height of nearly twenty feet.

(R. Frangula. Alder B. Without thorns. Flowers perfect. Style simple. Leaves entire, smooth. Berry two seeded.

Hedges. Grafton, \&c. $P_{n}$.

Shrub. May. Berries, July.

Ls. roundish. Fl. whitish. Berries dark-purple, purgative.)

\section{EUO'NYMUS. ${ }^{\prime} \quad$ Spindle-tree.}

E. europaus. Common Spindle-tree, or Prickwood. Flowers mostly four-cleft and tetrandrous. Petals acute. Branches smooth and even. E. B. 362. E. Theophrasti. G. E. 1468 .

Hedges, thickets.

Shrub, or small Tree. May.

Plant bruised fetid. Ls. nearly opposite, on short stalks, spearshaped, pointed, saw-toothed, the first pair entire. Fl. small, axillary, white, fetid, panicle straddling; the first flower that opens has five stam. as many pet. cal.-teeth, and caps. all the rest, with those parts in fours. Caps. pink, when ripe, or white, seed-coat, orange, pulpy.

The tough wood cut when the plant in fl. for spindles, skewers, organ keys, \&c. and for excellent crayon charcoal. Three or four berr. emetic, and purgative. Powdered and sprinkled in the hair they destroy lice.

\section{RI'BES. Currant, and Gooseberry.}

\section{* R. rubrum. Common Currant. No prickles. Clusters} smooth, hanging down. Flowers but slightly concave.

${ }^{1}$ Gr. " of good repute," meaning the direct contrary by antiphrasis; the plant having heen considered poisonous. 
Petals inversely heart-shaped. E. B. 1289. R. vulgaris, fructu rubro. G. E. 1593.

Hedges, thickets. Sb.

Shrub. April.

Bushy shrub. Ls. deciduous, on long foot-stalks, five-lobed, doubly saw-toothed. Bract. egg-shaped, concave, short. $F l$. nearly flat, yellowish-green. Berry globular, red, shining, acid.

Fruit of a cold climate, thriving ill in the south of Europe. Berry also pale pink, or white. Red berr. for jelly. Equal weights of picked currants, and pure sugar put over the fire become an agreeable jelly from the liquor that separates.

(R. alpínum. Near Bristol Hot Wells. Tur.

(Ribes nigrum. Black C. Oversley, Warwickshire. Pn.)

*R. Grossulária. Common Gooseberry. Prickles one, two, or three, under each bud. Branches otherwise smooth, spreading. Stalks single-flowered. Bracteas close together. Segments of the calyx bent back, shorter than the tube. E. B. 1292. ß. R. Uva crispa. E. B. $205 \%$ Sb. 84. Smooth Gooseberry. Uva crispa. G. E. 1324.

Hedges, thickets, waste ground. $\beta$. In Cowley Field. Headington. Whitewood. $\mathbf{S b}$.

Shrub. April.

Ls. three-lobed, Berr. pendulous, rough. Var. $\beta . \quad F r . s m o o t h$.

\section{HE'DERA. Ivy.}

H. Helix. Common I. Leaves near the flower eggshaped, others five-lobed, umbel upright. E. B. 1267. C. fas. 1. 16. H. corymbosa, and Helix. G. E. 857.

Woods, hedges, old buildings.

Shrub. September, October. Bx.

Stem and branches long, flexible, creeping; those attaching closely to trees or walls, by numerous short fibres, somewhat compressed. Upper branches round. Ls. evergreen, dark, veined with white; lowermost five-lobed, uppermost egg-shaped, all stalked. $\boldsymbol{F l}$. greenish-white, many, in umbels. Berry globular, black.

Whole plant aromatic. From the old stems bruised, a fragrant resin.

When trailing on the ground, $l s$. three-lobed, and no fruit produced. Almost every one acquainted with this common and

1 An. Sax.

F 2 
picturesque plant. The roots to whet the leather-cutter's knives on. Berries emetic, and purgative. Plant eaten by horses, sheep, and cows. Some of the largest sized, and soundest forest-trees are such as have been entwined with Ivy for a great length of time. The Ivy draws its support from its own root; its adhering fibres do not supply it with nourishment. Latest of our fl. plants. Ointment of the $l s$. for burns. Irish Ivy a var. with larger $l s$. of rapid growth.

\section{THE'SIUM. Bastard-toadflax.}

T. linophyllum. Flax-leaved B. Cluster branched. Bracteas three together. Leaves linear-spear-shaped. Tube of the calyx very short. E. B. $24 \%$.

High, open, chalky pastures. Stanton St. John. Sb. Streatley, Berks. Mr. L. Darwall, and $\boldsymbol{B} x$.

Per. July.

Stems several, reclining, rigid, taper, five or six inches, not much branched. $F l$. spikes branched, sometimes forming a panicle, solitary, on alternate flower-stalks. Cal. funnel shaped, very white above, and at the margin beneath.

\section{VINCA. ${ }^{I} \quad$ Periwinkle.}

*V. minor. Less $\boldsymbol{P}$. Stems lying down. Leaves ellipticspear-shaped, smooth-edged. Flowers stalked. Segments of the calyx spear-shaped. E. B. 917. C. fas. 3. 16 . V. pervinca minor. G. E. 894 .

Hedges, bunks. Magdalen College Walks. Right hand side of the road between Wolvercot and Yarnton. Cornbury. $\mathbf{S b}$.

Per. April.

Root creeping. Whole plant smooth, shining. Stems slender, leafy, in $\mathrm{fl}$. erect, afterwards prostrate, lengthened out, and rooting at the joints. $L s$. opposite, stalks short. $F l$. smaller than in V. major, darker blue. Cal. shorter, smooth, less tapering. Anth. stigm. and fruit curious in the genus.

Its evergreen $l s$. and early $f$. ornamental, in shady places and under trees. Astringent, both species. Var. Fl. white.

*V. major. Greater $\boldsymbol{P}$. Stems ascending. Leaves eggshaped, fringed. Flowers stalked. Segments of the calyx bristle-shaped, lengthened out. E. B. 514. C. fas. 4. 19. Clematis daphnoides major. G. E. 894 . Thickets, groves. Magdalen College Walks. Sb.

Per. April.

Roots creeping. Stems leafy, some trailing, throwing out roots,

1 From Lat. vincio, to bind. 
others erect, $f$.-bearing. Ls. opposite, stalked. $F l$. solitary, axillary, alternate. Cal. segm. as long as the fl. tube. Cor. purple, blue, large. Fruit seldom seen, unless the plant be cultivated in a pot; thus perhaps propelling the juices more copiously to the fl.

One of the greatest ornaments of the early season. Handful of the $l s$. of Periwinkle stamped, and the juice given to drink in red wine, highly recommended by Gerarde to stop spitting of blood, \&c.

\section{PENTANDRIA DIGYNIA.}

\section{CHENOPO'DIUM. Goosefoot.}

* Leaves angular.

Ch. Bonus Henrícus. Mercury G. Leaves triangulararrow-shaped, entire. Spikes terminal, compound, leafless, axillary. E. B. 1033 . C. 3. 1\% Bonus Henricus. G. E. 329.

Waste ground, road-sides. Not very common about Oxford. Bx. Per. June.

Plant clothed with unctuous mealiness. Spikelets alternate, stalkless. $\mathbf{F l}$. crowded, stalkless. Plant pyramidal.

The calyx universally regular, five-cleft, not much enlarged after flowering, clearly separates Chenopodium from Atriplex. Seeds of this genus, a large supply of food to the smaller birds.

Our only perennial Chenopodium, eaten when young, like spinach, and is very good tasted, laxative. 'The leaves may be applied as a poultice.

Ch. úrbicum. Upright $G$. Leaves triangular, toothed. Spikes crowded, lobed, very long and straight, approaching the stem, almost leafless. E. B. 717.

Dunghills, ditch-banks, way-sides.

An. August.

Stem stiff and straight. Ls. bright-green, smooth. Cal. smaller than in Ch. rubrum. Seed roundish, the size of rape-seed, five times as large as that of Ch. rubrum. Curtis.

The very long clusters of flowers, erect, and approximating the stem, distinguish this species, together with its seeds larger than Ch. rubrum.

Ch. rubrum. Red G. or Sow-bane. Leaves triangular, somewhat rhomboid, deeply toothed and sinuated. Spikes erect, compound, leafy. Seed very minute, about the size of common sand. E. B. 1791 . C. 6. 21. Atriplex sylvestris latifolia altera. G. E. 328. 
Waste ground, often in muddy situations. Sm.

An. August.

Plant more bushy than Ch. urbicum. Ls. more deeply toothed, considerably lengthened out at the base. Spikes of stalkless tufts interspersed with linear leaflets. Ls. thick, scarcely shining.

In exposed situations the whole plant becomes red. Said to be poisonous to swine.

Ch. murále. Nettle-leaved $G$. Leaves egg-shaped, acute, many-toothed, shining. Spikes aggregate, panicled, cymose, leafless. E. B. 1722. C. 6. 20.

Waste ground, about old walls, way-sides.

An. August.

Panicled, cymose; inflorescence distinguishes this species. Plant fetid, with dark, shining leaves. Seed larger than in Ch. rubrum, black, very minutely dotted. The dark, shining leaves and corymbose clusters distinguish this species. Stem often tinged with dark-purple.

Ch. hy'brìdum. Maple-leaved G. (Thorn-apple-leaved.) Leaves heart-shaped, pointed, with broad, angular, teeth. Spikes aggregate, panicled, cymose, straddling, almost leafless. E. B. 1919. C. 4. 23.

Waste ground, rather moist; one of the rarer species. Sm.

An. August.

Plant more slender than in most other species; $l s$. larger, of a full, bright-green. Seeds stripped of their pellicle, black, with irregular, large dots. Bunch at first compact, but forming a light panicle, when fully expanded.

Linn. named this species hybridum, supposing it might be produced from Ch. viride. Fl. Suec.

Ch. album. White G. Leaves rhomboid-egg-shaped, jagged, mealy; entire towards the base: upper ones oblong, entire. Seed quite smooth. E. B. 1723. C. 2. 15 .

Cultivated, and waste ground.

An. July.

Plant mealy when full grown, greasy to the touch, becoming dry and chaffy; aspect hoary or silvery. Subject to variety in the shape of its leaves: sometimes broad and roundish, [or narrow and green (Ch. viride. Linn.)] sometimes leaves nearly entire. Ls. diamond, triangular, on long foot-stalks. Spikes alternate, stalkless. Seeds not dotted. Bunches with small ls. but not intermixed with the flowers. Cal. frosted. $L s$. with three semitransparent veins springing from the base. May be boiled and eaten as greens.

Ch. ficifólium. Fig-leaved G. Leaves sinuated, jagged, 
somewhat halbert-shaped; entire towards the base: upper ones oblong, quite entire. Seed dotted. E. B. 1724. Ch. viride. C. 2. 16. Ch. serotinum. Sb. Waste ground, dunghills.

An. August.

Lobes of the $l s$. more round pointed, the middle one more lengthened out than in Ch. album. Greener hue than Ch. album, a purple stain at the base of the foot-stalks.

$$
\text { * * Leaves undivided, entire. }
$$

Ch. ólidum. Stinking G. Leaves egg-shaped, somewhat diamond-egg-shaped, entire. Spikes dense, crowded, leafless, axillary, and terminal. E. B. 1034. C. 5. 20. Atriplex olida, G. E. 32\%. Ch. Vulvaria. $\mathrm{Sb}$.

Rubbish, waste places. **

An. July.

Stems spreading or prostrate, covered with a greasy mealiness; on being handled exhale a filthy smell, like stale salt-fish. $L s$. alternate, stalked, smaller than in most Chenopodia, squarish egg-shaped. Fuller's anti-hysteric electuary made from this plant. Smell attractive to dogs.

Ch. acutifólium. Sharp Entire-leaved $G$. Leaves egg-shaped, acute, entire. Stem erect. Clusters spiked, compound, lengthened out, erect, partly leafy ; lower ones somewhat cymose. E. B. 1481. Ch. polyspermum. C. 2. 1\% Sb. Atriplex sylvestris sive Polyspermon. G. E. 324.

Cultivated ground, waste places. Not uncommon about London. Curtis.

An. July.

Stems square, red. Seeds reddish. Lower stems lengthened out, trailing on the ground. $\mathrm{Cal}$. half covering the seed. True $\mathrm{Ch}$. polyspermum found in Cornwall. Sm.

\section{ULMUS. Elm.}

U. campestris. Common Small-leaved E. Leaves doubly saw-toothed, rough. Flowers nearly stalkless, fourcleft. Capsule oblong, deeply cloven, naked. E. B. 1886. U. minor, folio angusto scabro. Goodr. in G. E. 1480 .

Woods, hedges. Magdalen Grove, Oxford, a fine plantation of elms. Tree. April. 
Bark of branches even. Trunk and branches rugged, crooked. As the fruit advances, the $l s$. appear. Ls. alternate, short stalked, egg-rhomboid, unequal at the base, one to three inches long. $\boldsymbol{F l}$. clusters, numerous, dense. Bract. fringed. Cal. light-red, or brownish. Stam, four, anth. large, roundish, purple.

Wood hard, tough, durable in wet situations. Decoct. of inner bark in Dropsy, in Lepra icthyosis. The dried ground bark mixed with meal (With.) for bread during a scarcity. Well adapted for shady walks, as not destroying the grass, its ls. acceptable to cattle; should be grafted on the Ulmus glabra to prevent the roots sending out suckers. Thrives in an open situation, black, clayey soil : bears transplantation. Caterpillar of Pap. Polychlóros, large Tortoiseshell Butterfly, and of Pap. Comma Album feed on the $l s$. Young $l_{s}$. food for silk-worms. Wood less liable to splinter than even oak; hence used in ship-building, naves of wheels, \&c.

*U. suberósa. Common Cork-barked E. Leaves pointed, rough, doubly and sharply saw-toothed. Flowers stalked, four or five cleft, Capsule almost circular, deeply cloven, naked. Branches spreading; their bark corky. E. B. 2161. U. vulgatissima, folio lato scabro. Goodr. in G. E. 1480.

Hedges, occasionally.

Tree. March.

Branches,-bark fissured.

U. montána. Broad-leaved E. Wych Hazel. Leaves taper pointed, rough, doubly saw-toothed. Flowers stalked, loosely tufted, five or six cleft. Capsule somewhat circular, slightly cloven, naked. Branches drooping; their bark even. E. B. 188\%. U. effusa. Sb. U. folio latissimo scabro. Goodr. in G. E. 1481.

Woods, hedges.

Tree. April.

Tree large, branches spreading, drooping; bark even. It flowers under thirty feet high. U. campestris seldom until after a greater height, and age. Timber less valuable than that of $U$. campestris. Ls. larger than in $\mathbf{U}$. camp. less rough, with longer points. $F l$. somewhat larger, on rather longer stalks, blushcoloured. Stam. five to six. Fruit larger than in U. camp. more skinny, and hop-like.

Magdalen College Eim, Oxford, two feet above ground, measures twenty-seven feet, four: breast high, twenty-one feet. 1831. R. W. A remarkably fine elm also at Fyfield, Oxfordshire.

CUSCUTA. Dodder.

C. europae. Great D. Flowers nearly stalkless. 
Corolla without scales. Stigmas acute. E. B. 378. H. L. 67. Cuscuta. G. E. $57 \%$.

Thistles, nettles, flax. Found near Newbury, Berks. Mr. Bicheno. Road to Hinksey. R. W.

An. August.

Stem thread-shaped, red, branched, parasitic, twining from right to left, two or three feet. $L s$. none. $\boldsymbol{F l}$. heads, dense, round, whitish, somewhat pentandrous. Cal. reddish. Dyes purplish.

C. Epithymum. Less $D$. Flowers stalkless, with a notched scale at the base of each stamen. Stigmas acute. E. B. p. 378. C. Europæa. E. B. 55. Sb. 63. Epithymum. G. E. 578 .

On common heath, furze, thyme. Tilehurst Common, Berks. R. W. Iffley. $S b$.

Per. July.

Stem parasitical, thread-shaped, much twisted, deep red. Fl. mostly four-cleft, with four stamens. Cal. red, acute. Cor. white. The seed is without cotyledons, puts forth a small spiral body, climbing from right to left up other plants. Ls. none. Smaller than C. europæa.

\section{GENTIA'NA.' Gentian.}

G. Amarella. Autumnal G. Corolla salver-shaped, five cleft; bearded in the throat. Segments of the calyx nearly equal. Stem flowering from top to bottom, with short axillary branches. E. B. 236. H. L. 33.

Limestone, chalky pastures. Sm. Bullingdon Green. Shotover Hill. Burford Downs. Sb.

An. July.

Stem square, erect. Ls. stalkless, egg-shaped, three nerved, darkgreen. Cal. pale, ribs green. Cor. tube twice as long as the cal. Segments rarely three or four. Fringe of the orifice purple. Cor. limb violet. $\dot{C} a l$. segments spear-shaped, acute, erect.

Whole plant, as its congeners, intensely bitter. Fringe under the mouth of the cor. a beautiful microscopic object.

G. campestris. Field G. Corolla salver-shaped, four cleft; bearded in the throat. Two outer segments of the calyx egg-shaped, very large. E. B. $23 \%$.

Elevated pastures. Shotover Hill. Sb. Bx.

An. September.

Plant paler in colour than G. Amarella, not so tall, $f$ l. fewer, more

${ }^{1}$ From its discoverer Géntius, king of Illyricum. 
corymbose. Distinguished by its cal. segments from G. Amarella. Cor pale violet. bitter.

Used by the poor instead of hops. $F l$. Suec. All the Gentians

\section{ERY'NGIUM. $^{\prime}$ Eringo.}

(E. campestre. Field $E$. Leaves clasping the stem; root-ones twice or thrice wing-cleft. Scales of the receptacle undivided. E. B. $5 \%$ E. med. G. E. 1162.

Pastures, rare.* Daventry, Northamptonshire. Morton. Opposite Brookhall, near Daventry. $E . F l$. Smith's.

Per. July, August.

Plant palish green. Pet. white or purplish, narrow, bent inwards sharply.)

Umbelliferous plants generally herbaceous, $l s$. for the most part repeatedly compound. Flowers white, reddish, or yellow. In dry or mountainous places aromatic, wholesome; marsh or aquatic, virulent and dangerous. $\mathbf{S} m$.

\section{SANI'CULA. ${ }^{2}$ Sanicle.}

S. europace. Wood S. Root-leaves simple, deeply lobed. Flowers all nearly stalkless. E. B. 98. S. sive Diapensia. G. E. 948.

Woods, groves.

Per. May.

Ls. about seven lobed, three cleft, shining. $F l$. numerous, crowded, cream-coloured, in small, stalked heads.

Herb bitter, acrid, somewhat aromatic, pungent.

\section{DAUCUS. Carrot.}

D. Caróta. Wild C. Bird's Nest. Bristles of the seeds slender. Leaflets wing-cleft, with linear-spearshaped acute segments. Umbels with a solitary, coloured, abortive flower; when in seed hollow. E. B. 1174 .

Banks of fields, dry pastures.

Bien. July.

$\boldsymbol{L} s$. twice, thrice winged. Neutral $\boldsymbol{f l}$. in the centre, blood-red. Leaf-stalks ribbed beneath.

Grateful, nutritious to cattle: carriage horses work upon them,

'See Nova Acta Acad. Naturce Curiosorum for 1824, and Hooker's Brit. Fl. in Umbellif. Plants.

2 So called from its supposed vulnerary qualities. 
nearly as well, as upon oats : if given beyond a certain time, apt to cause bloody urine in cattle. To destroy crickets, place a paste of powdered arsenic, wheat meal, and scraped carrots, near their habitation. Poultice of the boiled roots, mitigates the pain, and abates the stench of foul ulcers. See Walker on Carrots, 8vo.' The herb and seeds are diuretic, and esteemed useful in gravelly or calculous complaints. Garden carrot, a var. of this.

\section{CAU'CALIS. Bur-parsley.}

C. daucoídes. Small B. Umbels three cleft, without general bracteas; partial ones with three bracteas, and ripening about three fruits. Leaves repeatedly subdivided. E. B. 197.

Cornfields, on a chalky soil. Between Middleton Stoney and Bucknell. $\mathbf{S b}$. Frequent in the County of Oxford. Sm.

An. June.

Stems straddling. Ls. narrow, deep-green segments, very finely divided. Germs armed with hooked bristles. Pet. reddish.

\section{TO'RILIS, ${ }^{2}$ Hedge-parsley.}

T. Anthriscus. Upright $\boldsymbol{H}$. Umbels of many close rays, with numerous general bracteas. Leaflets wingcleft. Branches nearly upright. Caucalis Anthriscus. E. B. $98 \%$ C. $6.22 . \quad \mathrm{Sb} .93$. C. minor, flosculis rubentibus. G. E. 1022.

Hedges, borders of fields.

An. July.

Fl. white, or flesh-coloured, red underneath. Fruit purplish at the top. Styles bent back. Ls. twice wingerl. Leaflets eggspear-shaped. Seeds egg-shaped.

T. infesta. Spreading $\boldsymbol{H}$. Umbels of many close rays. General bracteas scarcely any. Leaflets wing-cleft. Branches spreading. Caucalis infesta. E. B. 1314. C. 6. 23. C. arvensis. Sb. 92 .

Fields, way sides.

An. July.

Seeds adhesive. Want of many leaved involucre, and straddling branches of this, distinguish it from 'T. Anthriscus. Terminating leaflet linear-spear shaped. Generally found in corn-fields, not under hedges.

1 Author of the well-known" Experiments and Observations on the Production of Artificial Cold." 1796. 8vo.

2 Torilis, toreuo, to carve, emboss, in reference to the seed. 
T. nodósa. Knotted $H$. Umbels from the sides of the stem, simple, nearly stalkless. Stem prostrate. Fruit partly granulated. Caucalis nodosa. E. B. 199. C. nodosa, echinato semine. G. E. 1022.

Banks, borders of fields, gravelly soil, or chalky, more frequent. Sm. An. June.

Fl. white. Ls. deep, glaucous green.

* ANTHRISCUS. Beaked-parsley.

A. vulgáris. Common Beaked-parsley. Fruit eggshaped, twice the length of its beak. Leaves thricewinged, wing-cleft. Scandix Anthriscus. E. B. 818. C. 1. 19. Sb.

Banks, waste ground, chiefly near large towns and villages.

An. May.

Stem very smooth, swollen under each joint. Ls. bright lightgreen. Umbels mostly from the sides of the stem. Sweetish, aromatic flavour. *Fruit ego-shaped, bristly, with a short, smooth beak. Pers. The petals inaccurate in E. B.

"The whole vegetable kingdom does not afford a more exquisite green, nor scarcely a more rich, and elaborate foliage, than the young plants of $\mathrm{A}$. vulgáris."

\section{SCANDIX. Shepherd's-needle.}

S. Pecten Véneris. Common Sh. Venus's Comb, or Needle-Chervil. Fruit nearly smooth, with a bristlyedged beak. Umbels simple; solitary or in pairs. Bracteas jagged. Petals bent inwards at the point. E. B. $139 \%$ C. 5. 21. Pecten Veneris. G. E. 1040 .

Cultivated fields.

An. May.

$L s$. three winged, somewhat smooth. Umbels of two or three rays. Leaflets linear, cut into many linear segments.

\section{CHÆROPHYLLUM. Chervil.}

Ch. sylvestre. Wild Ch. Smooth Cow-parsley. Umbels terminal, stalked. Bracteas egg-shaped, membranous. E. B. 752 . C. 4.25 .

Hedges, orchards, borders of pastures and fields.

Per. May.

$\boldsymbol{L} s$. three winged, deeply cut. $\boldsymbol{F l}$. whitish. Stem slightly furrowed. Fruit not at all furrowed. Umbels drooping before flowering. 
Cows fond of this. Roots eaten for parsneps, poisonous. Umbels dye yellow : leaves and stem afford a beautiful green. Used as a pot-herb in times of scarcity. Its presence indicates a fertile soil. Flavour of carrots: grateful to rabbits.

Myrrhis temulenta, has a more swelling, a spotted, and very rough stem, and bristly flower stalks to distinguish it.

\section{MYRRHIS. Cicely.}

Scandix and Charophyllum of Linn.

* M. odoráta. Sweet $C$. Seeds with very sharp, prominent angles, roughish towards the summit. Scandix odorata. E. B. $69 \%$ Sb.

Mountairous pastures. Rose Lane. Sb.

Not in Ray and Dillenius.

Per. May.

Three feet. Ls. somewhat triply winged; wing-cleft, pale, hairy, scented.

In the north of England, seeds for polishing, and perfuming oakfloors, and furniture. With. 'Young seeds gratefully stomachic.

M. temulenta. Rough Cicely. Rough Cow-parsley. Seeds furrowed, nearly smooth. Stem rough, swollen under each joint. Chærophyllum temulentum. E. B. 1521. C. 6. 24. Sb. Cerefolium sylvestre. G. E. 1038.

Bushy places, and under hedges.

Bien. June.

Ls. twice winged, wing-cleft, hairy. Stem speckled with purple. Umbels drooping, before flowering.

Sweetish, aromatic, no intoxicating qualities.

\section{BU'NIUM. Earth-nut.}

B. Alexuósum. Common E. Kipper, or Pig-nut. General bracteas scarcely three. Stem tapering and zigzag at the base. Fruit somewhat beaked. Styles nearly upright. E. B. 988 . B. Bulbocastanum. C. 4. 24. Bulb. minus. G. E. 1064 .

Grassy pastures, especially on a gravelly soil. Sm.

Per. May.

Root roundish, tuberous. Root-leaves thrice winged, segments linear. General involucre sometimes none; deciduous.

Roots eatable, nourishing: in some parts of England boiled in broth, and served up at table: little inferior to chestnuts. 


\section{SIUM. Water-parsnep.}

S. latifólium. Broad-leaved $W$. Leaves winged; leaflets oblong-spear-shaped, equally saw-toothed. $\mathbf{E}$. B. 204. H. L. 2. 110. S. majus latifolium. G. E. 256. Rivers ditches, fens.

Per. July.

Umbels large, nearly flat, white, terminal. Stems four or five feet, furrowed. Leaflets very equally, and neatly saw-toothed. Those that grow under water, often jagged.

Eaten by horses and swine. With. Acrid, poisonous. Root poisonous to oxen. Linn. Root leaves, at the beginning of Spring, supra-decompound, and twice winged, stalk-leaves, and those which are produced in the summer simply winged. Willd. Seeds of the plant of a poisonous quality.

S. angustifólium. Narrow-leaved $W$. Leaves winged; leaflets unequally lobed, and unequally saw-toothed. Umbels stalked, opposite to the leaves. Stem erect. E. B. 139. H. L. 2. 111 .

Ditches, rivulets. * Behind the Parks. Sb. (Ditch going to South Hinksey, \&c. $B x$.)

Per. July.

Less than S. latifolium. Umbels hemispherical. Lowermost pair of leaflets remote from the rest, and smaller in the lower leaves. $L s$. of the involucre, and involucellum large, conspicuous. The specific names Broad-leaved, and Narrow-leaved, mislead.

Possesses active properties. With.

S. nodiflórum. Procumbent $W$. Leaves winged; leaflets egg-shaped, almost equally saw-toothed. Umbels nearly stalkless, opposite to the leaves. Stem procumbent. E. B. 639 . S. umbellatum repens. G. E. 256, 258.

Ditches, and rivulets, frequent.

Per. July.

Involucre of one leaf, often wanting.

The juice in cutaneous disorders. Three large spoonfuls mixed with milk, twice a day. With.

S. repens. Creeping $W$. Leaves winged; leaflets roundish, deeply toothed. Umbels stalked, opposite to the leaves. Stem creeping, throwing out roots. E. B. 1431.

Boggy meadows, watery commons. Peat bogs on Bullingdon Green. Sb. and $B x$.

Per. June.

Involucre, and Involucret of many egg-shaped, spreading leaves. 
Leaflets opposite, stalkless, unequally saw-toothed: the terminal one, generally more or less three-lobed. Stem six to ten inches: a smaller plant even than S. inundatum. Purton.

S. inundátum. Least $W$. Leaves, above water, winged, cut; those below, in many compound, hair-like segments. Umbels five-flowered, in pairs. Sison inundatum. E. B. $22 \%$.

In ditches, pools, and wet ground overflowed in winter. Binsey Common. Port Meadow. Southleigh Heath. Otmoor. Sb.*

Duration? June.

Plant procumbent, or swimming. Called by Linn. in Fl. Suec. the smallest of umbelliferous plants. Habit and seeds those of Sium genus.

\section{SISON. Honewort. ${ }^{\mathrm{I}}$}

S. Amómum. Hedge H. Bastard Stone-parsley. Leaves winged; the upper ones divided into three. Umbels erect, of about four general rays. Bases of the styles globose. E. B. 954. Petroselinum Macedonicum F. G. E. 1016.

Marly, chalky, rather moist ground, under hedges. Sm.

Duration? July.

Stem tall, much branched, slender, weak, spreading. Leaflets egg-shaped, terminal one deeply cut, saw-toothed, three-cut. Seeds warm, aromatic, when ripe: in an early state nauseous. Smell of the whole plant the same, like bugs.

S. ségetum. Corn H. Leaves winged ; leaflets roundishegg-shaped, numerous. Umbels drooping, irregularly crowded. Bases of the styles dilated, depressed. E. B. 228 .

In rather moist fields, on a calcareous soil. Sm.

Duration? July.

Stem slender, rush-like, erect. Leaflets saw-toothed, set at nearly right angles with the stem. Slightly aromatic. Seeds more pungent.

\section{ÆTHU'SA. ${ }^{2} \quad$ Fool's-parsley.}

Æ. Cynápium. Common $\boldsymbol{F}$. Less Hemlock. Leaves uniform; leaflets wedge-shaped, running down the

1 Hone-wort, so called from its curing a hone, i. e. a swelling in the cheek. Ger.

2 Shining, Gr, from its shining leaves. 
stem, with spear-shaped segments. E. B. 1192. C.

1. 18. Cicutaria tenuifolia. G. E. 1063.

Gardens, cultivated fields.

An. July.

Herb dark, lurid green, glossy, fetid, poisonous. Ls. twice winged, with wing-cleft leaflets.

Occasions sickness: sometimes carelessly mistaken for Garden Parsley. It is poisonous to geese. Linn. Fl. Suec.

Cows, horses, sheep, goats, and swine eat it. With.

\section{CONI'UM. ${ }^{x}$ Hemlock.}

C. maculátum. Common $\boldsymbol{H}$. Stem polished and spotted, much branched. E. B. 1191. C. 1. 17. Cicuta. G. E. 1061.

Hedges, waste ground near towns and villages.

Bien. July.

Three to four feet. $L s$. large, repeatedly compound; deep-shining green. $\boldsymbol{F l}$. white.

Herb fetid, narcotic, sedative; much used in the form of extract for lowering the pulse in acute inflammatory disorders; and still more celebrated for relieving scrofulous and cancerous maladies. Sm.

The extract an uncertain preparation, whence powder preferred by some: dose fifteen to twenty five grains twice or thrice a day. Extr. particularly useful in hooping-cough. See Butter.

\section{ENANTHE. Water-dropwort.}

E. fistulósa. Common Water-dr. Root sending forth runners. Stem-leaves winged, cylindrical, tubular. General bracteas mostly wanting. E. B. 363 . Filipendula aquatica. G. E. 1060.

Ditches, ponds.

Per. June.

Root tuberous. Umb. general rays from three to seven, or eight. Stem creeping under water; above water erect, almost naked. Root leaves twice winged. Umbels, when ripe, resemble small prickly spheres. First umb. divided into three, the rest into more divisions.

E. peucedanifólia. Sulphur-wort. Water-dr. Leaflets all linear. General bracteas none. Knobs of the root stalkless, elliptical. E. B. 348. Filipendula angustifolia. G. E. 1059. 
Fresh water ditches, bogs. Banks of the Isis beyond Iffley. Peat bogs under Headington Wick Copse. Sb. * Bogs under Bullingdon Green. $\boldsymbol{B} x$.

Per. June.

Stalk thicker than in Enanthe fistulosa. Cal. erect, unequal. Stalk leaves winged, root-ones twice winged, leaflets linear. Umbellules often red about the centre, white towards the circumference.

E. crocáta. Hemlock Water-dr. Leaflets all wedgeshaped, many-cleft, nearly uniform. Fruit linearoblong, with slender intermediate ribs. E. B. 2313. Filipendula cicutæ facie. G. E. 1059.

Watery places, osier holts, about the banks of rivers. Near Bayswater. $\mathbf{S b}$.**

Per. July.

The plant contains a fetid yellow juice, very poisonous, especially the root. Cal. curved inwards. $L s$. many-clefted, large, blunt. $U m b$. terminal, large, convex. Anth. brown. Rays of universal umb. furrowed. Sheep eat it, cows and horses refuse it. Brood mares sornetimes eat the root, and are poisoned. Ehret, the draughtsman, experienced giddiness from the scent of the herb while drawing it.

\section{QE. Phellándrium. Fine-leaved Water-dr. Leaflets} all uniform, with narrow, wedge-shaped, cut, straddling segments. Fruit egg-shaped, with five broad ribs, and narrow intermediate furrows. Phellandrium aquaticum. E. B. 684: Cicutaria palustris. G. E. 1063.

Rivers, ditches.

Per. July.

Stem thick, hollow. Umb. opposite to the leaves. Lower $l s$. doubly compound, upper ones twice winged. Ls. thrice winged, smaller wings stalkless; under the water, long, hair-like. In running streams $l s$. lengthened out, and flowers rarely produced. Esteemed poisonous to horses, producing paraplegia: this effect owing to Curculio paraplecticus within the stem. The antidote is pig-dung. The roots and stem, in the course of the winter, become dissected, and afford a curious skeleton of net-work. Livn. Eaten by horses, sheep, and goats. Swine not fond of it: cows refuse it.

\section{SMY'RNIUM. Alexanders.}

S. Olusátrum. Common Al. Stem-leaves in threes, stalked, saw-toothed. E. B. 230. Hipposelinum. G. E. 1019 .

Waste ground, ancient ruins. ${ }^{*}$ Near Bensington. $\mathbf{S} b$.

Bien. May. 
Smooth, shining. Fl. pale, greenish white. Fr. black. Root-leaves, twice or thrice in threes.

Formerly eaten in many parts of Europe, as a salad, or potherb. Turns black when boiled: hence its name, Olus-atrum. Called formerly in Italy, and Germany, herba Alexandrina, as supposed to have been brought from Alexandria: hence its English name. Tusser, \&c.

Found near the sea-coast in many places.

\section{'APIUM. Parsley.}

A. gravéolens. Smallage P. Wild Celery. Leaflets of the stem-leaves wedge-shaped. Stem furrowed. Partial bracteas none. E. B. 1210.

Ditches, marshy ground. * Marston. Stanton-Harcourt Common. Southleigh. $\mathbf{S b}$. Near Elsfield. R. W.

Bien. June.

Smooth, pale-green. Umb. frequently almost stalkless.

Whole plant in its native ditches, acrid, dangerous. By culture, and blanching, the mild garden celery.

\section{EGOPO'DIUM. ${ }^{2} \quad$ Gout $^{3}$-weed.}

\section{Æ. Podagrária. Common G. Herb Gerarde. E. B.} 940. Herba Gerardi. G. E. 1001.

Moist, cultivated ground, shady wastes under hedges.

Per. June.

Root creeping. Leaflets egg-shaped, large, saw-toothed. Ls. on triangular foot-stalks. Root-leaves twice in threes, with broad, almost stalkless leaflets: those above in threes; leaflets with foot-stalks. Uppermost leaves opposite.

The young leaves in spring eaten as greens in Sweden and Switzerland. The root pungently aromatic. Formerly used as a cataplasm in the gout, whence specific name. $\mathbf{S m}$.

\section{ANGE'LICA. Angelica.}

(*A. Archangélica. Garden A. Terminal leaflet lobed. E. B. 2561. G. E. A. sativa 999 .

Watery places.* Broadmoore, near Birmingham, Warwickshire. With. in Tur.

Bien. June, September.

Stem polished, purple. Ls. rather glaucous (sea-green.) $\mathbf{k} l$. fleshcoloured.

Stalks candied, a sweet-meat.)

1 Persilia, Ang. Sax. Gloss.

2 Aix, a goat, and Pous, a foot: so called from the resemblance of the leaves to the foot of the goat.

${ }^{3}$ Gout-weed, perhaps a corruption of Goat-weed. 
A. sylvestris. Wild $A$. Leaflets equal, egg-shaped, saw-toothed. E. B. $1128 . \quad$ G. E. 999.

Watery places, alder cars, margins of rivers.

Bien. July.

Stem round, polished, often purple. Ls. twice-winged, rather glaucous. Fl. white, or flesh-coloured. Foot-stalks of the $l s$. sheathing. Lower leaflets somewhat two-lobed at the base.

Renders hay ungrateful to cattle. Lightf. Root anti-hysteric. Linn. Fl. Suec. Seeds sprinkled on the head destructive to lice. Id. Caterpillar of Pap. Macháon feeds on this plant. Flavour more bitter, and less grateful, than the Angel. Archangelica; virtues similar: garden species preferred.

\section{PIMPINE'LLA. Burnet-saxifrage.}

P. sáxifraga. Common Bur.-s. Leaves winged; leaflets of the root-ones roundish, toothed; of the uppermost in various linear segments. E. B. 407 P. dissecta. Sb. 102. a var. of this. Sm. Eng. Fl. Bipinella, sive Saxifraga minor. G. E. 1044.

Dry, gravelly, or chalky pastures.

Per. July.

Leaffets very various in shape and figure. Root highly aromatic and pungent, giving a blue oil.

Globularity of stigma not expressed in Eng. Bot. Var. (Pimp. dissecta of Sibth., Retzius, and De Candolle.) In this var., all the leaves winged, leaflets of many divisions, segments somewhat leafy, acute. Retz. Fasc. 3. 30. t. 2. Borders of fields, road sides.

P. magna. Great Bur.-s. Leaves winged; leaflets all egg-shaped, saw-toothed, somewhat cut; the terminal one three-lobed. E. B. 408. P. saxifraga. G. E. 1044.

Shady places, under hedges, chalky, limestone soil. Sm.

Per. July.

Larger than Pimp. saxifraga. Ls. uniform. Leaflets not subject to be sub-divided. Root weaker in flavour than Pimp. saxif. Stem furrowed. Leaflets almost broader than long, saw-toothed; as if besmeared with oil.

Root very acrid; hence used for tooth-ache, and to cleanse the skin from freckles. In asthma and dropsy in Germany. Larva of Pap. Macháon feeds on this, and Pimp. sáxifraga.

(P. dioica. St. Vincent's Rocks. Tur.)

CNI'DIUM. Pepper-saxifrage.

C. Siláus. Meadow P. Leaflets deeply wing-cleft; their segments opposite, running down the stem. 
General bracteas one or two. Peucedanum Silaus. E. B. 2142. Saxifraga anglicana, facie Seseli pratensis. G. E. 1047.

Rather moist meadows, pastures.

Per. July.

Whole plant smooth, darkish-green, varying in the shape of its leaves. $F l$. yellow, or greenish hue. Leaflets spear-shaped, as it were keeled; outermost united together. $L s$. thrice-winged. Germ. crowned with a glandular yellow receptacle, turning to a deep red as the seeds ripen.

Where this herb abounds in pastures it is found partially cropped; generally left almost entire.

\section{BUPLEURUM. Hare's-Ear.}

B. rotundifólium. Common $\boldsymbol{H}$. Thorow-wax. ${ }^{3}$ General bracteas wanting. Leaves perfoliate. E. B. 99. Perfoliąta vulgaris. G. E. 536.

Cornfields, especially a chalky soil. Sm. Parks. Southleigh. Middleton Stoney. $\mathbf{S b}$. Cornfields on Bullingdon Green. (Between Ferry Hinksey and Cumnor Hurst. $\quad B$ x.)

Stem alternately branched, hard, rigid and straightish, bent inwards, clothed with remarkably perfoliate leaves. Foot and a half high. large.

Plant reckoned among vulnerary herbs, in old herbals.

\section{HYDROCO'TYLE. ${ }^{2}$ White-rot. ${ }^{3}$}

\section{H. vulgáris. Common Wh. Marsh Penny-wort. Leaves} circular, target-shaped, smooth; cloven at the base. Umbels somewhat crowded. Flowers nearly stalkless. E. B. 751. C. 6. 19. Cotyledon palustris. G. E. 529. An. June.

Moist heaths, boggy commons, margins of rivulets.

Per. June.

Stems creeping. Ls. solitary, or clustered, on upright, simple footstalks, two or three inches high. Flower-stalks axillary. $F \boldsymbol{~}$. small, reddish-white. Umbellate head five to eight flowers.

Herb acrid.

\section{PASTINA'CA. Parsnep.}

P. satíva. Common Wild P. Leaves simply winged,

1 Thorou-wax, so called from the stem waxing, i. e. growing thorow, or through, the leaves.

${ }^{2}$ Hydrocotyle, from udor, water, and cotule, a cup.

${ }^{3}$ White-rot, from a supposition that the plant caused the disease in sheep, called the rot: the disease rather attributable to the moistness of the pastures. 
saw. toothed ; downy beneath. E. B. 556. P. sylvestris. Sb. 101. P. sylvestris latifolia. G. E. 1025. Borders of fields, hillocks, dry banks, chalky soil. Sm.

Bien. July.

Plant rough, rigid, three feet. $F l$. yellow. $F r$. large. Involucre none; foot-stalks smooth. $D C$.

Seeds have been used in intermittents. Linn. Fl. Suec. Roots highly nutritious, abounding in saccharine matter: brewed in the north of Ireland, with hops, and fermented with yeast. Hogs fatten on the roots quickly. leaves.

By cultivation the eatable garden parsnep, with larger, smoother

\section{HERACLE'UM. ${ }^{\top}$ Cow-parsnep.}

\section{H. Sphondy'lium. Common C. Hog-weed. Leaves} winged; leaflets wing-cleft, cut and saw-toothed. E. B. 939. Sphondylium. G. E. 1009.

Hedges, borders of fields, rather moist meadows.

Bien. Sm. July.

Four feet high. $\mathbf{F l}$. white, large, radiant: petals inversely heartshaped. Leaflets five-cleft, oblong, hairy, rough on both sides: terminal one three-lobed. Common stalk of the ls. with one large inflated ribbed stipula.

In Kamtschatka the foot-stalks of the root-leaves collected; the rind being peeled off, they are dried separately in the sun, then tied up in bundles, and laid in the shade: in a short time these dried stalks are covered with a yellow saccharine efflorescence: in this state, eaten as a great delicacy.

The stalks also fermented with bilberries (Vaccin. uliginosum;) and a strong liquor distilled from them. Gmelin. Fl. Siber. Swine and rabbits fond of this plant.

\section{TORDY'LIUM. Hart-wort.}

T. máximum. Great $\boldsymbol{H}$. Leaflets spear-shaped, deeply saw-toothed and notched. Flowers somewhat radiant; the outermost petal of two equal lobes. Stem rough, with close bristles bent downwards. E. B. 1173. Seseli creticum majus. G. E. 1050.

Banks and waste ground, very rare. Under the hedge on the north side of the Parks, Oxford. Dr. J. Sibthorp, and Mr. Woodward.** Not found, 1832. R. W. Hedges, near Eton Wick, very abundant. Tur.

An. June.

$F l$. white, or rose-coloured. Outward petals largest. Umb. rather

1 Heracleum, from Hercules, or Heraclea.-eion. Gr. 
small and dense. Involucre five-cleft, awl-shaped, spreading, shorter than the umbel. Stem slightly furrowed. Leaflets about seven cut, the odd one, twice the size of the others. Seeds flat, bristly; the border thicker, prickly, red. On the north, and west sides of the Parks: also on a bank beyond Jericho, about a quarter of a mile N. W. from the Oxford Observatory. Bx. 1819. Ray suspected this plant not to be a native, but an outcast from the garden.

\section{PENTANDRIA TRIGYNIA.}

\section{VIBURNUM. Guelder-rose.}

\section{Lántana. Mealy G. Way-faring Tree. Leaves} heart-shaped, saw-toothed, veiny; downy beneath. E. B. 331. Lantana. G. E. 1490.

Woods, hedges, especially on a chalky, or limestone soil. Sm.

Shrub. May.

Thickly branched: twigs round, mealy with radiated pubescence, like that of the fl.-stalks, backs, and upper sides of the leaves. Ls. opposite, somewhat elliptic, at the base heart-shaped, blunt, strongly veined. Fl. terminal cymes, white. Anth. yellow. Berry compressed: when young, red on the outermost side: when ripe, all black. Ls. dark-red in autumn.

Young shoots in the Crimea, for tubes of tobacco pipes. Bark of the root for birdlime. Berry astringent. The long, quick growing, tough branches, excellent bands for fagots.

V. 'Opulus. Common G. Water Elder. Leaves lobed. Foot-stalks beset with glands. E. B. 332. Sambucus aquatilis, sive palustris. G. E. 1424 .

Watery hedges, and swampy thickets.

Shrub, or small Tree. May.

Smooth. Ls. three-lobed. Cymes white, many flowered: perfect ones small, like those of the elder: marginal abortive ones of one large irregular, flat pet. Berry very succulent, bright, red, bitter. Autumnal $l s$. fine pink.

Guelder rose of the garden bears round bunches of abortive $f$. only, called Snow-ball Tree.

\section{SAMBU'CUS. Elder.}

S. 'Ebulus. Dwarf E. Danewort. Cymes with three main branches. Stipulas leafy. Stem herbaceous.

\footnotetext{
1 Ellarn. Ang.-Sax.
} 
E. B. 475 . C. 3. 18. Ebulus sive Sambucus humilis. G. E. 1426.

Waste ground, hedges. Parks, behind Wadham College. Near Ensham. $\$ b$.

Per. July.

Stems herbaceous, three feet, erect, leafy. $L s$. winged, dark-green. Leafl. egg-spear-shaped, acute, saw-toothed. Fl. stalked. Cor. dull blood-red. Stam. white, anth. red. Cal. purple. Berry globular, purplish-black.

Whole plant fetid, strongly purgative. Moles will not approach near where its ls., or those of the Common Elder laid. Root one drachm and a half, a strong cathartic. Berry to dye blue. Mice avoid the smell of this plant. Our ancestors supposed this plant to spring from the blood of their foes, the Danes. Seeds (one scruple) bruised, purgative, once a week, in dropsy. G. E. (" in a little secke.")

S. nigra. Common $E$. Cymes with five main branches. Stipulas obsolete. Leaflets egg-shaped. Stem treelike. E. B. 476. Sambucus. G. E. 1422.

Hedges, coppices, woods. Var. $\beta$. near Watlington. Bobart. Wixford. Purton.

Small Tree. June.

Branches full of light, white pith. Ls. winged. Leaft. about five, pointed, saw-toothed. $F \boldsymbol{F}$. cream-coloured, smell faint. Berry globular, purplish-black.

Inner bark strongly purgative; in smaller doses, diuretic, in dropsy. Berries made into a rob, in sore throat: laxative. Infusion of the ls. sprinkled on the buds of flowers to preserve them from caterpillars. Caterpillar of the delicate Phal. Sambucária feeds on its ls. The berries for wine. Sheep cured of the rot by the bark, and young shoots. (Var. $\beta$. with white berries, for wine : var. with jagged ls.)

Striking the boughs over different plants will keep off insects. Decoction of the fl. as a cooling fomentation. The fl. to flavour vinegar : fl. fatal to turkies, and to peacocks. Juice of the berry to colour wines. The pith for balls in electric experiments. When the elder is in flower the summer is established: when ripe the summer is entirely gone. Seed bruised, one drachm in dropsy. G. E. Inner green bark from half an ounce to one ounce, infused in white wine, moderately cathartic.

\section{PENTANDRIA TETRAGYNIA.}

PARNA'SSIA. Grass of Parnassus.

P. palustris. Common G. of $\boldsymbol{P}$. Leaves heart-shaped. 
Bristles of each nectary numerous. E. B. 82. Gramen Parnassi. G. E. 480.

Spongy bogs, commons. Peat bogs on Bullingdon Green. Under Headington Wick Copse. $\mathbf{S b}$. About a quarter of a mile north from Upper Heyford; also in a bog north of the Parsonage House. $B x$.

Per. July.

Stems about one span, angular, twisted. $F \boldsymbol{F}$. foot-stalks three or four times longer than the ls. $F l$. pet. veined with greenish ribs. Cor. elegant milk-white. Nect. balls yellow.

The stam. in succession, or nearly so, come over the stigm. and retire after shedding their pollen. The same phenomenon in the Rue, and in Saxifraga.

A most elegant plant. Physiology of the Nert. unknown.

\section{PENTANDRIA PENTAGYNIA.}

\section{LINUM. Flax. ${ }^{\mathrm{I}}$}

\section{* Leaves alternate.}

(L. usitatíssimum. Common Flax. Calyx-leaves eggshaped, acute, with three ribs. Petals notched. Leaves spear-shaped, alternate. Stem mostly solitary. E. B. 135\%. C. 5. 22. L. sativum. G. E. 556 .

Cultivated fields. Broome, Warwickshire. $P n$.

An. July.

Root small, fibrous. $\quad F l$. blue. Caps. ending in a point.)

(L. perenne. Perennial $\boldsymbol{F}$. Calyx leaves inversely eggshaped, blunt, obscurely five-ribbed, naked. Leaves linear-spear-shaped. Stems many, ascending. E. B. 40 .

Chalky hills. Sm. Northamptonshire. Ray. Worthorpe, and on the balks about Bernack Heath, and Withering Heath. Morton.

Per. June, July.

Root much branched at the summit, woody. $L s$. smaller and narrower than in L. usitatissimum. $\boldsymbol{F l}$. blue, but smaller than in the last. Caps. bluntish.)

$$
\text { * Leaves opposite. }
$$

L. cathárticum. Purging Flax. Mill-mountain. Leaves opposite, inversely egg-spear-shaped. Panicle forked;

'Ang. Sax. 
partly drooping. Petals acute. E. B. 382. C. 3.

19. L. sylvestre catharticum. G. E. 560 .

Dry pastures.

An. June.

Plant slender, smooth. Stems one foot, bowed at the base, then upright, simple, branching off into a forked, slender-stalked pani-

cle. $L s$. stalkless. $F l$. terminal, solitary, in bud, drooping; in fl., erect, white like those of an Arenaria. Cal. ls. egg-spearshaped, nerve one. Stam. monadelp. sometimes only four. Willd.

Infusion of two drachms or more of dried herb, excellent cathartic, diuretic in rheumatism.

\section{PENTANDRIA HEXAGYNIA. DRO'SERA. Sun-dew.'}

D. rotundifólia. Round-leaved S. Leaves pressed down, hollow in the middle, nearly circular, on hairy foot-stalks. Flower-stalks immediately from the root, racemose. E. B. 86\%. Ros Solis folio rotundo. G. E. 1556.

Mossy, turfy bogs. North side of Shotover Hill. Sb. (Bagley Wood.) Near Childswell Farm. $B x$.

Per. July.

$\boldsymbol{L} \boldsymbol{s}$. growing in a starry form, conspicuous by their green and red colour. Glandular bristles red, bent inwards, irritable, contractile, each tipped with a clear viscid globule. Fl. stalks naked, simple. $F l$. white, or blush-coloured. This species, and Dros. longifolia occasionally acquire a stem. Dr. Williams, Bot. Prof. Oxford.

Whole plant acrid, caustic. Juice mixed with milk, an application to remove freckles, and sun-burns. The unmixed juice to destroy warts and corns.

The upper surface of the $l s$. said to contract, when touched with a pin, centrically; hence insects sometimes found imprisoned in the $l s$. An experiment best made in hot, sunny weather, by placing an ant or any small insect on the $l s$. \&c. The distilled water of Sun-dew from a glass still, is of a golden colour, and colours silver like gold. G. E.

(D. longifólia. Long-leaved S. Leaves inversely eggshaped, erect, on naked foot-stalks. Flower-stalks immediately from the root, racemose. E. B. 868. Ros Solis folio oblongo. G. E. 1556.

1 From the small pellucid drops at the tips of the $l s$. remaining undried up in the fullest exposure to the sun. 
Mossy, turfy bogs. Bullmarsh Heath. Bogs in Windsor Great Park. Tur.

Per. July, August.

Like the last, but rather larger. Ls. oblong.

\section{PENTANDRIA POLYGYNIA.}

\section{MYOSU'RUS. Mouse-tail.}

M. minimus. Mouse-tail. E. B. 435. C. 4. 26. Cauda muris. G. E. 426.

Cornfields, gravel. Sm. Magdalen College Walks, near the meadow gate. Southleigh. North Aston. Sb. Between Bayswater and Stanton St. John's. Bx.

An. June.

Root fibrous. Herb smooth, variable in size, stemless. Ls. numerous, nearly upright, linear, somewhat battledore-shaped, pale-green. Stalks upright, longer than the $l s$., simple, round, each bearing a small upright $f$. of a pale yellowish colour. Stam. variable in number, about five. Pistil composed of a conical receptacle, with a great number of egg-shaped, slightly striated germens, two or three hundred, not unlike a mouse's tail. Plant acrid.

\section{Class VI. HEXANDRIA. Stamens 6. Each 3 equal.}

\section{Order I. MONOGYNIA. Pistil 1.}

(* Galanthus nivális. Common Snow-drop. Packington, Warwickshire. Tur. Sometimes difficult to draw the line of demarcation between indigenous wild plants, and exotics.)

\section{LEUCO'JUM. Snow-flake.}

L. astívum. Summer Snow-flake. Flowers several. Style club-shaped. E. B. 621. C. 5. 23. L. bulbosum majus polyanthemum. G. E. 148.

In moist meadows, and marshes near rivers. Sandford. $Y$. St. John's Island, opposite Kennington. Mr. Barnes, Christ Church, Oxford. Near Reading. Tur.

Per. May. 
Ls. numerous. Pet. uniform; top green.

\section{NARCISSUS. ${ }^{1}$ Narcissus, or Daffodil.}

N. Pseudo ${ }^{2}$-narcissus. Common Daffodil. Flowers solitary. Cup of the nectary bell-shaped, erect, crisped, with six marginal segments; its length equal to that of the egg-shaped petals. E. B. 17. Pseudo-narcissus anglicus. G. E. 133.

Rather moist woods, thickets. Noke Woods. Sb. North side of Shotover Hill. (Bagley Wood.) Bx.

Per. April.

Bulbous. Ls. erect, linear, with a blunt keel, and flat edges. $F l$. drooping, large; pet. lemon-yellow. Nect. large, deep-yellow.

One of the most beautiful of our native plants. $\mathrm{Fl}$. anti-spasmodic. By some the $f$. considered a kind of specific in hoopingcough. The extract of them in small doses only. Two or three drachms would destroy life in a few hours; half a grain, to one to two grains, every two, four, or six hours, according to patient's strength. Richard. Decoction of the roots purgative. G. E.

\section{'ALLIUM. Garlick. ${ }^{3}$}

* Stem leafy. Leaves somewhat cylindrical.

(A. oleráceum. Streaked Field Garlick. Umbel lax, bearing bulbs. Leaves semicylindrical, tubular, rough; channelled above; ribbed beneath. Bracteas pointed, longer than the umbel. Stamens simple, awl-shaped. E. B. 488. A. sive Moly montanum tertium. G. E. 188.

Cornfields, and their borders. Rosall. Pn. What county?

Per. July.

$F l$. reddish. Germ. rough at the top.)

A. vineále. Crow G. Umbel spherical, bearing bulbs. Leaves cylindrical, smooth. Three alternate stamens deeply three-cleft. E. B. 1974. A. sylvestre. G. E. 179.

Dry pastures, cornfields, waste ground, especially on chalk, or gravel. Sm. Meadows, near the Botley Road. Between Caversham and Mapledurham. $S b$. Walls of Godstow Nunnery. $B x$.

Per. June.

Root egg-shaped, bulbous. Stem two f. slender, upright, round,

1 From the youth supposed to be changed into the flower. Ovid. Metam.

2 Pseudo, i. e. false, to distinguish this species from the True N. of the ancients, or $\mathbf{N}$. pocticus.

${ }^{3}$ Garleac. Ang.-Sax. 
slightly furrowed. Ls. long, tapering, hollow, fading before the flowers come out. $\quad \mathbf{F l}$. pet. closed, pale-rose-colour, keels green. Spatha pointed, deciduous. Stam. longer than the pet., the hairlike, side extremities of three thrice divided ones, horizontally spreading. Young shoots in salad, or boiled.

* Stalks immediately from the root, naked.

A. ursínum. Broad-leaved G. Ramsons. Stalk immediately from the root, naked, semicylindrical, with four angles. Leaves elliptic-spear-shaped, stalked. Umbel level-topped. Stamens simple. E. B. 122. G. E. 179 .

Woods, hedges, meadows. Stow Wood. Bx. Headington Wick Copse. $\$ b$.

Per. June.

Root a slender bulb, fibres long, fleshy. The broad $l s$. all from the root. Spatha two-leaved. $\mathbf{F l}$. white, numerous, large.

Difficult of eradication. Communicates its nauseous flavour to milk and butter, when cows eat the plant.

\section{FRITILLA'RIA." Fritillary.}

F. Meleágris. ${ }^{3}$ Common F. Chequered Daffodil. Snake's. head. All the leaves alternate, linear-spear-shaped, pointed. Stem single-flowered. Nectary linear. Points of the petals bent inwards. E. B. 622. C. 3. 20. Baxter's Plates, 1. F. variegata. G. E. 149.

Moist meadows, pastures. Magdalen College Meadow. Cowley Meadows. Sb. Burghfield Meadows, near Reading. Mrs. Bockett. Standlake. $W h$.

Per. April.

Root a small bulb. Stem erect, about one foot, round, leafy. $\quad \boldsymbol{F l}$. bell-shaped, elegantly chequered with pale and dark purple, drooping. Fruit erect.

Var. Fl. white.

\section{TULIPA. ${ }^{4}$ Tulip. $^{5}$}

T. sylvestris. Wild $T$. Flower solitary, a little drooping. Leaves spear-shaped. Stigma triangular, abrupt.

1 Bear's, or bearish, Lat. Sir J. E. Smith observes,-the coarseness of its qualities, like the manners of some human beings, may, in both cases, justify a comparison. $\boldsymbol{E} . \boldsymbol{F}$.

2 From the chequered appearance of the flower, somewhat resembling a chess-board, fritillus.

3 Meleagris, from the resemblance of the flower to the painted wings of the Meleágris, Guinea-hen, or Pintado.

4 From toliban, Yers. a turban, from the shape and colour of the flower.

$s$ See Beckmann's History of Inventions, \&c. 
Stamens hairy at the base. E. B. 63. H. L. 19. Baxter's Plates, 2. T. bononiensis. G. E. 138.

Chalk pits. Near Bullingdon. Christ Church Meadow. Dr. Williams, Bot. Professor, Oxford.

Per. April.

Stem simple. A bulb is formed in this plant at the end of a long fibre. $F \boldsymbol{F}$. fragrant, yellow. Pet. spear-shaped, acute, outward ones greenish. Roots preserved in sugar eatable. G. E.

\section{ORNITHO'GALUM. ${ }^{\prime} \quad$ Star of Bethlehem.}

O. lúteum. Yellow Star of $B$. Stem angular, with one leaf at the bottom, and one or two at the top. Flower-stalks umbellate, simple, smooth. E. B. 21. O. luteum, sive Cepe agraria. G. E. 165.

Groves, pastures.** In woods about Oxford. Sir Joseph Banks, Bart. Woods near Ashford Mill. Fauler. Sb.

Per. April.

$L s$. spear-shaped. Floral $l s$. fringed with fine white hairs. Pet. pale-green externally, tipped with green within. Stam. and pist. yellow. An elegant plant.

Bulbous roots of all the species nutritious and wholesome.

* O. umbellátum. Common Star of B. Flowers corymbose; their partial stalks overtopping the main one. Filaments dilated, tapering, entire. E. B. 130. H. L. 45. Ornithogalum. G. E. 165.

Meadows, pastures, groves.** Near Barton. Sb. Christ Church Meadow. Sb. and Dr. Bridges, President of Corpus Christi College, Oxford. Copse, near Sandford Toll-gate. $B x$.

Per. April, May.

Ls. linear, bluntish, withering soon at the top, concave on the upper side, with a white rib. Stalk round, smooth, eight or ten inches. Corymb. of six, eight, or ten fl. Bract. spear shaped, acute, membranous, fading, about half as long as the fl.-stalks. $P e t$. pure, enamelled, white with a broad, permanent, green line along their backs. Germ. top-shaped, with six notches.

The boiled roots much used as food in the Levant. The Dove's Dung, mentioned 2 Kings, ch. vi. v. 25. supposed by Linn. to be the roots of this plant. Bochart interprets the Heb. word, as referring to the seed of vetches, or some vegetable food. See Gesen. Lex. in the Heb. word חדי?

* O. nutans. Drooping Star of $B$. with its large, white flowers, silvery and glaucous. E. B. $199 \%$.

${ }^{1}$ From Ornis, Gr. a bird, and gala, Gr. milk; from the whiteness of the petals in some species. 
Per. May.

Magdalen College Meadow. Miss Edwards.

\section{SCILLA. Squill.}

S. nutans. Hare-bell $S q$. Wild Hyacinth. Leaves linear. Cluster drooping. Flowers hanging down, cylindrical-bell-shaped; the points of their petals bent back. Bracteas in pairs. E. B. 37\%. Hyacinthus non scriptus. C. 2. 18. Sb. H. anglicus. G. E. 111. Thickets, groves, bushy fields, hedges.

Per. May.

$B$ Bulb. solid, acrid, poisonous, abounding with starch mucilage. Ls. acute, limber. Stalk erect. Fl. blue, sweet-scented. Bract. in pairs, linear, acute, blue, like the fl.-stalks.

An ornamental and graceful plant. Fresh roots poisonous, may be converted into starch.

$\operatorname{Var} . \mathrm{Fl}$. white, to flesh-coloured.

(Scilla autumnális. Autumnal S. E. B. 78. H. autumnalis minor. G. E. 110. Clifton, Gloucestershire. Tur.)

\section{(HYACINTHUS. Hyacinth.}

H. racemósus. Starch $\boldsymbol{H}$. Flowers egg-shaped, with six furrows; the upper ones stalkless and abortive. Leaves linear, channelled, limber. E. B. 1931. C. Mag. 122. H. botryoides cœruleus. G. E. 118.

Grassy fields, sandy soil, or among ruins. Near Newbury, Berks. Sm. Eng. Fl.

Per. May.

Fl. dark-blue, smelling like wet starch.)

(NARTHE'CIUM. Bog-asphodel.

N. ossifragum. ${ }^{1}$ Lancashire Bog-asphodel. Cluster uninterrupted. One bractea at the base, the other above the middle, of each partial stalk. E. B. 535. H. L. 139. Asphodelus Lancastriæ. G. E. 95.

Black, turfy bogs. Coleshill Bog, Warwickshire. Pn. Windsor Great Park. Tur.

Per. July, August.

Ls. sword-shaped. Stem. simple. $F l$. yellow, with red anth.)

1 Lat. i. e. bone-breaking; from a supposed effect in the plant fed upon, to soften the bones of cattle. 
(Aspáragus officinális. Common Asparagus. E. B. 339. G. E. 1110. Near Thornbury, Glouc. Tur.)

CONVALLA'RIA. ${ }^{\prime} \quad$ Lily of the Valley, and Solomon's Seal.

C. majälis. ${ }^{2}$ Lily of the $V$. Flower-stalk immediately from the root, naked, semicylindrical. Cluster simple. Flowers drooping, cup-shaped, with rather distant segments. E. B. 1035 . C. 5. 24. Lilium convallium. G. E. 410 .

Groves, heathy ground, rocky woods.** In the Beech-Woods, near Stokenchurch. Sb. Copse near Childswell Farm. J. Ireland, Esq. and $B x$.

Per. May.

Roots matted, creeping. Stalks scaly. Ls. mostly two, immediately from the root, long-stalked, elliptic, ribbed. Fl.-stalk solitary, naked, shorter than the $l s . F l$. white, racemed, highly fragrant. Berry ripe, scarlet.

The powdered $f$ l. excite sneezing. From the $l s$. a beautiful green colour prepared with lime.

Garden var. fl. double, or purple. One of our most favourite wild flowers. Extract from the $f_{\text {. }}$, or roots purgative. Dose, twenty to thirty gr.

(C. multifóra. Common Solomon's Seal. Leaves alternate, clasping the round stem. Stalks axillary, manyflowered. Stamens downy. E. B. 279. H. L. $3 \%$ Polygonatum. G. E. 903.

Woods, thickets. Corpus Wood, Streatley, Berks. Dr. Williams, Bot. Prof. Oxford. High Wycombe, Bucks. With.

Per. May, June.

Ls. elliptic. $F l$. smaller, scarcely bearded. Berr. bluish-black.)

\section{'ACORUS. Sweet Flag.}

A. Cálamus. Common S. F. Leafy summit of the flower-stalk rising high above the spadix. E. B. 356. A. verus, officinis falsò calamus. G. E. 62 .

Watery places, banks of rivers.** Dorchester. Sb. Between Oxford and Iffley. Between Iffley and Sandford. $\boldsymbol{B} x$. Per. July.

Root thick, spongy, strongly aromatic, rootlets long. Ls. two to three ft., upright, long, sword-shaped, bright-green, aromatic like the roots, but fainter. Spadix from the sides of the stem, cylin-

1 From vallis, a valley.

${ }^{2}$ From time of $\mathrm{fl}$. 
dric, tapering, naked. $F l$. very numerous, thick-set, green, seldom met with.

Dried root in ague.

\section{JUNCUS. ${ }^{1}$ Rush.}

* Leaves none.

J. glaucus. Hard $\boldsymbol{R}$. Stem naked, straight, glaucous. Panicle upright, far below the summit. Capsule elliptical, pointed, rather shorter than the awl-shaped-leaved calyx. E. B. 665 . J. acutus. G. E. 35.

Wet pastures, moist, waste ground.

Per. July.

Stem slender, somewhat crooked, about one and a half f., upright, naked, stiff, slightly furrowed, tapering to a sharp point, at the base brown, shining, sheathing scales, dark-chestnut below. Pan. from the side of the stem, branched, spreading upwards. Cal.ls. awl-shaped.

Discrim. by its glaucous green colour, and hard texture from $\mathbf{J}$. conglom. and J. effusus: in J. conglom. the stam. are only three.

J. conglomerátus. Globular-headed $\boldsymbol{R}$. Stem naked, straight. Panicle compact, globular, far below the summit. Capsule broadly egg-shaped, blunt. E. B. 835 ,

Pastures, road-sides.

Per. July.

Stems simple, slightly furrowed, about two f., not pungent at the end, but pointed. Panic. from a membranous, bordered, fissure, or chink, brownish-green.

Wicks for watch-lights; pith for toys. Stems for mats and chair bottoms, like J. effusus. Rushes used in Edward the Fourth's reign, and later, for strewing floors, before the introduction of carpets: a cover for a vast deal of filth : in making the wicks, two ribs of stalk should be left to support the pith. See White's Selborne, Let. 26.

J. effísus. Loose Panicled $\boldsymbol{R}$. Stem naked, not rigid, straight. Panicle diffuse, repeatedly compound, very far below the summit. Capsule blunt, inversely eggshaped. E. B. 836 . J. lævis. G. E. 35.

Wet pastures, boggy places.

Per. July.

Stem about two f., paler than in J. conglom., softer, and more pithy. Panic. a multitude of pale-green flowers. Cal.-ls. narrow, pointed.

1 See Davies in Linn. Trans, v. 10. p. 10. \&c. and Bicheno, v. 12. 
Stems inferior in softness, pliability aud length to Scirpus lacustris : for chair bottoms, ropes, and baskets, in some places.

\section{* Leafy.}

J. squarrósus. Moss $\boldsymbol{R}$. Goose Corn. Stem naked. Leaves numerous, bristle-shaped, immediately from the root, tufted, channelled. Panicle terminal, compound, with cymose branches. E. B. 933. Gramen ${ }^{1}$ junceum maritimum. G. E. 21.

Boggy spots, barren, sandy heaths.

Per. July.

$L s$. stiff, linear. Stem about one f., straight, stiff. Panic. the partial and general stalks proceed from a reddish-brown, long, sheathing, smooth bract. $F \%$ large, compared with the other common species. Cal. dark-brown: border narrow, filmy, white. Caps. inversely egg-shaped, shining.

J. compressus. Stalk-compressed $\boldsymbol{R}$. Stem simple, compressed; leafy below. Leaves linear, incurved at the edges. Panicle cymose, terminal, shorter than the bractea. Capsule roundish-inversely egg-shaped, longer than the blunt calyx. J. bulbósus. E. B. 934 .

Moist pastures.

Per. July.

Stems leafy at the root, about one f., simple, smooth, slightly compressed. Panic. erect, terminal, many-flowered, often surmounted by a less one on a longer stalk. Fl. small. Cal. bluntish, segments green with a broad, brown edge.

Root not bulbous, but creeping.

J. bufónius. Toad $R$. Stem forked, leafy. Leaves angular, channelled. Panicle forked, racemose, longer than the bracteas. Calyx-leaves spear-shaped, taperpointed, membranous, two-ribbed, longer than the oblong capsule. E. B. 802. Gramen junceum. G. E. 4 .

Marshy ground, watery, sandy heaths.

An. July.

Root fibrous. Stems numerous, upright, variable in height from one to ten inches. Upper part of the branches, terminating in simple rows of stalkless and stalked, green flowers. Plant smooth, paler than the rest of the species. Ls. linear-setaceous, acute. Bract. pellucid. Caps. slender, blunt.

The solitary $f$. and long silky cal. mark this species, and its grassy appearance. In germination the seed considerably elevated above ground by the plant.

1 The $l s$, and root resemble the plant. 
J. uliginósus. Little Bulbous $\boldsymbol{R}$. Stem leafy, bulbous at the base. Leaves bristle-shaped, channelled. Heads from the side of the stem, and terminal, about threeflowered. Capsule blunt, rather longer than the calyx. E. B. 801.

Moist, sandy, or turfy heaths.

Per. July.

Stems clothed at the base with the broad, red sheaths of the root-ls. $\mathbf{F l}$. reddish ; in wet seasons often viviparous, var. $\beta$. three together, in a kind of proliferous cluster. Bract. small, acute. Cal.ls. acute, three-nerved, chocolate-coloured in decay. Caps. prismatic.

J. acutiflórus. Sharp-flowered Jointed $R$. Leaves apparently jointed, slightly compressed. Panicle repeatedly compound, forked. Calyx-leaves all bristlepointed, somewhat shorter than the taper beak of the capsule. E. B. p. 2143, at the bottom. J. articulatus. E. B. 238. J. nemorósus. Sb. 114. Gramen junceum sylvaticum. G. E. 22.

Wet woods, watery places.

Per. July.

Stem obliquely ascending at the base, smooth, one f., or more than three. $L s$. alternate, few, sheathing, curved backwards, pointed, their cavity divided by partitions. Panic. terminal, branches long, slender, smooth.

This with J. lampocarpus, and some other species, produce bundles of slender leaves, instead of flowers, or intermixed with the $\mathrm{fl}$.

J. lampocarpus. Shining-fruited Jointed $\boldsymbol{R}$. Leaves apparently jointed, compressed. Panicle erect, compound, forked. Inner calyx-leaves bordered. Capsule egg-shaped, coloured, highly polished, longer than the calyx. E. B. 2143. J. compressus. Sb. 114. Gramen aquaticum. G. E. 13.

Boggy meadows, watery places, frequent.

Per. July.

Panic. branches, strong, lengthened out; heads of $f$. remote, one above another on each simple branch. C'aps. remarkable for its size, dark-chocolate, varnished. Stem about one f.

Discr. when early in $f_{\text {., }}$ its more simple panicle, and somewhat blunt cal. Bicheno. Var. Ls. fasciculated, (in bundles.)

J. obtusiflórus. Blunt-flowered Jointed $\boldsymbol{R}$. Leaves apparently jointed, cylindrical. Stem with internal 
partitions. Panicle repeatedly compound; branches straddling, and bent back. Calyx-leaves blunt, as long as the capsule. E. B. 2144.

Marshes.

Per. August.

Discr. Its pale, entangled, much branched panic., with last branchlets strongly bent back, l.-joints cellular. Ls. two, mostly. Stem erect, two or three f. Fl. small, from the side of the stem and terminal, in small heads.

\section{LU'CIOLA. ${ }^{x}$ Wood-rush.}

L. pilósa. Broad-leaved, Hairy Wood-r. Panicle subcymose, widely spreading, and last branches bent back. Flowers solitary. Capsule pointless. Crest of the seeds hooked. Juncus pilosus. E. B. 736 . C. 5. 25. Sb. 115. Gramen hirsutum nemorosum. G. E. 19 .

Shady groves, thickets.

Per. March.

Stems six to twelve inches, polished, leafy. Ls. flat, linear-spearshaped, bright-shining-green, pointed, entire, fringed with distant long white hairs. Panic. terminal. Fl. solitary, terminal, and from the side of the stem, each accompanied with a pair of sheathing, acute bract. Cal.-ls. spear-shaped, pointed, darkbrown, bordered with white. Anth. large, square, yellow. Caps. pale-yellowish in contrast with the brown cal.

Herbage dry, tough.

L. Forstéri. Narrow-leaved Hairy Wood-r. Panicle cymose, erect. Flowers solitary. Capsule pointed. Crest of the seeds straight and blunt. Juncus Forsteri. E. B. 1293. Luzula Forsteri. H. L. 68.

Groves. Beech-Wood about a mile and a half from Henley, near road to High Wycombe. $B \boldsymbol{x}$.

Per. May.

Ls. much narrower. Panic. smaller.

L. sylvática. Great Wood-r. Panicle sub-cymose, doubly compound. Flowers and bracteas crowded. Capsule pointed. Crest of the seeds scarcely distinguishable. Juncus sylvaticus. E. B.737. C. 5.26. Sb. 116.

1 From the heads of $f$, wet with dew, and sparkling by moonlight, giving an idea of the lucciola (Ital. for glow-worm.) Mr. Bicheno derived great assistance in distinguishing the species of $\boldsymbol{L}$., from the shape, and crest (coruncula) of the seeds. See Fig. in Linn. Trans. V. XII. 
Wouds, thickets. North side of Shotover Hill. Stow Wood. Tar Wood. Sb. (Bagley Wood. Copse between Childswell Farm, and Wootten Heath. $B x$.)

Per. May.

Discr. from L. pilosa by its greater size: by the $f$. growing in clusters, about three in each, branches of the panic. less straddling, not hanging down.

This with L. pilosa for packing, and stuffing mattresses.

Stem three or four ft. $\quad \boldsymbol{L} s$. flat, linear-spear-shaped, sharp-pointed, hairy at the margin, root-ones half an inch or more in breadth. Stem-ls. smaller, shorter. Bract. linear, acute, hairy.

L. campestris. Field Wood-r. Panicle of three or four egg-shaped, dense, partly stalked clusters. Capsule inversely egg-shaped, blunt, with a small point, shorter than the calyx. Seeds stalked, without a crest. Leaves flat. Juncus campestris. E. B. 6\%2. C. 2. 19. Sb. 116. Gramen exile hirsutum. G. E. 17.

Dry, barren pastures.

Per. April.

Conspicuous by its large, sulphur anth., and dark-copper-brown husks.

Root creeping. Stems four or five inches, simple, straight, leafy. Ls. linear-spear-shaped, acute, very hairy on the margin. Panic. terminal, at length drooping, one nearly stalkless. Fi. stalkless, three or four torn bract. at the base. Cal.-ls. spear-shaped, pointed. Style slender.

L. congesta. Many-headed Flaxen Wood-r. Panicle of numerous, roundish-egg-shaped, dense, partly stalked, clusters. Capsule inversely egg-shaped, blunt, with a small point, as long as the calyx. Seeds stalked without a crest. Leaves flat, rough-edged. Var. of $\mathbf{L}$. campestris? Juncus campestris $\beta$ elatior. Sb. Gramen capitulis globosis. G. E. 18. Purton Fl. p. 352. V. iii. pt. ii. fig.

Marshy, turfy ground. Peat bogs on Bullingdon Green. Ensham Heath. Sb. North side of Shotover Hill. (Bagley Wood. Bx.) Per. April.

Stem erect, eighteen inches. $L s$. much narrower than in L. campestris. Panic. very different, of seven or eight roundish, eggshaped, dense, blunt, clusters, the first almost stalkless, the rest on long, partly spreading stalks. Cal. paler, more taper-pointed, scarcely extending beyond the caps.

Discr. from L. campestris : size of the plant, quantity of flax-like substance, large cylindric heads, on fruit-stalks from an inch to an inch and a half, and its $f$. full a month later. Purton. 


\section{BE'RBERIS. ' Barberry.}

B. vulgáris. Common B. Thorns three-cleft. Clusters hanging down. Leaves inversely egg-shaped-oblong, with bristly serratures. Petals entire. E. B. 49. Spina acida, sive Oxyacantha. G. E. 1325.

Hedges. ** Medley. Sb. Walls of Godstow Nunnery. R. W. (Bagley Wood.) Between Middleton Stoney, and Ardley。 Bx. Shrub. May.

$\boldsymbol{L} \boldsymbol{s}$. deciduous, stalked, first $l s$. inversely egg-shaped, between sawtoothed, and fringed. Secondary $l s$. oblong, saw-toothed, in pairs. $F l$. yellow, sometimes streaked with orange. Berr. red.

Stam. irritable near the base. If the filaments be touched, the anth. immediately approach the stigm., and will burst to throw out the pollen or dust. The irritability may be successfully shewn, by touching the fil. with a pin, or needle.

Ls. acid. Berr. boiled with sugar an agreeable preserve. Infusion of the bark in white wine purgative. The roots dye wool, and leather yellow. The inner bark of the stem dyes linen a fine yellow. $L_{s}$. of the barberry supposed, but without any good reason, to occasion blight in corn, by the minute seeds of a parasitic fungus, Acidium Berberidis, ${ }^{2}$ being conveyed from its $l s$. to the corn.

\section{PEPLIS. Purslane.}

P. Pórtula. Water $\boldsymbol{P}$. Petals wanting, or scarcely visible. Leaves opposite, inversely egg-shaped, stalked. E. B. 1211 . C. 4. $2 \%$ Alsine rotundifolia, sive Portulaca aquatica. G. E. 614 .

Watery places, gravelly, sandy, or heathy soil. * Southleigh Heath, Ensham Heath, Nettlebed. Sb. Clay-pit, N. E. corner of Shotover Hill. (Bagley Wood.) Bx.

An. July.

Stems prostrate, a few inches long, resting in the mud, sometimes floating, square, smooth, leafy. $F$. small, axillary, stalkless, reddish. Pet. often wanting. Fil. pinky red. Ls. crowded at the extremity.

(Oxýria réniformis. Kidney-shaped Mountain Sorrel. Rumex dígynus. E. B. 910. Walls at Tortworth, Gloucestershire. Tur.)

1 Name Arabic.

2 A very different fungus from that which is found on the stems and leaves of wheat, \&c. Bx. 


\section{HEXANDRIA TRIGYNIA.}

RUMEX. Dock, and Sorrel.

* Flowers all perfect.

R. sanguineus. Bloody-veined D. $\quad$ B. Green-veined $D$. Permanent petals entire, oblong, one of them at least tubercled. Leaves spear-shaped; somewhat heartshaped. E. B. 1533. Lapathum sativum sanguineum. G. E. 390. $\beta$. viridis. Sb. 118. Rumex acutus. C. 3. 21.

Shady places, road sides. L. Green-veined. Headington Hill. Sb. and R. W. Magdalen College Walks. R. W. Church-yard, St. Peter in the East. $\boldsymbol{B} x$.

\section{Per. July.}

Stem two or three f., straight, branched, leafy, smooth, reddish. L Ls. stalked, smooth, veiny with deep-red. $F \boldsymbol{F}$. in distant, small clusters, drooping, alternate, almost leafless. Cal. and pet. entire, each with red, swelling rib. Fruit large, red tubercle. In var. $\beta$. ls. green. 'This var. distinguished from R. acutus, which last has more zigzag, leafy branches, shorter and smaller valves, all grain-bearing, and by its growth in marshy situations.

Root in dying affords from straw-colour, to a good olive, and a fine, deep green to cloths previously blued. With. under var. of $R$. acutus, that is var. $\beta$. of $R$. sanguineus.

R. crispus. Curled D. Permanent petals egg-shaped, entire, all tuberculated. Leaves spear-shaped, wavy, much curled at the edge, acute. E. B. 1998. C. 2. 20.

Waste ground, pastures, road-sides.

Per. July.

Stem two or three f., furrowed, leafy, branched. Ls. stalked, upper $l s$. narrower, almost stalkless. $\boldsymbol{F} l$. pale-green clusters drooping, near each other, leafy below. Fruit-valves large, eggheart-shaped, veined like net-work, waved; with a central grain, prominent.

Discrim. Curled $l$. and large, entire cal. $l$. Very injurious in clover fields. Fresh roots bruised, in ointment, or in decoction, for itch. Fl. Suec.

R. acútus. Sharp D. Permanent petals oblong, obscurely toothed, all tuberculated. Lowermost leaves oblong-heart-shaped at the base, pointed, upper ones, small narrow. Clusters leafy. E. B. 724. C. 3. 21. the figure. 
Low meadows, watery places.

Per. July.

Clusters spreading, lengthened out. Seed small.

R. obtusifólius. Broad-leaved $D$. Permanent petals toothed; one principally tubercled. Root leaves eggheart-shaped, blunt. Stem roughish. E. B. 1999. C. 3. 22. Lapathum sylvestre, folio minùs acuto. G. E. 388 .

Waste ground, pastures, road-sides.

Per. July.

Stems two or three f., upright, branched, leafy, furrowed. $L s$. root-ones very large: stem-ones much narrower, more pointed, shorter stalked, somewhat notched, slightly curled. $\quad \boldsymbol{F} l$. clusters rather close with few, sometimes not any leaves. Fruit-valves entire at the upper part, three sharp, prominent teeth, on each side, near the base.

Eaten by fallow deer with avidity, close to the root. Destroyed by frequent mowing.

Discrim. Its broad, large, root $l s$.

R. pulcher. Fiddle D. Permanent petals toothed; one principally grain-bearing. Root leaves somewhat violin-shaped. Stem smooth, straggling, E. B. 1576.

Pastures, church-yards, dry, waste ground. Near the Observatory. Christ Church Meadow. Dr. Williams, Professor of Bot., Oxford.

Per. August.

$L s$. root-ones on long stalks; stem-ones small, narrow, undivided. $F \boldsymbol{F}$. in distant, small clusters, green, hanging down; anth. yellow. Fruit-valves deeply, sharply toothed; grain oblong, reddish.

R. marítimus. Golden D. Enlarged petals permanent, triangular, tuberculated, fringed with taper teeth. Leaves linear. Whorls crowded. E. B. 725.

Marshes.** Otmoor, on the side of the road to Oddington. Professor Daubeny, and $B x$.

Per. July, August.

Flowers in close, leafy whorls, finally confluent (thronging together,) like the whole plant, assuming a rich, tawny-golden hue. Ls. stalked, acute, flat.

R. Hydrolápathum. Great Water D. Permanent petals egg-shaped-oblong, nearly entire, unequally grain-bearing. Leaves spear-shaped, tapering, acute at each end. Whorls rather crowded, almost entirely leafless. R. aquaticus. E. B. 2104.

Marsh land, ditches, stagnant waters, margins of great rivers. 
Per. August.

Largest of our docks. Root large, knobby. Stem four to five f. $L s$. lower ones heart-shaped at the base, to eighteen inches in length.

Discrim. Size of the $l s$., foot and a half long, or more.

Root very astringent. Good anti-scorbutic. Powdered root an excellent dentifrice. Wash in decoction for spongy gums.

*** Flowers dicecious.

R. Acetósa. Common Sorrel. Flowers diœcious. Leaves oblong, arrow-shaped, with segments approaching the foot-stalks. Permanent petals tuberculated, (grainbearing.) E. B. 12\%. Oxalis sive Acetosa. G. E. 396.

Meadows, pastures.

Per. June.

Stem mostly simple, erect, slender, striated, one to two f. Ls. somewhat succulent, root, and lower stem-ones, long stalked. Stip. slender, cylindric, sheathing, torn at top: upper $l s$. stalkless, gradually more entire. $F \boldsymbol{F}$. reddish, in a sort of compound, whorled spike, branches alternate, almost erect.

Plant acid, astringent, anti-scorbutic: in salads. The boiled juice to turn milk acid: an agreeable food to Laplanders, keeping a considerable time: cultivated for the table in France. Eaten with fish, in Ireland. Dried root boiled gives a fine red colour. What has been named Salt of Lemons may be prepared from this plant; the mucilaginous parts, separated by water mixed with pipe-clay, and the rest crystallized.

R. Acetósella. Sheep's Sorrel. Flowers diœecious. Leaves spear-shaped, halbert-shaped. Permanent petals without grains. E. B. 1674. C. 5. 29. Oxalis tenuifolia. G. E. $39 \%$.

Dry, gravelly pastures, fields.

Per. June.

About half the size of R. Acetosa, with stem more slender. Herb acid, somewhat astringent. $F l$. reddish. Spikes long, whorled. Fl.-stalks drooping, hair-like. Ls. narrow, lobes at the base point upwards, or horizontally, as it were hooked; in R. acetosa backwards. Ls, variable in shape.

Conspicuous from its bright red leaves, at the decline of the year.

\section{TRIGLO'CHIN. ${ }^{\prime} \quad$ Arrow-grass.}

T. palustre. Marsh $A$. Capsule nearly linear, of three cells; tapering at the base. Root fibrous. E. B.

1 From tris, Gr. three, and glochin, Gr. the point of a dart: from the capsules bursting in three points. 
366. H. L. 98. Gramen marinum spicatum. G. E. 20 .

Wet, boggy meadows.

Per. July.

Stalk one f., simple, naked. Ls. rushy, semi-cylindric, with a membranous, sheathing stip., within the $L s$. Fl. spike, long, thickset, slender; $f$. small, greenish.

Eaten by cattle. Cows fond of it.

\section{CO'LCHICUM. ${ }^{x}$ Meadow-saffron.}

C. autumnále. Common M. S. Leaves flat, spearshaped, erect. Segments of the corolla oblong. E. B. 133. C. anglicum purpureum et album. G. E. $15 \%$.

Moist, rich meadons. * * Coombe. Heythorp. Stanton Harcourt. Ashford Mills. Sb. Barton. Church Handborough. Bx. (Cumnor. $\quad$.)

Per. September.

Bulb large. $\mathbf{F l}$. pale-purple, immediately from the root, leafless.

Styles reaching to the root. Caps. large, somewhat egg-shaped.

Blossom-tube three-cornered.

The $f$. appear late in autumn, the germ. remains under ground close to the bulb until the following spring, when the caps. with its seeds, and the $l s$. rise above the ground: the seeds are ripened about June, and the $l s$. decay. As the plant blossoms late in the year, this is a providential contrivance to perfect, preserve, and at length to sow the seeds, buried deep in the ground, out of the reach of frost. See Paley's Nat. Theology.

Plant poisonous. . A tincture of the root and seeds used in gout, and rheumatism : a dangerous remedy in the former : the supposed basis of the eau-médicinale. It sometimes proves violently purgative, and debilitating; hence its danger in gout. Gerarde makes cow's milk an antidote to the deleterious powers of this plant. Farmers should be cautious of turning cattle into fields where this plant grows.

\section{HEXANDRIA POLYGYNIA.}

\section{ALISMA. Water-plantain.}

A. Plantágo. Great $W_{--p}$. Leaves egg-shaped, acute. Capsules bluntly triangular. E. B. $83 \%$ C. 5. $2 \%$ Plantago aquatica major. G. E. $41 \%$.

Pools, ditches, margins of rivers. 
Per. June.

Ls. root-ones erect, long stalked, ribbed. $F l$. stalk naked, two or three f., its branches numerous, whorled, compound, spreading, bracteated : each $f$. partially stalked, erect. $\boldsymbol{P} e t$. pale, reddishpurple, yellow at the base. Caps. about eighteen, egg-shaped.

(A. Damasónium. Star-headed W.-p. Leaves oblong, five-ribbed, slightly heart-shaped at the base. Styles six. Capsules tapering, six, spreading in the form of a star. E. B. 1615. C. 5. 28. Plantago aquatica minor stellata. G. E. 417. Actinocarpus Damasónium of $\mathrm{Br}$. , and $\mathrm{H}$.

Ditches and pools.* Winkfield Plain, near Windsor, Berks. Ditches about Southcote, near Reading, Berks. Tur.

Per. June, July.

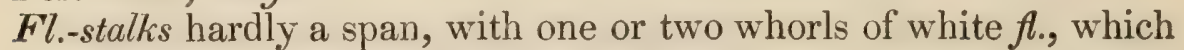
are yellow in the middle.)

A. ranunculoídes. Less $W_{\cdot-p}$. Leaves linear-spearshaped. Capsules angular, acute, numerous, in a globular head. Stem none. E. B. 326. H. L. 28. Plantago aquatica humilis. G. E. 417.

Swamps, turfy bogs. Cowley Marsh. B.x. Southleigh Heath. Otmoor. $\quad S b$.

Per. June.

L.-stalks long, spongy. Stalk upright, or lying down, bearing two or more whorls on long, round fl.-stalks, with small, membranous bract. at the insertion. Fl. pale-purple, yellow at the base. Cal. $l s$ s small, roundish, concave, permanent.

Discrim. The seeds in a globular head: in A. Plantago they are very blunt and compressed.

\section{Class VIII. OCTANDRIA. Stamens 8.}

Order I. MONOGYNIA. Pistil 1.

EPILO'BIUM. ${ }^{x}$ Willow-Herb.

* Flowers irregular.

E. angustifólium. Rose-bay W. Persian, or French Willow. Leaves seattered, linear-spear-shaped, veiny, smooth. Petals unequal. Stamens descending arch-

1 i. e. ion cpi lobon, Gr. violet on a pod. Beckmann. Lex. Botanicum. 


\section{wise. E. B. 194\% C. 2. 24. Chamænerion. G.} E. $47 \%$.

Woods. Grays, near Henley, Sm. Eng. Fl. Stokenchurch.

Sb. (Outside of a Copse beyond Childswell Farm. Bx.) Per. June.

Stems three to six f., erect, wand-like, leafy, smooth. Ls. numerous, nearly stalkless, acute, entire, or slightly toothed. Fl. in a long, upright spike, handsome. Stalks and Cal. reddish, larger, pet. inversely ego-shaped, or inversely heart-shaped, crimson, irregular. Style bent downwards. Pollen blue. Stigm. four-cleft.

$F l$. sometimes white: plant increases rapidly by root.

Suckers of the root eatable: infusion of the plant intoxicating: an ale in Kamschatca, brewed from the pith. Down of the seeds has been mixed with cotton or fur in manufacturing stockings, \&c. * Flowers regular. Stigma deeply four-cleft.

\section{E. hirsútum. Great Hairy W. Codlings and Cream.} Leaves half clasping the stem, egg-spear-shaped, hairy. Stem hairy, much branched. Root creeping. E. B. 838. C. 2. 21. Lysimachia siliquosa. G. E. 476 . Watery places, ditches, margins of rivers.

Per. July.

Stem four f., or more, leafy. Ls. toothed, somewhat saw-toothed, lower ones opposite, uppermost alternate, stalkless. Branches and fr.-stalks from the bosom of the leaves. $F \boldsymbol{F}$. corymbose, large, handsome, each with a small leaf. Pet. inversely heartshaped, twice as long as cal., pink.

Of a delicate, acid smell, pleasant, but transitory: hence name, codlings, \&c.

Discrim. from Ep. parviflorum, by its creeping root, tall, branching stem, broad $l s$. and much larger $f$.

If eaten by cattle, green or dried, the plant, from its rapid increase, in moist situations, would be worth cultivation.

E. parvifórum. Small-flowered Hoary $W$. Leaves stalkless, slightly toothed, spear-shaped, downy. Stem nearly simple, woolly. Root fibrous. E. B. 795. E. villosum. C. 2. 22. Sb. 121.

Watery places, banks of rivers.

Per. July.

Stem scarcely two f. Ls. middle-ones stalkless, upper, sometimes, on very short foot-stalks, lower-ones opposite, upper, alternate. $\boldsymbol{F l}$. small, corymbose, terminal, leafy, becoming a spike. $\boldsymbol{P}_{e t}$. inversely heart-shaped, pale rose-colour, or purplish. $F \boldsymbol{F}$. and ls. much smaller than in Ep. hirsutum, or in Ep. angustifolium.

E montánum. Broad Smooth-leaved $W$. Leaves stalked, egg-spear-shaped, toothed. Stem round. Stigma in 
four deep segments. E. B. 1177. C. 3. 24. Lysimachia campestris. G. E. 478.

Dry, shady, hilly, stony places.

Per. July.

Shoots red. Stem slender, very soft to the touch, erect, scarcely branched, leafy. Ls. smooth, often tinged with red, as the stem, lower ones opposite, uppermost alternate, and narrower. $F l$. cluster, simple, leafy, terminal, pale purple, sometimes white. *** Flowers regular. Stigma undivided.

E. tetragónum. Square-stalked $W$. Leaves spearshaped, stalkless, minutely toothed. Stem erect, unequally four-cornered. Stigma undivided. E. B. 1948. C. 2. 23. Lysimachia siliquosa glabra media, sive minor. G. E. 479.

Ditches, watery, marshy places.

Per. July.

Stem twelve to eighteen inches, branched, leafy, nearly smooth.

Ls. smooth, mostly alternate. $F \boldsymbol{F}$. few, in leafy clusters, small, pet. pale, purple, cloven. Stig. club-shaped.

Discrim. from Ep. palustre, by its square-like stalk, arising from two prominent lines from the base of the $l s$., known by its angular stem, generally narrow $l s$. very long pods, and undivided stigma.

E. palustre. Round-stalked Marsh $W$. Leaves stalkless, linear-spear-shaped, slightly toothed. Stem round. Stigma undivided. E. B. 346. Chamænerion alterum angustifolium. G. E. 477 .

Boggy, turfy ground.

Per. July.

Stem about one f., erect, leafy, round. $L s$. mostly opposite, upper ones alternate. $F l$. in an erect, small, leafy cluster, pale purple. $\boldsymbol{P}$ et. inversely heart-shaped. Sometimes nearly the whole plant smooth, or scarcely downy. Short, leafy branches from the bosom of the $l s$.

Discrim. From Ep. tetragonum, by its round stem, narrow $l s$. and in being generally smaller.

\section{CHLORA. Yellow-wort.}

C. perfoliáta. Perfoliate $\boldsymbol{Y}$. Leaves perfoliate. Panicle forked, many-flowered. E. B. 60. H. L. 2. Centaurium parvum luteum Lobelii. G. E. $54 \%$.

Chalky hills, or banks; also on a clay soil. Sm.** Penley Hangings. $\boldsymbol{S b}$. Stone-pit near the old road to Ensham. $\boldsymbol{B} x$.

An. July.

Whole plant glaucous, very bitter. $F$ l in a kind of umbel, of three rays, encompassed by the uppermost $l s$, the middle one 
bearing a single $f$. without any $l s$., the outer ones terminated by a leaf similar to the stem ones. Cor. full yellow. Stig. scarlet. A handsome plant.

\section{VACCI'NIUM. Whortle-berry. ${ }^{\mathrm{I}}$ \\ * Leaves deciduous.}

V. Myrtillus. Black W. Bilberry. Stalks solitary, single-flowered. Leaves egg-shaped, saw-toothed, membranous, smooth, deciduous. Stem acutely angular. Calyx wavy, nearly entire. E. B. 456. Vaccinia nigra. G. E. 1415.

** Stony heaths, woods where the soil is turfy. Sm. Checkendon. Woods near Clump House. Sb. (Bagley Wood.) $\boldsymbol{Y}$.

Shrub. April.

Stem forming small tufted bushes. Ls. alternate, bright-green, shortly stalked. $F l$. drooping, stalks short, round. Cor. nearly globular, bright-red, waxy in appearance, transparent. Berr. roundish, dimpled, bluish-black. Stam. generally ten. Anth. cloven and horned.

The tender $l s$, dried in the shade a good substitute for tea. The ripe berries in tarts: and food for moor-game: berries astringent.

\section{* Leaves evergreen.}

(V. Vitis Idca. Red $W$. Cow-berry. Clusters terminal, drooping ; with egg-shaped concave bracteas, longer than the flower-stalks. Leaves inversely eggshaped, rolled back, minutely toothed; dotted beneath. Corolla bell-shaped. E. B. 598. Vaccinia rubra. G. E. 1415 .

Dry, stony, turfy heaths, mountainous woods. Heaths between Middleton and Sutton, Warwickshire. $P$.

Shrub. June.

A low, box-tree-like shrub, with red berries.)

(V. Oxycoccus. Marsh W. Cranberry. Leaves eggshaped, entire, smooth, rolled back, acute. Stems creeping, thread-shaped, smooth. Flowers terminal. Corolla deeply four-cleft. E. B. 319. Vaccinia palustria. G. E. 1419.

Clear, watery, turfy bogs, among mosses. Pool in Chelmsley Wood, \&c. Bree.

Shrub. June.

Slender, trailing. Berries deep-red, at first spotted.)

1 Ang.-Sax. heord berian, i. e. stag's berry. 


\section{CALLU'NA. ${ }^{.}$Ling.}

C. vulgáris. Common Ling. Erica vulgaris. E. B. 1013. C. 5. 30 . G. E. 1380 . Sb. 124 .

Dry moors, heaths, open, barren wastes. $\beta$. Var. leaves densely hoary. Ensham Heath. SZ.

Shrub. July.

Anth. bearded, concealed. Style prominent. Cor. deeply cut, shorter than the coloured cal. Stems woody, much branched. $\boldsymbol{L} \boldsymbol{s}$. oppositely tiled, forming a four-angled figure. $\mathbf{F l}$. rosecoloured, shining, clusters longish. Cal.-ls. inner four large, concave, coloured.

$F l$. retain their colour when dried.

$L s$. and seeds food for grouse. Woody stems for brooms, and firing. In the Scotch Highlands, walls for cottages, with alternate layers of heath, and a mortar of black earth and straw; their beds made of it: a substitute for thatch. In the island of Ilay, ale brewed from one part malt, two parts of young heath tops; hops sometimes added. This liquor much used by the Picts, according to Boethius. Strong decoction of the tops dyes woollen cloth, boiled in alum water, of an orange colour. The stalks and tops to tan leather. The tops to fill up drains covered over. Where bees extract their honey from the flower, the honey reddish. Ropes made of them, strong, and durable: edging to garden-borders instead of box.

\section{ERI'CA. ${ }^{z}$ Heath.}

E. Tétralix. Cross-leaved $\boldsymbol{H}$. Anthers horned. Style nearly concealed. Corolla egg-shaped. Leaves fringed, mostly four in a whorl. Flowers in round tufts. E. B. 1014. C. 1. 21 .

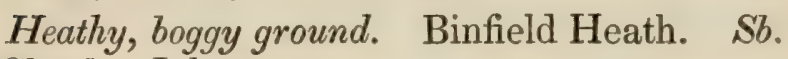

Shrub. July.

Stems leafy, branched at the bottom, determinately, or very like it, many branches, springing from one centre. $\boldsymbol{F l}$. like a cluster of berries. Cor. oblong, drooping, wax-like, delicate, from deep rose-colour to almost every shade of carnation: orifice small, four-toothed. Caps, with partitions from the centre of its valves. $L s$. bristly, spreading, sometimes five in a whorl.

Var. white $f$. $\quad S b$.

Most elegant plant.

E. cinérea. Fine-leaved H. Anthers crested. Style a little prominent. Stigma growing in a head. Corolla

1 Gr. Kalluno, to adorn, to sweep, to clean, alluding to its cleansing ase for brooms, or to the beauty of its $f$. Genus differs from Erica in its $f$. and capsule.

2 Cape of Good Hope plants. No American Erica known. 
egg-shaped. Leaves three in a whorl. E. B. 1015. C. 2. 25. E. tenuifolia. G. E. 1382 .

Dry, turfy heaths. Checkendon. Woods near Clump House. Sb. Shrub. July.

Stems branched, one f., or more. $L s$. in threes, with tufts of young ones, linear-spear-shaped, furrowed at the back, smooth. $F l$. in long, whorled, leafy, clustered spikes, drooping, bluish-purple. Cal. acute. Cor. less swollen than that of E. Tetralix, orifice segments four, upright.

Var. Fl. white.

\section{DAPHNE. Mezereon. Spurge-laurel.}

D. Mezéreum. Common M. Spurge-olive. Flowers naked on the stem, stalkless, about three together. Leaves spear-shaped, deciduous. E. B. 1381.

In woods. Near Appleton, Berks. Dr. Williams, Bot. Prof. Oxford. Wychwood Forest. Sm. Eng. Fl. Appleton Common. $B x$.

Shrub. March.

Plant four or five f., smooth, except the cal. tube. Fl. rosecoloured, or white, appear before the $l s$. Ls. scattered. Berr. red, globular.

$F l$. beautiful, fragrant. Plant acrid, a powerful deobstruent. Six of the berries will destroy a wolf. Twelve grains of the berries given to a girl, produced a vomiting of blood, which caused immediate death. Decoction of the root-bark in Syphilis. Daphne Mezereum, Verátrum album, and Menispermum cócculus, to communicate an intoxicating quality, and strong taste to weak beer: a dangerous and diabolical practice. Camphor an antidote to this poisonous plant. Supposed a native by Miller in Gard. Dict.

D. Lauréola. Spurge-l. Clusters axillary, simple, each of about five flowers, drooping, shorter than the smooth, inversely, egg-spear-shaped, evergreen leaves. Calyx blunt. E. B. 119. Laureola. G. E. 1404.

Woods, thickets, hedges. Shotover. Bx. Near Henley. Sb. Shrub. March.

Plant smooth. Stem round, about three f., naked below, tufted with $l s$. at the summit. $F l$. yellowish-green, inconspicuous, smell perceptible in the evening, disagreeable. Bract. concave, oval. Anth. orange. Berry black.

Plant acrid, brisk, severe purgative, in worm cases, and acute rheumatism: bark of the root strongest: largest dose, ten gr.

The elegant and fragrant D. Cneórum grafted on this by gardeners. 


\section{ACER. Maple.}

A. Pseudo-Plátanus. Great M. or Sycamore. Leaves five-lobed, unequally saw-toothed. Clusters drooping E. B. 303. A. majus. G. E. 1484.

Hedges, about houses.

Tree. May.

Bark smooth, ash-coloured. Ls. large, strongly veined. Fl. clusters axillary, long, many $f$. Cor. pet. green, much like the cal. segm. Fruit seed-wings often three, ripen in August; not so straddling as in A. campestre.

Handsome, quick-growing tree, not injurious to grass, but the $l s$. fall early. Wood soft. Sap sugary, made into wine in Scotch Highlands. Flourishes on a sandy soil: bears transplanting well: grows best near the sea. See Gent. Mag. 1757. p. 252. Its pollen, a curious microscopic object: when moistened, the globules burst into four cross-like valves.

A. campestre. Common M. Leaves five-lobed, blunt, somewhat cut. Clusters corymbose, erect. E. B. 304. A. minus. G. E. 1484 .

Hedges, thickets.

Tree. June.

Small tree. Branches straddling. Bark smooth: that of the stem fissured. Ls. smaller than in most of our trees, opposite. $F l$. green, much like those of A. Pseudo-platanus. Caps. much straddling.

Wood compact, fine grained, beautifully veined. The Romans set a high value on their tables of veined Maple-wood. Vessels of this wood turned so thin as to transmit light.

\section{OCTANDRIA TRIGYNIA.}

POLY'GONUM. ${ }^{2} \quad$ Persicária, Bistort, Knot-grass, and Buck-wheat.

* Styles usually but two.

P. amphíbium. Amphibious Persicaria. Styles two, united half way up. Stamens five. Spike egg-shaped. E. B. 436. C. 4. 28. P. angustifolium. G. E. 821 .

'i. e. false (plane.)

2 Polus, Gr. much, and gonu, Gr. a knee; from the stalks perhaps being geniculated or kneed. 
Ponds, ditches, or their banks.

Per. July.

Ls. smooth, fringed, floating on the water; out of the water, stems more erect. Ls. narrower, hairy, $f$. less numerous. Stem creeping, round, branched below, leafy. Stip. tubular, membranous. Ls. stalked, alternate, spear-shaped, or oblong, heartshaped at the base, acute. Spike erect, fl.-stalk reddish. Bract. egg-shaped, membranous, pointed. Stig. red, globular. Seed compressed.

Seed, food for water fowl. $F l$. ornamental to pieces of water. The only peren. spec. Plant strangely metamorphosed by change of situation.

P. Persicária. ${ }^{1}$ Spotted $\boldsymbol{P}$. Styles two, united half way up. Stamens six. Clusters dense, egg-oblong, erect, on smooth stalks. Stipulas fringed. E. B. 756. C. 1. 23. P. maculosa. G. E. 445 .

Ditches, wet fields, watery places.

An. August.

Stem erect, about two f., branched, alternate, leafy, often reddish, mostly swollen above each joint. Ls. almost stalkless, spearshaped, entire, generally marked with a black, horse-shoe spot. Stip. tubular. $\boldsymbol{F l}$. rose-coloured, or whitish at the tips. $\boldsymbol{F} l_{0}$ stalks springing from the stip. at the stem-joints.

$\operatorname{Var}$. $\beta$. $L$. hoary beneath. $\boldsymbol{\gamma}$. L. with a silvery hue, both common.

Taste slightly acid, and astringent. Plant dyes a yellow colour in woollen. $F l$. Suec.

P. lapathifólium. Pale-flowered P. Styles two, distinct. Stamens six. Flower-stalks rough, glandular. Stipulas beardless. Seeds concàve at each side. E. B. 1382. Sb. 129. P. pensylvanicum. C. 1. 24, 25. Hydropiper. G. E. 445.

Cultivated ground, dunghills.

An. August.

Several var. 1. with pale whitish $f$. 2. red $f$. and stem: 3. spotted stem: 4. ls. smooth. 5. Ls. hoary on under side. Specific character rests on the separate styles, rough glandular fl.-stalks, and beardless stip., not fringed. Stem. three f. Spikes thicker than those of P. Persicaria. Ls. egg-spear-shaped, uppermost dotted beneath with minute glands. Fruit-stalks covered with minutely stalked yellowish globules.

Var. $\gamma$. salicifolium. $S b$.

Seeds food for small birds.

P. Hydrópiper. ${ }^{2}$ Biting $P$. Styles two, forked, united

1 From the resemblance of the $l$. to those of the peach (Persica.)

2 i. e. Water pepper. 
half way up. Stamens six. Clusters lax, interrupted, drooping. Stem erect. Leaves spear-shaped, wavy, without spots. E. B. $989 . \quad$ C. 1. 26.

Ditches, watery places.

An. September.

Discrim. Its slender, drooping, lax spikes, light green $7 s$. spotless.

Cal. whitish, tipped with red, glandular. From P. minus by its

l. (of Hydropiper) waved, and not flat; and by its divided style.

$L s$. tapering to a point, alternate.

The acrid property of the plant, in an oil residing in the glandular dots scattered over. Dyes wool yellow: diuretic. Antiodontalgic.

P. minus. Small Creeping $\boldsymbol{P}$. Styles two combined. Stamens six. Clusters lax, slender, nearly upright. Stem trailing at the base. Leaves linear-spear-shaped, flat. E. B. 1043. C. 1. 28. Persicaria pusilla repens. G. E. 446.

Watery commons, marshes.** Otmoor. Sb. Port Meadow, opposite to Lower Woolvercot. Bx.

An. September.

Smaller than P. Hydrop. more trailing. $F l$. without glandular dots. Ls. flat, not acrid. Stems nine inches to one f. Styles sometimes slightly cloven into three.

\section{** Styles three.}

P. Bistorta. Great Bistort, or Snake-weed. Stem simple, with a single, spiked, cluster of flowers. Leaves egg-shaped, wavy, running down into footstalks. E. B. 509. C. 1. 22. Bistorta major. G. E. 399. Baxter's plates, 5 .

Meadows** Banks of the Isis beyond Iffley. Near Gosford Bridge. Sb. Oseney Meadow. Mr. C. B. Hewlett.

Per. May.

Stem about one f. and a half, leafy. Ls. veiny, fine green, footstalks winged. Stalks of the stem $l s$. dilated, sheathing. $F l$. numerous, pink, each standing on a slender, rose-coloured stalk. Bract. pair of membranous ones at the base.

Root powerfully astringent. Young shoots eaten for greens. Plant for tanning leather.

P. aviculáre. Common Knot-grass. Flowers axillary. Leaves elliptic-spear-shaped, rough-edged. Ribs of the stipulas distant. Stem trailing, herbaceous. E. B. 1252. C. 1. 27. P. mas vulgare. G. E. 565 .

Waste and cultivated grounds.

1 Twice, and twisted (root.) 
An. June.

Stems branches much straddling, slightly furrowed, glaucous, or purplish. Ls. alternate, entire. Stip. often red. Fl. clustered, on short stalks, small, red, white, and green, coloured. Seed black, polished. $F$. greenish on outside, white within, often tinged with pink; from egg-shaped, to spear-shaped, and even linear. Variable in shape, and size of $l s$. Stam. seldom ten.

Seeds food for small birds: for same uses as those of P. Fagópyrum. Hogs eat the plant with avidity. This one of the plants, which have acquired the name of grass, because eaten by cattle.

\section{*P. Fagópyrum. Buck-wheat, or Brank. Leaves} heart-arrow-shaped. Stem nearly upright, without prickles. Angles of the seeds even. E. B. 1044. Tragopyron. G. E. 89 .

Cultivated fields. From the East originally.

An. July.

Root fibrous. Plant succulent. Stem one f., or more, branched, rather zigzag, smooth, leafy, except a downy line on one side. Ls. acute, smooth; uppermost stalkless. Stip. small. $F \boldsymbol{F l}$. in panicled clusters, variegated with red and white; yellow glands between all the filaments. Styles divided to the base.

Very impatient of frost. Seeds made into meal-cakes here, and in Japan; food for pheasants, and poultry; plarited near bee-hives, as flowering late. Unwholesome food for sheep. Used for cleaning foul land: ploughed in as a manure when fully grown, or mown for fattening swine and poultry with the grain. An oil from the seeds.

P. Convólvulus. Climbing Buck-wheat. Black Bindweed. Leaves heart-arrow-shaped. Stem twining, angular. Segments of the calyx bluntly keeled. E. B. 941. C. 4. 29. Volubilis nigra. G. E. 863.

Cornfields, gardens.

An. July.

Stem climbing to five to six f., leafy, unsupported; the stem is short and trailing. Ls. alternate, stalked, waved, smooth. $F \boldsymbol{F l}$. greenish-white, found even as low as the base of the common fl.stalk; in terminal, interrupted spikes, each on a small drooping stalk.

Seeds for small birds, nutritious, like those of P. Fagop. but less in size.

1 i. e. Wheat resembling the beech (mast,) fugus, and puros. 


\section{OCTANDRIA TETRAGYNIA.}

\section{PARIS.' Herb Paris.}

P. quadrifólia. Common Herb Paris. Leaves eggshaped, mostly four, fixed to the top of the stalk. E. B. 7. Herba Paris. G. E. 405. Baxter's plates, 6 . Groves, shady places.** Headington Wick Copse. Sb. Wood in Mungewell. John Oylander, Esq. Wytham Wood. Bx.

Per. May.

Stem simple, about one f. Styles purplish-black, hardly so long as the berry. Blossoms pale-green. Cal.-leaflets green. Four oval, stalkless $l s$., whorled at the top of the stalk, with a single, greenish, central fl. and afterwards black berry.

Four the prevailing number in this singular plant. $L s$, three or five sometimes. Roots emetic, dose twice the quantity of ipecacuanha. Berry narcotic.

\section{'ADOXA. ${ }^{2}$ Moschatell. ${ }^{3}$}

A. Moschatéllina. Tuberous M. E. B. 453. C. 2. 26. Radix cava minima viridi flore. G. E. 1091.

Groves, thickets, shady hedges. Shotover Plantations. Southleigh. Woods near Ashford Mills. Sb.

Per. April.

Stem-root of fieshy, tiled scales, with fibres from the interstices. Herb pale-green, fleshy, smooth. Stem erect, three or four inches. $L s$. root-ones, doubly ternate, wedge-shaped, lobed; those on the stem three-cleft, opposite, simple, shorter stalked. $F l$. in a head of five, stalkless, whitish-green $f l$ : four of them from the side of the stem. The terminal one, having but eight stam. referred by Linn. to Octandria, according to his rule. Caps. of four cells, invested with fleshy cal.

\section{(ELA'TINE. Water-wort.}

E. tripétala. Small $W$. Leaves opposite, rough, with minute points. Flowers mostly three-cleft. E. Hydropiper. E. B. 955 . E. hexandra. H.

Margins of ponds or ditches, sandy soil. Near Binfield, Berks. Mr . T. F. Forster. Sm. Eng. Fl.

An. July, August.

Aquatic herb, not unlike Montia.)

1 From par, paris, equal, Lat. from the equality of the number four in this plant.

${ }_{2}^{2}$ Gr. Inglorious. From its modest, unassuming appearance, as it emerges from its wintry bed of dry leaves.

${ }^{3}$ From the musky smell of the fl. 


\section{Class IX. ENNEANDRIA. Stamens 9.}

\section{Order I. HEXAGYNIA. Pistils 6.}

\section{BU'TOMUS.' Flowering-rush.}

B. umbellátus. Common F. E. B. 651 . C. 1. 29.

Ditches and margins of rivers, on gravelly soil. Christ Church Meadow. Pools on the sides of the Botley Road. Near Ensham. Sb.

Per. June.

Only British plant of Enneandria.

Plant lower part immersed in water. Ls. all immediately from the root, erect, near three f., linear, triangular, pointed, flat in the upper part. Stalk taller than the $l s$. simple, solitary. Umbel terminal, simple, many-flowered. Bract. brown, sharp, spear-shaped. Fl. large, shaded rose-colour. Anth. red. Germ. red.

Amongst our peculiar, and most ornamental British plants. Not eaten by cattle in general.

\section{Class X. DECANDRIA. Stamens 10.}

\section{Order I. MONOGYNIA. Pistil 1.}

\section{MONO'TROPA. ${ }^{2}$ Bird's-nest.}

M. Hypópitys. ${ }^{3}$ Yellow $\boldsymbol{B}$. Flowers in a drooping cluster; side-one with eight stamens; terminal one with ten. E. B. 69. H. L. 105. Plot. 146. t. 9. f. 6.

Roots of beeches and firs. Stokenchurch. Woods between Nettlebed and Henley. Sb. Frequent in the Counties of Oxford, Bedford, Buckingham, and Berks. Huds. Stokenchurch Woods. Ray. Near Buckland, Berks. Mr. John Reddy. Slade Woods, Gloucestershire. Mr. Sandys, Pembroke College, Oxford.

Per. July.

Stem thick, fleshy, scaly, tiled, closely so at the lower part. Plant pale straw-colour, $f$., same colour. $F$. side ones from six to eight stam. Plant exhales a fragrant smell, during the process of its becoming dry, and black. Flower-spike nodding: it

1 From bous, an ox, Gr. and temno, to cut, Gr. because the sharp leaves cut the mouths of browsing cattle.

2 Gr. solitary, (Monot. Hyp.) and tropo, to turn.

3 i. e. Gr. Under the fir. 
becomes erect in seeding. Whole plant smells like the primrose, or like beans in blossom.

\section{PY'ROLA.' Winter-green.}

(P. rotundifolia. Round-leaved W.-gr. Stamens ascending. Style twice as long as the stamens; declining and bent down, curved upwards at the end. Cluster many-flowered. Calyx as long as the stamens. E. B. 213. Pyrola. G. E. 408.

Bushy places, dry heathy woods.* Slade and Randwich Woods, Gloucestershire. Mr. Sandys, Pembroke College, Oxford.

Per. July, August.

$L s$. nearly round. $F l$. rather drooping, snowy-white, bell-shaped. The largest of the Py'rolas, but varies in size.)

(Andrómeda polifólia. Over Heath. Tur.)

(P. média. Intermediate $W$. Stamens regularly bent in. Style twice as long, bending arch-wise. Cluster of many drooping flowers. Calyx shorter than the stamens. E. B. 1945 . H. L. 30.

Woods. Woods, Meriden, Warwickshire. Bree.

Per. July, August.

Py. média has been confounded with Py. minor : differs fiom Py. minor by its very spirally twisted, fl.-stalk, the declination, and greater length of style. $F l$. globose, milk white.)

P. minor. Less $W$. Stamens regularly bent in. Style the same length, straight. Stigma five-lobed, pointless, without a ring. Cluster of many drooping flowers. E. B. 158. bad. P. rosea. E. B. 2543.

Mossy woods, thickets.** Scrubby Copse, Mungewell. Woods between Nettlebed and Henley. S $b$. Wood about half a mile from Henley. Bx.

Per. June.

Smaller. Fl. rose-coloured. Style short.

\section{DECANDRIA DIGYNIA.}

CHRYsosPLE'NIUM. Golden-saxifrage.

(Ch. alternifolium. Alternate-leaved $G$. Leaves alternate. E. B. 54 .

\footnotetext{
1 From supposed resemblance of $l s$, to a pyrus, or pear-tree.
} 
Borders of shady rivulets. * Balsal Temple, Warwickshire. Pn. Dowdeswell Woods, Gloucestershire. Mr.W. C. Trevelyan. Per. May.

$L s$. kidney-shaped, and notched. Corymb. of deep yellow $f$.)

Ch. oppositifólium. Opposite-leaved $G$. Leaves opposite. E. B. 490. C. 2. 2\%. Saxifraga aurea. G. E. 841 .

Watery, shady places. Shotover Hill, near the spring. Shotover Plantations. Sb. Horspath Lane. R. W.

Per. April.

Plant fleshy, grows in broad patches of a yellowish hue. Is. stalked, inclining to heart-shaped, notched. Fls. corymb terminal, leafy, pale-yellow, mostly four.cleft. Seeds round, blackish. Paler than the first. Ls. smaller. Stamens eight mostly.

\section{SAXI'FRAGA. Saxifrage.}

* Calyx spreading. Leaves partly lobed. Stigmas mostly downy. Flowering-stems erect, more or less leafy.

S. granuláta. White Meadow S. Leaves kidneyshaped, lobed. Stem panicled, leafy. Root beaded. Germen half-inferior. E. B. 500。 C. 1. 30. S. alba. G. E. 841.

Meadows, pastures, gravelly, or sandy soil. Sm.

Per. May.

Stem one f. Root with several little grains, attached to one main fibre, with small fibres. Stem solitary, erect, branched above, hairs clammy, brown, or reddish. Ls. and cal,-teeth clothed with same kind of hairs. Ls. root-ones long stalked, upper ones nearly stalkless, sharply lobed. Cor. large, white, inversely egg-shaped, much longer than cal. Pet. three veined.

$V$ ar. double $f$. in gardens.

Has been recommended in stone and gravel, because its roots resemble small pebbles, the conclusion, therefore, from doctrine of signatures, should be irresistible. The doctrine of signatures attributed to any substance, having a resemblance to any organ, sovereign virtues in removing the diseases of that organ. B.T.F.

S. tridactylites. Rue-leaved S. Leaves wedge-shaped, with three or five segments ; the uppermost undivided. Stem panicled, leafy. Stalks single-flowered, alternate. Germen inferior. E. B. 501. C. 2. 28. Paronychia rutaceo folio. G. E. 624 .

Walls, roofs, dry, barren ground.

An. April.

Stems three or four inches, variable in height, erect, round, leafy, much branched above. Whole plant covered with clammy 
hairs. Ls. hand-shaped, in three, or pedate in five segments, swollen, fleshy, upper stalk ones undivided. Fl. small, white. Cal. urn-shaped. Pet. scarcely exceeding the cal. This plant flowers soon after Draba verna; becomes in sunny situations of red colour. Plant small. Stem in dry situations, sometimes unbranched, and $l s$. entire.

\section{SCLERAN'THUS. ${ }^{1}$ Knawel. ${ }^{2}$}

S. ánnuus. Annual K. Calyx of the fruit, with spreading, taper, acute, segments. Stems spreading. E. B. 351. Polygonum selinaides, sive knawel. G. E. 566.

Dry, sandy fields.

An. June.

Stems spreading in all directions, much branched, leafy, mostly pale, the outermost trailing at the base only. Ls. opposite, linear, somewhat keeled, acute, not glaucous, nor silvery. $\mathbf{F}$. colour of the herbage, stalkless; clusters, leafy, terminal. Cal. ten ribbed, stam. from five to eight, imperfect. Vapour of the decoction received into the mouth in tooth-ache. Fl. Suee.

(S. perennis. Perennial $K$. Fruit-calyx with segments blunt, and converging, edge broad, membranous. Stems trailing. E. B. 352. G. E. $56 \%$.

Sandy plains. * Creaton, Northamptonshire. Morton.

Per. August to October.

Hue of the plant glaucous, glistening; turning reddish with age. Discrim. 'The broad, white, membranous edges of the calyx. The coccus polonicus, an insect, affording a crimson dye, feeds on this plant. See Upsal Trans. 1742.)

\section{SAPONA'RIA. Soapwort. ${ }^{3}$}

S. officinális. Common S. Calyx cylindrical. Leaves elliptic-spear-shaped. E. B. 1060. C. 2. 29. Saponaria. G. E. 444 .

Meadows, river sides, under hedges. Headington Hill. Marston. Stanton Harcourt. Sb. Marston. R. W.

Per. August.

Stems upright, round, leafy, panicled, about eighteen inches. Plant smooth. $L s$. opposite, united at the base, three ribbed. Fl. panicle roundish. Cor. large, pale-pink, sweet scented. $\boldsymbol{P}$ et. claw four angled. Var. $f$. double.

Juice of the bruised ls, scour almost as well as soap. G. $\boldsymbol{E}$. Used instead of Sarsaparilla. See more on this, in Journal de Med. vol. 66. p. 478. or With. Arrang. and G. E.

I From its somewhat dry, hard flowers, Gr. skleros, hard.

3 From the leaves forming a lather with water.

Germars 


\section{DIANTHUS. ${ }^{1}$ Pink.}

* Flowers aggregate.

D. Arméria. Deptford $\boldsymbol{P}$. Flowers in bundles, tufted. Scales of the calyx spear-shaped, downy, as long as the tube. Petals saw-toothed. E. B. 317. H. L. 134. Caryophyllus pratensis. G. E. 594.

Pastures, hedges, on a gravelly soil. Sm. Near Caversham. Sb. Englefield, Berks. R. W.

An. July.

Stem round, leafy, erect, one foot, forked, and corymbose at the upper part. Ls. all opposite, lower ones broader, somewhat battledore-shaped; those at the stem joints, and under the $f$. narrow, spear-shaped, acute. Fl. small; pet. speckled, with white dots, one $f$. mostly opening at a time.

A degree of elegance about this plant, when minutely examined. * * Flowers solitary, several on the same stem.

(D. deltoides. Maiden $\boldsymbol{P}$. Flowers solitary. Scales of the calyx egg-spear-shaped, acute, seldom more than two. Leaves bluntish, somewhat downy. Petals notched, smooth. E. B. 61. Caryophyllus montanus purpureus. G. E. 593.

Pastures, on gravelly or sandy soil. Langley, Bucks. Salt Hill. Tur.

Per. July, October.

Ls. flat. $\mathbf{F l}$. small, pale rose-colour, with a purple circle.)

\section{DECANDRIA TRIGYNIA.}

SILE'NE. Catchfly, or Campion.

* Flowers in leafy racemes, clusters occasionally somewhat forked.

(S. ánglica. English Catchfly. Hairy and viscid. Petals slightly cloven. Flowers from the sides of the stem, alternate, erect. Lower capsules spreading or bent back. E. B. 1178 . C. 4. 30 .

Cultivated fields, gravelly or sandy soil. Near Burnham, Bucks. Tur.

An. July.

Ls. linear-spear-shaped. $F l$. white, or pale rose-coloured.)

* Stem forked; branches panicled.

S. infláta. Bladder Cam. or Catchfly. Flowers copiously panicled, drooping. Petals cloven half way

1 Flower of Jove, Gr. from the beauty and fragrance of the $\mathrm{Al}$. 
down, mostly without scales. Calyx smooth, swollen; veined like net-work. Stem erect. Leaves eggshaped, acute. Cucubalus Behen. E. B. 164. Sb. 139. Behen album. G. E. 678.

Fields, pastures, way-sides.

Per. June.

$L s$. root-ones tufted, battledore-shaped : stem ls., spear-shaped, or egg-shaped; all glaucous. Stem round, smooth, glaucous, one or two feet, repeatedly forked, panicled. Fl.-stalks long, slender.

$\mathrm{Cor}$. white. Cal. veined with purple and green. Anth. sometimes diseased, large and swollen, with purple dust.

Boiled $l s$., may be eaten as peas. The young shoots boiled, well flavoured.

$$
\text { *** Stem, and branches if ary, forked, leafy. }
$$

S. noctiflóra. Night-flowering $C$. Stem forked. Petals cloven, each with a cloven abrupt scale. Calyx with ten hairy ribs; its teeth linear, almost as long as the tube. E. B. 291.

Fields, on sand or gravel. * Headington. Cowley. Stanton Harcourt. Southleigh. Sb. (Near Wytham Wood, \&c. Bx.)

An. July.

Stem erect, round, leafy, repeatedly forked in the upper part. $L s$. spear-shaped, stalkless; lower ones broader, lowest inversely egg-shaped. $\boldsymbol{F l}$. solitary at the divisions of the stem; stalks hairy, clammy. Cal. white, angles and veins green. Cor. pet. cream-coloured, red tinged, unfolding in the evening, at that time becoming sweet-scented. Cal. very clammy; teeth very long. Seed vessel of first $f l$., conspicuous in the fork of the plant.

(S. nutans. Nottingham $C$. Harringworth, Northamptonshire. Morton.)

\section{STELLA'RIA. ${ }^{\prime} \quad$ Stitchwort.}

S. média. Common Chickweed. Leaves egg-shaped. Stems trailing, with a hairy alternate line on one side. Stamens from five to ten. E. B.53\%. Alsine media. C. 1. 20. A. minor, sive media. G. E. 611 .

\section{Waste and cultivated ground.}

An. April.

Stems several, brittle, slender at the bottom. Ls. opposite, smooth; stalks folded together at night. $F l$. very small, stalks solitary, axillary, or terminal. Cal. longer than the white petals. Seeds pale-brown. Stam. uncertain in number.

Seeds food for birds, as the whole plant. The fresh plant

I Lat. From its starry blossoms. 
bruised, a good cooling application to wounds, and ulcers. $\mathrm{Fl}$. open from nine in the morning until noon, unless rain, after which, they for some time droop. Shoots and ls., eatable when boiled, like young spinach.

S. holóstea. Great St. Leaves spear-shaped, finely saw-toothed. Petals inversely heart-shaped. Calyx without ribs. E. B. 511. C. 2. 30. Gramen leucanthemum. G. E. $4 \%$.

Groves, thickets, dry hedge bottoms.

Per. May.

Anciently called white flowering grass. Rather glaucous. Stems trailing at the base, slender, supporting themselves erect among bushes, and grass, square, brittle, woody in the inner part. $L s$. opposite, stalkless, long, sharp-pointed, mid-rib sharp, the surface slightly glancous. Stem fork-terminating, somewhat panicled. Fl. stalks, long, solitary. Cor. white, large. Anth. yellow. Fil. white. Very ornamental spring $f$.

S. graminea. Less St. Leaves linear-spear-shaped, entire. Panicle terminal, spreading, calyx three-ribbed, nearly as long as the petals. E. B. 803 .

Heathy pastures, bushy places, gravelly, or sandy soil. Sm.

Per. July.

Its white starry $f$., conspicuous: herbage concealed by bushes, or grass: stalks of the panicle very slender. Habit of St. holostea, but size smaller, not glaucous. $\boldsymbol{F}$. white, panicle straddling. Cal.-ls. pale; pet. segments linear, deeply divided. Anth. palereddish.

S. glauca. Glaucous Marsh St. Leaves linear-spearshaped, entire, glaucous. Flower-stalks partly scattered, erect. Calyx three-ribbed, half as long as the petals. E. B. 825. S. media. Sb. 141 .

Moist meadows, bogs, on gravel. Sm.* Otmoor. Sb. Between St. Clement's, and Iffley. $B x$.

Per. July.

Discrim. From St. graminea by its glaucous colour, smooth $l$. edges, and stem, larger $f l$. pet. nearly twice as long as the cal.

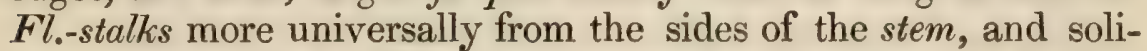
tary, less panicled. Three cal.-nerves less prominent. In size and habit approaches St. holostea, which wants the calyx-nerves, and rough leaf, and stem edges. The anthers are pale-reddish. Lower fl. solitary, axillary.

S. uliginósa, Bog-St. Leaves elliptic-spear-shaped, entire, with a callous tip. Flowers irregularly panicled, from the sides of the stem, or terminal. Petals 
shorter than the calyx. E. B. 1074. C. 6. 28. Alsine fontana. G. E. 613.

Rivulets, ditches, springs.

An. June.

Herb slender, smooth, pale, somewhat glaucous, green. Stems branched, four-angled, leafy. Ls. veins many, parallel. $\mathbf{F l}$. two or three together. Bract. membranous, spear-shaped. Pet. very small, segm. narrow, greenish-white. Styles from three, four, to five.

Discrim. peculiar inflorescence, short pet. Form and structure of the $L$ s. $\quad \boldsymbol{P}$ et. segm. straddling, deeply divided.

\section{ARENA'RIA. Sandwort.}

* Stipulas none.

A. trinervis. Plantain-leaved Chickweed, or S. Leaves egg-shaped, acute, stalked, ribbed. Calyx obscurely three-ribbed, with a rough keel. E. B. $1483 . \quad$ C. 4 . 31. A. trinervia. Sb. 141.

Shady, bushy places.

An. June.

Stems upright, one f, weak, much branched, round, downy. Ls. opposite, sometimes with five ribs. Fl. small, white: stalks longish, solitary, from the forks of the stem, and summits of the branches. Cal. longer than the pet. Ls. upper ones, nearly stalkless.

Discrim. From St. media by its small undivided pet. and threeribbed $l s$.

A. serpyllifólia. Thyme-leaved $\mathbf{S}$. Leaves egg-shaped, nearly stalkless, rough. Calyx hairy ; three outermost of its leaves five-ribbed. E. B. 923. C. 4. 32. Alsine petræa. G. E. 612.

Walls, dry, sandy ground.

An. June.

Stems several, three or four inches, spreading, a little branched, leafy, stiff, slender, forked upwards. Ls. small, entire, thymelike, slightly ribbed. Fl.-stalks erect, pet. white, shorter than the cal. Cal.-ribs a discriminating mark in this genus.

A. tenuifólia. Fine-leaved S. Leaves awl-shaped, pointed. Stem panicled at the extremities. Capsules erect, of three valves. Petals spear-shaped, shorter than the calyx. E. B. 219.

Dry, barren, sandy fields.** Rewly Abbey. Charlbury Stone Quarries. Cornfields near Nettlebed. $\mathbf{S b}$. Cheney Lane. Bx. An. June. 
Plant erect, slender. Ls. joined at the base, three-ribbed at the back, smooth. $F l$.-stalks solitary, single $f$., hair-like, erect, longer than the $l s$, numerous. $F l$. small, white, inconspicuous. Cal.-ls. spear-shaped, acute, margins membranous, white.

** Stipulas membranous.

A. rubra. Purple $S$. Leaves linear, bristle-pointed. Stipulas membranous, sheathing. Seeds compressed, angular, roughish. E. B. 852.

Sandy fields.* Shotover Hill, in a furze close, where sand had been dug. $S b$. (Gravel pits on the side of the Abingdon Road, running through Bagley Wood. Bx. Abundant about Rugby. $B x$.

An. June.

Spreads widely on the ground, the handsome small blossoms expand in bright weather. Stems limber and feeble, leafy, round, a little swollen at the joints. Ls. flat, narrow, rather fleshy. Stip. white, cloven. Fl.-panicles terminal, leafy, forked, the ends elustered: fl.stalks downy, clammy. Cal.-ls. hairy, ribless, margin membranous. Pet. purple, mostly shorter than cal. Seeds wedge-shaped, angular, rough on the outer edge, with sharp tubercles. The seeds a distinctive mark.

\section{DECANDRIA PENTAGYNIA.}

\section{COTYLE'DON. ${ }^{\prime} \quad$ Navel-wort. ${ }^{2}$}

\section{Umbilicus. Common $N$. Leaves target-shaped,} notched. Flowers in a long spike-like bunch, drooping. Bracteas entire. Root tuberous. E. B. 325.

old walls.

Per. June.

Stem and $l s$. fleshy. Stems nearly simple, round, purplish, erect. $F l$.spike branched, $f$. cylindrical, numerous, pale-yellow. $L s$. smooth, stalked; stem-ls. less target-shaped, at length changed for small, spear-shaped, entire bract. Cor. cylindric segments small, erect. Anth. in two rows.

The juice, a cooling application. G. E.

\section{SEDUM. Orpine, and Stonecrop. \\ * Leaves flat.}

S. Teléphium. ${ }^{3}$ Orpine, or Live-long. Leaves flattish, saw-toothed. Corymb leafy. Stem erect. E. B.

1 Kótule, a cavity, Gr. from the hollow leaves.

2 From the leaves.

\footnotetext{
3 Named after Télephus.
} 


\section{C. 3. 25. Crassula sive Faba inversa. G. E. 518.}

Borders of fields, hedges, bushy places. * Headington Wick Copse. Shotover Hill. Sb. (Bagley Wood. Bx.)

Per. July.

Plant fleshy. Root of tapering knobs, fleshy. Stems one or two f., erect, simple, leafy, round, mostly spotted with purple. $L s$. irregularly scattered, stalkless, egg-shaped, fleshy, somewhat glaucous, rib thick, coloured, gradually lost in the summit of the $l s$. Fl.tuft close, crimson, or purple; sometimes white. Pet. sharp. Anth. and stigm. more deeply coloured.

Norfolk rustics sometimes hang up this plant, which grows even when torn from the soil : pretending to judge by the plant's vigour, of the health of an absent friend. Decoction of $l s$. in milk, powerfully diuretic.

Ornamental plant.

* Leaves swollen, or somewhat cylindrical.

\section{S. dasyphýllum. Thick-leaved White Stonecrop. Leaves} egg-shaped, blunt, fleshy, stalkless; the lower ones opposite. Stems feeble. Panicles glutinous. E. B. 656. C. 3. 26.

Walls.

Per. June.

Root of small white fibres. Stems thread-like, weak, trailing. $F \boldsymbol{F}$. branching, panicled, clammy, downy. Ls. except those of the panicled stalk, closely tiled, very thick and fleshy. Fl.-panicle of few $f$. Pet. white, keel purple. Anth. dark-red. Small, pretty plant, fleshy.

\section{S. acre. Biting Stonecrop. Wall Pepper. Leaves} alternate, nearly egg-shaped, thick, swollen; spurred at the base. Cyme of three smooth branches, leafy. E. B. 839. C. 1. 32. Vermicularis, sive Illecebra minor acris. G. E. $51 \%$.

Walls, roofs, dry, sandy ground.

Per. June.

Stems tufted, weak. Roots small, fibrous. Branches upright. $L s$. grass-green, tiled, fleshy, fixed to the stem by the inner or upper surface, a little above their base. Fl.-cymes terminal, three-cleft, when luxuriant. Cal. segm. bluntish. Cor. goldenyellow. Pet. egg-shaped, acute. Caps. pointed, smooth.

A brilliant little flower. Plant acrid, biting to the taste. Said to be of great efficacy in scurvy, in decoction, or outwardly applied. See Raii Syn. The juice emetic. G.E. The plant will retain life, for some weeks, suspended in the air by the root. An oz. of the plant, boiled in twelve oz. of ale, taken in four doses, found useful in dropsy. Lightf. 
Discrim. Its upright, short, fleshy $l s$., closely tiled at the barren shoots. $H$.

S. album. White Stonecrop. Leaves scattered, oblong, blunt, nearly cylindrical, spreading, smooth. Panicle much branched in a corymbose manner. E. B. 1578. C. 1. 31. S. minus officinarum. G. E. 512. also 513. f. 7.

Walls, roofs. On several old walls at Upper Heyford. $B x$.

Per. July.

Root fibrous. Stems prostrate at bottom only, round, green, or purplish, leafy. $\quad \boldsymbol{F l}$.-stems upright, three to five inch. $\boldsymbol{L} \boldsymbol{s}$. scattered, light-green, frequently reddish, slightly attached, spreading at nearly right angles with the stem, smooth, very fleshy, from about half an inch to nearly an inch in length, oblong, blunt, nearly cylindrical, but some of them a little flatted above. $F \boldsymbol{F}$. numerous, white, sometimes tinged with red, produced in a smooth, much branched, somewhat corymbose panicle. Whole plant frequently of a reddish or purplish colour when growing in a dry exposed situation.

Discrim. From other British Sedums by the oblong, blunt, and cylindrical shape of the $l s . B x$.

S. refléxum. Crooked Yellow Stonecrop. Leaves awlshaped, scattered, spurred at the base; the lowermost curved back. Flowers cymose. Segments of the calyx egg-shaped. E. B. 695, Aizoon scorpioides. G. E. 513 .

Walls.

Per. July.

Stems one f., variously spreading, round, entangled, or hanging down, fleshy. Ls. fleshy, smooth, often reddish, attached by the flat inner side, a little above their base. Fl.-cyme, terminal, bright yellow. $F \boldsymbol{F}$. many, mostly of six pet. and germs., and twelve stam. Ls. of the barren branches crowded. This species remarkably tenacious of life.

(Sedum rupestre. St. Vincent's Rocks. Tur.)

\section{OXA'LIS. Wood-Sorrel.}

O. Acetosella. Common $W$. Stalks immediately from the root, single-flowered. Leaves in threes, inversely heart-shaped, hairy. Root with many scaly joints. Stamens all simple. E. B. 762. C. 2. 31. Oxys alba. G. E. 1201.

Groves, and shady places. 
Per. April.

Root with many fleshy, reddish scales. Ls. long-stalked, drooping at night, acid, often purplish beneath. Fl.-stalk, purplish. $P$ et. white, purple-veined, yellow at the base, adhering by a sinall glandular swelling on each side.

A pretty plant with large delicate fl. $L s$. of bright verdure. Caps. dart forth their seeds on the slightest touch, by the elastic seed-coat. Infusion of the $l s$. pleasant refrigerant in fever. From the $l s$. boiled with milk, an agreeable whey. The expressed juice evaporated affords a crystalline acid salt, (oxalic acid, as binoxalate of potash,) sold under the name of Salt of Lemons. Application to scrophulous ulcers. Ls. sensitive, when struck, or handled, droop.

\section{AGROSTEMMA.' Cockle. ${ }^{2}$}

A. Githágo. ${ }^{3}$ Corn $C$. Hairy, calyx teeth rising above the corolla. Petals undivided, without teeth. E. B. 741. C. 3. 27. Pseudomelanthium. G. E. 1087. Cornfields.

An. July.

Plant rough, hairs upright. Stem two or three f., branched, leafy, round. Ls. opposite, linear-spear-shaped. Fl. terminal, longstalked, solitary, large, showy, purple, with bluish streaks. Seeds black, elegantly rough.

An ornamental weed, on a level with the ripening corn, to be plucked up before flowering.

\section{LYCHNIS. Lychnis, or Campion.}

\section{Flos Cuculi. Meadow L. Ragged Robin. Petals} each in three, or mostly four linear segments. Capsule roundish, of one cell. Stem rough with bristles bent back. E. B. 573. C. 1. 33. Armoraria pratensis mas. G. E. 600 .

Moist meadows.

Per. June.

Stem erect, one or two f., angular, leafy, upper part clammy. Ls. united at their insertion, spear-shaped, nearly smooth. $\mathbf{F l}$. panicle forked, erect. Bract. two at each subdivision. Cal.ribs ten, dark purple. Pet. rose-coloured, limber, crowned with two sharp, erect teeth above the claw.

$F l$. of this plant extremely pretty.

$V$ ar. in gardens, $f$. double.

L. dioíca. Red, or White Campion. Flowers diøecious.

1 Agrou, and stemma, Gr. crown or chaplet of the fields.

${ }^{2}$ Ang. Sax. ${ }_{3}$ Gith, name for black seed, in Celtic. 
Each petal cloven, crowned with four teeth. Capsule of one cell. $\alpha$. Flowers red. E. B. 15\%9. C. 2.32. L. diurna. Sb. 145. L. sylvestris rubello flore. G. E. 469. $\beta$. Fl. white. L. dioica. E. B. 1580. L. vespertina. Sb. 146.

Hedges, fields.

Per. a. May. B. June.

Red $f$. Plant clothed with soft, prominent hairs, somewhat clammy. Stem upright, round, jointed, leafy, eighteen inches to two f., forked at top, panicled, spreading. Ls. upper stemleaves spear-shaped: lower, egg-shaped, soft, acute. $F \boldsymbol{F l}$. scentless, with partial stalks. Bract. somewhat membranous. Cal. dark red, in stamen-bearing $f l$., tubular; in pistil-bearing $f l$, eggshaped. Pet. rose-coloured. Claws whitish, crown four-cleft. $V$ ar. red double $f$., in gardens, called Bachelor's Buttons. Stamens and pistils in a pale var. sometimes in the same $f l$.

$V$ ar. white $f$. Whole plant taller than the red var. Ls. more spear-shaped. $\boldsymbol{F l}$. larger, white, or pale blush-coloured, fragrant in the evening, or before rain. The intermediate veins between the cal.-ribs of the pistil-bearing $f$., may discrim. from the red var.

\section{CERA'STIUM. Mouse-ear Chickweed.}

C. vulgátum. Broad-leaved M. Hairy, clammy, tufted. Leaves egg-shaped. Petals as long as the calyx. Flowers longer than their stalks. E. B. 789. C. viscosum. C. 2. 35 . Sb.

Fields, waste ground, dry banks.

An. April.

Discrim. of this species from C. viscosum by its light green hue, yellowish in decay, its broad egg-shaped $l s$., smaller $f$. Stems more erect. Pet. white, notched, scarcely longer than the cal.

C. viscósum. Narrow-leaved M. Hairy, clammy, lying down. Leaves spear-shaped-oblong. E. B. 790. C. vulgatum. C. 2. 34. Sb. 146.

Meadows, pastures, waste ground, walls.

Per. May.

Not more clammy than C. vulgatum.

Discrim. from C. vulgatum, in being peren., by its recumbent-stems, darker green hue, narrower $l s$. Fructification larger, pet. longer, more conspicuous. Fl.-stalks mostly longer. Seeds rugged. Cal.-ls, membranaceous, or skinny at the edge.

C. semidecandrum. Pentandrous $M$. Hairy, clammy. Stamens five. Petals slightly cloven. E. B. 1630. C. 2. 33. 
Waste, sandy ground. Walls.

An. April.

In habit resembling C. viscosum, but smaller in every part, herbage more frequently reddish. Stems spreading at the base,

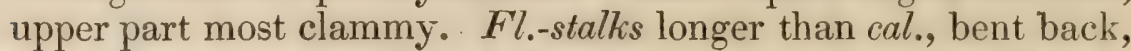
after flowering, finally erect. Cal.-ls. margin conspicuously white, dilated. Pet. white, mostly shorter than cal. Stam. seldom above five. Caps, about twice as long as the cal.

C. arvense. Field $C h$. Leaves linear-spear-shaped, bluntish; fringed at the base. Petals twice the length of the calyx; capsule shorter. E. B. $93 . \quad$ C. 6. 29. Caryophyllus Holostius. G. E. 595.

Fields on gravel, or chalk. Sm. Between the Parks and Wolvercot. Stanton Harcourt. Between Witney, and Burford. Sb. Between Elsfield and Noke Lane, at the back of the Red Lion, in Stow Wood. Bx. Road crossing the Hundred Acres, Bullingdon. R. W.

Per. May, June.

Stems very numerous, trailing at the base, tufted, four or five inches, branched alternately, round, leafy. $F l$. terminal, two or three, white, large, pet. heart-shaped, veined. Germ. globular. Caps. valves transparent.

$\boldsymbol{F l}$. resemble those of Stel. holostea, but somewhat smaller.

C. aquáticum. Water M. Leaves heart-shaped, stalkless. Flower-stalks from the side of the stem, solitary. Capsules drooping, egg-shaped, with five cloven teeth. Petals deeply divided. E. B. 538. C. 1. 34. Alsine major. G. E. 611.

Watery places, margins of rivers and ditches.

Per. July.

Stems two f., weak, trailing, unless supported ; branched, or forked, leafy, round, hairs glandular, prominent. Bark. very brittle, woody part tough. Ls. opposite, pointed, waved, mostly stalkless. $F l$.-stalks single $f$., from between the $l s$. and from the side of the stem-joint. Pet. white, about as long as the cal. Caps. deeply splitting.

In habit, deep-cut pet., shape of caps. rather a Stellaria; the five styles, however, are constant. This plant resembles Stellaria nemorum. Larbrea of DC.

\section{SPE'RGULA. Spurrey.}

S. arvensis. Corn Sp. Leaves whorled. Stalks when in fruit bent back. E. B. 1535 . C. 5. 31. Saginæ Spergula. G. E. 1125 .

Sandy cornfields.

An. June. 
Stems spreading, variously luxuriant, round, branched, jointed, clammy, especially the upper part. Ls. linear, blunt. Panicles terminal, forked, straddling. C Cal.-ls. egg-shaped, concave, edge skinny. Pet. egg-shaped, white, scarcely longer than the cal. Stam. sometimes five, or intermediate between ten. Seeds tuberculated.

Cattle fed with this plant, and poultry with the seeds, in Flanders, \&c. Bread, in time of scarcity, made from the seeds, in Finland, and Norway. A field, whitened with its blossoms, changed in appearance by the sudden closing of the petals, on a black cloud passing over, and discharging a few drops of rain. F. B. T.

S. nodósa. Knotted Sp. Leaves opposite, awl-shaped, smooth; upper ones clustered. Calyx without ribs. E. B. 694. C. 4. 34. Alsine palustris, foliis tenuissimis, seu Saxifraga palustris anglica. G. E. 56\%.6.? Moist, sandy turf.

Per. July.

Plant very smooth. Stems spreading, mostly trailing, numerous, slender. $L s$. smaller tufts of $l s$, from the larger pairs of $l s . \quad F l$. stalked near the extremities of the stems: large in proportion to the plant, brilliant white, elegant.

The five styles, and five valves of the fruit separate this plant from the Genus Arenaria. A pretty little plant in $f$.

(S. subulata. Fringed Sp. Leaves opposite, awl-shaped, bristle-pointed, fringed. Flower-stalks solitary, much longer than the leaves, a little hairy. E. B. 1082. C. 4. 35. S. saginoides.

Sandy heaths. Iver heath. Bucks. Tur.

Per. July, August.

Ls. with glandular hairs; their hair-like point very conspicuous; ill expressed in E. B. Pet. white, nearly as long as the cal. Stamens five or ten. Seeds pale-brown, encircled with a black line, but no dilated margin ; $f$. almost perfectly erect.)

Class XI. DODECANDRIA. Stamens 12-19 inclusive.

Order I. MONOGYNIA. Pistil 1.

'ASARUM. Asarabacca.

* A. europaum. Common $A$. Leaves two on each stem, kidney-shaped, blunt. E. B. 1083. Asarum. G. E. 836 . 
Mountainous woods, rare. Between Henley and Maidenhead. E. B. Per. May.

Stem short, simple, bearing two dark-green $l s$, and one drooping $f$.

\section{LYTHRUM. Purple Loosestrife.}

L. Salicária. Spiked P. L. Leaves opposite, spearshaped; heart-shaped at the base. Flowers in whorled, leafy spikes. Stamens twelve. E. B. 1061. C. 3. 28. Lysimachia spicata purpurea. G. E. 176 .

Ditches, watery places.

Per. July.

Stems erect, wand-like, two to four f., four angled, leafy; sometimes six angled. Ls. stalkless, three in a whorl. All opposite, or all alternate. With. $\mathbf{F l}$. spike reddish, variable purple. $\mathbf{C a l}$. teeth six long, six shorter, intermediate. Pet. waved. Stam. twelve, in two sets.

A showy plant. Useful in dysentery, and diarrhœa.

L. hyssopifólium. Hyssop-leaved P.L. Grass-poly. Leaves alternate, linear-spear-shaped. Flowers axillary, solitary. Stamens six. E. B. 292. Gratiola angustifolia. G. E. 581 .

Partially dried pits, or ditches; or places where water has stagnated during winter. * In watery pits, on the left hand of the first Turnpike Gate on the Banbury Road. Sb. Near Dorchester. G. E. Between St. Clement's and Cowley Marsh. Bx.

An. July.

Stems a span, several, the principal erect, often branched: side ones spreading, curved upwards, all square, purplish. $F l$. purple, delicate, small.

\section{DODECANDRIA DIGYNIA.}

AGRIMO'NIA. Agrimony.

A. Eupatória. Common A. Stem-leaves interruptedly winged; leaflets elliptic-oblong; terminal one stalked. Calyx encompassed with bristles. Spikes elongated. E. B. 1335. C. 5. 32. Agrimonia. G. E. 712.

Bushy places, road sides, borders of fields.

Per. July.

Stem upright, about two f., leafy, angular, hairy. Ls. alternate; leafl. deeply saw-toothed, and with various small intermediate leaflets. Fl.-spike terminal, long, many flowered, $f_{0}$., nearly stalkless, deep-yellow, small. Cal. bell-shaped. Bract. lobed. 
Cal. permanent, hardened, hooked with bristles, a caps. for the seeds.

Scent aromatic : plant astringent, bitter, a tonic remedy in infusion, as tea, among the vulgar. Infusion of the root in fever, among the Canadians.

\section{DODECANDRIA TRIGYNIA.}

\section{RESEDA. Rocket.}

\section{R. Lutéola. Dyer's R. Yellow-weed, or Weld. Leaves} spear-shaped, undivided. Calyx in four segments. E. B. 320. Luteola. G. E. 494 .

Waste ground, especially on chalk, and on walls.

An. June.

Stem wand-like, two or three f., erect, thick, branched, leafy. $L s$. alternate, blunt, smooth. $\boldsymbol{F l}$,-spikes, branch-terminating, $f$., numerous, pale, greenish. Pet. three, uppermost, three-lobed, middle lobe cloven, side ones simple, or three-lobed. Stam. hanging down.

Whole plant used for dyeing woollen yellow and green. Not unornamental. The yellow colour, called Dutch Pink, from this plant.

R. lútea. Base Rocket. Wild Mignonette. Leaves deeply three-lobed; lower ones wing-cleft. Calyx in six divisions. E. B. 321. R. Plinii. G. E. 277.

Chalky hills, waste places.** Bensington. Henley. $\$$ b. Old Stone Pits, Wheatley. Mr. John Lonegrove.

An. June.

Stems several, growing thick-tufted, round, smooth, leafy. $L \boldsymbol{s}$. alternate, segments three or more, linear, waved, pointed: lower ls. once or twice winged. $F l$.-spikes branch-terminating. $F l$. numerous, sulphur-coloured. Pet. six, most curiously lobed. Ornamental.

\section{DODECANDRIA DODECAGYNIA.}

\section{SEMPERVI'VUM. Houseleek.}

S. tectórum. Common $\boldsymbol{H}$. Leaves fringed. Offsets spreading. Edges of the petals hairy, entire. E. B. 1320. C. 3. 29. S. majus. G. E. 510 . Walls, cottage roofs.

Per. June.

$L s$. in a rose-like tuft, numerous, tiled, fleshy, egg-shaped, acute, 
above flattish, convex beneath. Fl.-stem, strong, round, leafy. Corymb. many flowered, branches racemose. Fl. short-stalked, bract. awl-shaped. Cor. rose-coloured, or pale-reddish buff, large, handsome.

Want of scales at the germ., may distinguish this genus from Sedum.

Bruised ls., a cooling, astringent, external application. Filtrated juice of the $l s$. with an equal quantity of Rectified Spirits of Wine. (Dispensary.)

Juice mixed with honey in aphthous cases.

Planted on the tops of cottages in the North of England. This was an ancient superstition, to defend from lightning. See Bourne's Antiquities, p. 241. Ed. 1810. 8vo.

\section{Class XII. ICOSANDRIA. Stamens 20, or more from the rim of the Calyx.}

\section{order I. MONOGYNIA. Pistil I.}

\section{PRUNUS. Plum, ${ }^{1}$ and Cherry.}

P. Cérasus. ${ }^{2}$ Wild $C h$. Flowers in nearly stalkless umbels. Leaves egg-spear-shaped, folded flat in the bud; somewhat downy beneath. E. B. 706. Cerasus vulgaris. G. E. 1502. $\delta$. C. nigra. G. E. 1505. Prunus 'Avium. Sb. (black-fruited.)

Woods, hedges.

Tree. April.

The wild black-fruited cherry, is the Pr. Avium of British writers, and with Pr. Cerasus, the red-fruited, forms one species.

Bark polished, ash-coloured. Fl.-umbels, few $f$. Cor. white. Stip. toothed. Cal. bent back. Fruit black. Var. with red fruit.

Fruits of Icosandrous plants wholesome.

(P. insititia. Wild Bullace-tree. Flower-stalks in pairs. Leaves spear-egg-shaped; rolled spirally while young; downy beneath. Branches thorny at the end. E. B. 841.

Hedges. Sb. (About Rugby. Bx.)

Tree. April.

1 Ang. Sax.

2 So named from a city of Pontus, whence the tree was brought into Italy, by Lucullus. The origin of the garden cherry. The gum equal to gumarabic : nutritious, so much so, as to support life. Hasselquist relates that more than one hundred men were kept alive by it, during a siege, for nearly two months. Wood hard, for turning : and stained to imitate mahogany. 
Branches variously spreading, round, stiff, bark reddish, rather glaucous. Ls. alternate, stalked. $F l$. single, or in pairs, stalks shortish. Pet. white, inversely egg-shaped, large. Fruit globular, black, bloom coloured blue, fruit sour, austere.

Bark of the root and branches styptic. Infusion of the fl., mixed with sugar mildly purgative.

Var. The more grateful white-fruited bullace.)

P. spinósa. Sloe, or Black-thorn. Flower-stalks mostly solitary. Leaves spear-shaped, smooth. Branches thorny at the end. E. B. 842, P. sylvestris. G. E. 1497.

Hedges, thickets.

Shrub. March.

Low, thorny, stiff, bark black, rather glaucous. Ls. stalked, early $l s$, inversely egg-shaped. Ls. saw-toothed, dark-green. Fl. white. Cal. spreading. Pet. roundish. Fruit globular, black, very austere, and astringent. $F l$. appear earlier than the $l s$., in great profusion, like a "flaky shower."

$\mathbf{F l}$. one of the harbingers of spring, appearing before the $l s$. Inspissated juice of the fruit, an astringent. Recent fruit to adulterate port wine. Dried $l s$. a substitute for tea. Green parts of plum and cherry tribe poisonous, fruit not so. Shrub for hedges, but too creeping. Wood hard for teeth of rakes. An infusion of a handful of the fl., purgative. Powdered bark in ague: dose, two drachms. Juice of the fruit, a marking ink upon linen, or woollen. The juice of wild plums, combined with muriatic, or sulphuric acid dyes rose-colour.

\section{ICOSANDRIA PENTAGYNIA.}

\section{ME'SPILUS. Hawthorn, and Medlar.}

M. Oxyacantha. Hawthorn, Whitethorn, or May. Thorny. Leaves blunt, variously three-lobed, sawtoothed, smooth. Styles about two. E. B. 2504. Cratægus monogyna. Sb. 156. Oxyacanthus. G. E. $132 \%$.

Thickets, copses, hedges.

Shrub, or small tree. May.

$L s$. alternate, stalked, deciduous, dark, shining green, segments deep, three or five. $\boldsymbol{F l}$. corymbose, terminal, white, large. Cal. bent back. Pet. concave, sometimes red. Anth. pink, changing to black. Fruit red, sometimes yellow, mealy.

A beautiful, hardy shrub; a substitute for the myrile of warmer climates. For fences; not creeping. Fruit food for birds, \&c. Wood hard, tough, Branches bear clipping, and close cutting. 
Var. Fruit white, at Bampton. Bobart. in Ray.

\section{PYRUS. Pear, ${ }^{\mathrm{T}}$ Apple, Service.}

\section{P. commúnis. Wild Pear-tree. Iron Pear. Leaves} simple, egg-shaped, saw-toothed. Flower-stalks corymbose. E. B. 1784. Pyrum strangulatorium majus. G. E. $145 \%$.

Woods, hedges. Cheney Lane. Headington. $\mathbf{S b}$.

Tree. April.

Tall, handsome tree. Branches in the end curved downwards.

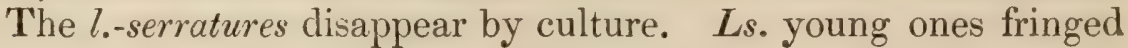
with white. Stip. linear. Fl. large, white. Fruit inversely egg-shaped, variable in flavour, astringent. Anth. pink.

Wood smooth, compact, for turning.

Its snow-white blossoms particularly handsome. As many as eighty varieties of this in Miller's Gard. Dict. Does not thrive well in moist soils (bottoms:) does not destroy the grass. $L s$. dye yellow; give a green to blued cloths.

P. Malus. Wild Apple-tree. Crab-tree. Leaves simple, saw-toothed. Flowers in a simple umbel. E. B. 179. Malus sylvestris. G. E. 1461 .

Woods, hedges.

Tree. April.

Ls. roundish, oval. $F l$. elegant, rose-coloured without, white within, large. Fruit globose, umbilicated, hard, mostly very acid. L.-serratures sometimes disappear by culture.

In fl., few shrubs surpass this in beauty. The original of all our varieties of the apple. Wood hard. Verjuice of the fruit for sprains and scalds. Bark dyes wool yellow. As a stock on which to engraft the better apples. From the verjuice, a grateful liquor might probably be made, by a due mixture of sugar.

For an account of the different apple, and pear-trees. See "Knight's Pomona."

P. torminális. Wild Service-tree. Leaves simple, somewhat heart-shaped, saw-toothed, seven-lobed; the lower lobes spreading. Flower-stalks corymbose, branched. Cratægus torminalis. Sb. 156. E. B. 298. Sorbus torminalis. G. E. 1471. Tragus. fig. p. 1010.!

Woods, hedges.* Stanton St. John's. Stokenchurch. Woods near Ashford Mills. Sb. (Bagley Wood. Bx.)

Tree. April.

Bark smooth, ash-coloured. Branches when young, green. $L s$. 
alternate, veined like net-work, deciduous. $F l$. numerous. Cymose-panic. large, terminal. Fl.-stalks and cal. downy. Pet. cream-coloured. Styles three, four, or five. Berries astringent, greenish-brown, dotted, pleasant acid flavour, when frost-bitten: occasionally sold in the market.

* P. aucupária. Quicken-tree, or Mountain Ash. Roan-tree. Leaves winged; leaflets uniform, sawtoothed, smooth. Flowers corymbose. Styles about three. Fruit globular. Sorbus aucuparia. E. B. 337. S. sylvestris, sive Fraxinus bubula. G. E. 1473.

Wouds. (Copse between Childswell Farm, and Wootten Heath. $B x$.) Warwickshire, not uncommon. $\boldsymbol{P}_{n}$.

'Tree. May.

Apples like berries, scarlet, sour. Seeds two.

A handsome tree, of slow growth, with a tough, close-grained, not very hard wood. The Roan-tree, a charm amongst Highlanders.

P.'Aria. White Beam-tree. White Wild Pear-tree. Leaves simple, elliptical, cut, saw-toothed, scored; downy beneath. Flowers corymbose. Styles about two. E. B. 1858. Aria Theophrasti. G. E. $132 \%$. bad fig.

Mountainous woods on a chalky soil.* Stokenchurch. Henley. Stanton St. John's. Sb. Streatley, Berks. $B x$.

Tree. May.

Handsome, small tree. Branches, young ones, also the stalks, cal., and under side of $l s$, mealy white. $L s$. stalked, alternate, acute, veins straight, sunk above. $F l$-corymb, large, terminal, white. Pet. longer than stam. Styles two, three, or four. Fruit scar let, globose, mealy, astringent; eatable when mellowed by frost. Wood hard.

Called by the Welsh, a lemon-tree, whence some wise travellers have recorded the growth of the tender lemon on the crags of Wales! Flourishes in gravel, or clay.

SPIRÆA. Spiræa, Dropwort, Meadow-sweet.

S. Filipéndula. ${ }^{1}$ Common Dr. Leaves interruptedly winged ; leaflets uniform, saw-toothed, smooth. Stem herbaceous. Flowers cymose, with many styles. E. B. 284. Filipendula. G. E. 1058.

Open elevated pastures, on a gravelly, or chalky soil. Sm. Banks of the Canal, going to Wolvercot. Burford Downs. Sb. Bullingdon Green, \&c. $\boldsymbol{B} x$. 
Per. July.

Root of elliptic knobs. Stem erect, about one f. Ls. few, alternate, leaflets opposite ones nearly equal in size, all saw-toothed, and jagged. Stip. pair of toothed, united at the base of each compound $l$., stalk-embracing. $F l$. cream-coloured, often redtipped. Styl. in this spec. and in Sp. ulmaria, numerous. Obs. Such irregular species are enumerated at the end of the order, or class to which they individually belong.

Var. fl., double in the gardens.

Plant astringent: roots eatable. Linn.

S. Ulmária. ${ }^{1}$ Meadow-sweet. Queen of the Meadows. Leaves interruptedly winged; downy beneath; the terminal leaflet largest and lobed. Stem herbaceous. Flowers cymose, with many styles. E. B. 960. C. 5. 33. Regina prati. G. E. 1043.

Moist meadows, banks of rivers, ditches.

Per. July.

Root fibrous. Stems erect, three, or four f., angular, furrowed, leafy, branched above. $L s$. leaflets very unequal in size, sharply saw-toothed, white, downy beneath. Stip. a pair rounded, saw-toothed, joining the common l.-stalk, stem-clasping. $\mathbf{F l}$.cyme, large, compound, its side branches much above the central one. Styl. six, or eight. $F l$. fulsome, sweet, hawthorn-scented. Recommended by Gerarde as a strewing herb, in halls and banqueting houses; the smell thereof making the heart merry, \&c.

\section{ICOSANDRIA POLYGYNIA.}

\section{ROSA. Rose. ${ }^{2}$}

Species difficult to discriminate. Scópoli observes that: "Every one knows a rose from a fungus, but to discriminate the true species is beyond the power even of the consummate botanist."

* Branches bristly. Prickles mostly slender, nearly straight.

(R. spinosissima. Burnet R. E. B. 187. Buckby, Northamptonshire. Morton.)

(R. Doniána? Dwarf Hairy R. Flower-stalks generally without bracteas; bristly, like the globular fruit and simple calyx. Stem bristly and prickly, like the downy foot-stalks. Leaflets elliptical, doubly and sharply saw-toothed, hairy on both sides. Petals spreading. Wood's Tr. of L. Soc. v. 12. 185. R.

1 From its eln-like leaves?

2 Greatly indebted to Mr. Baxter, for information on this Genus. R. W. 
Sabini $\beta$. Lindl. Ros. 59. R. Sabini. Purton. 3. 44.

Mountains. Allesley, Claverdon, Warwickshire. Rev. W. T. Bree.

Shrub. June, or July.

Pet. white and spreading.)

* * Branches without bristles. Prickles nearly straight.

R. tomentósa. Downy-leaved Dog R. Fruit broadly elliptical, bristly. Calyx copiously winged. Prickles slightly curved. Leaflets egg-shaped, acute, more or less downy. $\quad$ E. B. 990. R. villosa. Sb. 159 ?

Hedges, thickets. Marston Lane. Sb.

Shrub. June.

In size, habit, and form of leaflets, agrees with R. canina.

Discrim. from R. canina, by its ls. downy all over on both sides, greyish-green, slightly fragrant resinous smell. Pet. almost white in lower part; upper part, various shades of rose-colour, somewhat sweet. Fruit egg-shaped, scarlet, bristly, conspicuous by its roughness.

Between the north-end of Marston Lane and Headington Copse, a rose is found, styled by Mr. Sabine, Rosa tomentósa Oxuniensis. It is larger than the common R. tomentósa, with larger and more pointed leaflets: more glandular, but less downy: the fruit more hispid; the $c a l$. falls much earlier. $B x$.

*** Branches without bristles. Prickles hooked, compressed. Styles distinct.

R. rubiginosa. Sweet Briar, or Eglantine. Fruit inversely egg-shaped, bristly towards the base. Calyx winged. Prickles hooked, compressed; with smaller straighter ones interspersed. Leaflets elliptical, doubly saw-toothed, hairy; clothed beneath with rusty-coloured glands. E. B. 991. H. L. 116. R. sylvestris odora. G. E. 1269.

Bushy places. Clifton. Henley Park Hill. Wychwood Forest. Sb. Shrub. July.

Discrim. from R. tomentósa, by its leafl., more elliptic, brightgreen, slightly hairy above, reddish clammy glands beneath, most fragrant smell. $F l$. more constant and deeper red than other wild roses; of a pleasant smell. Fruit scarlet, often smooth, when cultivated.

Poets apt to confound the Woodbine, and the Eglantine.

For fragrant, but not very lasting hedges.

(R. micrantha. Small-flowered Sweet Briar. Fruit elliptical, somewhat bristly, contracted at the summit. Calyx winged, deciduous. Prickles hooked, scattered, 
nearly uniform. Stem straggling. Leaflets eggshaped, doubly saw-toothed, hairy; glandular beneath. E. B. 2490. R. rubiginosa $\beta$. H. L. 116. f. 10.

Hedges, thickets. Allesley, Bidford, \&c. Warwickshire. Ren. W. T. Bree. Near Bilton, Warwickshire. Bx.

Shrub. June, July.

Stems straggling. $L s$. less fragrant. $F \boldsymbol{~} \boldsymbol{l}$. smaller.)

R. Borréri. Downy-stalked Dog R. Fruit elliptical, smooth. Flower-stalks crowded, hairy. Calyx copiously, often doubly, winged, deciduous. Prickles hooked. Leaflets egg-shaped, doubly saw-toothed, hairy, without glands. R. dumetorum. E. B. 2579. $\beta$. R. rubiginosa inodora. H. L. 117 .

Hedges, thickiets.

Shrub. June, July.

Prickles much hooked. Pet. light-red.

R. sarmentácea. Trailing Smooth-leaved $\boldsymbol{R}$. Fruit broadly elliptical, naked. Flower-stalks crowded, smooth or minutely bristly. Calyx strongly winged. Prickles hooked. Leaflets egg-shaped, doubly sawtoothed, very smooth. Tr. L. S. 12. 213. R. canina. C. 5. 34. E. B. Suppl. 2595.

Hedges, bushy places.

Shrub. June, July.

Stem eight to ten f. $F l$. pink, fragrant.

R. Forstéri. Downy-ribbed Dog R. Fruit elliptical, smooth, like the crowded flower-stalks. Calyx copiously, and somewhat doubly winged. Prickles scattered, conical, hooked. Leaflets simply saw-toothed; smooth above; ribs hairy beneath. See E. B. Suppl.

Hedges.

Shrub. June, July.

Leaflets five, or seven.

R. canina. Common Dog $R$. Fruit egg-shaped, smooth, or somewhat bristly, like the crowded flower-stalks. Calyx winged, deciduous. Prickles strongly hooked. Leaflets simply saw-toothed, pointed, smooth. E. B. 992.

R. sépium. ' Small-leaved Sweet Briar. H. B. Fl. p.

1 Prickles numerous, the larger curved, the smaller awl-shaped; leaf. small, doubly saw-toothed, hairy, sharp at each end, glandulose beneath, cal.-seg- 


\section{5. ** On the Leys about a mile E. by $\mathbf{N}$. from Upper Heyford. Bx. See Appendix.}

Hedyes, woods, thickets.

Shrub. July.

Discrim. R. canina from R. tomentosa, and R. rubiginosa by its smooth, shining $l s$. R. arvensis, has the fruit globular, its $f$., more in cymes, pet., white, yellow tinged at the base. Stems and fruit mahogany hue. Fl.-stalks of R. canina peculiarly polished. Fruit very rarely slightly hispid, bright scarlet. Remarkable var. in Marston Lane, near Oxford, with doubly compound ls. Mr. Sabine.

R. canina very ornamental, with its graceful branches, and ls., elegant buds, and coral fruit. Scent of the fl., delicate. From the fruit, ripened by frost, the grateful conserve of Hips, a vehicle for powders, \&c. Petals of this, or other roses dried, a substitute for tea, in infusion. The moss-like excrescences in rose trees, habitations of the Cynips Rosæ. Infusion of the full-blown paler rose-petals, aperient. Those of the red-roses, before expansion, astringent.

**** Branches without bristles. Prickles hooked, compressed.

Styles combined.

(R sýstyla. Close-styled Dog $R$. Fruit egg-shapedoblong, smooth. Flower-stalks glandular. Calyx winged, deciduous. Prickles hooked. Leaflets simply saw-toothed. Floral receptacle conical. Styles combined, smooth. R. collina. E. B. 1895.

Hedges, thickets. At Donnington Castle, Berks. Mr. Bicheno.

Shrub. June, July.

Prickles dilated at the base. $F l$. pinkish, fragrant.)

R. arvensis. White Trailing Dog $\boldsymbol{R}$. Fruit globose or elliptical, smooth. Flower-stalks glandular. Calyx winged, deciduous. Prickles hooked, scattered. Leaflets simply saw-toothed. Floral receptacle slightly convex. Styles combined, smooth. E. B. 188.

Hedges, thickets, borders of fields.

Shrub. June.

Stems round, glaucous, often mahogany coloured, of which colour commonly the germens, and fl.-stalks. Ls. leaflets mostly five, oval, pointed, smooth. Fl.-stalks three, or five, cluster terminal, stalks not all exactly from one point. Bract. few, spear-shaped, on each stalk one fl., white, elegant. Fruit dark-blood-coloured, well flavoured, with simple base of the styles lengthened out.

A pretty species in $\mathrm{fl}$.

ments, and pinnas lengthened out, fruit egg-shaped, smooth. See H. Var. of R. rubigin. Lindl. Ros. 


\section{RUBUS. ${ }^{1} \quad$ Bramble, ${ }^{2}$ Raspberry. ${ }^{3}$}

Species of this genus, discriminated with difficulty.

* Stem shrubby, angular.

R. fruticósus. Common Bramble, or Blackberry. Stems angular, furrowed; barren ones arched and lengthened out. Prickles hooked. Leaves pedate, (bird-footed,) of five, stalked, egg-oblong leaflets; white and downy beneath. Panicle cylindrical, twice compound. Calyx bent back, unarmed. E. B. 715. Rubus. G. E. 1272.

Hedges, thickets, woods.

Shrub. June.

Stems long, trailing in an arched manner, woody, purplish. Ls. leaflets stalked, green, shining above. Stip. bristle-shaped. $\mathbf{F l}$. panicles terminal, downy. $\quad F l$. blush-coloured, or pink, sometimes white. Berry violet-black, fulsome, sweet. Green twigs astringent, used for dying woollen, and silk black. $L s$. food for silk-worms.

R. rhamnifolius. Buckthorn-leaved B. Stems angular. furrowed; barren ones arched. Prickles bent downwards, straight. Leaves slightly pedate, of five, or three orbicular, inversely egg-shaped, or somewhat heart-shaped, pointed leaflets; hoary beneath. Panicle twice compound, finely hairy. Calyx spreading. W. and N. 20.6. See E. B. Suppl.

Woods, hedges. Abundant in woods about Tangley, Oxfordshire. Mr. Bicheno.

Shrub. June, July.

(R. leucóstăchys. White-clustered B. Stems angular, downy. Prickles bent downwards, slightly hooked. Leaves of five or three roundish egg-shaped, or heartshaped, pointed, jagged leaflets; hoary beneath. Panicle cylindrical, and, like the unarmed bent-back calyx, minutely glandular. See E. B. Suppl.

Woods, thickets. About Newbury. Mr. Bicheno.

Shrub. July, August.

Pubescence shaggy and shining.)

(R. glandulósus. Glandular B. Stems angular; branches and foot-stalks hairy, with glandular bristles interspersed. Prickles bent dowuwards, partly hooked.

1 More on this Genus, and those of Rosa, and Salix, in our Supplement. R. W.

${ }^{2}$ Ang. Sax. ${ }^{3}$ From the resemblance of the fruit to a rasp, or file. 
Leaflets five or three, downy beneath. Panicle and calyx very prickly and hairy, with copious glandular bristles.

Woods, thickets, hedges. Near Newbury. Mr. Bicheno.

Shrub. July, August.

Panic. corymbose. Pet. white, narrow.)

(R. nitidus. Smooth Shining B. Stems bluntly angular, spreading, smooth. Prickles hooked. Leaflets five or three, somewhat hairy beneath. Panicle and calyx sparingly prickly, without bristles. W. and N. 17. 4 .

Thickets, woods. On Snclsmore Common, near Newbury. $M r$. Bicheno.

Shrub. July, August.

Panic. mostly simple. Pet. broadish.)

** Stems shrubby, round.

R. idaus. Raspberry. Stems round, erect, smooth, with downy branches; their prickles straight and slender. Leaves winged, of five or three egg-shaped, rather angular leaflets, very downy beneath. Clusters prickly, somewhat compound. Flowers drooping. E. B. 2442. G. E. 1272.

Mountainous woods, thickets. Stokenchurch. Mungewell. Sb. Near Witney. Mr. Haines, Radcliffe Library.

Shrub. May.

Stem shrubby, four f., branched, leafy, rough with small prickles. $\boldsymbol{L} \boldsymbol{s}$. lower ones winged, upper ones in threes only: leafl. eggshaped, sharply saw-toothed, strongly veined, green, above slightly downy, snow-white, cottony beneath. Foot-stalks channelled above, downy and prickly like the fl.-stalks. Pet. small, greenish-white. Fruit crimson, pulpy grains numerous, set with permanent styles: of a delicious perfume, and flavour. The fresh $l s$., a favourite food of kids.

R. corylifólius. Hazel-leaved B. Stems round, spreading; barren ones somewhat angular. Prickles scattered, straight, bent downwards. Leaflets five or three, roundish-heart-shaped; finely hairy beneath. Panicle minutely angular, as well as the bent-back calyx. E. B. 827 .

Hedges, thickets.

Shrub. July.

Discrim. From R. fruticosus, by its roundish stem, much more brittle, all the prickles nearly straight. Leafl. stalkless, or 
nearly so: fruit earlier, browner black, more gratefully acid: blossoms larger, white.

R. ca'sius. Blue B. or Dew-berry. Stems trailing, round, glaucous, prickly and bristly. Prickles bent downwards. Leaflets three; hairy beneath ; side ones lobed externally. Calyx embracing the fruit. E. B. 826.

Woods, bushy places.

Shrub. June.

Stems weak, trailing, pale-green with bright, glaucous tinge. $L s$. leafl., sharply, and doubly saw-toothed; side ones stalkless, mostly lobed on the outside. Stip. spear-shaped. Foot-stalks prickly, downy; prickles all slender. $F l$. few, terminal, and axillary, panicled, prickly. Cal. in the fl., spreading, points long. Fl. white, sometimes reddish. Pet. waved. Fruit black, its bloom brightly blue tinged: grains few, rather large, agreeably acid, very palatable, but not abundant.

\section{FRAGA'RIA. Strawberry.}

\section{(F. stérilis. See Potentilla Fragariastrum.)}

F. vesca. Wood S. Calyx of the fruit bent back. Hairs of the foot-stalks widely spreading; those of the partial flower-stalks close pressed, silky. E. B. 1524. Fragaria. G. E. 997.

Groves, thickets.

Per. May, June.

Root: runners long, creeping. Stems short, erect, nearly simple. Ls. mostly immediately from the root, long-stalked, in threes, veins parallel. $\mathbf{F l}$. upright, cymose, bracteated. Pet. white, notched. Fruit drooping, egg-shaped, fleshy, red, fragrant, studded with smooth seeds, each with its withered style.

The delicious strawberry with its var., the fruit of a cool climate. Fruit considered by Linnæus, very salutary for gouty constitutions.

(Fragária elátior. Hautboy S. Grounds round Coton House, Warwickshire. Mr. Nelson.)

\section{POTENTILLA. Cinquefoil.}

* Leaves winged.

P. anserina. Silver-weed, or Wild Tansy. Leaves interruptedly winged, saw-toothed, silky. Stem creeping. Stalks axillary, solitary, single flowered. E. B. 861. Argentina. G. E. 993.

Osier holts, spongy meadou's. 
Per. July.

Stem-runners reddish, rooting at the joints, where also the $l s$., and $f$., come forth. Ls. more silvery beneath, root-ones largest. $\mathbf{F l}$. large, handsome, yellow. Cal. intermediate segments generally notched. Pet. roundish, or slightly notched.

Var. Ls. smooth.

An elegant plant. Indicating clay under the surface. Linn.

$$
\text { ** Leaves fingered. }
$$

P. argéntea. Hoary Cinquefoil. Leaflets five, wedgeshaped, jagged; downy beneath. Stem ascending. E. B. 89. Quinquefolium Tormentillæ facie. G. E. 988.

Pastures on gravel. Henley Park Hill. Sb.

Per. June.

Stems woody, round, half-erect, one f., or more. Ls. alternate, upper sides green; lower, snow-white, like the cal., and upper part of the stem. Stem occasionally forked. $\mathbf{F l}$. yellow, small, panicled, corymbose.

In form and habit resembling a Tormentilla.

Discrim. The pure whiteness of its leaves.

(P. verna. St. Vincent's Rocks. Gloucestershire. Tur.)

P. reptans. Common Creeping $C$. Leaflets five, in. versely egg-shaped, saw-toothed. Stem creeping. Stalks axillary, single-flowered. E. B. 862. C. 1. 37. Quinquefolium vulgare. G. E. $98 \%$.

Meadows, pastures, way-sides.

Per. June, August.

Stems long, thread-shaped, rooting at the joints, like Pot. anserina. $L s$. in pairs from each joint; stalks long, erect; leafl., darkgreen. $F l$. large, yellow, rising higher than the $l s$. C'al. intermediate $l s$., deeper green. $P$ et. inversely heart-shaped, broad.

$$
\text { *** Leaves in threes. }
$$

P. Fragariastrum. Strawberry-leaved $C$. Leaflets three, roundish-egg-shaped, saw-toothed, hairy. Stems prostrate. Seeds wrinkled, hairy at the scar. Fragaria stérilis. E. B. 1785 . C. 3. 30. F. minimè vesca, sive sterilis. G. E. 998.

Dry, gravelly pastures.

Per. April.

Stems leafy without creeping runners. Lss.stalks long, hairy: leafl. broad, coarsely saw-toothed, silky. $\boldsymbol{F l}$. white. Seeds: receptacle small, and dry.

The habit and seeds of this agree with Fragaria: as wanting a pulpy fruit, it accords with the Genus Potentilla.

\section{TORMENTILLA. Tormentil.}

T. officinális. Common T., or Septfọil. Stem ascend- 
ing, branched. Leaves almost stalkless. Stipulas cut. E. B. 863. C. 5. 35 . Tormentilla. G. E. 992. Potentilla Tormentilla. Sb. 162.

Barren pastures, heaths, bushy places.

Per. June.

Root very large, woody. Stems slender, weak, wiry, often trailing, leafy, round. Ls. in threes, deeply saw-toothed. Fl.stalks, long, hair-like, solitary, opposite to the $l s$. Cal. segments egg-shaped, alternately smaller. Pet. inversely heart-shaped, yellow. $\mathbf{F l}$. occasionally of five pet., and ten cal., segments.

Plant eminently astringent.

T. reptans. Truiling $T$. Stem prostrate, scarcely branched. Leaves stalked. Stipulas undivided. E. B. 864. Potentilla procumbens. Sb. 162.

Hedges, borders of fields.

Per. June.

Root small, slender. Stems one, or two; eighteen to twenty inches, not rooting. Plant hairy, light-green. Ls. root-ones in fives, long-stalked : stem-ls. in threes, stalks shorter, all inversely egg-shaped, deeply saw-toothed. Floral-ls. stalkless, narrow, nearly entire. $F \%$. bright-yellow, twice as large as those of Tormentilla officinalis, the stalks long, hair-like, opposite to the ls. Stem sometimes not simple.

The term, reptans, or creeping, does not accord with the notrooting, trailing stem of this species.

\section{GEUM. Avens.}

G. urbánum. Common $A$. Herb Bennet. ${ }^{1}$ Stem leaves three-lobed, root-ones somewhat lyre-shaped. Stipulas rounded, cut. Flowers nearly upright. Styles naked. E. B. 1400. C. 2. 36. Caryophyllata. G. E. 994.

Woods, shady, dry hedges, thickets.

Per. Jure.

Root fibrous, blackish. Stem upright, two f., round, panicled, leafy. Ls. lobed, cut. $\boldsymbol{F}$ l. terminal, solitary, yellow, pet., mostly shorter than the cal. Seeds downy, awns brown, or purplish, hooked.

Root astringent, slightly aromatic.

G. rivále. Water $A$. Root leaves interruptedly winged, somewhat lyre-shaped. Stipulas egg-shaped, acute, cut. Flowers drooping. Styles hairy above the curva- 
ture, E. B. 106. Baxter's Plates, 3. Caryophyllata montana purpurea. G. E. 994 .

Moist meadons, woods. Marston. Nohe. Sb. Calve's Close, Headington. R. W. Elsfield Copse. R. W.

Per. Nay.

Root creeping, woody, reddish. Fl.-stem erect, round, gracefully drooping at the top; as the fruit ripens, becomes erect. Cor. tawny-brown, pet., erect. Cal. purplish-brown, erect. $F l$. terminal, two, or three.

Sir J. E. Smith considered this one of our most picturesque natives, from the rich combination of the dark leares, with the glowing reddish brown of the stem and cal., delicate colour of the pet., and graceful position of the flowers.

Grows also in Canada. Root astringent, very aromatic. Var. fl. double, in gardens.

(CO'MARUM. Marsh-cinquefoil.

C. palustre. Purple M. E. B. 172. Pentaphyllum rubrum palustre. G. E. 987.

Sponyy, muddy bogs, ditches. Allesley, Warwickshire. Bree. Coleshill Bogs, Warwickshire. Purton.

Per. June, July.

Ls. winged, with five, rarely seven, leaflets; upper ones threelobed. $F l$, and fruit, dark-purple.)

\section{Class XIII. POLYANDRIA. Stamens numerous, from the receptacle.}

\section{Order I. MONOGYNIA. Pistil 1.}

\section{CHELIDO'NIUM.' Celandine.}

C. majus. Common C. E. B. 1581. G. E. 1069 . Waste grounds, thickets, especially on chalk. Sm.

Per. May, June.

Plant brittle, tender, juice orange-coloured, fetid, about two f. $L s$. winged, smooth, rounded, lobed, notched. Fl. umbels, on long, axillary stalks. Cal. soon falling. Pet. roundish, golden. Stam. same colour. Pod. rugged.

Its orange juice probably suggested its being given in jaundice: so the bark of the barberry has been given for its yellow colour. A gay plant in May and $\boldsymbol{J}_{\text {une. }}$

1 Gr. Chelidon, a swallow, from its appearance and disappearance about the time of those birds. A Gr. tale. See Fl. Classica, by Billerbeck.

L 2 


\section{PAPA'VER. Poppy.}

* Capsules bristly.

P. hýbridum. Round-rough-headed $\boldsymbol{P}$. Capsule nearly globular, furrowed, bristly. Calyx hairy. Stem leafy, many-flowered. Leaves doubly wing-cleft. E. B. 43. Argemone capitulo torulo. G. E. 373.

Sandy, chalky fields.* Sm. Parks. Ensham. Sb. and R. W. 1830. Near the half mile trees, Ensham Road. $B x$. Beyond the Parks. R. W.

Stem weak, much branched, spreading. Ls. leaflets linear, narrow. $F l$. deep-crimson, or purplish, small, pet. crumpled; pollen bright-blue. Germ. bristles erect.

A permanent species.

P. Argémone. Long-rough-headed P. Capsule clubshaped, ribbed, bristly. Calyx slightly hairy. Stem leafy, many-flowered. Leaves doubly wing-cleft. E. B. 643. C. 5. 38. Argemone capitulo longiore. G. E. 373.

Cornfields, on gravel, or sund. Sm. Parks. Sb.

An. June.

Plant slender, delicate. Stem branched alternately, round, bristly. Fl. pale, or dull scarlet, short lived, solitary, terminal, small. Cal. deciduous. Pet. narrow, inversely egg-shaped. Stam. dilated upwards. Anth. stalked. Pollen blue. Caps. oblong, swelling upwards.

Var. $f$. double.

* Capsules smooth.

P. dúbium. Long-smooth-headed P. Capsule smooth, oblong, angular. Stem many-flowered, hairy. Bristles on the flower-stalks close-pressed. Leaves doubly wing-cleft. E. B. 644 . C. 5.37 .

Cultivated fields.

An. June, July.

Discrim. from P. Argemone, by its smooth pods. Stem about two f., leafy. Ls. segments broader than in P. Argemone, P. hybridum. Cor. light-scarlet; pet. broader than the length, notched. Pollen yellow.

Discrim. The close-pressed bristles of its fl.-stalks, from P. Rhœeas.

P. Rhoeas. Common Red P. Corn Rose. Capsule smooth, nearly globular. Stigma many-rayed. Stem many-flowered, rough, like the flower-stalks, with horizontal bristles. Leaves wing-cleft, cut. E. B. 645 . C. 3. 32 . G. E. 371 . 
Cornfields, too abundant.

An. June.

$\boldsymbol{L}$ s. once or twice wing-cleft, sawed. Cor. deep, bright scarlet. Pet. large, broad, glossy, crumpled, black spot sometimes near the base of each. Pollen purplish black. Caps. egg-shaped, smooth.

A most brilliant weed. Its syrup a gentle opiate, and to colour draughts, \&c. Many beautiful varieties with half double fl., rose colour and white.

* P. sómnĭferum. White $\boldsymbol{P}$. Capsule nearly globular, smooth as well as the calyx and stem. Leaves notched, clasping the stem, glaucous. E. B. 2145. P. sylvestre. G. E. 370 .

Uncultivated places.** Near the Observatory. By Godstow Nunnery. Sb. Between St. Clement's, and Cowley Marsh. Bx. An. June.

Plant glaucous, mostly smooth. Stem leafy, branched, three or four f. $L s$. simple, oval, roundish, blunt. $F l$. large, terminal, white or purplish, often a deep violet spot on each pet., $f$. drooping in bud, then erect, (soon falling.) Stigm. rays bent downwards.

Seeds oily, sweet, pleasant tasted, not narcotic. Caps. in infusion a mild, opiate fomentation. Opium is the dried, milky juice of the green caps.

NYMPHÆA. White Water-lily.

N. alba. Great White $W$. Leaves heart-shaped, entire; even beneath. Petals elliptic-oblong. Rays of the stigma sixteen, curved inwards. Root horizontal. E. B. 160 . G. E. 819 .

Clear pools, slow rivers.

Per. July.

$\boldsymbol{L} \boldsymbol{s}$. floating in the water, a span wide. $\boldsymbol{F l}$. large, white, spearshaped, of several rows, gradually lessening, and running into stamens. $\boldsymbol{F l}$. four or five inches wide. Cal.-ls. spear-shaped, white, base often tinged with light blush colour. Stalk of large tubes.

$\boldsymbol{F l}$. sink under water in the evening. Stimulus of the light and sun raises them; when that stimulus ceases, the fl., droop by their own weight to a certain depth. The still heavier fruit finally sinks to the bottom. A magnificent plant in $\mathrm{fl}$., with the air and habit of a tropical production. Sm.

NUPHAR. Yellow Water-lily.

N. lútea. Common Yellow $W$. Calyx of five leaves. Border of the stigma entire. Foot-stalks two-edged. 
Lobes of the leaves meeting each other. H. L. 141. Nymphæa lutea. E. B. 159 . G. E. 819. Rivers, pools.

Per. July.

$\boldsymbol{L} \boldsymbol{s}$. floating on the water, stalks two-edged. Ls. heart-shaped, smooth, even, rounded at the end. $\boldsymbol{F l}$. about two inches wide, golden yellow, large, but much smaller than those of $\mathrm{N}$. alba. $\boldsymbol{P}$ et. yellow with orange spot. Stam. and Anth. curved backwards. ( $\mathrm{Fl}$. have a brandy smell.) $\mathrm{Cal}$. concave, yellow, green outside. Stigm. flat, rayed. Seed-vessel a coated berry, bursting, irregularly. Whole plant somewhat smaller than N. alba.

\section{TI'LIA. Lime-tree.}

*T. europaea. Common Smooth L. Linden-tree. Nectaries none. Leaves twice the length of the footstalks, quite smooth, except a woolly tuft at the origin of each vein beneath. Cymes many-flowered. Capsule leathery, downy. E. B. 610 . T. fomina. G. E. 1483.

Woods, hedges. Stokenchurch Woods. Sb.

Tree, July.

Tall, upright tree; branches smooth, spreading. Ls. heart-shaped, alternate, saw-toothed. Fl.-stalks long, axillary. Bract., linear, entire, pale, affixed to each fl.-stalk about half its length. Cal. green. $\boldsymbol{P}$ et. yellowish. $\mathbf{F l}$. strongly fragrant.

Bark by maceration separates into layers, and is used for making gardener's mats : an export from Russia. Tree bears the smoke of a city to a certain degree. Made by Fenélon an ornamental tree in Calypso's island; perhaps to compliment the taste of Louis the Fourteenth, about whose palaces the Lime was profusely planted. Name of Linnæus derived from the name of this tree, in Swedish.

* (T. grandifólia. Broad-leaved Downy L. Nectaries none. Leaves downy; especially beneath; origin of their veins woolly. Branches hairy. Umbels mostly three-flowered. Capsule woody, downy, top-shaped, with five prominent angles. T. europæa $\beta$. rubra. Sb. 166.

Woods, hedges. Near Streatham Wells, Surry. Mr. Dubois in his Herbarium at Oxford. Stokenchurch Woods, apparently planted. $M r$. Bicheno. $\beta$. Stokenchurch Woods. Bobart. Not now to be found at Stokenchurch. Dr. Williams. One tree observed there by Mr. Bicheno, in the autumn of 1824 .

Tree. June, July. A fortnight earlier than T. europæa. 
Branches round, brown, shining red, in var. $\beta$. Ls. as large as in T. europæa, less entire at base, less pointed, foot-stallss rather longer, upper surface bright green, minutely hairy about the ribs, more or less so at the edges, between the saw-teeth; under sicle rather paler, not glaucous, ribs and veins curiously fringed, besides the woolly tufts there. Germ. large, densely hairy. Caps. five or six angled.

Some old Limes of this species in the church-yard of Sedlitz, in Bohemia, said to bear hooded ls., ever since the monks of a neighbouring convent hanged on them. See Jacq. Frag. 19. t. 11. f. 3. A protestant libel, no doubt.)

"(T. parvifólia. Small-leaved L. Nectaries none. Leaves smooth above; glaucous beneath, with scattered, as well as axillary, hairy blotches. Umbels compound, many-flowered. Capsule roundish, brittle, nearly smooth. E. B. 1705 .

Woods. Stokenchurch Woods, plentifully. Mr. Bicheno. New College Garden. R. W.

Tree. August, a month later than T. europæa.

Aspect peculiar. Ls. much smaller than in T. europæa, more glaucous beneath, more sharply saw-toothed, very often lobed towards the points. Stalks more slender. Fl. very fragrant, like Honeysuckle. Caps. small, coat very thin, tender.)

\section{CISTUS. Cistus.}

* Dwarf shrub, with stipulas.

\section{Heliánthemum. Common Dwarf $C$. Shrubby,} trailing, with fringed stipulas. Leaves elliptic-oblong; white and downy beneath. Calyx-ribs bristly; its outer leaves spear-shaped, fringed. E. B. 1321. C. 5. 36. Helianthemum anglicum luteum vel album. G. E. 1282 .

Hilly pastures on chall or gravel. Sm. Bullingdon Green. Shotover Hill. Stokenchurch. $\mathbf{S b}$.

Plant somewhat shrubby. July.

Root woody. Stems several, simple, springing from one root, leafy, round, hairs short. Ls. opposite, stalks short, slightly curved outwards, green above, hairs simple. Stip. spear-shaped, acute. Fl.cluster, loose, terminal, pet. bright yellow, sometimes white. Cal. three large $l s$, reddish, two outer $l s$. ten times smaller. Pet. roundish-heart-shaped.

$V$ ar. double fl. in gardens: a variable species. Stam. irritable, touched with a pin, \&c. they retire from the style: the experiment should be tried in calm, warm weather, on fresh opened $\mathrm{fl}$. An elegant, and ornamental plant: its delicate fl., very fleeting. 


\section{POLYANDRIA PENTAGYNIA.}

\section{DELPHI'NIUM. Larkspur.}

D. Consólida. ${ }^{I}$ Field $L$. Capsule solitary. Nectary of a single leaf. Stem subdivided, spreading. E. B. 1839. Consolida regalis sativa. G. E. 1082. f. $1,2$.

Sandy, or chalky cornfields. Near the Parks. Banbury. Bx. An. June, July.

$\boldsymbol{L} s$. in many divisions, with linear segments. $\boldsymbol{F} l$. blue.

\section{AQUILE'GIA. Columbine. ${ }^{2}$}

A. vulgáris. Common $C$. Nectaries about the length of the petals; their spurs curved inwards. Leaves and stem smooth. Capsules hairy. E. B. 297. A. corulea. G. E. 1093.

Meadows, pastures, thickets. Headington Wick Copse. Stow Wood, Wychwood Forest. $S b$.

Per. June.

Stem not very leafy, branched. Ls. mostly root-ls., stalks very long. $L s$. twice in threes, bluntly lobed, glaucous beneath; $l s$. on the stem nearly stalkless, uppermost of three entire, acute leafl. $F l$. drooping, purple, sonretimes rose-coloured.

In gardens, of various forms and colours. A handsome plant with its large irregular $\mathrm{fl}$.

\section{STRATIO'TES ALOI'DES. Water-soldier,}

Naturalized in abundance, in the pond of Magdalen College Meadow, by Mr. Baxter, Such naturalizations should of course be noticed, to prevent confusion in the stations of plants.

\section{POLYANDRIA POLYGYNIA.}

ANEMO'NE, Gr. Anémone.

A. Pulsatilla. Pasque-flower ${ }^{3}$ A. Flower solitary, nearly upright. Involucre in deep linear segments.

1 Name implies a supposed power of uniting wounds.

2 Columba, a dove; from the resemblance of the nectaries and petals to doves. Mrs. Bockett.

3 From its flowering about Easter. G. E. Some explain the name from the fi., being used to colour eggs purple, among catholics, and the Scotch, at Easter. Query. Do the flowers yield a purple dye? 
Petals six, erect. Seeds with feathery tails. Leaves doubly winged, cut, with fine linear lobes. E. B. 51. H. L. 44. A. pratensis. Sb. 169. Pulsatilla vulgaris. G. E. 385 .

High, open, chalky pastures. Sm. Wychwood Forest, near Cornbury Quarry. Burford Downs. $S b$. Streatley Downs, Berks. $B x$. Per. April.

$F \boldsymbol{F}$. dull, violet blue, outwardly silky. $P$ et. moderately spreading.

A plant of great beauty, including its silvery seed-plumes. Herb acrid, blistering the skin.

A. nemorósa. Wood $A$. Flower solitary. Petals six, elliptical. Seeds pointed, without tails. Involucre, leaves three, or five-parted, stalked, lobed and cut. E. B. 355 . C. 2. 38 . A. nemorum alba. G. E. 383. Groves, thickets, heuthy ground.

Per. April.

Root black outwardly. Stem solitary, simple, one-flowered. $L s$. root-ones, long, stalked. Fl.-cal., o. Pet. white, often purple at the back. Stam. much shorter than cor., sometimes changing into narrow pet.

On its $l s$. and pet. occasionally a minute fungus, Ecidium fuscum. Sow. Fung. 53.

An elegant decoration to our woods and thickets. Pet. expanded in fine weather, drooping and folded against rain. Var. fl., reddish.

\section{CLE'MATIS. Traveller's Joy.}

\section{Vitalba.' Common $T$. Leaves winged; leaflets} heart-shaped, partly cut. Footstalks twining, permanent. Panicles forked, not longer than the leaves. E. B. 612 . C. 4. 37 . Viorna. G. E. 886 .

Hedges.

Shrub. July.

Stems branching, long, $l s$. opposite. Panic. axillary, leafy. Cor. white, almond-scented: pet., leathery, downy. Seed, awn feathery, long.

Foliage a rich, mantling tapestry. Its abundant silvery seedplumes, in autumn and winter, make a beautiful appearance.

THALICTRUM. Meadow-rue.

T. flavum. Common M. Stem erect, furrowed, leafy. Leaves doubly winged; partly three-lobed. Panicle

1 White vine. 
compound, close, corymbose. Flowers and stamens erect. E. B. $36 \%$.

Wet meadows, about the banks of rivers and ditches.

Per. June.

Stem two or three feet. $L s$. alternate, twice compounded; base of the foot-stalks sheathing. Stip. toothed, within the $l s$. leaflets variable in breadth, veiny, glaucous beneath. $F l$. panicle much branched, leafy. Fl. yellowish-white. Anth. yellow. blister.

Plant acrid, yet eaten by cattle: bruised $l s$., produce a slight

\section{ADO'NIS. Pheasant's-eye.}

* A. autumnális. Corn Ph. or Adonis-flower. Petals about eight, inversely heart-shaped. Fruit egg-shaped. Stem branched. E. B. 308. C. 2. 3\%. Flos Adonis, flore rubro. G. E. 387. Baxter's Plates, $\%$.

Cornfields. * Near the Observatory. $\mathbf{S b}$.

An. May.

Stem much branched, upright, round, leafy, slightly furrowed. Ls. alternate, thrice compounded, segments linear, alternate, acute. Fl. solitary, terminal. Cor. pet., crimson, glossy, at the base deep purple. Stam. anth. and styles same colour. Cal. pale green, soon falling.

An elegant plant; its red pets., contrasted with the dark and green eye of the $f$. , give it a rich appearance.

\section{RANU'NCULUS. Crowfoot.}

* Leares simple.

R. Flámmula. Less spear-wort $C$. Leaves egg-spearshaped, bluntish, stalked. Stem reclining. Root fibrous. Seeds smooth. E. B. $387 . \quad$ C. $6.3 \%$ R. flammeus minor. G. E. 961 . B. R. flammeus serratus. G. E. 962 .

Watery places.

Per. July.

Roots long, fibrous. Stems numerous, round, branched, leafy, hollow. Ls. spear-shaped, acute, lower ones many ribbed, variable, partly entire, partly saw-toothed, Fl.-stalks long, round, terminal, also opposite the $l s$. bright golden. Cal. bent back. Cor. honey-pore very small.

Discrim. R. Lingua differs from this by its greater size, erect stem, and $l s$., more approaching to stalkless.

Distilled water of this for procuring instantaneous vomiting in some cases of poison. Plant very acrid, and blistering. 
R. Lingua. Great Spear-wort C. Leaves spearshaped, pointed, nearly stalkless, somewhat saw-toothed. Stem erect, many-flowered. Root fibrous. Seeds smooth. E. B. 100. H. L. 171. R. flammeus major. G. E. 961.

Marshes, reedy pools, ditches.** Banks of the Cherwell, near King's Mill. Sb. Ditch on the right hand side of the lane, beyond Folly Bridge. $B x$.

Per. July.

Fl. large, bright golden, all the parts of this much larger than those of R. Flammula. Vid. plant back. Acrid. More silky, with hairs close-pressed.

\section{R. Ficária. Pilewort C. Less Celandine. Leaves} heart-shaped, angular, stalked, smooth. Petals, numerous, elliptic-oblong. E. B. 584. C. 2. 39. Chelidonium minus. G. E. 816.

Meadows bushy places, hedge banks.

Per. April.

Root with long, fleshy knobs. Plant smooth, shining, somewhat fleshy. Stems several, a few inches high, one-flowered. $\boldsymbol{F} l$. erect, long-stalked. Cal. three or five leaved. Pet. varnished, golden, eight or ten.

Its glossy, yellow fls., turning white, abundantly enamel our banks and thickets in the month of April.

\section{* Leaves lobed, or cut.}

R. auricomus. Wood C. Goldilocks. Root leaves kidney-shaped, deeply three-cleft, notched ; stem-leaves divided to the base into linear segments. Stem manyflowered. Calyx coloured. E. B. 624. C. 2. 41. G. E. 954 .

Dry groves, bushy, shady places. Magdalen College Walks. R.W. Per. April.

Stem about one f., upright, branched, leafy, round. Ls. root-ones long-stalked, sometimes five-cleft : stem-ls., stalkless. $\boldsymbol{F} l$. terminal, solitary, erect, bright golden. Cal. pale yellow. Nect. a naked pore. Pet. sometimes wanting. Plant not caustic. Easily discrim., by the distinct character of the root, and stalk-ls.

R. scelerátus. Water C. Celery-leaved C. Stem erect, hollow, much branched. Leaves smooth; lower ones somewhat hand-shaped; upper fingered. Fruit oblong. Seeds very numerous, minute. E. B. 681. C. 2. 42. R. palustris rotundifolius. G. E. 962. Watery places.

An. June. 
Plant pale, shining green, juicy, smooth for the most part. $L s$. lower ones long-stalked, lobed, cut: upper $l s$., segments linear, entire. $F l$. numerous, small, palish yellow. Cal. bent back, shaggy. Honey-pore somewhat tubular. Fruit cylindric, blunt, seeds thick set.

Plant variable in size, virulently acrid, blistering the skin to cause a sore healed with difficulty. Used, it is said, by vagabonds for the effects mentioned above, to cause compassion; hence, perhaps, its name sceleritus, rascally.

R. bulbósus. Bulbous C. Butter-cups. Calyx bent back. Flower-stalks furrowed. Stem upright, manyflowered. Leaves compound. Root bulbous. Seeds smooth. E. B. 515. C. 1. 38 . G. E. 953.

Pastures, meadows, grass-plots, waste ground.

Per. May.

One to one and a half f. $L s$. in threes, three-cleft. $F l$. golden yellow. Root solid, roundish bulb, with fibres springing from it. Stems one or more, erect, one ft., branched above, round, hairy, hollow, leafy. Ls. hairy, compound, three-cleft. $F l$. large, yellow, terminal, solitary. Cal.-ls. egg-shaped, concave, turning back close to the stalk. Pet. roundish, notched at the end, concave, varnished. Nect.-scale inversely heart-shaped. Bulb for the next year formed on the top of the old one. Plant acrid, eaten by cattle. Such acrid plants mixed with the less pungent, a useful stimulus, perhaps, supplied by nature in food of cattle. $\operatorname{Var} . f$. double in gardens.

R. hirsútus. Pale Hairy $C$. Calyx bent back, pointed. Stem upright, many-flowered, hairy. Leaves three parted. Root fibrous. Seeds tuberculated. E. B. 1504. C. 2. 40 .

Moist meadous, waste, or cultivated grourd.* Southleigh Common. $S b$.

Per. June.

Stems one or more, upright, branched, leafy, round, hollow. Ls. hairy, pale, cut. $\quad \boldsymbol{F} l$.-stalks hairy. $\mathrm{Cal}$. rough with glandular hairs. Pet. shining yellow. Nect. covered with a scale. Seeds compressed, margined, rough on both sides with sharp tubercles.

R. repens. Creeping C. Calyx spreading. Flowerstalks furrowed. Scyons creeping. Leaves compound, cut; the uppermost entire. E. B. 516. C. 4. 38. R. pratensis etiamque hortensis. G. E. 951.

Meadows, moist pastures.

Per. June.

Discrim. By its fibrous root, and long, creeping runners, from $\mathbf{R}$. bulbosus. Fl.stems erect, branched, leafy. Ls. rather broader, 
darker than in $\mathbf{R}$. bulbosus, often marked with a black spot. $L s$. more distinctly three-partite; sometimes smooth.

Plant acrid, blistering.

Var. with double fl. in gardens.

R. acris. Upright Meadow C. Calyx spreading. Flower-stalks round and even. Leaves in three, deep lobed and cut segments; those of the uppermost linear and entire. Stem erect, covered with close hairs. E. B. 652. C. 1.39 .

Meadows, pastures.

Per. June.

$\boldsymbol{R}$ oot tuberous, long-fibred. Stem upright, two f., round, branched above. Ls. root-ones, the stalks long, hairy, upright, three or five partite, variously subdivided and cut: uppermost $l s$., comparatively stalkless, lobes linear, three. Pet. yellow, shining. Nert. scale one, notched.

Discrim. From R. auricomus by its scale nect., and by its cal., spreading; from R. bulbosus, and R. hirsutus, by its round fl.stalks from the last two also, and from $R$. repens. Bear in mind the smooth seeds to discr., it from those species with sharppointed prickly seeds.

Plant acrid. Vur. $f$. double.

R. arvensis. Corn $C$. Seeds very prickly at the sides. Leaves once or twice deeply three-cleft, with linearspear-shaped segments. Stem erect, much branched, many-flowered. E. B. 135 . C. 6.36. R. arvorum. G. E. 951 .

Cornfields.

An. May.

Plant pale. $F l$. small, yellow. Seeds strikingly armed on the side with prominent prickles, projecting more than those of $\mathbf{R}$. parviflorus.

Plant very acrimonious, producing in animals colic, and death, by gangrenous stomach. Poisonous to sheep, who greedily devour it. Three ounces of the juice killed a dog in four minutes. Best antidote vinegar. See Brugnon Mem. Turin, v. 4. 108. Cows and horses eat it.

R. parviflórus. Small-flowered C. Seeds armed at the sides with small hooked prickles. Leaves roundishheart-shaped, simple, hairy, sharply cut; upper ones three-lobed. Stem prostrate. E. B. 120.

Gravelly fields, hedges.* Bullingdon Green. Shotover Hill. Southleigh. Sb. Elsfield. B.x. Abingdon Road, near Oxford. R. W.

An. May.

Humble in growth. Ls. foot-stalks long, dilated. Ls. all notched; 
towards the end of the trailing branches, $l s$., often simple, spearshaped, entire, small. $\boldsymbol{F} l .-$ stalks solitary, opposite to the $l s . \quad F l$. small, yellow, pet. small, soon falling. Seeds compressed.

R. hederáceus. Ivy $C$. Seeds wrinkled. Leaves roundish-kidney-shaped, with three or five lobes, entire, smooth. Stem creeping. E. B. 2003. C. 4. 39.

Shallow rivulets, ditches, pools. Stanton Harcourt. Southleigh Ensham Common. Sb. Littlemore. R. W. Marston, \&c. Bx. Per. May.

Plant small, smooth, shining, juicy. Stems creeping, or floating when in the water, branched. Plant rooting at its joints. Ls. numerous, long-stalked, edges entire: brown spot sometimes in the disk of $l s . F l$.stalks simple, solitary, axillary, or opposite to the l-stalks. Pet. very small, oblong, white, claw yellow. Stam. five to ten. Seeds swollen, numerous, thick set in a roundish form.

R. aquátilis. White floating $C$. Seeds wrinkled. Leaves in hair-like segments under water; above water somewhat target-shaped, lobed, bluntly notched. E. B. 101. G. E. 829. R. heterophyllus. $\mathrm{Sb} .175$. Marston Lane. Southleigh. Sb. $\beta$. R. aquatilis. ${ }^{2}$ Sb. 175. Millefolium, sive Maratriphyllon, flore et semine Ranunculi aquatici, hepaticæ facie. G. E. 827. $\gamma$. R. circinatus. ${ }^{3}$ Sb. 175. Christ Church Meadow. Southleigh. Sb. $\delta$. R. fluviatilis. ${ }^{4}$ Sb. 176. Isis. Cherwell. Windrush. Sb.

Ditches, ponds : d. rivers.

Per. May, June.

Stems long, round; ls. alternate. Stip. broad, membranous. Ls. above the water five-lobed, broadly notched. Nect. tubular. $\boldsymbol{F l}$. white, large, elegant.

$V$ ar. in $l s$. several.

A beautiful ornament to ponds and ditches.

In var. $\beta$. the $l s$. all cut, and narrow. In $\gamma$. Ls. smaller, rounded, very finely cut. $\delta$. Ls. all gashed, and lengthened out by the rapid current of water, hence rarely flowering.

\section{HELLE'BORUS. Hellebore.}

H. viridis. Green $\boldsymbol{H}$. Stem many-flowered, leafy. Leaves fingered. Petals spreading. E. B. 200. C. 6. 34. Helleborastrum. G. E. 976 .

Various-leaved. $\mathbf{S} b$. leaved Water $\mathbf{C}$. Sh.
2 Milfoil-leaved. $\mathbf{S} b$.

4 Fennel-leaved Water $\mathbf{C}$. $\mathbf{s} b$.
3 Fine- 
Woods, thickets, on chalk.** Stoken Church. Woodperry Farm. Nuffield. Sb. In a wood at Mungewell. John Oglander, Esq. Merton College.

Per. February.

Root fleshy, fibres long, simple. Plant large in all its dimensions. Stem scarcely one f., round, once or twice divided. Ls. saw-toothed: root $l s$., larger. $F l$. solitary, foot-stalks shortish, all green. Pet. all green, spreading, permanent. Styles three or four. Whole plant smooth, bright green, shining.

Root acrid, purgative.

H. foe'tidus. Stinking H. Bear's-foot, or Setter-wort. Stem many-flowered, leafy. Leaves pedate, (bird footed.) Petals converging. E. B. 613. Helleboraster maximus. G. E. 976 .

Thickets, waste ground, on chalk.** Cornbury Stone Quarry. Sb. Wade's Farm, Rodborough Common, Gloucestershire. Mr. Sandys, Pembroke College, Oxford.

Per. March.

Stem branching, bushy, whole plant smooth. Ls. stalked, spreading, dark, dull green, lobes spear-shaped, saw-toothed. $\mathbf{F l}$.-panicle pale green. Bract. many, spear-shaped: these with the $f_{0}$, and whole inflorescence also pale green. The closing pet, outside tipped with dull purple. Nect. margin notched, honied. Styles three or four.

Earliest of our native fl. Whole plant fetid, acrid, violently purgative. Styles few in these two species for polygynia.

There is a beautiful flower bank of the Helleborus hyemális, a common, foreign, Europæan species, in the classical garden of St. John's College, Oxford, well worth the florist's inspection, in the early part of February.

\section{CALTHA. ${ }^{\prime}$ Marsh-marigold.}

C. palustris. Common M. Stem erect. Leaves heartshaped, rounded. E. B. 506. C. 1. 40. C. palustris major. G. E. $81 \%$.

Marshy meadows.

Per. April.

Root fibres simple, many. Stem one f., and a half, somewhat branched, leafy, roundish, furrowed. Ls. notched, veiny, smooth, dark green, shining: root-ls. on long, hollow, half cylindric stalks, the rest alternate, nearly stalkless. Stip. inside of the l.-stalk, sheathing, membranous, withering. $\mathbf{F l}$. very large, handsome, golden, axillary, and terminal, solitary. Pet. concave. Stam., and pistils, golden colour also.

The young buds pickled, a good substitute for capers. In the true caper, the germen simple.

I From Lat. cálathus, cup. 
This early flowering plant makes a rich and brilliant appearance in the spring. Var. $f$. double in gardens.

\section{Class XIV. DIDYNAMIA. Stamens 4 :}

\section{Two outermost longest.}

Order I. GYMNOSPERMIA. Seeds apparently naked; four at most.

\section{'AJUGA. Bugle.}

* Búgula. Fl. whorled blue.

A. reptans. Common B. Almost smooth, with a solitary stem, and creeping scyons. Lower lip of the corolla four-cleft. E. B. 489 . C. 2. 43. Bugula. G. E. 631.

Woods, moist pastures.

Per. May.

Stem erect, about one f., square, leafy. Scyons take root, here and there, at the insertion of their ls. Ls. opposite, egg-shaped, scolloped, tapering into broad foot-stalks. Stem-ls. nearly stalkless, in opposite cross pairs. $\boldsymbol{F l}$. in thick-set whorls: bract., purplish, scolloped. Cor. full blue, streaked with white: sometimes all white, or flesh-coloured. Whole plant generally with a purplish tinge.

Vulnerary according to the older writers; hence the French had this expression:- Those who have Bugle, and Sanicle, need no surgeon. Almost any other leaf would probably answer the same indication of excluding the air, and healing a wound, by what surgeons call the first intention.

(A. Chama'pitys, E. B. 77. Ufford, near Helpston Stone-Pits, Northamptonshire. Morton.)

\section{TEU'CRIUM. Germander.}

T. Scorodónia. Wood G. Wood Sage. Leaves heartshaped, hairy, saw-toothed, stalked. Clusters crowded, leaning to one side. Stem erect. E. B. 1543. C. 5. 40. Scorodonia seu Salvia agrestis. G. E. 662. Woods, heathy, bushy places.

Per. July. 
Stems erect, one, or two f., leafy, square, hairy. Fl.-spikes, one terminal, and several side ones: a pair of egg-shaped bract., at the base of their partial stalks. Ls. opposite, saw-toothed, or sharply notched, wrinkled, darkish green. Fl. pale yellow, with purple, projecting stamens.

Bitter : has been used as an innocent substitute for hops.

T. Scórdium. Water G. Leaves oblong, stalkless, downy, with tooth-like serratures. Flowers axillary, stalked, in pairs. Stem trailing. E. B. 828. Scordium. G. E. 661.

Low, wet meadows.** On the banks of the Isis, near HighBridge. Ensham Common. $\mathbf{S} b$.

Per. August.

Root creeping. Stem square, branched. Ls. opposite, veiny, somewhat downy. $F l$. pale purple.

Plant very bitter. Scent strong, disagreeable. This plant formerly to remove obstructions, \&c. Sir J. E. Smith observes of this plant: " a sort of key to all locks, now grown rusty and out of use." Decoct. of this, a useful fomentation for gangrenous sores.

T. Chamadrys. Wall G. Leaves somewhat eggshaped, stalked, deeply notched or cut. Flowers axillary, three together, stalked. Stem roundish, hairy. E. B. 680 . Chamædrys major latifolia. G. E. 656 . Old, ruined buildings, stony banks. ** Witney, on the right hand side of the old road leading to Burford. $S b$.

Per. June.

Root creeping. Stem bushy, nearly upright, six or eight inches, leafy. Branches and $l s$, opposite, lengthened out at the base. Cal. bell-shaped. Cor. reddish-purple. Lower lip with a large, round, concave, central lobe, and two small, sharp, side ones: the two others, erect, parallel, very sharp lobed sides, between which the stam., and style project upwards.

Whole plant very bitter : formerly much cultivated for medical use; as a deobstruent, and expectorant: not the appearance, from its stations, of being a native.

\section{NE'PETA. Cat-mint.}

N. catária. Common C. or Nep. Whorls stalked, crowded into spikes. Leaves finely downy, heartshaped, stalked, with tooth-like serratures. E. B. $13 \%$. Mentha felina, seu Cattaria. G. E. 682.

Banks, road sides, chalky, or gravelly soil. Sm.

Per. July. 
Root long, thready. Stems two or three f., square. Plant except cor., downy, velvet-like. Cal.-ribs strong, prominent. Spikes at the tops of the branches.

In E. B., the cal., represented reversed; the shorter teeth, (in nature,) the lowermost. Cor., white, or purplish, lower lip sprinkled with crimson, or purple dots. This genus marked, by its notched, central lobe.

Bruised herb aromatic, like penny-royal, (Ment. Pulegium.) Cats delight in its odour, (except when raised from seed,) chewing the young branches, and rolling in a kind of ecstacy upon the plant.

\section{VERBE'NA. Vervain.}

V. officinális. Common $V$. Stamens four. Spikes slender, panicled. Leaves oblong, deeply cut, with many clefts. Stem mostly solitary. E. B. $76 \%$ C. 1. 41. V. communis. G. E. 718 .

Road sides, dry, waste ground, near villages.

Per. July.

$\boldsymbol{R}$ oot branching, woody. Stem curved at the base, about one f., square, leafy, rough, panicled at the top. Ls. opposite, lower ones three-cleft. $F l$. small, stalkless; each with a small, spearshaped bract. Cal., tubular. Cor., pale lilac. Seeds ripened, marked with excavated dots. Fl.-branches opposite.

Root formerly worn round the neck superstitiously, in scrophulous cases, as a charm. Many species of Verbena have two stamens only. The plant called by the Romans Verbena, used as a token of mutual confidence between them, and their enemies: also for making wreaths and brooms for their altars, and chaplets for their priests: in a general sense, they called whatever was bound round the altar Verbena. Billerbeck in Fl. Classica, seems to consider our plant the same with that of the Greeks and Romans, p. 7. Pliny remarks, if the dining room be sprinkled with water, in which the herb has been steeped, the guests will be the merrier! G. E.

\section{MENTHA. ${ }^{\prime}$ Mint.}

M. sylvestris. Horse Mint. Spikes shaggy, scarcely interrupted. Leaves sharp, with deep toothed serratures; chiefly downy beneath. Bracteas awl-shaped. Calyx hairy all over. E. B. 686.

$W$ aste ground. Road side between Woodstock and Stonesfield, just after passing a Lodge on the outside of Woodstock Park. B.x. Bayswater, near the Mill. R. W.

1 Hairs of the calyx, and flower-stalk, afford good specific distinctions, in difficult cases. Sm. Lin. Tr. v. 5. 178. Herbage full of pellucid dots, lodg. ing an aromatic, and stimulant oil. 
Per. August, September.

Plant three f., hoary or greyish green. Cal. hairy. $F$. pale purple. Ls. upper surface hoary; under shaggy with close, white, soft hairs.

(M. rotundifólia. Round-leaved $M$. E. B. 446. Between High and West Wycombe, Bucks. Tur. For description, see the very useful Compendium of Sir.J. E. Smith's English Flora. 12mo : or Appendix.)

(M. víridis. Spear $M$. Spikes interrupted. Leaves stalkless, spear-shaped, acute, naked. Bracteas bristleshaped, somewhat hairy, as also the calyx teeth. Flower-stalks very smooth. E. B. 2424. M. romána. G. E. 680 .

Marshy places. Bilton, near Rugby, Warwickshire. $\boldsymbol{B} x$.

Per. August.

Plant deep green. Stems two or three f. Spikes panicled, acute, nearly all the whorls a little distant from each other. Cal. narrow, smooth; the teeth often hairy. Cor. light purple, generally longer than the stamens.)

M. hirsúta. Hairy M. Flowers in heads, or whorled. Leaves stalked, egg-shaped. Calyx clothed with erect hairs. Flower-stalks with hairs curved back. H. L. 166. थ. E. B. 44\%. M. aquatica. Sb. 182. M. aquatica, sive Sisymbrium. G. E. 684. ל. Flowers all whorled. About rivulets, \&c. Fl. Br. 618. M. Sativa. E. B. 448.

Watery places, very common.

a. The most common of all our Mints.

3. About rivulets on the side of Shotover Hill, near Oxford; Mr. Tilleman Bobart. Herb. Bobart. Banks of the Canal, beyond High Bridge. Otmoor. $\mathbf{S b}$.

Per. July.

Roots long, branched, creeping. Stem square, branched, purplish. Branches opposite. Ls. sometimes almost stalkless: spreading, pointed, saw-toothed from a little above the base to near the tip. $\mathbf{F l}$. lilac, in a large, round, terminal head, divided into three parts, accompanied by a pair, seldom more, of smaller axillary heads. Fl.-stalks, and cal., very hairy. Stam., generally longer than the cor.

Out of water it grows much smaller, more purple, with a single head of $f$. Very variable species. Under headed var., \&c. Sm. comprehends every plant that has been taken for Ment. aquatica, and Ment. hirsuta of Linn. L. Tr. v. 5. 195.

Every sort of mint, according to Linn., prevents the coagulation of milk. Eaten too largely by cattle, their milk coagulates with 
difficulty into cheese curd. $F l$. Suec. Mice, according to Mr. Macdonald of Scalpa, Hebrides, have a great aversion to the smell of mint: laying a few green or dry leaves on any articles will preserve them from the depredation of mice. $F . T .1$. p. 130.

(M. rubra. Tall Red M. E. B. 1413. G. E. M. Sativa rubra, 680. River side, a mile below Denham, Bucks. Tur. For description; see Compendium of Smith's English Flora, a highly useful manual: or Appendix.)

M. arvensis. Corn M. Flowers whorled. Leaves egg-shaped, saw-toothed. Stem much branched, diffuse. Calyx bell-shaped, short, covered all over with horizontal hairs. E. B. 2119. Calamintha aquatica. G. E. 684 .

Sandy cornfields frequent, especially where water has stagnated.

Per. July.

Root creeping by fleshy shoots. Ls. egg-elliptical, blunt, with somewhat stiff, prominent hairs. Fl.-stalks mostly smooth. $\mathrm{Cal}$. more bell-shaped than the other British species. $\mathrm{Fl}$. reddish lilac. Scent compared to cheese covered with blue mould. Plant pale green. Stam., equal in length to the limb of cor. Hooker supposes the Ment. agrestis, $\boldsymbol{E}$. B., not distinct from this. Fl. Scot. Whorls much shorter than the $l s$.

M. Pulégium. Penny-royal. Flowers whorled. Leaves egg-shaped, somewhat notched. Stem trailing. Flowerstalks and calyx all over downy; teeth fringed. E. B. 1026. Pulegium regium. G. E. 671.

Wet commons, margins of brooks. Binsey Common. Port Meadow. Otmoor. $S b$. On a Common, near Ipsdon. $B x$.

Per. July.

Smallest of the genus. Ls. small, downy, curved back. Fl.-whorls, numerous, close. $\mathrm{Fl}$. purplish, sometimes white. Smell peculiarly strong, resembling Thymus Népeta. Ls. underneath set with deep, semi-transparent dots. Stam. equal. Pistil as long as the stam. Stalks about one f., and a half, weak.

Antispasmodic, stimulant.

\section{GLECHO'MA. Ground-ivy.}

G. hederácea. Common G. Gill, or Ale-hoof. Leaves kidney-heart-shaped, notched. E. B. 853. C. 2.44. Hedera terrestris. G. E. 856 .

Dry, shady places, road sides, hedge banks.

Per. April.

Roots creeping, sending out trailing scyons. Ls. veiny, downy, 
dotted beneath with glandular points, from which the oil of the plant proceeds. $F l$. axillary, about three to each leaf, $f_{\text {. }}$-stalks short. Cor. bluish, under lip largest, marked with dark purple and white. Stam., sometimes imperfect. Stalks, lower part trailing, flowering part erect.

Herb strong-smelling: to give ale a flavour : used for this, until hops substituted, in Hen., the Eighth's reign. Infusion of the ls., gently aperient. Small protuberances of many cells found on the $l_{s}$; the nests of insects. Gradually expels plants growing near it.

\section{LA'MIUM. Dead-nettle. ${ }^{\mathrm{r}}$}

\section{L. album. White D., or Archangel. Leaves heart-} shaped, pointed, strongly saw-toothed, hairy. Flowers about twenty in a whorl. Tube of the calyx shorter than its teeth. Upper lip of the corolla notched; side teeth solitary, spear-shaped. E. B. 768. C. 2. 45. G. E. 702 .

Waste ground, borders of fields, road sides.

Per. April.

Root creeping. Stems upright, twelve to eighteen inches, square, leafy. Ls. in pairs. $\mathbf{F l}$. large, hairy, cream-coloured, handsome. Stam., hairy. Anth., black.

The sweet $\mathrm{fl}$. much frequented by bees. Called Dead-nettle from its not stinging, although resembling Urtica dioica, the Stinging-nettle. Herb not eaten in general by domestic animals. Fl, sometimes of a pinky tinge.

Young leaves eaten as a pot herb, in spring. $F l$. Suec.

L. purpúreum. Red D., or Archangel. Leaves heartshaped, bluntish, unequally notched, stalked; the upper ones crowded. Stem partly procumbent, partly leafless. Calyx-teeth spear-shaped. Tube of the corolla closed, near the bottom, with hairs. E. B. 769. C. 1. 42. L. rubrum. G. E. 703.

Waste, and cultivated ground.

An. April, \&c.

Not more than half the size of Lam. album. Stems ascending, leafy, a little branched below, then naked, in their upper part, thickly clothed with leaves. $F l$, purple, sometimes white. Pollen or anther-dust, lead-red. Ls., ends pointing mostly downwards. May be eaten like the last.

L. incisum. Cut-leaved D., or Archangel. Leaves heart-shaped, dilated, stalked, irregularly cut; the upper ones crowded. Stem partly leafless. Tube of 
the corolla internally naked; marginal teeth dilated, combined. E. B. 1933.

Cultivated, and waste ground. Cornfields beyond Cowley. J. Oglander, Esq. Merton College, Oxford. Between Rose Hill, and Cowley. Bx.

An. May.

Rather smaller than Lam. purpureum, resembling it in $l s . F l$, narrower than in Lam., purpureum, more like those of Lam. amplexicaule. Seeds abundant, producing plants like themselves; hence not deemed a var., of Lam., purpureum. The young $l s$., of this, and Lam., amplexicaule, may be eaten as a pot-herb.

L. amplexicaule. Great Henbit. Henbit D. Floral leaves stalkless, kidney-shaped, blunt, deeply notched, partly lobed, clasping the stem. Teeth of the calyx linear-awl-shaped, as long as their tube. E. B. $7 \% 0$. C. 2. 46. Alsine Hederula altera. G. E. 616 .

Sandy fields.

An. May.

Early $f l$., with an abortive, yet fertile cor. Red velvet tip of the cor., makes the plant conspicuous. Lobed $f_{0}$-ls., generally pale at their base. Pollen vermilion. Ls., lower on l.-stalks, heartshaped, blunt, saw-toothed bluntly. Fl. purple. Cal., very hairy.

\section{GALEOPSIS. Hemp-nettle.}

G. Ládanum. Red $\boldsymbol{H}$. Stem scarcely swollen below the joints. Leaves spear-shaped, somewhat sawtoothed, hairy. Upper lip of the corolla slightly notched, whorls remote. E. B. 884.

Dry, gravelly, chalky corrifields. Sm.

An. June.

Root fibrous. Stem about one f., oppositely branched, square, hairs bent down. Ls. stalked, veins hairy beneath : upper side with close-pressed, scattered hairs. Cor., rose-coloured, intermixed with crimson and white; upper lip slightly notched.

G. Tétrahit. Common $\boldsymbol{H}$. Stem bristly; swollen below the joints. Corolla twice the length of the calyx; upper lip nearly straight. E. B. 207. Cannabis spuria. G. E. 709 .

Cultivated ground.

An. June.

Plant one to two f., rough with sharp prickles, calyx-teeth very pungent. Cor.various in size and colour, from purple to white; base of the lip almost always, with elegant dark streaks. Anth., 
two-lobed, hairy. Upper whorls nearly contiguous. Ls. eggspear-shaped, hispid, saw-toothed. Cal.-teeth very long, bristleshaped. Colour of the $f$. variable.

Harvest men attribute to handling this plant, occasional severe inflammation of the hand, or finger. $F . T$.

G. versicolor. Large Flowered H., Bee-Nettle. Stem bristly, swollen below the joints. Corolla thrice the length of the calyx ; upper lip swollen; middle lobe of the lower lip heart-shaped. $\quad$ E. B. $66 \%$. C. 6.38 .

Sandy fields.** Near Bladon. Mrs. Thomas, Oxford, and Mr. Coles, Woodstock.

An. July, August.

$\mathbf{F l}$. larger than in $\mathbf{G}$. Tetrahit, yellow marked with red, or orange, on the palate: lower lip, middle segm., purple, bordered with white; upper lip, broad, very hairy, much notched: a handsome plant in $f$.

\section{GALEO'BDOLON. Weasel-snout.}

G. lúteum. Yellow W. Yellow Archangel. E. B. 787. G. Galeopsis. Sb. 185. Lamium luteum. G. E. 702 .

Shady, rather moist places.

Per. May.

Stems upright, simple, about one f., square, as in all this nat. order. $L s$. upper ones sub-egg-shaped, pointed, of various length, brightgreen, deeply, unequally saw-toothed, somewhat hairy. Fl. whorled, large, yellow, longer than the cal.; the under lip acute, spotted and streaked with red. Cal.-teeth spreading, bristly. Bract., linear. $\boldsymbol{L}$ s., uppermost egg-spear-shaped.

$F l$, of a Leonurus; habit of a Lamium. Leaves sometimes variegated.

\section{BETO'NICA. Betony.}

B. officinális. Wood $\boldsymbol{B}$. Spike interrupted. Middle segment of the lower lip notched. E. B. 1142. C. 3. 33. Betonica. G. E. 714 .

Woods, thickets. Shotover Hill. Stow Wood. Southleigh. Sb. Per. July.

Plant rough with stiff hairs: hence its power of provoking sneezing, when dried. Stem simple, about one f., and a half, almost leafless. Ls., root-ones on long stalks, egg-shaped, saw-toothed bluntly: uppermost $l s$., oblung, opposite, nearly stalkless. Spike blunt, of several whorls, the lowermost generally remote, with a pair of leaf-like bract. Small entire bract., to each $f$. Cor., dull-rose-colour, downy, sometimes pale, or white.

Said to be mildly astringent, and the root emetic, violently purgative, intoxicating, when fresh: often smoked as tobacco. In 
powder causes sneezing. Antonius Musa, physician to the Emperor Augustus, stated this plant to be a remedy for forty-seven disorders: hence the proverbial compliment:-" You have more virtues than betony." Another Italian proverb is:- "Sell your tunic, and buy betony."

\section{STA'CHYS. Woundwort.}

S. sylvática. Hedge $W$. Six or eight flowers in a whorl. Leaves heart-shaped, stalked. Stem solid. E. B. 416. C. 3. 34. Galeopsis vera. G. E. 704 . Hedges, shady situations.

Per. July.

Stems two or three f., hairy, leafy. $L s$. minute, strongly sawtoothed, deep, dull green, soft: upper ones on shorter footstalks, gradually smaller, diminishing to spear-shaped, entire bract. Spike erect, terminal. $\boldsymbol{F l}$, deep, dull blood-colour, marbled about the mouth, with a darker hue, intermixed with white.

Smell pungent, fetid : plant dyes yellow.

S. palustris. Marsh $W$. Six to ten flowers in a whorl. Leaves linear-spear-shaped, half embracing the stem, almost stalkless. Root tuberous. E. B. 1675 . C. 3. 35. Panax coloni. G. E. 1005.

Wet hedges, fields, banks of ditches, rivers.

Per. July.

Stems two or three f., straight, rough with bent down bristles. Ls., opposite, saw-toothed, silky above, rather woolly beneath, acute: upper ones heart-shaped at the base. Spike with whorls accompanied by two small $l s$., under each. Cor., purple, lower lip streaked with white.

Swine fond of the roots. In times of scarcity, the roots have been made into bread: increases much by root, hurtful in many cornfields. Old Gerarde gives a most solemn account of the supposed virtues of this plant in healing wounds.

S. germánica. Downy $W$. Many flowers in a whorl. Leaves notched, closely silky; woolly beneath. Stem woolly, erect. E. B. 829. S. F. G. E. 695.

Fields, hedges, road sides, on limestone.** Near Witney. Sb. and R. W. Stonesfield. On the road side, between Woodstock and Enstone. $\boldsymbol{S b}$. Between Blenheim and Ditchley. Woodward. Cornfields at Brize-Norton. Rev. Dr. Groodenough. Side of the road leading from Woodstock to Sturges Castle. $\boldsymbol{B} x$. Ducklington, Berks. Bicheno in $\boldsymbol{H}$. Fl.

Per. July.

$L s$. rather pointed, netted with veins : root-ones on long stalks, the rest smaller, nearly stalkless; floral.ls. spear-shaped, bent back. Whorls axillary, numerous. Bract., linear. Fl., purple within, 
streaked about the mouth with white; outside whitish, and very downy.

The Stachys lanáta of the garden has blunter leaves, stems trailing at the base, where they take root.

S. arvensis. Corn $W$. Six flowers in a whorl. Stem weak and slender. Leaves heart-shaped, blunt, notched, slightly hairy. Corolla scarcely longer than the calyx. E. B. 1154. C. 4.41 .

Gravelly, sandy, or chalky fields. Parks. Stanton Harcourt. Southleigh. $S b$.

An. August.

Stem spreading, often prostrate. Ls., opposite, on short foot-stalks, in some degree, three-nerved at the base. Cor., variegated with white, and pale purple. Smell disagreeable, as in the genus. Cal., stalkless, hairy.

\section{BALLO'TA. Black Horehound.}

B. nigra. Stinking B. $\boldsymbol{H}$. Leaves egg-shaped, undivided, saw-toothed. Calyx funnel-shaped, abrupt, with short spreading teeth. E. B. 46. Marrubium nigrum. G. E. 701 .

Hedges, waste places.

Per. July.

Stem two or three f., upright, branched. Ls., lower heart-shaped. Bract., bristle-shaped. Whorls half way round the stern. Cor., dull purple: upper lip with white hairs. Cal., attaining its full size long before the expansion of cor. Cor., upper lip cloven, vaulted, outwardly clothed with white hairs, more or less converging into a pointed tuft.

Smell pungent, disagreeable. Decoct., of plant recommended in nervous and hysteric disorders. Ray. Var. $f$., sometimes white: Littlemore. R. W.

\section{MARRU'BIUM. White Horehound.}

M. vulgáre. Common White $\boldsymbol{H}$. Calyx-teeth ten, bristle-shaped, hooked backwards. Leaves roundishegg-shaped, wrinkled, unequally saw-toothed. E. B. 410.

Dry, waste ground, road sides. ** Bullingdon Green. Sb. Marston Lane. Behind the Parks. R. W.

Per. July.

Stems several, bushy, simple in the upper part. Ls, stalked, veined. Whorls thick, axillary. Cor., white, lower lip in three segments, side ones small, sharp; middle one large, inversely heart-shaped, notched. Whole plant white with down. 
Plant aromatic, bitter, hoary. The extract a popular, but in reality an injurious remedy for coughs and asthmas. In large doses aperient. A case on record, where a salivation, which had continued more than a year, was stopped by an infusion of this, by Linn. The dry calyxes of the ripe fruit adhere like burs.

\section{CLINOPO DIUM. Wild Basil.}

C. vulgáre. Common Wild $\boldsymbol{B}$. Whorls bristly, involucral leaves awl-shaped. Flower-stalks branched. Leaves obscurely saw-toothed, egg-shaped. E. B. 1401. Acynos. G. E. 675 .

Bushy places, hedges, road sides.

Per. July.

Stems wavy. Ls., stalked, rather blunt. Whorls terminal, and axillary. $F l$., numerous, light purple; stalks hairy, branched; at the foot of the small fl.-stalks several bristly, hairy ls. Cal., ribbed, lower teeth longest. Cor., twice as long as the calyx, with two hairy knobs at the orifice.

Plant aromatic.

Discrim. By its bristle-shaped, floral ls.

\section{ORI'GANUM. Marjoram.}

O. vulgáre. Common $M$. Heads of flowers roundish, panicled, crowded, erect. Involucral leaves longer than the calyx, egg-shaped, smooth. Calyx with five acute, unequal teeth; throat hairy. E. B. 1143. C. 5. 39. Origanum anglicum. G. E. 666.

Bushy places, on limestone, or gravel. Sm. Under Woodstock Park Wall. About Henley. Near Headington Wick, \&c. Bx. Per. July.

Roots creeping. Stems about two f., leafy, purple. $L s$., opposite, shortly stalked, egg-shaped, entire, dotted with glandular spots. Fl., rose-coloured. Bract., purple, smooth, entire, spear-shaped. Cal., purple tinged.

Bees fond of the $f$. Smell of the plant fragrant, thyme-like. Stimulant, for culinary uses ; but $\mathrm{O}$. Marjorána preferred. Dried Is., in decoction as tea, grateful. The essential oil very acrid; an application to the painful nerve of a carious tooth. The tops dye purple. In some parts of Sweden put into ale, to give it an intoxicating quality, and to prevent its turning sour.

THYMUS. Thyme, or Calamint.

T. Serpyllum. Wild $T$. Flowers in small heads. Stems creeping, recumbent. Leaves flat, egg-shaped, 
blunt, entire; fringed at their base. E. B. 1514. C. 2. 4\%. Serpyllum vulgare. G. E. 570.

Heaths. Var. n. Bullingdon Green. Sb.

Per. July.

Roots fibrous, creeping. Stems crowded, filiform, (thread-like,) branched, leafy. $L s$., with resinous dots. $F l$., heads terminal,

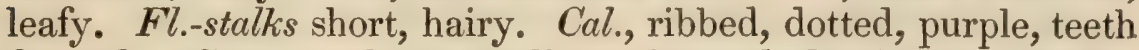
fringed. Cor., purple, lower lip variegated, deeply three-cleft.

The bruised leaves when trodden on, diffuse an aromatic smell. Several var., in size, uprightness, and hairiness. Diseased with downy swellings, as in Veronica Chamædrys, Cerastium, and Glechoma. The lemon-thyme a garden var. Essential oil very heating. Bees attached to the $f$. of this, and other aromatic plants. Larva of the handsome Phalæna Papilionaria feeds on this. Esteemed a nervine, as tea. An infusion of the ls., recommended by Linn., to remove head-ache, occasioned by an excess of the preceding evening. $\mathrm{Fl}$. Suec.

T. 'Acinos. Basil T. Flowers about six in a whorl, on simple stalks. Stem branched, ascending. Leaves oblong, shortly stalked, acute, saw-toothed. Calyx gibbous at the base. E. B. 411. C. 1. 43. Ocymum sylvestre. G. E. 675 .

Cultivated fields, especially on sand, gravel, or chalk. Sm. Headington Wick. Stonesfield. Southleigh. Sb.

An. July.

$L s$. in distant pairs, egg-shaped, variable in shape, to roundish, or oblong, acute, entire at the base. $L s$., sometimes entire: upper taper at the base. Cal., mouth fringed with hairs. Cor., lower, middle segment inversely heart-shaped, marked at the base with white, and a spot or two of crescent-shaped, darker purple. $F l$., bluish purple. Plant aromatic. $\boldsymbol{F l}$., sometimes white.

T. Calamintha. Common Calamint. Whorls on forked, many-flowered, axillary stalks. Leaves egg-shaped, blunt, with shallow serratures. Hairs in the mouth of the calyx not prominent. E. B. 1676. Melissa Calamintha. Sb. Calamintha vulgaris officinarum. G. E. 687 .

Way sides, borders of fields, chiefly on gravel. Near the Observatory. Ensham. Sb. Cowley Field. R. W.

Per. August.

Specific difference between this, and Thy., Nepeta, not easily defined. $L s$. , of this larger, with smaller serratures. Stem more constantly erect. $F l_{\text {.-stalks, lower, shorter than the } l s_{0}: \text { hairs }}$ at the mouth of the cal., less prominent. Fl.-stalks axillary. $L s$. , stalked, in opposite pairs. Flavour of this much less like Penny-royal, (Mentha Pulégium.) Cor., light purple, dotted with violet. 
Whole plant has a peculiarly sweet, aromatic flavour, and makes a pleasant tea, especially mixed with smaller portions of Pepper-mint, Balm, or some others of the same natural family. $\mathbf{S}$.

T. Népeta. Less Calamint. Whorls on forked, manyflowered stalks, longer than the adjoining leaf. Leaves saw-toothed. Hairs in the mouth of the calyx prominent. E. B. 1414. C. 6. 40. Melissa, Sb. 190. Calamintha odore pulegii. G. E. 687 .

Dry barks, way sides, on chalk. Sm. Ensham, on the road to Stanton Harcourt. $\mathbb{S} b$. Bank on the side of the Abingdon Road, going through Bagley Wood. $B x$.

Per. August.

Stems ascending, square, rough. Ls., stalked, egg-shaped. Fl.stalks axillary, repeatedly forked. Cal.-hairs closing it like a mouse-trap, very closely. Cor., variegated with pale purple, and white. Ls., smaller than in Thy., Calamintha.

Plant pungent, smelling like Penny-royal, (Mentha Pulegium,) used as a stomachic tea.

\section{SCUTELLA'RIA. Skull-cap.}

Cal. when in fruit, like a box with a fixed lid, or a helmet with its crest.

S. galericuláta. Common S. Leaves spear-shaped, notched, rugged; heart-shaped at the base. Flowers axillary. E. B. 523. C. 3. 36. Lysimachia galericulata. G. E. 477 .

Margins of rivers, ditches.

Per. July.

Stem erect, about one f., and a half, thickly clothed with $l s$., to the top, square, roughish. Ls., opposite, spreading, stalked. $F$., almost stalkless, a little drooping. Cal. on the upper side with a small, concave scale, enlarged after the fall of the cor. Cor., blue, the palate streaked with white, tube pale, purplish. Stam., and sty., white. Stig., simple.

'The cul., becoming dry divides into two parts, and thus the seeds are discharged. Plant bitter.

(S. minor. Less S. Leaves egg-shaped, nearly entire; heart-shaped, and occasionally lobed, at the base. Flowers axillary. E. B. 524. C. 4. 43. Gratiola latifolia. G. E. 581.

Moist heaths on gravel. Sm. Packington, Warwickshire. Tur. Per. July, August.

Scarcely one third the size of the former Sp. $L_{s}$., broader. Plant three to five inches. $F$., pale, reddish purple, or delicate pink. Lower lip white, dotted with red.) 
PRUNELLA.' Self-heal.

P. vulgáris. Common S., or Slough-heal. All the leaves egg-oblong, stalked. Teeth of the upper lip of the calyx scarcely discernible. E. B. $961 . \quad$ C. 4. 42. Prunella. G. E. 632.

Meadows, pastures.

Per. June.

Stems six to ten inches, square. Spikes terminal, solitary, cylindrical, blunt, close, with a pair of stalkless $l s$., at their base. Whorls each with a pair of kidney-shaped, purple edged, fringed bract. Cor., violet, sometimes red, or white. Ls. opposite.

Astringent. Asteróma Prunellæ, a new species found on this, by Mr. Haines, Radcliffe Library. Since found by Mr. Baxter. See Bax. Stirp. Crypt. Oxon. No. 79.

\section{DID YNAMIA ANGIOSPERMIA.}

\section{BARTSIA. ${ }^{2}$ Bartsia.}

B. Odontítes. Red B. Leaves spear-shaped, sawtoothed; the floral ones alternate. Flowers forming clusters, leaning one way. Stem square, branched. Root fibrous. E. B. 1415. Euphrasia Odontites. C. 1. 44. Sb. 192. Cratæogonon Euphrosine. G. E. 91 .

Meadows, pastures.

An. July.

Stem oppositely branched. Ls. stalkless, spreading, opposite, except the smaller floral ones. Fl.-clusters, long, leafy. Cor. rose-colour. Cal. purplish. Anth. lobed, acute. Whole plant reddish.

\section{RHINANTHUS. ${ }^{4}$ Yellow Rattle. ${ }^{5}$}

R. Crista-galli. Common Vellow R. Stem slightly branched. Leaves spear-shaped, saw-toothed. Calyx smooth. Style concealed by the uppèr lip. Seeds with a dilated membranous border. E. B. $65 \%$ C. 5. 43 .

1 Die Braune, quinsy, German, from its healing sores in the throat.

2 Named after a Prussian botanist. $H$.

4 Rin, nose, and anthos, flower. Gr.

5 From the ripe seeds rattling in the capsules. 
Meadows, pastures.

An. June.

Stem four-cornered, often spotted with red. Ls., opposite, stalkless, beneath grey, with a curious net-work of green veins. Spike terminal, leafy. $\boldsymbol{F l}$., on short stalks. Cor., twice as long as the calyx, yellow, upper lip compressed, tipped with two blue spots. Cal., bladdery, with strong ribs, and a net-work of veins, pale greenish-yellow, mouth contracted.

Cattle not fond of this plant.

\section{EUPHRA'SIA. Eye-bright. ${ }^{\circledR}$}

E. officinális. Common $\boldsymbol{E}$. Leaves egg-shaped, furrowed, deeply toothed. E. B. 1416. C. 5. 42. Euphrasia. G. E. 663.

Heaths, mountainous pastures.

An. July.

Stem mostly branching from the bottom, often purplish. Ls., stalkless. $\mathbf{F l}$., about the top of the stem, axillary, stalkless, solitary. Cor., generally white, striped with purple, and stained with yellow in front.

A weak astringent, in repute formerly in complaints of the eyes. The spot in its cor., something like a pupil, according to the exploded doctrine of signatures, an indication of marvellous virtues. See Saxifraga granulata. $F . T$.

\section{MELA'MPYRUM. ${ }^{2} \quad$ Cow-wheat.}

(M. cristátum. Crested $C$. Spikes four-cornered. Bracteas heart-shaped, closely tiled, finely toothed. E. B. 41 .

Woods, thickets. In a field that goes off Moreton Green in the road from Wendover to Ellesborough, Bucks. Tur.

An. July.

Cor. yellow, upper lip purple.)

(M. arvense. Purple C. Spikes conical. Bracteas lax, spear-shaped, wing-cleft. Calyx-teeth longer than the tube. Corolla closed. E. B. 53. M. coeruleum. G. E. 90 .

Cornfields, light soil. Packington, Warwickshire. Tur.

An. July.

Cor., yellow, tipped with purple. Bract., purple. Ls., spear-

1 Deserving of such an appellation from its bright eye-like blossoms.

2 Melas, black, puros, wheat. The authority for accentuation, adopted in this work, in general, is John Beckmann's Lexicon Botanicum, Exhibens Etymo. logiam, \&c. 8vo. 
shaped; one or two of the upper pairs, wing-cleft at the base, occasionally.

A beautiful plant in fl.)

M. pratense. Common Yellow C. Flowers axillary, stalkless, in partly distant pairs, leaning to one side. Corolla closed; lip direct, (straight.) Leaves spearshaped, upper floral-ones toothed at the base. E. B. 113. Cratæogonon album. G. E. 91.

Woods, bushy places. Copse under Shotover Hill. Stow Wood. Tar Wood. Sb.

An. July.

Stem slender, divided into several opposite, spreading branches. Cor. pale at the base, deep yellow towards the tip. Lip lower one straight, not bent downwards, as in M. sylvaticum : palate with two deep yellow, raised plaits. Anth., cohering at their tips. Discrim. Fl. of Mel., sylváticum, smaller, and mouth of cor . more gaping. Ls. shortly stalked, spear-shaped, taper-pointed. Upper Fl.-leaves, with long, awl-shaped, turned back teeth, ending in an acute spear-shaped point.

Cor. in M. pratense, four times as long as the closed calyx, lower lip protruded. $\mathrm{H}$.

Where this plant abounds, the butter "said by Linn., to be yellowest, and best. Swine fond of the seeds, and hunt for them. Fl. Suec.

(M. sylváticum. Wood C. Flowers axillary, in distant pairs, turned to one side. Corolla gaping; lip bent downward. Leaves nearly all entire. E. B. 804.

Mountainous woods, among firs. Sm. Wick Cliffs, Gloucestershire. Tur.

An. July, August.

$L s$. entire. Cor. deep yellow.)

\section{LATHR王A.' Tooth-wort. $^{2}$}

L. Squamária. Great T. Flowering branches erect, simple. Flowers axillary, on one side of the stem, drooping; lower lip in three lobes; upper cloven. E. B. 50. Dentaria major Matthioli. G. E. 1585.

Dry, shady places, where the sun's rays can scarcely penetrate, at the roots of hazels, or elms. Woodstock Park. Woods near Ashford Mills. Sb. (Copse close to Cumnor Hill.) Y.

Per. April.

Root or lower part of the stems scaly, tiled, fleshy. $L s$., root-ones none. Stems succulent, (ls., membranaceous, coloùred.) Flor.-

1 Lathraios, Gr. hidden, from its partly hidden stem.

2 From the resemblance of the scaly roots to teeth. 
ls., roundish, oval, one at the base of each fruit stalk. Cal., bellying. Cor. pale purple, except the lower lip. The real root fibrous and parasitical.?

\section{PEDICULA'RIS. ${ }^{x} \quad$ Louse-wort, ${ }^{2}$ or Red Rattle.}

P. palustris. Marsh L., Tall R. R. Stem solitary, branched. Calyx egg-shaped, hairy, ribbed, in two unequally notched, crested lobes. E. B. 399.

Marshes, boggy meadows. Peat bogs on Bullingdon Green. Behind Headington Hill. Southleigh Meadows. $\mathbf{S b}$.

Per. June.

Stem twelve to fifteen inches. Ls. scattered, here and there opposite, leaflets winged, wings egg-shaped, notched, with blunt segments. Fl. axillary, solitary, dark-rose-coloured, handsome, fl.-stalks short. Cal., inflated, can hardly be styled five-lobed. Cor. tube white, lip, upper much compressed. Caps., eggshaped, when ripe, projecting beyond the permanent cal.

Plant acrid, not acceptable to cattle. Blossom sometimes white.

P. sylvática. Pasture L., Dwarf R. R. Stems several, spreading, simple. Calyx oblong, angular, smooth, in five, unequal, notched segments. E. B. 400 . Pedicularis. G. E. 1071.

Moist, heathy pastures. Shotover Hill. Southleigh Heath. Sb.

Per. Sm. May.

Root thick. Stems many, short, three or four inches, central one erect. Ls., alternate, winged, leaflets acutely notched or sawtoothed. Fl.-ls. less compound. From the crown of the root, a circle of egg-shaped, undivided, curved back, notched $l s . \quad F l$. axillary, solitary, rose-coloured. $\quad C$ al. with four larger, and four smaller angles alternately. Cal. nearly half as long as the cor.

The expressed juice, an injection in sinuous and fistulous ulcers. Fl. Suec. G. E.

\section{ANTI'RRHINUM. ${ }^{3}$ Toad-flax, or Snap ${ }^{4}$-dragon. \\ * Leaves dilated. Stems limber.}

A. Cymbalária. Ivy-leaved $S n$. Leaves broadly heartshaped, five-lobed, alternate, smooth. Stems trailing.

1 From pedículus, a louse.

2 From a supposed quality of producing scab, and lice, in sheep, which feed on the plant: others say, because the plant destroys lice. Chiefly an Alpine genus.

${ }_{3} A$ Anti, and rin, Gr. nostrils; so called from the seed resembling the nostrils of a heifer. Plin.

4 'The corolla when pressed, laterally, between the finger and thumb, gapes, and when let go, elastically recloses. 
E. B. 502. C. 1. 45. Cymbalaria italica. G. E. 530 .

Old walls; from Italy originally.

Per. June.

Herb smooth, shining, often purplish. Stems very long. Ls. smallest with three lobes, on longish foot-stalks, often purple beneath. $F \boldsymbol{F}$. solitary, on simple, axillary stalks, purple; palate yellow, downy; spur as long as the cal. pale. Caps. bursting at the top. Seeds wrinkled.

The trailing branches of this elegant plant variously interwoven form a thick and beautiful kind of tapestry on old walls.

$\mathrm{Fl}$. sometimes white.

A. spúrium. Round-leaved Fluellin, or Sn. Leaves roundish-egg-shaped, downy, chiefly alternate. Stems trailing, hairy. E. B. 691. C. 3. 37. Veronica fœemina. G. E. 625.

Cornfields. Cowley. Southleigh. Sb. Between St. Clement's and Cowley Marsh. Between Bullingdon Green, and Shotover Hill. $B x$.

An. July.

$L s$. on short foot-stalks, broad, (roundish,) pointed, hairy, mostly entire. Fl.-stalks axillary, solitary, hairy, single-flowered. Cal. segments egg-shaped, pointed. Cor. spur curved back; the upper lip violet, the lower yellow. Lower fruit-stalks generally shorter, upper ones, longer than the $l s$.

$F l$. of this sometimes monstrous, as in Antir. Linaria, var. Peloria. Seeds of Ant. spurium, and of An. Elatine beautifully covered with net-work. $B x$.

A. Elátine. Sharp-pointed Fluellin, or Sn. Leaves chiefly halberd-shaped, alternate; lowermost eggshaped, opposite. Stems trailing, hairy. E. B. 692. C. 1. 46. Elatine altera. G. E. 625.

Cornfields, on gravel or chalk. Sm. Headington. Southleigh. Sb. Between St. Clement's and Cowley Marsh. Between Bullingdon Green and Shotover Hill. $B \boldsymbol{B}$.

An. July.

Stems and general habit resembling Ant. spúrium. Cal. segments approaching to spear-shaped. Cor. yellow, upper lip violet. Fl. occasionally regular, five-cleft, as in Ant. Peloria.

A quaint case, quoted by Gerarde from Lobel, where this plant proved eminently successful in saving an ulcerated nose, condemned to be cut off with one consent by divers eminent physicians and surgeons. Plant astringent.

** Leaves narrower. Stems upright.

A. repens. Creeping, Sweet-scented, Pule-blue Toadflax. Leaves linear, glaucous, scattered; partly 
whorled. Stem panicled. Calyx smooth, the length of the spur. E. B. 1253.

Chalky banks. Between Ewelme and Swincombe. Sb. Shooter's Hill. Pangbourn, Berks. R. W. In a clay pit, near a lane, leading off the Theale road, Berks, to Mr. Wilder's, Purley.

R. W. On a chalk hill, Henley. Dillen. and $\mathbf{S}$.

Per. July.

Stems numerous, erect, branched. Herbage smooth, glaucous. $\mathbf{L}$ s. entire, stalkless, narrow. $\boldsymbol{F l}$. in terminal spikes. $\mathbf{F l}$.-stem stiff, upright. $F l$. in some states of the atmosphere, fragrant. Cor. spur, and lower lip whitish, upper lip, and tube striped with greyish blue. Spur conical, shorter than the fl.-stalk.

A var. has been found near Southampton, with fl. like those of Ant. Linária, var. Peloria.

A. Linária.' Common Yellow T. Leaves linear-spearshaped, crowded. Stem erect. Spikes terminal. Flowers tiled. Calyx smooth, shorter than the spur. E. B. 658 . C. 1.47 . Linaria lutea vulgaris. G. E. 550 .

Hedges, borders of fields on gravel.* Sm. Stanton Harcourt. Southleigh. Dorchester. Sb. Near Summer Town. Near Stonesfield. Bx.

Per. August.

Stems erect, two f., leafy, scarcely branched. Ls. entire, spreading, little glaucous. Spike erect, many-flowered. Bract. spearshaped. Cor. large, bright yellow, handsome, masqued, with downy, orange coloured mouth. Spur awl-shaped, five times as long as the cal.

A deformed var. found with regular, tubular blossoms, mouth closed and pursed up, five equal stamens, with two to five spurs, termed Pelória. E. B. 260. C. 6. 41. §.: its roots planted in a barren soil, return to Ant. Linaria, but the seeds of Peloria sown in a rich soil preserve the monstrous appearance of the var. Willd. Other species of Ant. liable to the transformation.

$L s$. in infusion diuretic, purgative : in ointment with lard, mixed with the yolk of an egg for pain in hæmorrhoids. The expressed juice mixed with milk, poison to flies.

A small glass of the distilled water, with a drachm of the bark of Sambúcus 'Ebulus in powder, powerfully diuretic in dropsical cases. C.

A. minus. Least Sn. Leaves spear-shaped, blunt, downy, mostly alternate. Stem much branched, spreading. Calyx longer than the spur. E. B. 2014. C. 5. 41. A minimum repens. G. E. 549 .

1 From the leares resembling linum, flax. 
Sandy fields. Southleigh. Stanton Harcourt. Sb. Between St. Clement's, and Cowley Marsh. Between Bullingdon Green, and the Asylum. $\boldsymbol{B} x$.

An. June.

Root small, zigzag. Stem various in height, leafy. Ls. clammy. Fl.-stalks numerous, axillary, solitary, simple, somewhat longer than the $l s . F l$. small, inconspicuous, purplish, under lip white, three-cleft, palate yellow. Cal. segments unequal, battledoreshaped, with prominent, clammy hairs. Caps. egg-shaped, blunt. Seeds curiously furrowed.

* * Corolla without a prominent spur.

A. majus. Great Sn. Corolla with a rounded prominence at the base. Flowers in a dense cluster. Leaves spear-shaped. Segments of the calyx, egg-shaped, blunt. E. B. 129. An. purpureum, sive album. G. E. 549 .

Old walls. Sb. New College Lane. Jesus College Walls, \&c. R. W.

Bien. July.

Stems short, spreading, rod-like, leafy. $F l_{\text {-stems twelve to }}$ eighteen inches, smooth below, hairy, and clammy above. $F \boldsymbol{~}$. stalks, short, with a concave bract. at their base, and sometimes a pair of narrow-spear-shaped bract. close to the cal. Cal.-ls., brown and clammy on the outside. Cor. rose-coloured, sometimes white; a large, yellow spot on the protuberant part of the under lip.

A deep crimson var. in gardens. $L s$. dark-green, smooth, entire, on short foot-stalks, alternate; branch-ls. opposite.

The plant continues to live long enough to produce flowers, only in dry situations. Dioscorides reports two wondrous properties of Antirrhinum, the latter of importance, even in the present day; that, hanged about a person, it preserves him from witchery, and that it maketh a man gracious in the sight of people! $\boldsymbol{G}$. $\boldsymbol{E}$.

\section{SCROPHULA'RIA. ${ }^{\mathrm{I}} \quad$ Fig-wort.}

S. nodósa. Knotty-rooted $\boldsymbol{F}$. Leaves imperfectly heartshaped, acute; three-nerved at the base. Stem fourcornered. Root tuberous. E. B. 1544. S. major. G. E. 716 .

Hedyes, woods, thickets.

Per. July.

Root thick, beset with small knobs. Stem two to three f, upright, simple, leafy. Ls. upper ones nearly stalkless, spear-shaped, lower ones opposite, stalked, saw-toothed, shining, dark-green

1 From supposed virtues of the plant in scrophula. 


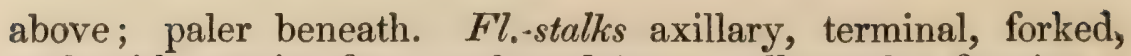
each with a pair of spear-shaped bract.; all together forming a compound, upright panicle. Cor. dull-green, with a livid, purple lip. Blossom-tube filled at the base with a honey-like liquor, whence the delight of wasps: as also Scr. aquática.

An ointment with the root, formerly used in piles, and scrophula. Scabby swine washed with a decoction of the $l s$. Infusion of the plant sudorific. Plant hung about the neck, or carried about one, supposed to keep a man in health, as, according to Old Gerarde's remark, " divers do rashly teach." $\boldsymbol{G}$. $\boldsymbol{E}$.

Bruised plant fetid, like elder. The knotty form of the root might suggest the notion of its use in glandular, and scrophulous swellings, agreeably to the doctrine of Signatures. See Saxifraga granulata.

ß. Paler-flowered variety of Bobart, at Cumnor, near Oxford.

S. aquática. Water $\boldsymbol{F}$. Water Betony. Leaves heart-egg-shaped, bluntish, on foot-stalks running down the stem. Stem winged. Root fibrous. E. B. 854. C. 5. 44. Betonica aquatica. G. E. 715 .

Watery places, margins of pools, and rivers, wet meadows.

Per. Juty.

Stem upright, nearly simple, three or four f., square, smooth, leafy.

Ls. opposite, stalked, egg-oblong, heart-shaped at the base, sawtoothed. $F l$. in small, forked panicles, oppositely compounded into a long, leafless, bracteated bunch. Cor. tube greenish, inflated, its larger lip, dark, dull blood-colour.

Planted with advantage near bee-hives. Bruised herb fetid : in poultice for scrophulous, and cancerous sores. A beautiful plant when variegated. $C$.

\section{DIGITA'LIS. ${ }^{x} \quad$ Fox-glove. ${ }^{2}$}

D. purpurea. Purple $F$. Segments of the calyx eggshaped, acute. Corolla blunt; its upper lobe scarcely cloven. Leaves downy. E. B. 1297. C. 1. 48. G. E. 790 .

Pastures, hedges, banks, on gravel, or sand. Sm.* Stokenchurch. Between Nettlebed and Henley. $\quad \mathbf{S b}$. Copse just above Childswell Farm. Bx. Mixbury. Mr. Roundell Palmer, Trin. Coll. Oxford.

Bien. July.

Stem upright, wand-like, leafy, three or four f. $L s$. alternate, eggshaped, or elliptic-oblong, notched, rugged, veiny, root-ones largest. L.-stalks half embracing the stem. Spike terminal,

1 From its resemblance to a thimble. Beckman.

${ }^{2}$ From the name of a German botanist, \&c. or from the Anglo-Saxon, foxes-glofe. See Benson's Anglo-Saxon Vocabularium. 
erect, simple, of numerous, large, drooping $f s$. each with a short stalk, and bract. Cor. one inch and a half, bell-shaped, purplish crimson, beautifully speckled with eye-like spots inside; margin slightly lobed. Stam. bent. Caps. egg-shaped, sharp-pointed.

A direct sedative; to be used with caution. Infusion, Tincture, or Powder. Mat. Medica. Important for alleviating the distressing symptoms of hydrothorax, or water on the chest. Combined with squill and blue pill, it enables the patient to hold out a considerable time. See the valuable Treatises on Digitalis, of Drs. Withering, and Hamilton.

$V a r$. with milk-white $f$. in our gardens.

A stately, and elegant plant.

\section{LIMOSELLA. ' Mud-wort.}

L. aquática. Common M. Leaves spear-shaped, or battledore-shaped? Foot-stalks twice as long as the flowerstalks. E. B. 35\%. H. L. 62.

Muddy spots, where water has stagnated during winter. * Binsey Common. Noke. $\mathbf{S} b$. Port Meadow. Cowley Marsh. Bx. An. July.

A diminutive plant escaping the notice of all but the scrutinizing observer.

Stem prostrate, or root with naked runners. Ls. root-ones smooth, entire. $\mathrm{Fl}$. solitary, from the root, small. $F l_{\text {.-stalks simple, as }}$ the fruit ripens, bent in. Cal. segments sharp. Cor. without, whitish; inside, red. Caps. globular, grooved in its upper side. Stam. four, two a little higher.

\section{OROBANCHE. ${ }^{2}$ Broom-rape.}

* Bracteas solitary.

(O major. Great Br. Stem simple. Corolla inflated; upper lip slightly notched; lower with acute, nearly equal segments. Stamens quite smooth in the lower part. Style downy. E. B. 421. C. 4. 44. Rapum genistæ, sive Orobanche. G. E. 1311.?

Bushy places on gravelly soil, on the roots of broom, or furze. Sm. Allesley, Bickenhill, Leek Wootten, Warwickshire. Bree. Pn. Flora.

Per. June, July.

I From limus, mud.

2 i. e. Strangle tare, Gr. Orobon anchei. The Orobanches are not altogether parasitical; they acquire sustenance, and stability, not only from the foster-plant, but also from the soil, by their root-fibres : their taste is acrid, and astringent. Rev.Dr. Sutton. Michéli mentions that the Orobanche is proscribed by public edict in Tuscany, on account of its choking the neighbouring plants. Curtis. 
Stem twelve to eighteen inches, simple, erect, succulent, with scattered, upright, spear-shaped, leafy scales; its base bulbous-formed, and more scaly. $\mathrm{Fl}$. stalkless, spike terminal, rather close-set, upright. Cor. dull, purplish yellow, soon turning brown, and withered. Bract. solitary, spear-shaped, mostly shorter than the fl. Cal.-segments spear-shaped, acute. Stam. rather shorter than the tube. Stig. of two, yellow, separate globules.

O. elátior. Tall Br. Stem simple. Corolla funnelshaped; lower lip with acute, nearly equal segments. Stamens downy. Styles smooth. E. B. 568. O. major. of Sb. 191. ${ }^{\text {' }}$

Never on the roots of broom, or furze.* Rev. Dr. Sutton. Fields near the road between Oxford and Woodstock, left hand, near the half-mile trees. $B \boldsymbol{x}$. Mr. Baxter gathered a specimen with a spike of sixty-five flowers. Near the Parks. Stanton Harcourt. Henley. $\mathbf{s} b$.

Per. July, August.

This species first well distinguished from Orob. major, by the Rev.

Dr. Sutton, in Linn. Trans. : as common as Orob. major, in some counties.

Discrim. from O. major as taller, more of a yellowish colour, the spike of $f$. much longer, more numerous, sometimes above one hundred. Cor. less inflated, border much curled, and fringed. Stam. downy on the inside from the bottom upwards for half their length, but smooth in the upper part. Stig. inversely heart-shaped. Cal.-ls. united at the base before.

O. minor. Less $\boldsymbol{B r}$. Stem simple. Corolla nearly cylindrical ; lower lip with curled segments, the middle one largest and lobed. Stamens fringed. Style smooth. E. B. 422.

Clover fields. In a clover field (Trifolium pratense, near Buckland, Berks. Dr. Williams, Professor of Botany, Oxford. Woods about Ewelme. The Rev. Dr. Lloyd, late Bishop of Oxford. Bx. Above Headington Wick Copse. R. W. 1832. An July, August.

Smaller than Orob. major, more purplish. Stem more inclined to be zigzag. Bract. solitary. Stam. in the lower part, fringed with projecting hairs. Stig. purple.

Dr. Williams, Prof. Bot. Oxford. 


\section{Class XV. TETRADYNAMIA. Stamens 6 .}

\section{Order I. SILICULOSA. Pistil 1.}

DRABA. Whitlow-grass.

D. verna. Common Whitlow-grass. Stalks immediately from the root, naked. Petals deeply cloven. Leaves spear-shaped, somewhat notched, hairy. E. B. 586. C. 1. 49. Paronychia vulgaris. G. E. 624 . Walls, banks, dry, waste ground.

An. March.

$F_{l}$.-stalks two or three inches, erect, simple, leafless. $F l$. white, small, in a corymb of many $f$., soon lengthened into a somewhat zigzag raceme. Pouch elliptical, smooth, crowned with the permanent, stalkless stig. $\quad L s$. flat on the ground, in a circle round the root; hairs simple, and forked also.

This unattractive plant, with its small, starry blossoms is viewed with pleasure from its early appearance: somewhat pungent, said to be good as a salad. Stalk and fl. drooping in the night, and in rainy weather. The true Whitlow-grass is not easily ascertained.

\section{CAMELI'NA. Gold of Pleasure.}

* C. sativa. Common G. Pouches inversely eggshaped, margined, style simple. Leaves spear-arrowshaped. Alyssum sativum. E. B. 1254. Myagrum. G. E. 273.

Cultivated fields. * Third field past Joe Pullen's tree, to Headington Hill. R. W. 1832.

An. June, July.

Plant two f. or more; more or less panicled above. Fl. small, pale yellow. Seed-pouches pear-shaped, large, on long footstalks, tipped with the styles, which are, according to Smith, commonly longer than represented in $E$. $B$.

\section{LEPI'DIUM. Pepper-wort.}

L. campestre. Common Mithridate $\boldsymbol{P}$. Pouch scaly, with glandular dots, notched; bordered at the summit. Style very short. Stem-leaves arrow-shaped, toothed. Thlaspi campestre. E. B. 1385 . C. 5. 45. Sb. 199. B. G. E. 262. T. vulgat.

Cultivated fields. Southleigh. Stanton Harcourt. Sb. Between Bullingdon Green, and Shotover Hill. $B x$. An. June.

1 pompous name not at all applicable to this homely species. 
Whole plant more or less hoary. Stem erect, about one f., branched above, leafy. Ls. lower spear-inversely-egg-shaped, stem-ls. clasping the stem. $\boldsymbol{F} l$. small, white, in small corymbs, soon lengthening into very long spikes. Pet. battledore-shaped, scarcely longer than the cal. Pouch roundish, protuberant.

$V$ ar. with smooth $l s$.

(L. ruderále. Narrow-leaved $P$. E. B. 1595. Thlaspi minus. G. E. 262. Almost every where about Bristol, Gloucestershire. Tur.) See Appendix.

(Hutchinsia petraea. Rock H. H. L. 31. Lep. petræum. E. B. 111. St. Vincent's Rocks, Gloucestershire. Mr. Sandys, Pembroke Coll. Oxford.)

\section{(TEESDA'LIA. ${ }^{\prime} \quad$ Teesdalia.}

T. nudicaulis. Naked-stalked, or Irregular T. Petals unequal. Iberis nudicaulis. E. B. $32 \%$ C. 6.42. Bursa pastoria minima. G. E. 276.

Dry, barren, gravelly fields.** Pond bank, near Tubney, Berks. Y. Coleshill Heath, Warwickshire. Purt. Fl.

An. May.

Ls. lyre-shaped. $F l$. minute, white.)

\section{THLASPI. ${ }^{2}$ Shepherd's Purse. Mithridate Mustard.}

T. arvense. Mithridate Mustard, or Penny Cress. Pouch flat and round, shorter than its stalk. Leaves smooth, oblong, toothed. Stem erect. E. B. 1659. C. 6. 43. T. Dioscoridis. G. E. 262.

Cultivated, or waste ground. Near Stow Wood. Stanton Harcourt. Southleigh. Sb. Broughton-Pogges. Dr. Goodenough. Field near Cowley Gate, \&c.

An. June.

Plant smooth. Stem erect, about one f., leafy, branched in the upper part. Ls. alternate, arrow-shaped, and clasping the stem at their base. Fl. many, extremely small, white. Pouch very large, erect, borders very broad, figure almost circular: the short style in a notch on the top.

The seeds, an ingredient formerly in the Mithridate confection. Taste pungent: flavour of plant like garlick: gives a taste to the milk of cows which feed on it. Seeds abound with oil, formerly in use for rheumatism.

1 After Mr. Robert Teesdale, F.L.S. ob. 1804.

2 From Gr. thlao, to break, because the fruit is in form rugged, and, as it were, broken. 
T. perfoliátum. Perfoliate Shepherd's Purse. Pouch inversely heart-shaped. Stem-leaves heart-shaped, rather sharp at the base, clasping the branched stem. Style very short. E. B. 2354. H. L. 46. T. rotundifolium. G. E. 266.

Limestone pastures. ${ }^{*} *$ Old stone quarries between Burford and Witney; Burford Downs. Sb., and Hooker. 1818.

An. April.

Stem in a rich soil branched from the bottom; four to six inches, spreading, smooth, leafy. Ls. glaucous, smooth, slightly toothed : root-ls. stalked, egg-shaped, blunt; the rest alternate. $F l$. white, small, not much longer than the cal., heads close, corymbose, gradually lengthened into long clusters of seedvessels. Pouch crowned with the stig. Cal. purplish.

T. Bursa Pastoris. Common Shepherd's Purse." Hairy. Pouch inversely heart-shaped, not bordered, somewhat triangular. Root leaves wing-cleft. E. B. 1485. C. 1. 50. Bursa Pastoris. G. E. 276. Capsella genus, of DC.

Waste, and cultivated ground, way sides.

An. April.

Root branched. Stem variable in height, branched, leafy. $\mathbf{F l}$. on branches, a corymb, and at length shooting into a spike-like bunch, small, white. Ls. root-ls. spreading, generally sharply toothed: stem-ls. oblong, stalkless, stem clasping, their base spear-arrow-shaped. Pouch margin scarcely dilated, crowned with the style. Seeds pendent.

The seeds and young fl. eaten by birds: plant found in almost every part of the globe. Ls. root-ones sometimes entire. Plant diseased by a minute, white, parasitic fungus, Urédo Thlaspi. Taste not pungent.

\section{COCHLEA'RIA. Scurvy-grass. (Horse Radish.)}

(C. officinális. Common Sc. Gr. Root leaves roundish; stem-leaves oblong, stalkless, sinuated. Pouch round. E. B. 551. H. L. 148. C. rotundifolia. G. E. 401. Rocks and muddy places by the sea-coast, as also upon high mountains. Packington, Warwickshire. Tur. An. May.

$L s$. succulent, smooth, shining. $F \boldsymbol{l}$. white, in corymbose tufts. Pouches obscurely veined, style-tipped.)

* C. Armorácia. Horse-radish. Root leaves oblong, notched; those of the stem lengthened out, spear-

1 From the shape of the pouch. 
shaped, either cut or entire, stalkless. E. B. 2323. Raphanus rusticanus. G. E. 241.

Common, as the refuse of gurdens. Sides of the Canal, near High Bridge. Banks of the Isis, near Iffley. $S b$.

Per. May.

Root very long, cylindrical, white, strongly pungent, and acrid, deep-rooted in the ground. Stems two f., erect, branched, leafy. $L s$. root-ones resembling those of a dock, large, long-stalked, veiny, wing-cleft occasionally. $\mathrm{Fl}$. white, numerous, corymbose, at length racemose. Pouch elliptic, compressed, with a short style, and large stigma. Fruit seldom perfected.

Root scraped, a condiment at table, anti-scorbutic: its infusion in cold milk, an excellent cosmetic. In palsy, and dropsy, a powerful stimulant, as compound spirit, Armor : and infusion compound. Strong infusion of the leaves, or root, emetic. Ls. in infusion dye straw-colour.

\section{SENEBIE'RA. ${ }^{\prime}$ Wart-cress.}

S. Corónopus. ${ }^{2}$ Common W. Swine's-cress. Pouch undivided, crested with little sharp points. Style prominent. Leaves wing-cleft, subdivided. Coronopus Ruellii. E. B. 1660. G. E. $42 \%$.

Waste ground, way sides.

An. June.

Stems prostrate, depressed, branched, leafy. Ls. alternate, segments mostly half-wing-cleft, along their fore-edges; terminating one linear spear-shaped, entire. $F \boldsymbol{F}$. clusters opposite the ls. corymbose, stalkless, lengthened out as the fruit swells. Cor. very small, white. Pouch kidney-heart-shaped, crowned with the short style, large, compared with the fl. Plant somewhat glaucous, taste mustard-like, acrid.

The ashes an ingredient in Stephens's once too much celebrated remedy for stone, and gravel.

The whole plant is nauseously acrid and fetid, and must require much boiling to render it eatable. Sm.

\section{IBE'RIS. Candy-tuft.}

I. amára. Bitter $C$. Stem herbaceous. Leaves spearshaped-linear, acute, partly notched. Flowers in oblong clusters. E. B. 52.

Chalky fields.** Henley. Nettlebed. Mungewell. Sb. About Henley and other places in Oxfordshire. Hudson. About Wallingford, Berks. E. Fl. Between the Asylum and Bul-

1 From Senebier, of Geneva, a physiological botanist.

2 Raven's foot. 
lingdon Green. Between Ipstone and Penley Hangings. B.x. Goring. Mr. L. Darwall, Trin. Coll. Cambridge.

An. June.

Stems spreading, numerous, each ending in a raceme of $\mathrm{fl} . \quad \overrightarrow{F l}$. showy, milk-white. Pouch sharply notched at the end. láta.

In gardens among our hardy annuals: smaller than Ib. umbel-

\section{TETRADYNAMIA SILIQUOSA.}

\section{(DENTARIA. Coral-wort.}

D. bulbifera. Bulb-bearing C. Lower leaves winged; upper leaves simple, with a bulb growing in their axils, (i. e. in the angles formed by the leaf-stalk, and stem.) E. B. 309. G. E. 984 .

Moist woods, rare. Woods at Loudwater, between Beaconsfield, and High Wycombe. Tur.

Per. April, May.

Axillary bulbs, dark purple, scaly, propagating the plant. Root toothed. $F l$., rather large, purple.)

CARDA'MINE. ${ }^{3} \quad$ Ladies'-smock, ${ }^{2}$ or Cuckoo-Flower ${ }^{3}$ * Leaves winged.

C. hirsúta. Hairy L. or C. Leaves winged, without stipulas; leaflets stalked, roundish-oblong, notched. E. B. 492 . C. 4.48 .

Waste and cultivated ground, moist, shady places. Southleigh Heath. Sb. A weed in garden ground, at Headington Quarry; also in several gardens, Warwickshire. $B x$.

An. April.

Stem three to twelve inches, erect, branched, leafy, zigzag, with scattered hairs. Ls. in a circle on the ground, alternate, lowermost leaflets round, or heart-shaped, the rest oblong, all of them notched, hairy, with stalks; opposite or alternate, rarely quite smooth. Fl. small, white, numerous. Corymb terminal, soon lengthening into a spike. Stam., two often deficient. Silique filiform.

As a salad in its early state, tasting like water-cress.

C. pratensis. Meadow L. or $C$. Leaves winged, without stipulas; leaflets of the root-ones roundish and

1 The i made long by Borrichius. Beckmann.

2 The profusion of the white $f$. of the $C$. pratensis gives the appearance at a distance of linen bleaching.

3 From the early appearance of the fl. about the time the cuckoo arrives. 
toothed; those of the stem-leaves spear-shaped, entire. Petals with a tooth upon the claw. E. B. 776 . C. 3. 40. Cardamine. G. E. 259.

Meudows, moist pastures.

Per. April.

Root sometimes toothed. Stem about one f., simple, leafy. $\quad \boldsymbol{F} l$. white, or pale purplish, in a handsome corymb, terminal, lengthening out.

The dried fl. in dose from half to two drachms, have been used in epilepsy, probably with little effect, from the obstinate nature of the disease. See $M e d . T r$. Ls. acrid.

$V a r$. with double $\mathrm{fl}$. in gardens; handsome, propagating itself by the leaflets. $L s$. in salad with other herbs.

C. amára. Bitter $L$. or $C$. Leaves winged, without stipulas; leaflets of the lowermost roundish; of the rest toothed or angular. Stem creeping at the base. Style obliquely lengthened out. E. B. 1000 . C. 3. 39.

Watery places, the sides of rivers and brooks.* Near Gosford Bridge. On the banks of the Thames, about three miles from Reading. $\mathbf{S} b$. Side of the Canal between Oxford and Wolvercot. The Rev. Dr. Whately, Protestant Archbishop of Dublin. Side of the Towing-path between High Bridge and Heyfield's Hut. Bx. Between St. Clement's and Marston. Banks of the Cherwell. $M r . T . W . W$ eaver.

Per. May.

Immediately distinguished by its violet-hued anth. and broadtoothed angulate leaflets of the upper $l s . \quad F l$. large, in a terminal corymb, white or cream-coloured. $L s$. much resembling those of the water-cress: pungent, nauseous, bitter, may be mixed in salads. The caterpillar of the pretty Pap. Cardamines feeds on the different species.

Suckers springing, but not always, from the bosom or axil of the leaves.

\section{NASTU'RTIUM. ${ }^{\prime} \quad$ Cress.}

N. officinále. Common Water-Cr. Leaves winged; leaflets roundish.heart-shaped, wavy. N. aquaticum, sive Cratæve Sium. G. E. 257. Sisymbrium Nasturtium. E. B. 855 . C. 6.44 . Sb. 206.

Clear springs, rivulets, ponds.

Per. Sm. June. Bien. Sb.

1 Name applied originally to some plant stimulating the nostrils. Plin. This genus separated from Sisymbrium by $B R .:$ the accumbent cotyledons, and short, thick swollen pods affording a clear character. 
Stems spreading, for the most part floating, branched, leafy, striking root from the under side. Ls. lower ones large, alternate, somewhat lyre-shaped, terminal leaflet largest. $\quad \boldsymbol{F l}$. white, in a flattish corymb, at length growing into a spike. Pods shortish, slender, curved upwards. Fruit-stalks horizontal.

Young ls. warm, pungent, agreeable to the taste: in salad: the expressed juice with that of brook-lime, and scurvy-grass, anti-scorbutic, stomachic: near London regularly cultivated. B. T.

\section{N. sylvestre. Creeping Yellow $C$. Leaves winged;} leaflets spear-shaped, deeply saw-toothed, or cut; those of the uppermost nearly entire. Root creeping. Sisymbrium sylvestre. E. B. 2324. C. 3.41. Sb. 206. Eruca aquatica. G. E. 248.

Gravelly, wet meadows, margins of rivers, ditches. Banks of the Canal beyond High Bridge. Port Meadow. Binsey Common. Otmoor. $S b$.

Per. June.

Stems erect, one f., or more, leafy, zigzag, furrowed. Ls. alternate, leaflets of the lower ones running down the stem, ellipticoblong, deeply cut, or toothed; those of the upper ones narrower, deeply saw-toothed, or entire. Common-footstalk channelled. Fl. bright yellow, numerous, in clusters, in a kind of panicle about the stem tops, each. cluster soon lengthening out greatly, and becoming zigzag. Pods seldom come to perfection, the plant increasing much by root.

N. terrestre. Annual Yellow $C$. Leaves wing-cleft, lyre-shaped, unequally toothed. Root tapering. Petals scarcely so long as the calyx. Pod curved, swollen. Sisymbrium terrestre. E. B. 1747. C. 5. 4.9. Sb. $20 \%$.

Banks of ditches. * Near the Diamond House. Sb. Merton College Meadow. Near Medley Lock. Otmoor. Bx.

An. June.

Stem about one f., nearly erect, branched, leafy. Ls. alternate or opposite, lobes confluent, i. e. run in with the mid rib of each 1. $\mathbf{F l}$. racemed, yellow, numerous, small. Fruit-stalks in cylindric clusters, partial stalks alternate, horizontal, each with a shortish, swelling pod.

N. amphibium is peren. has pet. larger, pods smaller, style longer. (Discrim.) from N. sylvestre by its wing-cleft $l s$. minute pet. and more swollen pods.

N. amphíbium. Amphibious Yellow C. Great Water Radish. Leaves oblong, spear-shaped, wing-cleft, or saw-toothed. Roots fibrous. Petals longer than the calyx. Pod elliptical. Sisymbrium amphibium. E. 


\section{B. 1840. Sb. 20\%. Raphanus aquaticus. G. E. 240.}

Rivers, ditches.

Per. July.

Roots long, perpendicular. Stem crooked at the joints. Ls. rootones stalked. $F \boldsymbol{F}$. yellow. Style lengthened out. Pods short, small, pointing upwards. Fruit-stalks longer than the pods, at length bending downwards.

Grows to a great size, with long, floating stems, and comb-like ls. under water : in dryer situations of a smaller form, and broader ls. Ends of the general fl.-stalk often swollen into a purplish substance, cauliflower-like. $L s$. variable in form; those under water deeply wing-cleft, otherwise deeply saw-toothed.

\section{SISY'MBRIUM. Hedge-mustard.}

S. afficinále. Common $\boldsymbol{H}$. Pods pressed close to the main stalk, awl-shaped, downy. Upper leaves mostly runcinate, hairy. Stem rough with bristles bent back. Erysimum officinale. E. B. 735 . C. 5. 50. Sb. 201. E. Dioscoridis Lobelii. G. E. 254.

Waste ground, by road sides and on banks.

An. July.

Stem two f. Easily known by its long, spreading branches, set with numerous, close-pressed seed pods, and terminating in a small, dense cluster of lemon-coloured $f$. Branches widely spreading, ascending. Ls. lower ones somewhat winged, upper ones halbert-shaped? terminal lobe nearly at the end, in both large, in former ls. rounded, in the upper oblong. Raceme very long. Fruit-stalks very short.

Infusion of the herb, or seeds, formerly recommended in asthma, and hoarseness: superseded by better remedies.

\section{S. 'Irio. Broad H. M. London Rocket. Leaves} runcinate, toothed, smooth as well as the stem. Pods erect. E. B. 1631 . C. 5.48.

Waste ground, banks, heaps of rubbish, ${ }^{*} *$ (chiefly about London.) Under Merton Wall. Rose Lane. Sb. and Bx. (1818.) Naturalized in the Botanic Garden. $B x$. Covered rubbish in the spring, after the great fire of London. Sm. $\boldsymbol{E} . \boldsymbol{F}$.

Morison, in his Præludia Botan. : seems to argue for its production by spontaneous generation, from the fixed and volatile salts, sulphur, \&c.

An. July.

Stem about two f., branched, round. Ls. alternate, wing-cleft, lobes recurved; lower ls., generally terminated by a long, halbert-shaped lobe; upper ones usually simple, spear-shaped, with one or two teeth towards the base. Fl. small, yellow. 
Siliques numerous, long, slender. Fruit-stalks short in comparison with the siliques: seeds protuberating a little through the valves, giving the appearance of a slightly jointed silique. Flavour of the plant like mustard.

S. Sóphia. Fine-leaved H., or Flix-weed." Leaves doubly wing-cleft, leaflets linear, a little hairy. Petals smaller than the calyx. E. B. 963. Sophia Chirurgorum. G. E. 1068.

Rubbish, dry banks, waste ground, dunghills.

An. June.

Stem about two f., erect, branched, very leafy. $L s$. alternate, spreading: last segment of leaflets spear-shaped, acute, entire, terminal ones largest. Fl. very small, pale-yellow. Corymb soon growing into a very long spike of numerous slender siliques, parallel to the stalk, which are erect on spreading stalks.

The feathery segments of the ls. not devoid of symmetry. The pods retain the seeds all winter: food for small birds. Vermifuge. Strength of gunpowder said to be increased, by adding to it a tenth of the seeds. Fl. Suec.

\section{BARBARE'A. ${ }^{2} \quad$ Winter-cress.}

\section{B. vulgáris. Bitter W. Yellow Rocket. Lower leaves} lyre-shaped, the terminal lobe roundish ; upper inversely egg-shaped, toothed. Barbarea. E. G. 243. Erysimum Barbarea. E. B. 443. Sb. 202.

Moist, waste ground, about hedges, or in marshy meadows.

Per. May.

Stem two or three f., simple, or branched, erect, angular. Ls. all alternate, deep, shining green, strongly veined, upper $l s$. stemclasping: leaf-rib broad. $F l$. in terminal corymbs, soon lengthening into a spike, numerous, yellow ; cal. also partly coloured. A winter salad of the young ls.

Var. double $\mathrm{fl}$. in gardens.

\section{ERY'SIMUM. $^{3} \quad$ Treacle $^{4}$-mustard.}

\section{E. cheiranthoides. Worm-seed $\boldsymbol{T r}$. Leaves spear-} shaped, obscurely toothed, roughish, with starry, three-

1 Flix-weed, i. e. flux, from its supposed quality in the seeds, (dose one drachm,) of curing fluxes of the bowels. Formerly called "Sophia Chirurgorum," "the wisdom of surgeons." Ger. observes the Paracelsians do brag very much of an herbe called Sophia, \&c. We must be content to accept of this for the true Sophia, until some one point out the true one, \&c.

2 From St. Barbara.

3 From eruo, Gr. to preserve, on account of its excellent qualities.

4 From its entering into the exploded Theriaca, or Vcnice Treacle. 
partite hairs. Siliques erect, on horizontal stalks. Stigma almost stalkless. E. B. 942. Camelina. G. E. 273.

Turnip fields, gardens, osier holts, hedyes.** Osier Holts, near Godstow. Southleigh, in the fields adjoining 'Tar Wood. $\mathbf{S b}$. Near Godstow Nunnery. $B x$.

An. June.

Stem erect, varying in size, and branching, leafy, angular. Ls. stalkless, sometimes quite entire. $\mathbf{F l}$. numerous, small, yellow, lengthening into a spike-like corymb. Cal. yellowish, erect.

E. Alliaria. Garlick Tr. Mustard; Jack by the Hedge; or Sauce alone. Leaves heart-shaped, broadly toothed, stalked. E. B. 796. C. 2. 48. Alliaria. G. E. 794.

An. April. Bien. $\mathbf{S b}$.

Stem upright, about one f., or more, leafy, branched slightly in the upper part. $L s$. alternate, deep, shining green, smooth. $\mathbf{F l}$. small, white. Siliques erect, spreading, long. Stam. glands four.

Bruised plant, a strong garlic smell: $l s$. may be eaten. Formerly used for seasoning: praised as an outward application in gangrene, considered as diaphoretic, diuretic : when fowls eat the ls., their flavour rendered very rank : boiled, when near its fl.-state, an excellent green, for food. Seeds bruised provoke sneezing.

\section{CHEIRANTHUS. ${ }^{\prime}$ Wall-flower.}

C. fruticulósus. Wild $W$. Leaves spear-shaped, acute; most hoary beneath, with simple, close hairs. Stem shrubby. Branches angular. Style prominent. E. B. 1934. Ch. Cheiri. Sb. 202. H. L.?

old walls.

Shrubby. May.

Roots and stems somewhat woody: branches green, numerous, angular, tufted, erect, leafy. $F \boldsymbol{F}$. in a corymb, simple cluster, bright golden; delightfully fragrant. $\boldsymbol{L} \boldsymbol{s}$. crowded, mostly entire, stalked. Cal. often purplish, or brown. Siliques erect, hoary.

Var. numerous in gardens.

\section{HE'SPERIS. Dame's-violet.}

H. matronális. D. V. Partial flower-stalks the length of the calyx. Leaves egg-spear-shaped, toothed.

I Anthos, a flower, and cheir, a hand, Gr. 
Stem upright, slightly branched. Pods smooth, irregularly swollen, equal-sided, nearly upright. $\mathrm{H}$. inodóra. E. B. 731. Viola matronalis. G. E. 462.

Hilly pastures, near rivulets, but rare. Fringford. Mr. Roundell Palmer, Trinity Coll. Oxford. (Near Cheltenham, on the Cotswold ridge.) $\mathbf{S} m$. Frequent in gardens.

Per. May, June.

Somewhat hoary. $\boldsymbol{F l}$. terminal, corymbose, pale purple, or white; very fragrant in the evening. $S m$. Pods without thickened margin.

\section{'ARABIS.' Wall-cress, or Rock-cress.}

\section{A. thaliána. Common Wall-cress. Leaves hairy, more} or less toothed; root-ones somewhat stalked, spearoblong. Stamens not much shorter than the petals. Stem branched. Pods pointing upwards. E. B. 901. C. 2. 49. Sisymbrium thaliánum. of $\mathrm{H}$. Br. Fl.

Walls, dry, sandy ground.

An. April.

Root tapering. Stem solitary, slender, upright, two to ten inches, branched, leafy. $L s$. root-ones close to the ground, the rest alternate, stalkless, smaller. $F l$. white, corymb-stalks small, growing at length into a lengthened out raceme. Cal. bristly upwards. Honey-bearing glands very minute, at the base of stams. Siliques slightly curved.

Plant pungent: soon withers away after seeding.

A. hirsúta. Hairy Wall-cress. Leaves toothed and bristly. Stem rough, with simple spreading hairs. Pods quite erect, with slightly keeled valves. Turritis hirsuta. Sb. 204. E. B. 587.

Old walls, stony banks.** Rewley Abbey. Sb. Holton Park wall. R. W. Bank on Shotover Hill. Bx.

Per. June.

Root woody. Stems many, one much stronger than the rest, erect, one f. and a half, leafy, branched. Ls. root-ones inversely eggshaped, slender at their base, stem-ls. halbert-spear-shaped, partly embracing the stem. $F$ \% small, white, corymb becoming racemose. Siliq. numerous, in a long spike, beaded as it were by the projecting seeds, crowned with the almost stalkless stigma.

By cultivation becomes almost smooth.

A. Turrita. Tower $W$. Upper leaves toothed, clasping the stem. Flower-stalks the length of the calyx, each with a leafy bractea. Pods linear, flat, thick-

1 Chiefly of a northern hemisphere. 
edged, curved back in one direction. E. B. 178. H. L. 176. Turritis major. G. E. 272.

Old walls.** Magdalen College walls. Sb. and Rev. Mr. White, Fellow of Magdalen Coll. Oxford. April, 1832. It grew formerly within the Old Quadrangle. R. W.

Bien. May.

Root woody. Stems full one f., simple, upright. Ls. pale green, root-ones rough, egg-shaped-oblong, lengthened out at the base; stem-ones regularly decreasing upwards in size, somewhat sawtoothed. Fl. pale sulphur, in a leafy spike. Siliq. very long, at first erect. Fl.-stalks short compared with the siliq.

\section{TURRI'TIS. Tower-mustard.}

T. glabra. Smooth T. Root leaves toothed, rough; the rest entire, clasping the stem, smooth. E. B. $77 \%$. C. 4. 47. Turritis. G. E. 272 .

Banks, road sides, gravelly soil.** Stow Wood. Sb.

An. June.

Stem straight, smooth, wand-like, two f., or more, leafy, at first simple. Ls. root ones in a tuft, spear-shaped; stem-ls. alternate, stalkless, upright, arrow-shaped. $F l$. sulphur, numerous, small, in a corymb, soon becoming a spike. Siliq. long, linear, opening at the base, approaching the stem, tiled.

\section{BRA'SSICA. Cabbage, Turnip, \&c.}

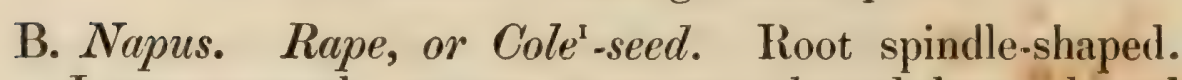
Leaves smooth ; upper ones spear-shaped, heart-shaped at their base, clasping the stem; lower ones lyreshaped, toothed, smooth. E. B. 2146. Bunias sylvestris, \&c. G. E. 235.

Cornfields, waste ground.

Bien. April.

Root forming a kind of trunk above ground. Stem branched, about two f., spreading, leafy, smooth. Ls. light green, somewhat glaucous: stem-ones alternate, broader; stalk-ones stalkless. $\boldsymbol{F} \boldsymbol{l}$. bright yellow. Cal. yellowish, much spreading. Siliq. on slender stalks, spreading, beaded, with an angular point.

Expressed oil from the seeds for the wool-comber: the seed cake remaining an excellent manure, half a ton to an acre, and for fattening cattle. According to Martyn, Fl. R. it is the residue of the lint-cake, (flax-seed c.) which is used for the latter purpose.

B. Rapa. Common Turnip. Root stem-like, fleshy, round, depressed. Root leaves lyre-shaped, rough;

1 Ang. Sax. 
those of the stem smooth; the uppermost entire, or slightly toothed. E. B. 2176. Rapum majus. G. E. 232.

Cultivated fields, and their borders.

Bien. April.

Root a continuation of the stem. Stem upright, branched, leafy, one to three f., and more smooth. Ls. upper stem ones, heartshaped, embracing the stem, tapering to a point, somewhat glaucous: root-ones stalked, deep green. $\boldsymbol{F}$. bright yellow, numerous, rather large, in terminal corymb, lengthening. Cal. widely spreading. Siliq. cylindric, veiny, smooth, sub-erect.

$\boldsymbol{R}$ oot winter food for cattle, and for the table: rendered sweet by cultivation. Aperient, flatulent: the fermented juice by distillation becomes an ardent spirit. The roots in a cellar, or in sand, send out winter sprouts for salad. Introduced into this country as an agricultural object of extent, by Lord Townsend, in the time of George the First. Root of extraordinary size occasionally; viz. thirty-six pounds, and four turnips together of an hundred weight. Martyn.

Turnip poultice useful application to broken chilblains. The Swedish turnip surely a distinct species.

B. campestris. Common Wild Navew ${ }^{\mathrm{I}}$. Root tapering. Root leaves lyre-shaped, rough; stem-leaves smooth, elasping, oblong, partly wing-cleft ; all somewhat glaucous. E. B. 2234 .

Sides of rivers, marsh ditches. Between Cropredy and Morlington. $\mathrm{Fl}$. $\mathrm{Br}$.

An. June, July.

Stem slender, erect, branched, leafy, one to two f., somewhat glaucous. Ls. stem-ones heart-shaped-arrow-shaped at the base, uppermost entire, tapering to a point. $\mathrm{Fl}$. yellow, pet. roundish in the limb. Siliq. upright, cylindric, or obscurely four-cornered, veiny. Seeds slightly project. Beak awl-shaped, slightly furrowed, square at the base.

$\operatorname{Var}$. $l$. white.

\section{SINA'PIS. ${ }^{2}$ Mustard.}

S. arvensis. Wild M. Charlock. ${ }^{3}$ Siliques with many angles, swollen, rugged, much longer than their own awl-shaped beak. Leaves toothed; partly lyre-

1 Naveau, Fr.

2 Seque lacessenti fletum factura sinápis. Columella.

3 Cerlice, Ang. Sax.

o 2 
shaped, or halbert-shaped. E. B. 1748 . C. $5.4 \%$ Rapistrum arvorum. G. E. 233.

Cornfields.

An. June.

Root tapering, stiff. Stem one to two f., more or less branched, slightly furrowed, leafy, rough. Ls. harsh, stalked; upper ones stalkless. Cal.-leaves linear, pale green. Cor. bright yellow, rather large. Pet. always yellow, veinless. Siliq. about eightangled.

Seed mixed with, or instead of mustard. Annoying weed in the cornfields, of course, to be weeded early before seeding. Seed will vegetate after having lain many years deep in the ground. Young plant may be boiled and eaten.

S. alba. White $M$. Pods bristly, rugged, spreading, shorter than their own broad and long sword-shaped beak. Leaves lyre-shaped. E. B. $167 \%$ C. 5.46. Sinapi album. G. E. 244.

Cultivated, and waste ground.

An. June.

Root small, tapering. Stem one to one ft. and a half, branched, leafy, slightly furrowed, rough. Ls. rough, jagged, toothed, lowest deeply wing-cleft, terminating segment very broad. Cal.ls. linear, green, horizontal. Cor. yellow, claws long, rather large. Fr.-stalks long, ascending. Seeds globose, yellow. Pod beak rough.

Young herb in salad, with cresses, Lepid. sativum. Seeds culinary, medicinal. See Cullen, \&c.

S. nigra. Common $M$. Siliques four-cornered, smooth, slightly beaked, close-pressed to the stalk. Lower leaves lyre-shaped, wing-cleft; upper linear-spearshaped. E. B. 969. Sinapi sativum pr. G. E. 244. Fields, waste ground.

An. July.

Root small. Stem three to four f., upright, much branched, spreading, smooth, leafy. Ls. lower, lobed and toothed, rough ; $l s$. of the smaller branches hanging down. Fl. many, bright yellow. $\mathrm{Cal}$. somewhat yellow. Seeds round, smooth, brown. Fl.stalk short.

Useful stimulant in cookery, and in medicine; its continued use not to be recommended. Powdered seeds, the common mustard for the table. Yield an oil not of much acrimony. A table spoonful of the whole seeds aperient: powdered, curdle milk, bruised infused seeds emetic; in cataplasm, as a stimulant applied to the soles of the feet, in sinking stage of fever: topically, in rheumatic pains. $L s$. in spring may be boiled, and eaten. See Cullen's Mat. Med. 


\section{RA'PHANUS. Radish.'}

R. Raphanistrum. Wild R. Jointed Charlock. Pods jointed, slightly furrowed, of one spongy cell. Leaves stalked, lyre-shaped. E. B. 856. C. 4. 46. R. sylvestris. G. E. 240.

Cornfields, troublesome.

An. June.

Root spindle-shaped. Stem one to two f., branching, glaucous, bristly, leafy. Ls. toothed, rough, uppermost simple, oblong. Fl. large, lemon, white, or violet-coloured, streaked with veins, which become dark-purple as the fl. advances in age. Cal. slender, bristly upwards. Siliq. erect, tapering, beaked, smooth, joints falling off separately.

Linnæus supposed the seeds eaten in bread to produce Raphania, a convulsive disease. Taste of the plant acrid. Were the seeds dangerous, they would make great ravages eaten elsewhere: this is not the case.

\section{Class XVI. MONADELPHIA.}

\section{Filaments combined in one set.}

\section{Order I. PENTANDRIA. Stamens 5.}

\section{ERO'DIUM. ${ }^{2} \quad$ Stork's-bill. $^{3}$}

E. cicutárium. Hemlock St. Stems trailing, hairy. Stalks many-flowered. Leaves winged; leaflets stalkless, wing-cleft, sharply cut. Stamens simple. E. B. 1768. Geranium cicutarium. C. 1.51. G. cicutæ folio inodorum. G. E. 945. $\gamma$. Erodium pimpinellæ folium. Sb. 211.

Waste ground. $\gamma$. Fields, Headington Hill. Cowley. Sb. Headington. R. W.

An. May, June.

Stems mostly branched, leafy. Ls. alternate towards the root, often opposite near the extremity of each branch: leaflets mostly alternate, hairy. Stip. in pairs, acute, egg-shaped, membranous. $\boldsymbol{F l}$. opposite to the $l s$. or axillary, lengthened out, umbellated, rose-coloured; pet. inversely egg-shaped. Plant not inodorous.

Appendages of the seeds in Erod. cicutarium, and Erod. Mos-

1 Rædic, Ang. Sax.

Erodios, Gr. a heron. H.

3 Beaks twisted like a cork.screw, heardcd within. Abbot. 
chatum contract into a spiral form when dry, and straighten themselves when moist: its different movements may be seen by alternately moistening and drying them, on a white plate before the fire.

$\operatorname{Var} . \boldsymbol{\gamma}$. the Erod. pimpinellæfolium of $\mathbf{S} b$. has two or three of its pet. marked with a green depression near the base: a variable mark.

* E. moschátum. Musky St. Stems depressed, hairy. Stalks many-flowered. Leaves winged ; leaflets nearly stalkless, elliptical, unequally cut. Perfect stamens toothed at the base. E. B. 902. Geranium moschatum. G. E. 941.

Mountiinous pastures. On Shotover Hill, near Oxford. Goodenough, Bishop of Carlisle, in $\mathbf{E} . \mathbf{F l}$. From some garden probably: found in gardens, in, and near Oxford, occasionally. R.W. An. June, July.

Strong musky smell. Plant very like Erod. cicutarium, more hairy. Ls. broader. $F l$. smaller, more numerous, in a roundish head. Stems swollen, and crooked at the joints. Ls. leafl. terminating one three-cleft.

\section{MONADELPHIA DECANDRIA.}

\section{GERA NIUM. Crane's-bill.}

G. pratense. Bhue Meadow Cr. Stalks two-flowered. Leaves in about seven deep segments, sharply wingcleft and saw-toothed. Capsules hairy all over. Stamens smooth, much dilated at the base. E. B. 404 . C. 4. 49 . G. batrachoides. G. E. 942 .

Rich, moistish pastures, thickets. St. Clement's. Marston. Southleigh. Sb. Mr. Morrell's meadow, Headington Hill. R. W. (Meadows near the Devil's Backbone, going to South Hinksey.) Ditch side between the Diamond House, and Woodstock Road, \&c. $B x$.

Per. June.

Stems two f. or more, erect, round, red and swollen at the base, branched above in a forked manner, with a l. or two at each subdivision, with one or two pairs of brown, spear-shaped stip. Ls. root-ones on long foot-stalks. $\quad F l$.-stalks long with four bract. at their division. Pet. very large, inversely egg-shaped, veiny, fine blue. Cal. awned, drooping and closed after flowering. Style longer than the stam.

Discrim. Ls. in G. sylvaticum much less deeply cut. Its large purple $f$. and many and deeply divided $l s$. 
Var. Fl. white.

G. robertiánum. Stinking Cr. Herb Robert. Stalks two-flowered. Leaves three, and five-cleft, thricewing-cleft, somewhat pedate (bird-footed,) outline fiveangled. Calyx with ten angles. Capsules wrinkled, simply keeled. E. B. 1486 . C. 1. 52. G E. 939 $W$ aste ground, walls, banks, hedges.

An. June.

Stems spreading, round, red, especially in exposed situations, and in autumn with the $l s$. Ls. opposite, long-stalked, in threes, exterior leafl. running one into the other at the base. $\mathbf{F l}$. on long, cloven, axillary, and terminal stalks. Partial 1.-stalks short. Cal. hairy. Pet. purple, undivided, a hand-shaped white mark at the base. Herb rank smelling, fleshy.

Astringent: smell of the bruised $l s$. to drive away bugs: infusion for cattle in hæmaturia. Perhaps recommended by the doctrine of signatures from its red $l s$.

G. lúcidum. Shining Cr. Stalks two-flowered. Leaves five-lobed, roundish. Calyx bellying-pyramidal, transversely wrinkled. Capsules wrinkled, thrice-keeled. E. B. 75. H. L. 32. G. saxatile. G. E. 938. deser. n. 3.

Walls, shady places.

An. June.

Stems branched in a sprearling manner, swelling at the joints, glossy, succulent, often red. Ls. opposite, shining, stalks long, lobes three-cleft, blunt. $F l$. rose-red, small.

An elegant and delicate plant.

G. molle. Dove's-foot $\mathrm{Cr}$. Stalks two-flowered, alternate, opposite the leaves, which are rounded, or kidneyshaped, many-lobed, notched, and downy. Capsules numerously wrinkled, smooth. Seeds without dots. E. B. 778 . C. 2. 50 . G. columbinum. G. E. 938.

Meadows, pastures, way sides.

An. May.

Stems spreading or trailing, reddish, hairs expanding horizontally. Ls. roundish, lobed, segments broadish. Fl.-stalks solitary. $\mathbf{F l}$. erect, larger than thuse of G. pusillum. Pet. cloven. Stip. two-partite. "Smell musky."

Var. Fl. white.

Discrim. In G. rotundifolium the seeds are dotted, and pet. entire.

G. pusillum. Small-flowered Cr. Stalks two-flowered. 
Leaves kidney-shaped, hand-shaped, cut, downy. Cap4. sules keeled, even, clothed with erect hairs. Seeds without dots. Anthers only five. E. B. 385. G. parviflorum. C. 6.36. Sb. 213.

Gravelly fields, waste ground.

An. June.

Stems trailing when unsupported, branched, variable in luxuriance. $L s$. mostly linear, sharp segments. $F$. small, pale purple. Cal. awnless.

Discrim. From G. molle, by its even, downy seed-coat: from G. rotundifolium, by the downiness of that part being closepressed, pointing upwards, and by its smooth seeds: the pet. scarcely exceed the calyx, not so deeply cloven as those of G. molle.

G. pyrenáicum. Perennial Dove's-foot Cr. Stalks two-flowered. Petals twice the length of the calyx. Leaves kidney-shaped, lobed. Capsules keeled, even, somewhat downy. Seeds without dots. E. B. 405. C. 3. 42 .

Meadows, pastures.

Per. June.

Stems erect, two or three f., branches spreading, hairy. Pet. deeply cloven, lobes roundish. $F \boldsymbol{F l}$.-stalks axillary. $\quad \boldsymbol{F l}$. pretty large, bluish purple.

Discrim. From G. molle, by the seed-cases, being even, not wrinkled. $F l$. much larger.

Var. Fl. white.

G. rotundifólium. Soft Round-leaved Cr. Stalks twoflowered. Petals entire. Leaves kidney-shaped, cut, downy. Capsules even, hairy. Seeds veined like net. work. E. B. 157.

Waste ground, barren pastures, walls, banks.

An. June.

Stems straggling, downy. Ls. downy, somewhat pale, roundish. $\mathrm{Fl}$. small, rose-coloured. Cal. awned.

Discrim. Seeds dotted, petals entire, rounded.

G. dissectum. Jagged-leaved Cr. Stalks two-flowered. Petals cloven. Leaves in five, deep, jagged segments, nearly to the base of the foot-stalk. Capsules hairy. Seeds veined like net-work. E. B. 753. C. 6.45. G. columbinum majus, dissectis foliis. G. E. 938 .

Gravelly, waste ground, hedges, fallow fields.

An. June.

Stem branched, straggling. Ls. lobes narrow. Fl.-stalks axillary, short. Cal. pointed. Pet. pale-crimson, notched. 
G. columbinum. Long-stalked $C r$. Stalks two-flowered, thrice as long as the leaves, which are in five, very deep, jagged segments. Capsules quite even and smooth. Seeds veined like net-work. E. B. 259.

Fields, dry banks, on a gravelly, or limestone soil. Sm. Cowley. Between Witney and Burford. Sb. (North Hinksey.) Rer. Mr. Round, Balliol College, Oxford. Near Headington Wick Copse. Field near the path, between 'Tagg's Farm, and Forest Hill. R. W.

An. July.

Plant slender. $L s$. segments linear. $F \boldsymbol{~}$. delicate, pale purple. Anth. blue. Seeds with minute dots.

Discrim. Its long fl.-stalks, large, five-angled cal. awned; hairs of the stem and stalk point downwards, the rest upwards.

\section{MONADELPHIA POLYANDRIA.}

\section{MALVA. Mallow.}

M. sylvestris. Common M. Stem upright, herbaceous. Leaves with about seven acute lobes. Footstalks and flower-stalks hairy. E. B. 671. C. 2.51. G. E. 930 .

Hedges, road sides.

Per. June.

Stem much branched, spreading, round. $L s$. alternate, somewhat heart-shaped, saw-toothed, plaited. Cor. pet. inversely heartshaped, longer than the cal. rose-coloured, veined with deeper purple than in the next, shining.

Discrim. From M. rotundifolia, by its upright, bushy stem, and large purple $\mathrm{fl}$.

Mucilaginous, emollient, but less so than the Althæa officinalis (Marsh Mallow.) Fibres of mallows beautiful, finer than camel's hair.

M. rotundifólia. Dwarf $M$. Stems trailing. Leaves roundish-heart-shaped, about five-lobed bluntly. Stalks when in fruit bent downwards. E. B. 1092. C. 3. 43. M. sylvestris pumila. G. E. 930 .

Waste ground, way sides in towns or villages.

Per. June.

Stems short, straddling, not much branched. Ls. notched, plaited, slightly lobed: foot-stalks very long, hairy. $F l$. on shorter stalks, axillary. Cor. twice the length of cal. notched, pale purple, or lilac, smaller than in M. sylvestris.

Mucilaginous, emollient. 
M. moscháta. Musk M. Root leaves kidney-shaped, cut ; the rest in five, deep, wing-cleft, jagged segments. Calyx hairy; its outer leaves linear-spear-shaped. E. B. 754 . C. 4.50 .

Grassy borders of fields, way sides, on gravelly soil. Sm.* Culham Heath. Southleigh. Between Witney and Burford. $\mathbf{S b}$. Headington. Mrs. Lorina Walker. N.E. corner of Cowley Marsh, \&c. $B x$. Mixbury, and Finmere. $R . P r$.

Per. June.

Stems about two f. round. $L s$. root-ones on long stalks : stem-ls. on shorter stalks. $\quad F l$. axillary, on long stalks, large, rose-coloured. Pet. abruptly jagged. odour.

A beautiful plant during the hot months diffusing a musky $V$ ar. White $f$. in gardens.

\section{Class XVII. DIADELPHIA. Filaments combined in two sels.}

\section{Order I. HEXANDRIA. Stamens 6.}

FUMA'RIA. Fumitory.

* Pod with many seeds. Nectary single.

(F. sólida. Solid Bulbous $F$. Stem mostly simple, erect. Leaves twice in threes. Bracteas hand-shaped, longer than each flower-stalk. E. B. 1471. Radix cava minor. G. E. 1091.

Groves, thickets, sparingly: perhaps a doubtful native. Sm. Woods near Studley, Warwickshire. $P$ n. Fl.

Per. April, May.

Root bulbous, solid. Fl. tipped with purple.)

( ${ }^{*}$ F. lútea. Yellow $F$. Pods nearly cylindrical, shorter than their stalks. Stem angular, erect. Bracteas minute. Spur short, rounded. E. B. 588. G. E. 1088.

Old Walls; perhaps naturalized. Caversham, near Reading, Berks. Mr. L. Darwall, Trin. Coll. Cambridge. Broadway Hills, Gloucestershire. $\boldsymbol{P}_{n} . \boldsymbol{F} \boldsymbol{~}$.

Per. May.

Root fibrous, $\boldsymbol{F l}$. lemon-coloured, with yellow tips.)

* Pod single-seeded. Nectary single. 
F. officinális. Common F. Cluster rather lax. Pods single-seeded, globose, abrupt, on upright stalks, twice as long as the bracteas. Stem spreading. Segments of the leaflets spear-shaped. E. B. 589. C. 2.52. F. purpurea, G. E. 1088.

An. May.

Stem much branched, spreading, leafy. Plant smooth, glaucous, somewhat fleshy. $L s$. doubly winged, principal divisions mostly alternate. Chusters of $f$. opposite the $l s$., simple, many-flowered. $\mathrm{Fl}$. alternate. Bract. small. $\mathrm{F}$ \% rose-coloured, keel green to the upper and under pets. which are deep red at the summits. Spur short, blunt.

Tonic. Expressed juice dose two ounces twice a-day, to cleanse the skin from leprous disorders. Cullen. Infusion of the ls. a cosmetic, and to remove freckles.

F. capreoláta. Ramping $F$. Cluster rather lax. Pods single-seeded, globose. Stem climbing by means of the twisting foot-stalks. Leaflets wedge-shaped, lobed. E. B. 943 . C. 6.47 .

Cultivated fields. Behind the Parks. Sb. Garden ground, Headington. $\mathrm{R}, \mathrm{W}$.

An. June.

Stem three or four f. Pet. pale red, tipped with deep red.

Discrim. From F. officinalis by its (F. capreol.) greater size, less glaucous hue, twisting foot-stalks, paler, less gaping fl., spur more projecting, larger cal.-ls. pods more globose.

\section{DIADELPHIA OCTANDRIA.}

\section{POLY'GALA. Milk-wort.}

P. vulgáris. Common M. Flowers crested. Bracteas three, at the base of each flower-stalk, deciduous. Wings about equal to the corolla. Stems ascending, simple, herbaceous. Leaves linear-spear-shaped. E. B. 76. Polygala. G. E. 563. 3. 4. 564. 5 .

Gravelly, heathy pastures.

Per. June.

Stem lying down, and ascending. Ls. deep green, smooth. $F l$. blue, white, flesh-coloured, or purple, always marked with green lines, in terminal bunches. Crest of the cor. elegantly fringed. Cal. permanent, becoming green, wrapping up the young pod. Cal.-wings about as long as the cor. Fil. in two sets, 
like two expanding hands, with four fingers to each. Anth. yellow.

Plant bitter; in infusion, about a quarter of a pint, daily in the morning fasting, expectorant in catarrhous cough : in powder, dose of the root three grains.

\section{DIADELPHIA DECANDRIA.}

\section{SPA'RTIUM. Broom.}

S. scopárium. ${ }^{\mathrm{I}} \quad$ Common B. Leaves in threes, or solitary. Branches angular, without thorns. Filaments all in one set at the base. Legume fringed. E. B. 1339. C. 5. 52. Genista. G. E. 1311 .

Dry, gravelly thickets, fields. * Henley. Sb. (Bagley Wood. Bx.) Stem strong, tough. Branches numerous, straight, smooth, evergreen. Ls. deciduous, often simple on the upper end of the branch. Fl. mostly solitary, axillary, drooping, large, bright yellow, often orange outwardly. Stam. monadelphous at the base, four long, and six short. Style twisted almost into a circle. Seeds polished.

Broom tea, a useful remedy in dropsy. The seeds, and ashes have been also used with the same indication. Young $f$., sometimes pickled. The black, ripe pod discharges its seeds by ar elastic movement. A flaxy substance has been procured from this plant. The twigs for carpet brooms.

\section{GENISTA. Green-weed.}

G. tinctóriu. Dyer's Gr. Wood-waxen. Leaves spear-shaped, smooth. Branches round, slightly furrowed, erect, without thorns. E. B. 44. Genistella tinctoria. G. E. 1316.

Pastures, thickets, dry borders of fields. * Under Headington Wick

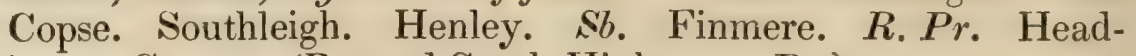
ington Copse. (Beyond South Hinksey. Bx.)

Shrub. June.

Branches low in growth. Fl. bright yellow. Pod nearly cylindric. $L s$. alternate, stalkless, undivided. $F l .-l s$. shorter than the blossom.

Seeds mildly purgative.

Plant dyes a good yellow colour; with woad a good green. Milk of cows feeding upon it is rendered bitter. Ray.

G. ánglica. Needle Gr. Petty Whin. Thorns nearly

1 From Scopa, a broom. 
simple. Flowering branches unarmed. Leaves eggspear-shaped. E. B. 132. G. aculeata. G. E. 1320.

Moist, boggy heaths. * Kidlington Common. Ensham Heath. Sh. (A little beyond Childswell Farm. B $x_{\text {. }}$ )

Shrub. May.

About one f., woody. Fl. small, lemon-coloured. Standard yellow. Pods oval, swollen. Old branches without $l s$., beset with thorns.

\section{ULEX. Furze. ${ }^{\mathrm{I}}$}

\section{U. europaus. Common F. Whin, or Gorse. ${ }^{\text {. Teeth }}$} of the calyx scarcely observable, converging. Bracteas egg-shaped, lax. Branches erect. E. B. 742. Genista spinosa vulgaris. G. E. 1319.

Sandy, gravelly heaths, commons.

Shrub. April; and occasionally at all seasons.

Stem shrubby. Branches dense, green, thorny. Ls. awl-shaped, solitary, pungent, deciduous. $\quad \boldsymbol{F}$. axillary, large, bright yellow: Pod oblong, downy.

Blossoms make a brilliant appearance, spread over our heaths; Linnæus fell on his knees at such a brilliant appearance, on viewing this plant in full blossom in England. Impatient of cold. Team horses supported by this plant, cut young, with the thorns bruised in a mill. Blossoms honey scented.

The wood is very hard. The chief use of this shrub is to afford firing for the poor. Its full growth is attained in four years, and it ought not to be cut more frequently. $S m$.

(U. nanus. Dwarf F. Teeth of the calyx spear-shaped, spreading. Bracteas minute, close-pressed. Branches reclining. E. B. 743. Genista aculeata minor, sive Nepa Theophrasti. G. E. 1321.

Dry, elevated heaths. Coughton Park. Dunnington Heath. Studley, and Ashwood Commons. Pn. Fl.

Shrub. August, October.

Scarcely half the size. $\quad F l$. smaller, and paler.)

\section{ONO'NIS. Rest-harrow. ${ }^{2}$}

O. arvensis. Common R. or Cammock. ${ }^{3}$ Stem hairy. Branches at length thorny. Flowers mostly solitary. Leaves generally simple; entire towards their base. E. B. 682. E. B. Suppl. 2659. Sb. 220. ß. O.

1 Ang. Sax.

2 From its strong, woody roots stopping the harrow.

3 Ang. Sax. 
spinosa. Sb. 220. Anonis sive Resta bovis. G. E. 1322.

Barren pastures, sandy road sides.

Per. June.

Root strong, woody. Branches in a barren soil, and on an old root terminating in a spine. Ls. alternate, stalked, lower ones often in threes. $\mathbf{F l}$. axillary, short stalked, rose-coloured. Standard twice as long as the wings, and keel. Smith considers Ononis spinosa of some authors as a var. of this, in an older, or more starved state.

\section{ANTHYLLIS. Kidney-vetch.}

A. vulnerária.' Common K., or Ladies' finger. Herbaceous. Leaves winged, unequal. Heads of flowers in pairs. E. B. 104. A. leguminosa. G. E. 1240. Chalky limestone, dry pastures. Sm. ${ }^{*}$ Bullingdon Green. Burford Downs. Stokenchurch Hills. $\mathbf{S} b$. Various places in the neighbourhood of Headington. R. W.

Per. June.

Stems not quite erect, leafy, terminated by two heads of thick-set, stalkless yellow fl. Bract. fingered. Cal. membranous, hairy. Filam. their structure singular. sheep.

Fl. sometimes scarlet, or white. Herbage, good pasturage for

\section{'OROBUS. Bitter-vetch.}

O. tuberósus. Common B. Heath Pea. Leaves winged, elliptic-spear-shaped. Stipulas half-arrowshaped; toothed at the base. Stem simple, erect. E. B. 1153. C. 1. 53. Astragalus sylvaticus. G. E. $123 \%$.

Woods. * Between Caversham and Mapledurham. Near Henley. Sb. Shotover Hill. R. Pr. (Bagley Wood. Mr. F. T. Scott, Worcester Coll. Oxford.)

Roots tuberous, outwardly black. Stems one f. $L s$. the common stalk projects beyond the leaflets. $\boldsymbol{F}$. purple and red, in longstalked, axillary clusters. $\boldsymbol{P}$ od tipped with a permanent, channelled style.

Highlanders said to chew the sweetish roots, which will for a long time repel the attacks of hunger; and brew a sort of liquor from them. This supposed to be the nutritive Chara mentioned in Cæsar's Commentaries, and by Dio.

An elegant plant.

1 From its supposed vulnerary qualities. 


\section{LA'THYRUS. Vetchling, and Everlasting Pea.}

* Flowers mostly solitary.

\section{L. 'Aphăca. Yellow V. Stalks single-flowered. Ten-} drils without leaves. Stipulas between heart and arrow-shaped. E. B. 1167 . Pn. fig. C. 5. 51. Aphaca. G. E. 1250.

Borders of sandy, or gravelly fields.** Under the hedge, south side of the road, going from St. Clement's to Cowley Marsh. Hedge on the south side of the same Marsh. $B x$. Between the Roman Catholic Chapel, and the Asylum. Meadow near the Iffley Road. R. W. Between Caversham and Mapledurham. Sb. An. June.

Ls. none. Tendrils springing from a pair of large, opposite, stalkless, leaf-like stipulas of an oblong triangular form. $F \boldsymbol{l}$. drooping, lemon-coloured, stalks long. Herbage glaucous tinged. Seeds of this, and the other species nutritious.

L. Nissólia. Crimson V. Grass Vetch. Stalks mostly single-flowered. Leaves simple, without tendrils. Stipulas awl-shaped. E. B. 112. C. 6.51. Ervum sylvestre. G. E. 1249.

Bushy places, grassy borders of fields.** Nuneham, on the right hand side of the London Road, near the four mile stone. Southleigh. $S b$. Between the old and new road to Ensham, about half a mile from the Bridge. Near old stone-pits about half a mile, S.W. from South Hinksey. $\boldsymbol{B} x$.

An. June.

Distinguished by its simple, grassy $l s . F l$. rich crimson. Pods long, linear. Plant, unless in flower, easily overlooked: beautiful plant in blossom.

* * Flowers numerous on each stalk.

L. pratensis. Yellow Meadow $V$. Stalks manyflowered. Tendrils mostly simple, each bearing a pair of spear-shaped leaflets. E. B. $6 \% 0$. C. 3. 44 .

Meadows, pastures, thickets.

Per. June.

Stems angular, smooth, two or three f. Stip. unequally arrowshaped, stem-embracing. $F l$. large, bright yellow, on long, erect stalks.

This vetch supplies excellent fodder, early and late, makes good hay, and thrives on a clay soil. First sow the seeds, then part the roots. Said, however, not to be agreeable to cattle: besides producing very few seeds.

L. sylvestris. Narrow-leaved, Everlasting P. Stalks many-flowered. Tendrils branched, each bearing a 
pair of sword-shaped leaflets. Stem winged. E. B. 805. C. 6. 52.

Groves, thickets, moist hedges. In a Copse under Shotover Hill. Sb. Side of the ditch round Headington Copse, not far from Marston Lane. Bx. (About Bagley Wood. Bx.)

Per. June.

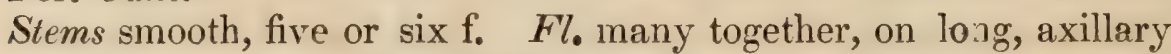
stalks: variously tinted with purple and violet, with a green tinge. Wings violet.

(L. latifólius. Broad-leaved Everlasting $\boldsymbol{P}$. Stalks many-flowered. Tendrils branched, each bearing a pair of elliptical leaflets. Stem winged. E. B. 1108. L. major latifolius. G. E. 1229.

Woods, rare; by some supposed a doubtful native. Spernal Park. Warwickshire. $P$ n. Fl.

Per. July, August.

Larger, smooth. $F l$. large; pet. all rose-coloured.)

L. palustris. Blue Marsh $V$. See Appendix.

VI'CIA. Vetch.

* Stalks lengthened out, many-flowered.

V. sylvática. Wood $V$. Stalks many-flowered. Leaflets elliptical. Stipulas crescent-shaped, deeply toothed. E. B. 79 .

Woods, hedges. * Medley Grove. $\quad S b$. Hedges by the side of the road, going from Burford to Wychwood Forest. Between Fulbrook, and the Hit or Miss public-house. $B x$.

Per. June.

Stems very numerous, weak, zigzag, slightly furrowed, six to seven f. Stip. tipped with a minute bristle. $F \%$. whitish, elegantly streaked with a purple, and greyish blue.

An elegant plant.

V. Cracca. Tufted $V$. Stalks many-flowered. Flowers tiled. Leaflets spear-shaped, downy. Stipulas halfarrow-shaped, mostly entire. E. B. 1168. C.5. 54 .

Hedges, thickets, osier grounds, low meadows.

Per. June.

Stem when climbing, three or four f. Each leaf consists of many spear-shaped, entire leaflets. $\boldsymbol{F l}$. numerous, violet. $\boldsymbol{P}$ ods hanging down, light.brown.

Rather an ornamental plant, with its close long spike of purple flowers. At the extremity of the keel, two deep purple spots. ** Flowers axillary, nearly stalkless.

V. sativa. Common $V$. Flowers nearly stalkless, 
mostly in pairs. Leaflets elliptic-oblong; lower ones abrupt. Stipulas with a blackish depression beneath. Seeds round, smooth. E. B. 334 .

Cornfields, cultivated grounds.

An. June.

Ls. winged; tendril terminating the leaf-stalk branched. $\boldsymbol{P}$ et. purplish crimson.

Plant varies in size, and in the form and breadth of the $l s$.

Sown as pasturage for horses. Seeds food for pigeons.

V. angustifólia. Narrow-leaved Crimson $V$. Flowers solitary, nearly stalkless. Leaflets linear; lower ones inversely heart-shaped. Stipulas with a pale depression beneath. Seeds round, smooth. Sb. 224. E. B. Suppl. 2614.

Grassy pastures, on chalk, or gravel. Sm. Shotover Hill. Stow Wood. Sb. Hills between Wytham and Ensham bridge. Bx. An. June.

Plant smaller than any variety of Vicia sativa: of a slender, delicate habit, distinguished by its very conspicuous, elegant, crimson $\mathrm{fl}$., white at the keel, and lower edge of the wings, and rather large in proportion to the other parts. $\mathbf{E} . \mathbf{F l}$.

(V. lathyröı́des. Spring $V$. Flowers solitary, nearly stalkless. Leaflets elliptic-oblong; lower ones inversely heart-shaped. Tendrils simple, shorter than the leaflets. Seeds cubic, warty. E. B. 30.

Fallow fields, gravelly soil, chalky pastures, dry banks. Sm. Side of the bridle road from Spernall to Studley, Warwickshire. $\mathrm{Pn} . \mathrm{Fl}$. An. April, May.

Stem three to four inches, downy. $F l$. bluish purple.)

V. sépium. Common Bush $V$. Flowers about four together, in short axillary clusters. Legumes upright, smooth. Leaflets egg-shaped, blunt; the upper ones gradually smaller. E. B. 1515. V. maxima dumetorum. G. E. $122 \%$.

Thickets, hedges.

Per. May.

Stems about two f. weak, climbing with tendrils. Stip. more or less crescent-shaped, and toothed. Cor. variegated with blue, dull purple, and greenish white.

Has been recommended as excellent food for cattle.

ERVUM. Tare.

E. tetraspermum. Smooth-podded T. Flowers mostly 
in pairs. Legume smooth, with four seeds. Leaflets oblong, bluntish. E. B. $1223 . \quad$ C. 1. 55.

Cornfields, hedges, thickets.

An. June.

Stem branched, weak, climbing, square. Leaft. numerous, alternate, their common stalk ending in a branched tendril. $\mathrm{Fl}$. on long, slender, axillary stalks, drooping, pale blue, veiny. Cal. hairy.

The names Smooth Tare, and Hairy Tare, are applicable to the pods alone, for the herbage is most hairy in the Erv. tetraspermum, or Smooth Tare.

E. hirsútum. Hairy-podded T. Clusters many-flowered. Legumes hairy, with two seeds. Leaflets abrupt. E. B. 970 . C. 1. 54. V. sylvestris, sive Cracea, minima. G. E. 1228.

Cornfields, and other cultivated ground.

An. June.

Stems branched, nearly smooth, climbing by branched tendrils. Leafl. numerous, alternate, elliptic, notched at the end. $F$. from about five to seven, on short partial stalks, on a longish, axillary, common stalk, small, pale blue, with a dark spot on each side of the point of the keel. Pods, drooping, short.

\section{ORNI'THOPUS. Bird's-foot.}

O. perpusillus. Common B. Leaves winged. Flowers in heads, accompanied by a leaf. Legumes curved inwards, beaded. E. B. 369. C. 6. 53. Ornithopodium minus. G. E. 1241.

Sandy, gravelly pastures. * Between Shotover and Cuddesdon. Sb. An. June.

Stems more or less trailing, leafy. Ls. winged, with an odd leaflet, small. $\boldsymbol{F l}$. stalkless, in little terminal heads. Standard, and wings elegantly striped with red and white, keel greenish. A small, and beautiful plant.

\section{HIPPOCRE'PIS. Horse-shoe-vetch.}

H. comósa. Tufted $H$. Legumes umbellate, rough; their joints bowed, serpentine, neither dilated, nor bordered. E. B. 31 .

Dry, chalky banks. Bullingdon Green. Stokenchurch Hills. Burford Downs. $S b$. Headington Quarry. Henley. $\boldsymbol{B} x$.

Per. May.

Stems numerous, trailing. $\mathrm{Fl}$. pale yellow, streaked with brown.

The singular figure of the pods must strike the most casual observer. 


\section{HEDYSARUM. Saint-foin. .}

* H. Onóbry̆chis. Common Saint-foin. Leaves winged with an odd one, nearly smooth. Legume singleseeded, toothed at the margin and ribs. Wings of the corolla not longer than the calyx. Stem lengthened out. E. B. 96. Onobrychis seu caput gallinaceum. G. E. 1243.

Dry, chalky hills, open downs.

Per. June.

Plant lying down, two to three f. $F \%$ spiked, crimson, variegated. Standard egg-shaped, with a little tooth in the notch at the end, red in the middle, with eight or ten deeper coloured lines, white at the edges, and mottled with red: wings red and white; keel reddish, with deeper coloured lines.

Valuable for feeding cattle; grows luxuriantly where grass or corn would yield but small produce.

\section{ASTRA'GALUS. Milk-vetch.}

\section{A. glycyphyllos. Sweet M. Wild Liquorice. Stem} prostrate. Legumes obscurely triangular, curved inwards. Leaves longer than the flower-stalks; leaflets oval. E. B. 203. Hedysarum glycyrrhizatum. G. E. 1233.

Woods, thickets, borders of fields, on gravel or chalk." Sm. (Between the two Hinkseys: beyond South Hinksey, not uncommon. Bx.) Side of a ditch round Headington Copse, near Marston Lane. R. W. Cuddesdon, near the Palace. R. W. Per. July.

Stem two to three f., more or less zigzag. Ls. alternate, leafl. roundish or oval, with an odd one. Stip. egg-shaped, pointed at the base. $F l$.-spikes axillary, $f l$. pale sulphur coloured, often with a brownish tinge. Pods reddish.

Chewed ls. of a sweetish taste, changing to a somewhat unpleasant bitter.

A. hypoglottis. ${ }^{2}$ Purple Mountain M. Stem prostrate. Flowers in round heads. Legumes egg-shaped, deeply channelled along the back, compressed, hairy; hooked at the point. Leaflets blunt. E. B. 274.

Downs, dry pastures. ** Burford Downs. Sb. Under a wall on the side of the road between Witney and Burford, about three or four miles from the latter place. $B x$.

Per. June.

1 Sain-foin, Fr.

2 i. e. with ls. somewhat tongue-shaped.

P 2 
Stem zigzag. Ls. alternate, spreading, winged with an odd one: leafl. elliptic-egg-shaped, gradually lessening, with the terminal one smaller, hairy beneath, nearly smooth above. $F l$. heads erect, axillary, scarcely longer than the $l s$. until after flowering. Stalk and cal. clothed with black hairs, mixed more or less with white ones. Cor. fine violet.

Var. Fl. white.

\section{TRIFO'LIUM. Trefoil, Clover, and Melilot.}

The $f$. of all the species, dried and powdered, may be made into bread. Ls. in all the British species in threes, hence the name trefoil, three $l s$.

* Flowers in clusters, or spikes. Seeds one or more. Melilotus.

T. officinále. Common Melilot. Clusters on one side of the stem only. Legume prominent, acute, transversely wrinkled, hairy, with two seeds. Stem erect. Stipulas awl-shaped. E. B. 1340.

Thickets, hedges, borders of fields.

An. June.

Stem branched, leafy. Ls. in threes, rarely more, stalked: leafl. upper ones inversely egg-shaped, narrow, saw-toothed. $\overrightarrow{F l}$. yellow, in long, axillary stalked spikes, with small bracteas. Standard folded. A newly observed Melilot species with white flowers, described, in $\boldsymbol{H} . \boldsymbol{B} r . \boldsymbol{F} \boldsymbol{l}$., Melilótus leucantha.

The leaves when dry, and seeds have a flavour approaching to that of bitter almonds; hence a bad weed among bread-corn. Fresh ls. taste and smell like hay.

* * Flowers in heads. Seeds several.

\section{(T. ornithopodioídes. See Appendix.)}

T. repens. White T. Dutch Clover. Heads globose, resembling umbels. Flowers somewhat stalked. Legume within the calyx, four-seeded. Stems creeping, solid. E. B. $1769 . \quad$ C. 3. $46 . \quad$ T. pratense. G. E. 1185.

Meadows, pastures.

Per. May.

$\boldsymbol{L}$ s. alternate, on long, upright stalks : leafl. on small, partial stalks, inversely heart-shaped, or roundish, finely toothed, smooth. Ls. generally stained after flowering, the fl.-heads spread outwards and downwards, like an umbrella. Fl. cream-coloured, rarely reddish, (sometimes become leafy,) hanging down in decay.

Valuable fodder for cattle in the dry, autumnal months : an excellent bottom in pastures. Where this plant abounds spontaneously, an indication of a good soil.

$$
\text { *** Seeds single. Calyx generally hairy. }
$$


T. subterráneum. Subterraneous T. Heads hairy, of about four flowers. Involucre central, bent back, rigid, starry, embracing the fruit. E. B. 1048. C. 2. 54 .

Dry, gravelly pastures, barren heathy places. ** Shotover Hill, by the road to Cuddesdon. $\boldsymbol{S} b$. and $\boldsymbol{B} x$.

An. June.

Stems trailing, spreading close to the ground, almost concealed by the broad, sheathing stip. of the numerous $l s$. Leafl. inversely heart-shaped, entire. $\boldsymbol{F}$ l.-stalks at first erect, before the fruit ripens, bent to the ground, producing from their extremities white thick fibres, star-like at their tips. The long slender milk-white petals render this plant conspicuous. Cal. teeth long, hairy.

T. pratense. Common Purple Clover. ${ }^{\mathrm{I}}$ Honey-suckle Trefoil. Spikes close. Stem ascending. Petals unequal. Calyx hairy, four of its teeth equal. Stipulas egg-shaped, bristle-pointed. E. B. 1770.

Meadows, pastures.

Per. June.

Stems about one f., slightly branched, leafy. Leaft. elliptic, more or less acute, with a pale, crescent-shaped, angular mark. Spikes terminal, solitary, between a pair of nearly stalkless $l s . F l$. many, fragrant, light purple, petals united at the base, and to the stam.

Var. Fl. white.

Most valuable for fodder or hay; most nutritious of its tribe. The "holy trefoil's" leaf formerly supposed a potent charm against witches, probably from its three leaves being emblematic of the Trinity. The heads dye woollen green, with alum, or copperas.

T. médium. Zigzag T. Spikes lax. Stems zigzag and branching. Petals nearly equal. Stipulas tapering, converging. Two upper calyx-teeth rather the shortest. E. B. 190.

Elevated, dry, chalky, or gravelly pastures. Sm.

Per. June.

Differs from Trif. pratense, in its lax head of fl., longer and narrower stip., and more unequal caly.x, and its remarkably zigzag stem. Fl.-heuds rather larger. Pet. purple. Leafl. spear-shaped, with minute serratures invisible to the naked eye.

T. arvense. Hare's-foot $T$. Spikes close, egg-shaped, cylindrical, very hairy. Stipulas spear-shaped, bristlepointed. Calyx-teeth longer than the corolla, permanently bristle-shaped. Leaves linear-inversely-eggshaped. E. B. 944. C. 6. 50. Lagopodium, Pes leporis. G. E. 1193. 
Sandy, barren fields.

An. July.

Stem mostly erect, much branched, somewhat zigzag. Ls. stalked, leafl. nearly stalkless. $F l$. numerous, pale reddish. Cor. almost concealed by the teeth of the cal.

A weed, not worthy of cultivation : aromatic when dried.

T. scabrum. Rough Rigid $T$. Heads stalkless, axillary, also terminal and egg-shaped. Calyx-teeth unequal, spear-shaped, rigid; finally curved back. Stems trailing. E. B. 903. C. 6. 48 .

Chalky, dry, sandy fields. * Near Jericho, on the road side, going to Port Meadow. Sb. Side of the road between the Asylum, and Shotover Hill. Old stone-pits on Bullingdon Green. B.x. Shotover Hill, by the old London Road. R. W.

An. June.

Stems four to seven inches, stiff, round, hairy. Leaft. inversely egg-shaped, or inversely heart-shaped, toothed. Stip. spearshaped. Fl.-heads of many thick-set, white, or pale blushcoloured 1. Segments of the cal. in its seeding state most remarkably bent back.

T. striátum. Soft Knotted $T$. Heads stalkless, both axillary and terminal, egg-shaped. Calyx elliptical, furrowed, hairy; with straight bristle-shaped teeth. Stems trailing. E. B. 1843.

Dry, barren, sandy fields, and pastures. * Jericho. Bullingdon Green. Wychwood Forest. Sb. Bullingdon Green. B.x. 1831.

An. June.

Stems often downy, zigzag. Ls. alternate, distant, the lower on long, the upper on short stalks. Leafl. inversely egg-shaped, or inversely heart-shaped, finely toothed, downy. Stip. eggshaped, broad, pointed. Cal. with ten deep furrows, and five green teeth tapering, which are lengthened out after flowering. Cor. pale rose-coloured.

Discrim. The ribs of the cal. and the cal. itself rounded, nearly globular in shape: by the downy softness of the plant.

**** Calyx of the fruit inflated, bladdery.

T. fragífërum. Strawberry-headed $T$. Heads roundish. Calyx finally inflated, bent back, with two terminal teeth. Stems creeping. E. B. 1050. C. 2. 55. G. E. 1208 .

Moist meadows, pastures.

Per. August.

Ls. on long stalks. Leafl. inversely egg-shaped, or inversely heart-shaped, sharply toothed. Stip. spear-shaped, large, acute. Fl.-heads roundish. Pet. rose-coloured. Cal. greatly inflated in the upper side, tinged with crimson. Plant, the habit of Trif. repens. 
Produce late, and inconsiderable.

**** Standards bowed archwise, dry and membranous.

T. procumbens. Hop T. Heads oval, tiled, manyflowered. Standard finally bowed archwise, furrowed. Stems spreading, or trailing. Common leaf-stalk longest at the base. E. B. 94.5. T. agrarium. C. 3. 45.

Dry, gravelly fields and pastures.

An. June.

Leafl. inversely egg-shaped, notched at the end, toothed. $\boldsymbol{F l}$. lemon-coloured, permanent, at length brown, and membranous, and distinguished by its broad, furrowed standard. Acceptable to cattle.

T. minus. Less, Yellow, T. Heads hemispherical. Flower stalks straight, stiff. Standard nearly even. Stem trailing. Common foot-stalk of the leaf very short. E. B. 1256 . T. procumbens. C. 5. 53. T. luteum minimum. G. E. 1186. T. dubium. Sb.231.

Dry, gravelly fields and pastures.

An. June.

Stems little branched, six to twenty four inches. $L s$. the central leaflet on a more partial stalk than in Tr. procumbens, or in Tr. filiforme. The leafl. of all three species inversely egg-shaped, notched at the end, and toothed. $F l$. twelve to fifteen, yellow, standard not broad.

T. filiforme. Slender Yellow T. Clusters lax, of few flowers. Common stalks hair-like, wavy. Standard even. Stems trailing. Leaflets all nearly stalkless. E. B. $125 \%$.

Sandy, or gravelly, grassy pastures. Sm. Bullingdon Green. Southleigh Heath. $\mathbf{S} b$.

An. May.

Plant very slender. $F l$. three to eight, leaning one way, yellow, small.

\section{LO'TUS. Bird's-foot-trefoil.}

L. corniculátus. Common B. Heads flattened at the top, of few flowers. Stems lying down, pithy. Legumes spreading, nearly cylindrical. Claw of the standard inversely egg-shaped. Filaments all dilated. E. B. 2090. C. 2.56. Trifolium siliquosum minus. G. E. 1190.

Open, grassy pastures. 
Per. June.

Stems much spreading, leafy, angular, with close-pressed hairs. $L_{s}$. alternate, hairy, leafl. in threes: a pair of leafy stip. at the lase of their common stalk. Leafl. inversely egg-shaped, acute. $F l .-s t a l k s$ axillary, solitary, very much longer than the $l s . F l$. two to five, fine yellow, as they fade, turning orange, a leaf at the base of the fl.-head; keel pale yellow, striped with red at the base. Cal.-teeth, spaces between rounded. Legume shining purple.

Fl. greenish when dried; plant worthy of cultivation, pasturage for sheep: makes good hay.

L. major. Great B. Heads flattened at the top, manyflowered. Stems erect, tubular. Legumes drooping, cylindrical. Claw of the standard linear. Shorter filaments not dilated. E. B. 2091. Var. C. villosus. $\mathrm{Sb}$.

Wet, bushy places, osier holts, hedges.

Per. June.

Stem one to two, or three f., hairy, like the 1s. Fl. six to twelve, duller orange than in Lot. corniculátus. Cal.-teeth, spaces between, narrow and acute, not rounded, as in Lot. corniculátus.

L. ténŭis. (H. Br. Fl.) Slender B. Heads depressed, umbellated, from six to ten flowers. Stem prostrate, slender. Leaflets spear-shaped. Flower-stalks very long. Calyx-teeth shorter than the tube. E. B. Suppl. 2615. L. decumbens. Smith's E. Fl.

Meadows, fields.* In the broad, green-sward path, leading off the Cowley road, near the gate up to the Asylum. R. W. 1832.

Per. June, August.

Discrim. 'The general slenderness of the plant, and its spearshaped leaflets, from L. cornic. and L. major.

\section{MEDICA'GO. Medick.}

(* M. sativa. Purple M. or Lucerne. Clusters upright. Legumes spiral. Stem erect, smooth. E. B. 1749. Trifolium Burgundiacum. G. E. 1189 . Hedges, pastures, borders of fields. Grafton, Warwickshire. Pn. Fl. Per. June, July.

Fl. violet. Perhaps a variety of M. falcata.)

M. lupulina. Black M. or Nonesuch. Spikes eggshaped, erect. Legumes, (pods) kidney-shaped, rugged 
and veiny, single-seeded. Stem trailing. E. B. 971. C. 2. 5\% Trifolium luteum lupulinum. G. E. 1186. Meadows, pastures, cultivated fields.

An. June.

Stems several, widely spreading, leafy. Ls. like those of a trefoil, leafl. inversely egg-shaped, finely toothed at the front edge. $\mathbf{F l}$. small, bright yellow. Pods very black, with traces of a spiral structure.

In Norfolk called Nonesuch, usually mixed for a crop with rye grass (Lol. perenne.) Excellent fodder for sheep.

M. maculáta. Spotted M. Stalks two, or three flowered. Leaflets inversely heart-shaped, spotted. Stipulas dilated, sharply toothed. Legumes, spiral, depressed, fringed with long, spreading bristles. Sb. 232. M. polymorpha. E. B. 1616. C. 3. 47. Trifolium cordatum. G. E. 1190.

Gravelly soil. Sm. Near the Physic Garden. Sb. Christ

Church Meadow. Bx. Between St. Clement's and Iffley, growing near Salvia verben. R. W.

An. June.

Fl.-stalks axillary, solitary, slender. Legumes coiled up into a ball, like a snail's shell, brown. $F l$. yellow.

Fodder for cattle.

\section{Class XVIII. POLYADELPHIA.}

\section{Filaments combined, in more than two sets.}

\section{Order I. POLYANDRIA. Stamens numerous.}

\section{HYPE'RICUM. St. John's-wort. ${ }^{1}$}

\section{H. Androsamum. ${ }^{2}$ Tutsan, ${ }^{3}$ or Park leaves. Styles} three. Capsules pulpy. Stem shrubby, compressed. E. B. 1225. C. 3.48. Clymenon Italorum. G. E. 543.

1 St. John's Wort, in former times, considered as powerful for the expulsion of witches, for the prognostication of the fates of young men, and maidens. In Lower Saxony, girls gather sprigs of it on Midsummer night, and fasten them-to the walls of their chamber. If the sprig, the next morning, remain fresh, a suitor may be expected, if it drop, or wither, the maiden is destined to an early grave. Hyp. perforátum was the species used in this country. $\boldsymbol{F l}$. $\boldsymbol{B} . \boldsymbol{T}$. Transparent dots of the ls. lodge an essential oil.

2 i. e. andros, aima, man's blood, as if the plant flowed, when bruised, with a juice like blood.

Tout-sain, Fr. all-heal. 


\section{POLYADELPHIA POLYANDRIA. Hypéricum.}

Moist, shady lanes, thickets and woods.* Shotover Plantations. Stokenchurch. Nettlebed Woods. Sb. In a ditch on the top of Shotover Hill, a little before you come to the gate leading to Mr. Schutz's. Bx.

Shrub. July.

Stem woody, perennial. Ls. opposite, stalkless, wide-spreading, egg-shaped, or rather heart-shaped, entire, veiny, smooth, as the rest of the plant. Panicles terminal, more or less accurately three-forked. Pet. and stam. yellow. Styles of the same colour changing to purple. Fruit purple-black, elliptic.

Discrim. Its shrubby stem, large fl., and black fruit.

H. quadrángulum. Square S. W. St. Peter's-wort. Styles three. Stem herbaceous, with four sharp angles. Leaves with copious, pellucid dots. Segments of the calyx spear-shaped. E. B. 370 . C. 4. 52. H. quadrangulare. Sb. 235.

Moist meadows, thickets, and about the banks of rivers.

Per. July.

Stems perfectly erect, two f. $L s$. opposite, elliptic, or egg-shaped, each pair crossing those next to them. $F l$. small, pale yellow.

Odour of bruised plant, lemon-like.

H. perforátum. Common Perforated S. W. Styles three. Stem two-edged. Leaves blunt, with copious transparent dots. Segments of the calyx spear-shaped. E. B. 295 . C. $1.5 \%$ Hypericum. G. E. 539.

Groves, thickets, hedges.

Per. August.

Stems about two f., perfectly erect, leafy. Ls. opposite, each pair crossing those below them, oblong, somewhat elliptic, entire. A short, simple, leafy bianch from the bosom of each l., the upper ones bearing $\mathrm{fl}$., and forming a forked, leafy panicle, terminating the stem. $F \boldsymbol{F l}$. bright yellow. Edges of the cal. and pet. as well as their outward surface, marked with dark purple spots and lines, containing a red, essential oil, staining the fingers.

The fl. tinge spirits and oil of a fine purple.

\section{(H. dubium. See Appendix.)}

\section{H. humifúsum. Trailing S. $W$. Styles three. Flowers} somewhat cymose. Stem compressed, trailing. Leaves elliptical, smooth. Segments of the calyx egg-shaped, leafy. E. B. 1226. C. 3.50. H. supinum glabrum. G. E. 541 .

Sandy, gravelly, heathy, rather boggy pastures. Sm.* Bullingdon Green. Southleigh Heath. Sb. (Bagley Wood.) Bx. Road side, between Shotover Hill, and Cuddesdon. R. W.

Per. June. 
Stems several, slender. Ls. stalkless, opposite, dotted, thin, membranous. $\mathrm{Fl}$. axillary, also terminal, mostly solitary, yellow, in a sort of forked corymb. Cal. edges toothed with purple glands, as also the margins of the pet. Stam. styles, and germ. yellow. Fruit turns red, as it ripens: lower ls. assume the same hue.

Discrim. Small size, slenderness, few flowers.

A pretty plant.

H. monténum. Mountain S. W. Styles three. Calyx with close, prominent, glandular serratures. Stem erect, round, smooth. Leaves egg-shaped, naked, clasping the stem. E. B. 371.

Wild, bushy hills, gravelly, or challyy woods. Sm.* Stokenchurch. Henley. Mapledurham. $\mathbf{S} b$.

Per. July.

Stems two f. or more. Ls. opposite, their margin dotted with purple beneath. $\boldsymbol{F l}$.-panicle terminal, upright, of few, lengthened out, forked branches, destitute of ls. Bract. opposite, spear-shaped, fringed with a row of brown, stalked glands. Pet. lemon-coloured. The fringed cal.-ls. give the fl. some resemblance to the moss-rose.

An elegant plant. Distinguished from Hyp. hirsutum by its smoothness, and the panicle quite destitute of ls.

H. hirsútum. Hairy $S$. Styles three. Calyx spearshaped, with glandular serratures. Stem erect, round. Leaves egg-shaped, downy. E. B. $1156 . \quad$ C. 3. 49. Ascyrum. G. E. 542.

Thickets, hedyes.

Per. July.

Stem about two f., leafy, more or less hairy, panicled in the upper part. $\mathbf{F l}$. yellow, very numerous. Bract. cal.-ls. and tips of the pet. fringed with blackish stalked glands. Ls. in cross pairs. A handsome plant.

H. pulchrum. Small Upright Handsome S. W. Styles three. Calyx egg-shaped, with glandular serratures. Stem erect, round. Leaves clasping the stem, heartshaped, smooth. E. B. $122 \%$ C. 1. 56.

Woods, and bushy, heathy places. Bullingdon Green. Shotover Hill. Southleigh. $\mathbf{S b}$.

P.er. July.

Whole plant smooth. Ls. in distant pairs, stalkless, mostly bent downwards. Fl.-pet. golden yellow, outwardly tipped with scarlet, their edge glandular. Anth. red.

An elegant plant, with its tall, straight, slender, panicled stems, bearing numerous, yellow buds, tipped with red, intermixed with already expanded fl. 
(H. elódes. Marsh S. W. Styles three. Calyx blunt, glandular. Stem trailing, creeping, round, shaggy, like the roundish, blunt leaves. Panicle of few flowers. E. B. 109. H. tomentosum. G. E. 540. Ascyron supinum elodes. G. E. 542.

Spongy, especially rather mountainous, bogs. Sm. Coleshill bog, and pool, Warwickshire. $\boldsymbol{P} n, \boldsymbol{F}$.

Per. July, August.

Stems spongy. $\boldsymbol{F l}$. lemon-coloured with green lines.)

\section{Class XIX. SYNGENESIA. Anthers}

\section{united into a tube. Flowers compound.}

\section{Order I. POLYGAMIA AEUALIS. Florets all}

perfect, five stamens each, and one pistil, producing one seed.

Obs. A compound flower is enclosed by one common calyx. Surface of receptacle concave, or flat, or convex, or pyramidal, or globular. Sometimes naked, i. e. marked only with small dots, or cells; or hairy, or chaffy, for separating the florets. Plants of the class Syngenesia generally bitter, but few poisonous. Purton's $\mathrm{Fl}$.

A natural tribe, consisting of the genuine Compound Flowers, having a common calyx, and combined anthers. Sm.

* Florets all strap-shaped; a natural order.

\section{'TRAGOPO'GON. Goat's-beard.}

T. pratensis. Yellow G. Calyx about equal to the corolla. Leaves keeled, tapering ; dilated and somewhat wavy at the base. Flower-stalk cylindrical. E. B. 434. T. luteum. G. E. 735.

Grassy pustures and meadows.

Bien. June.

Plant eighteen inches to two f., very milky. $F l$. solitary, terminal, bright yellow, opening at day-break, and closing before noon, unless the weather be cloudy; hence called, "Go to bed at noon." Ls. grass-like, sheathing the stalk at the base, alternate, sharp pointed, widening at the base. Seeds with feathery crowns, lightly cohering like a cobweb.

Cal. in Huntingdonshire specimens always exactly equal with the corolla, Norfolk ones invariably exceeding it. Woodward in With. Germ., with a tuft of hairs at the summit. 
The root cultivated in gardens for Asparagus. Livn. in Fl. Suec. Before the stems shoot up, the roots, boiled like Asparagus, have the same flavour, and are nearly as nutritious. With. Gerarde, in his Herbal, observes, that in delicate taste, they far surpass either carrots, or parsneps. 'The spring shoots eaten in the same manner: but the Trag. porrifolius, Salsify, was usually cultivated for culinary purposes.

\section{PICRIS. ${ }^{1} \quad$ Ox-tongue.}

P. echioídes. Bristly $O$. Outer calyx of five, broad, prickly scales. Down stalked. Leaves wavy. E. B. 972. C. 3. 51. Buglossum luteum. G. E. 798. Hedges, boiders of fields.

An. July.

Plart covered with stiff spines, each growing out of a white tubercle, bright, shining green. $\mathrm{Fl}$. bright yellow. Upper $l s$. heart-shaped, clasping the stem; lower spear-shaped. Inner cal. of eight equal leaves, each producing a winged, purplish awn.

Seeds appear beautifully wrinkled when magnified. $F l$. sometimes remains open until nine at night. With. Agreeable pot herb when young, aperient.

P. hieracioides. Hawkweed $O$. Outer calyx of numerous scales, much shorter than the inner. Leaves spear-shaped, wavy, embracing the stem; root-ones toothed. Down stalkless. Stem rough. E. B. 196. Hieracium asperum. G. E. 298.

Dry bunks, borders of fields, gravelly, or chalky. $s_{m}$. Headington Wick. Bladon. Stanton Harcourt. Sb. (Between Ferry Hinksey and Cumnor Hurst. B $x_{0}$ ) Near Headington Wick Copse. R. W. Between Headington and Shotover. R. W.

Bien. July.

Plant rough with short hairs, dark green. $F$ l. bright yellow, with spear-shaped bracteas. Branches furrowed, purple on the upper side, and in their axils. $F \boldsymbol{F}$. from the side of the stem, rising on branches lengthened out above that which terminates the central stem. Fl. corymbose. Fruit-stalks loosely scaled up to the cal. Globe of seeds and feathers a perfect ball.

\section{SONCHUS. Sow-thistle.}

S. arvensis. Corn S. Flower-stalks and calyx bristly, somewhat umbellate. Leaves runcinate, finely toothed, upper ones heart-shaped at the base. Root creeping. E. B. 674. C. 4. 53. S. arborescens. G. E. 294.

1 So called from the bitterness of the plant, picros, Gr, bitter. 
Cornfields, hedges, chalky soil. Sm.

Per. July.

Figure of the $l s$. various. Plant three to four f. Cal. flowerstalks, and upper part of stem clothed with brown, glandular hairs. Cor. large, deep yellow, sometimes outwardly reddish. $L s$. the uppermost of all entire. Cal. after flowering swelling at the base. L.-segments triangular.

A troublesome weed from its creeping root of oblong, fleshy branches. The flower follows the course of the sun very regularly. Flowers close between eleven and twelve at noon. Horses fonl of it. Hairs of cal. and fruit-stalks pale green, terminated by yellow globules.

S. oleráceus. Common S. Flower-stalks cottony. Calyx smooth. Lower leaves runcinate, toothed. E. B. 843. C. 2.58. S. lævis. G. E. 292.

Cultivated, and waste ground.

An. July.

Shape of the $l s$. variable. Young flower-stalks clothed with a white, cottony web, soon falling off. Cal. smooth, at first cylindrical, afterwards swelling much at the base. Flower-stalks both axillary, and terminal, cymose. Cor. yellow. Upper ls. oval-spear-shaped, saw-toothed on the edges. Stem brittle.

May be used as a cooling cataplasm. Young leaves in some countries are boiled, and eaten. Flowers open about six, or seven, shut at eleven, or twelve. Linn. Fl. Suec.

Horses and rabbits very fond of this plant.

\section{LACTU'CA. Lettuce.}

L. virósa. Strong-scented $L$. Leaves horizontal, finely toothed; their keel prickly. E. B. 195\%. L. sylvestris major, odore opii. G. E. 309.

Hedges, borders of fields.* Marston Lane. Sb. Side of the New Road, going from Botley to Ensham. Bx. Between Dunchurch and Southam, Warwickshire. B.x.

Bien. July.

Ls. deep green. Whole plant abounds with a milky juice, smelling like opium: this issues on the slighest touch from the calyx, and more tender leaves. Root-leaves inversely eggshaped, the rest, smaller, clasping the stem, waved, or indented (toothed.) Floral leares, heart-shaped, pointed. Fl. small, palish yellow, their stalks with numerous small bracteas. Rootleaves broad, entire. Lightf. One leaf at the base of each flowering branch. $F l$. opens about seven, closes about ten, forenoon?

The extract useful in dropsy, in doses from eighteen grains, to three drachms, in twenty-four hours. It proves laxative, promotes urine, and gentle sweats, abates the thirst. Collin. According 
to Swediaur it is sedative, and diuretic, and useful in dropsy, as opium often proves. See Mat. Med.

\section{PRENANTHES. Wall-lettuce.}

P. murális. Iry-leaved $W$. Florets five. Leaves runcinate. E. B. $45 \%$ C. 5.58 . Sonchus lævis muralis. G. E. 293.

Old walls, woods, chalky soil. Sm. On the top of Stanton Harcourt Kitchen. Stokenchurch Woods. Sb. Magdalen College. Long Wall, \&c. R. W.

Per. July.

Plant smooth, brittle. $F l$. bright yellow, small. Ls. wing-cleft, with sharp lobes pointing backwards; root-ls. on footstalks, the rest embracing the stem. It varies with entire leaves on the stem. Ls. often purplish beneath. Terminal lobe of the leaves five-angled, three-lobed. Uppermost leaves spear-shaped. $\quad \boldsymbol{F} l$. buds drooping.

\section{LEO'NTODON. ${ }^{\prime}$ Dandelion. ${ }^{2}$.}

L. Taráxăcum. Common D. Outer scales of the calyx bent back. Leaves runcinate, toothed, smooth. E. B. 510. C. 1. 58. Taraxacum officinale. Sb. Dens Leonis. G. E. 290.

Meadows, pastures.

Per. August.

Plant stemless. $\mathbf{F l}$. solitary, large, bright yellow. $\mathbf{F l}$. stalks simple, round, hollow, brittle. Whole plant milky, bitter. $\mathrm{Fl}$. open in the morning, and in fine weather only. Down on a long footstalk.

By culture, and especially by blanching, this herb sufficiently mild to be eaten in a salad. $\boldsymbol{S} m$. Eng. Fl. Leaves early in spring, an excellent ingredient in salads. The French eat the roots, and blanched leaves, with bread and butter. Many of the inhabitants of Minorca, subsisted on this plant, after the destruction of their harvest. Small birds fond of the seeds. An excellent deobstruent in visceral obstructions. Mr. Purton recommends prescribing with it, Fumaria officinalis. May be blanched by the simple process of laying a tile upon the plant. Mat. Med. in Extr. and Decoct.

('T. palustre. See Appendix.)

i. e. Lion's tooth, from Le6n, odous, Gr.

2 Dent de lion, Fr. From the supposed resemblance of the leaf, to the tooth of the lion. 


\section{APA'RGIA. Hawkbit.}

A. hispida. Rough H. Stalks naked, single-flowered. Leaves runcinate, sparingly toothed, rough. Florets hairy at their orifice; glandular at the tip. Seeds scarcely beaked, all with feathery down. Hedypnois hispida. E. B. 554. Leontodon hispidum. C. 5 . 56. Sb. 239. Hieracium dentis leonis folio hirsutum. G. E. 303.

Pastures, especially on chalk, or limestone. Sm.

Per. July.

Root spindle-shaped, black. Fl. bright yellow, drooping in bud, in flower erect. Seeds uniform. Ls. generally covered with forked, stiff hairs. Stalks upright, hairs forked. Florets their summits terminate in five teeth, at the back of each a triangular cluster of brown glands.

$F l$. opens about four in the morning, shuts at three in the evening generally. Linn. $F^{\prime} l$. Suec.

A. hirta. Deficient H. Stalks naked, single-flowered. Leaves toothed, rough. Calyx nearly smooth. Outer row of seeds crowned with scales only. Hedypnois hirta. E. B. 554. Leontodon hirtum. C. 6. 59. Sb. 238. Thríncia hirta. H. Br. Fl.

Gravelly heaths, commons. Sm.

Per. July.

Root abrupt. $F l$. smaller than in Apargia hispida, without its yellow hairs at the orifice, and without the brown glands at the back of the tip of the florets. $\mathbf{F l}$. droop before flowering. Cal. nearly smooth. $F l$. reddish beneath.

\section{A. autumnális. Autumnal H. Yellow Devil's Bit.} Common stalk branched; partial ones scaly. Leaves spear-shaped, toothed, or wing-cleft, nearly smooth, leaf-stalks swollen beneath the flower, tapering downwards. Hedypnois autumnalis. E. B. 830. Leontodon autumnale. Sb. 238. Hieracium minus, sive leporinum. G. E. 296.

Meadows, pastures.

Per. August.

$\mathbf{F l}$. bright yellow, small, often reddish outside, numerous. Cal. and top of stalk slightly downy. Root abruptly bitten off, with long, simple fibres from its sides. Flower-stalks scaly, hollow, each containing a small tuft of very white cotton. The root becomes abrupt in the second or third year of the plant's growth. 
Seed-down of central flowers sometimes tapering out into a kind of short, small foot-stalk, feathered, brownish white, which colour readily distinguishes it from Hypochæris radicáta.

\section{HIERA'CIUM. ${ }^{x}$ Hawkweed. ${ }^{2}$}

H. Pilosella. Common Mouse-ear $\boldsymbol{H}$. Leaves elliptical, entire; cottony beneath. Scyons creeping. Stalks single-flowered, naked. E. B. 1093. C. 4. 54. Pilosella repens. G. E. 638.

* Stalk naked, single-flowered, immediately from the root.

Dry, open pastures, banks.

Per. June.

Florets pale yellow above, elegantly striped with red beneath. According to Gerarde powerfully astringent. A cochineal insect (coccus,) found on the roots, according to Linn. Fl. Suec. ** Stem leafy.

H. murórum. Broad-leaved Wall $\boldsymbol{H}$. Stem corymbose, with a solitary leaf. Leaves egg-heart-shaped, wavy, with radiating teeth chiefly at the base. E. B. 2082. Pulmonaria gallica, sive aurea latifolia. G. E. 304.

Old walls. $\mathbf{S} m$. Magdalen College Walks. Bx.

Per. June.

Smith in Eng. Botany, under plant figured for Hier. murorum (2082) observes: Hier. sylvaticum t. 2031, we presume to be the murorum of all our local Floras.

"The Hier. murorum of Dr. Sibthorp's Fl. Oxon. is, undoubtedly, the H. sylvaticum of Sir J. E. Smith's Eng. Flora, which is now (September, 1831) growing in great plenty on the walls of Wadham College garden, but where I could not find a single plant of $\mathrm{H}$. murorum.

There are no specimens of perfect plants, that I know, of Dr. Sibthorp's in the Sherardian Herbarium; but when he arranged that collection according to the Linnæan arrangement, he appears to have considered the $\mathbf{H}$. murorum, maculatum, and sylvaticum of Smith as mere varieties of the same species." $B x$.

H. sylváticum. Wood $\boldsymbol{H}$. Stem simply racemose, many-leaved, solid. Leaves egg-spear-shaped, toothed chiefly about the base; teeth pointing forward. E. B. 2031. H. murorum. Fl. Br. 830, a. Sb. 241.

Dry, chalky woods, dry banks, old park walls. Sm. Wadham College Wall. Stow Wood. $\mathbf{S b}$. Magdalen College Walks. $B x$.

Per. July.

1 A most intricate and difficult genus. 2 Ang.Sax.

Q 
Hier. sylváticum differs from Hier. murorum in the root-leaves being spear-shaped, and slightly toothed; the leaf-stalks being longer in shape, the stem-leaves more than one, and the whole plant considerably larger. With. ed. 1818. p. 898. Root slender, slightly creeping, with long, simple fibres. Stem panicled.

H. sabaudum. Shrubby, Broad-leaved $H$. Stem erect, copiously leafy, many-flowered. Leaves egg-spearshaped, sharply toothed, rough-edged, somewhat clasping; hairy beneath. Flowers corymbose. E. B. 349. Coppices, groves, thickets.

Per. July.

Plant somewhat shrubby, rough, stiff. Fl. numerous, bright yellow, open in the forenoon only. Ls. alternate, broad, acute, dark green, almost smooth above; paler, somewhat glaucous, very hairy beneath: lower ones spear-shaped elliptical, lengthened out at the base; greater part of those on the stem eggspear-shaped, half embracing the stem. Flower-stalks erect, downy, forming a thin corymb, liable to many different appearances. In shady places, plant sometimes smooth, but always stiff. Stems two to three f. or more. Stigmas covered with blackish hairs.

H. umbellátum. Narrow-leaved $\boldsymbol{H}$. Stem erect, leafy, almost solid, imperfectly umbellated. Leaves scattered, linear, slightly toothed, nearly smooth as well as the calyx. E. B. 1771 . C. 6. 58. H. intybaceum. G. E. 298 .

Groves, gravelly thickets.

Per. July.

$F l$. yellow, on long fl.-stalks, in a corymbose umbellated form, terminal. Points of the outer segments of the calyx turned back.

Plant used to dye wool of a fine yellow colour. Linn. Fl. Suec.

* H. amplexicaule. See Appendix.

CRE'PIS. Hawk's-beard.

C. tectórum. Smooth H. Smooth Succory Hawkweed. Root leaves runcinate; the rest clasping, spearshaped, and arrow-toothed. Stem smooth. Calyx rough. Seed-down stalkless. E. B. 1111. C. 5. 55. Hieracium aphacoides. G. E. $29 \%$

Dry pastures, meadows, waste ground, thatched roofs.

An. June.

Root tapering. Herb very various in size and luxuriance. Stem upright, smooth, rarely a little hairy, generally stained with purple just above each branching. Panicle upright, forked, corymbose, and with small leaves. $F l$. rather small. Down 
rough, stalkless. Cal. furrowed, sprinkled lengthways with clammy hairs. Styles, as soon as they have passed through the anthers, brown.

\section{HYPOCHÆRIS. Cat's-ear.}

\section{H. maculata, and H. glabra. See Appendix.}

H. radicáta. Long-rooted C. Leaves runcinate, bluntish, rough. Stems branched, naked, smooth. Flowerstalks scaly. Down of all the seeds stalked. E. B. 831. C. 3. 52. Hieracium longiùs radicatum. G. E. 298.

Pastures, waste ground.

Per. July.

$L s$. all from the root, close to the ground. $F l$. large, bright yellow. Root very long. Recep. beset with long, sharp, chaffy scales among the florets, the character of the genus. Down on the stalk feathery, rough. Flor. purplish on the outside. Flowerstalks thickest nearest the flower. Cal.-scales roughish at the keel. Scales spear-shaped, one at the base of each branch, with a few white, bristly teeth at the base on each side.

\section{LA'PSANA. Nipple-wort. ${ }^{x}$}

L. communis. Common $N$. Calyx of the fruit angular. Stem branched, panicled, leafy. Leaves egg-shaped, stalked, toothed. Flower-stalks cylindrical, even, slender. E. B. 844. C. 1.59. Lampsana. G. E. 255. Waste and cultivated ground.

An. July.

Ls. slightly toothed. Root-ls. lyrate, the rest egg-shaped, alternate, stalkless, pointed, fl.-stalks alternate, erect, with a small pointed bractea at the base of each. $F \boldsymbol{~}$. small, bright yellow. Cal. smooth, permanent.

The young ls. in spring, taste like radishes: eaten by the inhabitants of Constantinople, raw as a salad. In some parts of England, boiled as greens. Lightf. Fl. Scot.

L. pusilla. See Appendix.

\section{CICHO'RIUM. Succory.}

C. 'Intybus. Wild S. Flowers in pairs, both nearly stalkless. Root leaves runcinate. E. B. 539. C. 4. 56. C. sylvestre. G. E. 284.

Borders of fields, road sides.

Per. July.

Stem two or three f., hard and tough, alternately branched, with lateral flowers from the side of the stem, mostly in pairs, with

1 From its supposed virtue in the cure of sore nipples. 1 Ang.-Sax.

Q 2 
small, stem.clasping leaves. $F \boldsymbol{F}$. large, handsome, brilliant sky-blue. Cylinder of the anthers striped blue, and white.

The ls. blanched, a salad in spring, and the roots may be eaten at table. 'This plant different from Garden Endive, Cich. Endivia. Root roasted, a substitute for coffee in some parts of Germany, said, when dried, to have served to make bread. The herb in a cultivated state, excellent early fodder for horses and cows.

Flowers found white, but rarely.

* * Florets all tubular, with a fire-cleft spreading limb; a natural order.

\section{'ARCTIUM. Burdock.'}

\section{A. Lappa. ${ }^{2}$ Common B. or Clot-bur. Leaves stalked,} heart-shaped, wavy, without prickles. Calyx when in seed nearly smooth. E. B. 1228. C.4 . 55. Bardana major. G. E. 809.

Waste ground, way sides, dunghills.

Bien. July.

Plant branched, spreading. Stem erect. $L s$. on hollow footstalks, very large, when full-sized. $\boldsymbol{F l}$. numerous, nearly stalkless, purple. Cal. of numerous narrow scales, each tipped with an incurved hook, by means of which the whole calyx, laden with ripe seeds, easily separating from its stalk, adheres to clothes or the coats of animals, a curious provision by which the seeds are dispersed, the calyx being rubbed to pieces by the animals attempting to remove the encumbrance. Recept. bristly. Cor. tube white, bordered. Anth. bluish purple.

Root and stalks eatable, and nutritive: the stalks should be cut before the plant flowers, the rind peeled off, and then boiled; or they may be eaten raw as a salad. Lightfoot. Decoction of the roots a good substitute for that of Sarsaparilla. Has been given in success in dropsy. Seeds food for birds: recommended to fatten poultry. C.

\section{A. Bardána. Woolly-headed $B$. Leaves stalked,} heart-shaped, nearly entire and even, without prickles. Calyx when in seed cottony. E. B. 2478.

Waste yround, way sides, rubbish. (Bagley Wood. Bx.) Lane leading from Bullingdon Green to Cheney Lane, nearly opposite the windmill. $B x$.

Bien. July, August.

Like the foregoing in size and habit, $l s$. less waved, (undulated) more downy beneath. Stem of a dull red. Cal. globose. Sm. This species raised from seed is found constant. Willd. Blossom purple.

1 Ang.-Sax.

${ }^{2}$ From labein, Gr. (to seize:) from its taking hold of soft clothes, \&rc. Mixta tenax segeti crescere lappa solet. Ovid. 


\section{SERRA'TULA. Saw-wort."}

S. tinctória. Common S. Leaves with copious, bristly serratures, wing-cleft, somewhat lyre-shaped; terminal lobe largest. Seed-down roughish. E. B. 38. Serratula. G. E. 713.

Groves, thickets, grassy pastures.

Per. July.

$L s$. smooth on both sides: lower ones generally undivided, sometimes all. Plant firm, rigid. $\boldsymbol{F}$. purple, sometimes white; somewhat corymbose at the top. Down of the seed glossy, with a brown, or gold tinge. Cal. scales of an elegant brown colour. Globular form of the florets resembles an old fashioned wineglass. Ls. half embracing the stem. Stigma forked deeply. Plant diœeious in effect.

Affords a yellow dye for coarse woollen: used in Sweden for that purpose. This plant untouched by cattle.

\section{CA'RDUUS. Thistle. ${ }^{2}$}

\section{* Leaves running down the stem.}

C. nutans. Musk $\boldsymbol{T}$. Leaves not running all the way from one leaf to another, thorny. Flowers solitary, drooping. Calyx-scales spear-shaped; their upper part spreading. E. B. 1112.

Waste ground, fallow fields, dry, barren pastures.

An? July.

Stem two or three f., slightly furrowed, slightly cottony. $L$ s. alternate, green on both sides. $F$ \% smell strongly of musk in warm weather. $\boldsymbol{F}$ l.-stalks woolly, round, naked. Cal.-scales leafy points, slightly cottoned. Ls. with a white rib. Styles

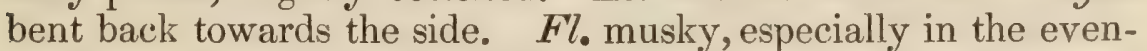
ing. Linn. Cal.-scales dull red: the outward spines wide and open, the inward ones erect: terminate in a strong, yellow thorn. Pollen grey, globular, set with fine points. Small stalks naked.

The dried flowers of this, and of Car. lanceolatus, used in some countries for a rennet to curdle milk. Many kinds of moths hover over the flowers at night. The down of this may be used as a material in making paper.

C. acanthǒides. Welted $T$. Leaves running down the stem, sinuated, very thorny. Flowers crowded, somewhat stalked. Calyx globose; scales linear, partly curved back. E. B. 973. C. polyacanthos. C. 6. 54. Sb. 245. Polyacanthos. G. E. 1173. Thistle upon Thistle.

$$
{ }^{1} \text { Ang.-Sax. Anga-Sax. }
$$


Hedges, dry, waste ground.

An. July.

Three f., or more : more green than Card. tenuiflorus : clothed on every side with scalloped leafy wings: edges of these, as well as of the leaves, fringed with numberless straddling thorns of various lengths. The lengthened out flowering-branches terminate in irregular clusters of purple, erect flowers, less than those of Card. nutans. Cal.-seales slightly woolly. Partial flowerstalks thorny: inner calyx-scales coloured; not close as in Cnicus palustris.

Discrim. from Card. nutans, by its upright calyx. Florets cloven half way down, the lowermost segments separated nearly to the base.

C. tenuifórus. Slender-flowered T. Leaves running down the stem, sinuated, thorny. Flowers crowded, stalkless. Calyx nearly cylindrical; scales egg-shaped at the base; somewhat curved back at the point. E. B. 412 . C. 6.55 .

Dry, sandy ground. Sm. * Dorchester. Bensington. Sb. Yarnton, near the Church. $B x$.

An. July.

Root-ls. on short footstalks, somewhat lyrate, and a little cottony beneath, (as are the upper ones.) $\mathbf{F l}$. long, clustered, erect, pale rose-coloured. Cal.-scales with a membranous margin, and strong yellow terminal thorn; pale in their lower part, green at the tip. Florets ten to fifteen, or more. Plant three or four feet high.

$$
\text { * Leaves stalkless. }
$$

C. mariánus. Milk T. Our Lady's Thistle. Leaves wavy, thorny, clasping the stem; root ones wing-cleft. Calyx-scales leafy, curved back, channelled; thorny at the margin. E. B. 976 . C. 3.54 . C. Mariæ. G. E. 1150 .

Waste ground, banks of ditches. * Near Abingdon. Bx.

An. June.

$\boldsymbol{L} \boldsymbol{s}$. shining, deep green, elegantly marbled along the veins with white, which botanists of the dark ages report to have been caused by the milk of the Virgin Mary falling upon a plant of this species. $F \boldsymbol{F}$. large, purple, solitary, at the end of each branch. Cal.-scales each terminating in a long, bent back, strong thorn, fringed at its base with smaller spines. Four or five feet high. Cal. stem naked.

When young, eaten as salad. The young stalks peeled and soaked in water, excellent. Scales of the cup as good as Artichokes. Root good to eat, early in the spring. With. An emulsion may be formed from the oily seeds. 


\section{CNICUS. Plume-thistle.}

* Leaves running down the stem (decurrent.) Stem winged.

Cn. lanceolátus. Spear P. T. Leaves running down the stem, wing-cleft, hispid, with variously-spreading, thorny lobes. Calyx egg-shaped, shaggy. Stem furrowed, hairy. Carduus lanceolatus. E. B. $10 \%$ Sb. 244. Carduus lanceatus. G. E. $11 \%$.

Waste ground, banks by road sides.

Bien. July.

Three or four f. $F l$. terminal, erect, large, purple. Stem covered like the back of the leaves and calyx with a cotton-like web. Cal.-scales spear-shaped, thorny, spreading. Point of the leaves long, very sharp. $L s$. green, rough on the upper side, hoary underneath. Cal.-scales innermost bristly, dry, unarmed. Recept. hairy, conical.

A shelter for other plants: one of the first to grow where other plants would not thrive. The fl. like those of the artichoke curdle milk. Larva of Cin. Cárdui feeds on this. Almost all the species of Card. and Cnicus, may be eaten, when young. Biennial weed, readily destroyed by mowing it before it seeds.

Cn. palustris. Marsh P. T. Leaves running down the stem, wing-cleft, toothed, thorny, rough. Flowers crowded. Calyx egg-shaped, minutely thorny, nearly smooth. Carduus palustris. E. B. 974. C. 6. 56. Sb. 245 .

Moist meadows, pastures, watery spots by road sides.

Bien. July.

Stem erect, three to six f., very straight, with long, wand-like branches, deep green, often purplish. $L s$. dark green. $F l$. terminal, deep purple, sometimes white. $\mathrm{Cal}$. with abrupt, close scales, tippped with small, short, harmless prickles. Cal.-scales woolly, green, tipped with deep purple, without a rib along the back.

** Leaves stalkless, or partially running down the stem. Stem not winged.

Cn. arvensis. Creeping P. T. Cursed Thistle. Leaves stalkless, wing-cleft, thorny, nearly smooth. Stem panicled, solid. Calyx egg-shaped; outer scales thorny. Root creeping, tuberous. Carduus arvensis. E. B. 975 . C. $6.5 \%$ Sb. 245. C. vulgatissimus viarum. G. E. 1173.

'Jermyn's (now Mrs. Ford's) Butterfly Collector's Vade Mecum : a pleasing, useful work, on British Butterflies. $12 \mathrm{mo}$. 
Cultivated fields, way sides, very common, troublesome weed.

Per. July.

$\boldsymbol{R}$ oot deeply creeping, very tenacious of life. Stem panicled, solid, angular, smooth, three or four f. Fl. palish purple, sometimes white.

The burnt plant yields good ashes for glass-making. Ray. The down, a useful ingredient in paper-making. $W i t h$.

Cn. erióphŏrus. Woolly-headed $\boldsymbol{P} . \boldsymbol{T}$. Leaves stalkless, wing-cleft, with two-ranked, thorny segments; bristly above. Calyx globular, densely woolly, leafy at the base. Carduus eriophorus. E. B. $386 . \mathrm{Sb}$. 246. C. eriocephalus. G. E. 1152.

Dry pastures, road sides.

Bien. July.

Stem three f. or more, erect, much branched, many angled, hairy. $\boldsymbol{L} \boldsymbol{s}$. with two ranks of oblong, straddling segments, alternately pointing upwards and downwards, and armed with very strong thorns. Upper side of leaves rough: under, cottony. $\mathbf{F l}$. solitary, terminal, erect, very large, six or eight inches in circumference. Cal.-scales mostly terminating in a linear, blunt, leafy appendage, fringed, thorny. $\boldsymbol{F l}$. sometimes white. $\boldsymbol{L} \boldsymbol{s}$. lower spreading on the ground, often two feet long. Cal. as long as an egg.

Recept. eatable like the artichoke.

Cn. pratensis. Meadow P. T. Leaves stalkless, spearshaped, wavy or lobed, fringed with unequal prickles; loosely cottony beneath. Stem downy, slightly leafy, single flowered. Calyx cottony, with tapering, small scales, closely tiled. Carduus pratensis. E. B. $17 \%$ Sb. 246. Cirsium anglicum. G. E. 1183. C. montanum anglicum. G. E. 1183. f. 5.

Low, wet pastures, meadows.

Per. June.

Root fibrous, creeping. Stem slightly furrowed, one to two f. Lower $l s$. somewhat cut. Differs from $\mathrm{Cn}$. heterophyllus by the leaves not being woolly underneath, but downy. Generally one flower, and two stem-leaves, half embracing the stem. Fl. red. Anth. with five horny, yellow, spear-shaped points.

Cn. acaulis. Dwarf P. T. Stalks immediately from the root, single-flowered, shorter than the smooth calyx. Carduus acaulis. E. B. 161. Carlina acaulos minor, flore purpureo. G. E. 1158.

Pastures, meadows.

Per. July.

$L s$. wide-spreading, depressed close to the ground, smooth, shining, 
wing-cleft, very thorny. Cal.-scales narrow, smooth, rather blunt. $\mathbf{F l}$. erect, deep crimson. Plant nearly stemless.

The leaves spread, and exclude other plants from growing beneath them. The different Cnici and Cardui afford nourishment to the larvas of several insects. When cultivated, and without cultivation, $\mathrm{Cn}$. acaulis acquires a stem.

\section{ONOPORDUM. Cotton-thistle.}

\section{O. Acánthium. Common C. T. Calyx-scales awl-} shaped, spreading in every direction. Leaves eggoblong, sinuated, woolly on both sides. E. B. $97 \%$. C. 5.5\% Acanthium album. G. E. 1149 .

Waste ground, hedge banks, road sides.

Bien. July.

Hoary green, five f. high, clothed with a white, cottony web. Stem winged up to the calyx. Ls. completely running down the stem, edged with large, unequal thorns. $F l$. terminal, solitary, purple. Cal. thorns in the lower part bent back. Cal. globose. Lower $l s$. with deep, triangular teeth, which are again toothed, each tooth terminated by a sharp, whitish thorn. Upper $l s$. spear-shaped, with a few distant teeth.

The receptacle, and young stems may be boiled, and eaten. The ancients supposed this plant a specific in cancer. $F l$. Suec. The seeds a favourite food of small birds, particularly gold-finches. Heads of this, and Card. marianus, used by bird-catchers as a decoy to small birds.

\section{CARLI'NA. Carline-thistle.}

C. vulgáris. Common C.T. Stem corymbose, manyflowered. Flowers terminal. Outer calyx-scales wingcleft; inner whitish. E. B. 1144. C. sylvestris major. G. E. 1159.

Dry, sandy, heathy pastures, fields.

Bien. July.

Stem one f., stiff. Fl. erect. Cal.-scales, inner, long, linear, smooth, radiating, yellowish white, everlasting, like the rays of flowers in Polygam. Superf. Anth. with two bristles at the base. $L s$. alternate, sinuated, very thorny, veiny; two yellow spines to each small tooth. Florets central, tubular, purplish.

The dry plant will remain standing a year and more, battered and bleached, a miserably looking skeleton. Linn. Fl. Suec. Presence of this plant indicates a very barren soil. Said to be useful in hystéria. Aman. Acad.

Named after the Emperor Charlemagne, because reported that a Carlina was pointed out to him by an angel, to cure his 


\section{SYNGENESIA POLYGAMIA AQ. Eupatóriun.}

army of the plague. Root pungent, bitter, tonic; the flowers close before rain; retain this property for a long time.

** Florets all tubular, level generally; flowers mostly with no ray.

\section{BIDENS.' Bur-marigold.}

B. tripartita. Three-lobed B. Leaves in three segments. Bracteas unequal. Bristles of the seeds two or three, erect. E. B. 1113. C. 4. 5\%. Eupatorium cannabinum fomina. G. E. 711.

Watery places, sides of ditches and ponds.

An. August.

Stem two or three f. Ls. opposite, toothed, cut into one large lobe with two or three smaller at its base. $F l$. solitary, terminating each branch, rather drooping, surrounded with several simple, spreading, entire, rough-edged leaves. Cal.-scales streaked with brown. Ls. upper simple, oval-spear-shaped. Cal. leafy at the base.

Woollen and linen may be dyed yellow with a decoction of this plant. The Cyprinus auratus, gold-fish, has been destroyed by the seeds adhering to the gills and jaws.

B. cérnua. Nodding $B$. Leaves spear-shaped, deeply saw-toothed. Flowers drooping. Bracteas nearly equal, entire. Bristles of the seeds about four, erect. E. B. 1114 . C. 3.55 .

Ditches, ponds.

$\boldsymbol{\gamma}$. Bidens minima, i. e. smallest. Dry places where water has been, and margins of ponds. A starved specimen of this plant found on the north side of Shotover Hill. $\quad S b$.

An. August.

Stem less spreading than in Bid.tripartita. Ls. embracing the stem, undivided. $F \boldsymbol{F}$. large, brighter yellow than in Bid. tripartita. Fl. sometimes with large, radiant, strap-shaped female florets, is the Coreopsis bidens of Linn.

\section{EUPATO'RIUM. ${ }^{2}$ Hemp-agrimony.}

E. cannábinum. Common $\boldsymbol{H}$. Leaves opposite, in three, or five, deep, spear-shaped segments ; the middle one longest. E. B. 428. E. cannabinum mas. G. E. 711 .

Watery, boggy places.

Per. July.

Stems two or three f. or more, reddish, erect, branched, downy,

From the two teeth in the genus.

${ }^{2}$ From Eúpator, King of Pontus. Plix. 
leafy. $F l$. very numerous, light reddish purple, in a thick, terminal, clustered corymb. Florets about five, or six, with projecting, long, cloven styles: silvery bristles crown the germen and seed, separating the florets. Plant slightly aromatic. Leaft. towards the point very entire. Fl. sometimes white. Germ. with minute, shining globules. In young plants, the upper $l s$. simple.

Decoction of the roots violently emetic, and cathartic; a rough medicine in jaundice, and dropsy. An infusion of the plant used to foment ulcers with by Boerhaave. Tournefort mentions that the Turks cure the scurvy with this plant. One ounce of the juice, or one drachm of extract, a dose. Lightf. See G. E.

\section{SYNGENESIA POLYGAM. SUPERFLUA.}

* Discoid flowers (rayless.)

\section{TANACE'TUM. Tansy.}

T. vulgáre. Common $T$. Leaves doubly wing-cleft, deeply saw-toothed, naked. E. B. 1229. Tanacetum. G. E. 650 .

Hilly pastures, hedges, road sides.* Shotover Hill. Southleigh. Sb. Per. July.

Stems erect, one or two f. $\boldsymbol{L}_{s}$. numerous, alternate. $\boldsymbol{F l}$. in a terminal, flat corymb, yellow. Perfect florets of disk tubular, five-cleft: of the ray, few, strap-shaped, with three teeth; these florets often wanting.

Plant strong-smelling, very bitter: the seeds to destroy worms, the leaves used to flavour a kind of pudding. A curled var. found in gardens, more grateful to the stomach. One drachm of the dried flowers beneficial in hysteria arising from suppressions. Lightf. A green dye from this plant. The fly avoids meat rubbed with this plant.

\section{ARTEMI'SIA.' Wormwood, and Mugwort. ${ }^{2}$}

A. Absinthium. Common W. Leaves in many deep segments, clothed with close silky down. Flowers drooping, hemispherical. Receptacle hairy. E. B. 1230. Absinthium latifolium sive ponticum. G. E. 1096.

Waste ground, villages.

Per. August.

${ }^{1}$ So called from Artemisia, Queen of Halicarnassus, wife of Mauślus.

2 Ang.-Sax. 


\section{SYNGENESIA POLYGAM. SUPERF. Gnapháliam.}

Stems hard, in tufts about one f., furrowed, leafy. Plant pale, whitish green. $L s$. alternate, doubly wing-cleft, edges entire. $F l$. in a leafy panicle, broad. Plant intensely bitter, and strongly aromatic. Ls. root-ones thrice wing-cleft. Stalk-ls. twice wing-cleft; floral spear-shaped, undivided. Ls. green above, white underneath.

A substitute for hops. The oil used to destroy worms. The leaves destroy the sharpness of sour beer, as does the salt. Infusion of the leaves, combined with a salt, strongly diuretic in some dropsical cases. The long continued use of bitters, destroys the tone of the stomach. See Cullen. The flesh of sheep, and the milk of cows, rendered bitter, by eating this plant. Turkies fond of it. A fomentation of the plant, steeped in boiling water, good recent and repeated application to a bruise. With. \& c. Smell of the plant will drive away ants. Scopoli. Often laid in drawers and chests in the country to drive away insects.

A. vulgáris. Muguort. Leaves wing-cleft, flat, cut; (segments long, opposite,) downy beneath. Clusters simple. Flowers egg-shaped. Receptacle naked. E. B. 978. A. mater herbarum. G. E. 1103.

Waste ground, hedges, borders of fields.

Per. August.

Stems three or four f., leafy, branched, with numerous, longitudinal, purplish ribs. Ls. alternate, somewhat lyrate, smooth, and dark green above; cottony and very white beneath; threelobed at the end. $F l$. in axillary, simple, leafy spikes, or clusters, erect, or straddling, egg-shaped, stalkless. Floral-ls. undivided, linear, spear-shaped. Florets longer than the calyx. Stems sometimes green. Plant weakly aromatic, slightly bitter. Pliny, according to Gerarde, ascribes an extraordinary influence to this plant, worthy the attention of modern travellers, if they could believe, or feel its power : "The traveller or wayfaring man, that hath the herb tied about him, feeleth no wearisomeness at all!" G. 1104. The cottony covering of the herbage, rubbed off, forms the moxa of the Japanese, for performing actual cautery. Lightfoot remarks that the moxa is prepared from the pith, (medulla) of the stalk. The young leaves eaten as a pot-herb by the Highlanders. Lightf. Moxa prepared by beating, and rubbing the dried tops and leaves of this plant between the hands, until only the fine, internal, woolly fibres remain, which are then combed and formed into little cones.

Sheep fond of this plant.

\section{GNAPHA'LIUM.' Cudweed. ${ }^{2}$}

* Calyx white, or reddish.

\section{G. dioícum. Mountain $C$. Shoots trailing. Stem}

1 So called from gnáphalon, Gr. dowu, or woolliness.

2 From its supposed power to excite rumination in cattle. Ray. 
unbranched. Corymb simple, terminal. Flowers diœcious. Seed-down feathery, various. E. B. 26\%. G. montanum purpureum et album. G. E. 640 .

Dry, mountainous, or heathy pastures. ** Woodcot Heath. Sb.

Per. June.

Ls. battledore-shaped, pointed, entire, bright green, and smooth above; beneath very white, and cottony. $L s$. of the trailing shoots mostly opposite. Flowering stem three or four inches, with alternate, spear-shaped leaves, half embracing the stem, terminated by a simple corymb of four or five flowers, white or reddish; of the nature of the flowers, styled Everlastings.

** Calyx brown, and less ornamental.

G. rectum. Upright Wood $C$. Stem simple, erect, panicled, many-flowered, leafy. Leaves linear-spearshaped, naked on the upper side; silky beneath. E. B. 124. G. anglicum. G. E. 639.

Groves, thickets, pastures, in a soil which is dry, or gravelly.

Per. August.

One and a half to two f. Cal. brown with a blush-coloured hue. $\boldsymbol{F l}$. terminal, and also axillary, stalkless, spiked. Fl.-stalks very short, from the sides of the stem, from the bosom of the leaves, from one to five, or more flowers, the lowermost somewhat distant, the upper crowded.

G. uliginósum. Marsh C. Stem much branched, spreading. Leaves linear-spear-shaped, somewhat embracing the stem, cottony on both sides. Flowers in close, terminal tufts, shorter than the leaves. E. B. 1194. G. vulgare. G. E. 639.

Sandy, watery places, or where water has stood during winter.

An. August.

Stem three to nine inches: distinguished by its very numerous, spreading branches, each terminated by a close head of yellowish brown, shining flowers, encompassed with many leaves. Branches erect at their extremities, alternately subdivided. Cal.-scales spear-shaped, acute, dark, shining brown.

G. minimum. Least $C$. Stem erect, branched. Leaves spear-shaped, acute, flat. Flowers conical, in small side and terminal tufts, longer than the leaves. E. B. 115\% Filago montana. Sb. 262. F. minor. G. E. 641 .

Barren, sandy, or gravelly soil. Shotover Hill, near the road to Cuddesdon. $S b$.

An. June.

Stem a few inches, slender, simple, naked below, forked, corymbose above. $L s$, alternate, pressed to the stem, woolly on both 


\section{SYNGENESIA POLYGAM. SUPERF. Erigeron.}

sides. $\boldsymbol{F}$. small, stalkless, often solitary. Cal.-scales awlshaped, keeled.

G. germánicum. Common C. Stem erect, proliferous at the top. Leaves spear-shaped. Heads globose, many-flowered, from the side in the axils of the branches, as well as terminal. Calyx-scales bristlepointed, smooth. E. B. 946. H. L. 43. Filago germanica. Sb. 262. F. sive Herba impia. G. E. 642.

Pastures, fields, waste ground, on gravelly soil. Sm.

An. July.

Easily distinguished by its proliferous stem or two or more branches springing from a single head, and as it were overtopping its parent; hence according to Gerarde, called Herba impia, or Wicked Cudweed. Ls. numerous, alternate, erect, waved, woolly on both sides. Cal. five-cornered. Branches horizontal, mostly two, and sometimes three from below the head terminating the main, and thicker stem : rising above the main stem.

The plant is astringent: the powder and decoction have succeeded in dysentery and diarrhœa. Lightf.

\section{CONY'ZA. Spikenard.}

C. squarrósa. Plowman's S. Leaves spear-shaped, downy, notched. Stem herbaceous, corymbose. Calyxscales leafy, curved back. E. B. 1195. Baccharis monspeliensium. G. E. 792.

Chalky, or limestone situations. Sm.

Bien. August.

Plant downy, bitter, slightly aromatic, upright, two or three f. Stem reddish. Ls. wrinkled; root-ones large, tapering at the base, notched; upper ones entire. $F \boldsymbol{l}$. in a terminal, leafy corymb. Cal. egg-shaped, outer scales with green tips, the inner erect, reddish, fringed. Florets dusky purple, or yellow. The root-leaves resemble somewhat in shape those of the Foxglove. Recept. tuberculated. $\boldsymbol{F} l_{\text {. }}-l s$. small, one on each fruitstalk.

$$
\text { ** Radiated flowers. }
$$

\section{ERI'GERON. Flea-bane. ${ }^{\prime}$}

E. acris. Blue $F$. Stem racemose. Stalks mostly single-flowered. Leaves spear-shaped, or tongueshaped, stalkless. Ray erect. Seed-down as long as the florets of the ray. E. acre. E. B. 1158. C. 1. 60. Conyza cærulea acris. G. E. 484. 
Dry, gravelly, or chalky pastures. $\mathrm{Sm}$.

Bien. July, August. Sometimes in April. Ray.

Stem one or two f., upright, straight, furrowed, purplish, hairy. $F l$. many in a racemose form, in long, bracteated, alternate footstalks. $L s$. scattered, the lowermost inversely egg-shaped, often coarsely saw-toothed. The flowers appear delicately streaked with blue, from the numerous, linear florets of the ray, encompassing the disk. Seed-down copious, long, rough, by which the plant is easily recognised. Taste of the plant acrid.

\section{TUSSILA'GO.' Colt's-foot, ${ }^{2}$ and Butter-bur.}

T. F'írfara. Colt's-foot. Stalks single-flowered, clothed with scaly bracteas. Flowers radiant. Leaves roundish heart-shaped, angular and toothed. E. B. 429. C. 2. 60. Tussilago. G. E. 811 .

Moist, shady situations, chalky or marly soil. Sm.

Per. March.

$\mathbf{F l}$. terminal, solitary, in bud drooping; in expansion erect, lemoncoloured. Cal. of several simple, parallel, equal scales; a few scattered scales at the base. Ls. on long foot-stalks, from short, side branches. Ls. very smooth above, cottony, and veiny beneath. Younger $l s$. rolled back. The leaves appear after the flower.

Leaves bitterish, mucilaginous, astringent. Troublesome weed from its deep, creeping root. Roots destroyed by cutting off the crown of them in March. Basis of herb-tobacco. Plant recommended by Cullen in scrophula, in decoction. Cul. Mat. M. and Fuller. Med. Gym. With. \&c. The roots consolidate clay on the banks of rivers. Linn. Custom of smoking this plant through a reed, very ancient, mentioned by Pliny, as a remedy for cough. A room may be cleared of gnats, by opening the windows, and smoking or burning this plant, or tobacco. Curtis. The cotton impregnated with salt-petre, makes good tinder. Sherard, and $W_{i t h}$. The leaves, either smoked like tobacco, or taken in infusion, reputed good for coughs.

T. Petasites. ${ }^{3}$ Butter-bur. Thyrsus close, egg-oblong. Flowers tubular, discoid. Leaves heart-shaped, unequally toothed, approximating, three-ribbed at the base. E. B. 431. C. 2. 59. Petasites. G. E. 814.

Moist, boggy meadows, rivulets, margins of rivers. Sandford Lane. $\mathrm{Sb}$. and $\mathrm{R}$. W.

Per. April.

1 From tussis, a cough, the plant being reputed good in coughs.

2 From the shape of the leaf. ${ }_{2}$ Ang.-Sax.

${ }^{3}$ So called from its large leaves, supposed to resemble a pétasus, or cap. 
$F l$-stalks ten or twelve inches, simple, purple, scaly, rising before the leaves. Florets pale red, all hermaphrodite, in appearance. $L s$. on long foot-stalks, growing to two or three feet in diameter, downy beneath. Cal. of four series of reddish, spear-shaped scales.

Planted near bee-hives, as an early flowering plant, by some Swedish economists. The root in the spring resinous, aromatic.

\section{SENE'CIO.' Groundsel, ${ }^{2}$ or Ragwort.}

* Flowers without rays.

S. vulgáris. Common G. or Simson. ${ }^{3}$ Flowers dispersed, without rays. Leaves wing-cleft, toothed, segments blunt, smoothish; clasping at the base. E. B. 747. C. 1. 61. Erigerum. G. E. 278 .

Cultivated, or waste ground, dry banks, tops of walls, very common. An. At almost all seasons.

Plant slightly fleshy. $\mathbf{F l}$. terminal, somewhat corymbose. Florets all tubular, yellow, hermaphrodite, so that the species belongs strictly to Polyg. æqualis. Seed-down stalkless, rough. Cal.scales spear-shaped, at the base; at length spreading, and starlike in appearance. $\boldsymbol{L} s$. alternate.

A strong infusion of the plant emetic. The bruised leaves a suppurative application to boils: the plant is good against worms; the juice may be given to horses for this end. Birds in cages, fed with the young buds, and leaves.

* * Fl. with rays, becoming rolled back.

S. viscósus. Stinking $G$. Rays rolled back. Leaves wing-cleft, clammy. Outer calyx lax, almost as long as the inner. Stem with many spreading branches. E. B. 32. Erigerum tomentosum. G. E. 278.

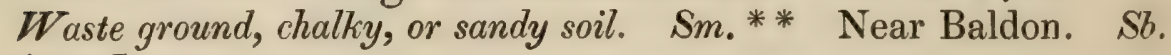
An. June.

Whole plant covered with a clammy, fetid liquor, arresting insects, \&c., hairy. Stem straggling, not simple, as in Sen. sylvaticus. $\mathrm{Fl}$. twice as long as those of sylvaticus. Cal. hairy. Cal.-scales approaching at the top. $F \boldsymbol{F l}$. in loose umbels, of two or three.

S. sylváticus. Mountain G. Rays rolled back. Leaves stalkless, wing-cleft, lobed and toothed. Outer calyx short, with bluntish discoloured tips. E. B. 748.

Bushy, heathy, places, gravelly, or sandy soil. Southleigh Heath. Ensham Heath. $S b$.

An. June.

1 From Senex, an old man, because the seeds are downy, and hoary, like the grey locks of age. Plin.

3 Corruption of the Fr. Seneçon.

2 Ang.-Sax. 
Fetid, hairy, clammy. Stem straight, upright, wand-like, about three $f$. Upper $l s$. more finely divided than in Sen. viscosus. $F l$. corymbose, numerous, small, pale, with short, snall, curved back rays. Ls. segments alternately large, and small. *** Fl. with spreading rays. Leares wing-cleft.

* S. squálidus. Inelegant Ragwort. Rays spreading, elliptical, entire. Leaves smooth, wing-cleft, with distant, and somewhat linear, segments. E. B. 600.

Plentiful on almost every wall in and about Oxford. Dillenius sent seeds of this to Linnæus, from the Oxford garden, perhaps the plant, originally a native of Sicily, and South of Europe.

An. June, October.

Stem erect, branched, sometimes slightly hairy. Ls. embracing the stem, flat, rather fleshy, often purplish beneath. $F \boldsymbol{F}$. solitary at the end of terminal, straggling, bracteated, corymbose stalks. Cal. smooth, almost hemispherical, its outer scales few, small. Smell somewhat resembling tansy. Fl. bright golden colour, large. Florets broad. At first sight, much like a var. of Sen. Jacobæa.

S. tenuifólius. Hoary $\boldsymbol{R}$. Rays spreading, oblong. Leaves wing-cleft, somewhat rolled back; paler, and downy beneath. Stem erect, loosely cottony. E. B. 574. S. erucifolius. C. 5. 64 .

Woods, hedges, road sides, chalky, or gravelly soil. Sm.

Per. August.

Stem simple, erect, wand-like, one to three f., leafy, furrowed, downy, white. Ls. alternate, the uppermost with linear segments, little toothed. $F l$. corymbose, bright yellow. Cal.scules broad, green, more or less woolly, with a white membranous border. Rays soon become turned back. Ls. wings linear-awl-shaped: lower ls, on long leaf-stalks. Mid-rib of the ls. underneath protuberating.

No plant is more variable in the appearance of its leaves. The plant is found with but little hoariness, lower $l s$. stalkless, segments rather broad.

S. Jacobrea. ${ }^{1}$ Common $R$. Rays spreading, oblong, toothed. Leaves doubly wing-cleft, somewhat lyreshaped, with spreading, toothed, smooth segments. Stem erect. Seeds of the disk hairy. E. B. 1130. Jacobra. G. E. 280.

Pastures, waste ground, road sides.

Per. July.

Stem erect, two or three f., furrowed, leafy, corymbose. Ls. alternate, deep, shining green; lower, on stalks, the rest em-

${ }^{1}$ From Jacóbus, Lat. for James; in reference to the Saint of that name. 


\section{SYNGENESIA POLYGAM. SUPERF. Solidágo.}

bracing the stem. $F \boldsymbol{F}$. numerous, in terminal, upright corymbs, bright golden colour. Seeds of the ray smooth. Cal. and flower-stalks often covered with a cottony web. Bruised herb, fetid. Ls. less segments broader towards the end.

A decoction of the flowers dyes yellow: larva of the handsome Phal. Jacobææ feeds on this.

S. aquáticus. Marsh $R$. Rays spreading, ellipticoblong. Leaves lyre-shaped, saw-toothed; the lowermost inversely egg-shaped, and undivided. Seeds smooth. E. B. 1131.

Marshes, watery places.

Per. July.

$L s$. smooth, variable in form, from egg-shaped, to deeply wingcleft, of a lighter colour than those of Sen. Jacobæa. Fl. also fewer, larger than S. Jac. $L s$. terminal segment largest.

**** Fl. radiant. Leaves undivided.

*? S. saracénicus. Broad-leaved R. Rays spreading, nearly entire. Flowers corymbose. Leaves spearshaped, saw-toothed, minutely downy. Stem solid. E. B. 2211. Solidago sarracenica. G. E. 429.

Moist meadows, and pastures, watery lanes, rare. Sm. Shotover Plantations. $B x$.

Per. July, August.

Three to five f., smooth. Fl. yellow. Seeds mostly smooth.

\section{SOLIDA'GO. ${ }^{I}$ Golden-rod.}

S. Virgaúrea. Common G. Stem slightly zigzag, angular. Clusters downy, panicled, crowded, erect. Leaves partly saw-toothed. E. B. 301. Virga aurea. G. E. 430.

Groves, thickets, grassy lanes, heaths.***

Per. August.

Stem branched above, from ten inches to three f., curved below, then erect, leafy. Ls. roughish, paler beneath on winged footstalks, root-ones inversely egg-spear-shaped, saw-toothed to notched. Stem-ls. alternate, rolled back, more entire. Fl. yellow, in terminal, and axillary clusters. Bracteus spearshaped, downy. Rays of the flower from five to nine or ten. Bruised herb smells like wild-carrot. Cal-scales spear-shaped, with a green line along the back, and a membranous border.

Valuable plant near bee-hives, flowering late, and thriving on a poor soil. Esteemed vulnerary, diuretic. See Gerarde, and his strange commendations of its virtues.

1 From a supposed vulnerary power of solidating wounds. 


\section{INULA. Elecampane, and Flea-bane.}

\section{* ? I. Helénium. ${ }^{\mathrm{I}}$ Elecampane. Leaves egg-shaped,} rugged, clasping the stem; downy beneath. Calyxscales egg-shaped, leafy. E. B. 1546. Helenium. G. E. 793.

Moist meadows, pastures.** Stanton St. John's. Sb. Near a foot-path leading from the new to the old road to Ensham, about three miles from Oxford. R. W. Meadow near the Plough Public-house, Horton. R. W.

Stems a yard or more, thick, leafy, branched above, downy. Ls. alternate, large, more downy beneath, slightly saw-toothed, veiny; root-ones on stalks; the rest clasping the stem. Fl. very large, terminal, solitary, bright, golden. Rays of very numerous, linear, spreading florets. Sceds four-angled. Whole plant of large dimensions. Lower $l s$. spear-shaped.

$R$ oot useful to promote expectoration. Decoction of the root cures sheep of the scab. Bruised and steeped in urine, with balls of ashes and whortle-berries, it dyes blue.

I. dysentérica. Common Flea-bane. Leaves oblong, downy, clasping the stem with their arrow-shaped base. Stem woolly, panicled. Calyx-scales bristleshaped, hairy. E. B. 1115. C. 3. 56. Conyza media. G. E. 482.

Watery places by road sides, clear ditches.

Per. August.

Stem one f. or more, upright, branched in a corymbose manner, woolly, with alternate, oblong, spreading leaves veiny, their under side more densely clothed with hoariness. $F l$. numerous, terminal, solitary, bright yellow. Anth. with two long bristles at the base. Seeds rough. Plant exhales a soapy smell. Ray. Russian soldiers cured of a dysentery by this herb, according to General Keith's report. Livin. $F$. Suec.

I. pulicária. Small Flea-bane. Leaves clasping the stem, wavy. Stem much branched, hairy. Flowers hemispherical; ray scarcely longer than the disk. E. B. 1196 . C. 3. $5 \%$ I. uliginosa. Sb. 256. Conyza minima. G. E. 482.

Moist, sandy, heuthy spots, where water has stagnated during winter." Noke. Sb. Horton road, leading on to Otmoor. R. W.

An. August.

Stem near two f., erect, spreading, or lying down, often purplish, zigzag, leafy. Ls. spear shaped, or oblong, curved back, hairy

${ }^{1}$ From having been said to spring from the tears of Helen. Plin. See also Ger. 
on both sides, fetid. $F l$. mostly solitary, soon overtopped by other flower-branches, erect, hemispherical, dull, pale yellow. Recept. tuberculated. Cal. hairy. Anth. bristles very small.

\section{CINERA'RIA. Flea-wort.}

C. integrifólia. Mountain Fl. Flowers simply and imperfectly umbellate, with several spear-shaped bracteas resembling an involucre. Root-leaves elliptical, obscurely toothed; the rest spear-shaped; all shaggy. Stem unbranched. E. B. 152. Sb. 255. C. campestris. H. L. 75 .

Chalky downs. Sm. ** Downs of Dorsetshire, and Oxfordshire. Hooker. Mungewell, on Grime's Dyke. Burford Downs. Sb. Downs, near Streatley, Berks. $B \boldsymbol{B}$.

Per. May.

Root long, thready. Root-ls. spreading on the ground, egg-shaped, battledore-shaped, or inversely egg-shaped, lengthened out at the base, generally bent back at the margin. Stem-ls. alternate. Stem six to twelve inches, ereet, simple, furrowed, woolly. Cal.scales with a membranous margin. Florets of the ray generally broadest in the middle. $F l$. bright yellow, three or four.

\section{BELLIS. Daisy.}

B. perennis. Common D. Root creeping. Flowerstalk immediately from the root, one-flowered, naked. E. B. 424. C. 1. 62. B. sylvestris minor. G. E. 636 . Pastures, meadows, almost every where.

Per. May, November. Sm.

Tufts of leaves spreading in a star-like form upon the ground. $L s$. inversely egg-shaped, blunt, notched, slightly hairy, all chiefly from the root. Stalks three or four inches, generally upright, round, hairy. Cal. dark green, spreading: scales in two rows. Ray of several spreading, somewhat linear florets, notched at the tip, polished white, mostly tinged with crimson at the end, especially underneath. Disk yellow, tubular. Recept. very conical, hollow.

Taste of the leaves somewhat acrid. Not acceptable to cattle, or to geese. Gerarde makes this strange observation: the juice of the leaves and roots " given to little dogs with mills keepeth them from growing great." The leaves indeed are aperient. Schroder imputes to them similar powers.

Double, as well as proliferous, daisies, red, white, or speckled, common in gardens.

1 From its closing at night. 
SYNGENESIA POLYGAM. SUPERF. Py'rethrum. 245

CHRYSA'NTHEMUM. Ox-eye.

* Rays white.

Ch. Leucánthemum. Great White O. Moon Daisy. Leaves clasping the stem, oblong, blunt, cut; toothed in a wing-cleft manner at the base; root-ones inversely egg-shaped, stalked, saw-toothed, inclining to notched. E. B. 601. C. 5. 62. Bellis major. G. E. 634.

Pastures, way sides.

Per. June.

Stem erect, two f., furrowed, with red, intermediate ribs. Ls. lower stem ones on long foot-stalks, saw-toothed, cut: the rest stalkless, embracing the stem, alternate, oblong, jagged, toothed, in a winged form about the base. $F$. handsome, large, solitary at the end of each branch: disk flat, yellow, rays pure white, elliptical, two ribbed. Seeds black, with white, elevated ribs.

The young leaves may be eaten in salads.

* Rays and disk yellow.

Ch. ségetum. Yellow O. Corn Marigold. Leaves clasping the stem, glaucous; jagged-saw-toothed upwards; toothed at the base. E. B. 540. C.6.60. G. E. 743 .

Corn fields, turnip fields, abundant.

An. June.

Stem two or three f., erect, alternately branched, leafy, smooth, and glaucous. Ls. alternate, oblong, pointed, more or less cut, and jagged, three-cleft frequently at the end. $\mathbf{F l}$. solitary, terminal, their branches gradually thickened upwards, large, handsome, bright golden. Ray-florets in a single series, inversely heart-shaped.

A law obliges the farmer in Denmark to root up this very handsome weed. Dried, is eaten by horses: it dyes yellow.

\section{PY'RETHRUM. ${ }^{x}$ Feverfew. ${ }^{2}$}

This genus distinguished from Chrysanthemum by the crown of the seed.

P. Parthénium. ${ }^{3}$ Common $\boldsymbol{F}$. Leaves stalked, compound, flat; leaflets egg-shaped, cut; the uppermost running one into another at the base. (With.) Flowerstalks corymbose. Stem erect. Rays shorter than the diameter of the disk. E. B. 1231. Matricaria. G. E. 652. M. Parthenicum. Sb. 258.

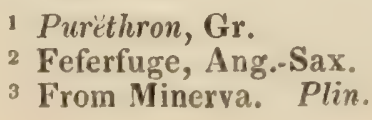


Waste ground, hedges, walls.* Headington, near the Black-boy, on a wall in the lane, leading to Barton. R. W. Walls of St. John's College, Oxford. $\boldsymbol{B} x$.

Per. June.

Stem branched, leafy. Ls. alternate, simply, or doubly winged, segments running down the $1_{\circ}$-stalk, dull, palish green. $\boldsymbol{F l}$.stalks long, thickest towards their summit. Ray sometimes wanting. $F l$. often double, the florets of the disk all becoming strap-shaped, and white. Leaft. two or three pairs, a large one terminating, wedge-shaped, with lobes, the middle of which is three-cleft, the side ones scalloped; magnified leaflets appear sprinkled with minute spangles.

Anti-hysteric, drunk as an infusion. Expressed juice vermifuge. Light. Plant bitter, aromatic, yields an oil by distillation.

P. inodórum. Corn F. Scentless Mayweed. Leaves stalkless, two-winged; in numerous, hair-like, pointed segments. Stem branched, spreading. Crown of the seeds entire. E. B. 676. H. L. 101. Chrysanthemum inodorum. Sb. $25 \%$.

Cultivated fields, way sides.

An. July.

Stem about one f., branched, leafy, smooth. Ls, winged in a lyrate manner. $F l$. terminal, solitary, large, much resembling Chry. Leucanthemum. Stalks naked. Disk yellow, ray white. Cal.-scales smooth. Recept. conical, naked. Seeds with a membranous, undivided border.

Py'rethrum distinguished from 'Anthemis, by a naked recept. and from Matricária by its crowned seed. From Matric. chamomilla by its larger flowers, and its seed crowned at the top, with a very shallow, whitish, membranaceous border.

\section{MATRICA'RIA. Wild-Chamomile.}

This genus differs from Pyrethrum in the total want of a crown to the seed, and in the sharply conical, nearly cylindrical, receptacle. Sm.

M. Chamomilla. Common Wild-C. Leaves mostly smooth, two-wing-cleft; leaflets linear, simple, or divided. Rays spreading. Calyx-scales dilated, bluntish. E. B. 1232. C. 5. 63. Chamæmelum. G. E. 754 .

Cultivated, and waste grounds, dunghills, road sides.

An. June.

Stem about one f., much branched, very leafy, smooth. Ls. stalkless, clasping the stem, smooth, twice wing-cleft in the lower, often simply winged in the upper leaves. $\mathbf{F l}$. numerous, terminal, solitary, about the size of the Anth. nobilis, or Common 
Chamomile, partaking of a somewhat similar smell. Recept. between a conical, and cylindric form, smooth, naked. Disk greenish yellow. Ray white.

Distinguished from Anth. arvensis, by its smooth, and naked recept. Anth. arven. also more hoary in its appearance. Anth. Cótula, distinguished from M. Chamomilla, by its fetid smell, lighter hue, and narrow, bristly scales of recept.

Properties similar to those of the common chamomile. Lightfoot observes that twenty or thirty grains of the flowers, are sudorific: a blue oil obtained from the flowers.

\section{'ANTHEMIS. Chamomile.}

$$
\text { * Rays white. }
$$

*A. nóbilis. Common C. Leaves doubly winged, semicylindrical, acute, a little downy. Stem trailing. Scales of the receptacle membranous, blunt, shorter than the florets. E. B. 980. Chamæmelum roma. num. G. E. 755 .

Open, gravelly pastures, commons.* Southleigh Heath, near the Hill Houses. Otmoor. $\mathbf{S b}$.

Per. July.

Stems about one f., branched, soft-haired. Leafl. slender, entire, or two and three-cleft. Fl. terminal, solitary, white, with a yellow disk. Whole plant intensely bitter, but not disagreeable in smell.

The cold infusion of the flowers, stomachic: the warm, excites vomiting. The tonic, powdered flowers have succeeded in ague. Leaves and flowers for antiseptic fomentations. The double flowers weaker in power than the single.

A. arvensis. Corn Ch. Receptacle conical; its scales spear-shaped, acute, keeled, prominent. Seeds crowned with a four-angled border. Leaves doubly wing-cleft, hairy; segments parallel. E. B. 602.

Cultivated fields. Cornfields. Sb. Near Botley Pound. Mr. James Benwell, ${ }^{1}$ and B.x. Tunbridge field, Stanton St. John's.

1 James Benwell, employed many years in the Botanic Garden, a very intelligent, although uneducated man, singularly conversant with the Botany, and localities of Oxfordshire plants, and well acquainted with the practical part of some other branches of Natural History. He died Oct. 7, 1819, aged 84 years. John Ireland, M.D. liberally honoured his memory with a respectable funeral: some of the principal scientific persons, in Oxford, attended his remains, at the Doctor's request; carrying in their hands sprigs of rosemary, to throw into the grave of this humble son of science. A print, I am told, a striking and characteristic likeness, was published of Mr. Benwell, in his S2nd year; and a short memoir may be seen in Jackson's Oxford Paper, from the pen of Dr. Ireland. R. W. "Mr. Benwell's integrity, and industry, and a natural propriety, and civility of manners, gained him general respect. Though in a humble station, his merits, like those of Willisel, the companion of Ray, deserve commemoration."-Oxford Journal, Oct. 19th, 1819. 
R. W. Field, near Ireton Hill, Bayswater. Headington, near the London Road. R. W.

An. or Bien. July.

Plant with hoary pubescence. Stem upright, about one f., much branched. Ls. alternate. Herb covered with soft, cottony hairs; little or no smell. $F l$. terminal, disk yellow, ray broad, white, becoming curved back. Cal. woolly, its inner scales broad, and membranous at the edge. Leafl. cut into two, or three narrow segments. $F l$. pleasantly scented.

A. Cótula. Stinking Mayweed, or Ch. Receptacle conical; its scales bristle-shaped. Seeds without any border. Leaves doubly wing-cleft, slightly hairy; segments spreading. E. B. 1772. C. 5. 61. Cotula foetida. G. E. 757 .

Cornfields, waste ground.

An. May.

Stem a foot and a half, upright, much branched, leafy, smooth.

Ls. alternate, two or three wing-cleft, stalkless, flat, bright, palish green, nearly smooth. Cul.-scales narrow, slightly bordered. Fl.-disk lemon-coloured, convex. Rays white, three toothed. Bristle-shaped scales of the recept. shorter than the florets.

Plant strongly fetid; acrid, covered with minute glands, so as to blister the hand of the reaper.

Said to drive away fleas (Linn. Fl. Suec.) by its abominable smell.

\section{ACHILLE'A.' Yarrow.}

The short, broad, rounded florets of the ray afford a good distinction of this genus. $S m$.

A. Ptármica. ${ }^{2}$ Sneese-wort $Y$. Goose-tongue. Leaves linear, pointed, equally, and sharply saw-toothed, smooth. E. B. $75 \%$ C. 5. 60. Ptarmica. G. E. 606.

Wet hedges, thickets, banks of rivers.

Per. July.

Root creeping. Stems firm, erect, about two f., smooth. $\mathrm{Fl}$. in a corymb of several flowers; disk and ray white. Fl. rather few, somewhat large. Ls. stalkless, alternate. Florets of the centre very short, dirty yellow.

Juice applied to the mouth provokes the saliva. The dried plant powdered occasions sneezing. Young tops pleasant in salads.

A. Millefólium. Common $Y$. or Milfoil. ${ }^{3}$ Leaves

3 From Achilles, the pupil of Chiron.

2 From ptairo, Gr. to sneeze.

3 Mille, a thousand, from its numerously divided leaves; feuille, a leaf. 
doubly wing-cleft, slightly hairy; segments linear, toothed, pointed. Stem furrowed. E. B. 758. C. 6. 61 .

Meadows, pastures.

Per. July.

Distinguished from Achil. Ptarmica, by its compound leaves and smaller, corymbose flowers, generally white; often with a reddish, or purplish ray.

Stem erect, furrowed, about one f. Leafl. numerous, three to fivecleft, variable. $L s$. compounded of twenty or more wings, each of which is subdivided into three or seven pairs of smaller wings, which are again cut into three, or five-cleft, spear-shaped segments.

Leaves aromatic, astringent. An ointment made of the leaves to heal up wounds. A leaf thrust up the nostril occasions bleeding; hence the old English name, nose-bleed. The plant mixed by the Dalecarlians in beer, during fermentation to increase its intoxicating powers. The bruised leaves applied to wounds for healing them.

\section{SYNGENESIA POLYG. FRUSTRANEA.}

\section{CENTAURE'A.' Knapweed ; and Blue-bottle ; and}

Star-thistle.

* Caly $x$-scales fringed.

C. nigra. Black $K$. Calyx-scales oval, fringed with upright, hair-like teeth. Lower leaves somewhat lyreshaped, with angular lobes; upper ones egg-shaped. Flowers discoid. Seed-down very short, tufted. E. B. 2\%8. Jacea nigra. G. E. $72 \%$.

$V$ ar. $\beta$. with radiant flowers.

Pastures, road sides. B. Near Oxford. Dill. Between Bladon and Yarnton. Dill. Southleigh. Shotover Hill. Sb. This var. not uncommon. R. W.

Per. July.

Stem rough, firm, stiff, angular, about two f. Branches alternate. $L s$. hard; lower, spear-shaped, many of them somewhat lyrate: upper entire; all alternate, but a little clustered under the flowers. $F l$. terminal, solitary, red, hermaphrodite, commonly without a ray, tubular. Cal.-scules black.

A decoction of the hoads of this, said to have afforded relief in diabétes. With.

C. Cýanus. Corn Blue-bottle. Calyx-scales saw-

1 From the Centaur, Cbiron. 
toothed. Leaves linear-spear-shaped, entire; lower ones toothed towards their base. E. B. 277 . C. 6 . 62. Cyanus vulgaris. G. E. 732.

Cornfields.

An. July.

Stem two, or three f., erect, angular, much branched alternately. $L s$. stalkless, light greyish green, with three ribs, and somewhat cottony beneath; lower ones generally toothed; root-ones (in the young plants) entire. Fl. solitary. Cal.-scales with brown indentations. Flor. of the ray, bright, shewy blue, horizontal, very large; of the disk, smaller, purplish. Filam. just below the anth. with a fringe of silvery hair.

Fl. dye sugar blue. Livn. Fl. Suec.

White and dark-purple varieties introduced into our gardens, but not permanent. The flowers afford a blue colour; the expressed juice mixed with cold alum water. The separate floret in Eng. Bot. coloured with this, by way of experiment, has stood well for thirty years. $\mathbf{S} m$.

C. Scabiósa. Greater Kn. Calyx-scales egg-shaped, fringed, somewhat downy. Leaves wing-cleft; segments bluntly spear-shaped, roughish, partly toothed. E. B. 56 . Jacea major. G. E. 72\%.

Borders and ridges of cornfields, way sides.

Per. July.

Stem hard, about two f., erect, alternately branched, leafy. $F l$. solitary, on long foot-stalks, shewy. Cal.-scales triangular, acute, comb-like in the margin, tipped with black. Cal. globular, permanent, becoming bent back, very conspicuous from its silvery hue. Ls. alternate, root-ones on long foot-stalks. Fl. purple, very large, sometimes white. Seeds food for small birds.

(C. solstitiális. Yellow St. T. Not far from Cirencester. Bobart. in Tur. See Appendix.) 


\section{Class XX. GYNANDRIA. Stamens}

situated either on the style, or germen.

Order I. MONANDRIA. Stumen, or Stalkless Anther, $I$. $\stackrel{*}{*}$ An

Anther of two, distinct, vertical cells, fixed to the summit of the ORCHIS. Orchis.

The three outer leaves of the flower, in the Orchis tribe, are termed the calyx, the two inner leaves, petals, by Sir J. E. Smith. See his Introduction to Botany, p. 461.

Salep is prepared from the different roots of Orchises; nourishing, and supposed invigorating. Mr. Moult describes his method of making Salep in Phil. Trans. v. 59. p. 1. See also Percival's Essays, Pt. II. p. 37.

Mr. Salisbury assures us that he found no difficulty in making the seeds of various Orchideæ germinate, and raised plants in this way. See his Latin Paper in Linn. Trans. v. 7. p. 31. Other persons have also succeeded in raising plants of this tribe from seed.

* Knobs of the root roundish, undivided.

O. bifólia. Butterfly $O$. Knobs of the root oval, taperpointed. Lip of the nectary spear-shaped, entire, about half the length of its very long spur. Side calyxleaves spreading downwards. E. B. 22. C. 6.65. O. hermaphroditica. G. E. 211.

Groves, thickets. Shotover Hill. Tar Wood. Sb. Fields, near Begbroke. (Bagley Wood. Bx.)

Per. May.

$L s$. immediately from the root, oval, two, sometimes three. Those on the stalk resemble spear-shaped stipulas. Spike long, lax. $F$ l. palish white, greenish, very fragrant, especially morning, and evening. $L s$. resemble those of the Lily of the Valley (Convallaria majalis.)

O. pyramidális. Pyramidal $O$. Knobs of the root oval. Lip of the nectary in three, equal, entire lobes, with two protuberances above; spur long and slender. E. B. 110. H. L. 106. Cynosorchis major. G. E. 205.

Grassy hills, chalk banks. Sm.** Wychwood Forest. Between Woodstock and Enstone. Caversham Warren. Sb. (Old Stone- 
pit, about half a mile west of South Hinksey. Road side between Witney and Burford. Bx.) Slope of the hill, opposite Basildon Grotto, Berks. R. W.

Per. June.

Ls. spear-shaped, acute, five or six. Plant silky, glossy, palish green. Spike close, with buds erect, assuming a pyramidal form, whilst the flowers are expanding. $F l$. purple, but are sometimes found white, fragrant. Flowers later than most of the orchis tribe. Bract. coloured, the length of the germen.

O. Morio." Green-uinged Meadow $O$. Knobs of the root oval, double. Lip of the nectary four-cleft, or three-lobed, somewhat notched; spur blunt, ascending. Calyx many-ribbed, converging. E. B. 2059. C. 3. 59. Cynosorchis morio fomina. G. E. 208.

Meadows and pastures, in somewhat moist grass.

Per. May.

Root-knobs nearly globose. Ls. spear-shaped, deep green. Spike rather loose, from four to eight, or ten flowers: colour from pale, to reddish purple, but in all the varieties, the calyx-leaves pre. serve their green-ribbed markings. Disk of the lip pale, dotted with purple. Common stalk, bract. and germ. more or less tinged with purple. The calyx-leaves converge, and form a vaulted arch over the stamens. Stem six inches to a foot.

O. máscula. Early purple 0 . Knobs of the root oval. Lip of the nectary three-cleft, notched, middle lobe twocleft; spur blunt. Calyx-leaves three-ribbed; two side ones bent upwards. E. B.631. C. 2. 62. Cynosorchis morio mas. G. E. 208.

Pastures, groves, dells.

Per. April.

$L s$. root-ones spear-shaped, broad, generally more, or less spotted. Stulk a foot high, with a large, loose, upright spike of purplish red flowers: bract. of the same hue. Lip spotted at the base.

Discrim. Its early bloom, and spotted leaves. From Or. Morio, by its taller stem, numerous flowers, side calyx-leaves bent upwards. $\mathrm{Fl}$. rarely white.

Roots of this species said to be used particularly for the making of Salep: the roots of the other species probably equally well adapted. Salep is thus made : the largest and soundest bulbs are gathered, skinned, and boiled over a gentle fire for half an hour; afterwards they are strung upon a thread, and hung up to dry in the shade: these, reduced to powder are the restorative and nutritious Salep.

1 Mório, in allusion to the shape of part of the flower. Gerarde in his Herbal observes in regard to another species. Morio mas, (the Or. mascula) that the flowers are "in shape like to a foole's hood;" hence the name of Morio, a fool, or jester. 
O. ustuláta. Dwarf Scorched-flowered $O$. Knobs of the root oval. Lip of the nectary three-lobed, the middle one two-partite, longer, rough with small points. Spur blunt, not half the length of the germen. Calyx approaching at the top. Leaves spear-shaped. E. B. 18. H. L. 36. Cynosorchis minor pannonica. G. E. $20 \%$.

Dry, open, chalky spots. Sm.* Burford Downs. Caversham Warren. Sb. Streatley Downs, Berks. Bx. Road from Ensham to Abingdon. Benwell, and $W h$.

Per. May.

The upper part of the flower, purple brown, lower part, or nect. white, sometimes slightly tinged with purple, and speckled with dark brown points. The flowers on a cursory view, especially before expansion, appear as if scorched, or blackened by heat. Ls. five or six. Stem four to eight inches. Spike short, close set. Helmet of the flower has a burnt appearance.

O. militáris. Military $O$. Knobs of the root oval. Lip of the nectary five-lobed, downy; two middle lobes dilated, rounded. Spur blunt, not half the length of the germen. Calyx approaching at the top, taper-pointed. E. B. Suppl. 2675. Tr. L. Soc. 12. 31. Chalky hills. Sm.* On hills by the Thames, near Cawsham (Caversham) bridge, a mile from Reading, and on several hills, on the other side the water, towards Wallingford; first observed by Mr. Brown. Merrett, Ray. At Streatley, between Reading and Wallingford; also at Penley Hangings, Stokenchurch, where Dr. Williams first found it. $\mathbf{M} \mathbf{r}$. Bicheno. Sm. in Eng. Fl. Beech Woods between Fawley Court, and Bix. gibwen, about a mile and a half from Henley. Professor Daubeny, and $B x$.

Per. May.

Chief character of this species, the regular, linear, incurved segments of the lip, broader than in Or. tephrosanthos, and not notched and ragged as in Or. fusca, but much narrower. Bicheno in Tr. Linn. Soc. 12. 32. Fl. distinguished by their silvery ash colour, and the total want of the dark ribs, or stains in Or. fusca. (Or. militaris, E. B. 16.) Sm. E. $F l$.

Discrim. Tapering points, and grey hue of the calyx, and the more lengthened out lip, contracted in the middle.

O. tephrosanthos. ${ }^{I}$ Monkey $O$. Knobs of the root oval. Lip of the nectary downy, in five lobes; four of them equal, linear, entire. Spur blunt, not half the length

I From its ash-coloured spike, tephros, ashes. Gr. 
of the germen. Calyx approaching at the top, taperpointed. H. L. 82. O. militaris. E. B. 1873. Sb. 10.

Chalky hills. Sm.* Found by Mr. Brown, between.Wallingford and Reading. Merrett. On Ridgway hill, near Mapledurham, Oxfordshire. Dr. Lamb. Among bushes on the rising ground to the west of the great chalk-pit, near Caversham, facing the Thames. Mr. Bicheno. Caversham Warren. Sb. Goring, near Reading. $M r, L$. Darwall.

Per. May.

Lip three-partite, smooth, segments linear, the intermediate one two-cleft, with a sharp point between, petals (calyx-ls.) acute. Spur somewhat incurved, twice as short as the germen. Bract. very short. W. This plant easily known by the narrow segments of the lip, and the petals (calyx $x$-ls.) tapering to a point. A delicate plant, smaller than Or. militaris, or Or. fusca. Spike remarkably abrupt in its termination. Bicheno in Trans. Linn. Sor. 12. 34 .

Smith in $E . F l$. is doubtful with regard to this species and Or. militaris, both of which differ from Or. fusca, in their taperpointed calyx. All three smell like Woodruff in drying. $\quad \boldsymbol{E}$. $\boldsymbol{F}$. ** Knols of the root tapering, clustered.

O. viridis. Frog $O$. Knobs tapering, clustered, handshaped. Lip of the nectary linear, with three teeth; the middle one much the smallest. Spur very short, slightly cloven. Satyrium viride. E. B. 94. Sb. 11. Habenaria viridis. H. L. 130. Serapias batrachites altera. G. E. 224.

Moist pastures, meadows. Shotover Hill. Southleigh. Cornbury. Burford Downs. Sb.

Per. June.

$F l$. pale, greenish. Calyx-leaves approaching, forming a helmet in shape. Stem five to eleven inches. Bract. awl-spear-shaped, keeled, much longer than the flowers, somewhat incurved. Stem-ls. spear-shaped, pointed, lower ones broadish, blunt. Nect. sides purplish red, inner part yellow. *** Knobs of the root hand-shaped (palmate.)

O. latifólia. Marsh Broad-leaved, Palmate O. Knobs imperfectly hand-shaped. Lip of the nectary convex, notched, slightly three-cleft, sides bent back; spur conical. Bracteas longer than the flowers. Stem hollow. E. B. 2308. C. 5. 65. Palma Christi mas. G. E. 220. Serapias palustris latifolia. G. E. 222.

Murshes, moist meadows. 
Per. May.

Stem leafy, one to two feet. Ls. sheathing, spear-shaped, broadish, commonly unspotted. Spike close, many-flowered. Bract. erect, leafy, sometimes coloured. $\boldsymbol{F l}$. pale flesh-coloured, or full rose, or crimson; the spreading calyx dotted. Lip its middle variegated. Spur bent downwards. Cal. two outer segments bent back.

Discrim. Its scarcely three-cleft lip, broad, nearly erect, sharpened leaves, and by its bracteas longer than the germen.

O. maculáta. Spotted Palmate O. Knobs hand-shaped, spreading. Lip of the nectary flat, notched, threelobed; spur cylindrical, rather shorter than the germen. Bracteas shorter than the flowers. E. B. 632. H. L. 112. Palma Christi fomina. G. E. 220.

Meadows, pastures, woods.

Per. June.

Plant slender. Stem leafy, simple, twelve to eighteen inches. Ls. spear-shaped, keeled, spotted on both sides. Spike egg-shaped. Bract. purplish, awl-shaped. Ground of the flower, in general, white, tinged with a purple blush, the spots deep purple. Lip intermediate segment, small, and sharp. $F l$. sometimes white. $\mathrm{Cal}$. three inner segments approaching at the top, the side ones spreading. The Or. Morio, and Or. mascula, have also frequently, spotted leaves.

The bulb destined to bear the next year's plant will sink in water; that from which the present plant springs will, from its comparative lightness, swim in the water. Linn. Fl. Suec.

O. conópsea. ${ }^{\mathrm{I}}$ Aromatic 0 . Knobs hand-shaped. Lip of the nectary in three entire, equal lobes; spur very long and slender, twice as long as the germen. Calyx widely spreading. E. B. 10. Serapias minor, nitente flore. G. E. 222. S. gariophyllata. G. E. 223.

Moistish meadows, pastures.** Rough pastures adjoining Cowley Common. Sb. Bogs under Headington Wick Copse. $M r$. Thomas Perry, Headington. (N.W. of Wytham Wood. Bx.) Per. June.

Stem twelve to eighteen inches, angular above. $L s$ s. spear-shaped, pointed, lower stem-leaves sheathing, upper ones stalkless. Spike long, lax. $F l$. flesh-coloured, or pale purple, very fragrant. Calyx-ls. two outer spear-shaped, at right angles with the lip. Spur semitransparent. $F l$. sometimes white.

Discrim. Great length of the almost bristle-shaped spur, and its hand-shaped root, sufficient.

1 From an imaginary resemblance ố an insect genus, called conops. 


\section{HERMI'NIUM. Musk-Orchis.}

This genus clearly marked by the petals and lip nearly resembling each other, being all three-lobed. $\mathbf{S}$.

H. monórchis. Green Musk-O. Root leaves two, spear-shaped. H. L. 138. Ophrys monorchis. E. B. 71. Testiculus odoratus. G. E. 218.

Chalky banks, hillocks, not common. Sm. Stokenchurch Woods. J. Oglander, Esq. Purton's Fl. Found also in Berkshire. Sm. E. Fl. Bank, near Rodborough Common, Gloucestershire. Mr. Sandys, Pembroke Coll. Oxford. Near Great Kimble, Bucks. Miss Mainstone and $B x$.

Per. June, July.

This species has, to the casual observer, but one bulb: the bulb for the following year, being slowly and distantly formed at the end of one of the root fibres: one of the least species of the Orchis tribe. Stem four or five inches high. Stalk nearly naked. Lip of nectary cross-shaped. Fl. yellowish-green, sweet. Ls. root ones sheathing : stem-ls, one, or two, stalkless. Bract. spear-shaped.

\section{UPHRYS. Insect-Orchis.}

O. muscifera. Fly Ophrys. Lip twice as long as the calyx, with four, expanded lobes, somewhat downy; the disk polished. Petals linear. Column blunt. E. B. 64. H. L. 31. Orchis myodes. G. E. 313.

Challyy pastures. ** Near Wormsley. Sb. Several parts of Berkshire. Sm. E. Fl. In a Beech Wood, near Henley, near the road to Fawley, almost opposite Fawley Court; in $f$. May 23rd, 1831. $B x$.

Per. June.

Cal. widely spreading, green. Pet. ascending, linear, resembling the feelers of an insect, very narrow, chocolate colour. Lip oblong, blackish purple, with a blue band, below the upper lobes. Stem nine to fifteen inches. $L \boldsymbol{L}$ s. three or four, spearshaped, many-veined. Bract. spear-shaped, sheathing, longer than the germen.

Linn. considered all those species of Ophrys which resemble insects, as var. of one species.

O. apifera. Bee Ophrys. Lip the length of the calyx, swollen, with five, bent back, marginal lobes ; the terminal one awl-shaped; the rest hairy above. Calyx coloured. Column with a hooked point. E. B. 383. C. 1. 66. Baxter's (Generic,) plates, 8. Testiculus vulpinus secundus sphegodes. G. E. 212. 
Meadous, pastures, on chalk. Sm.** Penley Hangings. Sb. (Near some old stone-pits, S.W. of South Hinksey. Bx.) South side of Shotover Hill. Bx. Appleton, Berks. Miss Hoskins. Near Nuffield. Rev. Mr. Gore, Magd. Coll. Oxford.

Stem leafy, a foot high. Nect. purplish brown, spotted with yellow. Calyx-ls, rose-coloured.

Discrim. Most allied to Oph. aranifera, from which it differs in having the three calyx-leaves reddish, and a nect. of five lobes instead of three: the central lobe (a hooked proboscis,) also forms a recurved point, compared by some, to the sting of the bee.

The plant from the curious resemblance of its flower to the bee, is too generally rooted up with avidity by florists, as are other similar species. Every true botanist will gather with a sparing hand, whatever rarity he may meet with.

O. aranifera. Early Spider Ophrys. Lip the length of the calyx, swollen, hairy, rounded, with four shallow, bent back, marginal lobes. Column acute, curved inward. Cells of the anther near together. Petals linear, smooth. E. B. 65 . O. fucifera. C. 6. 67. Orchis andrachnitis. G. E. 216.

Dry, chalky, limestone, or gravelly pastures, and pits. Sm.** Old Stone Quarries, near Wheatley. Between Witney and Burford, on the road side near the four mile stone. Caversham Warren. S6. Not found about Wheatley, in 1831. $B \boldsymbol{x}$.

Per. April.

Stem less tall than (1). apifera. Cal.-leaves, and petals, green, shorter than the nect. Nect. slightly notched at the end, hairy, except the spot tuwards the base, lusky, with greenish margin, green underneath.

Discrim. From Oph. apifera, by its large middle lobe of the nect. simply notched, and not ending in three recurved points: it also flowers two or three months earlier.

Curtis in Flor. Lond. gives his mode of successfully cultivating this species.

* Anther parallel to the stigma, permanent.

\section{NEO'TTIA. Ladies' Traces. ${ }^{\top}$}

N. spirális. Sweet Ladies' Traces. Leaves egg-shaped, stalked. Spike spirally twisted, on one side only of the stem. Bracteas downy, swollen. Lip egg-shaped, entire. Ophrys spiralis. E. B. 541. C. 4. 59. Triorchis. G. E. 218.

1 The protuberant germens, placed one above the other, somewhat resemble plaited hair, whence perhaps the name: traces for tresses. 
Open pastures, chalky, or gravelly soil, meadows. Sm. On the south side of Shotover Hill. Sb. Shotover Hill. R. W. 1831. Per. August.

Bulbs several, oblong. Stem single, five or six inches, with a few small, sheathing leaves. Spike terminal, erect, of many, small, greenish-white, stalkless, sweet-scented flowers, leaning to one side, but arranged in a spiral line, each overshadowed by a concave, pointed bractea. Calyx-leaves, three glued together appearing as one.

Generally found with three bulbs, and a small rose of leaves, and the stem almost bare to the flower-spike.

\section{LISTERA. ${ }^{\mathrm{I}} \quad$ Listera, or Twayblade.}

L. ováta. Common Twayblade. ${ }^{2}$ Leaves elliptical, opposite. Nectary with two linear-oblong, nearly parallel, lobes. Column with a posterior hood, and with an appendage, in which is placed the anther. Ophrys ovata. E. B. 1548. C. 3.60. Ophris bifolia. G. E. 402.

Groves, thickets, meadows, pastures. Stow Wood. Shotover. South-Leigh. $\mathbf{S} b$.

Per. May.

Root fibrous, perennial. Whole plant greenish. Stem a foot, or eighteen inches, with a pair, generally, of sheathing, elliptical, ribbed, smooth leaves, like those of plantain. Below the leaves, the stem angular, smooth; above them, round, downy, terminating in a long spike of numerous green flowers, each on a foot-stalk, with an acute bractea, not half the length of the germen. Cal. lightly tinged with brown. $\mathrm{Fl}$. fragrant. Seedvessel globose.

L. Nidus avis. Bird's-nest $\boldsymbol{L}$. Leaves none. Stem clothed with sheathing scales. Nectary with two spreading lobes. H. L. 58. Ophrys Nidus avis. E. B. 48. Satyrium abortivum, sive Nidus avis. G. E. 228.

Shady woods, especially beech, on chalk, or loam. Sm.** Most abundantly in the fine beech woods about Hurley, Berks. Sm. Eng. Fl. Tar Wood. Stokenchurch Woods. Sb. (Bagley Wood. Bx. and Rév. Mr. White, Fellow of Magd. Coll. Oxford. Wood, near Cumnor Hill. $\quad$ Y.)

This plant in habit nearly approaches to the genera Orobanche, Lathræa, and Monotropa, found among decayed leaves.

Bulbs in bundles. Whole plant pale brown. Bract. sheathing,

1 After Dr. Martin Lister, the conchologist.

2 From its two leaves, tway, or two, for twain. 
dry, scaly. Root fixed on one side only. Stem brittle, twelve to fifteen inches, thickest at the base. Spike cylindrical. Small turned up fibres of the root somewhat resemble a bird's-nest.

*** Anther terminal, fixed.

\section{EPIPACTIS. Helléborine.}

E. latifólia. Broad-leaved $H$. Leaves egg-shaped, clasping the stem. Lower bracteas longer than the drooping flowers. Lip shorter than the calyx, entire, with a minute point. Germen downy. H. L. 102. Serapias latifolia。 E. B. 269. Helleborine. G. E. 442.

Shady woods, thickets. * North-Leigh. Stokenchurch Woods. Sb. Beech Woods, between Fawley Court, Bixbrand, and Henley, May 23rd, 1831. Bx. (Bagley Wood. Bx.)

Per. July.

Root creeping horizontally. Stem simple, erect, nearly two feet. Ls. many, alternate, all the leaves strongly nerved, thin, somewhat stiff. Spike erect, many flowered. Fl. on short stalks, brownish-green, or dark-purple. Cal. and pet. egg-shaped, green, tinged with purple. Smell of the flower faint, aromatic. $L s$. and floral-ls. gradually narrower, as they are placed higher on the stem. Nect. margin purplish, disk dull red, or tawny.

E. palustris. Marsh $\boldsymbol{H}$. Leaves spear-shaped, clasping the stem. Flowers slightly drooping. Lip rounded, blunt, notched, as long as the petals, with a notched protuberance on the disk. H. L. 89. Serapias palustris. E. B. $2 \%$. S. longifolia. Sb. 14 .

Watery places, swampy meadows, especially on chalk or gravel. Sm.* North side of Shotover Hill. Bogs near Stow Wood. Combe. Sb. Bogs under Bullingdon Green. $B x$. Between the old and new road, going to Ensham. $B x$.

Per. July.

Root creeping. Stem erect, simple, twelve to eighteen inches. $L s$. lower ones, inclining to egg-shaped, upper, spear-shaped, all ribbed. Spike erect. Bract. spear-shaped, about equal to the germen. $\boldsymbol{F l}$.-stalks and germ. downy, purple. $\boldsymbol{F l}$. larger than in Ep. latifolia. Pet. internally white, striped, and streaked with crimson, and a yellow, central line. Germ. long, narrow: in Ep. latifolia, it is short, and inversely egg-shaped.

E. grandiflóra. Large White $\boldsymbol{H}$. Leaves elliptic-spear. shaped. Bracteas longer than the smooth germen. Flowers stalkless, erect. Lip abrupt, shorter than the calyx, with elevated lines on the disk. E. pallens. $\mathbf{H}$. L. 76. Serapias grandiflora. E. B. 271.

Woods, thickets, rhiefly on rhulk. Sm.* Shotover Plantations. 
Stokenchurch Woods. (Ray adds : not far from the way learling from (Oxford to London. Ray's Synopsis.) Sb. Plentiful, along with Orchis bifolia, in the beech woods above Hurley, and Bisham Abbey, Berks. Sm. Eng. Fl.

Per. July.

Root creeping. Stem about a foot. Ls. ribbed, various in breadth, half sheathing. $\boldsymbol{F} l$. three to eight, large, white. Bract. lower ones, like leaves in form. Germ. long, nearly stalkless, slender, deeply furrowed. Pet. not much expanded, enclosing the lip of the nect.

(E. ensifólia. Narrow-leaved White $\boldsymbol{H}$. Leaves spearshaped, pointed. Bracteas minute, much shorter than the smooth germen. Flowers stalkless, erect. Lip abrupt, half as long as the calyx, with elevated lines on the disk. H. L. $7 \%$ Serapias ensifolia. E. B. 494. and Purton's Fl. fig. vol. ii. p. 428.

Mountainous woods, but rarely. Sm. Oversley Wood. Ragley Woods. Purton's Fl. Coleshill, Leek Wootten, and Allesley, Warwickshire. Bree in $\mathrm{Pn} . \mathrm{Fl}$.

Per. June.

Stem one f., very leafy. Ls. narrow, two-ranked. $\mathrm{Fl}$. white.)

(E. rúbra. Purple H. Leaves spear-shaped. Bracteas longer than the downy germen. Flowers stalkless, erect. Lip tapering to a point, with elevated undulating lines on the disk. Serapias rubra. E. B. $43 \%$. Helleborine angustifolia sexta Clusii. G. E. 442.

Stony, mountainous woods, very rare. Sm. Steep Bank, sloping to the South, Hampton Common, Gloucestershire. Tur.

Per. June, July.

Fl. purple. Lip white.)

(Cypripedium Calcéolus. Lady's Slipper. E. B. 1. found in Gloucestershire, by a Botanist, resident at Woodchester. See Turner's, \&c. Bot. Guide, and Appendix to Flora.)

\section{GYNANDRIA HEXANDRIA.}

\section{ARISTOLO'CHIA. Birthwort.}

A. Clematitis. Common B. Leaves heart-shaped. Stem erect. Flowers crowded, upright. Calyx growing on one side only. E. B. 398. H. L. 149. A. Saracenica. G. E. $84 \%$. 
Woorls, thickets, ruins of nunneries, and abbies. Near the walls of Godstow Nunnery. Sb. On the mound, south and west of Godstow Nunnery. Sept. 1832. J.H. Near Kencott. Rev. Dr. Goodenough. Garden ground, at Sir Alexander Croke's, Studley Priory. R. W. 1832.

Per. July.

Stems nearly two feet, round, erect, slightly furrowed, zigzag. Ls. alternate, stalked, entire, the side nerves branching in a pedate manner. $\quad F l$. axillary, on shortish stalks, pale yellow. Cal. of one leaf, globose at the base with six furrows, then funnelshaped, ending in a tongue-like figure. Stamens very short and thick, grow out of the style. It rarely ripens its fruit, (in fine fruit at the Oxford Botanic Garden, 1832. Bx.) except by the assistance of some small insect, 'Tipula pennicornis, which enters the flower, and being imprisoned there, brushes the pollen about the stigma. This insect observed within the globular base of the flower by Mr. Baxter, Oxford, several times. Purton's Fl. See Sm. Introd. to Botany, pp. 256, 257. edit. 3.

An abbey plant; among those formerly cultivated in their gardens.

Roots bitter, acrid, emmenagogue; violently emetic. An ingredient in the once celebrated Portland Powder for gout, now deservedly exploded: the long continued use of bitters very injurious to the stomach. See Cullen Mat. Med. Leaves smell like tincture of Opium, (Laudanum.)

\section{Class XXI. MONOECIA. Stamens and Pistils in separate flowers, on the same plant.}

\section{Order I. MONANDRIA. Stamen 1.}

\section{EUPHO'RBIA.' Spurge.}

What in this genus was formerly considered as a single flower, is now denominated an involucre including one central, pistil-bearing flower without anthers, and several anther-bearing, monandrous ones: each stamen is in itself considered as an imperfect flower. The number of the stamens is inconstant. Best specific characters from the shape of the nect.-leaves, and involucres: number of rays in the umbel, variable. $H$.

* Umbel of three branches.

E. Peplus. Petty S. Wart-wort. Umbel mostly three-branched, repeatedly forked. Bracteas egg-

' So called from Euphorbus, physician to King Juba. Plin. 25. 7. 
shaped. Leaves inversely egg -haped, stalked, entire. Nectaries crescent-shaped. Seeds dotted. E. B. 959. C. 1. 35. Peplus sive Esula rotunda. G. E. 503 . A common weed.

An. July.

Root tapering. Stem erect, mostly branched at the base, leafy. $L s$. or partial involucres, opposite, nearly stalkless. Seeds marked with depressed dots. Plant light-green.

Discrim. From Euph. helioscopia, by being rather more slender, by its entire leaves, horned nect., and three-cleft umbel.

Juice of this, and especially Euph. helioscopia used for destroying warts.

E. exígua. Dwarf $S$. Umbel mostly three-branched, forked. Bracteas spear-shaped. Leaves linear-spearshaped. Nectaries horned. Seeds wrinkled. E. B. 1336. C. 4. 36. Esula exigua. G. E. 503. Gravelly cornfields. Sm.

An. June.

Root small. Stem one, or more, erect, three to six inches, leafy. Plant slender, smooth, pale green. Ls. alternate, stalkless, upright, acute, entire. Nert. each with a pair of green horns. Seeds four-angled. $\mathbf{F l}$. yellow. Umbel of three, four, or five rays. Involucre of two, three, or four leaves, somewhat bent back. Involucellum of two leaves, hollowed out.

** Umbel of four branches.

*?(E. Láthyris. Caper S. Umbel four-branched, forked. Leaves opposite, four-ranked, stalkless, entire ; heartshaped at the base. E. B. 2255. Lathyris seu Cataputia minor. G. E. 503.

Dry, stony thickets, probably naturalized. In several places about Ufton, near Reading, Berks, springing up periodically for a year or two after the bushes have been cut, and until choked by briars, \&c. Rev. Dr. Beeke, Dean of Bristol.

Bien. June, July.

Erect, two to three feet, purplish. $F l$. in the forks.)

*** Umbel of five branches.

E. helioscópia. ${ }^{\mathrm{S}}$ Sun S. Common W'art-wort. Umbel of five, then three-cleft, then forked branches. Bracteas inversely egg-shaped, leaves wedge-shaped, both saw-toothed. Nectaries four, entire, roundish. Capsule smooth. E. B. 883. C. 1. 36. Tithymalus helioscopius. G. E. 498.

1 From its umbel being turned to the sun, as the flower of most other plants. 
A common weed.

An. July.

Main stem upright, generally with side branches at the base. $L s$. scattered. Nect. at first green, then yellow. Involucellum of three leaves. Plant bright green.

The corrosive, ulcerating juice applied to remove warts, should be used with caution, near the eyes. The plant gives a disagreeable taste to the flesh of cattle, feeding on it. Linn. Fl. Suec. ***** Umbel of six, or more branches.

E. amygdaloides. Wood S. Umbel of about six forked branches; with numerous long, axillary flower-stalks beneath. Bracteas rounded, perfoliate. Leaves blunt, hairy. Capsule smooth. E. B. 256. Tithymalus characias amygdaloides. G. E. 500.

Woods, groves, thickets.

Per. April.

Stems several, two feet, curved, round, downy, often red, leafy above. $L s$. thickset, alternate, spreading, inversely eggshaped, spear-shaped, blunt, paler beneath, downy. $F l$. small, yellow. Nect. crescent-shaped. The leaves almost evergreen, although of a delicate texture; the plant is elegant in appear. ance; somewhat shrubby.

A var, with variegated leaves in gardens.

\section{ZANNICHE'LLIA." Horned-pondweed.}

\section{Z. palustris. Common $\boldsymbol{H}$. Anther of four cells. Stig-} mas entire. E. B. 1844.

Ponds, ditches.* Between Headington and the Wick. Sb. In the stream of water that divides Cowley Marsh from Bullingdon Green. $B x$.

An. June.

Plant with the habit of a Potamogeton, floating, rising to the surface when in flower. Stem thread-shaped, much branched, leafy. Ls. opposite, linear, narrow, acute, entire, grassy. Bract. axillary, tubular, including a pair of flowers. Germ. oblong, compressed, mostly toothed at the back. Stigma much dilated, target-shaped. The collective capsules somewhat resemble a bird's claw.

1 So named, in honour of a Venetian apothecary. 


\section{MONOECIA TRIANDRIA.}

TYPHA. Cat's-tail, or Reed-mace.

T. latifólia. Great C. or Reed-mace. Leaves somewhat sword-shaped, convex beneath. Catkin continuous, germen, and stamen-bearing parts close together. Receptacle hairy. E. B. 1455. T. major. C. 3. 61 . Typha. G. E. 46.

Ponds, ditches, slow streams, among reeds. On the side of the pond under Headington Wick Copse. Sb. Pond between the Minchery, and Sandford. $B x$.

Per. June.

Plant conspicuous by its tall stems, and large, mace-like, brown spikes. Stem six feet, or more, straight, simple, leafy at the bottom. Ls. erect, linear, half an inch to an inch wide. Catkin club-like, terminal, erect. Pistil-bearing part, dark-brown ; stamen-bearing yellowish, with a leaf, or two from the base, or middle among the stamens. Each seed on a feathery stalk.

The roots have been eaten in salads: the down used to stuff mattresses; the leaves to bind the hoops of casks. The creeping roots soon choke up a small piece of water.

T. angustifolia. Less C. or Reed-mace. Leaves slightly semicylindrical; channelled above. Barren catkin divided from the fertile one. Receptacle scaly. E. B. 1456. T. minor. C. 3. 62.

Pools, ditches. More rare than the last. Cowley, near the London Road. Sb. Banks of the Cherwell, near King's Mill, and Marston. Rev. Mr.Huntley, All Souls' Coll. Oxford. Bx.

Smaller, more slender than Typ. latifolia: height nearly equal. $L s$. more convex on the underside, not half so broad.

Discrim. The bare space between the pistil, and stamen-bearing catkins, in $\mathbf{T}$. angustifolia.

\section{SPARGA'NIUM.' Bur-reed.}

S. ramósum. Branched $B$. Leaves triangular at the base, with concave sides. Common flower-stalk branched. Stigma linear. E. B. 744. $\quad$ C. 5. $66 . \quad$ G. E. 45 .

Ditches, margins of ponds, and rivers.

Per. July.

Stem upright, two or three feet, leafy, smooth, divided at the top into many, alternate, slightly zigzag, flowering branches. $L S$.

- Spárganon, (swarlding clothes) a bandage, as the broad leaves may be used for bandages. 
root-ones sword-shaped, crect; stem-leaves merely hollow, and sheathing at the base. Fl.-heads alternate, stalkless, manyflowered: lowermost pistil-bearing; upper, stamen-bearing, smaller, more numerous, closer together. Parts of fructification vary in number. Fruit in brown, prickly heads.

The $l s$. without sharp points serve well for package.

S. simplex. Unbranched Upright $\boldsymbol{B}$. Leaves triangular at the base, with flat sides. Common flower-stalk simple (not branched.) Stigma linear. E. B. 745. C. 5. 6\% S. latifolium, G. E. 45 .

Pools, ditches. Otmoor. Sb. Christ-church Meadow. Port Meadow. $B x$.

Per. June.

Lowermost head of $\mathrm{fl}$. mostly on a partial stalk. Cal. of a paler brown than in Sp. ramosum; also a smaller plant, though the flower-heads are larger. Anth. (in Sp. simp.) of the stamenbearing heads, pale yellow.

\section{CAREX. Carex, or Sedge.}

In distinguishing the different species of this genus, attention must be paid to the root, the vagina, or sheathing leaves, the shape of the spikes, of the glumes, the number of the stigmas, the shape of the fruit, and irregularities produced by soil, and situation.

The young leaves, and flower-stalks of many Cárices are eaten by cattle, and though coarse, afford early pasturage. The large, coarser sorts, might be wrought up, with other materials for thatching, and protection against weather. Carices with creeping roots, are well qualified to give stability to the surface of boggy land. Those growing by the side of rivers, enable the banks to resist the violence of their currents. Cattle not fond of these; and thus man receives more benefit from their growth. See Goodenough on British Cárices, in Linn. Trans. vol. 2nd. throughout.

Leaves used for tying young hop-plants to the poles.

Where a species of this genus, is said to have vaginas, or sheathing leaves, the spikes are necessarily on foot-stalks; the term vagina, sheath, referring to the floral leaf, embracing the whole, or part of the foot-stalk, or flower-stalk. IId.

\section{* Dioecious.}

C. dioíca. Creeping Separate-headed C. Spikes simple, diøecious. Fruit egg-shaped, ribbed, ascending, finely saw-toothed at the edges. Root creeping. E. B. 543. Schk. Car. A. 1. Host, t. 41.

Spongy bogs. Peat bogs on Bullingdon Green. Under Headington Wick Copse. $\mathbf{S} b$.

Per. June.

Stem five, or six inches, simple, slender, roundish, leafy below $\boldsymbol{r}$, 
sheathing, triangular, very narrow. Stip. very short and blunt. Spike linear, erect, blunt, solitary. Scales brownish. Stam. slender. Anth. long, sulphur-coloured. Stig. two: ls. and culm (strawstem) smooth. Fem. spike becomes egg-shaped, or roundish.

\section{* Spike solitary, simple.}

C. pulicáris. Flea $C$. Spike simple; florets in the upper half with stamens; in the lower with stigmas. Fruit spreading, bent backwards, polished, lengthened out at both ends. Stigmas two. E. B. 1051. H. L. 17\%. Schk. Car. 9. A. 3. Host, t. 75.

Spongy, muddy bogs. Peat bogs on Bullingdon Green. $\mathbf{S b}$. Per. June.

The dark-brown, bent back, highly polished seed-cases give this species a very characteristic appearance. Stem simple, slender, from three to ten inches, sheathed at the base, with several slender, smooth, spreading leaves.

The fibrous root at all times distinguishes this from Car dioica, the root of which is creeping.

*** Spikelets crowded, each composed of barren and fertile florets.

Stigmas two.

C. stelluláta. Little Fruit-Prickly Pointed C. Spikelets three or four, roundish, slightly distant. Barren florets at the base. Fruit diverging, with a tapering, scarcely divided beak. E. B. 806. Schk. Car. 45. C. 14. Host, t. 53. C. echinata. Sb. 28.

Boggy meadows. Peat Bogs on Bullingdon Green. South-Leigh Heath. Sl.

Per. June.

Root fibrous. Stem six to twelve inches, erect, simple, except at the base, triangular. Ls. flat, keeled. Spikelets compound, all at nearly equal distances. A leafy bractea generally under the lowest spikelet. Glumes, egg-shaped, with a white edge, and broad, green nerve. Fruit ending in a rough-edged beak, notched at the end, but not deeply cloven, nor gaping.

(Carex curta. See Appendix.)

C. ovális. Oval-spiked C. Spikelets about six, oval, crowded, alternate, with a bractea under the lowermost. Fruit spear-shaped, rough-edged, bifid, slightly furrowed, nearly entire, the length of the spear-shaped, acute scales. E. B. 306 . Schk, Car. 39. B. 8. Host, t. 51. C. leporina. Sb. $2 \%$.

Marshes, watery meadows. Peat Bogs on Bullingdon Green. SouthLeigh Heath. Sb. Between Headington Quarry and Shotover

1 From its flea-like appearance. 
Hill, near the foot-path. (Bagley Wood.) $B x$.

Per. June.

Culm (straw stem), a foot, to sixteen inches. $L s$. sheathing the lower part of the stem, rising about equal to it. General Spike terminal, erect, largest spikelet terminal. Bracteas solitary, spear-shaped, similar to the scales, but broader, and longer at the base of each spikelet, the lowermost longer than the rest, and ending in a leafy, bristly point. In each spikelet a few of the lower flowers male, the rest female. Scales egg-spearshaped, acute.

Distinguished in all its stages by the number of the spikelets, the acuteness of the scales, and the situation of the male and female flowers. G.

\section{C. remóta. Remote C. Spikelets several, solitary,} simple, remote, nearly stalkless. Bracteas very long, overtopping the stem. Fruit egg-shaped, with a slightly cloven beak. E. B. 832. Schk. 46. Car. E. 23. Host, t. 52.

Moist, shady places, and by ditches. Marston Lane. Tar Wood. Sb.

Per. June.

Plunt slender, weak, pale, whitish grcen. Stem about one foot, triangular upwards, roundish below, leafy. Ls. long, narrow. Spikes, except the uppermost, placed in the axil of the leaves, alternate, six, eight, or more, of male and female flowers, three or four of the lowermost very distant, each accompanied by a very long, upright, leafy bractea, taller than the top of the stem; the upper spikelets nearer to each other, with very short bracteas. Glumes egg-shaped, membranous. Stig. two.

An elegant species.

\section{C. intermédia. Soft Brown $C$. Spikelets numerous,} crowded into an oblong, close spike; the lowermost and terminal ones fertile; intermediate ones barren. Stem upright, triangular. E. B. 2042. Schk. Car. 16. B. \%. Host, t. 50. C. disticha. Sb. 26.

Marshy, watery meadows.

Per. May.

Root creeping. Stems, twelve or eighteen inches, or more, leafy at the bottom only. $\boldsymbol{L} s$. few, nearly upright. Spike oblong, bluntish, rusty brown, composed of numerous, crowded, ascending, egg-shaped spikelets, of which two or three of the lowermost, and one or two of the uppermost, are almost entirely with stigmas, the rest, nearly, as completely with stamens. Bract. egg-spear-shaped, membranous, brown, the lowest ending in a leafy point. Stig. two, sometimes three. Lower spikelets some- 
what remote. Resemhles Car. ovalis in habit, but its spikelets more numerous, smaller, more spear-shaped. Style in Car. intermedia divided to the base; in C'ar. ovalis only about one fourth.

C. muricáta. Great Fruit-Prickly Pointed C. Spike oblong, close, prickly, with the broad, rough-edged, cloven, spreading beaks of the fruit. Spikelets roundish, mostly simple. Root fibrous. E. B. 1097. Schk. Car. 20. E. 22. Host, t. 54. C. spicata. Sb. 27.

Moist pastures, shady places; especially on a sandy soil. Sm. Cowley. Littlemore. $\$ \mathbf{S}$.

Per. June.

Root fibrous. Herbage bright green. Stem upright, twelve or eighteen inches, naked, except at the base. $L s$. flattish, narrow, taller than the stem. Spikelets about ten, rather crowded, lower ones distant. Bract. egg-shaped, membranous, the lowermost generally tipped with a rough, leafy point. Glumes eggshaped. Fruit deeply cloven at the point. Stig. two.

Like Car. vulpina, but smaller; its spike never more than doubly compound, and straw not enlarged under the spike, as in Car. vulp.

C. divulsa. Grey C. Spike lengthened out, lax. Spikelets above, approximating; of its lower half finally very distant, mostly single. Fruit erect, smoothedged; roughish at the cloven point of the beak : root fibrous. E. B. 629. Schk. Car. 20. W. w. 89. Host, t. 55.

Moist, shady pastures.

Per. May.

Plant pale greyish hue. Stem a foot, or more, weak, reclining. Ls. sheathing, taller than the stem, with white, membranous, torn sheaths, and stipulas. Spike erect, lengthened out, interrupted, sometimes branched at the bottom. Spikelets alternate, bracteated, nearly stalkless, upright, egg-shaped. Stig. two, downy, long. Caps. a little spreading, but not diverging. The figure in Engl. BBot. wants the fruit.

Dr. Hooker considers Car. divulsa, a var. of Car. muricata, in Fl. Scot.

C. vulpina. Great Rough C. Spike thrice compound, close, less compact in the lower part, blunt. Fruit spreading, with a notched, rough-edger beak. Scales pointed. The three angles of the stem compressed, 
very sharp. E. B. 307. Schk. Car. 17. C. 10. Host, t. 56. Gramen palustre cyperoides. G. E. 21.

Watery places, margins of ponds, and vivers.

Per. June.

Stems many, erect, naked, about two feet, stout. Ls. sheathing the lower part, long, deep green, very rough on the edges, and nerve. Spikelets several, alternate, rather remote, with a linear bractea to each. Stig. 2. Stem above the lowest spikelet much diminished in thickness.

This species marked by the stoutness of its straw, the closeness and stiff nature of the spike, and the supra-decomposition : nearly allied to Car. muricata.

C. paniculáta. Panicled $C$. Spike more than doubly compound, loosely panicled, interrupted, acute. Fruit spreading, with an abrupt, saw-toothed beak. Stem sharply triangular, with flat interstices. E. B. 1064. Schk. Car. D. 20. Host, t. 58.

Wet pastures, spongy bogs. Peat bogs on Bullingdon Green. Under Headington Wick copse. $\mathbf{S b}$.

Per. June.

Root fibrous, of very large, firm tufts. Stems two or three feet, erect. Ls. upright, broadish, rough on the edges, and keel. Bract. egg-shaped, terminating in a bristle. Stig. two. Spike more or less branched.

The lax, branchy spike discriminates this species. The whole spike, at its first opening, three sided, oblong, and acute. This Car. well suited for consolidating boggy, loose ground, by its immense, large-raised tufts.

**** Stamen-bearing, and pistil-bearing florets in separate spikes; the Stamen-bearing one solitary, very rarely or occasionally more than one. Bracteas leafy, often sheathing. (*Pistil-bearing spike, long, and linear. Stamen-bearing spike, terminal.)

C. péndula. Great pendulous $C$. Sheaths nearly as long as the flower-stalks. Fertile spikes cylindrical, very long, drooping, Fruit densely crowded, eggshaped, beaked. E. B. 2315. C. 3. 63. Schk. Car. 100. Q. 60. Host, t. 100.

Most woods, hedges. Tar Wood. Sb. Ditches on both sides of the Faringdon road, going up the hill, just beyond Botley. $B \boldsymbol{B}$. Per. June.

Root fibrous. Stem three to five or six feet, erect, leafy, triangular. Ls. long, broad, harsh. Spikes on shortish stalks, cylindrical, very long, from five to seven.

Discrim. Its great size, very long, cylindrical, drooping, elegant spikes; very small capsules for its size.

C. strigósa. Lonse pendulous $C$. Sheaths nearly equal 
to the flower-stalks. Spikes slender, loose, slightly drooping. Fruit spear-shaped, triangular, ribbed. E. B. 994. Schk. Car. 94. N. 53.

Groves and thickets, *. Noke Wood. Sb. (In Wytham Wood, near Oxford. Rev. Dr. Sheffield.

Per. June.

Root fibrous. Stem erect, slender, two feet, leafy, triangular, taller than the leaves. Ls. light green, broadish. Spikes, female, four, five, or more, on thread-shaped stalks, slender, soon drooping. Stig. three. Seed elliptical, triangular. Spikes all sheathed at the base.

Discrim. From Car. sylvatica, by its flower-stalks scarcely longer than the sheath, by its three cornered and acute capsules, but not with a long, taper beak.

C. sylvática. Pendulous Wood $C$. Sheaths not half the length of the flower-stalks. Spikes slender, rather loose, drooping. Fruit egg-shaped, triangular, beaked, without ribs. E. B. 995. Schk. Car. 111. L. I. 101. Host, t. 84 .

Woods, especially on a clay, wet soil. Sm.

Per. June.

$\boldsymbol{L} s$. in tufts from the joints of the roots, yellowish green. Capsules smooth, and with a beak nearly as long as the capsule, cloven at the end. Stig. three. Stamen-bearing spikelet generally single.

The drooping spikes, and their thread-shaped stalks, pale green of the leaves, and bending of the stem, render this an elegant plant.

The Laplanders form a wadding of this plant, carded and dressed, for their shoes and gloves, to protect them from the winter cold, and summer heat. Linn. The leaves of this (and of other Carices), are used for binding wine flasks of glass, bottoming common chairs, and for stopping the interstices of casks, by the cooper. Linn. Fl. Suec.

*** Pistil-bearing spikes cylindrical, or oblong, egy-shaped, or roundish.

C. Pseudo-cypérus. Bastard-cyperus $C$. Sheaths scarcely any. Pistil-bearing spikes dense, cylindrical, drooping, many-flowered. Scales awl-shaped. Fruit spreading, spear-shaped, furrowed, rough-edged, with a deeply cloven beak. E. B. 242. Pseudo-cyperus. G. E. 29. (Host, v. 1. 63. t. 85.)

Wet, shady places; margins of rivers and ponds. Sm. ** Ditch bank at the foot of the bridge, in Binsey Lane. Bx. Ditches near Eton, Bucks, not uncommon. Tur.

Per. June. 
Stem one foot, or more, with three, sharp, rough angles. Spikelets one and a half, to two inches, green, on rough stalks. An elegant species.

C. palléscens. Pale $C$. Sheaths very short. Pistilbearing spikes cylindrical, stalked; at length drooping. Fruit inversely egg-shaped, triangular, inflated, smooth, very blunt, with a minute abrupt beak. E. B. 2185. H. L. 178. Schk. Car. 108. K, k. 99.

Meadows, pastures, moist, shady places. * Copse under Shotover Hill. Sb. Wytham Wood. Y. Headington Copse. Headington Wick Copse. $B x$.

Per. June.

Stem erect, twelve, or eighteen inches. Ls. rather short, flat, pale. Bract. leafy, upright, longer than the stem, very slightly sheathing at the base. Spike, stamen-bearing one, single, erect, close, pale brown. Pistil-bearing ones, two or three, short, somewhat egg-shaped, blunt. Fruit nearly equal in length to the glumes, closely set, swollen, smooth, light green.

Discrim. Its palish green colour when in fruit. All the spikes near the top of the stem. Pistil-bearing spikes in their mature state nearly cylindrical.

C. Alava. Yellow C. Sheaths short, nearly equal to the flower-stalks. Pistil-bearing spikes roundish, eggshaped. Fruit triangular, smooth, with a cloven beak curved downward. Stem nearly smooth. E. B. 1294. Schk. Car. 72. H. 36. Host, t. 63. Gramen palustre echinatum. G. E. $1 \%$.

\section{Boggy meadows.}

Per. June.

Stem erect, about a foot generally, triangular, leafy at the base. $L s$. bright green, erect, broadish, marked with two rough lines on their upper side. Bract. leafy, remarkably spreading, with very short sheaths. Stamen-bearing Spike spear-shaped, erect, mostly solitary.

Discrim. Its long, straddling, leafy bract. and prickly, round, pistil-bearing heads. Varies greatly in height, and luxuriance.

\section{(Carex Oederi, and C. fulva. See Appendix.)}

C. distans. Distant Smooth $C$. Sheaths tubular, lengthened out, nearly equal to the flower-stalks. Pistil-bearing spikes elliptic-oblong, widely distant. Scales pointed. Stem smooth. E. B. 1234. Schk. Car. 102. T. 68. Host, 1. t. $7 \%$.

Muddy marshes.

Per. June. 
Root fibrous. Stem twelve to eightcen inches, weak. Ls. short, rather broarl, flower-leaves longer, narrower; their upper sheaths almost concealing the flower-stalk: lower sheath enclosing about half the flower-stalk. Fruit cloven at the summit.

Discrim. The great distance of the pistil-bearing spikes from each other : the smoothness of the leaves, and capsules discrim. from Car. hirta.

(C. binervis. See Appendix.)

C. pracox. Early Spring $C$. Sheaths about equal to the very short flower-stalks. Spikes elliptical, rather crowded. Scales of the pistil-bearing ones pointed. Fruit pear-shaped, downy, with an abrupt, entire point. E. B. 1099. H. L. 22. Schk. Car. 68. F. 2\%. Host, 1. t. 68 .

Dry heaths, hillocks, open, barrer pastures. Shotover Hill. Sb.

Per. April.

Root creeping. Stem ascending obliquely, from three to six inches, firm, naked. Ls. root-ones short. Bract. erect, often wanting. Stamen-bearing spike rather blunt, club-shaped, their glumes elliptical, or egg-shaped. 1'istil-bearing one egg-shaped.

Discrim. From Car. pilulifera by its shortly stalked spikes, and its fl.-stalks with a sheath nearly equal to the fl.-stalk in length ; its creeping root, and erect stalk. Conspicuous in spring, by its numerous, tufted anthers.

C. pilulifera. Round-headed $C$. Sheaths none. Pistilbearing spikes two or three, stalkless, close together, almost globular, with pointed scales. Fruit triangular, roundish, downy, with a short, cloven beak. E. B. 885. Schk. Car. 78. I. 39. Host, t. 84.

Heaths, moors. North-Leigh Heath. $\mathbf{S} b$.

Per. June.

Root fibrous. Stem weak, reclining, naked, six to twelve inches. Ls bright-green, shorter than the straw. Bract. narrow, short, stalkless, without any perceptible sheath. Spike, stamen-bearing one, spear-shaped, glumes pointed.

Discrim. Capsule somewhat downy as in Car. præcox, but the linear, stamen-bearing spike, the pistil-bearing ones stalkless, and the reclining straw-stalk, distinguish it in every stage.

C. panicéa. Pink-leaved C. Sheaths lengthened out, about half the length of the flower-stalks. Pistilbearing spikes one or two, distant; lower one rather lax. Fruit swollen, smooth, cloven at the summit. Stem smooth, bluntly triangular. E. B. 1505. Schk. Car. 110. L. 1. 100. Host, 1. t. 79. 
Meadows, moist pastures.

Per. June.

Root creeping. Stem erect, ten to fifteen inches, smooth. $L s$. glaucous, shorter than the straw-stalk. Bract. acute, shorter than the stem. Sheaths long, furrowed, pale. Spike, stamen. bearing spike one, sometimes two, spear-shaped, acute. Pistilbearing spike remote, erect, on slender stalks, twice the length of the sheath; their scales loosely tiled, egg-shaped, pointless. Fruit longer than the scales, egg-shaped, bluntish, capsule rather distant, of a light greenish, or yellowish hue. Sheath lower, enclosing about half the foot-stalk, upper ones nearly the whole. Caps. often affected with the smut, and turned into sooty dust.

Discrim. Its loose, rather distant capsules. In its younger state resembles young specimens of Car. recurva: but in Car. panicea, the lowermost sheath is full half the length of the footstalk, in Car. recurva, about one quarter.

C. recurva. Glaucous Heath C. Sheaths short. Pistilbearing spikes two or three, cylindrical, close, drooping, on long, at length recurved stalks. Fruit elliptical, triangular, roughish, blunt, slightly notched. E. B. 1506. C. flacea. Schk. Car. 11\%. O. P. 5\%. Host, 1. t. 90 .

Moist meadows, pastures, groves, wet, barren, heathy ground.

Per. June.

Root creeping. Whole plant glaucous. Stem upright, from eight to eighteen inches, roundish, with three angles. $L s$. erect, broadish, shorter than the stem. Bract. erect, about as high as the stem; sheaths short, with a small appendage on each side. Stamen-bearing spikes linear-spear-shaped, mostly solitary. Pistil-bearing spikes, at first erect, soon drooping, cylindrical, very close, glumes egg-shaped, blackish. Stig. three. Fruit closely tiled, elliptical, bluntly three-angular, swelling, entire, soon black.

Discrim. (Varies much in size and habit.) Its cylindrical, drooping, black spikes, glaucous leaves, short, ear-appendaged sheaths, roundish caps., smooth straw-stalk, creeping root.

C. caspitósa. Tufted Bog C. Stigmas two. Sheaths none. Pistil-bearing spikes, cylindrical, blunt, erect; uppermost stalkless, the lowermost sometimes stalked. Leaves and ear-appendaged bracteas, linear, erect. Fruit permanent, elliptical, flat, many-ribbed, with a very short, abrupt beak. E. B. 1507. Schk. Car. 57. A, a, and B, b. 85. Host, t. 91 .

Marshes, wet, shady places.

Per. May. 
Root creeping. Stems nine to twelve inches. $\boldsymbol{L} s$. erect, almost as tall as the stem, narrow, acute, bright green. Bract. at the base, a pair of round, black, ear-like appendages. Stamenbearing spike mostly solitary, spear-shaped, erect, with greenribbed scales. Pistil-bearing sp. cylindrical, shortish, blunt, close, its scales elliptical, black, green-ribbed. Fruit permanent after it is ripe. Black glumes of the pistil-bearing spikes appear to the eye, as if deeply marrined with a lighter colour. Scales shorter than the ripe, black caps.

Discrim. Fruit in Car. stricta falling almost as soon as ripe. Car. cæspitosa, flowers nearly a month later.

(C. stricte. Císucous Sirvaight-lcared $C$. Stigmas two. Sheaths none. Pistil-bearing spikes nearly stalkless, erect, cylindrical, lengthened out, acute; often barren-flowered at the top. Bases of the leaves like net-work. Fruit elliptical, flat, with a short, cloven beak, falling off (deciduous.) E. B. 914. Schk. Car. 60. t. V. 73.

Marshes. At Pophills, side of a ditch, near to the river Arrow. Purton's Fl. v. 3. pt. II.

Per. April.

Rather glaucous, erect, one and a half to two f. Spike two inches.)

**** Barren and fertile florets in separate spikcs. Barren spikes two or more.

C. acuita. Slender-Spiked C. Stigmas two. Spikes cylindrical, slender; drooping in flower; afterwards erect. Fruit elliptical, with a blunt, undivided beak. E. B. 580. Schk. Car. 61. E, e. 92. Host, 70. t. 95. C. gracilis. C. 4. 62. Sb. 32.

Watery meadows, about ditches and pools.

Per. May.

Root creeping. Stem variable in height, from three inches to one, two, or three feet. Its summit drooping in flower, soon becoming erect. $L s$. bright, deep green, drooping near the top. Spikes scales of the stamen-bearing ones spear-shaped, bluntish; of the pistil-bearing ones linear, sharpish. Bract. one at the base of each pistil-bearing spike.

Discrim. In its young state resembles Car. pendula, distinguished from it by its two stigmas. Discrim. Its slenderness of habit, drooping flowers, compressed, undivided caps. Flowers a week or two later than Car. riparia, and Car. paludosa. Sheaths none.

C. paludósa. Smaller Common C. Stigmas three. Stamen-bearing spikes cylindrical, bluntish, erect; the pistil-bearing ones with taper-pointed scales. Fruit egg-shaped, triangular, compressed, with a notched 
beak. E. B. $80 \%$ Schk. Car. 121. O, o. 103. Host,

\section{1.t. 92. C. acuta. C. 4. 61 . Sb. 32 .}

Boggy meadows, about the margins of ditches, and rivers.

Per. April.

Root very creeping. Ls. about half an inch broad, erect. Stem one to two feet. Spikes generally three pistil-bearing, and three stamen-bearing; the latter terminal, near together, with scales oblong, blunt. Bract. sheathless, a leafy one accompanying each pistil-bearing spike; one or two of the lower ones longer than the stem.

Discrim. From Car. acuta, by its less slender, and more erect form, and its three stigs. From Car. riparia, by its more, or less blunt, and not pointed glumes, in stamen-bearing spike; very acute in Car. riparia ; its caps. very slightly divided at the summit, but not beaked or forked. Fruit smaller, less inflated, than in Car. riparia.

C. ripária. Great Common C. Stigmas three. Stamenbearing spikes erect, with taper-pointed scales. Fruit egg-shaped, swollen, with a deeply-cloven beak. C. 4. 60. E. B. 579. Schk. Car. 122. Q. q. o. C. crassa. Host, 1. t. 93.

Watery places, very common.

Per. April.

Root widely creeping. Stem two or three feet, leafy, angles three, very sharp at the edges of the leaves. Ls. broad, erect, those of the stem with a sheathing, veined-like net-work at the base. Spikes mostly three stamen-bearing, and three pistil-bearing. Scales of pistil-bearing spikcs spear-shaped, tipped with a small, rough awn. Stamen-bearing spikes crowded, three-angular, generally acute at the end. Bract. sheathless, a leafy one to each pistil-bearing spike, one or two of the lower ones often overtopping the stem: upper bract. somewhat stalkless.

Discrim. Its black, triangular, acute, stamen-bearing spikes, and pointed, forked capsules. Stamen-bearing spikes, before flowering, brownish black; in flower, reddish brown; out of flower, light-brown. Larger than Car. paludosa, broader leaves, thicker spikes.

(C. lavigáta. See Appendix.)

C. vesicúria. Short-spiked Bladder C. Pistil-bearing spikes cylindrical, short, abrupt, on short stalks. Scales all spear-shaped, acute. Sheaths none. Fruit eggshaped, inflated, with a lengthened out, cloven beak. E.B. r\%9. Schk. Car. 124. S, s. 106. Host, 1. t. 98. Murskes, wet meadows. About Oxford, but rather rare. Bobart. Cowley Field, on the banks of the Cherwell. Sb. Ditch round Christ-church Meadow. Bog under Bullingdon Green. Long Meadow. $B x$. 
Per. June.

Root creeping. Stem upright, two feet. Ls. erect, bright green, longer than the straw-stalk, at the time of flowering. Spikes about three stamen-bearing, and three pistil-bearing, the former slender, acute, with linear, spear-shaped scales. The latter thick, and short, with sharp scales; lower-ones stalked, longer. Stig. three. Fruit thickly ranged, spreading, longer than the scales, egg-shaped, pointed, yellowish, shining, when ripe. Bract. leafy, stalkless, each pistil-bearing spike longer than the extending under straw-stem. Shorter bract. often extending under the stamen-bearing spikes.

Discrim. Its yellow hue, narrow, short scales, and green, inflated, smooth, conic, bladder-like capsules.

C. ampullácea. Slender-beaked Bottle C. Pistil-bearing spikes cylindrical, lengthened out, with short footstalks. Scales all spear-shaped, acute. Sheaths none. Fruit inflated, globose, with a linear, cloven beak. E. B. 780. Schk. Car. 125. T, t. 107. Host, 1.t. 99. C. rostrata. Sb. 32.

Pools, marshes, margins of rivers. Peat bogs on Bullingdon Green. Under Headington Wick Copse. Beyond Iffley, on the banks of the Isis. $\quad \mathbf{S} b$.

Per. June.

Root creeping. Ls. narrow, longer than the straw-stalk. Strawstalk one to two feet. Spikes two or three stamen-bearing; about the same number of pistil-bearing; topmost stamen-bearing spike often slightly curved, very slender. Bract. one accompanying every spike, upper ones shorter than the strawstem, one or two of the lower ones much longer, all stalkless.

Discrim. Pistil-bearing spikes longer, and more slender than those of Car. vesicaria, consisting of numerous, spreading, yellowish, inflated, roundish capsules, each terminating in a linear beak, nearly the length of the caps. and cloven at the point, resembling a long necked bottle with a cloven beak.

C. hirta. Hairy C. Plant hairy. Pistil-bearing spikes egg-shaped-cylindrical, remote. Scales awned. Sheaths nearly as long as the flower-stalks. Fruit hairy, swollen, with a deep-cloven beak. Stem rough-edged. E. B. 685. Schk. Car. 12\%. U, u. 108.

Wet meadows, woods, watery places.

Per. June.

Root creeping, downy. Straw-stem erect, about two feet. $L s$. scarcely so tall as the stem, most hairy beneath; sheath generally woolly. Bract. a leafy one to every pistil-bearing spike, one or two lower ones often higher than the culm (straw-stem.) Spikes pistil-bearing ones, two or three: stamen-bearing, spear- 
shaped, with egg-shaped, brown, rather pointed scales, outwardly hairy. Fruit egg-shaped, acute.

Discrim. The thick down of the leaves, and particularly of the sheaths, and capsules.

\section{(C. filiformis. See Appendix.)}

\section{MONOECIA TETRANDRIA.}

\section{ALNUS. Alder.}

\section{A. glutinósa. Common A. Leaves roundish-wedgè-} shaped, wavy, saw-toothed, glutinous, blunt ; downy at the branching of the veins beneath. H. L. 59. Alnus. G. E. 14.7\% Betula Alnus. E. B. 1508. Sb. 64 . Watery places, moist woods.

Tree. March.

Branches dark, spreading, crooked, glutinous, when young. Ls. alternate, footstalked, deep, shining green, with many almost parallel veins. Cutkins, stamen-learing ones, long, urooping, cylindrical : pistil-bearing ones, small, oval, ascending, reddish brown.

Valuable for piles of bridges, \&c., enduring moisture well. The bark and leaves for dying, tanning, and staining nets. Wood used by the wheelwright, and turner. The knots beautifully veined. Sheep will feed on the leaves. Plant astringent. The catkins dye green. Grass grows well under its shade; a picturesque tree, spreading over the still pool: planted in a low meadow, the ground round it becomes boggy.

Wood hard, used for clogs or pattens. The bark dyes linen of a dull red, and, with iron, brown, or black. Sm.

\section{URT $^{\prime}$ ICA $^{\mathrm{x}}$. Nettle.}

U. urens. Small Stinging $N$. Leaves opposite, sharply saw-toothed, elliptical, with about five longitudinal ribs. Clubs nearly simple. E. B. 1236. C. 6. $\% 0$. U. minor. G. E. 707 .

A troublesome weed.

An. July.

Plant much branched, pale green, covered with stinging bristles. Bract. small, bent back.

Discrim. From Ur. dioica, by its smaller size, annual, fibrous root, brighter colour, and elliptical leaves.

1 So called, ab urendo, from burning, or stinging. 
The chopped leaves mixed with the food of young turkies. Sting a fine-pointed tube, perforated at top, with a bag of poison at its base. The skin being punctured by the sharp point, the acrimonious fluid rises to the top, and is carried into the wound. A leaf applied of the Dock (Rumex), or of Plantago lanceolata, or of the Nettle itself, is a speedy remedy for the painful sting. Sting of this species peculiarly inflammatory.

U. dioica. Great Stinging Nettle. Leaves opposite, heart-shaped. Clusters much branched, in pairs, mostly diocious. Root creeping. E. B. 1750 . C. 6. 69. U. urens. G. E. 706.

Waste ground.

Per. July.

Occasionally monøecious. Roots creeping. Stems erect, three feet, leafy, simple, bluntly four angled, clothed with stinging bristles. Ls. stalked, pointed, veiny, saw-toothed. Stip. eggshaped. Clusters axillary, in pairs, spreading; longer than the footstalks.

The stalks, like flax or hemp, may be converted into cloth, or paper. Astringent: a leaf put on the tongue, and pressed against the roof of the mouth, stops bleeding at the nose. Paralytic limbs have been advantageously excited by urtication, or striking them with Nettles. The young spring shoots eaten boiled. Asses browse on the leaves. The leaves are fed on by the larvas of Pap. Atalanta, Urticæ, Páphia, C. Album, and Io; five of our most beautiful butterflies. Nettle tea considered by the vulgar as a diet-drink to purify the blood.

Woollen stuffs dyed green with the juice. The roots, with alum, dye yellow. A rennet made from a strong decoction of Nettles; a quart of salt to three pints of decoction, to be bottled up for use. A table spoonful of this will coagulate a large bowl of milk.

\section{MONOECIA PENTANDRIA.}

\section{BRYO'NIA. Bryony.}

B. dioíca. Red-berried $B$. Leaves somewhat fivelobed, hand-shaped, rough on both sides with hard points. Barren and fertile flowers on separate plants. E. B. $439 . \quad$ B. alba. G. E. 869 .

Hedges, thickets.

Per. July.

Root very large. Stems annual, climbing by simple tendrils. Ls. alternate. $F l$. in axillary bunches, between the tendril and leaf. Cor. whitish, veined with green. Stam. of three, short 
filaments, two of which bear each of them two anthers, the third mostly one. Style divided into three branches. Berries red, of one cell, full of fetid juice. Leaf-lobes obscurely triangular.

loot purgative, acrid: one dr. in wine a dose. Cataplasm of the root a powerful discutient. One pound of the fresh root in decoction, a purgative for horued cattle. The roots have been formed into the human shape to represent mandrakes. In summer, the root less juicy, and weaker in its power. Ger. reports to have seen a root of this plant of half a hundred weight.

The true B. alba of Linn, found on the continent, has black fruit, boing called alba, from its white root, in contradistinction to Tamus, the black-rooted Bryony. Sm.

\section{MONOECIA POLYANDRIA.}

\section{CERATOPHYLLUM. Hornwort.}

C. dencrsum. Common H. Fruit armed with three spines. Segments of the calyx notched at the extremity. E. B. $94 \%$.

Ditches, fish ponds.

Per. July.

Plant much branched, floating under water. Fl. stalkless, whorled, each in the bosom of a leaf. $L s$. whorled, twiceforked, saw toothed, leaflets bristle-shaped; lower ones linear: leaves closer upwards, crowded close towards the end.

\section{MYRIOPHYLLUM. Water-Milfoil ${ }^{x}$.}

\section{M. spicútum. Spiked Water-M. Flowers in whorled,} interrupted, leafless spikes. E. B. 83.

Ditches, pools.

Per. July.

Conspicuous by its numerous red flower-spikes, erect, above the surface of the water, to prevent injury to the pollen. Stems slender, much branched upwards. Ls. in fours, spreading, very delicately comb-like, sunk in the water. Cal. acute, fringed. Pet. blunt, concave, entire. Whorls, lower ones of pistil-bearing flowers more distant.

M. verticillátum. Whorled Water-M. Flowers all axillary, from the whorled leaves. E. B. 218.

Ponds, ditches; less common than Myr. spicatum. Sm. By the bridge on the Botley road, near the lane going to Medley. S6. Per. July.

Ls. in fives, lower ones comb-like; upper, comb-like-wing-cleft.

1 From its numerously divided leaves. Mille, a thousand. 
Stem, upper part raised above the surface of the water, clothed to the top with leaves, less finely cut than those under water; all whorled. $F l$. axillary, pale green, sometimes hermaphrodite, but lower ones mostly pistil-bearing; upper, stamenbearing. Stig. four, short, finely tufted.

\section{SAGITTA'RIA. Arrow-head.}

\section{S. Sagittifólia, Common A. Leaves arrow-shaped,} tapering to a point. Stalk simple. E. B. 84. Sagitta major et minor. G. E. 416.

Ditches, ponds, margins of rivers.

Per. July.

Stems and footstalks triangular, spongy. Fl. pistil-bearing, few, forming one or two of the lowermost whorls. $L s$, on long footstalks; those under water linear. $\boldsymbol{F l}$. three in a whorl. Bract. one at the base of each flower oval, spear-shaped. $\boldsymbol{F} l$. white, with a purplish tinge at the claw of the petals, which are very transient.

A bulb at the lower part of the root. This a considerable article of food among the Chinese, who cultivate the plant. $F \boldsymbol{F}$. Suec.

Very ornamental plant.

A var. with small $L s$. $\beta$. parvifólia. $\mathbf{S} b$. Dorchester. $\mathbf{S} b$. Sagitta aquatica omnium minima. Ray. 258.

\section{ARUM. Cuckoo-pint.}

\section{A. maculátum. Common C. or Wake Robin. Stem} none. Leaves halbert-arrow-shaped, entire. Spadix hollow, club-shaped, blunt. E. B. 1298. C. 2.63. A. vulgare. G. E. 834 .

Groves, bushy places, borders of fields, hedge banks.

Per. May.

$\boldsymbol{L}_{\mathrm{s}}$. root ones generally spotted with black. Stalk immediately from the root, simple. Sheath ercet, large, acute, hollow, pale green, sometimes spotted, enfolding the pillar of fructification, whose summit is cylindrical, blunt, purplish, spongy within: below this several rows of glands tipjed with fil. then a crowded band of purple anthers, below which stand numerous germens.

The scarlet spike of berries appears conspicuous in the autumn, without leaves. The root abounds with a mucilage, which affords (an acrid, G. E.) starch : the fresh root very acrid: mild by drying. The root dried and powdered used by the French to wash the skin, and called Cypress powder; a good cosmetic. The dried root affords a wholesome nourishment, like flour. The naked summit of the flower-stalk gives out considerable heat, (R.W.) 
for several hours subsequent to the first opening of the sheath. See Sm. Intr. Bot. p. 70.

Roots of the plant taken up after the leaves decay, continue acrimonious for a long time. The root has been substituted for soap. The berries acrimonious.

\section{POTE'RIUM. Salad-Burnet.}

\section{P. Sanguisorba. Common Salad B. Thorns none.} Stem somewhat angular. Stamens much longer than the calyx. E. B. 860 . C. 2. 64 . Pimpinella hortensis. G. E. 1045 .

Chalky hills. Sm.

Per. June.

Stems upright, branched, leafy, smooth. Ls. winged with an odd one; Leaflets round, saw-toothed. $\mathrm{Fl}$. in round heads, footstalks long, upright, terminal. Stamen-bearing flowers below, pistil-bearing flowers above: this unusual. Stam. hang out of the flower, like purple silk. Anth. yellow. Stig. purple, radiated. Habit of Sanguisorba officinális.

Taste of the leaves resembling cucumber; used in salads. Has been cultivated for cattle: bears mowing three times during the summer : it does not answer.

\section{QUERCUS. Oak.}

Q. Robur ${ }^{1}$. Common British Oak. Leaves deciduous, (falling off,) inversely egg-shaped, oblong, broader towards the extremity; sinuses of their indentations rather acute; lobes rounded. Fruit-stalks lengthened out. E. B. 1342. Q. vulgaris. G. E. 1339, 1340.

Woods, hedges.

Tree. April.

Ls. alternate, nearly stalkless, somewhat inversely egg-shaped, deeply sinuated, lobes blunt. $\boldsymbol{F l}$. stamen-bearing ones in slender, drooping, stalked, yellow clusters: pistil-bearing three or four, their stalk long: Calyx of these latter, entire, scaly, subsequently the cup of the acorn.

Tree remarkable for its picturesque appearance, slowness of its growth, bulk, and longevity. Thrives on a hilly soil of marl or loam. Roots deep; does not bear much lopping. Wood hard, tough, somewhat flexible: preferred for our glorious navy in shipbuilding, as not easily splintering. Oak saw-dust used for dying fustian, of a drab, or brown colour. The black obtained from the

${ }^{1}$ Strength : classical name for the oak. 
oak apples, bright, but not durable: that from the genuine galls more durable. Bark for tanning leather: from its astringency valuable in medicine, e. g. in ague, \&c. The galls, used in making ink, or balls on the leaves, arise from a small insect, a Cynips, depositing an egg on the perforated leaf: the ball grows with the insect worm hatched in its centre. This larva or worm changes to a four winged insect, like its parent. The larvas of various butterflies and moths feed on the leaves.

The oak in a rich soil, and suitable climate, nearly triples its value of timler in about nine years. An oak in about fifty years becomes fit for the dock-yard, and ship-building. The oak derives its chief nourishment from its tap root, which should, therefore, be prescrved from injury. Wilh. The acorns formerly the food of Britons!! Pheasants and hogs eat the acorns also. Timber of this species better than that of Q. sessiliflora. See Ger. Em. 1341. I. Strange remarks on oak apples.

"Dr. Stuleley, in his Itinerarium Curiosum, thus notices the oak which very many inbabitants of Oxford remember to have stood near the entrance of the Water-walk in Magdalen College. " The old oak is still standing nigh to which the founder ordered his college to be built.' The foundation of the college was in 1448. The tree must have been old and large when the founder assigned the northern boundary to be near the great oak. If we suppose it to have been then between three and four hundred years old, it may have been planted about the time of the Norman conquest. It fell in 1789. It had become hollow, and was much decayed at the root. Its girth was twenty-one feet nine inches; the heirht about seventy-two feet." -J. S. Duncan's Botanical Theology. Edit. 2nd. p. 84.

Evelyn in his Sylva mentions that this oak may be "scen,whose branches shoot sixteen yards from the stem." Evelyn's Silva, (an. 1662.) by Hunter, p. 49s. Edit. 1766. Plot in his Oxfordstire (edit. anno 1677.) observes of this once gigantic tree: that " there might 256 horses stand under that tree; or allowing two square feet for a mun, 3456 mer. Plot, pages 158, 159. An oak to supply the place of the abovementioned celebrated tree was planted, April 8th, 1807, by Mr. Robert Penson, Gardener, Oxford, " on the left as you enter the walk on the spot where the large oak grew."--Robert Penson, Oct. 1832.

Q. sessiliflóra. Stalkless fruited oak. Leaves on stalks lengthened out, falling off, oblong; with opposite, acute sinuses. Fruit stalkless. E. B. 1845.

Woods, less common than the first. In Bagley Wood, and divers other places, first observed by Mr. Bobart. Ray. (Bagley Wood. Bx.) I found two vars. of this species, one with stalkless leaves; and another with longish, tiled (imbricated) scales, the first at Stanton St. John's; the second, between Shotover and Cuddesdon. An eminent Botanist to whom the 
specimens were sent, informs me, that $Q$. sessiliflóra "varics with sessile (stalkless) leaves, and that the acorn-cups, in the second var. are in a curious state, producing its scales in the form of abortive leaves." R. W. 1832.

Tree. April, May.

Wood far inferior. Ls. more equally wing-cleft; in var. $\beta$. downy.

\section{FAGUS. Beech, and Chestnut.}

* F. Castánea. Sueet C. Leaves spear-shaped, sharply saw-toothed; smooth beneath. Prickles of the outer calyx compound and entangled. Stigmas six. E. B. 886. Castanea. G. E. 1442.

Woods, plantations.

Tree. May.

The Spanish Chestnut, Fagus Castanea, occurs, but we presume not as indigenous.

F. sylvática. Common B. Leaves egg-shaped, indistinctly saw-toothed. Prickles of the outer calyx simple. Stigmas three. E. B. 1846. Fagus. G. E. 1444. Woods, on chalky hills. Sm.

Tree. April.

Bark very smooth. Ls. shining, waved, finely fringed. $F l$. in small, round, hairy tufts, long-stalked, with spear-shaped bracts. $\mathbf{C a l}$. of the fruit egg-shaped, silky. Nuts sharply triangular.

A beautiful tree, bears lopping well, but allows no verdure to flourish under it: thrives in a rich soil : retaining its old leaves during winter, it forms excellent cut hedges for shelter. The wood brittle, soon decaying in the air: under water durable: burnt affords a large quantity of potash. The leaves gathered in autumn form tolerably good mattresses. The nuts, when dried and powdered, make wholesome bread: they fatten swine. The poor in Silesia use the expressed oil of the nuts for butter.

The branches and leaves of this tree feather almost to the ground. The var. with purple foliage very ornamental in shrubberies. The boards of this thinly splitting wood formerly used by the bookbinder for covers of books. Fat of hogs fed on the mast not solid. Linn. Ceesar (De Bello Gallico,) lib. 5. c. 12. asserted, that there was no beech timber in Britain, nor fir.

\section{BE'TULA. Birch.}

B. alba. Common B. Leaves egg-diamond-shaped, acute, unequally saw-toothed, nearly smooth. E. B. 2198. Betula. G. E. 1478 .

Woods.

Tree. April.

$\boldsymbol{B}$ ark of the trunk white, with paper-like outer bark (cpidermis) 
rugged and dark, when old. Branches elegantly drooping. $L s$. alternate, stalked. The foliage in autumn of a full yellow. There is a var. with more drooping branches.

This a very hardy tree. Wood firm, tough, white. The slender twigs formed into brooms and rods: or as Mr. Lightfoot expresses it: "answer the purposes of cleanliness, and correction." The leaves dye yellow. Hats, surtouts, and cups made of the bark, in the North of Europe, also shoes, coverings for houses, torches. A hole bored in the tree in spring, exudes a sweet sap, which properly fermented, with sugar added, forms a pleasant wine. Bark may be used for tanning, and for rope-making. Canoes made of it. The inner bark anciently used to write upon. The knotty excrescences a beautifully veined wood. Lightfoot in Fl. Scot., recommends Birch-wine as a substitute for the "poisonous whiskey," and suljoins a receipt for the wine. Horse harness made of the twisted boughs of the birch in some parts of the Scotch Highlands. Garnett.

\section{CA'RPINUS. Hornbeam.'}

* C. Bétulus. Common H. Bracteas of the fruit flat, oblong, saw-toothed, with two side lobes. E. B. 2032. Betulus sive Carpinus. G. E. 1479 .

Woods, hedyes.

Tree. May.

A low, rigid, elm-like tree. $\mathbf{S m}$.

\section{CO'RYLUS. Hazel-nut.}

C. Avellána. Common H. or Stock-nut. Stipulas egg-shaped, blunt. Leaves roundish, heart-shaped, pointed. Young branches hairy. Calyx of the fruit bell-shaped, torn at the edge, shorter than its nut. E. B. 723. H. L. 17. C. sylvestris. G. E. 1438. Hedges, copses.

Small tree. March.

$L s$. producel after the flowers, doubly saw-toothed, veiny. The catkins fall off entire. Styles vivid crimson, twelve or fourteen.

Makes good charcoal. Regular revenue raised from nut-woods, cut every sixteen years: freeholders of $£ 15$. or $£ 20$. per annum, make regularly $£ 60$. a-year by their nut-woods. (With.) The wood for fishing-rods, hoops; the shoots for springles to fasten down thatch, and for hurdles. Chips of hazel put into turbid wine to clear it. Twigs of hazel, twisted together, so as to be full of chinks, and steeped in ale during its fermentation, then hung up to dry, put into wort, instead of yeast. An oil from the nuts, used by painters. 'The divining rod, for the supposed discovery of water-springs, and metal, taken from the young forked twigs. See

1 From the hardness of the wood. 
Evelyn's Sylva, by Hunter, p. 223. See Quarterly Review. No. 44. in Article "Popular Mythology of the Middle Ages," pages 373, 374. and "Curiosities for the Ingenious." Duod. pages 155. to 161. "The divining-rod when held in a certain position, and under certain circumstances, is said to discover the situation of metals, \&c. in the earth, by dipping as it approaches the place beneath which they immediately lie."

\section{Class XXII. DIOECIA. Stamens and Pistils in separate flowers, on different plants.} (MONANDRIA. Stamen I.) Several willows. $\mathbf{S m}$.

\section{DIANDRIA.}

\section{SALIX. Willow, Sallow, and Osier.}

Linnæus observes, that the species of this genus are made out with very great difficulty. $S p . P l .1449$.

The differences found in the germens, styles, and stigmas, together with the shape of the leaves, afford good specific marks for the discrimination of Salices. Seasons for studying the Salices, or Willows, are 1st. their flowering time: 2ndly, the early part of summer, to observe their stipulas, before the leaves come to their full size, and 3rdly, when the leaves come to their full size. They inust be observed in their growing state for several seasons, to be well discriminated. The flowering period of willows is of short duration, during the greatest part of the summer we have no flowers to assist our investigations. The willows afford food for a great variety of insects. The large excrescences, on the branches and leaves of willows, are the nests of different species of insects (the Cynips.) The stamen-bearing willows should alone be planted in walks: the pistil-bearing ones multiply too fast, and form a thicket. ${ }^{1}$

\section{* Full grown leaves saw-toothed, smooth, or nearly so.}

\section{S. triandra. Long-leaved Triandrous $W$. Leaves} linear-oblong, saw-toothed, smooth; rather unequally sloping at the base. Stamens generally three. Germen stalked, egg-shaped, compressed, smooth. Stigmas nearly stalkless. E. B. 1435.

Wet woods, hedges, osier-grounds.

1 The Botanist will find a valuable collection of Grasses, British Willows, and Roses, cultivated in the Botanic Garden, Oxford. Several Willows have been lately planted round Christ-church Meadow. 
Tree. May and Auyust. Sm.

If suffered to grow, becomes a large tree. Ls. smooth on both sides, the base narrow, and sloping off, towards the stalk. Catk. cylindrical, yellow, with hairy, blunt scales. Nect. very blunt. Stig. spreading, cloven. Stam. twice as long as the scales.

It casts off its bark annually in large portions, like the planetree. Bark lightly astringent, bitterish, has been found serviceable in the cure of agues: in doses of one or two drachms.

Sa. amygdalina very much resembles this species. The narrower-leaved willows generally named osiers; this one of the most valuable for white basket work, producing rods eight or nine feet long, tough, and very durable. $\mathbf{S}$.

\section{S. Hoffmanniána. Short-leaved Triandrous $W$. Leaves} egg-shaped-oblong, saw-toothed, smooth ; slightly rounded at the base. Stamens three. Germen stalked, egg-shaped, compressed, smooth. Stigmas nearly stalkless. C. 6.72. E. B. Supp. 2620.

Bunks of rivulets. "Common almost every where about Oxford. Frequent also abont Rugby, Warwickshire, 1831." $B x$.

Shrub, or small tree. May.

A handsome species, growing from ten to fifteen feet high, casting its bark in the autumn like the other triandrous willows. Ls. egg-shaped, or egre-spear-shaped, with a very taper point; the under side light green, scarcely glaucous.

Differs from sa. triandra in its humbler growth, in the leaves being rounded at the base, and in the larger, rounded, ear-shaped stipulas: and from Sa. amygdalina in the leaves being not glaucous underneath, and in wanting the deep furrows of the young twigs, so remarkable in that species." Bx.

(S. amygdalina. Broad-leaved Triandrous $W_{0}$; or Almond-leaved W. Leaves egg-shaped, saw-toothed, smooth; rounded and unequal at the base. Stamens three. Germen egg-shaped, compressed, smooth ; its stalk almost as long as the scale. Stigmas nearly stalkless. Young branches furrowed. E. B. 1636.

Banks of rivers and ditches. $\mathrm{Pn}_{n} . \mathrm{Fl}$.

Shrub, or small tree. April, May; and again in August.

A large, bushy shrub, casting its bark.)

* S. pentandra. Sweet Bay-leaved W. Leaves eggshaped, pointed, notched, glandular, smooth. Foot. stalks glandular at the summit. Stamens five, sometimes less or more, hairy at the base. Germen eggshaped, tapering, smooth, nearly stalkless. E. B. 1805.

Neur vivers. Banks of the Cherwell, Christ-church Meadow, Oxford. $B x$.

Tree. June, July. 
Ls. broad, shining, closely notched, smooth on both sides. Footstalks short, glandular. Stipulas scarcely any. Catk. stamenbearing, ycllow, handsome, fragrant, rather thick. Ls. alternate, ascending. From fifteen, to twenty feet high.

Deserving of cultivation for its beauty and fragrance. Known by its broad, odoriferous leaves, whose serratures exude a yellow resin, and by its numerous stamens. The leaves afford a yellow dye. The down may be used for cotton, mixed with cotton. Down of willows, a lining for the nests of some kinds of birds.

* S. nígricans. Dark-broad-leaved $W$. Leaves ellipticspear-shaped, acute, notched, smooth, with a downy rib above; glaucous beneath. Stamens two, thrice the length of the hairy scales. E. B. 1213.

Fens, osier-grmunds. Banks of the Cherwell, Christ-church Meadow, Oxford. $B x$.

Shrubby. April.

Ls. a little rounded at the base, dark green. Foot-stalks very broad at their base. Catk. thickish, with inversely egg-shaped, brown, hairy scales. Branches brittle, dark coloured. Scarcely forms a tree. Ls. in drying become black. Ls. in the pistilbearing plant shorter, and less notched, more tapering towards the base.

S. vitellina." Yellow IV. or Golden Osier. Leaves spear-shaped, tapering to a point, with cartilaginous serraturss; smooth above; glaucous and somewhat silky beneatl. Stipulns minute, spear-shaped, fallingoff (deciluous, smooth. Germen stalkless, eggr-spearshaped, smooth. Scales linear-spear-shaped, acute, fringed at the base, longer than the pistil. E. B. 1389.

Osier-grounds, swamps.

Tree. May.

Branches yellow, shining. Ls. alternate. Catk. cylindrical, acute, appear with the leaves.

Known at a distance by the ycllow colour of its branches. A handsome tree of a moderate height, conspicuous for its gracefully drooping, golden twigs. The down of the seeds has been made into paper: the bark used for dying. Used for palms at Easter in the Greck Russian churches. A tough and flexible osier. Wood tough and white. The lopped pistil-bearing branches bccome straight.

* S. decipiens. White Welsh, or Varnished $W$. Leaves spear-shaped, pointed, saw-toothed, very smooth;

${ }^{1}$ From vitellus, the (yellow) yolk of an egg. 
floral ones partly inversely-egg-shaped and curved back. Foot-stalks somewhat glandular. Germen tapering, stalked, smooth. Style longer than the cloven stigmas. Branches smooth, highly polished. E. B. $193 \%$. Low meadows, moist hedges, osier-grounds. Christ-church Meadow, Oxford. $B x$. Tree. May.

"There is a large tree of this species of willow, growing by the side of the ditch round Christ-church Meadow, about a. stone's throw from the junction of the Cherwell and Isis. I should guess, from its size, that it cannot be less than fifty years old, and fifty feet high. The trunk, near the ground, measures six feet ten inches in girth. It has been confounded with Sa. fragilis, by some botanists, but it is very distinct from that, and may readily be distinguished from most other willows, by its cane-coloured shining twigs, as if varnished, and when not in leaf, having much more the appearance of a poplar, than a willow; whence it has been called the poplar-willow, and sometimes the cane-willow. The Rev. Dr. Walker, in his History of the Hebrides, vol. ii. p. 267, ' thinks it may probably be the Sa. amarina, of Pliny. Hoffmann appears to have been the first who distinguished this as a species. He has described, and figured it in his Historia Sálicum, published in 1785-7. The tree in Christ-church Meadow must, I think, have been growing there prior to that time." Bx. Oct. 23, 1830 .

S. frágilis. Crack $W$. Leaves egg-spear-shaped, pointed, saw-toothed throughout, very smooth. Footstalks glandular. Germen egg-shaped, abrupt, nearly stalkless, smooth. Scales oblong, about equal to the stamens and pistils. Stigmas cloven, longer than the style. E. B. $180 \%$.

Marshy grounds, banks of rivers.

Tree. April.

Catk. appearing with the leaves, coming forth at the base of the foot-stalk, with two or three very small leaves. Branches with a slight blow break off. Calk. stamen-bearing ones, cylindrical, scales inversely egg-shaped, villose (with soft hairs.) Nert. of two glands, yellow, the largest between the stamens and spike-stalk (rachis,) the smallest between the stamens and scale. Several other smooth willows are also brittle.

Remarkable for the crookedness of its branches, and its large, broad, dark, shining leaves.

Bees fond of the stamen-bearing flowers of this, and other willows. Caterpillar of the white satin moth, (Salicis) feeds on the leaves. Roots boiled for a considerable time, used by the Swedes to stain eggs purple. Fl. Suec. A similar ancient practice, in Scotland, at Easter. See Anemone Pulsatilla. 
(S. Russelliaina. Bedford W. Leaves spear-shaped, tapering at each end, saw-toothed throughout, very smooth. Foot-stalks glandular, or leafy. Germen tapering, stalked, longer than the scales. Style as long as the stigmas. E. B. 1808.

Banks of rivers, and ditches. $P$ r. $\mathrm{F} \%$

Tree. April, May.

A more handsome tree, of a brighter hue. Branches slender and straight, not angular at their insertion like Sa. fragilis. Timber and bark very valuable.) $\boldsymbol{S} m$.

* S. purpúrea. Bitter Purple W. Branches trailing, lying down. Leaves partly opposite, inversely eggspear-shaped, saw-toothed, very smooth; narrow at the base. Stamen one. Stigmas very short, egg-shaped, nearly stalkless. E. B. 1388 . C. 6.71 . f. 5 .

Low meadows, banks of rivers and ditches. In a ditch round Christchurch Meadow, Oxford. Bx.

Shrub. March.

Branches long, slender, tough, frequently purplish. Catk. stamenbearing ones, very slender, nearly stalkless. Scales black at the tip, hairy. Anth. orange-coloured, double, or four-lobed. Pistil-bearing catk. same in size and form. Germen stalkless, small, egg-shaped, silky.

Leaves and twigs extremely bitter.

Discrim. Differs, according to Sm. from Sa. Helix, by its spreading, decumbent habit, never becoming a tree; by its purple branches, smaller, and more slender catk. by its small, eggshaped, blunt, nearly stalkless stigmas. More rare than Sa. Helix.

Hoffmann unites the species Sa. purpurea, and Sa. Helix, under the name of Sa. monandra, followed in this by Curtis, and approved by Hooker in Fl. Scot. But see H. British Fl. 1830 .

Valuable osier for fine basket-work, but more especially for platting in a growing state into low, close fences, to keep out hares and rabbits, the leaves and bark being so bitter, that those animals will not touch either.

S. Helix. Rose $W^{2}$ Branches erect. Leaves partly opposite, oblong-spear-shaped, pointed, slightly sawtoothed, very smooth; linear towards the base. Stamen one. Style nearly as long as the linear, divided stigmas. E. B. 1343. S. monandra. C. 6.71. Sb. 16. Marshes, osier-grounds, banks of rinulets.

- So called, because the tops of the branches are sometimes expanded into little scaly heads, somewhat resembling roses: this is the effect of an insect. Curtis. 
Tree. May.

Discrim. Nine to ten feet. $L s$. more truly spear-shaped, and taperpointed than those of Sa. purpurea. Catk. pistil-bearing ones, somewhat longer, twice as thick, stand on longer stalks. Germen stalkless, egg-shaped, silky. Style considerably lengthened out, smooth, and naked. Stig. linear, lengthened out. Ls. also less glaucous, and not so bitter as in Sa. purpurea.

Branches pale yellowish, or purple ash. Ls. much lengthened out. Planted to keep up gravelly banks of rivers. Sa. purpurea, a more rare plant than this.

S. Lambertiána.' Boyton $W$. Branches erect. Leaves partly opposite, inversely egg-spear-shaped, pointed, saw-toothed, smooth; rounded at the base. Stipulas none. Stamen one. Stigmas egg-shaped, blunt, notched, very short, nearly stalkless. E. B. 1359.

Low meadows, osier-grounds, banks of rivers. At Harley Ford, near Henley-upon-Thames. Eng. Fl. and Turn. and Dillwyn, Bot. Guide.

Tree. March, April.

In height, and appearance resembles Sa. Helix, but with shorter leaves, foot-stalks short. Catk. smaller than in Sa. Helix; scales round, black; stig. different in shape. The young branches, and leaves much resemble those of a honey-suckle in their glaucous hue, with a purplish tinge, in their upper part. Ls. broad, spear-shaped, dilated above the middle, broader and shorter than those of Sa. Helix.

S. rubra. Green-leaved Osier. Stamens combined below. Leaves linear-spear-shaped, lengthened out, acute, smooth, with shallow serratures; green on both sides. Stigmas egg-shaped, undivided. E. B. 1145.

Low meadows, osier-grounds; rare. Between Maidenhead and Windsor. J. Sherard.

Tree. April, May.

A small tree, with long and narrow tawny brown leaves.

* Full grown leaves entire, more or less silky.

S. répens. Creeping Dwarf $W$. Leaves elliptic-spearshaped, straight, somewhat pointed, nearly entire; almost naked above; glaucous and silky beneath. Stipulas none. Stem depressed, with short, upright branches. Germen stalked, egg-shaped, downy. Capsules becoming smooth. E. B. 183. S. depressa. Sb. 16.

Sandy, mountainous heaths, where the ground is rather moist. Sm.

1 Found by Mr. Lambert, abundantly, near his family seat, at Boyton, Wilts. A good osier. Considered by Dr. Hooker, as a very slight variety of Sa. purpurea, or Sa. Helix, in Fl. Scotica But see his Br. Fl. p. 414. 1830. 
Shrub. May.

Young twigs woolly. Ls. egg-shaped, or ovally oblong. Catk. from the sides of the stem. Seed-ressel somewhat red. Stems taking root. Ls. with short foot-stalks, terminated by a short point. C'atk. numerous, alternate, short, blunt, scales inversely egg-shaped, blunt, hairy, reddish. Root thick, creeping, knotty, blackish. Ripens its caps. in June, and July.

Smallest of our common willows.

Sa. cinérea. See Appendix.

S. auríta. Round-eared, Trailing Sallow. Branches trailing. Leaves somewhat saw-toothed, convex, inversely egg-shaped, blunt, with a small, hooked point; hairy, and netted with veins, on both sides. Stipulas roundish, convex, toothed. Germen silky, stalked. Stigmas nearly stalkless. E. B. 1487.

Moist woods, and thickets.

Shrub. April.

Very branching, small tree, with hoary, brownish, ash-coloured branches. Ls. alternate, with short foot-stalks, when fully grown, curled, and waved. Stip. more frequently rounded, toothed, soft-haired, veiny, and persistent. Catk. from the very short side branches, solitary, cylindrical, scales brown, more or less hairy.

Smallest of the Sallows; not so general as Sa. aquatica : covered with small catk. in April, or May, while the leaves are just budding. Branches shoot horizontally to a great extent. $L \boldsymbol{s}$. vary much in size: known by their great ruggedness, inversely egg-shaped, or blunt form, and hooked point.

S. aquática. Water Sallow. Stem and branches erect. Leaves slightly saw-toothed, inversely egg-shapedelliptical, minutely downy, flat; rather glaucous beneath. Stipulas rounded, toothed. Germen silky, stalked. Stigmas nearly stalkless. E. B. 143\%. S. cinérea. With. S. acumináta. Sb. 17.

Wet hedge-rows, woods, swamps, banks of ponds, or rivers.

Shrub, or small tree. April.

$L s$. with short foot-stalks, more or less acute, even, scarcely rough, all soft, ash-coloured green, the upper surface ultimately becoming smooth, underneath sea-greenish, veiny, and a little hairy.

Nearly allied to Sa. aurita; much smaller in all its parts, than Sa. caprea. Catk. cylindrical, with small, brown-tipped, hairy scales, an oblong nect. to each. Ls. vary in size and shape, more or less inversely egg-shaped, downy, and veiny; thin, soft, pliable, flat, and not crisped, or waved, in which latter particulars they differ greatly from those of Sa. cinerea, and $\mathbf{S a}$. aurita. 
Dr. Hooker unites Sa. cinerea, and Sa. aquatica into one species. Fl. Scotica. But see his Br. Fl. p. 424-5.

One of the most common of all our willows. The bark has been made into coarse paper, and pasteboard; the wood excellent for fuel, also for stakes, and hurdles, and for waggon staves.

S. cáprea.' Great Round-leaved S. Stem erect. Leaves roundish, egg-shaped, pointed, saw-toothed, waved; pale and downy beneath. Stipulas somewhat crescent-shaped. Catkins thick and oval. Germen stalked, egg-shaped, silky. Stigmas nearly stalkless, undivided. Capsules swelling. E. B. 1488.

Woods, hedges.

Tree. April.

Twigs downy. Ls. variable in shape, alternate, foot-stalked, upper surface somewhat bare, and smooth. Stamens yellow. Seed-vessels foot-stalked, oval, bellying out at their base, shaggy.

Stip. only to the uppermost leaves.

Its showy, copious, yellow blossoms make a cheerful appearance in early spring. Its bark bitter, and astringent; has been recom. mended as a substitute for the Peruvian bark. Its wood useful for hurdles. Its bark may be used for tanning, and for dying linen yarn black. The wood tough, makes good charcoal for gun-powder, and for crayons. The catkins early food for bees.

Discrim. Easily known by its large, broad, roundish leaves, waved at their edges, and clothed beneath with a thick, white, cottony down. Catkins very thick, and blunt. Scales of the flower-buds silvery before expansion. Succeeds best in a dry soil.

The catkins vulgarly called goslings, from their similarity of colour, and appearance, about the time when goslings are hatched: covered with blossoms before the leaves appear.

Wood used for cutting-boards and whetting-boards of shoemakers, to smooth their knives upon. Lightfoot.

S. acumináta? ${ }^{2}$ Long-leaved S. Stem erect. Leaves spear-shaped-oblong, pointed, wavy, finely toothed; glaucous and downy beneath. Stipulas half-eggshaped; then kidney-shaped. Catkins cylindrical. Germen stalked, egg-shaped, hairy. Style as long as the undivided stigmas. E. B. 1434. S. caprea latifolia. G. E. 1390. leaves.

1 Literally goat's (willow, from supposition of goats browsing on it.

2 "Sibth. seems to include under this species, the Salix cinerea, and Sal. aquática of the Eng. Fl., both very common about Oxford. I have not yet met with the true Salix acuminata of Sm. Fl. Brit. Oct. 1830." Bx. S. acumináta var. rugósa. Sm. Common about the Cherwell. Christchurch Meadow. $B x$. With smaller, more rugged leaves, $\mathrm{Sm}$. 
Rather moist woods and hedyes, frequent. Sm.

Tree. April.

Tree scarcely so large as Sa. cáprea. $L s$. three to four inches, by one inch.

S. viminális. Common Osier. Leaves linear, very long, inclining to spear-shaped, lengthened out, taperpointed, entire, wavy : snow-white and silky beneath. Branches straight and slender. Germen stalkless. Style as long as the linear, undivided stigmas. E. B. 1898.

Wet meadows, osier-grounds, banks of rivers.

Tree-like. May.

Branches very long, silky. Ls. scattered, with short foot-stalks, somewhat erect: under side of the leaves with an elevated nerve, and numerous, diverging, somewhat parallel veins. Style lengthened out, and thread-shaped. Ls. longer than in any other species, narrow, almost linear. Caps. stalkless, eggshaped, silky.

Many varieties of this species, cultivated in osier-grounds: the value of the common-osier, for basket-work is universally known : is used also for hoops. Planted to keep up the banks of rivers. In thriving situations, and where osiers are in demand, osier-grounds have been known to pay an annual rent of ten pounds an acre: ordinarily, if properly managed, they pay four or five. With.

The specific distinctions of Sa. stipularis, and Sa. mollissima, rest, according to Dr. Hooker, upon very slight grounds; so nearly allied are they to Sa. viminális. Fl. Scotica. But see his Br. Fl. p. 423.

Discrim. Silvery appearance of the leaves underneath, the long, and slender nect. of the stamen-bearing flowers, and the very long style of the pistil-bearing flower.

Osiers differ from sallows in their long, straight, flexible, and mostly tough twigs; their generally stalkless germens, and lengthened out styles and stigmas. $\mathbf{S}$.

(S. Smithiána. Silky-leaved Osier. Leaves spearshaped, pointed, slightly wavy, minutely toothed; soft and scarcely visibly downy above; whitish and silky beneath. Stipulas crescent-shaped, minute. Catkins egg-shaped. Germen stalked. Style shorter than the linear, deeply divided stigmas. S. mollissima. E. B. 1509.

Meadows and osier-grounds. Pn. Fl.

Shrub. April, May.

Shrub, with reddish, wand-like, but brittle twigs.) Sm.

(S. stipulúris. Auricled Osier. Leaves spear-shaped, pointed, slightly wavy, obscurely notehed; soft and 
nearly naked above; white and downy beneath. Stipulas half-heart-shaped, stalked, very large. Nectary cylindrical. Germen egg-shaped, nearly stalkless, as well as the linear, undivided stigmas. E. B. 1214. Osier-beds. Pn. Fl.

Shrub. March.

Shrub, with upright, downy, reddish, tall, but brittle twigs. Ls. about a span, almost upright.)

S. alba. Common White $W$. Leaves elliptic-spearshaped, pointed, saw-toothed, silky on both sides; the lowest serratures glandular. Stamens hairy. Germen smooth, almost stalkless. Stigmas deeply cloven. Scales rounded. E. B. 2430. Salix. G. E. 1389.

Moist woods, low pastures, meadows.

Tree. May; often again in July. Sm.

$L s$. alternate, with short foot-stalks, taper-pointed, acutely and regularly, finely saw-toothed. Catk. lengthened out, slender. Scates elliptically spear-shaped, brown, downy. Stamens yellow, a little longer than the scales.

When allowed to grow without lopping, becomes a very large and lofty tree; soon decays, if lopped. The wood is white, agreeable to burn, as not smoking, and affording a regular heat: from its whiteness preferred for making milk-pails, and butter-firkins: used also for flooring, for chests, and boxes. The bark, boiled with water, in a copper vessel, will dye wool or silk of a blood-red; with the addition of a little alum, of a cinnamon colour. The bark recommended in the cure of agues by the Rev. Mr. Stone, Phil. Trans. v. 53. p. 195. a drachm of the powdered bark, given every four hours, between the fits. The bark of the Sa. triandra, Sa. fragilis, and Sa. caprea, have the same properties. See White's Observations, \&c. on the Broad-leaved Willow, (Sa. caprea,) Bath, 1798. This species one of the best in the genus for tanning: of very rapid growth: a good tree to plant in avenues, for its agreeable shade, and the beautiful, silvery appearance of the leaves. The inner bark has afforded a miserable substitute for bread.

\section{DIOECIA TRIANDRIA.}

\section{RUSCUS. Butcher's-broom. ${ }^{\text {I }}$}

R. aculeátus. Common B. Leaves egg-shaped, with very sharp-pointed thorns, flowering on the upper side without a leaflet. E. B. 560. Ruscus. G. E. $90 \%$. Hedges, woods. Between Caversham and Mapledurham. Sb. 
Woods in Counties of Oxford, and Berks; not far from Reading. Bobart in Raii Syn.

\section{Per.? March.}

Biennial? evergreen for one winter, herbaceous. Stems about two feet, round, branched, stiff, slightly furrowed. Ls. dark green, alternate, spreading, twisted, hard, entire, tipped with a sharp thorn; bearing a solitary flower about the middle, on the upper side. Berry globular, large, scarlet. Fl. in reality, on a foot-stalk, from the bosom of the leaf, yellowish white.

Bacon and cheese defended from the mice, by its sharp, prickly leaves and boughs placed round them.

\section{DIOECIA TETRANDRIA.}

\section{VISCUM. Mistletoe.}

$\boldsymbol{V}$. album. Common White M. Leaves spear-shaped, blunt. Stem forked, with stalkless, intermediate heads, of about five flowers. E. B. 1470. Viscum. G. E. 1350.

Parasitical on the Apple-tree, Oak, \&c. Near Bland's Court. Sb. Ipston. $B \boldsymbol{B}$.

Small Shrub. May.

Stems straddling, repeatedly forked, pale greenish. Ls. opposite, entire, smooth, permanent, colour of the stem, leathery. $\mathbf{F l}$. in small, axillary heads, stalkless, yellowish. Anth. pitted over. Berry globose, white, semi-transparent, full of clamrny pulp.

Bird-lime from the berries, and bark. The berries eaten by the Thrush, Fieldfare, \&c. pass through them, and adhere to the bark of trees, where they vegetate. Plant eaten greedily by sheep. This the sacred plant of the Druids. ${ }^{1}$ Used to dress up churches and houses at Christmas. ${ }^{2}$ Formerly prescribed in epilepsy.

\section{DIOECIA PENTANDRIA.}

\section{HU'MULUS. Hop.}

H. Luipulus. Common Hop. (One sp. only known.) E. B. $42 \%$ Lupus salictarius. G. E. 885 .

Thickets, hedges.

Per. June.

Stems twining, from right to left, angular, rough, leafy. Ls. opposite, foot-stalked; upper heart-shaped, undivided; lower ones, three, or five-lobed, saw-toothed, veiny, rough. Stip. bent back. $F l$. greenish-yellow, pistil-bearing ones, bitter, fragrant.

1 See History of Druidism, in Henry's England, vol. i.

2 See "Selection from Gent. Mag." vol. i. p. 245. 
Its climbing twigs, vine-like leaves, and clustered, and catkined flowers ornamental. The use of the catkins of the hop in beer, first introduced in the beginning of the sixteenth century, and then considered as an adulteration of the liquor. Covering hop-grounds with stones recommended to prevent the breed of insects, (áphides) upon them. The young shoots eaten in the spring. Cloth, and paper, may be made from the stalks, steeped in water and beaten. The plant will dye wool yellow.

Tinct. and extract of hops, mild opiates. Pillow of hops said to have the same opiate effect. Linn. in Sp. Pl. puts this strange question under H. Lupulus: what is that electric murmur, like very distant thunder, when the wind agitates the hop-poles? Seeds used in constipation. $\quad \boldsymbol{F}$. Suec.

\section{DIOECIA HEXANDRIA.}

\section{TAMUS. Black Bryony.}

T. communis. Common B. Leaves heart-shaped, undivided, acute. E. B. 91. Bryonia nigra. G. E. 871 . Hedges, thickets, groves, woods.

Per. June.

Root blackish outwardly. Stems slender, long, twining, though without tendrils. $L s$. dark green, variable in shape, from kidney, to heart-spear, and triangular-spear-shaped, and to halbert-shaped. $\mathbf{F l}$. greenish. Berries red.

The tawny leaves, and red berries, a decoration to our hedges, in autumn. Root acrid, formerly used as a stimulating plaster. The young shoots eaten as asparagus.

\section{DIOECIA OCTANDRIA.'}

\section{PO'PULUS. Poplar.}

P. alba. White P. Abele-tree. Leaves lobed and toothed; somewhat heart-shaped at the base; snowwhite and densely downy beneath. Fertile catkins egg-shaped. Stigmas four. E. B. 1618. G. E. 1486.

Moist woods.

Tall tree. March.

Root creeping, with abundance of suckers. Bark smooth: branches 
horizontal. Ls. nearly triangular, alternate, more or less deeply cut into rather acute lobes; above dark green, smooth. Stip. on young branches, linear-spear-shaped, toothed. Scales of the catk. hand-shaped, hairy, jagged. Anth. violet. Leaf-stalks flat, grooved on each side. $\mathbf{F l}$. like those of Pop. trémula. Ls. roundish in the young trees. Ls. without glands at the base and serratures. Linn.

Eaten by horses, sheep, and goats. Of very quick growth, at maturity in some places in twenty years. For avenues in moist grounds. Wood not easily liable to take fire, nor to blaze. The wood is white, soft, tough, and of a close grain, serving for wainscotting, floors, laths, packing boxes, \&c.

P. canéscens. Grey $\boldsymbol{P}$. Leaves roundish, deeply waved, toothed; hoary and downy beneath. Fertile catkins cylindrical. Stigmas eight. E. B. 1619. P. alba, foliis minoribus. G. E. $148 \%$.

Wet, turfy meadous. Sm.

Tree. March.

Branches more upright and compact than in Pop. alba. Trunk grey, silvery, wood much firmer. Ls. rounder, much less white, less deeply or acutely lobed, than those of Pop. alba. Pistilbearing catk. longer, scales more cut and hairy. Stig. spreading in two opposite directions.

P. trémula. Aspen, or Trembling $P$. Leaves nearly round, toothed; smooth on both sides. Foot-stalks compressed. Young branches hairy. Stigmas four, erect, with an ear-appendage at the base. E. B. 1909. P. Lybica. G. E. $148 \%$.

Moist woods.

Tree. March.

$L s$. with a little point, bluntly toothed, entire at the base, quivering with almost every breath of air, by their long, vertically flattened foot-stalks. Stip. bristle-shaped, visible on the most luxuriant shoots only. Catk. scales of the pistil-bearing flowers hand-shaped,jagged. Germen short, thick. Stig. crimson. At the base of the young leaves, two united glands.

Leaves beset sometimes with red globules, the nest of a Tipula, (an insect.) Bark smooth, green, used for torches: favourite food of beavers. $\mathbf{F l}$. Suec. Drives away crickets. $\mathbf{F l}$. Suec. Grows in all situations, and in all soils. Wood light, woolly, soft, durable in the air. The Highlanders, according to Lightfoot, suppose our Saviour's cross made of this tree, and that hence its leaves never rest.

P. nigra. Black $P$. Leaves deltoid, pointed, sawtoothed, smooth on both sides. Catkins all lax and 
cylindrical. Stigmas four, simple, spreading. E. B. 1910. G. E. 1486.

Watery places, banks of rivers.

Tree. March.

Footstalks only half as long as the leaves. Is. trowel-shaped, deep green. Catk. drooping. Germ. lengthened out, slender, egg-shaped.

Wood not apt to splinter : for gun-stocks. Bark to support the nets of fishermen. 'The red berry-like substances on the leaves, occasioned by an insect. Grows rapidly; bears cropping. Inner bark has been converted into bread, in Kamtschatka. Paper may be made of the cotton-down of the sceds. Roots dissolve into a jelly-like kind of substance, formerly used for bringing on a callus in fractured bones.

\section{DIOECIA ENNEANDRIA.}

\section{MERCURIA'LIS. Mercury.}

M. perennis. Perennial Rough M. Stem perfectly simple. Leaves rough. Root creeping. E. B. 1872. C. 2. 65. Cynocrambe. G. E. 333.

Banks, bushy places, groves.

Per. April.

Stems one foot high. Ls. rough, opposite, stalled, egg-shaped, saw-toothed, dark green. Supposed nect. very narrow, rising above the styles. Starnon-bearing spikes longer than the leaves. Caps. rough, hairy. Fl. green.

Fetid, very poisonous. Sir H. Sloane, in Raii Syn. Has been recommended as a pot-herb: its virulence diminished by boiling. In drying, turns blue: steeped in water, affords a fine, deep blue, not fixable. Lightfoot mentions that the infusion has been taken to bring on a salivation : the experiment dangerous with so poisonous a plant.

M. ánnua. Annual Smooth M. Stem with branches crossing. Leaves oblong, smooth. Root fibrous. Barren flowers in numerous, spiked, alternate tufts. E. B. 559. C. 5. 68. M. mas et fomina. G. E. 332. Waste, or cultivated ground.**?

An. August.

Plant darkish, fleshy, shining green, fetid. Ls. egg-shaped, acute, saw-toothed. Pistil-bearing flowers axillary, on simple footstalks, about two together, sometimes with a stamen-bearing $f$. Caps. double, prickly. 
Qualities similar to those of M. perennis, but less virulent: removes warts : mucilaginous: purgative, as a syrup.

\section{HYDRO'CHARIS. Frog-bit.}

\section{H. Morsus rance. Common F. E. B. 808. C. 3. 64. Morsus ranæ. G. E. 818.}

Ditches, ponds.

Per. July.

$F l$. proceeding from brown, membranous stip. with straight, sim. ple roots. Plant smooth. Ls. floating, kidney-shaped, entire, often purple underneath. $F l$. white, centre yellowish, sometimes with six pet. The removal of the outer skin of the dry leaves, discovers a beautiful net-work of veins. Plant increases by runners.

\section{DIOECIA MONADELPHIA.}

\section{JUNI'PERUS. Juniper.}

J. commúnis. Common $J$. Leaves three in each whorl, tipped with a thorn, spreading, longer than the ripe fruit. Stem erect. E. B. 1100. Juniperus. G. E. 1372. Hills, heathy downs. Stokenchurch Hills. Sb. Between Blenheim and Ditchley. $\boldsymbol{M r}$. Woodward. Juniper Hill. E. B. Headington Quarry. $B x$. Near the Grotto, Basildon, Berks, R. $W$.

Low shrub. May.

Stems and branches intricate, widely spreading. Ls. sharp-pointed, linear, smooth, evergreen, glaucous on the upper side. Catk. axillary, small, stalkless, with tiled bract. Berry round, green; when ripe, in two years dark purple, with a glaucous tinge, sweetish. Juice of the plant resinous. Plant variable in growth.

Easily transplanted. Wood hard, durable, for veneering, \&c. Bark for ropes. From the berries gin, diuretic. Gum Sandarach, or Pounce, from this shrub. The true Geneva, a malt spirit, distilled a second time, with Junipers added. The berries, according to With., left out, and the flavour given to the spirit by oil of turpentine. Berries eaten by thrushes and grouse, give the flesh a pitchy taste. Infusion of the berries with gin, for dropsical patients. A Beer from the berries, among the Swedes. Juniper wood cinders keep light a long time. Oil of Juniper acts on the kidnies powerfully like turpentine. 


\section{TAXUS. Yew'}

*T. baccáta. Common Y. Leaves two-ranked, crowded, linear, flat. Receptacle of the barren flowers globular. E. B. 746. Taxus. G. E. 1370 .

Woods. Churchyards. Cornbury Quarry. Sb. A very ancient Yew, in Iffley Church Yard. J. H.

Tree. March.

Trunk straight, smooth, with deciduous bark. Ls. dark green, smooth, evergreen. Fl. axillary, with tiled bract. Stamenbearing $f$. sulphur-coloured, without cal. Pistil-bearing ones with a small, green cal., which at length becomes of a fine red colour, waxy, and soft, surrounding the seed.

Wood hard, beautifully red grained: at present, for inlaying, and for mill-wheel cogs. Planted in church yards for its funeral appearance, and for archers' bows anciently. Bears clipping well, hence suited to the now obsolete Dutch taste of gardening, and cut into various grotesque shapes. Makes excellent screen-hedges. The berries sweet, innocent: the green leaves deadly poisonous. Tree said to attain more than four hundred years. 'Tree of great diameter: one mentioned by Lightfoot, and seen by Pennant, of fifty-six feet and a half in circumference. Bears transplanting when old. Berries of the yew, sweet, mucilaginous, eatable. R. W. Seeds poisonous? J. H. See Richard, Botanique Medicale.

\section{Class XXIII. POLYGAMIA.}

\section{Order I. MONOECIA.}

A'TRIPLEX. Orache.

A. pátula. Spreading Halbert-leaved 0 . Stem herbaceous, spreading. Leaves triangular-spear-shaped, somewhat halbert-shaped. Calyx of the fruit (warty) tuberculated at the sides. E. B. 936. A. hastáta. C. 2. 66 . Sb. 90. A. sylvestris vulgaris. G. E. 326.

Cultivated, and waste ground, dungliills.

An. August.

Root fibrous. Ls. alternate, stalked, mealy beneath : lower ones halbert-shaped, one of the auricles sometimes wanting, deeply, irregularly toothed; the upper more narrow, spear-shaped, mostly

1 Ang. Sax. See some fine lines to the "Yew," in Mr. Gillet's pleasing little volume, entitled the "Juvenile Wreath," \&c. p. 37. Duod. 1832. See also, "Selection from Gent. Mag." vol. i. p. 346. 
entire. $\boldsymbol{F l}$. clusters terminal, and from the side, long, interrupted, somewhat leafy. Valves of the seeds toothed only at the edges. Seeds dotted.

Sometimes used for a pot-herb, like spinach. $L s$. and stem beautifully studded with shining particles, when covered with early dew.

A. angustifólia. Spreading Narrow-leaved O. Stem herbaceous, spreading. Upper leaves spear-shaped, entire; the lower ones somewhat halbert-shaped. Calyx of the fruit halbert-shaped, slightly warty at the sides. E. B. 1774. A. patula. Sb. 90. A. sylvestris angustifolia. G. E. 326.

Cultivated and waste ground.

An. August.

Stems more straddling than in Atr. patula; deep, glaucous hue, slightly furrowed. Ls. lower ones, halbert-shaped, not toothed, nor sinuated : upper, spear-shaped, entire, all spreading horizontally. Cal.valves entire at the edge, disk either smooth, or with only a few tubercles. Seed half the size of Atr. patula, scarcely dotted.

Considered by Hooker as a var. of Atr. patula, in Fl. Scotica. Doubtfully distinct: not constant to its characters. Greville.

Found with Atr. patula: both species conspicuous by their long, straight, straddling branches, with enlarged calyx, by which last mark, an Atriplex is distinguished from a Chenopódium.

END OF THE PHENO'GAMOUS ' FLORA OF OXFORDSIIRE, AND its CONTIGUOUS COUNTIES.

1 Phanogamous plants, are flowering plants, in contradistinction to Mosses, Lichens, \&c. of the Class Cryptogamia. 



\section{APPENDIX.}

(MOSTLY PLANTS OF THE CONTIGUOUS COUNTIES.)

* Fráxinus heterophylla. Simple-leaved Ash. Leaves both simple and compound, with tooth-like serratures. E. B. 2476 .

Woods and hedges. See Flora, page 3.

Tree. April, May.

$L s$. occasionally in threes, or even of five leaflets.

A variety of $\mathbf{F r}$. excelsior? $\mathbf{S} m$.

Gálium ánglicum. Wall Bed-straw. Leaves about six in a whorl, spear-shaped, pointed, fringed with prickles. Stem straggling, rough. Flower-stalks cloven. Fruit granulated, without hairs. E. B. 384.

Walls, and dry, sandy ground. Warwickshire. Pn. Fl.

An. June, July.

Scarcely a span. $\mathbf{F l}$. few, pale yellow. $\mathbf{S}$.

Rúbia peregrina. Wild Madder. Leaves four or more, in a whorl, elliptical, shining and smooth on the upper side. Flowers five-cleft. E. B. 851.

Thickets, on stony, or sandy ground. St. Vincent's Rocks, Gloucestershire. Turner.

Per. June, August.

Ls. evergreen, broad. Berry black. Sm.

Lonicéra Xylósteum. Upright Fly Honeysuckle. Stalks two-flowered. Berries distinct. Leaves entire, downy, E. B. 916. Periclymenum rectum germanicum. G. E. 1294 .

Thickets, and rocky places; rare. Edgbaston Park. P. Warwickshire. Withering in Tur.

Shrub. July.

Stem erect, bushy, four to five feet. $F l$. small, reddish, or creamcoloured. Sm.

Ribes alpinum. Tasteless Mountain Currant. No prickles. Clusters always erect. Bracteas longer than 
the flowers. Leaves polished at the back. Berries smooth. Stem erect. E. B. 704.

Woods, rare. See Flora, p. 67.

Shrub. May.

Berry red, insipid, mucilaginous. Sm.

Ribes nigrum. Black Currant. No prickles. Clusters hairy, drooping, with a separate flower-stalk at the base of each. Flowers oblong. E. B. 1291. R. n. 3. G. E. 1593.

Sandy swamps and thickets, banks of rivers. See Flora, p. 67.

Shrub. May.

Ls. strongly scented when rubbed. Berry black. Sm.

Pimpinella dioica. Dwarf Burnet-saxifrage. Leaflets all nearly linear. Umbels panicled. Flowers diøcious. E. B. 1209. Peucedanum púmilum. G. E. 1054.

Limestone rocks; rare. See Flora, p. 83.

Per. May, June.

Glaucous, even, about a span high. $S \mathrm{~S}$.

Scilla autumnális. Autumnal Squill. Leaves linear, numerous. Cluster slightly corymbose. Flower-stalks without bracteas, ascending, the length of the flowers. E. B. 78. C. 6. 25. Hyacinthus autumnalis minor. G. E. 110. See Flora, p. 94 .

Dry pastures.

Per. September.

Stalk three inches. $L$ s. channelled, numerous. $F$. rosecoloured. Stam. reddish; pistil blue. Sm.

Oxy'ria reniformis. Kidney-shaped Mountain-sorrel. Rumex digynus. E. B. 910 .

Near mountain rills. See Flora, p. 101.

Per. June.

Stem erect, eight inches. Ls. kidney-shaped, abrupt. Sm.

Andrómeda polifólia. Marsh Andromeda. Clusters terminal. Leaves alternate, spear-shaped, rolled back; glaucous beneath. E. B. 713.

Mossy bogs. Iver Heath. Bucks. Tur.

Shrub. June.

Six to nine inches, evergreen. $\mathbf{F l}$. white, or reddish, drooping. $\mathbf{S} m$.

Siléne nutans. Nottingham Catchfly. Panicle with drooping, partly forked, branches; from one side of the stem only. Petals deeply cloven, with linear-segments, and an acute, cloven scale. Leaves elliptic-spear 
shaped, downy. E. B. 465. Lychnis sylvestris alba nona Clusii. G. E. 470.

Limestone rocks. See Flora, p. 122.

Per. June, July.

Cal. half an inch long, its ribs downy. $F l$. white, fragrant in the evening. $\mathrm{Sm}$.

Sedum rupestre. St. Vincent's Rock Stonecrop. Leaves glaucous, spurred at the base, those of the branches awl-shaped, erect, in five close rows. Flowers imperfectly cymose. Calyx segments, elliptical, blunt. E. B. 170 .

Rocks, rare. See Flora, p. 127.

Per. July.

Reddish, eight to nine inches. $L s$. closely tiled. Pet. yellow. $\mathbf{S} m$.

Rosa spinosissima. Burnet Rose. Flower-stalks without bracteas, mostly smooth, as well as the simple calyx. Fruit globose, abrupt, somewhat depressed. Prickles of the stem straight, unequal, numerous, intermixed with glandular bristles. Leaflets roundish, smooth, with simple serratures. E. B. 187.

Sandy heaths. See Flora, p. 138.

Shrub. July.

Of humble growth. Pet. white. Fruit black. Sm。

"Rosa sépium. Small-leaved Sweet-briar. Prickles numerous, larger curved, smaller, awl-shaped. Leaflets small, doubly saw-toothed, hairy, acute at each end, glandulose beneath. Calyx-segments and pinnæ lengthened out. Fruit smooth, (ovate)" Lindl. Syn. p. 101. De Cand. Fl. Fr. ed. 3. v. 6. p. 538.

Near Bridport, Warwickshire. Rev. W. T. Bree.

Shrub. June.

A densely branched bush, about three feet high, distinguished in the common French plant by long, slender, flexuose twigs, with large, nearly straight, or falcate, or even uncinate, prickles, and small, distant, spear-shaped leaflets, mostly seven, acute, (mostly, but not invariably, ) at the base as well as at the point. 'The petioles are glandulose, sometimes hairy, and bear a few straightish or curved prickles. The peduncles and calyxtube are usually naked, but occasionally both, or the former only, bear setæ, which are larger on the base of the tube, although less remarkably than in R. rubiginosa. The calyxsegments are variously glandulose, and the narrowly spearshaped pinna issue more or less exactly at right angles, and have little sharp divaricated, gland-tipped teeth. The 
styles are included, and very slightly hairy. In Mr. Bree's plant, which I have seen only under cultivation, I find but little difference, except that the ramuli are less flexuose, and the leaflets not remarkably distant, rather larger, and more hairy, almost shaggy beneath. The pinna of the calyx are less divaricated, and have glands on the edges only, (as they have in a specimen gathered by Mr. Woods, at Troyes, which, also, has larger leaflets.) The flowers are white, clustered or solitary, according, as usual, to their situation on the bush. The fruit is scarlet, egg-shaped, (rounded at the base,) when solitary: I have no note of its shape in the bunches.' The prickles, which have a few setce among them, are numerous, the larger ones strongly hooked. Whether setæ exist in the foreign plants I know not; I find none in $\mathrm{my}$ limited number of specimens. Desvaux, Journ. de Bot. for 1813. v. ii. p. 116. assigns to this species nine vars. and describes five of them as wanting glands, or bearing them only on the petioles. He expresses a strong persuasion that both $\mathbf{R}$. sepium and $\mathbf{R}$. rubiginosa pass into $\mathbf{R}$. canina." Hooker's Brit. Fl. v. 1. p. 235, 236.

Potentilla verna. Spring Cinquefoil. Root leaves of five or seven inversely-egg-wedge-shaped, partly saw. toothed, furrowed leaflets; bristly at the edges and ribs beneath. Upper stipulas dilated. Calyx-segments partly three-ribbed. Stems trailing. E. B. 3\%. Pentaphyllum incánum minus repens. G. E. 989.

Elevated pastures. See Flora, p. 145.

Per. April, May.

Stems spreading all round. $\boldsymbol{P} e t$. yellow.

* Stratiótes aloídes. Water Aloe, or Water-soldier. Leaves sword-shaped, channelled, with a prominent rib, and sharp marginal prickles. E. B. 379. Militáris aizoídes. G. E. 825.

Pools, and ditches. In the Isis, near the cottages, Nuneham Park. Mr. Hewlett, Botanic Garden, Oxford. Fen ditches, Northamptonshire. Morton in Turner, \&c. See Flora, p. 152.

Per. July.

Putting forth suckers (stoloniferous, floating. $F l$. white; some imperfect. $S m$.

'Ajuga Chama'pitys. Ground Pine. Yellow Bugle. Stem spreading, branched. Leaves in three, deep, linear, entire segments. Flowers solitary, axillary, shorter than the leaves. E. B. 77 . Chamæpitys mas. G. E. 525 .

1 De Candolle describes the fruit of the French plant as longer than that of $\mathbf{R}$. rubiginosa. 
Sandy fields, rare. See Flora, p. 160.

An. April, May.

Hairy, glutinous, aromatic. $\mathrm{Fl}$. yellow.

Mentha rotundifolia. Round-leaved Mint. Spikes interrupted, somewhat hairy. Leaves elliptical, blunt, wrinkled, sharply notched, shaggy beneath. Bracteas spear-shaped. E. B. 446.

Moist, waste ground, rare. See Flora, p. 163.

Per. August, September.

Green, viscid; smell acrid. Stam. prominent. Sm.

Mentha rúbra. Tall Red Mint. Flowers whorled. Leaves egg-shaped. Stem upright, zigzag. Flowerstalks, and lower part of the calyx, very smooth; its teeth hairy. E. B. 1413. M. sativa rubra. G. E. 680.

Ditches, and watery places. See Flora, p. 164.

Per. September.

Smoothish, four to six flowers. $\mathbf{F l}$. large, reddish. $\mathbf{S m}$.

Lepídium ruderále. Narrow-leaved Pepperwort. Stamens two. Petals none. Leaves smooth; lower ones wing-cleft, toothed; upper, linear, entire. Pouch notched. E. B. 1595. Thlaspi minus. G. E. 262. Waste ground, muddy, or calcareous soil. See Flora, p. 184.

An. June.

Plant one foot. Ls. fleshy. $\mathrm{Fl}$. minute. $\mathrm{Sm}$.

Hutchinsia petraa. Rock Hutchinsia. Leaves winged, entire. Petals scarcely equal to the calyx. Stigma stalkless. Seeds two in each cell. H. L. 31. Lepidium petræum. E. B. 111.

Limestone rocks, and walls. See Flora, p. 184.

An. March, April.

Stem branched, two to three inches, smooth. $F l$. small, white. Sm.

Láthyrus palustris. Blue Marsh Vetchling. Stalks many-flowered. Tendrils branched, each bearing several elliptic-spear-shaped leaflets. Stipulas spear-shaped. E. B. 169 .

Boggy meadows and thickets. Wood near Abingdon, Berks. Tur. Per. July, August.

Plant four feet, stalk winged. Fl. variegated with blue and purple. Sm.

Trifólium ornithopodioides. Bird's-foot Trefoil. Flow$\mathrm{x} 2$ 
ers about three together. Legume prominent, eightseeded, twice as long as the calyx. Stems reclining. E. B. 1047 . C. 2. 53 .

Barren, gravelly pastures. Near Oxford. Ray.

An. June, July.

$\boldsymbol{F l}$. slender, pale reddish; keel very small. $\mathbf{S}$.

Hypericum dúbium. Imperforate St. John's wort. Styles three. Stem obscurely four-angled. Leaves blunt, nearly destitute of transparent dots. Segments of the calyx elliptical. E. B. 296.

Rather mountainous groves and thickets. Near Meriden, Warwickshire. Tur.

Per. July, August.

Young root shoots bright red. $F l$. yellow. Sm.

Leontodon palustris. Marsh Dandelion. Outer scales of the calyx shorter, tiled, egg-shaped. Leaves sinuated and toothed, not quite smooth. E. B. 553.

Low, boggy meadows. Rare. Bog in Windsor Great Park, Berks. Tur.

Per. June, July.

Smaller. Fl. stained with red outside. Sm.

Hierácium amplexicaule. Stem-clasping Hawkweed. Glandulous hairy. Stem corymbose. Leaves toothed: root ones oblong-egg-shaped, with leaf-stalks; stalkleaves heart-shaped at the base, clasping the stem. Allionii Flora Pedemontana, tab. xv. f. 1. Suppl. E. B. 2690.

Walls. Naturalized on the walls of Oxford Garden.

Mr. Bicheno observes, that it has an equally good right to a place in the British Flora as Senecio squalidus, and some other plants.

Per. August.

A most distinct and well marked species, every where clothed with brownish glandular hairs, most thick on the peduncle and involucre. The lower stalk-leaves are more or less oblong, the upper ones truly heart-shaped. Hooker's British Flora. The plant smells like tallow. $B \cdot x$.

Hypochæris maculáta. Spotted Cat's-ear. Stem solitary, rearly naked, mostly simple. Leaves egg-shapedoblong, undivided, toothed. E. B. 225. Hieracium primum latifolium. G. E. 301 .

Chalky hills. Bernak Heath. Ray in Tur.

Per. July. 
Ls. rough, spotted. $\quad F l$. large, yellow. Sm.

Hypochæris glabra. Smooth Cat's-ear. Nearly smooth. Calyx oblong, regularly tiled. Stems branched, somewhat leafy. Leaves toothed or sinuated. Down of the marginal seeds stalkless. E. B. 575. C. 3. 53.

Gravelly yround. On the gravelly grounds near Middleton, Warwickshire. Ray. Washwood Heath, near Birmingham. Withering in Tur.

An. June, August.

Various in size. $F l$. small, bright yellow. $S m$.

Lápsana pusilla. Dwarf Nipple-wort. Swine's Succory. Stalks immediately from the root, leafless, subdivided; swelling and tubular at the summit. Leaves inversely-egg-shaped, rough-edged, toothed. H. L. 65. Hyóseris minima. E. B. 95. H. mascula. G. E. 288 .

Gruvelly fields. Sandy fields, Spratton, plentifully, Northamptonshire. Morton in Tur.

An. June.

Ls. depressed. $\mathbf{F l}$. small, yellowish. Sm.

Centauréa solstitiális. Yellow Star-thistle. St. Barnaby's thistle. Flowers terminal, solitary. Calyx-scales doubly thorny. Stem winged, from the spear-shaped, unarmed leaves running down the stem (decurrent); root leaves lyre-shaped. E. B. 243. Cárduus solstitialis. G. E. 1166 .

Cultivated fields, hedges; rare. See Flora. p. 250.

An. July to September.

Stem one foot and a half to two feet. $F l$. bright yellow. Sm.

Cypripédium Calcéolus. Common Lady's Slipper. Stem leafy. Appendage to the column elliptical, blunt, channelled. Lip somewhat compressed, shorter than the petals. E. B. 1. H. L. 4\%. Calceolus Mariæ. G. E. 443 .

Mountainous woods; very rare. See Flora, p. 260.

Per. June.

One foot. $F l$. of a rich dark brown; lip swollen, yellow. $\mathbf{S m}$.

Carex curta. White Carex. Spikelets about six, elliptical, slightly distant, scarcely bracteated. Scales eggshaped, membranous, about as long as the egg-shaped, swollen, smooth fruit. E. B. 1386. Host. V. 1. 3\%. 48. Schk. Car. 43. t. C. 13. 
Watery meadows, borders of pools and ditches. At Virginia Water, Windsor Forest. Bp. of Carlisle. Sm. E. Flora.

Per. June.

One foot. Spikes short, of a silvery hue. $\mathbf{S}$.

Carex Oederi. Oederian Carex. Sheaths and flowerstalks all very short. Fertile spikes, roundish-eggshaped. Fruit globular, triangular, direct, smooth, with a straight cloven beak. Stem smooth. E. B. 1773.

Wet commons. See Purt. Flora.

Per. July.

Of humble growth, and less yellow than C. flava. Sm.

Carex fulva. Tawny Carex. Sheaths tubular, lengthened out, shorter than the flower-stalks. Fertile spikes, egg-shaped, erect. Scales pointless. Fruit egg-shaped, triangular, direct, smooth, with a straight, cloven, rough-edged beak. Stem rough. E. B. 1295. Schk. Car. 101. t. T. $6 \%$

Boggy meadows. Virginia Water, Windsor Forest. Rev. Dr. Goodenough, in Tur.

Per. June, July.

Slender, twelve to fifteen inches. Spikes tawny brown. Fruit brownish. $\mathrm{Sm}$.

Carex binervis. Green ribbed Carex. Sheaths tubular, lengthened out, shorter than the flower-stalks. Fertile catkins cylindrical, distant; partly compound. Scales pointed. Stems smooth. Fruit with two principal ribs. E. B. 1235 . Schk. Car. t. R. r. r. 160. (Schkur's Carices is styled by Smith an admirable and most correct work.)

Dry heaths. Black Park. Windsor Great Park, Berks. Tur.

Per. June.

Larger and stouter. Spikes blackish. Sm.

Carex lavigáta. Smooth-stalked Beaked Carex. Spikes cylindrical; fertile ones stalked. Scales all pointed. Sheaths very long. Fruit triangular, with a cloven beak. E. B. $138 \%$ Schk. Car. t. S. ss. 162. Willd. C. patula. Ibid. t. B. b. b. 116. C. æthiopica. Ibid. 10\%. t. Z. 83.

Mershes and boygy thickets. Bog in Great Windsor Park. Tur.

Per. June.

Bright green, smooth, three feet. Fruit green. Sm. 
Carex filiformis. Slender leaved Carex. Fertile spikes, egg-shaped. Scales pointed. Sheaths nearly equal to the short flower-stalks. Fruit egg-shaped, hairy, with a deeply cloven beak. Leaves linear, channelled, smooth. E. B. 904. Schk. Car. 82. t. K. 45 .

Boggy meadows, not common. Shortwood near Pucklechurch, Gloucestershire. Tur.

Per. June.

About two feet, smooth. Ls. narrow. Spikes blackish. Sm.

Salix rubra. Green leaved Osier. Stamens combined below. Leaves linear-spear-shaped, lengthened out, acute, smooth, with shallow serratures; green on both sides. Stigmas egg-shaped, undivided. E. B. 1145. Low meadows, osier-grounds, \&c. Between Maidenhead and Windsor. J. Sherard, in Sm. E. Fl.

Tree. April, May.

A small tree, with long, tawny branches. $L s$. long and narrow. Sm. 



\section{DIFFERENCES OF NOMENCLATURE.}

Sb. Sibthorp. E. B. English Botany. C. Curtis Fl. Lond.

H. Hooker Fl. Lond.

Chara híspida, is the Chara tomentósa of Sb.

Callitriche aquática, is the $\mathrm{C}$. aquática of $\mathrm{E}$. B.

Cládium Mariscus, is the Schøenus Mariscus of E. B.

Fédia Genus, formerly part of the genus Valeriána of E. B. \&c.

Rhynchóspora Genus, formerly part of the genus Schœnus of E. B. \&c.

Scirpus caricínus, is the Schœnus compressus of E. B.

Eleócharis genus, part of the genus Scirpus of E. B. \&c.

Phálaris arundinácea, is the Calamagrostis colorata of $\mathrm{Sb}$.

Phleum ásperum, is the Phleum paniculátum of E. B., and the Phalaris paniculáta of $\mathrm{Sb}$.

Alopecúrus agrestis, is the Al. myosuroídes of $\mathrm{C}$.

Agrostis vulgáris, is the Agr. tenuis of $\mathrm{Sb}$.

Aira cristáta, is the Poa cristáta of Sb.

Holcus avenáceus, is the Avéna elátior of $\mathrm{C}$.

Glycéria genus, is part of the genus Poa of Linn. \&c.

Glycéria fluitans, is the Festúca fluitans of Sb.

Triódia decumbens, is the Poa decumbens of E. B. and the Festuca decumbens of $\mathrm{Sb}$.

Festuca ovina, is the Fest. tenuifolia of Sb. gigantéa, is the Brom. gigantéus of $\mathrm{C}$. and $\mathrm{Sb}$. sylvatica, is the Bromus sylvaticus of $\mathrm{E}$. B. pinnata, is the Bromus pinnatus of $\mathrm{E}$. $\mathrm{B}$.

Bromus racemósus, is the Bromus pratensis of E. B. and Bromus arvensis of E. B.

asper, is the Bromus hirsútus of $\mathrm{C}$. and $\mathrm{Sb}$.

Galium saxatile, is the Gal. procumbens of $\mathrm{Sb}$. 
Galium tricorne, is the Gal. spurium of $\mathrm{Sb}$.

Mœ'nchia erecta, is the Sagína erecta of E. B., C., and $\mathrm{Sb}$ 。

Myosótis palustris, is the Myos. scorpioídes palustris of $\mathbf{C}$. versícolor, is the Myos. nana of Sb.

Prímula vulgáris, is the $\mathrm{Pr}$. acaulis of $\mathrm{C}$. and $\mathrm{Sb}$. veris, is the Pr. officinalis of $\mathbf{C}$.

Villársia nymphæoídes, is the Menyanthes nymphæoídes of E. B. and $\mathrm{Sb}$.

Anagallis cærúlea, is the An. arvensis, var. $\beta$. of Sb.

Erythræa Centaúrium, is the Chirónia centaurium of E. B. and $\mathbf{C}$.

Chenopodium ficifolium, is the Chen. viride of $\mathrm{C}$., and the $\mathrm{Ch}$. serótinum of $\mathrm{Sb}$.

olidum, is the Ch. Vulvária of Sb.

acutifolium, is the $\mathrm{Ch}$. polyspermum of $\mathrm{C}$. and $\mathrm{Sb}$.

Ulmus montána, is the Ulmus effusa of $\mathrm{Sb}$.

Cuscuta Epithymum is the C. Europæa of E. B. and Sb.?

Tórilis Anthriscus, is the Caúcalis Anthriscus of E. B., C., and Sb.

- infesta, is the Caúcalis infesta of E. B. and C., and C. arvensis of $\mathrm{Sb}$.

- nodósa, is the Caucalis nodósa of E. B. \&c.

Anthriscus vulgáris, is the Scandix Anthriscus of E. B., C., and $\mathrm{Sb}$.

Myrrhis odoráta, is the Scandix odoráta of E. B. and Sb.

C., and $\mathrm{Sb}$.

temulenta, is the Chærophyllum temulentum of E. B.,

Búnium flexuosum, is the B. Bulbocástanum of C.

Sium inundátum, is the Sison inundátum of E. B. \&c.

Enanthe Phellándrium, is the Phellándrium aquaticum of E. B. \&c. Pimpinella dissecta of $\mathrm{Sb}$. is a var. of $\mathrm{P}$. saxifraga of the $\mathrm{Fl}$. of Cxfordshire, \&c.

Cnídium Siláus, is the Peucédanum Siláus of E. B. \&c.

Pastináca sativa, is the Past. sylvestris of $\mathrm{Sb}$.

Scilla nutans, is the Hyacinthus non scriptus of $\mathrm{C}$. and $\mathrm{Sb}$.

Juncus compressus, is the $\mathbf{J}$. bulbósus of E. B. \&c.

acutiflórus, is the $\mathbf{J}$. articulatus of $\mathrm{E}$. B. and the $\mathbf{J}$. ne-

morósus of $\mathrm{Sb}$.

Juncus lampocarpus, is the $\mathrm{J}$. compressus of $\mathrm{Sb}$.

Luciola genus, is part of the genus Juncus.

Rumex sanguineus, is the Rumex acútus of $\mathbf{C}$. Rumex $\beta$. viridis of $\mathrm{Sb}$. is a var. of $\mathrm{R}$. sanguineus of the $\mathrm{F}$. of $\mathrm{Oxfordshire.}$ 
Rumex Hydrolápathum, is the R. aquáticus of E. B. \&c.

Epilóbium parviflórum, is the Epilob. villósum of $\mathrm{C}$. and $\mathrm{Sb}$.

Callína vulgaris, is the Eríca vulgáris of E. B., C., and Sb.

Poly'gonum lapathifólium, is the Pol. pensylvánicum of C. Polyg. salicifólium of Sb. is a var. of Pol. lapathifolium of Sm.

Py'rola minor, is the Pyr. rósea of E. B. 2543.

Siléne infláta, is the Cucúbalus Behen of $\mathrm{E}$. B. and $\mathbf{S b}$.

Stellária média, is the Alsíne média of C. \&c. glauca, is the Stel. media of $\mathrm{Sb}$. uliginósa, is the Lárbrea aquatica of DC.

Lychnis dioica, comprises the Lych. diurna, and Lych. vespertína, of Sb. Both these species of Sb. considered by Sm. as var. of Lych. dioica.

Cerástium vulgátum, is the C. viscósum of $\mathrm{C}$. and $\mathrm{Sb}$. viscósum of $\mathrm{C}$. the vulgátum of $\mathrm{C}$. and $\mathrm{Sb}$.

Prunus Cérasus, and Prunus 'Avium, See Fl. of Oxfordshire.

Méspilus Oxyacantha, is the Cratægus monógyna of $\mathrm{Sb}$.

Pyrus torminális, is the Cratægus torminalis of E. B. and Sb. aucupária, is the Sorbus aucupária of E. B.

Rosa tomentosa, is the R. villósa of Sb. ? micrantha, is the R. rubiginósa $\beta$. of H. Fl. Lond. Borréri, is the R. dumetorum of $\mathrm{E}$. B. and the R. rubiginósa inodora of $\mathrm{H}$. L.

— sarmentacea, is the R. canina of C. sépium, is a var. of R. rubiginosa, Lindley Ros. sy'styla, is the R. collina of E. B.

Potentilla Fragariastrum, is the Fragária sterilis of E. B., C., \&c. Tormentilla officinális, is the Potentilla Tormentilla of Sb. reptans, is the Potentilla procumbens of $\mathrm{Sb}$.

Nuphar lútea, is the Nymphæa lútea of E. B., Sb., \&c. Tília Europæa $\beta$. rubra of $\mathrm{Sb}$. is a var. of $\mathrm{T}$. grandifólia of the $\mathrm{Fl}$. of Oxfordshire.

Anemóne Pulsatilla, is the An. pratensis of Sb.

Ranunculus aquátilis, contains Sibthorp's R. heterophyllus, R. aquatilis, R. circinátus, and R. fluviátilis, under it as varieties.

Mentha hirsúta, is the M. aquatica of Sb. Mentha sativa of E. B. is a var. of M. hirsuta of Sm. E. Fl.

Galeóbdolon lúteum, is the Galeóbdolon Galeopsis of $\mathrm{Sb}$.

Thymus Calamintha, is the Melissa Calamintha of Sb. Nepeta, is the M. Nepeta of Sb.

Bártsia Odontítes, is the Euphrásia Odontítes of C. and Sb. 
Orobanche elátior, is the Or. major of $\mathrm{Sb}$. (Dr. Williams, Prof. Bot. Oxford.)

Camelina sativa, is the Alyssum sativum of E. B.

Lepidium campestre, is the Thlaspi campestre of E. B., C., and $\mathrm{Sb}$.

Hutchinsia petræa, is the Lepídium petræum of E. B.

Teesdália nudicaulis, is the Ibéris nudicaulis of E. B. and C.

Senebiéra Corónopus, is the Corónopus Ruellii of E. B.

Cardamine hirsúta, is the C. flexuósa of Withering.

Nasturtium officinale, is the Sisymbrium Nastúrtium of E. B., $\mathrm{C}$, and $\mathrm{Sb}$.

sylvestre, is the Sisym. sylvestre of E. B. \&c.

terrestre, is the Sisymb. terrestre of E. B., C., and

$\mathrm{Sb}$.

and $\mathrm{Sb}$.

amphíbium, is the Sisymb. amphibium of E. B.

Sisymbrium officinale, is the Ery'simum officinale of E. B., C., and $\mathrm{Sb}$.

Barbaréa vulgáris, is the Erysimum Barbarea of E. B. and Sb.

Cheiranthus fruticulosus, is the $\mathrm{Ch}$. Cheiri of $\mathrm{Sb}$.

Hésperis matronalis, is the Hesp. inodóra of E. B.

'Arabis thaliána, is the Sisymb. thalianum of $\mathrm{H}$. Br. Fl.

hirsúta is the Turritis hirsuta of $\mathrm{Sb}$. and $\mathrm{E} . \mathrm{B}$.

Erodium cicutárium $\boldsymbol{\gamma}$., is the Erod. pimpinellæfólium of $\mathbf{S b}$. cicutarium, is the Geránium cicutárium of $\mathbf{C}$.

Geranium pusillum, is the Geránium parviflorum of $\mathrm{Sb}$. and $r$,

Trifolium procumbens, is the Trif. agrárium of $\mathbf{C}$. minus, is the Trif. procumbens of $\mathbf{C}$.

Lotus major, is the $V$ ar. $\beta$. villosus of $\mathbf{S b}$.

— tenuis, is the Lotus decumbens of Sm. E. Fl.

Medicágo maculata, is the Med. polymorpha of E. B. and C.

Hypéricum quadrangulum, is the Hyp. quadranguláre of $\mathrm{Sb}$.

Leóntodon Taráxacum, is the Taraxacum officinale of Sb.

Apárgia híspida, is the Leóntodon hispidum of $\mathrm{Sb}$. and C., and the Hedy'pnois hispida of E. B.

hirta, is the Hedy'pnois hirta of E. B. and Leóntodon hirtum of $\mathrm{C}$. and $\mathrm{Sb}$. and the Thríncia hirta of $\mathrm{H} . \mathrm{Br}$. Fl.

autumnális; is the Hedyp. autumnalis of E. B. and

Leóntodon autumnale of Sb.

Hierácium sylváticum, is the Hierac. murórum of Sb.

Carduus acanthoides, is the polyacanthos of $\mathrm{C}$. and $\mathrm{Sb}$. 
The Genus Cnicus, made part of the genus Carduus of Linn.

Gnaphálium mínimum, is the Filágo montána of Sb. germanicum, is the Filágo germanica of Sb.

Senécio tenuifólius, is the Sen. erucifólius of C.

I'nula pulicária, is the In. uliginósa of Sb.

Cinerária integrifólia, is the Cin. campestris of $\mathrm{H}$.

Py'rethrum inodorum is the Chrysanthemum inodor. of $\mathrm{Sb}$.

Orchis tephrosanthos, is the Orchis militáris of Sb. and E. B.

- víridis, is the Saty'rium viride of $\mathrm{Sb}$. and $\mathrm{E} . \mathrm{B}$. and Habenária viridis of $H$.

Hermínium monorchis, is the Ophrys monorchis of E. B.

Epipactis latifolia, is the Serápias latifolia of E. B.

fólia of $\mathrm{Sb}$. ralustris, is the Ser. palustris of E. B. and Ser. longi-

grandiflora, is the Epipactis pallens of H. L. and Ser. grandiflóra of E. B. ensifólia, is the Ser. ensifolia of E. B. rubra, is the Ser. rubra of E. B.

Typha latifólia, is the Typ. major of $\mathrm{C}$.

angustifolia, is the Typ. minor of $\mathrm{C}$.

Carex stelluláta, is the Ca. echinata of $\mathrm{Sb}$.

- ovális, is the Ca. leporína of Sb.

- intermédia, is the Ca. dísticha of $\mathrm{Sb}$.

muricáta is the Ca. spicáta of $\mathrm{Sb}$.

recurva, is the Ca. flacea of Schkr. acuta, is the Ca. grácilis of $\mathrm{C}$. and $\mathrm{Sb}$.

— paludósa, is the Ca. acúta of C. and Sb. ripária, is the Ca. crassa of Host.

- - ampullacea, is the Ca. rostrata of $\mathrm{Sb}$.

Alnus glutinósa, is the Bétula Alnus of E. B. and Sb.

Salix Helix, and Salix purpúrea, are united by Curtis, and Hoffmann, under the single appellation of the Salix monandra.

Salix repens, is the Salix depressa of $\mathrm{Sb}$. With. aquática, is the Sa. acuminata of Sb.? and Sa. cinerea of Smithiana, is the Sa. mollíssima of E. B.

Atríplex pátula, is the Atr. hastáta of C. and Sb.

- ... angustifólia, is the Atr. pátula of Sb. 



\section{NDEX}

OF THE

PRINCIPAL ENGLISH NAMES.

Abele-tree

Acorus, or Sweet-flarg

Adonis-flower

Agrimony

\begin{tabular}{l} 
Alder Hemp \\
Ale-hoof \\
Alexanders \\
Alkanet \\
\hline All-heal (Tutsan) \\
Aloe, Water \\
Andromeda, Marsh \\
Anemone \\
Angelica \\
Apple-tree \\
Archangel \\
\hline
\end{tabular}

Arrow-grass head

Asarabacca

Ash

Mountain

Asparagus

Aspen

Asphodel, Bog, Lancashire

Avens

\section{Barberry}

Barley

Bartsia

Base-rocket

Basil, Wild

Bastard-Alkanet

Cyperus

Stone-parsley

Toad-flax

Beaked-parsley

Beak-rush

Beam-tree, White

Bear's-foot

Bed-straw

Beech.

\begin{tabular}{|c|c|c|}
\hline Page & & Page \\
\hline 296 & Bee-nettle & 167 \\
\hline 95 & Bee.Orchis (Ophrys) & 256 \\
\hline 154 & Bell-flower & 56 \\
\hline 132 & Bennet Herb & 146 \\
\hline 234 & Bennet Way & 32 \\
\hline 277 & Bent-grass & 18 \\
\hline 66 & Betony & 167 \\
\hline 164 & _ Paul's & 3 \\
\hline 81 & W Water & 180 \\
\hline 49 & Bilberry & 109 \\
\hline 49 & Bindweed & 55 \\
\hline 217 & Birch & 283 \\
\hline 152,3 & Bird's-foot & 210 \\
\hline 304 & - trefoil & 215 \\
\hline 152 & Bird's-nest & 117 \\
\hline 82 & $\longrightarrow$ (carrot & 74 \\
\hline 136 & Birthwort & 260 \\
\hline 165 & Bistort & 112 \\
\hline 167 & Bitter-sweet & 63 \\
\hline 104 & Bitter-vetch & 206 \\
\hline 280 & Blackberry & 142 \\
\hline 131 & Black-Bindweed & 115 \\
\hline $\mathbf{3}, 303$ & - Bryony & 296 \\
\hline 137 & - Horehound & 169 \\
\hline 95 & Thorn & 135 \\
\hline 297 & Bladderwort & 7 \\
\hline 94 & Blinks & 34 \\
\hline \multirow[t]{2}{*}{146} & Blue-bottle & 249 \\
\hline & Bog-Asphodel & 94 \\
\hline 101 & - bean & 52 \\
\hline 32 & -rush & 12 \\
\hline 173 & Borage & 50 \\
\hline 133 & Bramble & 142 \\
\hline 170 & Brank & 115 \\
\hline 49 & Brome-grass & 28 \\
\hline 270 & Brooklime & 4 \\
\hline 79 & Brookweed & 64 \\
\hline 68 & Broom & 204 \\
\hline 76 & — Butcher's & 294 \\
\hline 12 & rape & 181 \\
\hline 137 & Bryony, Black & 296 \\
\hline 159 & ---Red-berried & 278 \\
\hline 37,303 & Buck-bean & 50 \\
\hline 283 & Buck-thorn & 65 \\
\hline
\end{tabular}


Buck-wheat

Bugle

Bugloss

Bullace

Bull-rush

Burdock

Bur-marigold

Burnet

Burnet-rose

— Salad

Bur-parsley

Butcher's-Broom

Butter Bur

Butter-cups

Butter-wort

Cabbage

Calamint

Caltrops, Freshwater

Cammock

Campion (Catchfly)

Canary-grass (Lychnis)

Candy-tuft

Carex

Carline-thistle

Carrot

Catchfly

Cat-mint Nottingham

Cat's-ear

Cat's-tail-grass

Celandine (Reed-mace)

Celery, Wild

Centaury

Chaffweed

Chanomile

\begin{tabular}{l}
\hline Chara -- Wild \\
Charlock \\
\hline Chequered Daffodil \\
Cherry \\
Chervil Needle \\
\hline Chestnut \\
Chick weed \\
\hline- Germander \\
\hline - Mouse-ear \\
\hline Chironia \\
Christmas \\
Cicely \\
Cinquefoil water \\
\hline Cistus - Marsh
\end{tabular}

\begin{tabular}{|c|c|c|}
\hline Page & & Page \\
\hline 112 & Clary & 8 \\
\hline 160 & Cleavers & 39 \\
\hline 51 & Clot-bur & 228 \\
\hline 51 & Clover & 212 \\
\hline 134 & Club-rush & 12 \\
\hline 12 & Cockle & 128 \\
\hline 228 & Cock's-foot-grass & 25 \\
\hline 234 & Codlings and Cream & 107 \\
\hline 264 & Cole-seed & 194 \\
\hline 41 & Colt's-foot & 239 \\
\hline 138 & Columbine & 152 \\
\hline 281 & Comfrey & 50 \\
\hline 304 & Coral-wort & 187 \\
\hline 75 & Cornel & 41 \\
\hline 294 & Corn-marigold & 245 \\
\hline 239 & Corn-salad & 11 \\
\hline 156 & Cotton-grass & 14 \\
\hline 6 & Hare's-tail & 14 \\
\hline & Cotton-thistle & 233 \\
\hline 194 & Couch-grass & 33 \\
\hline 171 & Cow-berry & 109 \\
\hline 44 & Cow-parsley, rough & 77 \\
\hline 205 & smooth & 76 \\
\hline 321 & Cow-parsnep & 85 \\
\hline 128 & Cowslip & 52 \\
\hline 16 & Cow-wheat & 174 \\
\hline 186 & Crab-tree & 136 \\
\hline 265 & Cranberry & 109 \\
\hline 233 & Crane's-bill & 198 \\
\hline 74 & Cress & 188 \\
\hline 121 & - Penny & 184 \\
\hline 304 & - Rock & 193 \\
\hline 161 & - Swine's & 186 \\
\hline 227 & -Wall & 193 \\
\hline 16 & - Wart & 186 \\
\hline 264 & — Water & 188 \\
\hline 147 & Winter & 191 \\
\hline 82 & Crocus & 11 \\
\hline 64 & Cross-wort & 37 \\
\hline 41 & foot & 154 \\
\hline 247 & Cuckoo flower & 187 \\
\hline 246 & $\longrightarrow$ pint & 280 \\
\hline 1 & Cudweed & 236 \\
\hline 195 & Currant & $66,303,4$ \\
\hline $\mathbf{1 9 7}$ & Cursed-thistle & 231 \\
\hline 92 & Cyperus, Bastard & 270 \\
\hline $\begin{array}{r}134 \\
76\end{array}$ & Cypress-grass, Millet & 14 \\
\hline 76 & Daffodil & 91 \\
\hline 283 & -Chequered & 92 \\
\hline 122 & Daisy & 244 \\
\hline 5 & - Moon, or Ox-eye & 245 \\
\hline 129 & Dame's-violet & 192 \\
\hline 124 & Dandelion & 223 \\
\hline 34 & Dane-wort & 86 \\
\hline 64 & Darnel & 31 \\
\hline 43 & Dead-nettle & 165 \\
\hline 77 & Deadly-nightshade & 62 \\
\hline 144 & Devil's-bit & 35 \\
\hline 147 & Yellow & 224 \\
\hline 151 & Dew-berry & 144 \\
\hline
\end{tabular}


PRINCIPAL ENGLISH NAMES.

Dock

Dodder

Dog-rose

Dog's-tail-grass

Dog-wood

Drop-wort

Duckweed

Dwale

\section{Earth-nut}

Eglantine

Elder

Water

Elecampane

Elm

Enchanter's Night-shade

Eringo

Everlasting

Everlasting-Pea

Eye-bright

Featherfoil

Fescue-grass

Feverfew

Field Madder

Figwort

Flag, Sweet

Flax

- Toad

Flax-seed

Flea-bane

Flea-wort

Flix-weed

Fleur-de-luce

Flowering-rush

Fluellin

Fly-honeysuckle

Fool's-parsley

Forget-me-not

Fox-glove

Fox-tail-grass

French-willow

Fringed Water-lily

Fritillary

Frog-bit

Fumitory

Furze

\section{Garlick \\ Gentian \\ Geranium \\ Gerarde, Herb \\ Germauder}

Germatkweed

- speed well

Gill

Gipsy-wort

Goat's-beard

\begin{tabular}{|c|c|c|}
\hline Page & & Page \\
\hline 102 & Golden-rod & 242 \\
\hline 72 & saxifrage & 118 \\
\hline 140 & Goldilocks & 155 \\
\hline 25 & Gold of Pleasure & 183 \\
\hline 41 & Gooseberry & 66 \\
\hline 137 & Groose-corn & 97 \\
\hline 80 & $\longrightarrow$ foot & 69 \\
\hline 7 & _ grass & 38,39 \\
\hline 62 & - tongue & 248 \\
\hline & Gorse & 205 \\
\hline & Gout-weed & 82 \\
\hline 77 & Grass, Arrow & 104 \\
\hline 139 & Barley & 32 \\
\hline 86 & - Bent & 18 \\
\hline 86 & - Brome & 28 \\
\hline 243 & - Canary & 16 \\
\hline 71 & Cat's-tail & 16 \\
\hline 3 & _ Cock's-foot & 25 \\
\hline 74 & Cotton & 14 \\
\hline 236 & _ Couch & 33 \\
\hline 207 & _ Dog's-tail & 25 \\
\hline 174 & __ Fescue & 25 \\
\hline & Fox-tail & 17 \\
\hline 53 & - Goose & 38,39 \\
\hline 25 & - Hair & 19 \\
\hline 245 & _ Hare's-tail Cotton & 14 \\
\hline 36 & __ Heath & 24 \\
\hline 179 & - Knot & 112 \\
\hline 95 & __ Lyme & 32 \\
\hline 88 & _._. Mat & 15 \\
\hline 176 & __ Meadow & 23 \\
\hline 46 & Melic & 21 \\
\hline 243 & - Millet & 18 \\
\hline 244 & —_ Millet Cypress & 14 \\
\hline 191 & _ Oat & 30 \\
\hline 11 & _ of Parnassus & 87 \\
\hline 117 & _ poly & 132 \\
\hline 177 & _ Quaking & 24 \\
\hline 303 & L_Rye & 31 \\
\hline 79 & Scorpion & 46 \\
\hline 46 & Leurvy & 185 \\
\hline 180 & - Soft & 21 \\
\hline 17 & SW Sweet & 22 \\
\hline 106 & — Timothy & 16 \\
\hline 53 & _ Vernal & 9 \\
\hline 92 & _ Wheat & 33 \\
\hline 299 & ___ Whitlow & 183 \\
\hline 202 & Great Water-radish & 189 \\
\hline 205 & Greek-valerian & 56 \\
\hline & Green-weed & 204 \\
\hline 91 & Grey-mill, or Millet & 48 \\
\hline 73 & Gromwell & 48 \\
\hline 198 & Ground-ivy & 164 \\
\hline 82 & Ground-pine & 306 \\
\hline 160 & Groundsel & 240 \\
\hline 5 & Guelder-rose & 86 \\
\hline 5 & & 10 \\
\hline 4 & Hair-grass & 19 \\
\hline 164 & Hare-bell & 91 \\
\hline 8 & Hare's-ear & 84 \\
\hline 220 & Hare's-tail-grass & 14 \\
\hline
\end{tabular}


Hart-wort

Haver

Hawk-bit

Hawk's-beard?

Hawk-weed

Hawthorn

Hazel-nut

Heart's-ease

Heath

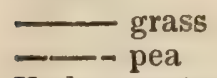

Hedge-mustard

Hellebore

Helleborine

Hemlock

- Less

Hemp-agrimony

Hemp-nettle

Henbane

Hen-bit

- Small

Herb-bennet

- Gerarde

- Paris

- Robert

- two-pence

High-taper

Hog-weed

Holly

Hone-wort

Honey-suckle

- Fly

Hooded-milfoil

Hop

Horehound, Black.

- Water

Hornbeam

Horned-pondweed

Hornwort

Horse-radish

Horse-shoe-vetch

Hound's-tongue

Houseleek

Hutchinsia

Hyacinth

wild

Insect-orchis

Iris, Yellow-water

Ivy

Ground

Jack-by-the-hedge

Jacob's-ladder

John's-wort, St.

Jointed Charlock

Juniper

Kidney-vetch
Page

85
30
22

224

226

225

135

284

72

60

110

24

206

190

75

158

259

80

79

234

166

62

166

6

146

82

116

199

54

61

85

43

79

65

303

7

295

169

8

169

284

263

279

185

210

49

133

184

94

94

256

95

95

164

192

56

217

197

299

206
Kipper-nut

Knapweed

Knawel

Knot-grass

Lady's-finger

Lady's Traces

Lady's Bedstraw

- Mantle

- Slipper

- Smock

- Thistle

Lamb's Lettuce

Lancashire Bog-Asphodel

Larkspur

Laurel, Spurge

Less-Hemlock

Lettuce

- Wall

Lily of the Valley

Lily, Water, White

- Yellow

Lime-tree

Linden-tree

Ling

Liquorice, Wild

Listera

Live-long

London Rocket

Loosestrife

Lousewort

Lychnis

Lyme-grass

Madder, Field

Madder, Wild

Madwort, Mountain

Mallow

Mantle, Lady's

Maple

Mare's-tail

Marigold, Bur

- Corn

Marjoram

Marsh Andromeda

- Cinquefoil

- Marigold

- Penny-wort

- Trefoil

Mat-grass

May

May-weed

Meadow-grass

- rue

- saffron

sweet

Meadows, Queen of the

Medick

Medlar
Page

112

206

257

187

230

11

94

152

111 
Melic-grass

Melilot

Mercury

Mezereon

Mignonette, Wild `

Milfoil

Hooded
Wilkwort

Milk-vetch

Millet-Cypress-grass

Millet-grass

Mill, or Millet, Grey

Mill. Mountain

Mint

Cat

Mistletoe

Mithridate Mustard

Moenchia - Pepper-wort

Money-wort

Moon Daisy

Moschatell

Mountain Ash

Germander

Madwort

Sorrel

Speedwell

Mouse-ear (Myosotis)

Mouse-tail

Mud-wort

Mugweed

Mugwort

Mullein

Musk-orchis

Mustard thistle

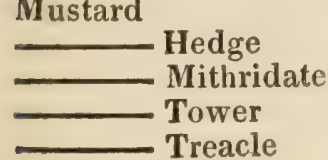

Narcissus

Navel-wort

Navew, Wild

Needle-chervil

Shepherd's

Nettle

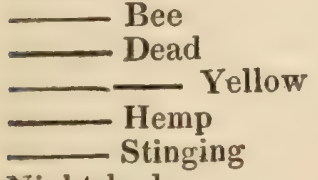

Nightshade

Nipple-wort

Nonesuch

\section{Page}

21
212
298
111
133
248

279

203

211

14

18

48

88

162

161

162

295

184

183

46

54

245

116

137

4

101,304

4
46

129

90

181

37

236

61

256

229

195

190

184

194

191

91

125

195

76

76

277

167

165

167

166

277

63

62

3

227

236
Nottingham Catchfly

Nut, Earth

- Hazel

Kipper

- Pig

Oak

Oat, or Oat-grass

Olive, Spurge

Orache

Orchis

Insect

Orpine

Osier

Our Lady's-Thistle

Ox-eye Daisy

Ox-tongue

Pansy

Paris, Herb

Park-leaves

Parnassus, Grass of

Parsley

_ Bastard Stone

Beaked

- Bur

- Fool's

- Hedge

- Piert

- - Rough Cow

Parsnep

- Water

Pasque flower

Paul's Betony

Pea, Everlasting

- Heath

Pearl-wort

Pear-tree

Pellitory of the Wall

Penny-Cress

- royal

Penny-wort, Marsl

Pepper-saxifrage

- Wall

— wort

Periwinkl Mithridate

Page

304

77

284

77

77

281

30

111

300

251

256

125

285

230

245

221

60

116

217

87

82

79

76

75

79

75

42

77

76

84

78

152

3

207

206

45

136

42

184

164

84

83

126

183

183

Persian-willow

Persinarillow

Peter's-wort, St. 218

Petty-whin 204

Pheasant's-eye 154

Pig-nut

Pile-wort 155

Pimpernel 54, 304

W_- Water 64

54

Pink 121

Plantain Water $\quad \begin{array}{r}40 \\ \hline\end{array}$ 


\begin{tabular}{|c|c|c|c|}
\hline Plantain leaved Chickweed & $\begin{array}{l}\text { Page } \\
124\end{array}$ & Rye-grass & $\begin{array}{r}\text { Page } \\
31\end{array}$ \\
\hline Plowman's Spikenard & 238 & & \\
\hline Plum & 134 & Saffron, Meadow & 105 \\
\hline Plume-thistle & 231 & Sage & 8 \\
\hline Pond-weed & 43 & Wood & 160 \\
\hline - Horned & 263 & Saintfoin & 211 \\
\hline $\begin{array}{l}\text { Poplar } \\
\text { Poppy }\end{array}$ & 296 & $\begin{array}{l}\text { Saint John's-wort } \\
\text { Saint Peter's-wort }\end{array}$ & 217 \\
\hline $\begin{array}{l}\text { Poppy } \\
\text { Potentilla }\end{array}$ & 148 & $\begin{array}{l}\text { Saint Peter's-wort } \\
\text { Salad, Burnet }\end{array}$ & 218 \\
\hline Prickwood & $\begin{array}{r}144 \\
66\end{array}$ & $\begin{array}{l}\text { Salad, Burnet } \\
\text { L Corn }\end{array}$ & 11 \\
\hline Primrose & 52 & Sallow & 285 \\
\hline Print, or Prim Print & $\mathbf{3}$ & Sandwort & 124 \\
\hline Privet & $\mathbf{3}$ & Sanicle & 74 \\
\hline Purple-loose-strife & 131 & Yorkshire & 6 \\
\hline Purse, Shepherd's & 184 & Sauce-alone & 192 \\
\hline Purslane & 101 & Saw-wort & 229 \\
\hline Quaking-grass & 24 & Saxifrage Burnet & $\begin{array}{r}119 \\
83,304\end{array}$ \\
\hline Queen of the Meadows & 138 & _ Golden & 118 \\
\hline Quicken-tree & 137 & Pepper & 83 \\
\hline Quinsy-wort (see Squinancy- & & Scabious & 35 \\
\hline wort) & 36 & — Devil's-bit & 35 \\
\hline Radish & 197 & $\longrightarrow$ Sheep's-bit & 58 \\
\hline - Horse & 185 & Scorpion-grass & 46 \\
\hline - Great Water & 189 & Scurvy-grass & 185 \\
\hline Ragged Robin & 128 & Sedge & 265 \\
\hline Ragwort & 240 & Self-heal & $\mathbf{1 7 3}$ \\
\hline Ramsons & 92 & Septfoil & 145 \\
\hline Ranunculus & 154 & Service, Wild & 136 \\
\hline Rape & 194 & Setter-wort & 159 \\
\hline Raspberry & 142 & Sheep's-bit, scabious & 58 \\
\hline Rattle, Red & 176 & Shepherd's-needle & 76 \\
\hline - Yellow & 173 & —_- purse & 184 \\
\hline Red-rattle & 176 & $\longrightarrow$ staff & 34 \\
\hline Reed & 31 & Sherardia & 36 \\
\hline Reed-mace & 264 & Silver-weed & 144 \\
\hline Rest-harrow & 205 & Skull-cap & 172 \\
\hline Rib-wort & 40 & Slipper, Lady's & 260 \\
\hline Roan-tree & 137 & Sloe & 135 \\
\hline Robert, Herb & 199 & Slough-heal & 173 \\
\hline Rock-cress & 193 & Smallage & 82 \\
\hline Rocket & 133 & Smooth Cow-parsley & 76 \\
\hline - Base & 133 & Snake-weed & 114 \\
\hline — London & 190 & Snake's-head & 92 \\
\hline - Yellow & 191 & Snap-dragon & 176 \\
\hline Rock-rose & 151 & Sneeze-wort & 248 \\
\hline Rose-bay & 106 & Snow-drop & 90 \\
\hline Rose & 138 & Soap-wort & 120 \\
\hline - Burnet & 138 & Soft-grass & 21 \\
\hline - Dog & 140 & Soldier, Water & 152 \\
\hline — Rock & 151 & Solomon's-Seal & 95 \\
\hline Rough Cow-parsley & 77 & Sorrel & 102 \\
\hline Rush & 96 & — Mountain & 101,304 \\
\hline$\longrightarrow$ Beak & 12 & —- Sheep's & 104 \\
\hline - Bog & 12 & -W Wood & 127 \\
\hline _ Bull & 12 & Sow-bane & 69 \\
\hline — Club & 12 & Sow-thistle & 221 \\
\hline __ Flowering & 117 & Speedwell, Germander & 5 \\
\hline — Spike & 14 & Speedwell, Mountain & 4 \\
\hline — Twig & 9 & Spikenard, Plowman's & 238 \\
\hline _ Wood & 99 & Spike-rush & 14 \\
\hline
\end{tabular}


PRINCIPAL ENGLISH NAMES.

Spindle-tree

Spiræa

Spurge

_- Olive

Spurrey

Squill

Squinancy-wort

Star of Bethlehem

— earth

thistle

- - wort Water

Stinging-nettle

Stitchwort

Stock-nut

Stone-crop

Stone-parsley, Bastard

Stork's-bill

Strawberry

Succory

Sulphur-wort

Sun-dew

Sweet-Briar

_- Flag

Swine's-cress

Sycamore

Tansy

Tare

Teasel

Teesdalia

Thistle

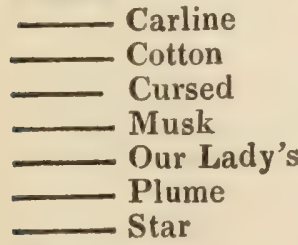

Thorow-wax

Thyme

Timothy-grass

Toad-flax

- Bastard

Tooth-wort

Tormentil

Tower-mustard

Traveller's-joy

Treacle-mustard

Trefoil

—_ Bird's-foot

Tulip

Turnip

Tutsan

Tway-blade

Twig rush

Two-pence, Herb

Valerian

\begin{tabular}{|c|c|c|}
\hline $\begin{array}{r}\text { Page } \\
66\end{array}$ & & Page \\
\hline $\begin{array}{r}66 \\
137\end{array}$ & $\begin{array}{l}\text { Valerian, Greek } \\
\text { Valley, Lily of the }\end{array}$ & $\begin{array}{l}56 \\
95\end{array}$ \\
\hline 261 & Venus' comb & 76 \\
\hline 111 & Vernal-grass & 9 \\
\hline 111 & Vervain & 162 \\
\hline 130 & Vetch & 208 \\
\hline 304 & - Bitter & 206 \\
\hline 36 & Horse-shoe & 210 \\
\hline 93 & —- Kidney & 206 \\
\hline 40 & Milk & 211 \\
\hline 249 & Vetchling & 207 \\
\hline 2 & Villarsia & 53 \\
\hline 277 & Violet & 59 \\
\hline 122 & —- Dame's & 192 \\
\hline 284 & - Water & 53 \\
\hline $\begin{array}{r}125 \\
79\end{array}$ & Viper's-bugloss & 51 \\
\hline 197 & Wake Robin & 280 \\
\hline 144 & Wall-cress & 193 \\
\hline 227 & _ flower & 192 \\
\hline 80 & - lettuce & 223 \\
\hline 89 & — pellitory & 42 \\
\hline 139 & - pepper & 126 \\
\hline 95 & Wart-cress & 186 \\
\hline 22 & Wart-wort & 262 \\
\hline 186 & Water Aloe & 152 \\
\hline 112 & - Betony & 180 \\
\hline & _- Chickweed, small & 34 \\
\hline 235 & __ Cress & 188 \\
\hline 209 & - - Dropwort & 80 \\
\hline 34 & — Elder & 86 \\
\hline 184 & _- Horehound & 8 \\
\hline 229 & _ris, yellow & 95 \\
\hline 233 & _ Lily, fringed & 53 \\
\hline 233 & $\begin{array}{l}\text { Lily, (white and yellow) } \\
\text { Milfoil }\end{array}$ & 149 \\
\hline 231 & $\begin{array}{l}\text { M Milfoil } \\
\text { Parsnep }\end{array}$ & 279 \\
\hline 229 & & 78 \\
\hline 230 & __ Pimpernel & 64 \\
\hline 231 & -__ Plantain & 105 \\
\hline 249 & - Soldier & 152 \\
\hline 84 & $\begin{array}{l}\text { Starwort } \\
\text { Violet }\end{array}$ & 2 \\
\hline 170 & $\begin{array}{l}\text { Wiolet } \\
\text { - wort }\end{array}$ & 53 \\
\hline 16 & & 116 \\
\hline 176 & $\begin{array}{l}\text { Way-bennet } \\
\text { Wayfaring-tree }\end{array}$ & 32 \\
\hline 68 & $\begin{array}{l}\text { Wayfaring tree } \\
\text { Weasel-snout }\end{array}$ & 86 \\
\hline 187 & Weasel-snout & 167 \\
\hline 145 & Weed, Green & 204 \\
\hline 194 & Weld, or Yellow-weed & 133 \\
\hline 153 & Wheat, Buck & 112 \\
\hline 191 & $\begin{array}{l}\text { — Cow } \\
\text { - grass }\end{array}$ & 174 \\
\hline 212 & Whin grass & 33 \\
\hline 215 & $\stackrel{\text { Whin }}{\longrightarrow}$ Petty & 205 \\
\hline 92 & $\overline{\text { White-beam-tree }}$ & 204 \\
\hline 194 & $\begin{array}{l}\text { White-beam-tree } \\
\text { - Horehound }\end{array}$ & $\begin{array}{l}137 \\
169\end{array}$ \\
\hline 217 & $-\operatorname{rot}$ & 84 \\
\hline 258 & - thorn & 135 \\
\hline 9 & White Water-lily & 149 \\
\hline \multirow[t]{2}{*}{54} & Whitlow-grass & 183 \\
\hline & Whortle-berry & 109 \\
\hline 10 & Wild Basil & 170 \\
\hline
\end{tabular}


INDEX OF THE \&c.

\begin{tabular}{l} 
Wild Celery \\
Chamomile \\
Hyacinth \\
Liquorice \\
Madder \\
Mignonette \\
Navew \\
Oat, or Haver \\
Pear-tree \\
Tansy \\
Willow \\
\hline Winter-cress \\
\hline Woodbine \\
Woodruff \\
Wood-rush \\
Wood sage \\
- sorrel
\end{tabular}

\begin{tabular}{r|l} 
Page & \\
82 & Wood waxen \\
246 & Worm-seed \\
94 & Wormwood \\
211 & Woundwort \\
303 & Wych elm \\
133 & - Hazel \\
195 & Yarrow \\
30 & Yellow-Devil's-bit \\
136 & - Pimpernel \\
235 & - Rattle \\
285 & - Rocket \\
106 & Water-Iris \\
191 & - - W \\
65 & - \\
36 & weed, or weld \\
99 & Yew wort \\
160 & Yorkshire Sanicle \\
127 &
\end{tabular}




\section{INDEX}

To

THE GENERA.

N. B. Figures in first columns refer to the Introduction pages.

AcER
Achillea
Acorus
Adonis
Adoxa
Egropodium
Ethusa
Agrimonia
Agrostemma
Agrostis
Aira
Ajuga
Alchemilla
Alisma
Allium
Alnus
Alopecurus
Anagallis
Anchusa
Andromeda
Anemone
Angelica
Anthemis
Anthoxanthum
Anthriscus
Anthyllis
Antirrhinum
Apargia
Apium
Aquilegia
Arabis
Arctium
Arenaria
Aristolochia
Artemisia
Arum
Arundo
Asarum
Asparagus
Asperula
Astragalus
Atriplex

\begin{tabular}{|c|c|c|}
\hline & Page & \\
\hline 109 & 112 & Atropa \\
\hline 127 & 248 & Avena \\
\hline 108 & 95 & \\
\hline 116 & 154 & Ballota \\
\hline 110 & 116 & Barbarea \\
\hline 104 & 82 & Bartsia \\
\hline 105 & 79 & Bellis \\
\hline 113 & 132 & Berberis \\
\hline 112 & 128 & Betonica \\
\hline 94 & 18 & Betula \\
\hline 94 & 19 & Bidens \\
\hline 117 & 160 & Borago \\
\hline 97 & 42 & Brassica \\
\hline 108 & 105 & Briza \\
\hline 107 & 91 & Bromus \\
\hline 130 & 277 & Bryonia \\
\hline 94 & 17 & Bunium \\
\hline 99 & 54 & Bupleurum \\
\hline 98 & 49 & Butomus \\
\hline 111 & 304 & \\
\hline 116 & 152 & Callitriche \\
\hline 105 & 82 & Calluna \\
\hline 127 & 247 & Caltha \\
\hline 93 & 9 & Camelina \\
\hline 102 & 76 & Campanula \\
\hline 123 & 206 & Cardamine \\
\hline 118 & 176 & Carduus \\
\hline 125 & 224 & Carex \\
\hline 104 & 82 & Carlina \\
\hline 115 & 152 & Carpinus \\
\hline 120 & 193 & Caucalis \\
\hline 125 & 228 & Centaurea \\
\hline 111 & 124 & Centunculus \\
\hline 128 & 260 & Cerastium \\
\hline 126 & 235 & Ceratophyllum \\
\hline 132 & 280 & Chærophyllum \\
\hline 96 & 31 & Chara \\
\hline 113 & 131 & Cheirantbus \\
\hline & 95 & Chelidonium \\
\hline 97 & 36 & Chenopodium \\
\hline 123 & 211 & Chlora \\
\hline 135 & 300 & Chrysanthemum \\
\hline
\end{tabular}

\begin{tabular}{rr} 
& Page \\
100 & 62 \\
95 & 30 \\
& \\
117 & 169 \\
120 & 191 \\
118 & 173 \\
126 & 244 \\
106 & 101 \\
117 & 167 \\
132 & 283 \\
126 & 234 \\
135 & 50 \\
121 & 194 \\
95 & 24 \\
95 & 28 \\
130 & 278 \\
103 & 77 \\
104 & 84 \\
110 & 117 \\
& \\
91 & 2 \\
109 & 110 \\
116 & 159 \\
119 & 183 \\
100 & 56 \\
120 & 187 \\
125 & 229 \\
129 & 265 \\
125 & 233 \\
131 & 284 \\
103 & 75 \\
127 & 249 \\
97 & 41 \\
112 & 129 \\
131 & 279 \\
102 & 76 \\
91 & 1 \\
120 & 192 \\
115 & 147 \\
101 & 69 \\
109 & 108 \\
127 & 245 \\
& \\
\hline
\end{tabular}


INDEX TO THE GENERA.

\begin{tabular}{|c|c|c|c|c|c|}
\hline \multirow{2}{*}{$\begin{array}{l}\text { Chrysosplenium } \\
\text { Cichorium }\end{array}$} & \multicolumn{2}{|c|}{$\begin{array}{cc} & \text { Page } \\
111 & 118\end{array}$} & \multirow{2}{*}{$\begin{array}{l}\text { Fraxinus } \\
\text { Fritillaria }\end{array}$} & \multicolumn{2}{|c|}{$\begin{array}{rr}\text { Page } \\
92 & 3,303\end{array}$} \\
\hline & 124 & 227 & & 108 & 92 \\
\hline Cineraria & 127 & 244 & Fumaria & 122 & 202 \\
\hline Circæa & 92 & 3 & & & \\
\hline Cistus & 115 & 151 & Galanthus & 107 & 90 \\
\hline Cladium & 92 & 9 & Galeobdolon & 117 & 167 \\
\hline Clematis & 116 & 153 & Galium & 9637, & , 303 \\
\hline Clinopodium & 117 & 170 & Genista & 122 & 204 \\
\hline Cnicus & 125 & 231 & Gentiana & 101 & 73 \\
\hline Cnidium & 104 & 83 & Geranium & 121 & 198 \\
\hline Cochlearia & 119 & 385 & Geum & 114 & 146 \\
\hline Colchicum & 108 & 105 & Glechoma & 116 & 164 \\
\hline Comarum & 114 & 147 & Glyceria & 95 & 22 \\
\hline Conium & 103 & 80 & Gnaphalium & 126 & 236 \\
\hline Convallaria & 107 & 95 & & & \\
\hline Convolvulus & 90 & 55 & Hedera & 101 & 67 \\
\hline Conyza & 126 & 238 & Hedysarum & 123 & 211 \\
\hline Cornus & 97 & 41 & Helleborus & 116 & 158 \\
\hline Corylus & 131 & 284 & Heracleum & 105 & 85 \\
\hline Cotyledon & 112 & 125 & Herminium & 128 & 256 \\
\hline Crepis & 124 & 226 & Hesperis & 120 & 192 \\
\hline Crocus & 93 & 11 & Hieracium & 124 & 225 \\
\hline Cuscuta & 101 & 72 & Hippocrepis & 123 & 210 \\
\hline Cynoglossum & 98 & 49 & Hippuris & 91 & 1 \\
\hline Cynosurus & 95 & 25 & Holcus & 95 & 21 \\
\hline \multirow{2}{*}{ Cypripedium } & 128 & 260 & Hordeum & 96 & 38 \\
\hline & & & Hottonia & 99 & 53 \\
\hline Dactylis & 95 & 25 & Humulus & 133 & 295 \\
\hline Daphne & 110 & 111 & Hutchinsia & 119 & 184 \\
\hline Datura & 99 & 62 & Hyacinthus & 107 & 94 \\
\hline Daucus & 102 & 74 & Hydrocharis & 134 & 299 \\
\hline Delphinium & 115 & 152 & Hydrocotyle & 104 & 84 \\
\hline Dentaria & 120 & 187 & Hyoscyamus & 99 & 62 \\
\hline Dianthus & 111 & 121 & Hypericum & 124 & 217 \\
\hline Digitalis & 118 & 180 & Hypochæris & 124 & 227 \\
\hline Dipsacus & 96 & 34 & & & \\
\hline Draba & 119 & 183 & Iberis & 119 & 186 \\
\hline \multirow[t]{2}{*}{ Drosera } & 106 & 89 & Ilex & 97 & 43 \\
\hline & - & & Inula & 127 & 243 \\
\hline Echium & 98 & 51 & Iris & 93 & 11 \\
\hline Eleocharis & 94 & 14 & & & \\
\hline Elymus & 96 & 32 & Jasione & 100 & 58 \\
\hline Epilobium & 109 & 106 & Juncus & 108 & 96 \\
\hline Epipactis & 128 & 259 & Juniperus & 135 & 299 \\
\hline Erica & 109 & 110 & & & \\
\hline Erigeron & 127 & 238 & Lactuca & 125 & 222 \\
\hline Eriophorum & 94 & 14 & Lamium & 117 & 165 \\
\hline Erodium & 121 & 197 & Lapsana & 125 & 227 \\
\hline Ervum & 123 & 209 & Lathræa & 118 & 175 \\
\hline Eryngium & 102 & 74 & Lathyrus & 123 & 207 \\
\hline Erysimum & 121 & 191 & Lemna & 92 & 7 \\
\hline Fry thræa & 99 & 64 & Leontodon & 125 & 223 \\
\hline Euonymus & 101 & 66 & Lepidium & 119 & 183 \\
\hline Eupatorium & 126 & 234 & Leucojum & 107 & 90 \\
\hline Euphorbia & 129 & 261 & Ligustrum & 92 & 3 \\
\hline \multirow[t]{2}{*}{ Euphrasia } & 118 & 174 & Limosella & 118 & 181 \\
\hline & & & Linum & 106 & 88 \\
\hline Fagus & 131 & 283 & Listera & 128 & 258 \\
\hline Fedia & 93 & 11 & Lithospermum & 98 & 48 \\
\hline Festuca & 95 & 25 & Lolium & 96 & 31 \\
\hline Fragaria & 114 & 144 & Lonicera & 10065 & 303 \\
\hline
\end{tabular}


INDEX TO THE GENERI.

Lotus

Luciola

Lychnis

Lycopsis

Lycopus

Lysimachia

Lythrum

Malva

Marrubium

Matricaria

Medicago

Melampyrum

Melica

Mentha

Menyanthes

Mercurialis

Mespilus

Milium

Moenchia

Monotropa

Montia

Myosotis

Myosurus

Myriophyllum

Myrrhis

Narcissus

Nardus

Narthecium

Nasturtium

Neottia

Nepeta

Nuphar

Nymphæa

CEnanthe

Ononis

Onopordum

Ophrys

Orchis

Origanum

Ornithogalum

Ornithopus

Orobanche

Orobus

Oxalis

Oxyria

Papaver

Parietaria

Paris

Parnassia

Pastinaca

Pedicularis

Peplis

Phalaris

Phleum

Picris

Pimpinella

Pinguicula

\begin{tabular}{rr|l} 
& Page & \\
124 & 215 & Plantago \\
108 & 99 & Poa \\
112 & 128 & Polemonium \\
98 & 51 & Polygala \\
92 & 8 & Polygonum \\
99 & 54 & Populus \\
113 & 132 & Potamogeton \\
& & Potentilla \\
121 & 201 & Poterium \\
117 & 169 & Prenanthes \\
126 & 246 & Primula \\
123 & 216 & Prunella \\
118 & 174 & Prunus \\
95 & 21 & Pyrethrum \\
116 & 162 & Pyrola \\
99 & 52 & Pyrus \\
134 & 298 &
\end{tabular}

$97 \quad 40$

$95 \quad 23$

$100 \quad 56$

$122 \quad 203$

$110 \quad 112$

$134 \quad 296$

$98 \quad 43$

$114 \quad 144$

130 281

$125 \quad 223$

$99 \quad 52$

$117 \quad 173$

$113 \quad 134$

$127 \quad 245$

$111 \quad 118$

$114 \quad 136$

$134 \quad 298$

114135

$94 \quad 18$

$98 \quad 46$

$110 \quad 117$

$96 \quad 34$

$98 \quad 46$

10690

$130 \quad 279$

$103 \quad 77$

Quercus

$131 \quad 281$

Radiola

Ranunculus

Raphanus

Reseda

Rhamnus

Rhinanthus

Rhynchospora

Ribes

Rosa

$107 \quad 91$

$94 \quad 15$

$107 \quad 94$

$\begin{array}{ll}120 & 188\end{array}$

$128 \quad 257$

$117 \quad 161$

115149

$115 \quad 149$

10380

$123 \quad 205$

$125 \quad 233$

$128 \quad 256$

$128 \quad 251$

$117 \quad 170$

$107 \quad 93$

$123 \quad 210$

$\begin{array}{ll}118 & 181\end{array}$

$123 \quad 206$

$112 \quad 127$

108101,304

115148

Rubia

Rubus

Rumex

Ruscus

Sagina

Sagittaria

Salix

Salvia

Sambucus

Samolus

Sanguisorba

Sanicula

Saponaria

Saxifraga

Scabiosa

Scandix

Schœenus

Scilla

scirpus

Scleranthus

Scrophularia

Scutellaria

$\begin{array}{ll}97 & 42\end{array}$

$110 \quad 116$

$106 \quad 87$

10584

$118 \quad 176$

107101

$94 \quad 16$

$94 \quad 16$

$125 \quad 221$

Sedum

Sempervivum

Senebiera

Senecio

Serratula

Sherardia

Silene

Sinapis

Sison

Sisymbrium

$\begin{array}{ll}98 & 46\end{array}$

$116 \quad 154$

$121 \quad 197$

113133

$100 \quad 65$

$118 \quad 173$

$93 \quad 12$

10166,303

$114 \quad 138$ 303

$114 \quad 142$

$108 \quad 102$

$133 \quad 294$

$\begin{array}{ll}98 & 45\end{array}$

131280

$132 \quad 285$

$\begin{array}{ll}92 & 8\end{array}$

$106 \quad 86$

$100 \quad 64$

$97 \quad 41$

$\begin{array}{ll}102 & 74\end{array}$

$111 \quad 120$

$111 \quad 119$

$96 \quad 35$

10276

$93 \quad 12$

10794,304

$93 \quad 12$

$111 \quad 120$

$\begin{array}{ll}135 & 179\end{array}$

$\begin{array}{ll}117 & 172\end{array}$

$112 \quad 125$

$113 \quad 133$

$119 \quad 186$

$127 \quad 240$

$126 \quad 229$

$97 \quad 36$

111 121, 304

$121 \quad 195$

10379

$120 \quad 190$ 
INDEX TO THE GENERA.

Sium

Smyrnium

Solanum

Solidago

Sonchus

Sparganium

Spartium

Spergula

Spirrea

Stachys

Stellaria

Stratiotes

Symphytum

Tamus

Tanacetum

Taxus

Teesdalia

Teucrium

Thalictrum

Thesium

Thlaspi

Thymus

Tilia

Tordylium

Torilis

Tormentilla

\begin{tabular}{rr|l} 
& Page & \\
103 & 78 & Tragopogon \\
104 & 81 & Trifolium \\
100 & 63 & Triglochin \\
127 & 242 & Triodia \\
125 & 221 & Triticum \\
129 & 264 & Tulipa \\
122 & 204 & Tussilago \\
112 & 130 & Typha \\
114 & 137 & \\
117 & 168 & Ulex \\
111 & 122 & Ulmus \\
152,340 & Urtica \\
98 & 50 & Utricularia \\
& & \\
133 & 296 & Vaccinium \\
126 & 235 & Valeriana \\
135 & 300 & Verbascum \\
119 & 184 & Verbena \\
117 & 160 & Veronica \\
116 & 153 & Viburnum \\
101 & 68 & Vicia \\
119 & 184 & Villarsia \\
117 & 170 & Vinca \\
115 & 150 & Viola \\
105 & 85 & Viscum \\
103 & 75 & \\
114 & 145 & Zannichellia
\end{tabular}

Page

$125 \quad 220$

$123 \quad 212$

108104

$95 \quad 24$

$96 \quad 33$

$108 \quad 92$

$127 \quad 239$

129264

$122 \quad 205$

10271

$\begin{array}{ll}130 & 277\end{array}$

$\begin{array}{ll}92 & 7\end{array}$

$109 \quad 109$

$93 \quad 10$

9961

$117 \quad 162$

$92 \quad 3$

10586

123208

$99 \quad 53$

$100 \quad 68$

10159

$133 \quad 295$

129263 


\section{DEX}

TO THE

\section{PRINCIPAL TECHNICAL TERMS, \&c.}

WHICH OCCUR IN THE

\section{INTRODUCTION.}

ACERINEE
Acotyledonous plants
Aculeus
Alæ
Albumen
Alburnum
Algæ
Alismaceæ
Amarillideæ
Amentaceæ
Amentum
Anther
Apetalous plants
Apocyneæ
Aquifoliaceæ
Arillus
Arista
Aristolochieæ
Aroideæ
Asparagineæ
Asphodeli
Atripliceæ
Awn
Beard
Berberideæ
Berry
Betulineæ
Blossom
Boragineæ
Bractea
Buds
Bulb
$\quad$ coated
$\quad$ scaly
Bulbils
Bunch

\begin{tabular}{|c|c|c|}
\hline Page & \multirow[b]{2}{*}{ Bundle } & Page \\
\hline 65 & & 34 \\
\hline $55,56,59$ & Calyx, & 13 \\
\hline 33 & acute & 15 \\
\hline 16 & augmented & 14 \\
\hline 36 & blunt & 15 \\
\hline 41 & caducous & 15 \\
\hline 22 & ciliated & 15 \\
\hline 60 & deciduous & 15 \\
\hline 61 & double & 14 \\
\hline 68 & entire & 15 \\
\hline 14 & imbricated & 14 \\
\hline 17 & lopped & 15 \\
\hline 56,57 & many-flowered & 14 \\
\hline 63 & obtuse & 15 \\
\hline 67 & persistent & 35 \\
\hline 36,50 & prickly & 15 \\
\hline 14 & serrate & 15 \\
\hline 61 & single & 14 \\
\hline 60 & squarrose & 14 \\
\hline 60 & tiled & 14 \\
\hline 60 & wanting & 14 \\
\hline 62 & Cambium & 40 \\
\hline 14 & Campanulaceæ & 63 \\
\hline & Caprifoliaceæ & 64 \\
\hline 16 & Capsule & 18 \\
\hline 65 & cell & 18 \\
\hline 18 & column & 18 \\
\hline 67 & dissepiment & 18 \\
\hline 15 & loculament & 18 \\
\hline 63 & partition & 18 \\
\hline 33 & suture & 18 \\
\hline 45 & valve & 18 \\
\hline 25,45 & Caryophylleæ & 66 \\
\hline 25 & Catkin & 14 \\
\hline 25 & Celastrineæ & 67 \\
\hline 25 & Cell & 18 \\
\hline 45 & Celtideæ & 67 \\
\hline 33 & Characea & 59 \\
\hline
\end{tabular}


Chenopodeæ

Chorisanthery

Cichoraceæ

Cister

Clasper

Classes

Classifications

Cluster

Colchicaceæ

Columella

Compositæ

Cone

Confervæ

Coniferæ

Convolvulaceæ

Corolla

bell-shaped

butterfly-shaped

caducous

campanulate

ciliate

crenate

cross-shaped

cruciform

deciduous

denticulate

dipetalous

folded

fringed

funnel-shaped

gaping

hexapetalous

marcescent

monopetalous

notched

papilionaceous

persistent

personate

plicate

polypetalous

revolute

ringent

rosaceous

rotate

salver-shaped

serrate

toothed

twisted

undulate

waved

wheel-shaped

Cortical layers

Corymb

Corymbiferæ

Cotyledonous plants

Cotyledons

Crassulaceæ

Cruciferæ

Cucurbitaceæ

Culm

\begin{tabular}{r|lr} 
Page & & Page \\
62 & Cup, (see Perianth and Calyx) & 68 \\
64 & Cupuliferæ & 34 \\
64 & Cyme & 64 \\
66 & Cynarocephalæ & 60 \\
33 & Cyperaceæ & \\
21,58 & Dicliny & 67 \\
21,22 & Dicotyledonous plants & 61 \\
53 & Dicotyledons & 55 \\
33 & Dipsaceæ & 64 \\
60 & Dissepiment & 18 \\
50 & Down & 33 \\
64 & Droseraceæ & 66 \\
19 & Drupaceæ & 67 \\
59 & Drupe & 18 \\
68 & nupe
\end{tabular}

63

Embryo

36,52

Embryonate plants

Endocarp

Epicarp

Epicorolly

Epidermis

Epipetaly

Epistaminy

Ericineæ

Euphorbiaceæ

55,59

50

50

64

39

64

61

Fasciculus

Ferns

Filament

Flags

Floral-leaf

Floret, ligulate radiate tubulose

Flower-cup

Flowers

radiate 20

simple 19

tubulose $\quad 20$

umbelliferous $\mathbf{1 4}$

Flower-stalk 26

axillary 26

clustered 26

opposite to a leaf $\quad 26$

scattered $\quad 26$

terminal 26

Fluviales $\quad 60$

Fragariaceæ 67

Frond 26

Fructification 13

64 Fruit 50

55, 56 Fulcra

36 Fumariaceæ $\quad 65$

66 Funguses 22

66 Gemmule 52

26 Genera 24 
PRINCIPAL 'TECHNICAL 'TERMS, \&

Gentianeæ
Genus
Geraniaceæ
Germen
Germination of seeds
Gland
Glume
Grafting
Gramineæ
Grossularieæ
Hair
Halorageæ
Helmet
Hepaticæ
Hilum
Honey-cup
Husk
Hydrocharideæ
Hygrobieæ
Hypericineæ
Hypocorolly
Hypopetaly

\section{Ilicineæ}

Inembryonate vegetables

Inflorescence

Integument, herbaceous

Involucre

\section{partial}

universal

Irideæ

Jasnineæ

Junceæ

Junci

Keei

Kernel

Labiatæ

Leaf, acerose

acuminate

acute

alternate

amplexicaul

arrow-shaped

awl-shaped

battledore-shaped

bijugate

bilobate

binate

bipartite

bipinnate

bipinnatifid

biternate

blunt

bundled

canaliculate

carinate

cauline

Page
63
54
65
17
52
33
14
4
60
66
33
66
16
22

36,52

17

14

61

66

65

62

63

63

60

16
Leaf, chaffy

channelled

comb-like

conjugate

connate

cordate

costate

crenate

crescent-shaped

cuneiform

curled

cylindric

dagger-pointed

decurrent

decussate

deltoid

demersed

dentate

depressed

diamond-shaped

digitate

doubly-winged

doubly ternate

egg-shaped

elliptic

emarginate

emersed

ensiform

entire

equitant

erect

fasciculated

fiddle-shaped

fingered

fleshy

furrowed

halbert-shaped

hand-shaped

hastate

heart-shaped

horizontal

imbricated

jagged

jointed

keeled

kidney-shaped

laciniate

lanceolate

linear

linguiform

lobed

lopped

lunulate

lyrate, or lyre-shaped

mucronate

natant

needle-shaped

notched

oblong - 27

obovate $\quad 27$

ointuse 


Leaf, orbiculate
oval
ovate
palmate
panduriform
partite
pectinate
pedate
peltate
perfoliate
pinnate

pinnate

\begin{tabular}{|c|c|c|}
\hline age & & Page \\
\hline 26 & Ieaf, three-lobed & 28 \\
\hline 27 & thrice-ternate & 31 \\
\hline 27 & tiled & 33 \\
\hline 28 & tongue-shaped & 30 \\
\hline 28 & toothed & 29 \\
\hline 28 & triangular-shaped & 27 \\
\hline 28 & trilobate & 28 \\
\hline 32 & trowel-shaped & 27 \\
\hline 31 & truncate & 29 \\
\hline 32 & tubular & 30 \\
\hline 30 & tufted & 33 \\
\hline 31 & tripartite & 29 \\
\hline 31 & twice-ternate & 31 \\
\hline 31 & two-ranked & 33 \\
\hline 31 & undulate & 30 \\
\hline 31 & unequal & 29 \\
\hline 31 & vaginant & 32 \\
\hline 28 & veiny & 29 \\
\hline 28 & verticillate & 32 \\
\hline 29 & waved & 30 \\
\hline 29 & wavy & 29 \\
\hline 29 & wedge-shaped & 27 \\
\hline 32 & whorled & 32 \\
\hline 30 & wing-cleft & 28 \\
\hline 32 & winged & 30 \\
\hline 32 & abruptly & 31 \\
\hline 27 & alternately & 31 \\
\hline 29 & decursively & 31 \\
\hline 29 & interruptedly & 31 \\
\hline 28 & oppositely & 31 \\
\hline 30 & with an odd one & 31 \\
\hline 26 & wrinkled & 29 \\
\hline 26 & Leaf-stalk & 26 \\
\hline 29 & Leaves & 26,46 \\
\hline 29 & compound & 26,30 \\
\hline 28 & determinate & 26,31 \\
\hline 27 & simple & 26 \\
\hline 29 & Legume & 18 \\
\hline 32 & Leguminosæ & 67 \\
\hline 30 & Liber & 40 \\
\hline 31 & Lichen & 22 \\
\hline 32 & Lilia, and Liliaceæ & 60 \\
\hline 29 & Lineæ & 65 \\
\hline 29 & Linnæan classification & 20 \\
\hline 32 & Liverwort & 22 \\
\hline 29 & Loculament & 18 \\
\hline 32 & Lorantheæ & 64 \\
\hline 29 & Lysimacheæ & 62 \\
\hline 27 & & \\
\hline 27 & Malvaceæ & 65 \\
\hline 31 & Medullary tube & 41 \\
\hline 32 & Megocarp & 50 \\
\hline 32 & Monocotyledonous plants & 59 \\
\hline 27 & Monohypogyny & 59 \\
\hline 30 & Monoepigyny & 61 \\
\hline 26 & Monoperigyny & 60 \\
\hline 27 & Monopetalous plants & 56,57 \\
\hline 30 & Mosses & 22 \\
\hline 32 & Narcissex & 61 \\
\hline 30 & Natural familie & of 5 \\
\hline
\end{tabular}


PRINCIPAL TECHNICAL TERMS, \&C.

Natural families, Key to
Nayadeæ
Nectary
Nut
Nutrition
Nymphæaceæ
Onograriæ
Orchideæ
Orders

Angiospermia

Gymnospermia

Polygamia æqualis frustranea necessaria segregata

Siliculosa superflua

Siliquosa

Organs of reproduction

Orobancheæ

Oxalideæ

Palate

Panicle

Papaveraceæ

Paronychieæ

Pediculares

Peduncle

Perianth

of the flower

of the fructification of the fruit

Pericarp

Perichætium

Pericorolly

Perigonium

Peripetaly

Peristaminy

Petiole

Pistil

Germen

Stigma

Style

Pith

Placenta

Plantaginex

Plantule

Podosperm

Polemoniaceæ

Pollen

Polygaleæ

Polygoneæ

Polypetalous plants

Pomaceæ

Pome

Portulaceæ

Potameæ

Potamophileæ

Prickles

Primulaceæ

I'rops

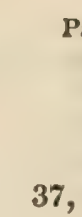

7,48

61

66

61

22

22

22

23

23

23

23

23

23

23

49

62

65

16

34

65

66

62

26

13

13

13

13

$18,36,50$

14

63

49

66

62

26

17

17

18

17

42

50

62

52

50,51

63

17

65

62

56,57

67

18

66

60

60

24,33

62

33
Raceme

Ranunculaceæ

Receptacle

bristly

chaffy

common

naked

of flower

of fructification

of fruit

of seeds

proper

Resedaceæ

Rhamnex, Rhamni

Ribesieæ

Root

bitten

branching

bulbous

creeping

fibrous

fusiform

granulated

premorse

ramose

repent

spindle-shaped

tuberous

Rosaceæ, Roseæ

Rubiaceæ

Salicarieæ

Salicineæ

Sanguisorbieæ

Santalaceæ

Sap

Sarcocarp

Saxifrageæ

Scape

Scrophularix

Scrophularineæ

seed

coat

cotyledon

eye, or scar

Semperviveæ

Sheath

Silicle

Silique

Solaneæ

Spadix

Spatha

Species

Spike

Spikelet

Spine

Spiraceæ

Stalk

Stamens

anther

epigynous
Page

33

65

19

19

19

19

19

19

19

19

19

19

66

67

66

24, 38

25

25

25

25

25

24

25

25

25

25

24

25

67

64

67

67

67

62

48

36,50

66

26

62

19, 52

36

36

52

66

14

18

18

63

14

14

24, 54

33

34

33,48

67

26

17

17

56,57 
INDEX TO THE \&c.

Stamens, filament

hypogynous perigynous

Standard pollen

Stem, augular climbing creeping dichotomous diffuse erect flexuous forked repeatedly jointed lax procumbent proliferous radicant repent rooting round scandent straight trailing turning twining upright winged

Stems zigzag

Stigma

Stipe

Stipula

Straw

Strobile

Style

Supports

Sutures

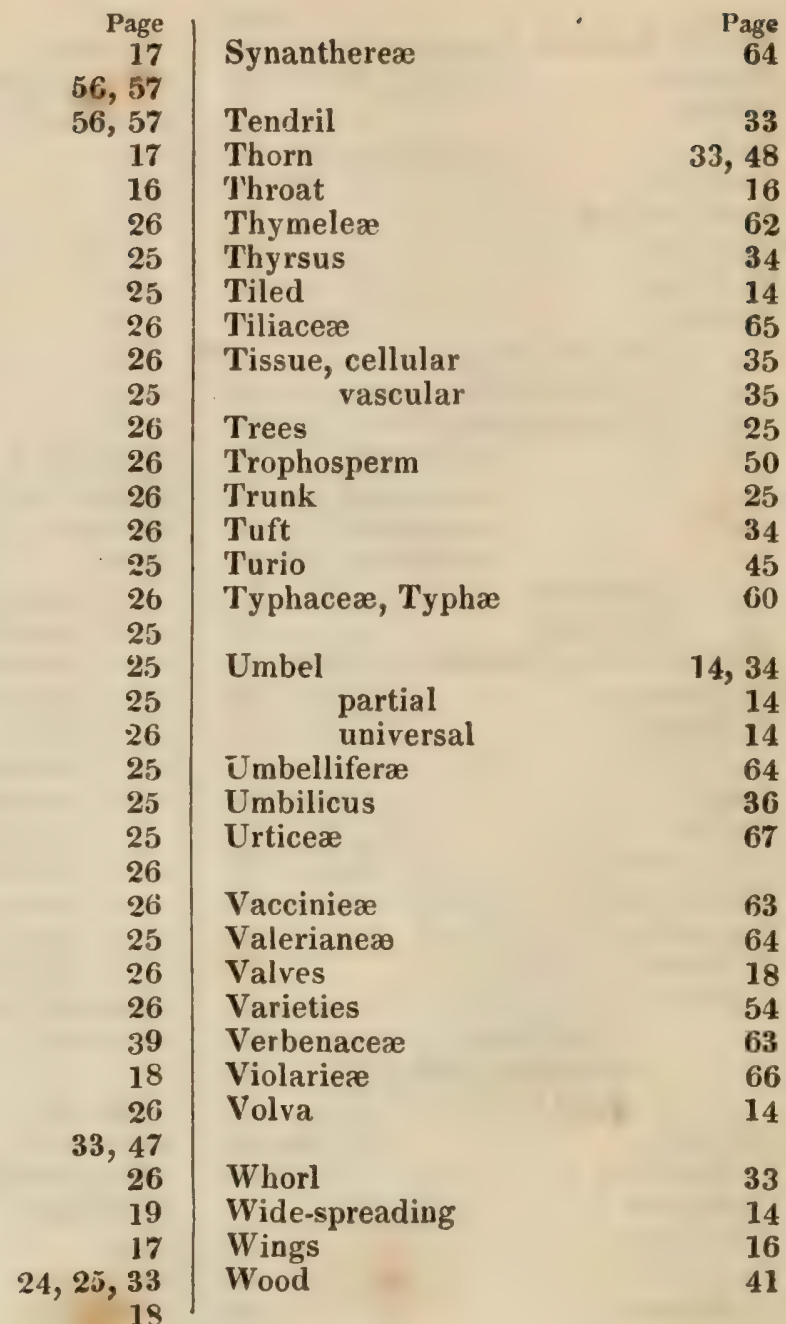




\section{CORRECTIONS AND ADDITIONS.}

Page 9. To C. Mariscus-add E. B. 950. G. E. 29. Cyp. long. inod. sylvestris. For Thames, read Thame.

Page 11. Fedic olitoria - add : Not uncommon about Headington. R. W.

Page 15. E. pubescens-add E. B. Suppl. 2633.

Page 17. For P. paniculata, read Phalaris, \&c.

Page 40. Expunge the first $i$, in Plaintain.

Page 49. After Anchusa, **.

Page 57. C. rapunculoides-add Near Adderbury, Road-side. Mrs. Roundell.

Page 59. For Viola, read Violet.

Page 87. Add, White berried elder. Sir Joseph Lock's Grounds, Headington, near the London Road. R. W.

Page 91. Expunge Bx. hábitat, for Narcissus Pseudo, \&c.

Page 97. Top-for Octandria, read Hexandria.

Page 116. Expunge Elátine tripet: and description.

Page 118. Andromeda, \&c.-for Over Heath, read Iver, \&c. and expunge Mr. Sandys' habitat.

Page 124. A. tenuifólia-add Headington, on a wall, and on the ground. 1832. R.W.

Page 127. S. album-add Islip. $B \boldsymbol{B}$.

Page 130. Expunge under C. aquat. Larbrea of DC.

Page 148. Papaver hybrid.-for Ensham road, read Woodstock, \&c.

Page 152. After Banbury, add Road.

Page 162. Mentha sylvest.-add Cuddesdon, by the Wheatley Road-side, near the Palace. R. W.

Page 168. S. sylvatica-for Ls. minute, read acuminate, (i. e. taper-pointed.)

Page 178. A. repens-add after chalky banks, an *, for scarce.

Page 178. A. Linária-add Path between the Asylum, and Bullingdon Green. R. W.

Page 182. O. elátior-add Field between Barton, and Sandhill. R. W. 
Page 187. On the first $a$ in Dentária, place an acute accent.

Page 217. In note to St. John's-wort-for drop, read droop:

Page 223. For T. palustre, read $L$. \&c.

Page 246. After College, add Gardens.

Page 280. In Sagittifólia, substitute a small s.

Page 282. For 1448, read 1458.

Page 299. After Hydrócharis-add i. e. delighting in water. Gr.

Page 300. Taxus-for funeral, read funéreal.

P. Ixxxii. For pinnatified, read pinnatifid.

Page civ. For White-root, read White-rot.

Drummond's Letters, \&c. A few passages in this interesting little work, to be read with caution and explanation.

The following is a list of several plants, mentioned in Sir Alexander Croke's critical and elegant edition of the "Régimen Sánitatis Salernitánum." Talboys, Oxford, 1830 :-Sage, Wormwood, Poppy, Fennel, Mallows, Mint, Primrose, Tansy, Mustard, Violet, Nettle, Chervil, Elicampane, Penny-royal, Celandine, Sallow, Vervain, Henbane.

Respecting the Elsfield hábitat for Lonicéra Caprifolium, Flora, p. 65. See Lady Smith's interesting Memoir and Correspondence of the late Sir J. E. Smith, 1832. vol. i. p. 438. See also in the same work, vol. i. a concise Memoir of the scientific and munificent Professor, Dr. J. Sibthorp, with three of his letters, \&c.

Any mistakes pointed out by the reader or critic, will be corrected in a future Supplement to this Work. Number of Plants, introduced into the Flora of Oxfordshire, and its Contiguous Counties, about eight hundred, and ninety-four. Callítriche; see more in H. Br. Fl. and Arrott in Journ. of Nat. and Geog. Sc. vol. i. p. $426, \& c$.

L. rugósum, naturalized between Oxford and Iffley, and in Christ Church Meadow. $B \boldsymbol{B}$.

Antirrhinum purpureum, not uncommon on old walls in Oxford. R. W.

Insert after Aquilegia, p. exv. Gen. Char. of Stratio'tes. Sheath two-leaved. Cal. three-cleft. Cor. three-petalled. Berry angular, six-celled. N. O. Hydrocharideæ. Richd.-Page 152. 
Edited by the same Author.

ARISTO'TELIS

DOCTRIN屟 MORALIS EPITOME,

PER THEOPH.' GOLIUM.

Oxonii: Typis N. Bliss, 1814, duod.--Little more than a hasty reprint of a once scarce work.

\section{ANTONII RICCOBONI PARAPHRASIS IN RHETORICAM ARISTOTELIS.}

AD EDITIONEM HANC ACCESSERUNT, MURETI SUMMA BREVIORES.

LONDINI, 1820, 8vo.

By the same Author.

PLAIN AND CURSORY THOUGHTS

ON

CATHOLIC EMANCIPATION, \&c.

BY CHAS. MACKLIN, ESQ. 1829.

A FRIENDLY LETTER, \&c。

BY PHILIPPUS ANTI-OSIANDER, S.T.P.

Oxford, 1831.

See Christian Remembrancer, May 1831. p. 282.

A FEW WORDS IN FAVOUR OF

PROFESSOR POWELL, AND THE SCIENCES, \&c.

BY PHILOMATH : Oxoniensis, 1832.

See Gent. Mag, for December 1832. p. 450.

Latin Works preparing for publication, by the same Author.

1. SPECIMENS OF LATIN STYLE, from the earliest existing Records of the Language, to the Extinction of the Western Empire; with a short Critical, and Biographical Account of the several Authors, whose works are quoted.

2. THE LTFE OF WILLIAM OF WAYNFLE'TE, FOUNDER OF MAGDATEN COLLEGE, OXFORD, including a Sketch of the Manners, Customs, Literature, and general Staie of Society, in the Age in which the Founder lived. 







Cob $0=0$

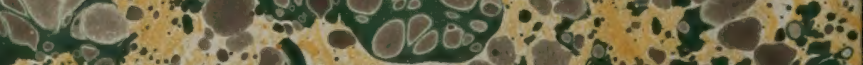

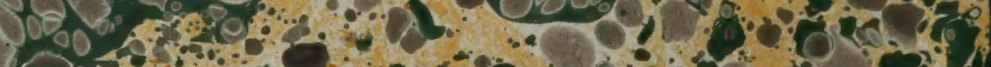

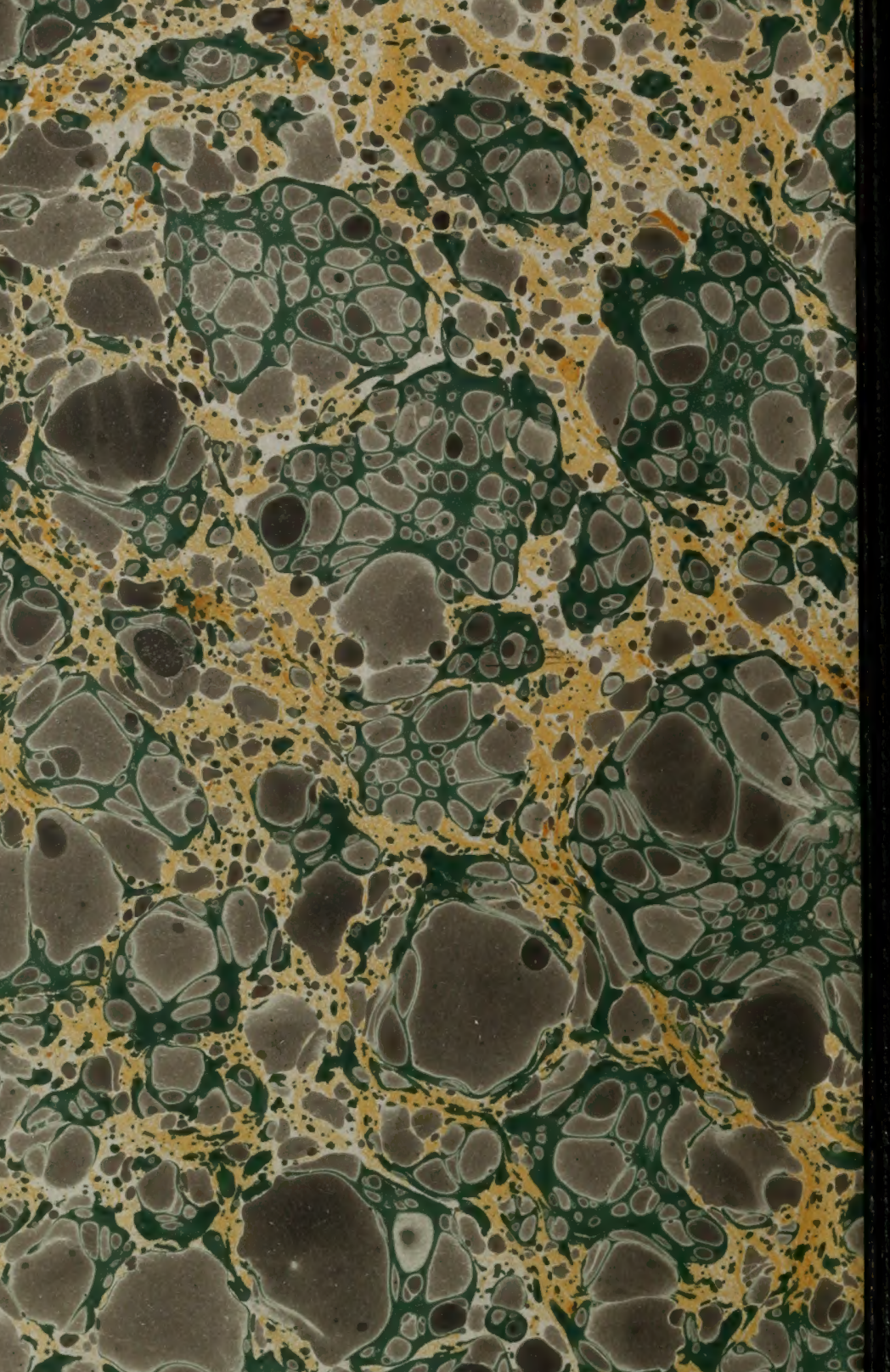

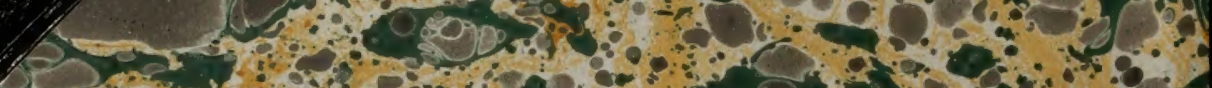

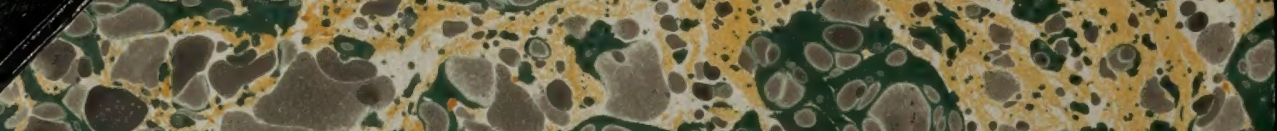

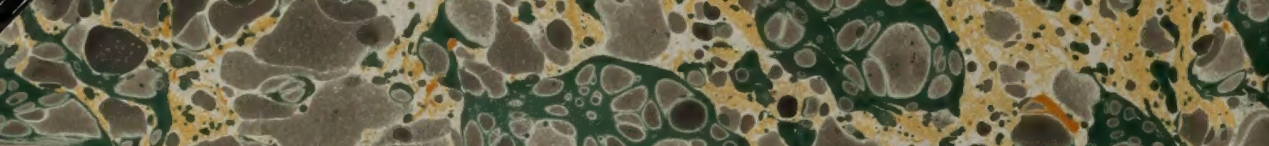

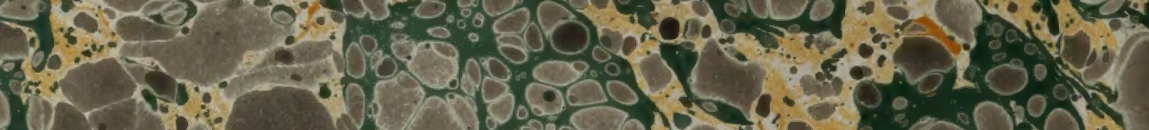

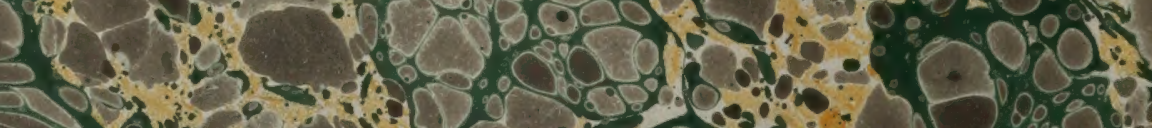

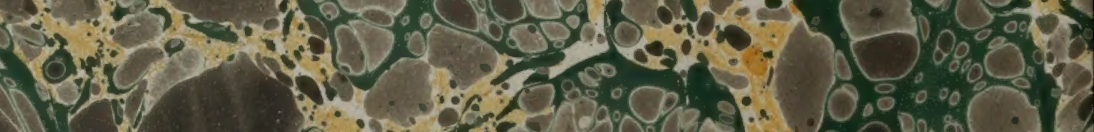

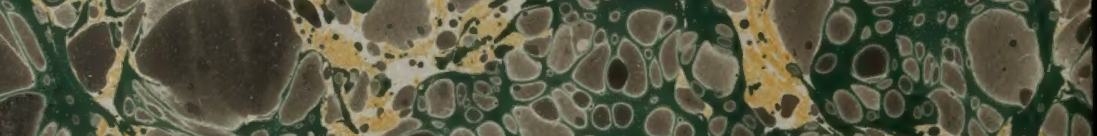

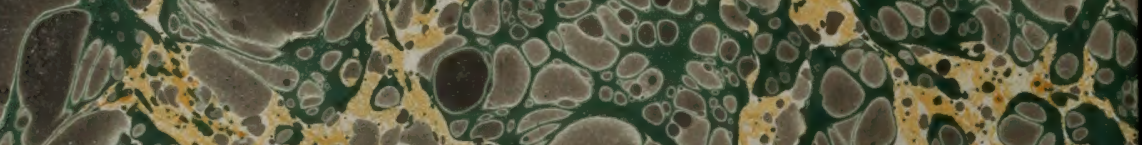

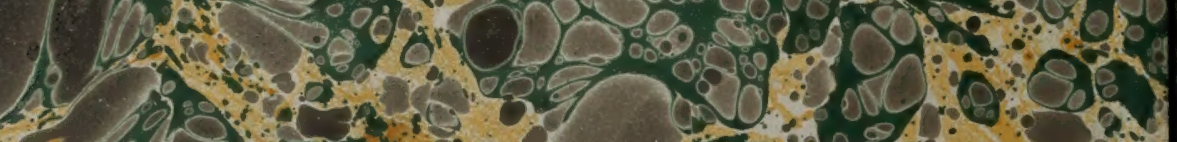

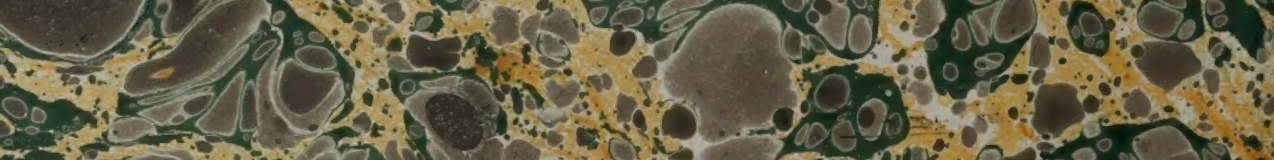
on 20.0.

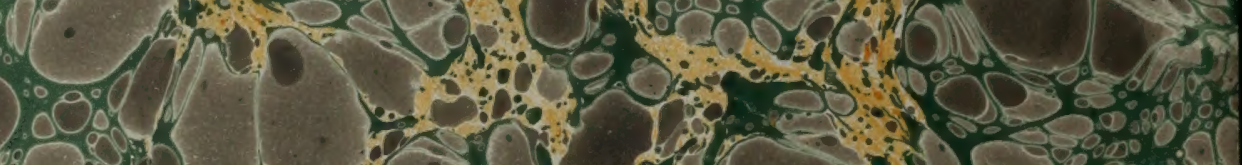

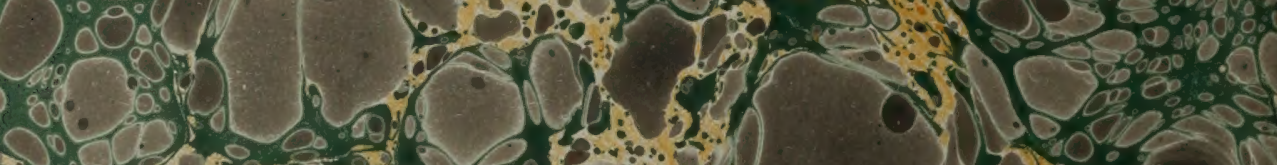

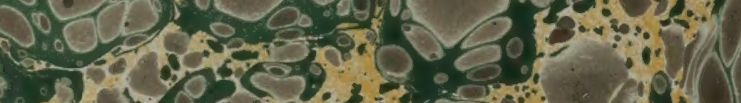

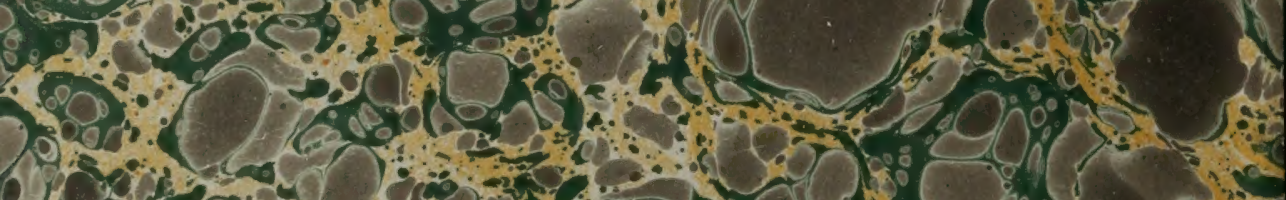

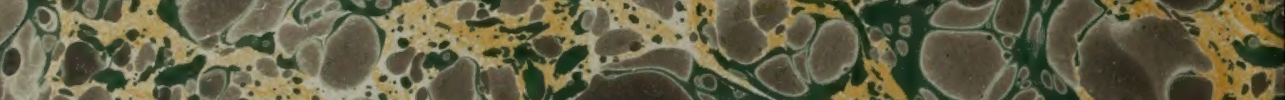

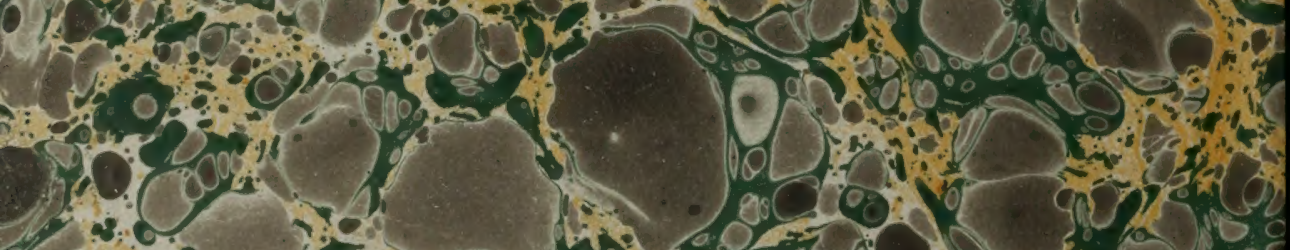

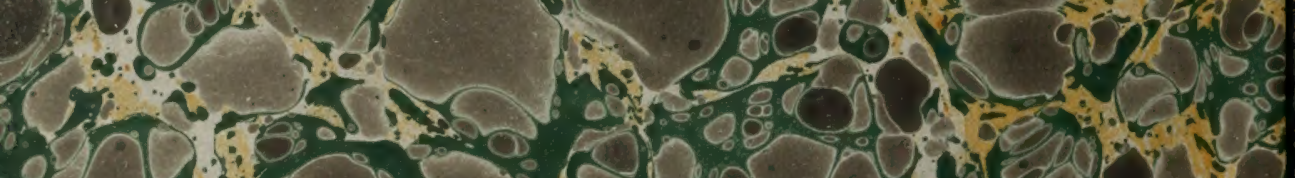

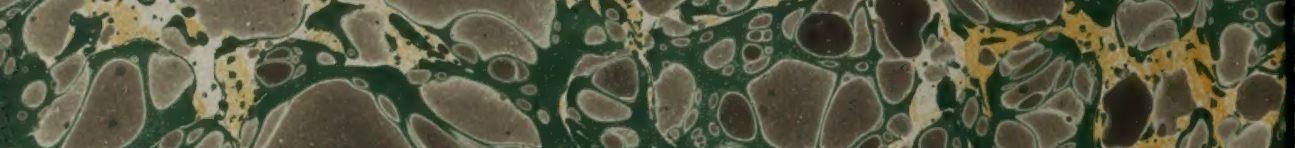

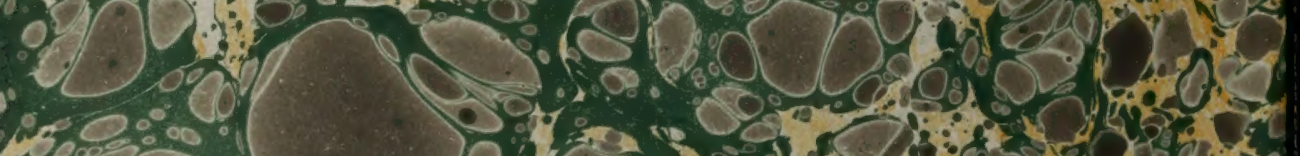

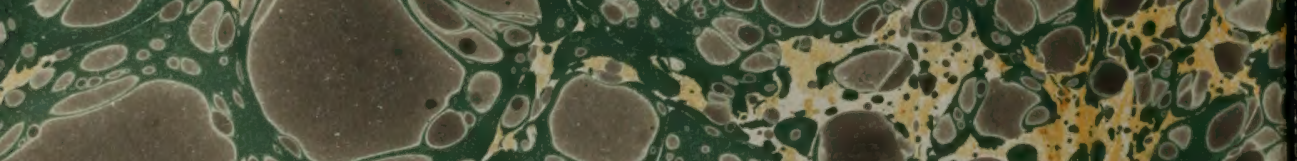
a Q.

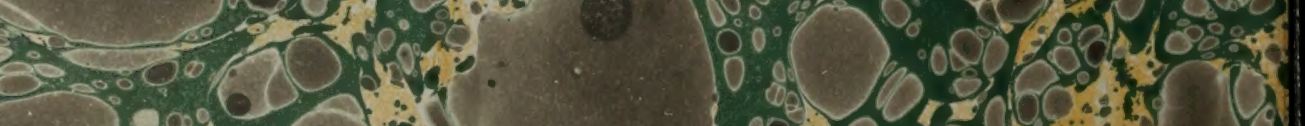

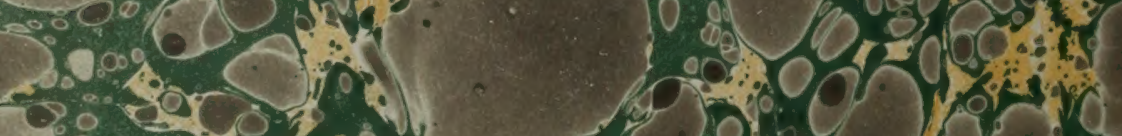

